\title{
EL TEATRO DE QUEVEDO
}

DIRECTORA DE LA TESIS: ROSA NAVARRO DURÁN

DePARTAMENTO DE Filología HisPÁNICA DE LA U.B.

PROGRAMA DE DOCTORADO: “HISTORIA E INVENCIÓN DE LOS TEXTOS LITERARIOS

HISPÁNICOS" (BIENIO: 2004-2006) 
-2 - 


\section{ÍNDICE DE CONTENIDOS}

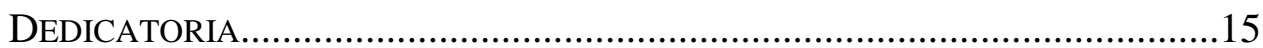

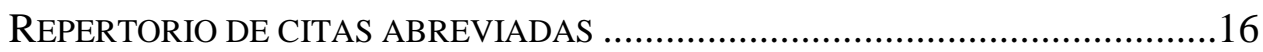

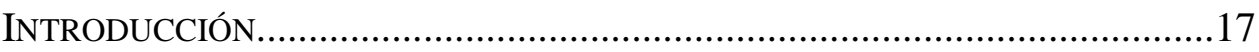

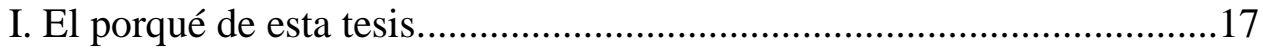

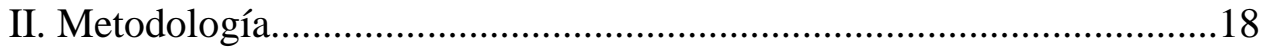

III. Estado de la cuestión.........................................................................24

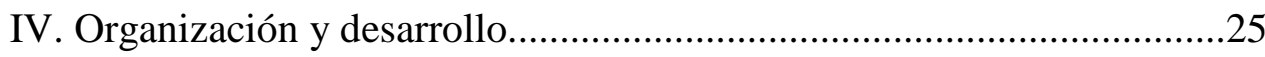

1. El teatro de Quevedo (Volumen I)..............................................26

2. Apéndice. Teatro inédito atribuido a Quevedo (Volumen II)............30

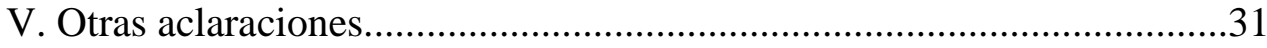

Capítulo I. El teatro DE Quevedo Y SUS TESTIMONIOS

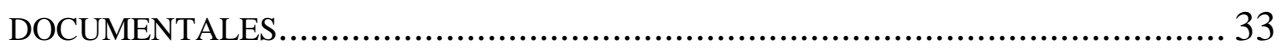

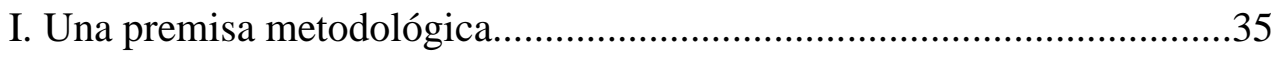

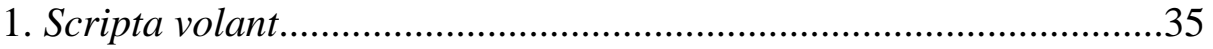

2. La fijación textual del teatro aurisecular.............................................37

3. Los manuscritos e impresos teatrales de Quevedo.............................40

4. ¿Autógrafos de entremeses? El ductus de un polígrafo.....................48

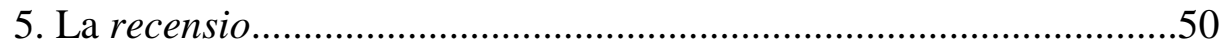

II. Catálogo bibliográfico del teatro de Quevedo......................................54

1. Comedias de atribución segura..........................................................54

2. Comedias inéditas atribuidas........................................................57

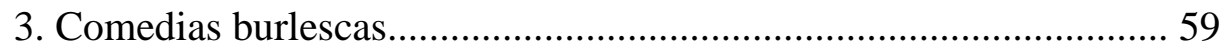


4. Entremeses de atribución segura.....................................................62

5. Entremeses de dudosa atribución......................................................66

6. Entremeses de Miguel de Mulsa.........................................................71

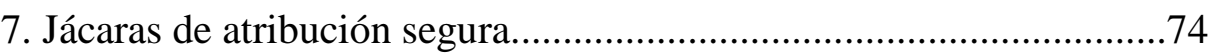

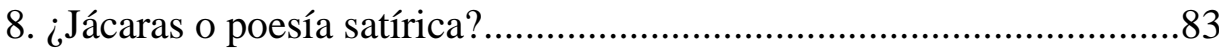

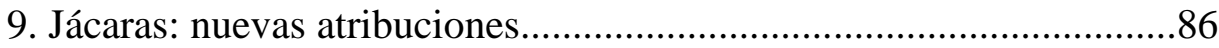

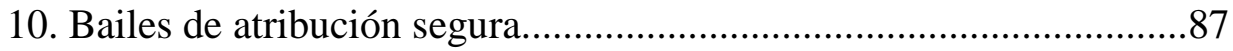

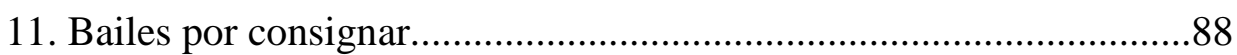

III. El corpus textual: nómina y cronología...............................................92

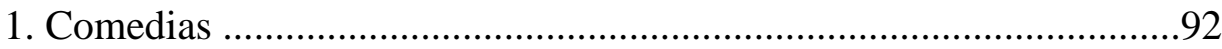

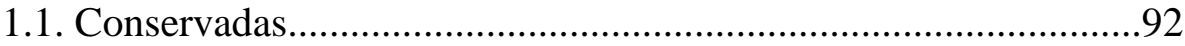

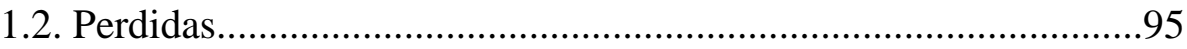

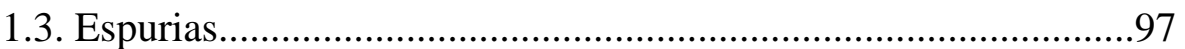

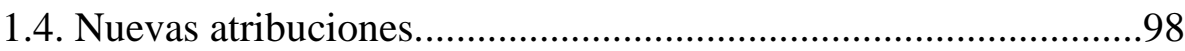

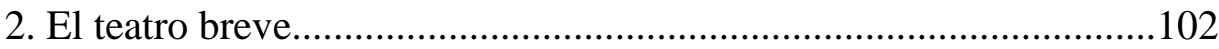

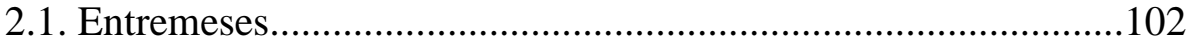

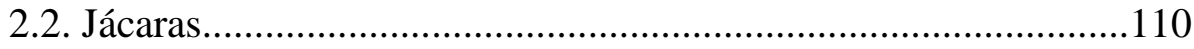

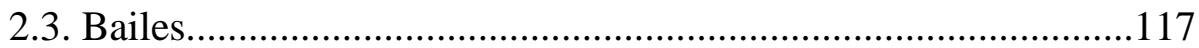

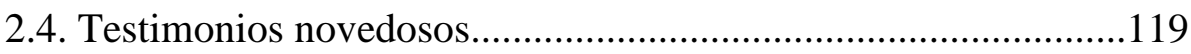

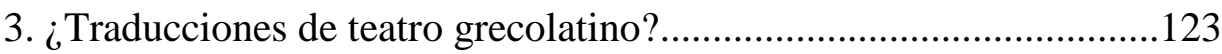

CAPÍTULO II. QUEVEDO Y EL TEATRO CORTESANO...................................125

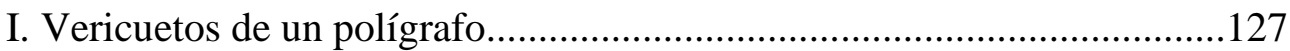

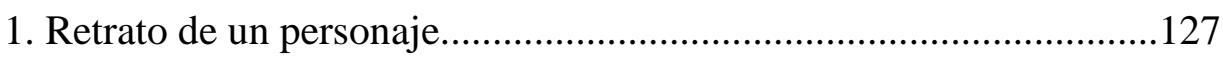

2. Entre la calle y la alcoba palaciega.................................................129 
3. Las fiestas oficiales de la monarquía............................................132

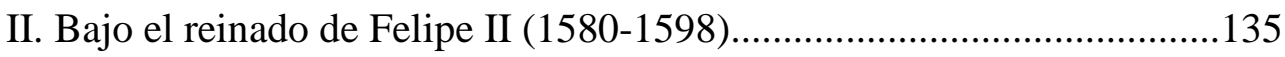

1. Las paradojas de un rey melancólico.............................................135

2. El teatro escolar de jesuitas........................................................ 138

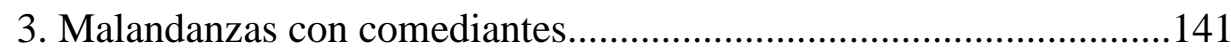

III. La monarquía de Felipe III (1598- 1621).........................................145

1. La liberalización de las costumbres...............................................145

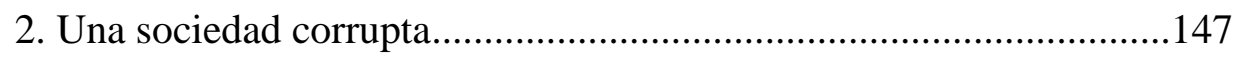

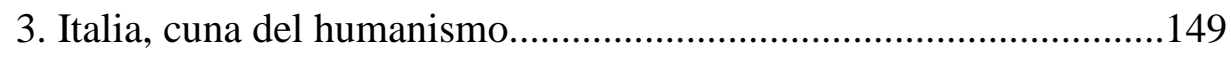

4. El esplendor del teatro cortesano.................................................153

5. El Duque de Osuna: escándalo y farándula.......................................155

IV. Felipe IV y el teatro político cortesano $(1621-1627) \ldots \ldots \ldots \ldots \ldots \ldots \ldots \ldots \ldots . . . . .158$

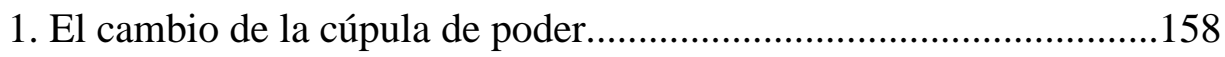

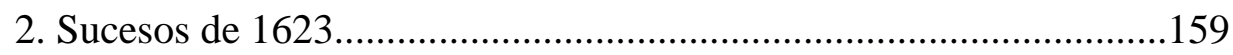

3. Expediciones y entremeses....................................................... 162

4. Una comedia para el cumpleaños de la reina....................................163

V. Bajo el Índice de libros prohibidos (1627-1632).................................166

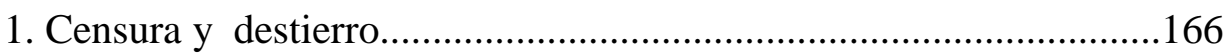

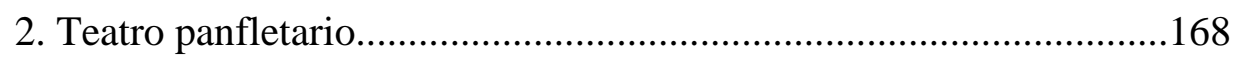

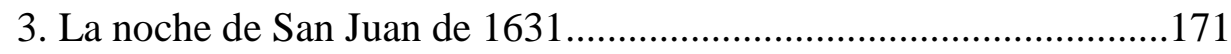

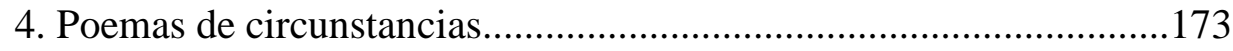

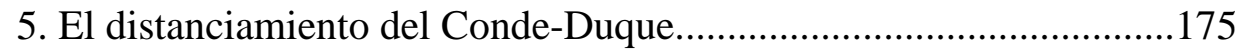

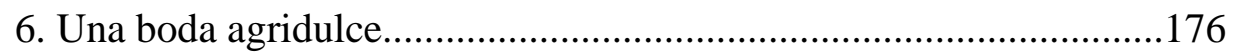

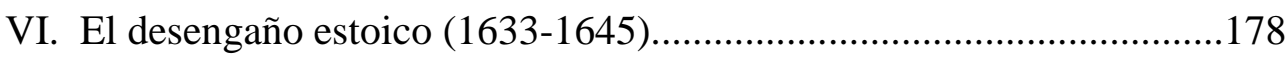




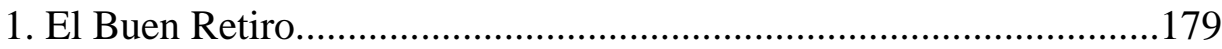

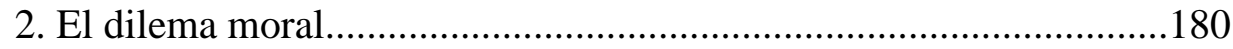

3. El desprecio a las vanidades del teatro.............................................182

CAPÍTULO III. ENTRE COMEDIAS Y DRAMATURGOS...................................187

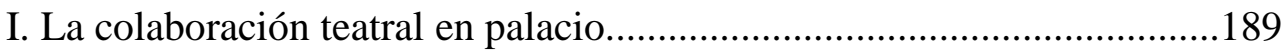

1. Condiciones de la obra por encargo...............................................189

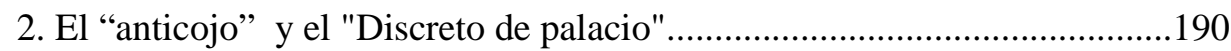

3. Algunos datos sobre Mateo Montero...............................................193

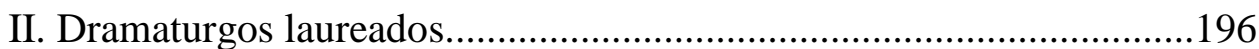

1. Jorge Ferreira de Vasconcellos y su Comedia Eufrosina..................196

2. Todo lo bueno "Es de Lope"..........................................................197

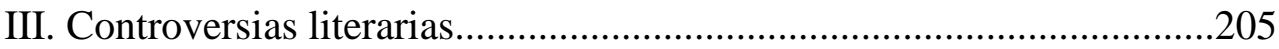

1. Un combate de esgrima con Pacheco de Narváez...........................205

2. Pérez de Montalbán, el "licenciado libruno".....................................211

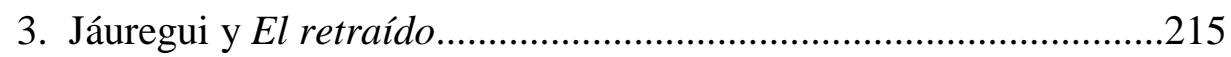

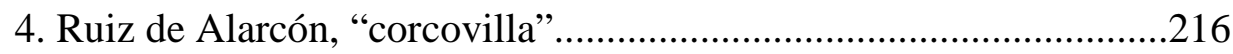

5. Y Góngora... No tan lejos de Quevedo..........................................219

IV. Las huellas de Quevedo en el teatro.................................................226

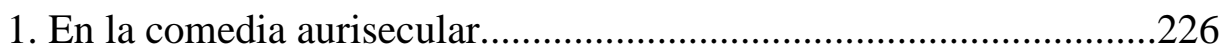

2. Innovaciones quevedescas del entremés.......................................227

3. Maestro del "pontífice de los bailes y entremeses"..........................229

4. La impronta de las jácaras de Quevedo.........................................235

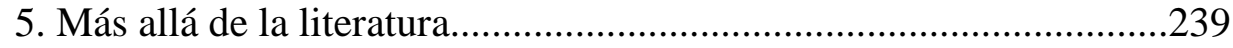




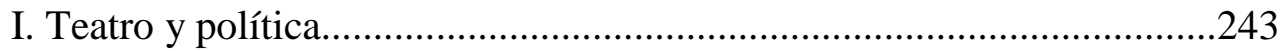

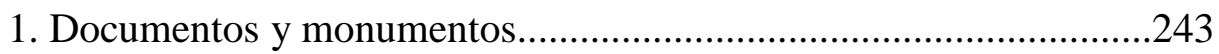

2. El Conde-Duque de Olivares y las comedias por encargo..............248

3. La privanza y el pensamiento político de Quevedo.........................252

3.1. Definición del privado............................................................253

3.2. Los peligros del valimiento..................................................256

3.3. La relación con el monarca.....................................................258

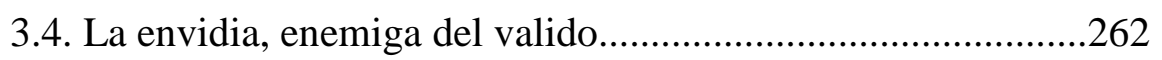

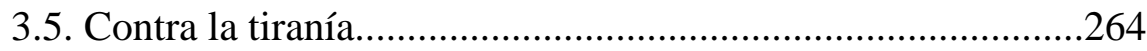

II. Cómo ha de ser el privado: una pieza desdramatizada........................266

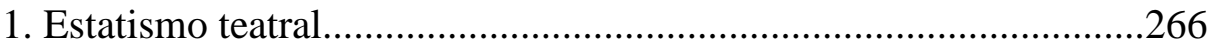

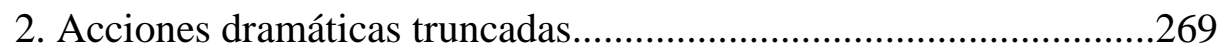

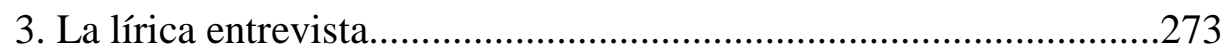

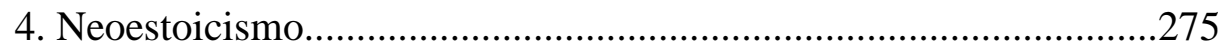

III. Comedias perdidas e incompletas.................................................279

1. El autoplagio en Pero Vázquez de Escamilla...............................279

2. Un breve fragmento de comedia....................................................283

3. La reconstrucción de Quien más miente, medra más......................284

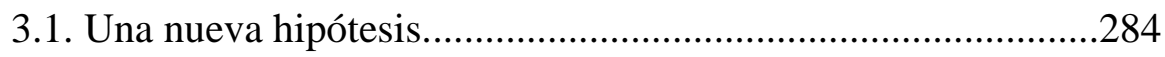

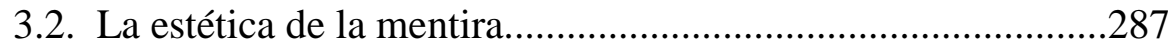

IV. Comedias inéditas atribuidas a Quevedo.........................................292

1. La Privanza desleal y voluntad por la fama..................................292

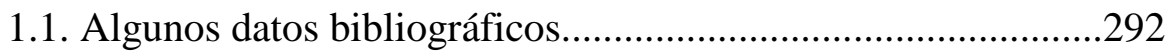

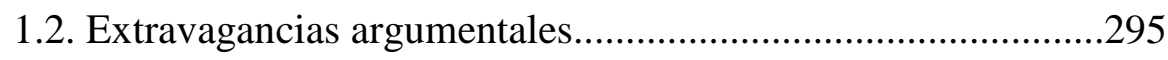


1.3. ¿Una comedia palatina de enredo? .296

2. El galán fantasma 300

2.1. Un manuscrito escondido..........................................................300

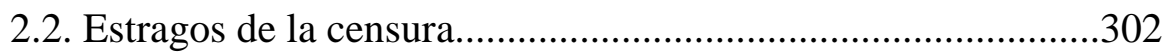

2.3. La obra homónima de Calderón................................................306

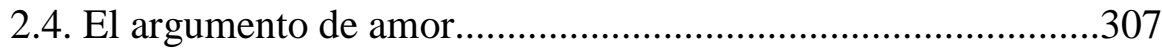

2.5. El pícaro Gorrión........................................................................313

CAPÍTULO V. LOS ENTREMESES DE QUEVEDO..............................................319

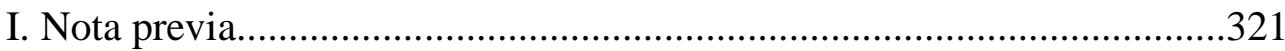

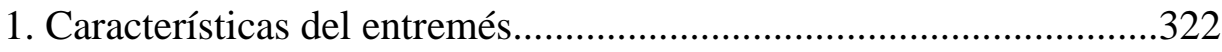

2. Criterios de clasificación...................................................................325

II. El arte de desplumar femenino.........................................................326

1. La avaricia cortesana en el Niño y Peralvillo de Madrid ..................330

2. La picaresca femenina en La polilla de Madrid................................334

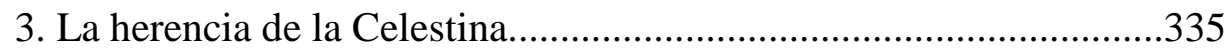

3.1. Pidonas y esgrimistas en La destreza....................................338

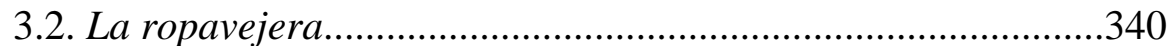

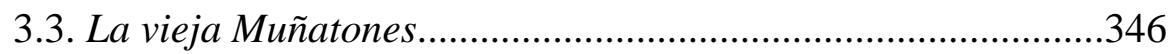

4. El duelo de sexos en El Caballero de la Tenaza..............................350

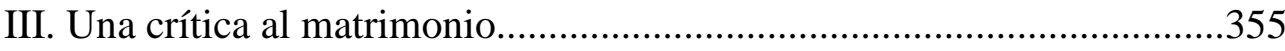

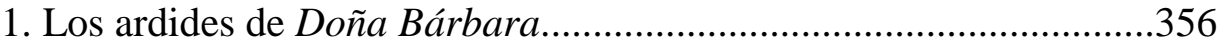

2. Diego Moreno o el "cornudo cartujo".................................................360

3. El intercambio de roles en El marión .................................................367

4. El marido pantasma o el temor de enyernar....................................374 
5. Los malmaridados de dos falsos autógrafos.

5.1. El hospital de los malcasados. .383

5.2. Los refranes del viejo celoso. .385

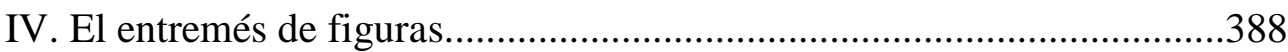

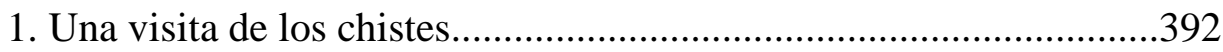

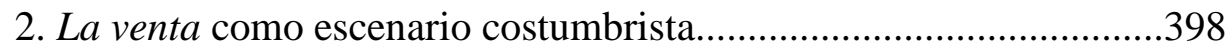

3. Un juicio moral representado en El zurdo alanceador.....................405

V. ¿Miguel de Mussa o Miguel de Mulsa?..................................................410

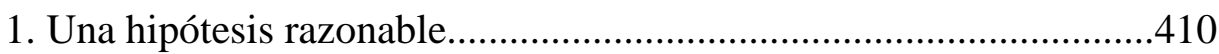

2. ¿Un pseudónimo de juventud?.......................................................411

3. Dos entremeses de Miguel de Mulsa..............................................414

3.1. El Entremesico famoso de las verdades del Zonzo.................417

3.2. El Entremesico del Hurto del nene..........................................424

Capítulo VI. Dos Comedias buRlescas ATRIBUIDAS A QueVEDO..........433

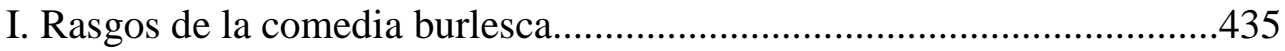

II. El premio de la hermosura ...............................................................438

III. ¡Qué villano es el amor! ........................................................................450

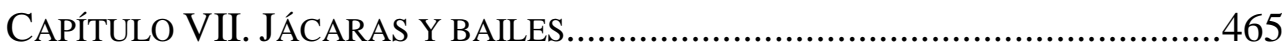

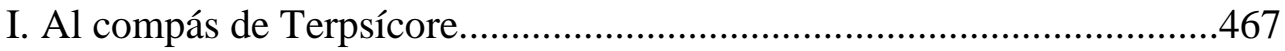

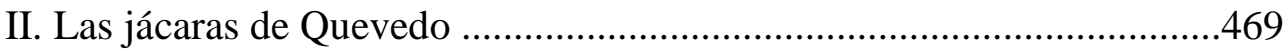

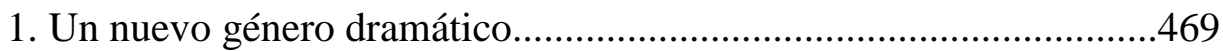

2. La edición de González Salas.........................................................472

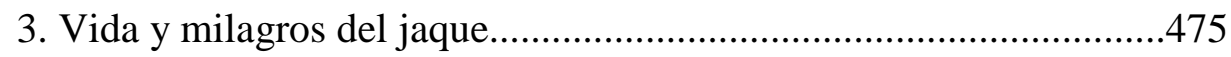


4. Martirio y estoicismo. Relación con la novela picaresca..............480

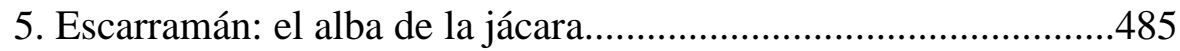

6. Pero Vázquez de Escamilla : la jácara en la comedia.................489

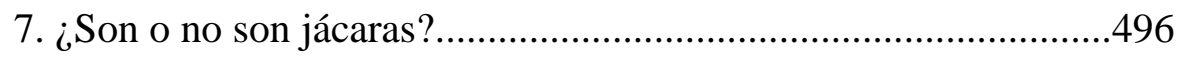

7.1. La toma de Valles ronces...................................................497

7.2. A los amores del rey Rodrigo y la Cava...........................499

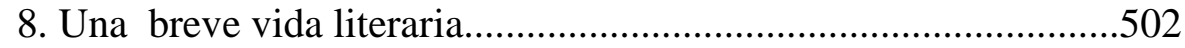

III. Los bailes de Quevedo ................................................................506

1. Un contexto intrincado.............................................................501

2. González Salas: orígenes y evolución del baile...........................509

3. Los bailes al final de los entremeses de Quevedo.......................511

4. Clases de baile en el Parnaso...................................................515

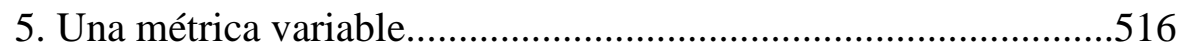

6. Los asuntos de los bailes............................................................519

6.1. Evolución temática. El modelo griego...............................519

6.2. La descripción del mundo hampesco.................................521

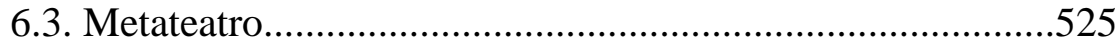

6.3.1. La sátira de las danzas antiguas..........................525

6.3.2. Instrumentos musicales, pasos y movimientos...526

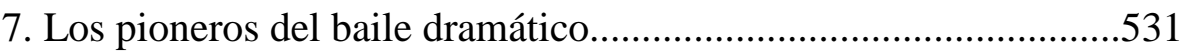

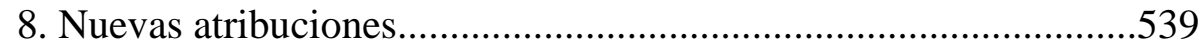

8.1. La Comedia de las dependencias de España......................540

8.2. "Picarilla, picarilla.............................................................543 


\section{CAPÍTUlo VIII. LA FUERZA VERBAL DE QUEVEDO. ELEMENTOS SEMIÓtICOS}

DE SU TEATRO BREVE. 551

I. El pirotécnico del lenguaje 553

1. Un juego literario 553

2. Agudeza e ingenio 555

II. La dicción encorsetada de la comedia quevedesca. 558

III. La libertad carnavalesca del teatro breve. 564

1. Escarceos lingüísticos de los entremeses.. .564

2. Tradición e innovación. .569

3. Diatribas germanescas en las jácaras y bailes. 572

IV. Dispositivos semióticos del teatro breve. 576

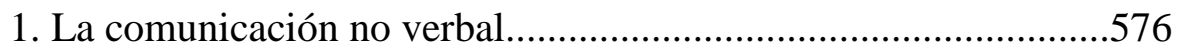

2. La música, la coreografía y los bailes. 577

3. El vestuario .581

4. Metateatralidad. .585

5. El espacio teatral. 587

CAPÍTULO IX. HACIA UNA FILOSOFÍA DEL TEATRO. .591

I. Quevedo y los géneros 593

1. Una inmensa escritura. 593

2. Qué es lo dramático .594

3. La teatralidad de la prosa satírica de Quevedo. .597

II. Quevedo, crítico teatral. 601

1. El flagelo de los dramaturgos memos 601

2. Sátiras de los poetas chirles y hebenes. .602 


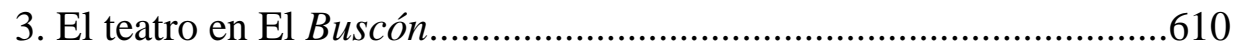

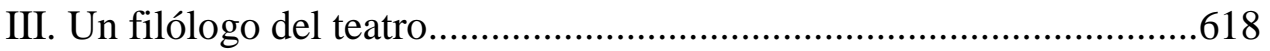

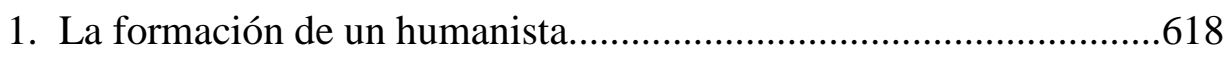

2. La biblioteca de Quevedo...............................................................62

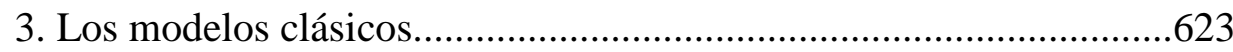

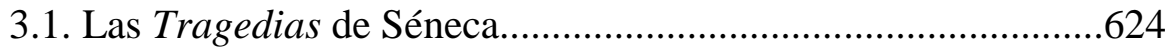

3.2. Las Comedias de Plauto.......................................................627

3.3. Notas al Eunuco, de Terencio.................................................632

3.4. Anotaciones a la Retórica de Aristóteles.................................635

IV. Homme du dieu: el teatro del orden...............................................645

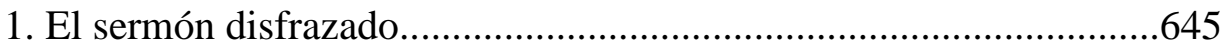

2. Ejemplos morales del teatro grave...............................................646

V. Homme du diable: el teatro del desorden............................................653

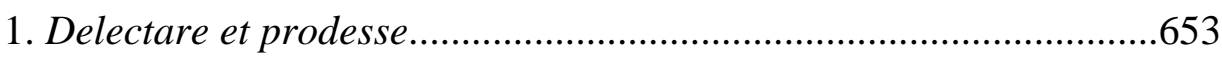

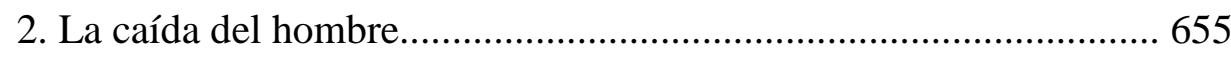

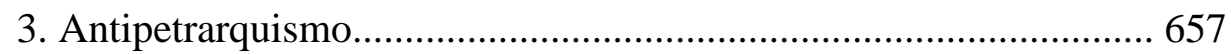

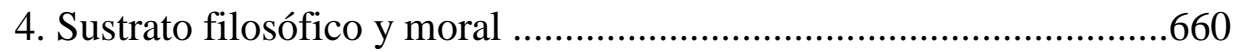

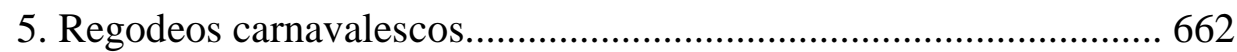

VI. Teatro del mundo, teatro de la conciencia...........................................668

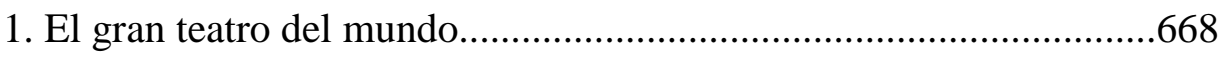

2. El gran teatro de la conciencia.....................................................673

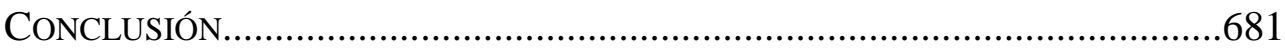

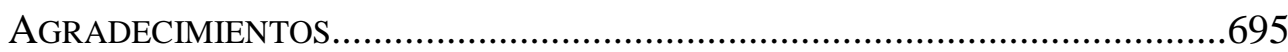


I. Ediciones modernas del teatro de Quevedo.........................................699

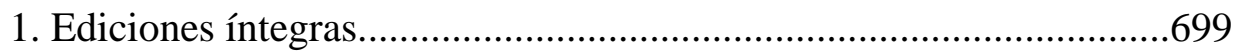

2. Publicaciones en revistas, estudios y antologías............................... 700

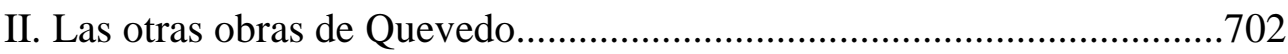

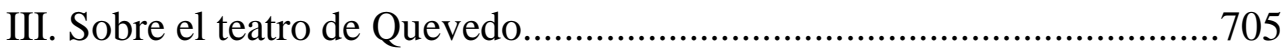

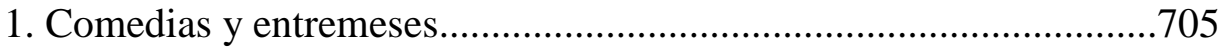

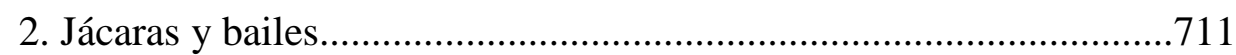

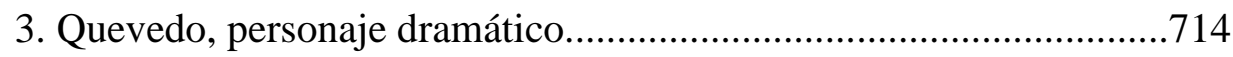

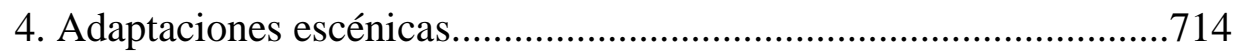

IV. Sobre Quevedo, lo que no es teatro..................................................715

V. Teatro y dramaturgos del Siglo de Oro................................................725

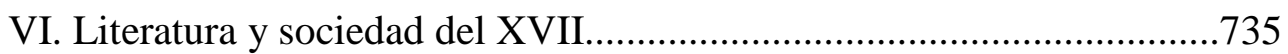

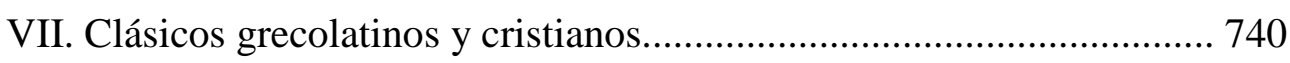

VIII. Literatura medieval y del Renacimiento......................................... 742

IX. Teoría y metodología literaria............................................................ 745

X. Catálogos y repertorios bibliográficos...............................................747

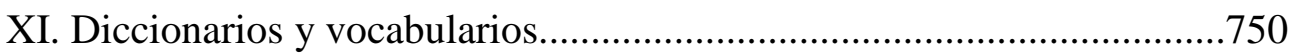


A mi madre, María Fernández Martínez,

que se doctoró en abuela. 


\section{REPERTORIO DE CITAS ABREVIADAS}

ACA: $\quad$ Archivos de la Corona de Aragón (Barcelona)

BC: $\quad$ Biblioteca Colombina (Sevilla)

BHSA: Biblioteca de la Hispanic Society of America (Nueva York)

BMP: $\quad$ Biblioteca Menéndez Pelayo (Santander)

BNC: $\quad$ Biblioteca Nacional de Catalunya (Barcelona)

BNE: $\quad$ Biblioteca Nacional Española (Madrid)

BPR: $\quad$ Biblioteca del Palacio Real (Madrid)

BRAH: Biblioteca de la Real Academia de la Historia (Madrid)

IT: $\quad$ Institut del Teatre (Barcelona)

POC: $\quad$ Quevedo, F. Poesía Original Completa. Edición y notas de J.M. Blecua. Barcelona: Planeta, 1983. 


\section{INTRODUCCIÓN}

¿Teatro del mundo? Más bien, teatro de la conciencia. ¿Cómo no advertir que todas esas máscaras y disfraces ocultan o revelan, según el caso, al mismo Quevedo?

OCtavio PaZ, Reflejos: réplicas (Diálogos con Francisco de Quevedo). Madrid: Ediciones La Palma, 1996, p.12.

\section{EL PORQUÉ DE ESTA TESIS}

Como reza el lema latino: Verba volant, scripta manent. Las palabras se las lleva el viento, pero la escritura permanece, porque es un soporte elemental de la memoria. Sólo podemos conversar con los difuntos a través de los documentos que han sobrevivido a los siglos. Por eso es nuestro deber rescatarlos, antes de que perezcan deshechos en el polvo, en motines de guerra o bibliotecas de Alejandría; entre arbitrarias censuras o inclementes plagas de gusanos de papel. Los filólogos -amantes de la palabra, traductores del tiempo y arqueólogos de la escritura- trabajamos para recomponer la historia de nuestra civilización con la voluntad de ser fieles a una hipotética realidad.

Es indispensable seleccionar y sintetizar el pasado para poder asimilar los datos más relevantes del presente y proyectarlos hacia el futuro. Pero, ¿qué criterios utilizaremos para hacer esa criba? ¿Cómo saber qué es lo realmente importante, lo que las generaciones venideras deberán recordar? 
¿Qué información merece la pena seleccionar y difundir? El canon literario está vivo, es mutable y proteico, tanto como la lengua en que se escriben las grandes obras de nuestra literatura. Existen documentos que han dormido en el sueño de los justos y que, de súbito, como el teatro breve barroco, son redescubiertos sin el reproche de su licitud moral, sin el visado de las honras patrias y la oficialidad solemne.

La presente tesis doctoral pretende reformular la historia de un autor consagrado, don Francisco de Quevedo y Villegas, a partir del análisis exhaustivo y multidisciplinar de su faceta teatral, quizás la menos conocida de nuestro polígrafo. Este estudio se basa en los testimonios documentales ya consignados y en otros inéditos atribuidos, que serán presentados en un apéndice. Una vez esclarecida una nómina y datación de la obra dramática de Quevedo, nos adentraremos en su relación biográfica con las tablas y los dramaturgos de su época, el análisis literario de las piezas catalogadas, los rasgos fundamentales de su lenguaje, las particularidades de su concepción del género, la descripción de sus lecturas dramáticas y la armonización del mentado corpus con su concepción teleológica de la literatura.

\section{METODOLOGÍA}

¿Cómo se hace una tesis? Empiezo citando a Umberto Eco y a su método infalible, la fórmula mágica para escribir una tesis doctoral:

Lo importante es hacer las cosas con gusto. (...) la tesis puede vivirse como un juego, como una apuesta, como una búsqueda del tesoro. 
Hay una satisfacción deportiva en dar caza a un texto que no se encuentra; hay una satisfacción enigmática en encontrar, tras muchas reflexiones, la solución a un problema que parecía insoluble.

Tenéis que vivir la tesis como un desafío. El desafiante sois vosotros: os habéis planteado al principio una pregunta a la que todavía no sabíais responder. Se trata de buscar la solución en un número finito de movimientos. Otras veces la tesis puede vivirse como una partida mano a mano: vuestro autor no quiere confiaros su secreto, entonces vosotros tenéis que rodearlo, interrogarlo con delicadeza y hacerle decir lo que no quería decir pero hubiera debido decir. En ocasiones, la tesis es un solitario: tenéis todos los peones y se trata de ponerlos en su sitio. [1989: 255-256]

Una vez confiado este secreto a voces, el sentimiento íntimo de aventura -de Indiana Jones de los libros-, de desafío intelectual y de juego detectivesco que tiene todo investigador novel tras embarcarse en el trayecto hacia esa tierra prometida que llaman doctorado, nos acordamos, a propósito del método, de ese viejo debate sobre si la investigación literaria es o no una ciencia exacta.

¿Existe un método científico para estudiar la literatura?¿Existe una Ciencia Literaria? Eso se pregunta, precisamente, Darío Villanueva [1991: 15] en su brillante introducción de El polen de ideas. Se inspira en la tradición crítica precedente y señala que, a su parecer, sí existe una Ciencia Literaria amparada en cuatro disciplinas que se retroalimentan: la teoría, la crítica, la historia y la literatura comparada.

Si nos avenimos al falsacionismo de Popper, en todo caso, es posible pretender un método objetivo de estudio. El conocimiento, dice este filósofo metacientífico, aumenta y se perfecciona a partir de las conjeturas erróneas 
precedentes (negative feed back). ${ }^{1}$ Esto quiere decir que el conocimiento surge del error enmendado y trascendido. En este sentido, el estudio literario puede ser una ciencia, pero ¿se trata de una ciencia exacta? Hay mucha imaginación en juego. (Galileo, mientras experimentaba, tampoco sabía $a$ ciencia cierta si estaba practicando una ciencia...)

A estas cuatro disciplinas, sin embargo, añadimos una premisa metodológica: la ecdótica o crítica textual. Una de las operaciones preliminares de toda investigación filológica es la compilación del material evaluable, la fijación del corpus literario y la valoración de la paternidad, autenticidad y datación de los textos que se quieren estudiar. A pesar de que solventar esta problemática inicial a menudo exige la inversión de una prodigiosa cantidad de perspicacia y esmero, esta ardua tarea es previa a la labor crítica propiamente dicha. Sin ella, el análisis filológico y la comprensión histórica de la obra de un autor pueden verse considerablemente limitados por generalidades confusas y lagunas de información.

La ecdótica es irrevocable cuando nos hallamos ante una tradición literaria semiborrada y de frágiles testimonios, como la del teatro aurisecular español, y se hace indispensable ante la obra dramática de un autor que, canonizado en la literatura universal por su poesía y prosa satírica y moral, apenas ha sido valorado como dramaturgo. ${ }^{2}$

1 Cfr. Popper, Objective Knowledge [1972: 67-75].

2 He utilizado, fundamentalmente, el Manual de crítica textual de José Manuel Blecua [1990]. 
Así pues, en primer lugar, nos vemos abocados a la recensio: la reunión y ordenación de los materiales disponibles, sean manuscritos o impresos. La mayoría de estudiosos hallamos esas fuentes en las bibliotecas, de ahí que sea relevante rastrear las más fructíferas e idóneas para el tipo de documentos que buscamos. Algunas nociones de biblioteconomía no están de más para moverse con familiaridad entre catálogos u otras obras de consulta que constituyen un importante bagaje.

En ocasiones, hechos meramente bibliográficos, como el número y volumen de ediciones, tienen aplicación y valores literarios: pueden ser representativos de los índices de censura, manipulación y fama de una obra o revelar si ésta fue particularmente revisada por su autor o si, por el contrario, fue fijada textualmente por copistas o editores poco escrupulosos. Esta bibliografía enumerativa ${ }^{3}$ es necesaria para resolver cuestiones de primer orden de la historia literaria.

Sin embargo, a veces los catálogos son insuficientes. Por ello, el investigador debe confeccionar y actualizar su propio inventario como tarea previa a la fijación del corpus. Esta labor es particularmente urgente en muchos fondos de reserva de las bibliotecas peninsulares. ${ }^{4}$

3 Cfr. R. Wellek y A. Warren [1966: 71]: "La bibliografía descriptiva, que hace uso de todas las artes de cotejar y estudiar la estructura propiamente dicha de un libro, debe distinguirse de la bibliografía enumerativa, o sea, la recopilación de catálogos bibliográficos, que proporcionan datos descriptivos que sólo bastan para identificar las obras."

4 Producto de esta necesidad emergente, han surgido iniciativas como la del grupo Edad de Oro adscrito a la BNE, que ha sistematizado su método de trabajo en su Manual de investigadores [2003]. 
Tras reunir y catalogar el material, es relevante realizar una edición, si el texto es inédito o no existe ninguna publicación filológicamente competente. No olvidemos que los manuscritos e impresos de nuevas obras atribuidas a Quevedo no figuran en ninguna edición moderna y que algunos de ellos tienen un valor literario intrínseco, fueren o no del autor que nos ocupa. ¿Cuántas obras dramáticas han dejado de estudiarse por estar bajo el anonimato y no poderse relacionar con la producción de un escritor específico?

La recensio bibliográfica permite fijar una nómina de obras sobre la que trabajar. Hemos de establecer qué piezas son de atribución segura y, por tanto, deben tratarse como de nuestro autor, y cuáles están por consignar y merecen una argumentación esclarecedora. Confío, asimismo, en que pronto este corpus podrá ser utilizado para realizar las concordancias pertinentes mediante los programas de software lingüístico que están emergiendo como útil herramienta filológica, sobre todo en lo que atañe a estos espinosos temas de atribución literaria. ${ }^{5}$

Una vez asentado el corpus literario mediante las pautas prescritas por la ecdótica o crítica textual y, tras la sucinta edición de los textos inéditos, hemos procedido con la interpretación, análisis y valoración literaria de la obra dramática de Quevedo. Para ello, hemos tenido en cuenta las cuatro disciplinas anteriormente mencionadas: la crítica literaria, que intenta hallar el rasgo que hace artístico el lenguaje desde una perspectiva sincrónica; la

5 He creído conveniente dejar esta labor de cotejo informático para más adelante, para cuando el nivel de sofisticación de estos programas sea algo más elevado. He utilizado, sin embargo, los Índices de la poesía de Quevedo de Azauste Galiana y Fernández Mosquera [1993], así como los rudimentarios buscadores de Word y Acrobat Reader. 
historia literaria, que analiza la literatura de manera diacrónica, como un hecho condicionado por la ideología imperante en una época, que se gesta e incide en la sociedad; la teoría literaria, que analiza la literatura como connotación y que indaga en aspectos semiológicos, y la literatura comparada, que confronta textos e investiga sus vínculos y diferencias.

¿Qué vicios hemos procurado evitar? En primer lugar, la datofagia que denunciaba Ortega y Gasset, la bulimia de información no asimilada: el ingrato género tesis doctoral puede asfixiar su frescura con la camisa de fuerza de la cita bibliográfica. Por otra parte, tampoco hemos querido caer en lo que Harry Levin denunciaba como pura logomaquia, la especulación gratuita que acaba perdiendo a los textos de vista. ${ }^{6}$

Hemos madurado nuestras hipótesis interpretativas a través de instrumentos o técnicas que agudizan la labor detectivesca del filólogo: el cuestionario, la lectura creadora, el comentario de textos y, claro está, el cotejo fluido y constante de nuestras certezas e intuiciones con la bibliografía descriptiva que hay disponible sobre el asunto que nos ocupa. Las pesquisas de los que nos precedieron son siempre los faros, brújulas y mapas de nuestro periplo intelectual. ¿Cómo avanzar sin tener presente el estado de la cuestión? Porque en este preciso instante hay miles de manos que teclean este trabajo, miles de manos tras las mías.

${ }^{6}$ Cfr. Darío Villanueva, El polen de ideas [1991: 16]. 


\section{ESTADO DE LA CUESTIÓN}

La mejor edición vigente de la obra dramática completa de Quevedo es la que reúne J. M. Blecua [1981], que con notable habilidad sintética, además de los catálogos de Fernández Guerra [1852] y de Barrera y Leirado [1860], se vale de los estudios de sus antecesores: M. Artigas [1927], editor de las comedias quevedescas del ms. 108 de la BMP (Biblioteca Menéndez Pelayo, de Santander); Astrana Marín [1932], responsable de las Obras completas en verso de la editorial Aguilar, y, ante todo, E. Asensio [1965], descubridor del célebre manuscrito de Évora (Cod. CXIV/1-3) y determinante punto de inflexión en el estudio del los entremeses en prosa de Quevedo. Es también relevante la aportación de Crosby [1967], centrada en el estudio de manuscritos por entonces de su propiedad -Los refranes del viejo celoso y el Hospital de los malcasados- los cuales ya edita Astrana Marín en 1932. Desde 1981, estos pertenecen a la BHSA (Nueva York).

La edición de Blecua, sin embargo, carece de un aparato crítico completo y de notas semánticas y contextuales que faciliten la comprensión del texto al lector. Dicha empresa la hemos visto emerger en la edición de Gentilli [2004] de la comedia Cómo ha de ser el privado, y en la publicación de algunos entremeses sueltos de Quevedo a título de artículo de revista o de antología de teatro breve del barroco. Tal ha sido la labor de Bergman [1970], Huerta Calvo [1985], García Valdés [1985; 1997; 2001], Buezo [1992; 2005] y Arellano [1997; 2001]. En el primer número de la revista Perinola, de hecho, I. Arellano y C. C. García Valdés [2001: 41] aseguraban que el GRISO (Grupo de Investigación Siglo de Oro, de la 
Universidad de Navarra) se hallaba "en el camino hacia una edición crítica y anotada del teatro completo de Quevedo". No obstante, a pesar de los importantes trabajos realizados por el mentado grupo en esta dirección, todavía [2009] no ha aparecido dicha publicación.

En todo caso, para una edición rigurosa, el investigador ha de clarificar de antemano qué obras son efectivamente de Quevedo y cuáles de atribución dudosa. Así procede G. Vega García-Luengos [1993] con La privanza desleal. El proceso de compilación y análisis manuscrito e impreso de la obra dramática de Quevedo es imprescindible para desvelar su autoría y efectuar una edición filológica de la misma. Es necesario seguir el procedimiento de Asensio y perderse en fondos antiguos de bibliotecas a medio catalogar para completar la publicación del legado dramático de Quevedo.

\section{ORGANIZACIÓN Y DESARROLLO}

La presente tesis doctoral está concebida en dos volúmenes. El primero, titulado El teatro de Quevedo, contiene propiamente el estudio teórico de la materia que nos ocupa. El segundo es un apéndice que incluye la trascripción modernizada del Teatro inédito atribuido a Quevedo. 


\section{EL TEATRO DE QUEVEDO (VOLUMEN I)}

La organización en capítulos de El teatro de Quevedo está muy relacionada con los enfoques metodológicos que hemos especificado con anterioridad.

El capítulo I -EL TEATRO DE QUEVEDo Y SUS TESTIMONIOS DOCUMENTALES- pretende, desde la ecdótica, la búsqueda de todos los testimonios manuscritos e impresos de la obra dramática de Quevedo y la elaboración de un catálogo bibliográfico completo, que permita establecer una nómina y cronología del corpus dramático que cimentará nuestra investigación. Es el primum mobile de la tesis doctoral.

Los capítulos II y III delimitan el marco sociopolítico, el contexto cultural y la relación de don Francisco con otros escritores que admiró o vapuleó del entorno teatral coetáneo.

En el capítulo II -QUEVEDO Y EL TEATRO CORTESANO-, ubicamos a nuestro autor, que retratamos inicialmente a brochazos, en un contexto urbano y palaciego, que alterna la chispa de la conversación de las ventas y tabernas con la suntuosidad y protocolo del entorno cortesano. Bajo el ribete de tres reinados distintos, profundizamos en las circunstancias teatrales que vivió nuestro autor: sus primeros años de formación con los jesuitas y sus primeros contactos con el mundo farandulesco bajo el reinado de Felipe II (1580-1598); sus más tempranos pinitos literarios, la inmersión en el humanismo italiano y su servidumbre al Duque de Osuna durante la monarquía de Felipe III (1598-1621); y su apogeo dramático ya en tiempos 
de Felipe IV (1621-1645), que terminará con el sabor agridulce del desengaño estoico.

En el capítulo III- ENTRE COMEDIAS Y DRAMATURGOS-, analizamos más detenidamente los pormenores de la colaboración teatral de Quevedo en palacio durante el reinado de Felipe IV y su participación en la escritura de algunas comedias por encargo cortesano, confeccionadas con otros ingenios como Antonio Hurtado de Mendoza y Mateo Montero. A partir de los documentos conservados, describimos su relación con otros escritores de su tiempo abocados al teatro: los que admira (Jorge Ferreira de Vasconcelos, por su Comedia Eufrosina, y el fecundo Lope de Vega) y los que critica con dureza (Pacheco de Narváez, Pérez de Montalbán, Jáuregui o Ruiz de Alarcón). Afrontamos su relación con Góngora sin los estigmas que ha conferido la crítica moderna, mediante un objetivo análisis de documentos que testifiquen esa hipotética enemistad literaria. Aludimos, por último, a la impronta literaria de Quevedo en el teatro aurisecular, mucho más determinante de lo que se podría conjeturar a simple vista.

Los capítulos IV-VII proceden con un análisis temático y lingüístico del corpus dramático de Quevedo propiamente dicho.

El capítulo IV - EL QUEVEDO COMEDIÓGRAFO- se centra, en primer lugar, en las comedias de privanza, que se relacionan con el ideario gubernativo de don Francisco. Las comparamos con los opúsculos políticomorales de nuestro autor, como la Política de Dios y gobierno de Cristo, el Discurso de Privanzas o la Vida de Marco Bruto. De este cotejo inferimos la concepción que tenía del valimiento. Acto seguido, estudiamos por separado la única comedia quevediana completa de atribución segura, Cómo 
ha de ser el privado, las comedias perdidas (las de 1625 y 1631) e incompletas (del ms. 108 de la BMP de Santander: Pero Vázquez de Escamilla y Fragmento) y dos comedias inéditas atribuidas a Quevedo en los catálogos (La privanza desleal y voluntad por la fama, una comedia palatina de enredo, y El galán fantasma, diferente a la homónima calderoniana, que hemos localizado en el IT de Barcelona.)

El capítulo V - LOS ENTREMESES DE QUEVEDO-, uno de los más extensos de nuestro trabajo, enumera, previamente, las características de este subgénero teatral y los criterios de clasificación que hemos establecido para los entremeses de don Francisco. Analizamos, en primera instancia, aquellas piezas fundamentadas en la avaricia femenina (el Niño y Peralvillo de Madrid, La polilla de Madrid, La destreza, La ropavejera, La vieja Muñatones y El caballero de la Tenaza, tal vez apócrifo). Desplegamos pormenorizadamente, a continuación, aquellos entremeses que desarrollan o contienen una crítica al matrimonio (Doña Bárbara, Diego Moreno, El marión, El marido pantasma y los falsos autógrafos: El hospital de los malcasados y Los refranes del viejo celoso). Después reflexionamos sobre el entremés de figuras, como La venta o El zurdo alanceador. Indagamos, por último, en dos entremeses atribuidos a un tal Miguel Mussa o Mulsa (el Entremesico famoso de las verdades del zonzo y el Entremesico del Hurto del nene): ¿se trata del mismo Quevedo enmascarado tras un pseudónimo de juventud?

El capítulo VI -Dos COMEDIAS BURLESCAS ATRIBUIDAS A QUEVEDOdefine sucintamente este subgénero teatral, a caballo entre el entremés y la comedia al uso, y establece pros y contras de la paternidad de dos piezas 
atribuidas a Quevedo en algunos estudios y catálogos: El premio de la hermosura y iQué villano es el amor!

El capítulo VII -JÁCARAS Y BAILES- describe las particularidades de estas dos modalidades del teatro breve, que González de Salas publicó bajo la musa Terpsícore del Parnaso (1648). Desentrañamos a un Quevedo pionero en el retrato de la vida y milagros de jaques de la talla de Escarramán. Nos cuestionamos los límites de estos subgéneros de contornos difusos, que ya se encuentran, en estado embrionario, en la novela picaresca. $\mathrm{Y}$, nos planteamos, a su vez, nuevas atribuciones, fundamentadas en la pista de los catálogos más recientes.

Los capítulos VIII y IX inscriben el teatro de Quevedo dentro del marco global de su inmensa escritura.

El capítulo VIII - LA FUERZA Verbal DE QUEVEdo. Elementos SEMIÓticos DE SU TEATRO BREVE- concibe a don Francisco como un pirotécnico del lenguaje, un genio literario que experimenta verbalmente y juega con la agudeza y el ingenio. Veremos, sin embargo, cómo la dicción de sus comedias está condicionada por la premura y tirantez del encargo palatino. Estas limitaciones desaparecen cuando nos centramos en su teatro breve, dotado de la frescura y libertad carnavalesca, que ha aprendido a expresarse en lengua de germanía. Haremos referencia, por último, a los dispositivos semióticos de estas piezas dramáticas burlescas, a aspectos no verbales del teatro como la gestualidad, la escenografía, la música y la danza.

El capítulo IX -HACIA UNA FILOSOFÍA DEL TEATRO- es una reflexión sobre la concepción quevedesca del teatro como género literario. ¿Qué es lo 
dramático para nuestro autor? Por un lado, confecciona una Antipoética contra los dramaturgos memos de su tiempo, diseminada con sarcasmo a lo largo de su obra festiva y que, por otro, Quevedo, como todo humanista, estudió el teatro clásico grecolatino e hizo sus anotaciones pertinentes, documentos que se conservan en la actualidad.

Según veremos, don Francisco, homme du dieu, homme du diable, a lo largo de su obra dramática, no ha hecho sino personificar el vicio y la virtud, figuras que escenifican el gran teatro de la conciencia.

\section{APÉNDICE. TEATRO INÉDITO ATRIBUIDO A QUEVEDO (VOLUMEN II)}

Los textos teatrales que aparecen editados en el apéndice son composiciones actualmente inéditas que sólo pueden leerse en sus testimonios originales. Nos referimos a esas obras cuya paternidad quevedesca está todavía por consignar: la comedia de valimiento $L a$ privanza desleal y voluntad por la fama, la comedia de enredo El galán fantasma, la comedia burlesca ;Qué villano es el amor!, los dos entremeses atribuidos a Miguel Mulsa (el Hurto del Nene y Las verdades del Zonzo), la "jácara" A los amores del rey Rodrigo y la Cava y los bailes "Picarilla, picarilla..." y la Comedia de las dependencias de España.

He optado por hacer una trascripción modernizada de los textos. Las comedias al uso están precedidas por un registro del testimonio fuente utilizado, un resumen del argumento y un esquema métrico. Las piezas de teatro breve carecen de la síntesis de la trama y, en el caso de las jácaras y 
los bailes, su edición sólo va encabezada por la signatura del manuscrito base.

Disponemos todo el material de estudio al alcance de la comunidad científica para que, más allá de esta tesis doctoral, pueda proseguirse con el estudio de la faceta bambalinesca de un autor universal e inagotable.

\section{OTRAS ACLARACIONES}

Los estudios literarios son cada vez menos individualistas y exigen el trabajo conjunto de diferentes expertos con tal de lograr mejores resultados. Celebramos que así esté ocurriendo actualmente. Hay diversos focos de investigación que trabajan al unísono la obra de don Francisco de Quevedo: Alfonso Rey coordina la edición de sus Obras completas (Madrid: Castalia); asimismo, el GRISO, posibilita publicaciones periódicas sobre don Francisco en La Perinola.

Abogamos por un estudio de la literatura cada vez más abocado al objetivo genuino de la filología: la recuperación, memoria, estudio y desarrollo del patrimonio cultural que atesoramos.

José Manuel Blecua decía en el prólogo de su edición de la Poesía Original Completa de Quevedo que el sueño de todo erudito es que su labor sea continuada, corregida y mejorada por futuros investigadores: que se entable un diálogo en el tiempo. Soy consciente de las taras posibles de este trabajo, la primera expedición filológica que emprendo. Por ello, retomo las palabras del maestro y pido al futuro investigador que enmiende mis errores. 
Porque lo importante es hacerle justicia al artista, al creador, al autor de la obra: él es el verdadero protagonista de este trabajo.

A juzgar por la bibliografía, esta tesis se ha erigido sobre los cimientos de muchos años de investigación precedente, del esfuerzo de aquellos que consagraron su tiempo a la reconstrucción de la vida y la obra de un genio. Y así seguirá sucediendo, hasta que Quevedo recupere la gloria total que le corresponde. 


\section{Capítulo I}

EL TEATRO DE QUEVEDO Y SUS TESTIMONIOS DOCUMENTALES 
-34 - 


\section{UNA PREMISA METODOLÓGICA}

\section{SCRIPTA VOLANT...}

La historia de un autor consagrado puede ser rescrita. Porque los documentos literarios que han logrado sobrevivir a los estragos del tiempo no permanecen estáticos. Circulan entre subastas, librerías de viejo, herencias familiares y bibliotecas privadas y públicas. Muchos desaparecen del anonimato al ser convenientemente catalogados. A otros, los deterioran el azar y la ignorancia. ${ }^{2}$

Las implicaciones filológicas de estos cambios de domicilio son alarmantes. El investigador tiene la responsabilidad intelectual de revisar los trabajos anteriores, consultar catálogos actualizados y buscar entre los fondos nuevos de las bibliotecas. Si procede de esta manera, puede encontrarse ante nuevas obras atribuidas y, si la Fortuna (esa diosa arbitraria de ojos vendados) está de su parte, el hallazgo de inéditos.

\footnotetext{
${ }^{1}$ Reformulación del lema latino: Verba volant, scripta manent.

2 ¿Cuántas Bibliotecas de Alejandría siguen ardiendo en los motines de guerra o en los banquetes silenciosos de los gusanos de papel? En el conflicto bélico de Irak perdimos las tablillas cuneiformes del Poema de Gilgamesh. Los manuscritos aljamiados de Tombuctú precisan de un rescate a tiempo (se construyó una biblioteca en 2003 que fue incendiada e inundada varias veces). El fondo manuscrito de reserva de la Biblioteca de la UB está catalogado por un solo hombre y precisa de una fumigación general. El manuscrito del Mío Cid fue encontrado en un pajar. ¿Acaso no nos sorprende la precariedad de la literatura?
} 
Ésta ha sido la premisa de la presente investigación: el amor hacia la palabra como objeto. Y ha permitido, de momento, la localización de dos nuevas cartas autógrafas de Quevedo ${ }^{3}$ y, como más adelante se verá, la ubicación de teatro inédito atribuido.

Los testimonios teatrales de Quevedo que se conservan actualmente apenas constituyen la punta del iceberg. No obstante, son pocos si se comparan con el resto de su producción literaria. Él era un humanista con mayúsculas, y abarcó todos los moldes posibles de composición. Los genios literarios son los que entierran géneros para reinventarlos.

¿Cómo estudiar la obra de un autor sin antes delimitar un corpus? ¿Cómo anteponer el análisis a la previa investigación bibliográfica y a la recensio de todos los documentos disponibles? La Crítica Textual sólo puede ocuparse de las tradiciones orales cuando éstas quedan asentadas en forma de texto. Esta disciplina plurisecular ha ideado un método que pretende eliminar en lo posible el trato subjetivo de los documentos, con tal de evitar catástrofes exegéticas irremediables. ${ }^{4}$

En el siglo XIX se establece un ars critica conocida como "método de Lachman" que, si bien, a raíz de un polémico artículo de Bédier ${ }^{5}$, fue

${ }^{3}$ Cfr. María Hernández, "Carta inédita autógrafa de Francisco de Quevedo"; Revista de Erudición y crítica, 2 (febrero de 2007); "Un texto autógrafo inédito de Francisco de Quevedo", Revista de Erudición y crítica, 3 (junio-septiembre de 2007).

${ }^{4}$ Estas catástrofes exegéticas afectan sobre todo a los libros sagrados, el Antiguo y el Nuevo Testamento todavía no disponen de una edición crítica.

5 Véase J. Bédier, "La tradition manuscrite du Lai de l'ombre. Réflexions sur l'art d'éditer les anciens textes", Romania, 54 (1928), pp. 161-196, 321-356 [reimpreso en París, Champion, 1970]. 
aplicado con escepticismo a los textos en lengua romance, tras las contribuciones de Contini $^{6}$ y sus discípulos, ha vuelto a ser el método generalizado en los estudios de filología románica.

El método neolachmaniano o translachmaniano se retoma por primera vez en una edición de clásicos castellanos en 1964 con la publicación del Libro de Buen Amor por parte de Giorgio Chiarini. Y, en 1965, el primer filólogo español se estrena con una edición crítica de una obra de Quevedo: el Buscón de Lázaro Carreter. ${ }^{7}$

Por ello, nos hemos acogido a este marco metodológico, la Crítica Textual, como premisa del análisis y estudio de la obra dramática de Francisco de Quevedo. Es un procedimiento determinante a la hora de aportar material novedoso al tema que nos ocupa.

\section{LA FIJACIÓN TEXTUAL DEL TEATRO AURISECULAR}

Los documentos sobre los que trabajamos presentan un problema que condiciona el resultado de nuestros estudios y ediciones. La tarea de fijación textual del teatro áureo es, por lo general, compleja.

De las piezas dramáticas que escribió Quevedo, varias son conocidas desde hace mucho, otras las ha aportado la reciente erudición filológica.

${ }^{6}$ Cfr. G. Contini, Breviario di Ecdotica. Milán-Nápoles: Ricciardi, 1986.

7 Véase la "Advertencia preliminar" del Manual de crítica textual de Alberto Blecua [1990: 9-13]. 
Parte de los silencios críticos al respecto se deben a las dificultades de transmisión textual inherentes al género dramático aurisecular.

Vapuleadas por la Inquisición, anotadas por actores y coreógrafos y encaminadas a la representación de las compañías, las obras de teatro del siglo XVII nos han llegado en muy mal estado, porque su plasmación manuscrita o impresa era algo subsidiario en su época. Además, debido a su transmisión oral, recitada o cantada, los testimonios dramáticos presentan notables ausencias y alteraciones.

El original, autógrafo o no, solía venderse al autor de comedias. Éste, probablemente, lo encargaba bajo estrictas directrices argumentativas, condicionadas por una celebración o evento. El cliente se convertía en único propietario de la obra. En muchas ocasiones, incluso, el escritor había llegado a quedarse sin una copia de su creación. A menudo, esta creación se modificaba en pro de las exigencias semióticas de la representación. Y, frecuentemente, los autores de comedias, para mantener la exclusiva, se negaban a imprimirlas.

Las copias manuscritas desfilaban entre la farándula y, tras ser representadas, solían destruirse o eran mal refundidas por memorillas, espías literarios o pícaros poetastros que cobraban por ir a los teatros y memorizar pasajes u obras enteras. Estas piezas se convertían más tarde en pasto del plagio.

Las obras de teatro, en general, estaban adulteradas por modificaciones ingratas y rapiñas. ${ }^{8}$ Estas dificultades de transmisión textual no fueron

${ }^{8}$ Cfr. Germán Vega García- Luengos, "La transmisión del teatro en el siglo XVII", en Historia del teatro español (ed. Javier Huerta Calvo) [2003: 1289-1320]. 
ajenas a Quevedo: las literaturizó sagazmente en el Buscón (capítulo IX, libro III), concretamente en el pasaje en que Pablos se enrola en una compañía.

Las composiciones teatrales más afortunadas fueron las que publicaban los libreros, sueltas o en Partes de comedias. Pocos escritores las editaron en persona. Se forjaron laberintos de falsas atribuciones, lagunas y errores de versificación.

No debemos olvidar, a su vez, las controversias auriseculares sobre la licitud del teatro. ${ }^{9}$ Fue común el ataque de algunos moralistas, como Fray José de Jesús María que, en su Primera parte de las excelencias de la virtud de la castidad (1600), calificó al teatro de género lascivo e indecoroso. Este autor, además, tildó a los entremeses de "serpiente Anfisbena", el monstruo mitológico que tenía dos cabezas ponzoñosas, una en cada punta del cuerpo. ¿Tan pérfido podía resultar el teatro para la salvación de las almas? ¿Tan cercanas eran todas las representaciones seglares a la prostitución y el pecado?

La transmisión de muchos entremeses del Siglo de Oro ha sido gravemente afectada por la mutilación de los cómicos y el público de la época, que desgajaba las obras de los compendios para asistir a la función con el texto en la mano.

Alusiones metafóricas al entremés en clave denigrante denuncian el poco prestigio moral que gozaba este género breve en el siglo XVII. Fray Diego Niseno censuró, en un escrito del 1 de julio de 1629, el Discurso de todos los diablos (Girona, 1628) de Quevedo, utilizando las siguientes

\footnotetext{
9 Véase el repertorio compilado por E. Cotarelo y Mori [1904].
} 
expresiones: "relaciones entremesadas", "entremés ridículo", "fábula entremesada" y "hechos entremés sus pecados". ${ }^{10}$

Las consideraciones puristas acerca del teatro incrementaron los escrutinios católicos. Fruto de las polémicas moralistas, menguó el propósito de conservación de este legado. Los predicadores no cesaron de lanzar improperios contra los teatros. De este modo, consiguieron cerrarlos en varias ocasiones $\mathrm{y}$, desde el púlpito, incitaron a los beatos a la destrucción de las comedias.

Los jesuitas, por otra parte, pretendieron suplantar el espectáculo literario de los corrales por obras dramáticas de enrevesado mensaje moral que se representaban en sus colegios. ${ }^{11}$

Múltiples vicisitudes, en definitiva, obstaculizaron la expansión del género dramático aurisecular en su vertiente escrita. Esta carencia puede explicar, de entrada, los notables silencios críticos a propósito del teatro de Quevedo.

\section{LOS MANUSCRITOS E IMPRESOS TEATRALES DE QUEVEDO}

Además de las causas generales inherentes al teatro áureo, hay otros motivos específicos de nuestro autor que se suman a las mentadas dificultades de transmisión textual de su obra dramática. ${ }^{12}$

\footnotetext{
${ }^{10}$ Véase Krzysztof Sliwa [2005: 435-438].

${ }^{11}$ Cfr. Armando Cotarelo [1945:51].
} 
El estudio y sistematización del corpus literario de Quevedo que queremos analizar tiene muchos entresijos. ${ }^{13}$ El filólogo habrá de enfrentarse con autógrafos inexistentes, atribuciones dudosas, versiones dispares, "inéditos en colección" y hallazgos inauditos como el de Eugenio Asensio, que en 1965 publicaba entremeses inéditos de Quevedo, compilados en un manuscrito de la Biblioteca Pública de Évora. ${ }^{14}$

Nos encontramos en un terreno abrupto, lleno de silencios e inseguridades, porque el acerbo de los testimoni critici solventes -autógrafos o ediciones de autor- es prácticamente nulo y la celebridad de nuestro escritor estimula la adscripción de obras espurias. ${ }^{15}$

Los versos de Quevedo circularon manuscritos en vida. Eran recitados de memoria en corrillos y tertulias. Sólo cuatro de sus entremeses fueron publicados póstumamente en su siglo y con escaso rigor por Pedro Alderete (1670) en Las tres musas últimas castellanas: El Niño y Peralvillo de Madrid, La Ropavejera, El Marido Pantasma y La Venta.

Quevedo, si bien editó la poesía de Fray Luis de León, Francisco de Torre y proyectó, incluso, la de Francisco Aldana, ${ }^{16}$ tan sólo publicó en vida algunas composiciones poéticas de juventud que figuran en las Flores de

12 "Podría escribirse un precioso volumen de introducción a la crítica textual sólo con los problemas que la transmisión de la obra quevedesca plantea a cualquier editor de hoy." Blecua, Obra poética [ 1999, I : XI].

${ }^{13}$ Cfr. José Manuel Blecua [1981: 9].

${ }^{14}$ Cfr. Eugenio Asensio [1965].

15 Germán Vega [1993: 109].

${ }^{16}$ Cfr. Quevedo, Obras completas en prosa [2003: Vol. I, Tomo I: 124-182]. 
poetas ilustres de Pedro Espinosa, cuya dedicatoria está fechada el 20 de septiembre de 1603.

El resto de su poesía fue objeto de numerosas correcciones del autor, una labor de lima que no siempre pudieron abarcar González de Salas y Pedro Alderete en sus ediciones. ${ }^{17}$ Por ello, el editor actual debe hacer frente a un gran número de lectiones diferentes y contar con que las versiones impresas no tienen por qué coincidir con las variantes que dio el escritor por últimas y definitivas.

Muchos de los entremeses de Quevedo se han extraviado. Lo sabemos porque nos han llegado documentos que corroboran su fama y que aluden a textos que no se han recuperado. El tribunal de la justa venganza dice, por ejemplo, de Quevedo, que "lo más agudo que ha producido su ingenio [es] el friísimo cuanto bien silbado entremés Cara aquí me iré y otros semejantes a éste" [1943: 1102]. ¿Alguien sabe dónde se ubica esta obrilla?

La Inquisición vedó las obras impresas de Quevedo anteriores a 1631. Así aparece en el Novum librorum prohibitorum et expurgatorum index (Madrid, 1632). También hemos localizado, al respecto, la carta perpleja del jesuita P. Andrés Mendo. Éste se pregunta si podrá conservar el entremés de El zurdo alanceador:

En el expurgatorio tratando de Quevedo, dice que todas sus obras que se intitulan y dicen ser suyas se prohíben. El papelillo, que Vm. me envió se dice ser suyo, y ha corrido por tal; Vm. se informe de algún padre docto de los que ayudaron al padre Pineda, si el dicho papel esta prohibido ex vi, de aquellas palabras, ítem si lo está un entremés del mismo autor que se intitula El zurdo alanceador, y la razón de dudar es

${ }^{17}$ Cfr. José Manuel Blecua [1999: I, XXX]. 
porque parece que lo que quisieron quitarle fueron los sueños, discursos y política y no estas menudeces. ${ }^{18}$

Tras la muerte del autor, no cesó esta presión prohibitiva. En una carta para el monarca de Fr. Juan Ponce de León (Madrid, 25 de octubre de 1646), escrita con motivo de la persecución del Buscón, hallamos la reducida nómina de libros quevedescos admitidos:

Pues en la dicha nota de las obras de don Francisco de Quevedo dice vuestra Alteza que sus libros se le permitan los que el autor confiesa ser suyos, como son la Vida de Santo Tomás de Villanueva, La defensa del Patronato de Santiago, Los juguetes de la niñez, La cuna y la sepultura, la Traducción de Epicteto, la Traducción del Rómulo, la Traducción de la vida de San Francisco de Sales, El conocimiento propio, Consolación de Séneca y Galión. Y concluyendo Vuestra Alteza con estos libros como corrientes añade luego esta cláusula: todos los demás libros y tratados impresos y manuscritos que corren con el nombre de dicho autor se prohíben [...] [Krzysztof Sliwa, 2005: 790].

Ni una sola obra de teatro. Las piezas dramáticas de Quevedo, según esta misiva, son hijos bastardos de su producción literaria.

${ }^{18}$ Cfr. Asensio [1965:178]. La carta se cita "ilegible" en Krzysztof Sliwa [2005: 610]. En abril de 2007 procuré acceder a este texto, que se encuentra ubicado en el ms. 9-3687 [Colección de Jesuitas, tomo 114] de la Biblioteca de la RAH (Madrid). Si bien por el mal estado del ms. (que exige una rápida reencuadernación) me impedían consultarlo, el amable personal de la biblioteca me permitió transcribir bajo supervisión el f. 309v que reproduzco ortografiado, la postdata en la carta del P. Andrés Mendo hablando del entremés de $E l$ zurdo alanceador (20 de noviembre de 1632). 
El impreso R/4418 de la BNE es, asimismo, un ejemplar del Parnaso expurgado, cuyas crueles tachaduras - que provocaron la indignación de Gallardo, incapaz de reprimirse en sus anotaciones al impreso- están documentadas en el Novissimvs librorum prohibitorum et expurgandorum index pro Catholicis Hispaniarum Reguis, Philippi V. Reg. Cath. Ann. 1707. Abunda el escrutinio de versos de jácaras y bailes:

Pág. 342, Xacara 1 [849, III, p. 264, vv. 65-68], bórrese desde Monseñor hasta por su potestad. $=$ Págin. 343, Xacara 2 [850, III, p. 276, vv. 23-24], bórrese desde En el dar ciento hasta à Dios serà. = Pág. 345 [850, III, p. 280, vv. 137-148], bórrese desde Esta Quaresma hasta el primero Satanàs. = Págin. 347, Xacara 3 [851, III, p. 283, vv. 85-86], bórrese desde Con su poquito hasta sin desmayo. = Págin. 348, Xacara 4 [ 852, III, pp. 285-6, vv. 62, 77 y 91] , bórrese Con barba Sacerdotal, y después Es Canonigo de pala, y después Peca con mucha cordura= Pág. 349 [853, III, p. 288, v. 24], bórrese Mas habladores que Monjas. = Pág. 352, Xacara 6 [854, III, p. 293, v. 75], bórrese A manera de Rosarios. = Págin. 358, Xacara 8 [856, III, p. 307, vv. 129-132 y 139-140], bórrese desde Despues que el Padre hasta Catalàn; y después bórrese desde Que aun con Dios hasta querrà estar. = Pág. 394, Bayle 8 [872, III, p. 392, vv. 111-112], bórrese desde Son, si lo apuras hasta de Curas. = Págin. 396, Bayle 10 [874, III, p. 407, vv. 5-6], bórrese desde Va con passos hasta amantes. $^{19}$

Hubo, además, revuelo de los papeles de Quevedo durante los trances de su prisión y su muerte. Al morir don Francisco en 1645, Pedro Coello, editor y amigo del escritor, quiso imprimir sus inéditos, que paraban en manos de su heredero, don Pedro Aldrete y Villegas. Éste, asesorado por un

\footnotetext{
${ }^{19}$ Esta trascripción con el apunte de los versos exactos de los poemas expurgados figura en el Apéndice III de la edición de Blecua [1999: III, 522-523].
} 
agente llamado Juan de Molina, tanteó las sumas que le ofrecían diversos editores y finalmente aceptó los 700 reales de plata con que le obsequiaba el impresor, según figura en el contrato. Sin embargo, estas obras poéticas, tituladas las Nueve Musas, ya no estaban completas:

bien visto le fuere para rrecoger los quadernos que assí 1 bendo (que se entiende faltan), para que no salga su ynpression diminuta, y tenga el lustre que se pretende con esta diligencia. ${ }^{20}$

La cláusula concuerda con lo que Coello escribe en la dedicatoria que dirige a Pedro Pacheco Girón, en la Enseñanza entretenida y donairosa moralidad (1648), donde de nuevo lamenta la pérdida de gran parte de la obra literaria de Quevedo:

Murió en Villanueva de los Infantes; y de papeles muchos originales de sus escritos, que siempre traía consigo, se echaron entonces menos gran suma. De manera que de sus poesías, lo que yo pude alcançar, con todo género de negociación, no fue de veinte partes, una, según aseguraron los mismos que en aquella ocasión las vieron $[\ldots]^{21}$

Coincidirán González Salas ${ }^{22}$ e, incluso, Tarsia, el primer biógrafo de nuestro autor, en condolerse por este naufragio de papeles.

\footnotetext{
${ }^{20}$ Cfr. Crosby [1967: 240].

${ }^{21}$ Cfr. Blecua [1999: I, XIII].

22 González Salas en las Ilustraciones al "Parnaso" [ed. Blecua, 1999: I, 91] advierte lo siguiente: "Fácil le tuvo, ígneo y arrebatado, y por esa ocasión no pocas veces se resistió a la emendación y a la lima, remitiendo este estudio a otra sazón y a mejor ocio. Continuo fue
} 
Pero no terminan aquí las dificultades. El investigador puede hallar una obra a nombre de Quevedo y no por ello deberá olvidar que hubo escritores de segunda y libreros que abusaron de su popularidad para incrementar el número de ventas o el prestigio de obras ajenas. Para obtener una ligera idea de lo que ello supone, baste con ojear las diversas entradas consignadas al nombre de nuestro autor en el Diccionario de seudónimos literarios españoles de P. P. Rogers y F. A. Lapuente:

Con el nombre del conocido escritor apareció la obra Casa de locos de amor de Antonio Ortiz Melgarejo [...]. Diego de Tovar y Vallderrama usó el nombre del insigne escritor para firmar El entremetido don Reimundo (aparentemente la codicia de los libreros ante el éxito de la obra de Quevedo ocasionó este seudónimo, que el gran autor tuvo que delatar). [...] A nombre del insigne escritor publicó Antonio Valladares y Sotomayor un Memorial contra el Conde-Duque en el Semanario Erudito [...] y también, usando el nombre del mismo Quevedo, publicó Antídoto contra las calumnias que la ignorancia y la envidia han esparcido para deslucir las ... acciones del Conde-Duque de Olivares [...] [1977:370-371].

por muchos años el ejecutarle yo por esta diligencia, prorrogándomela siempre, hasta que llegando antes el término de su vida que el cumplimiento, no sólo no se logró, sino las poesías mesmas, que muchas había ya repetido de poseedores extraños y juntándolas en volúmenes grandes, se derrotaron y distrujeron. Summo dolor causa el referirlo. No fue de veinte partes una la que se salvó de aquellos versos, que conocieron muchos, quedaron en su muerte; y yo traté y tuve numerosas veces en mis manos, por nuestra continua comunicación. Lástima y piedad, pues, a su ingenio bien debida, pudo moverme a la atención de restaurar, si pudiese algo, esta pérdida (aunque molesta ocupación) cuando faltara el superior apremio de mandármelo ansí quien en mis más difíciles acciones ha de hallar siempre blanda obediencia." 
Es, además, difícil adivinar el estilo de Quevedo en su obra dramática, a menudo compuesta bajo las premisas del encargo palatino (la censura, la manipulación propagandística, la premura de la redacción). Estas composiciones, subyugadas a la intencionalidad del poder político y representadas para un público aristócrata, eran escritas con frecuencia en colaboración con otros autores palaciegos, como Mateo Montero o Antonio Hurtado de Mendoza. ¿Cómo reconocer las palabras de un autor si éstas se entremezclan con las de otros escritores y están condicionadas por la aprobación y capricho de los poderosos?

Por todo lo expuesto, el primer paso indispensable para la cimentación de cualquier estudio sobre el teatro del Siglo de Oro - el de Quevedo, en nuestro caso- ha de ser la catalogación y localización de los testimonios manuscritos e impresos disponibles, en ocasiones ignorados y dispersos en bibliotecas de todo el mundo. $^{23}$

Entonces, el investigador calza las botas de arqueólogo aventurero, improvisa un ligero equipaje y carga con su inseparable cuaderno u ordenador portátil en busca de pequeños tesoros de la literatura. $\mathrm{O}$, alejado de los fútiles romanticismos de la juventud y achacado por las limitaciones de la vida adulta, contacta con el corresponsal conveniente o solicita por correo o vía telefónica una copia de los documentos microfilmados.

\footnotetext{
${ }^{23}$ Sigo, en cuestión, el criterio expuesto por Germán Vega, y que puede seguirse en dos breves vídeos, La ilocalización de los manuscritos teatrales y La falta de la catalogación de los originales, disponibles en la web: http://www.cervantesvirtual.com/FichaObra.html?portal=0\&Ref=11073\&video=1
} 


\section{4. ¿AUTÓGRAFOS DE ENTREMESES? EL DUCTUS DE UN POLÍGRAFO}

A raíz de una conversación con Pablo Jauralde Pou, averigüé que los pretendidos entremeses autógrafos publicados antaño por Crosby [1967] - El hospital de los malcasados y Los refranes del viejo celoso- habían sido vendidos por éste a la Biblioteca de la Hispanic Society of America, ubicada en Nueva York. Miguel Martínez, colega corresponsal de la Revista de Erudición y Crítica, me facilitó las signaturas de ambos. Julia Ibarz, amiga y viajera empedernida, me proporcionó las copias de los testimonios digitalizados. Cotejándolos con otros autógrafos del autor pude ver que la caligrafía no se correspondía en absoluto.

A pesar de que no se ha profundizado en los aspectos grafológicos de la literatura, es innegable que para reconocer un autógrafo, el ojo del investigador ha de estar "acostumbrado" a los rasgos de escritura del autor que estudia. Y que, para justificar si es o no suya la letra, ha de saber, como mínimo, describir sus rasgos distintivos.

El ductus de Quevedo es irregular y condensado, rígido e inarmónico. Son comunes los choques entre líneas, la ilegibilidad, el poco respeto de los márgenes, en especial el derecho. A veces es propenso a la confusión de las letras, al embrollo.

Su escritura es estrecha (con pocos espacios entre palabras, líneas y renglones). Más angulosa que redonda, está bastante verticalizada, ya que sólo se inclina muy ligeramente hacia la derecha. Se advierte la presión suave de su pluma (en muchas ocasiones la coloración de la tinta es poco oscura), los óvalos cerrados muy rellenos de trazos, el uso frecuente de 
espirales, especialmente en las mayúsculas y en las letras iniciales de comienzo, y muchos bucles. Los trazos finales son breves.

En ocasiones, Quevedo enlaza las preposiciones en, con o el adverbio tan con una palabra que empieza con $p$, y cambia la $n$ por $m$. No acentúa, no acostumbra a sangrar y utiliza profusamente mayúsculas en el interior de la frase. Es amigo de separar las palabras al final de línea.

En los textos algo extensos, apreciamos una escritura algo ensiforme (en algunos documentos las últimas letras son más pequeñas que las anteriores). Las comas suelen ser angulosas. Destaca el movimiento descendente de las consonantes $p$ y $q$. La $u$ y la $n$ son muy similares. Son letras reflejas o singulares la $z$, la $g$ y la $j$, de un tamaño mayor que las demás consonantes y largas por arriba y por abajo. $\mathrm{Su} d$, asimismo, tiene un palo muy corto y frecuentemente curvado: suele enlazar con la vocal siguiente.

Cuando Quevedo introduce citas, acostumbra a subrayarlas si están en estilo directo, pero nunca los títulos de las obras, de acuerdo con el hábito extendido entre sus coetáneos. Tampoco, como ya es sabido, acostumbra a ortografiar ni puntuar los textos tal y como lo hacemos actualmente (la ortografía actual no se fija hasta el siglo XVIII, cuando la RAE determina reglarla). La puntuación de Quevedo, en ocasiones, puede parecer ilógica y arbitraria. $^{24}$

${ }^{24}$ Véase A. Rey [1985: 60-61]: "Hace muchos años que Percy Simpson y Morris Croll llamaron la atención sobre los principios rítmicos que podrían condicionar la puntuación de los textos ingleses de los siglos XVI y XVII. Estudios posteriores, como el de Vivian Salmon sobre puntuación y estructura de la frase, o los libros donde A.C. Partidge se ocupa de la puntuación de Ben Jonhson y Shakespeare, ofrecen una visión más matizada, completada por la consideración de datos de diversa índole. No parece que en el ámbito de 
Estos son, a grandes rasgos, las peculiaridades de la escritura de Quevedo, las constantes que podemos apreciar en sus documentos autógrafos. Basta comparar la letra de, por ejemplo, las anotaciones de Quevedo a su Retórica de Aristóteles o las cartas escritas de su puño con los dos entremeses que Crosby reputaba por autógrafos para comprobar que, lamentablemente, los testimonios manuscritos conservados de Los refranes del viejo celoso y El hospital de los malcasados no están escritos de su puño y letra. (Dejamos para mentes más imaginativas el análisis grafológico del ductus de don Francisco.)

\section{LA RECENSIO}

Las bibliotecas públicas atesoran en sus fondos manuscritos un acervo importante de nuestra literatura aurisecular. La catalogación de dichos testimonios documentales es el paso previo de la recuperación de este patrimonio literario. La elaboración de un inventario detallado de sus obras es indispensable para proceder con el consiguiente estudio y edición de los autores clásicos. $^{25}$ Por ello, según hemos especificado, la metodología de nuestra investigación marcaba como primer paso la elaboración completa de un catálogo de la obra dramática de Francisco de Quevedo.

la filología española haya interesado una investigación similar, la cual, entre otras consecuencias posibles, facilitaría la tarea del editor de textos del Siglo de Oro. "

${ }^{25}$ Cfr. Pérez Cuenca [1997: 9]. 
Como punto de partida, el Catálogo bibliográfico y biográfico del teatro antiguo español de Barrera y Leirado [1860] nos sirvió para establecer qué nómina de la obra dramática de Quevedo era vigente a finales del siglo XIX. La entrada destinada a don Francisco consiste en la trascripción de una carta de Aureliano Fernández Guerra, que por aquel entonces trabajaba la edición de las obras completas de nuestro autor, reeditadas en la BAE [1951-1953]. En su metódica enumeración, encontramos un primer intento de filiación bibliográfica y la determinación de sus obras dramáticas (inéditas, de atribución segura y espurias).

Con todo, la principal fuente de información bibliográfica sobre la obra teatral de Quevedo es el "Catálogo" de José Manuel Blecua [1981], revisado por Jauralde Pou [1986: 63-73] y Pérez Cuenca [1997: 10]. Blecua, revisa los documentos de los catálogos de las ediciones de Astrana Marín y Buendía, así como los novedosos descubrimientos de Eugenio Asensio [1965] en el manuscrito evorense.

Para ampliar el corpus dramático de don Francisco y aportar inéditos, fue conveniente trazar un recorrido por aquellas bibliotecas que aparecían mencionadas en las ediciones modernas y en catálogos posteriores a la edición de Blecua, como el de Isabel Pérez Cuenca [Catálogo de los manuscritos de Francisco de Quevedo en la Biblioteca Nacional, 1997] o el de Miranda [Manuscritos quevedianos en las bibliotecas portuguesas, 1988].

También intentamos cerciorarnos de que no había obras perdidas o no registradas en otros dominios públicos, por lo que destinamos algunos días de investigación a bibliotecas de otros fondos reservados -como el de la 
universidad salmantina-, a pesar de que no fueran mencionadas en ninguno de los anteriores catálogos. Cuántas veces regresé a casa con las manos vacías.

Mi itinerario abarcó, fundamentalmente, las bibliotecas más relevantes de Madrid (la BNE, la BRAH, la BPR) y, naturalmente, las de Barcelona, la ciudad donde resido (la del IT, la BNC, y los ACA). En sucesivos viajes, amplié horizontes hacia otras bibliotecas españolas (la BMP de Santander, la BC de Sevilla y la de la Universidad de Salamanca), si bien con pocos resultados novedosos. ${ }^{26}$ Muchos de estos viajes, evidentemente, fueron estériles. Podría parecer una locura pretender ampliar la nómina teatral de Quevedo en vez de empezar analizando su obra disponible en ediciones modernas. Pero pensé que, dada la escasez de su teatro y las evidencias de dispersión del mismo, era inconveniente empezar la casa por el tejado.

Con el faro del descubrimiento de Asensio, me encaminé hacia las bibliotecas lusitanas (la BN de Lisboa, la Biblioteca Pública de Évora y la Biblioteca de la Universidad de Coimbra), terreno que, a mi parecer, podía estar poco explorado. En la tierra del saudade y de los fados, aunque con el escepticismo de quien sabe que no escasean las copias de obras falsamente atribuidas a Quevedo, me aventuré en la selva del teatro menor barroco, donde cualquier tentativa de fijar cronología y originalidad de atribución son terrenos altamente arriesgados y espinosos.

\footnotetext{
${ }^{26}$ Véase en la Bibliografía del presente estudio el apartado destinado a los Catálogos y repertorios bibliográficos, donde especifico los catálogos consultados de las bibliotecas enumeradas.
} 
Pero hay lugares a los que sólo se puede llegar a pie. Hay catálogos que no existen y descubrimientos in situ, fruto del azar. Sea como fuere, de cuantos más testimonios dispongamos, menos oscura será la reconstrucción de nuestro particular rompecabezas del pasado. De ahí, nuestra premisa metodológica: elaborar un catálogo de manuscritos e impresos antiguos de la obra dramática de Quevedo. Para ello, ha sido inestimable la experiencia como corresponsal y colaboradora del Grupo Edad de Oro, adscrito a la BNE y coordinado por Pablo Jauralde, cuyas pautas de catalogación contenidas en su Manual de investigadores [2003] he seguido con fidelidad. 


\section{CATÁl Ogo bibliográfico del TEATro de QUEVEDo}

\section{COMEDIAS DE ATRIBUCIÓN SEgURA}

\subsection{Cómo ha de ser el privado}

\section{MANUSCRITOS}

BMP (Santander), ms. 108. Fragmentos no impresos hasta hoy de don Francisco de Quevedo Villegas. Manuscrito del segundo tercio del siglo XVII, de copista probablemente andaluz. ${ }^{27}$ Contiene Cómo ha de ser el privado ["La luz de los desengaños..."] en los ff. 1r-70r.

Según Astrana Marín [1932: 592], existe otra copia incompleta en la Biblioteca de don Luis Valdés, pese a que críticos posteriores - Blecua, Gentilli - consideran que éste constituye el único manuscrito.

\section{IMPRESOS}

Teatro inédito de don Francisco de Quevedo y Villegas. Edición y estudio introductorio de Miguel Artigas. Madrid: RAE, 1927, pp. 1-115.

Obras en verso, Obras completas. Edición de Luis Astrana Marín. Madrid: Aguilar, 1932, pp. 1-115. Parte fundamentalmente de la edición de Artigas.

Obra poética. Teatro y traducciones poéticas (vol. IV). Edición de José Manuel Blecua. Madrid: Castalia, 1981, pp. 148-221. Se trata de la edición más rigurosa. Subsana errores de puntuación y trascripción cometidos por

\footnotetext{
${ }^{27}$ Cfr. Miguel Artigas [1927], Blecua [1981] y Gentilli [2004].
} 
Artigas. No obstante, su aparato de notas carece de comentarios lexicográficos y contextuales.

Cómo ha de ser el privado. Edición crítica, introducción y notas de Luciana Gentilli. Viareggio-Lucca: Mauro Baroni, 2004. La edición reproduce el ms. 108 de la Biblioteca Menéndez Pelayo, único ejemplar disponible hasta el momento. En el estudio introductorio (pp. 9-54), L. Gentilli insiste en el valor historiográfico de la "comedia noticiera o drama documental" -tradicionalmente vituperada por la crítica- y la ubica en la "trilogía del Conde-Duque" junto con el romance Fiesta de toros literal y alegórica $(P O C, 752)$ y El chitón de las tarabillas. ${ }^{28}$ Su edición de la obra, que considera "un intrincado collage", diverge de la de Blecua en algunos puntos, que matiza en las pp. 51-53.

\subsection{Pero Vázquez de Escamilla}

\section{MANUSCRITO}

BMP (Santander), ms. 108. Contiene Pero Vázquez de Escamilla ["Argomendo, esta rencilla..."] en los ff. 138r-148r. Contiene la siguiente nota final: "Este fragmento de comedia dejó empezado el autor, de cuyo original borrador se sacó esta copia. Algunas razones que no van bien colocadas es la culpa y la mala letra que hacía, más para ser adivinada que leída. Su original tiene D. Diego de Arroyo y Figueroa mi amigo."

${ }^{28}$ L.Gentilli sigue la tesis de M. Urí Martín en su "Introducción" de El Chitón de las tarabillas [1998: 13]. 


\section{IMPRESOS}

En las tres ediciones modernas ya citadas: Miguel Artigas [1927: 231249], Astrana Marín [1932: 231-249] y Blecua [1981: 224-235].

Arellano, I. "La jácara inicial de Pero Vázquez de Escamilla de Quevedo". Crítica textual y anotaciones filológicas de las obras del Siglo de Oro. Ed. I. Arellano y J. Cañedo. Madrid, Castalia, 1991, pp. 13-15. El artículo incluye la edición de la jácara inicial de esta comedia inacabada.

1.3. Fragmento que de letra del autor estaba scripto en el reverso de una carta

\section{MANUSCRITO}

BMP (Santander), ms. 108. El Fragmento ["¡De ayer casado...!"] aparece en el f. 148v. Hay una nota marginal de la letra del copista que señala "No había más desto".

\section{IMPRESOS}

En las tres ediciones modernas ya citadas: Artigas [1927: 251-252], Astrana Marín [1932: 251-252] y Blecua [1981: 237-238]. 


\section{COMEDIAS INÉDITAS ATRIBUIDAS}

\subsection{La privanza desleal y voluntad por la fama}

\section{IMPRESO}

Famosa 46/ comedia de la/ privanc, a [sic.] desleal, y vo-/lvuntad por la fama./ Las figuras que hablan en esta Comedia son las siguientes./ Minandro Rey./ Cleonarda Reyna./ Anarda Infanta/ D. Mayor, Duquesa./ Aluaro Conde./ Lisandro Secretario./ Euandro caballero./ cesar cavallero./ Rosicelo caballero./ Tiberiano general.// Liviano Soldado./ Horacio alabardero./ Onorio alabardero./ Norandino lacayo./ Armando criado./ Tirseo villano./ Vato villano./ Gerardo villano./ Galafron villano./ Florey cortesano. [“Tieneme loco/la voluntad que muestra el rey Minandro...”]. Impreso en $4^{\circ}$ ubicado en cajas sin catalogar de la BNE, 46-67 pp. numeradas sobre el recto. El impreso tiene una fisonomía que lo sitúa entre las categorías de "desglosable" y "desgajado". En el Catálogo de las comedias impresas en $4^{o}$ sueltas anteriores a 1750 que existen en la Biblioteca de Don Agustín Durán (ms. 14690) el impreso se adscribe al siglo XVII. La comedia, que en el Catálogo de Barrera y Leirado [1860: 313] aparece como perdida, ha sido encontrada por Germán Vega en la BNE (signatura T-55293-21). Éste, tras analizar la textura métrica de la obra, el tema de la privanza y sus notables deficiencias dramáticas (tal vez síntomas de su carácter de comedia palatina por encargo, escrita en un breve lapso temporal), determina que su “desmayada calidad artística no podrá ayudar a 
Quevedo, ni a ningún otro escritor, a avanzar en los repechos del Parnaso.” [1993: 116-121].

\subsection{El galán fantasma}

\section{MANUSCRITO}

IT (Barcelona), ms. de la vitrina A, Estante 5. El galán fantasma. Comedia ["Qué te parece tu prima..."]. La letra es del siglo XVII, el códice consta de 65 ff. En el folio inicial, aparece con el mismo tipo de tinta, el nombre del autor-Fco. de Que -, varias rúbricas para probar la pluma y una suma $(1046+750+936=2732)$, que se corresponde con el número de versos de cada una de las tres partes. En el folio final recto se incluyen, a su vez, las censuras del Dr. Peyron (Zaragoza, 13 de enero de 1641), de Juan Navarro de Espinosa (Madrid, 12 de enero de 1640) y del "planificador del Santo Oficio" Fr. Juan Ba Palacio (Valencia, 16 de octubre de 1640). La obra fue representada: de ello son claros testimonios el sinnúmero de tachones en el texto -dificultad añadida para su trascripción- y la anotación de los nombres de los actores junto a los dramatis personae. En el margen derecho del primer folio de la comedia, aparece en la misma tinta tenue que apuntaba los actores, la fecha de 1637, tal vez el año de composición de la obra. ${ }^{29}$ Además del Ex-libris de Arturo Sedó, incluye el del Marqués de Pidal. Sabemos, asimismo, que perteneció a la Biblioteca de Osuna. Esta comedia, de título similar al entremés El marido fantasma, con el que ha

\footnotetext{
${ }^{29}$ Cfr. Simón Palmer [1977, no 535].
} 
llegado a confundirse en el mismo catálogo del IT, no ha sido hasta ahora analizada en ningún compendio crítico. Hallamos una obra homónima de Calderón, cuyo texto, sin embargo, es distinto ["De vuestras señas llamado..."]. ${ }^{30}$ Queda pendiente un análisis exhaustivo para ofrecer pruebas que verifiquen si nos encontramos o no ante un nueva comedia de Quevedo.

\section{Comedias burlescas}

\subsection{La Infanta Palancona, una pieza espuria}

\section{IMPRESOS}

Entremes./ Famoso de la Infanta Palancona./ Son figuras. Vn maese de Campo. Un Correo. El Emperador. Un Page. La Infanta. Rey Cachumba./El Rey Azofeyto./ [Debajo de los personajes tres grabados en madera de figurillas entre orlas incompletas]. Al final se lee: Con licencia, impresso en Madrid por Bernardino del Guzman, año de 1625. ["Soy Júpiter y este es rayo..."]. $4^{\circ}$, cuatro hojas sin numerar, impresas a dos columnas. Acerca del entremés La Infanta Palancona, señala Montaner [1951:103]: "Esta graciosa obrilla, atribuida por Don Aureliano Fernández Guerra y La Barrera a Quevedo, que la compuso según ellos escudado en el pseudónimo de Félix Persio Bertiso es realmente del poeta Don Félix Persio Betiso". Cotarelo [1911: LXXIII] y Rosa Navarro [2003:101-115] así lo corroboran.

\footnotetext{
${ }^{30}$ Véase Calderón de la Barca, Obras completas. Comedias II. [1960: 637- 671].
} 
Entremeses/ nuevos,/ de diversos/ avtores./ Primera parte./ Con licencia./ En Çaragoça, Por Pedro Lanaja y Lamar/ ca, Impresor del Reyno de Aragón,/ y de la Universidad, / Año 1640./ A costa de Pedro Esquer Mercader/ de Libros, pp. 3-30. Cfr. Barrerra y Leirado [1860] y Montaner [1951: 108-115].

\subsection{Inéditas atribuidas}

\subsubsection{El premio de la hermosura}

\section{MANUSCRITO}

BNE, ms. 15288. Ovras de don Francisco de Quevedo. Comedia en vn acto El premio de la hermosura. Comedia burlesca ["De Júpiter la grandeza..."]. ${ }^{31}$ El códice es del siglo XVIII, escrito en un solo tipo de letra y consta de 7 ff. Foliación a lápiz, encuadernación holandesa con puntas. Constituye una obra inédita, que ya atribuida en el Catálogo de Barrera y Leirado [1860], que perteneció a Durán. Florencio Janer [1919: 38-46], Astrana Marín [1932] y Armando Cotarelo [1945: 69] no la consideran de Quevedo, bajo el argumento de que en la decimosexta parte de las comedias de Lope de Vega hay una tragicomedia de título homónimo. Ésta, sin embargo no coincide con la obra que nos ocupa ["Si tu vida me servía..."]. ${ }^{32}$

\footnotetext{
${ }^{31}$ Cfr. Pérez Cuenca [1997].

${ }^{32}$ Véase Lope de Vega, "El premio de la hermosura", en Obras escogidas. Teatro II. [1962:1497-1523.].
} 
Por lo tanto, resulta erróneo confundir ambas comedias homónimas con una sola. La desestimación de esta obra en la nómina teatral de Quevedo requiere de un análisis más riguroso.

\subsection{2. ¡Qué villano es el amor!}

\section{MANUSCRITOS}

BNE, ms. 15070. Qué villano es el Amor. (Satirica) en 1 acto. Comedia burlesca ["A las orillas del Duero..."]. Debajo del título, con el mismo tipo de letra -del siglo XIX- se indica: "se cree de Don Francisco de Quevedo y Villegas". 18 ff. en octava. Si bien Barrera y Leirado [1860: 311] considera esta comedia de Quevedo y señala que la posee don Agustín Durán, Astrana Marín [1932: 26] califica la obra de espuria, "producción del siglo XVIII", sin ofrecer más explicaciones. Del timbrado se infiere que la obra, probablemente, está escrita en papel de oficio de 1821. Armando Cotarelo [1945:69-70] señala al respecto: "Comedia anónima, incompleta e inédita, que perteneció a Durán y hoy para en la Biblioteca Nacional; es posterior a Quevedo".

IT (Barcelona), ms. 47184. Qué villano es el amor. Es una copia del ms. 15070 de la BNE. 34 cuartillas anotadas por Emilio Cotarelo, que señala, en portada: "No es entremés sino un fragmento de una comedia burlesca. Por los equívocos y retruécanos puede muy bien ser de Quevedo. Que pertenece al siglo XVII no cabe duda. Menciona al Conde de Castilla. Debe faltar 
mucho, pues aun no se adivina un enredo, ni figuran $\mathrm{D}^{\mathrm{a}}$ Ava ni la mora Abdumele." ${ }^{33}$

\section{ENTREMESES DE ATRIBUCIÓN SEGURA}

\section{MANUSCRITOS}

Biblioteca Pública de Évora, Cod. CXIV/1-3. Obras de don Francisco Gómez de Quevedo y Villegas Cauallero del hábito de Santiago. Manuscrito con letras de los siglos XVII y XVIII. Hallazgo de Eugenio Asensio [1965: 255-258]. Están paginados de 2 a 1.018 los poemas y piezas quevedescos. Entremés de Diego Moreno, la primera parte ["No trae vm. bien los dedos, $S^{\text {or }}$ capitán..."], pp. 745-782, y la segunda parte ["Y, como digo a vmd. querémonos los dos con mucho estremo..."], pp. 782-815. Entremés de Bárbara, la primera parte ["Señora Bárbara, y no, no soy yo tam bárbaro y loco..."], pp. 816-859, y la segunda ["iAmor, amor! Benturoso se puede llamar el que se biere libre de tus niñerías..."], pp. 860-894. Entremés de la Venta ["Mas líbranos del mal, Amén, Jesús..."], pp. 895-913; Entremés de los enfadosos ["La mayor comisión es que se ha visto..."], pp. 914-934; Entremés de la destreza ["Arojamiento tienes de muchacho..."], pp. 935952; Entremés de la polilla de Madrid ["Buena as puesto a tu madre y a tu hermana..."], pp. 953-987; y Entremés de la vieja Muñatones ["Teníanme quebrada la cabeça con este Madrid..."], pp. 991-1018.

\footnotetext{
${ }^{33}$ Cfr. Simón Palmer [1977, n 548].
} 
BNE (Madrid), ms. 3794. [Obras varias poéticas]. Bajo el título Entremés de los casados (f. 226-230v) aparece el texto conocido como el Entremés del marido pantasma ["Sea el señor Muñoz bien venido..."]. Manuscrito de los siglos XVII y XVIII, 232 f., 200x 145 mm. Cfr. Pérez Cuenca [1997].

BNE (Madrid), ms. 17376. Marido (El) Fantasma ["Sea el señor Muñoz bien venido..."]. De la segunda mitad del siglo XVII, el manuscrito consta de 7 f. Deducimos por la numeración que el entremés queda desglosado de un tomo mayor. Posee dos foliaciones, una en tinta (f. 49-54) y otra en lápiz (1r- 7v), motivo que ha suscitado cierta confusión entre la crítica. Cfr. Pérez Cuenca [1997] y Paz y Meliá [1934].

Biblioteca Colombina (Sevilla), ms. 82-30-40. ${ }^{34}$ Entremés del Zurdo, que no es otro que el Entremés de los enfadosos ["La mayor comisión es que se ha visto..."] en el f. 102. Blecua [1981:123] señala que nos hallamos ante un copista andaluz, y que la calidad de trascripción es inferior a la versión del ms. de Évora. Cfr. Astrana Marín [1932].

IT (Barcelona), ms. de la vitrina A, Estante 5. El marido fantasma ["Sea el señor Muñoz muy bien benido..."]. Letra del siglo XVII, 5 pp. En portada y con letra moderna consta la fecha 1626. Perteneció a la Biblioteca Sedó y lleva ex- libris del marqués de Pidal. Cfr. Simón Palmer [1977, n 536]. También I. Arellano y C.C. García Valdés [1997]. La crítica ha llegado a cuestionarse si nos hallamos ante un autógrafo. El manuscrito corrige

\footnotetext{
${ }^{34}$ El ms. no aparece en J. Francisco Sáez Guillén [2002]. Tampoco hemos encontrado la referencia en el catálogo virtual: http://biblioteca.institucioncolombina.org/cgibin/abweb.dat/X5102/ID11596/G0. Transcribo la signatura que ofrece Astrana Marín.
} 
algunas erratas del otro testimonio del mismo entremés, el ms. 17376 de la BNE. Cfr. J. Montaner [1951: 221].

IT (Barcelona), ms. 47179. La Venta ["Mas líbranos del mal, amén Jesús..."]. Se trata de una copia con letra de Cotarelo y Mori la edición de este entremés en la segunda parte de las comedias de Tirso. 12 cuartillas con notas de Cotarelo. Cfr. Simón Palmer [1977, nº 539].

BHSA (Nueva York), ms. B2900. Entremés de los refranes del viejo celoso ["Xusta querida, Xusta de quien gusta..."], sin lugar ni fecha. Manuscrito del XVII, 6 hojas sin encuadernar, 22 x16 cm. Comprado a Crosby el 16 de diciembre de 1981, junto con otros textos y documentos no teatrales. Lógicamente, por una cuestión cronológica, no aparece en el repertorio bibliográfico de Rodríguez-Moñino [1965-66.]. Esta pieza fue reputada por autógrafa en su momento. Cfr. Crosby [1967: 205-218]. ${ }^{35}$

\section{IMPRESOS $^{36}$}

El zurdo alanceador. Entremés famoso de don Francisco de Quevedo. ["La mayor comisión es que se ha visto..."] Representole Amarilis en Sevilla. Segovia: Impr. de Diego Flamenco, 1628. Cfr. Barrera y Leirado [1860: 312] y Astrana Marín [1932: 577].

Segunda parte/ de las/ Comedias/ del Maestro/ Tirso de Molina./ Recogidas por sv sobrino/ Don Francisco Lucas de Auila./ Dedicadas a la

\footnotetext{
35 Agradecemos esta valiosa información a Miguel Martínez y la colaboración de Júlia Ibarz Pascual en la adquisición de los facsímiles. No describimos el ms. del Famoso entremés delospital (sic) de los malcasados porque consideramos, con Blecua [1981:10], que no pertenece a Quevedo.

${ }^{36}$ Para las ediciones modernas, véase la bibliografía.
} 
venerable y piadosa Congregación de los Mercaderes del Libros desta Corte, en la Tutela del Glorioso Doctor S. Geronimo./ En Madrid./ En la Imprenta del Reino, año 1635. 300 ff. Contiene el Entremés de la Venta ["Mas líbranos del mal, Amén Jesús..."] en los ff. 261v- 264v. Aparece atribuido a Tirso. Cfr. Montaner [1951: 107-108].

Entremeses/ nuevos,/ de diversos/ avtores./ Primera parte./ Con licencia./ En Çaragoça, Por Pedro Lanaja y Lamar/ ca, Impresor del Reyno de Aragón,/ y de la Universidad, / Año 1640./ A costa de Pedro Esquer Mercader / de Libros. 250 pp. Contiene el Entremés de la Venta ["Mas líbranos del mal, Amen Jesus..."] en las pp. 113-123. De este entremés se señala que "representole Avendaño". Cfr. Montaner [1951: 108-115].

Ramillete/ gracioso./Compuesto de entre-/meses famosos, y bailes/ entremesados./ Por diferentes ingenios./ Año [un jarrón con flores] 1643./ Con licencia, En Valencia, por Syluestrel Esparsa, en la calle de las Barcas./ Vendense a la puerta de Magdalenas. 239 pp. Contiene el Entremés del marido fantasma ["Sea el señor Mendoza bien venido..."] pp. 65-74. Cfr. Montaner [1951: 117-125].

Entremeses de varios autores o Entremeses de Cadiz. Edición de Francisco Iuan de Velazco en la plaça de los Escrivanos. Cádiz, 1646/ 1647. Incluye el Entremes/ famoso /el Marion./ De don Francisco de Quevedo/ Primera y segunda parte. La primera parte ["O calles cuyas piedras son diamantes..."] ocupa los ff. 25-29; la segunda ["Vive Christo que si algo me replica..."], los ff. 29v.- 32v. Cfr. Barrera y Leirado [1860]. Véase también Montaner [1951: 129] y A. Vázquez Estévez [1995: I., 144$145]$. 
Las tres musas últimas castellanas. Segunda cumbre del Parnaso Español de Don Francisco de Quevedo Villegas. Sacadas de la librería de Don Pedro Aldrete Quevedo y Villegas. En Madrid: En la Imprenta Real. Año de 1670. Es la edición príncipe del segundo volumen de sus obras poéticas. Cfr. Las tres musas últimas castellanas. Incluye el Entremés del Niño y Peralvillo de Madrid ["Angelito, mis ojos..."], pp. 95-102; el Entremés de la Ropavejera [¡Válgame Dios, qué extraordinaria cosa...!"], pp. 103-107; el Entremés del Marido pantasma ["Sea el señor Mendoza bien venido..."], pp.108-116; y el Entremés de la venta ["Mas líbranos del mal, Amen Jesus..."], pp. 117-123. Consúltese la ed. facsímil de Felipe B. Pedraza Jiménez y Melquíades Prieto Santiago [1999].

\section{ENTREMESES DE DUDOSA ATRIBUCIÓN}

\section{MANUSCRITOS}

BNE, ms. 14516/44. Entremés de Pandurico de Payatos y del muerto fingido. S.XVIII, 6 ff. Manuscrito sin encuadernar con un solo tipo de letra. Obra "adquirida por el gobierno en 1863", ff. 2-6 ["No me dirá vsted, señor Mejía..."]. Pieza teatral atribuida a Quevedo por Barrera y Leirado [1860] y Astrana Marín [1932:25], que señala que dicho entremés es auténtico, en tanto que son plagios espurios del mismo El muerto, El muerto resucitado, El muerto fingido y Pandero y Poyatos.. Asimismo, Astrana Marín [1932: 542] señala que el ms. perteneció al Duque de Osuna y que El muerto es una refundición de este entremés. Asensio [1965: 222], no obstante, desacredita 
la paternidad de Quevedo. Cfr. Pérez Cuenca [1997], Buendía [1988], Paz y Meliá [1934].

BNE, ms. 17089. Entremés de Pandurico. Manuscrito del siglo XVII, 7 f. Foliación a lápiz. Todos los folios están restaurados excepto el 3. F. 1-7 ["No me dirá busted, señor Mexía/..."]. Pérez Cuenca [1997], Buendía [1988], Paz y Meliá [1934].

IT (Barcelona), ms. 47180. Las sombras. Entremés. ["Qué es esto? ¿Dónde estoy? ¿Qué sitio es éste?..."]. Es una copia con letra del siglo XIX de Entremeses nuevos (Alcalá: Francisco Ropero, 1643). 14 cuartillas. Barrera y Leirado [1860] lo atribuye a Quevedo conforme a la carta de Fernández Guerra. Señala, al respecto, Astrana Marín [1932:582]: “No debe considerarse de Quevedo el entremés denominado Las sombras, inspirado en este de El viejo celoso y El sueño de la muerte. Las sombras, inserto en Entremeses nuevos de diversos autores, es obra de Quiñones de Benavente, que tanto imitó a Quevedo.” Bergman [1975: 397], no obstante, considera que sucede precisamente a la inversa: "Esta pieza, cuya atribución a Quevedo merece tomarse en serio, sugirió Los refranes del viejo celoso a otro entremesista, probablemente Quiñones de Benavente". Cfr. Simón Palmer [1977, $\left.\mathrm{n}^{\mathrm{o}} 540\right]$.

IT (Barcelona), ms. 47181. El muerto. Entremés. ["Esta burla he de hacer..."]. Es una copia de Entremeses nuevos (Alcalá, 1643) con letra del siglo XIX. 12 cuartillas con notas de Cotarelo. Astrana Marín [1932] lo considera plagio de Pan Durico y obra de la pluma de Quiñones de Benavente; Cotarelo [1911] y Asensio [1965] también lo tachan de espurio, 
por lo que Blecua [1981] sostiene que "podemos con toda tranquilidad escardar ese entremés de los auténticos”. Cfr. Simón Palmer [1977, n 538].

IT (Barcelona), ms. 47182. El médico. Entremés. ["Bras Mojón, ya sabéis que ha muchos días..."]. Se trata de una copia de Entremeses nuevos (Alcalá, 1643) con letra del siglo XIX. Hallamos 16 cuartillas con notas de Cotarelo. Publicado por Astrana Marín [1932], cabe decirse que Asensio [1965] y Blecua [1981] no reconocen en esta obrilla el particular trato satírico que hace Quevedo a los médicos. Cfr. Simón Palmer [1977, n 537].

IT (Barcelona), ms. 47.183. ${ }^{37}$ El caballero de la Tenaza. Entremés. ["Tira más quedo, ganapán tapado..."]. Es una copia de Flor de entremeses (Madrid, 1657) con letra del siglo XIX. 12 cuartillas con anotaciones de Cotarelo. Astrana Marín [1932] lo editó como de Quevedo sin aludir a que en el impreso que le sirvió de base para hacer la edición la obrilla aparece sin atribución. Hannah E. Bergman considera que probablemente el entremés está inspirado en las Cartas del caballero de la Tenaza, aunque "la versificación ingeniosa y el alto porcentaje de rima en las silvas desdicen de la práctica quevediana en los entremeses incluidos en las Tres musas últimas." Cfr Simón Palmer [1977, no 534], Blecua [1981: 14] у Hannah E. Bergman [1965: 277].

\footnotetext{
${ }^{37}$ Los manuscritos 47.178- 47.198 de la Biblioteca del Institut del Teatre aparecen reunidos en el mismo cartapacio azul, hecho que facilita la consulta del investigador. Constituyen una serie de copias de puño y letra de Cotarelo y Mori, probablemente un borrador para una edición del teatro de Quevedo. Esta publicación nunca llegó a llevarse a cabo. Y nos preguntamos si habría formado parte de su inacabada Colección de entremeses, loas, jácaras y bailes [1911].
} 
BHSA (Nueva York), ms. B2901. Famoso entremés delospital (sic) de los malcasados [sin lugar ni fecha], manuscrito del XVII, 5 hojas sin encuadernar, $21 \times 15.5 \mathrm{~cm}$. Al igual que el Entremés de los refranes del viejo celoso, el ms. fue propiedad de Crosby [1967: 219-225]. La biblioteca se los compró en 1981. Fernández Guerra y Barrera y Leirado [1860] lo consideran "inédito y autógrafo", perteneció a la biblioteca del primero según señala en la carta incluida en el Catálogo. Blecua [1981], al igual que Asensio [1965], se resisten a incluirlo como de Quevedo.

\section{IMPRESOS}

Comedias portugueisas. Feitas pello excelente poeta, Symāo Machado... Nesta segunda impressāo, enmendadas e acrescentadas, dous Entremeses, $e$ quatro Loas famosas. Lisboa: Antonio Álvarez, 1631. Existe un ejemplar en la Biblioteca Nacional de Lisboa. Incluye, sin la numeración impresa en tinta, el apócrifo La Endemoniada fingida y chistes de Bacallao ["En mi casa, infame..."], ff. 95r- 98r, "compuesto por don Francisco de Quebedo"; y La Infanta Palancona ["Soy Júpiter y este es rayo..."], ff. 98v-102v: de ésta, escrita "en forma de comedia, con primera, y segunda, y tercera parte"; tan siquiera se especifica la autoría de Quevedo. Estos dos entremeses espurios fueron publicados en las Obras completas de Quevedo dirigidas por Florencio Janer [1953, III]. Cfr. G. Vega García-Luengos, R. Fernández Lera, A. del Rey Sayagués [2001, no 1476, 1477, 2112, 2113] y Montaner [1951:103].

Entremeses nuevos de diversos autores para honesta recreación. Alcalá de Henares: por Francisco Ropero, 1643. Volumen en octavo, 118 pp. 
Contiene: El muerto ["Esta burla he de hacer...”]; Las sombras [“¿Qué es esto? ¿Dónde estoy? ¿Qué sitio es éste...?”]; y El médico [“Bras Mojon, ya sabes que há muchos días...”], pp. 107-112.

Entremeses y flor de sainetes de varios autores. Madrid: Antonio del Ribero Rodríguez, mercader de libros, 1657. 88 ff. $2^{\text {a }}$ edición, por Menéndez Pelayo (Madrid: Fortanet, 1903), que señala "Carece de portada el único ejemplar conocido, y "en ninguna bibliografía le hallamos mencionado". Contiene El caballero de la Tenaza. Entremés ["Tira mas quedo, ganapan tapado..."], ff. 75v -79r. Cfr. Montaner [1951: 138]; G. Vega García-Luengos, R. Fernández Lera, A. del Rey Sayagués [2001: nº 623]; Cotarelo [1930, n 561]; y A. Schaeffer [1898, n 56].

Teatro poético. Repartido en veinte y vn Entremeses nuevos. Escogidos de los mejores ingenios de España. Con licencia. En Zaragoça: Por Iuan de Ybar. Año 1658. A costa de Iusepe Galbez, Mercader de Libros. Véndese en su casa a la Esquina de la Platería; 8. Contiene El muerto ["Esta burla he de hacer...”]. Cfr. Barrera y Leirado [1860].

Verdores/ del Parnaso/ en veinte y seis entre-/meses, bayles, y sainetes,/ de diversos autores./ Dedicados/ A Don Christoval del Ponte Llarena Xuarez y Fonseca, Maes-/tre de Campo de la Milicia de la Isla/ de Tenerife./ Con Privilegio./ En Madrid: por Domingo García Morrás, Im/pressor del Estado Eclesiástico de la Coro-/na de Castilla, y León, año de 1668./ A costa de Domingo de Palacio y Villegas, vendesel en su casa frontero del Colegio/ de Atocha. Consta de 4 pp. sin numerar, más 251 numeradas, en $8^{\circ}$. Perteneció a la colección teatral de Arturo Sedó. Contiene el Entremés de Pandurico [“No me dirà busted señor Mexia...”], pp. 51-65. 
Cfr. Montaner [1951: 153-162]. Véase la edición de R. Benítez Claros (Verdores del Parnaso. Madrid: CSIC, 1969).

\section{ENTREMESES DE MIGUEL DE MULSA}

\subsection{Entremesico del Hurto del Nene}

\section{MANUSCRITOS}

BNE, ms. 14780. Entremesico [satis est] del Hurto del Nene. Entremés ["Válgante doce diablos por caballo ..."]. Letra del siglo XVII. Perteneció a la Biblioteca de Osuna. Desde el Catálogo de Barrera y Leyrado [1860] se ha reputado por autógrafo de Miguel de Mulsa, aunque nosotros discernimos de ello. Dice que es autógrafo en portada y con letra moderna. No se ha revisado el parecer de Cotarelo y Mori [1911: LXXII] al respecto. Está firmado, y la letra de la firma es harto distinta de la del corpus textual. Tachada la fecha. 5 pp. $4^{\circ}$. Cfr. Paz y Melià [1934: I, nº 1727] y Simón Díaz [1992: $\left.n^{\circ} 4192\right]$.

IT (Barcelona), ms. 61565. Hurto (del) del nene. Entremesico. Letra de Aureliano Fernández Guerra. Con toda seguridad es una copia del ms. precedente de la BNE. El ms. está reencuadernado junto con otros entremeses pertenecientes a la Biblioteca de Osuna en un volumen titulado Teatro antiguo Español: 92. BAI-ENT-MOG. (mss. 61528 - 61568): “Entremeses, mojigangas, bailes, jácaras, manuscritos copias manuscritos originales u rápidos juicios, con noticias curiosas de puño y letra de D. 
Aureliano Fernández Guerra.” El ejemplar sólo aparece registrado en el catálogo digital de la biblioteca. $7 \mathrm{hs}$ de 210x145mm. En la primera hoja contiene las siguientes anotaciones de Fernández Guerra: "162...Ms. autógrafo del primer tercio del siglo 17 de la B.O. Asunto disparatado: estilo correcto: versos largos como los mejores de aquel tiempo. Al fin tiene una linda coplilla. Mulsa es autor del entremés de la Perendeca. Tituló el presente entremesico por no darle importancia: así es que al lado de este nombre puso satis est.”

IT (Barcelona), ms. 46999. Entremesico del Hurto del Nene. Letra de Cotarelo y Mori. El entremés está reencuadernado con otras piezas antiguas de teatro breve, en un volumen titulado Entremeses varios A-M. Varios autores. (mss. 46965- 46999). 6pp. de 210x145mm. + 18 cuartillas de 220x155. Copia del ms. de la BNE. En la primera hoja, tiene las siguientes anotaciones de Cotarelo: “Conjunto de despropósitos unidos sólo para hacer reír. Es una verdadera mojiganga." Cfr. Simon Palmer [1977, no 502], Simón Díaz [1992, nº 4191].

\subsection{Entremesico de las verdades del zonzo}

\section{MANUSCRITOS}

BNE, ms. 15269. Entremesico famoso de las verdades del zonzo. Entremés [“Tú de Bruto mi bien, tú apazguatado...”]. Letra del siglo XVII y firmado por Miguel de Mulsa. Como El hurto del nene ha sido reputado por 
autógrafo, y también disentimos. Procede de la biblioteca Ducal de Osuna. 4 pp. 4º Cfr. Paz y Meliá, I, no 3762; Simón Díaz [1950, n 4194].

IT (Barcelona), ms. 61566. Las verdades del zonzo. Entremesico famoso. Letra de Aureliano Fernández Guerra. Es una copia del ms. precedente de la BNE. Está reencuadernado junto con otros entremeses pertenecientes a la Biblioteca de Osuna en un volumen titulado Teatro antiguo Español: 92. BAI-ENT-MOG. (mss. 61528 - 61568): "Entremeses, mojigangas, bailes, jácaras, manuscritos copias manuscritos originales u rápidos juicios, con noticias curiosas de puño y letra de D. Aureliano Fernández Guerra.” El ejemplar sólo aparece registrado en el catálogo digital de la biblioteca. 7 pp. de 210 x $145 \mathrm{~mm}$. Viene acompañado de las siguientes notas de Don Aureliano: "Ms. Autógrafo del primer tercio del siglo XVII./ Miguel de Mulsa es autor de la Perendeca y del Hurto del Nene. El estilo de las verdades del Zonzo es muy parecido al de los entremeses de Cervantes, como se puede notar en los pasajes que muestran esta señal \#. El argumento de la piececita tiene la índole de los rasgos de Quevedo. Cuadro importante para juzgar de la moralidad de aquella época."

IT (Barcelona), ms. 46998. Entremés famoso de las verdades del Zonzo. Letra de Cotarelo y Mori. El entremés está reencuadernado con otras piezas antiguas de teatro breve, en un volumen titulado Entremeses varios A-M. Varios autores. (mss. 46965 - 46999). 6 pp. de 215 x 159 mm. +16 cuartillas de 220 x $155 \mathrm{~mm}$. También es una copia del ms. de la BNE. Y tiene en la primera y el reverso de la segunda hoja las siguientes anotaciones: "Ms. Autógrafo de 1620. Intervienen María de Alcaraz/ Cristóbal de León/ Isabel.// Incorrecto el original: Buen entremés intencionado contra la 
liviandad femenina.// Lo mismo en este que en el otro suyo titulado El hurto del nene no suele seguir Mulsa una norma regular en lo concerniente a la rima, a lo mejor abandona la consonante y escribe en verso libre para volver luego a tomar aquella cuando le parece. La letra de los mss es perfectamente legible.” Cfr. Simón Palmer [1977, n 503] y Simón Díaz [1992, nº 4193].

\section{JÁCARAS DE ATRIBUCIÓN SEGURA}

7.1. Carta de Escarramán a la Méndez (POC, 849): "Ya está guardado en la trena..."

\section{MANUSCRITOS}

BNE, ms. 3795. Tejuelo: Poesías manuescritas [sic.]. 1. Letra del siglo XVII. ff. $324 \mathrm{v}-325 \mathrm{v}$.

BNE, ms. 3920. Tejuelo: Parnaso español 10. Antología con poemas de A. Hurtado de Mendoza, Céspedes, Miguel Cejudo, Góngora y otros. Letras distintas del siglo XVII, f. 282.

BNE, ms. 3940. Tejuelo: Obras de Quevedo. Los 45 ff. iniciales contienen los Grandes anales de quince días. Copia del siglo XVII, ff. 173v-175v. "Ya está aguardando [tachado: querido] y en la trena..." Cfr. Buendía [1960: 1145], Blecua [1999: I, 21].

BNE, ms. 19387. Tejuelo: Sátira de Oquendo. Portada: Cartapacio de de (sic.) diferentes versos a diversos asuntos por el año de 1598 y los siguientes. A pesar de la fecha indicada, el ms. tiene poemas de 1612. Copia 
de finales del siglo XVI y los primeros años del siglo XVII, f. 202: "Ya está metido en la trena..."

\section{IMPRESOS}

Jácara. Aquí se contiene la adversa fortuna del valiente Escarramán, natural de Sevilla, al cual prendieron por muchos delitos que cometió. Cuéntase el trato de otros camaradas suyos, y el fin de todos, y lo que con ellos le sucedió en la cárcel estando presos, y el castigo y fin del Escarramán./ Sabido por una carta que escribió a una mujer que le favorecía. Lleva la respuesta que ella le invió, donde se hallarán famosos chistes, y el testamento que hizo Escarramán./ Compuesto por don Francisco de Quevedo. Año 1613. En Barcelona, en casa de la viuda de Dotil, año 1613. ${ }^{38}$

Parnaso [Madrid, $1648^{39}:$ 341]; [Zaragoza, $1649^{40}: 243$ ].

\footnotetext{
${ }^{38}$ Astrana Marín [1932:215] lo cita como pliego suelto que perteneció a la biblioteca de don Luis Valdés. Blecua [1999: I, 40] asegura no haber encontrado ningún ejemplar.

${ }^{39}$ EL/ PARNASO ESPAÑOL,/ MONTE EN DOS CUMBRES DIVIDIDO, / con las/ NUEVE MVSAS CASTELLANAS./ Donde se contienen/ POESIAS/ DE DON FRANCISCO DE QUEVEDO VILLEGAS,/ CABALLERO DE LA ORDEN DE SANTIAGO,/I SEÑOR DE LA VILLA DE LA TORRE DE IVAN ABAD:/ Que con Adorno, i Censura, ilustradas, i corregidas,/ salen ahora de la Librería del DON IOSEPH ANTONIO GONZALES DE SALAS,/ CABALLERO DE LA ORDEN DE CALATRABA,/ i señor de la antigva casa de los Gonzalez/ de Vadilla/ [Un libro abierto dentro de una orla con la leyenda o divisa Scire tvvm nihil est/ nisi sciat alter] / EN MADRID, / Lo imprimio EN SV OFFICINA DEL LIBRO ABYERTO/ DIEGO DIAZ DE LA CARRERA,/-/ Año MDCXLVIII./ A costa de Pedro Coello, Mercader de Libros.
} 
Romances varios $^{41}[1645],{ }^{42}\left[1648^{43}: 195\right],\left[1655^{44}: 396\right],\left[1663^{45}: 1\right]$, $\left[1664^{46}: 388\right]$

Hill $^{47}$ [1945: 233].

${ }^{40}$ El Parnassso/ Español,/ Monte en dos cvmbres/ Dividido/ con/ las Nveve Mvsas/ Castellanas,/ Donde se contienen poesias de/ Don Francisco de Quevedo Villegas, Cavallero de la/ Orden de Santiago y Señor de la/ Torre de Iuan Abad:/ Que con adorno y censura ilustradas y corregidas, salen/ aora de la Libreria de/ D. Ioseph Antonio González. de Salas,/ Cavallero de la orden de Calatrava, y Señor de la/ antigua casa de los Gonzalez. de Vadilla.[Adorno] Con licencia,/ En Zaragoça, en el Hospital Real, año de 1649./ A costa de Pedro Esquer, Mercader de Libros. Reproduce la edición anterior, pero carece de muchas notas de González de Salas.

${ }^{41}$ Consúltese Antonio Rodríguez- Moñino, Manual bibliográfico de Cancioneros y Romanceros (Siglo XVII), núms. 209-210. La primera edición conservada de los Romances varios de diversos autores es de 1640; no obstante, Chevalier [1992: 141] considera que hacia 1635 o 1636 sale a la luz, verosímilmente, la primera edición.

${ }^{42}$ Cfr. Chevalier [1992: 142], señala esta edición madritense, que no cita Blecua.

${ }^{43}$ Romances/ varios/ de diversos/ avtores./ Corregido, y emmendado. en/ tercera impression./ [Grabadito]/ Con licencia:/ En Cordoua por Saluadot de/ Cea. Año de 1648.

${ }^{44}$ Romances/varios,/ de diversos/ avtores./ Añadidos, y enmendados/ en esta vltima im-/ pression./ (21)./ Con licencia./ En Madrid, por Pablo/ de Val. Año 1655./ A costa de Santiago Martin, Mer-/ cader de Libros. Vendese en su/ casa en la calle de Toledo.

${ }^{45}$ Romances/ varios,/ de diversos avtores./ Agora nuevamente re-/cogidos por el Li/cenciado Anto/nio Diez/ [Adorno]/ Con licencia./ En Zaragoça: En la imprenta de/ la Viuda de Miguel de Luna, Im-/pressor de la Ciudad y del Hos-/pital Real, y Gnal. de N. S./ de Gracia. Año 1663.

${ }^{46}$ Romances/ varios/ de diversos/ autores/ Añadidos, y enmenda-/dos en esta vltima/ impression/ (21)/Con licencia/ [Adorno]/ En Madrid: por Iuan de Nogues/ Año de 1664/ A costa de Manuel Melendez, Mer/ cader de Libros./Vendese en su/ casa a la Puerta del Sol. Al final: Con licencia/ En Madrid: Por Iuan/ de Nogues, Año/ de 1664. 
7.2. Respuesta de la Méndez a Escarramán (POC, 850): "Con un menino del padre..."

\section{MANUSCRITOS}

BNE, ms. 3940. Obras de Quevedo, ff. 177-179v. Cfr. Buendía [1960: $1145]$.

BNE, ms. 3795. Poesías manuescritas 1, ff. 81v.-82. Presenta variantes notorias respecto al ms. fijado tradicionalmente: "Recibí en letra las ciento...".

IMPRESOS

Parnaso [Madrid, 1648: 343]; [Zaragoza, 1649: 246].

Romances varios [1655: 400], [1663: 5], [1664: 392].

7.3. Carta de la Perala a Lampuga, su bravo (POC, 851): "Todo se sabe, Lampuga..."

\section{MANUSCRITOS}

BNE, ms. 3773. [Cancionero poético de varios autores], ff. 3v-33r.

BNE, ms. 3940. Obras de Quevedo, ff. 97r-98v.

IMPRESOS

Parnaso [Madrid, 1648: 345]; [Zaragoza, 1649: 246].

Romances varios $\left[1643^{48}: 60\right],[1655: 64],[1663: 11]$.

${ }^{47}$ Hill, J. M. Poesías germanescas. Bloomington: Indiana, 1945.

${ }^{48}$ Romances/ varios./ De diversos/ avtores./ Añadidos, y enmenda-/ dos en esta tercera/ impression./ 18:1/[Adorno]/ Con licencia,/ En Çaragoça, Por Pedro/Lanaja, Año 1643. 
7.4. Respuesta de Lampuga a la Perala (POC, 852): "Allá va en letra Lampuga..."

MANUSCRITOS

BNE, ms. 3940. Obras de Quevedo, ff. 98v-99v. Cfr. Buendía [1960: $1145]$

BNE, ms. 3773. [Cancionero poético de varios autores], ff. 33v-36r.

Ms. de Antonio Rodríguez Moñino. Jácara suelta. Ver la descripción de Blecua en su Poesía original [1963: CL].

IMPRESOS

Parnaso [Madrid, 1648: 347]; [Zaragoza, 1649: 250].

Romances varios [1643: 62], [1655: 67], [1663: 15], [1663: 62].

7.5. Villagrán refiere sucesos suyos y de Cardoncha (POC, 853):

"Mancebitos de la carda..."

IMPRESOS

Parnaso [Madrid, 1648: 349]; [Zaragoza, 1649: 251].

Romances varios [1648: 19], [1655: 407], [1663: 19], [1664: 399].

7.6. Milagros de Montilla (POC, 855): "En casa de las sardinas..." MANUSCRITO

BNE, ms. 3773. [Cancionero poético de varios autores], f. $23 .{ }^{49}$

IMPRESOS

Parnaso [Madrid, 1648: 353]; [Zaragoza, 1649: 255].

${ }^{49}$ Podría confundirse con el f. 27 porque hay un problema de paginación: el f. anterior está numerado como 22 y el siguiente como 28 . 
Romances varios $\left[1640^{50}: 148\right],[1643:$ 242], [1648: 114], [1655: $227]^{51}$, [1663: 29], [1664: 236].

Hill [1945: 234-235]

7.7. Relación que hace un jaque de sí y de otros (POC, 856): "Zampuzado en un banasto..." Blecua [1999: 1145]: "El poema, por la alusión en el v. 178, es posterior a febrero de 1623, en que se decreta el cierre de las mancebías."

\section{MANUSCRITOS}

BNE, ms. 3773. [Cancionero poético de varios autores], ff. 130v-133r. Ofrece la variante: "Zampuzado en un canasto..."

BNE, ms. 3811. [Poesías varias], varios tipos de letra del siglo XVII, f. $146 r$.

BNE, ms. 3940. Obras de Quevedo. ff. 113r-117r. Se inicia con el verso: "Çan puçado en vn banasto..."

Ms. XVI de la Hispanic Society (Nueva York). Cancionero recogido por algún andaluz, con predominio de romances anónimos. Letra del siglo XVII, f. 156r. Cfr. Rodríguez Moñino [1965], Blecua [1999: I, 31].

IMPRESOS

Parnaso [Madrid, 1648: 356]; [Zaragoza, 1649: 257].

Romances varios [1640: 42,253], [1643: 76], [1648: 42, 238], [1655: 81], [1663: 36], [1664: 84].

\footnotetext{
${ }^{50}$ Romances varios./ De diversos/ avtores./ [Adorno]/ Con licencia,/ -/ En Zaragoça, por Pedro Lana-/ja, Impressor del Reyno,/ Año 1640.

${ }^{51}$ Chevalier [1992: 142] no cita este contenido.
} 
7.8. Sentimiento de un jaque por ver cerrada la mancebía (POC, 857):

"Añasco el de Talavera..." El cierre de las mancebías se decreta el 4 de febrero de 1623 por orden de Felipe IV.

MANUSCRITOS

BNE, ms. 3795. Poesías manuescritas 1, f. 182.

BNE, ms. 3940. Obras de Quevedo, ff. 46-48.

BNE, ms. 17717. Poesía mística de algunas cosas espirituales de Fray Luis de León con otras de diferentes autores, letras diversas del siglo XVII, f. 216 .

Ms. de la Biblioteca de Antonio Rodríguez Moñino. En el f. 3, con una orla dibujada se lee: Obras del Conde de Villamediana que no se han impreso. Las obras de Quevedo se hallan en los ff. 97r-209v; f. 123r. Cfr. Blecua [1999: I, 35].

BMP, ms. 152. Obras de diversos, como Villamediana, Lope de Vega y otros. Letra del siglo XVII, f. 154r.

IMPRESOS

Parnaso [Madrid, 1648: 359]; [Zaragoza, 1649: 260].

Romances varios [1640: 237], [1643: 331], [1648: 216], [1655:311], [1663: 43], [1664: 311].

Primavera y flor de los mejores romances [Madrid: 1621: 117v.]; [Zaragoza: 1636].

Hill [1945: 235]. 
7.9. Desafío de dos jaques (POC, 858): "A la orilla de un pellejo..."

MANUSCRITO

BNE, ms. 3797. Poesías manuescritas 3, ff. 236r - 239v.

IMPRESOS

Parnaso [Madrid, 1648: 361]; [Zaragoza, 1649: 261].

Romances varios [1655: 415], [1663:46], [1664: 410].

Hill [1945: 235].

7.10. Refiere Mari Pizorra honores suyos y alabanzas (POC, 859):

"Con mil honras, ¡vive cribas!..."

IMPRESOS

Parnaso [Madrid, 1648: 363]; [Zaragoza, 1649: 263].

Romances varios [1655: 420], [1663:52], [1664: 416].

7.11. Mojagón, preso, celebra la hermosura de su iza (POC, 860):

"Embarazada me tienen..."

IMPRESOS

Parnaso [Madrid, 1648: 364]; [Zaragoza, 1649: 264].

Romances varios [1655: 423], [1663:54], [1664: 419].

7.12. Pendencia mosquito (POC, 861): "A la salud de las marcas..."

MANUSCRITOS

BNE, ms. 3797. Poesías manuescritas 3, ff. 215-217.

BNE, ms. 3884. Poesías varias. Tomo I. Letra del siglo XVII, f. 352. 
Ms. LXXXIV de la Hispanic Society (Nueva York). Poesía de varios ingenios Ant. y Modern. las más de D.L. Góngora Letra del siglo XVII, f. $161 \mathrm{v}$.

IMPRESOS

Parnaso [Madrid, 1648: 366]; [Zaragoza, 1649: 265].

Romances varios [1640: 24], [1643: 121], [1648: 24], [1655: 128], [1663:58].

Hill [1945: 235].

7.13. Postrimerías de un rufián (POC, 862): "Descosido tiene el cuerpo..."

MANUSCRITO

BNE, ms. 3797. Poesías manuescritas 3, ff. 234r-236r.

IMPRESOS

Parnaso [Madrid, 1648: 371]; [Zaragoza, 1649: 269].

Romances varios [1655: 427], [1663:70], [1664: 423].

Hill [1945: 236].

7.14. [Jácara de la venta] (POC, 863): "Ya se salen de Alcalá..."

MANUSCRITO

BNE, ms. 3700. Tejuelo: Poesías diversas. En la portada figura un soneto del colector. Letra del siglo XVII, ff. 72r-73r. 
7.15. Jacarandina (POC, 864): "Estábase el padre Ezquerra..."

MANUSCRITOS

BMP, ms. 108, f. 192. Astrana Marín sólo edita 88 vv. (faltan del 37 al 80).

BMP, ms. 142. Casi todo de Quevedo. Algunos autógrafos. Perteneció a Salazar y lleva notas marginales de Gallardo. Letras del siglo XVII, f. 36. Cfr. Blecua [1999: I, 24].

De la biblioteca de don Luis Valdés. Jácara de Quevedo. Copia de Gallardo de un ms. del siglo XVII. Cfr. Blecua [1999: I, 38].

\section{8. ¿JÁCARAS O POESÍA SATÍRICA ${ }^{52}$}

8.1. A una dama señora, hermosa por lo rubio (POC, 854): "Allá vas, jacarandina..."

Blecua [1999: 1137]: "Posterior a 1607, en que Pablo Charguías establece el negocio de abastecer la nieve de Madrid. Véase James Crosby, opus cit., p. 107. No es propiamente una jácara, como verá el lector, pero González Salas la incluye en el grupo. Nosotros, por no deshacerlo, la hemos mantenido en este lugar."

IMPRESOS

Parnaso [Madrid, 1648: 351]; [Zaragoza, 1649: 253].

Romances varios [1655: 411], [1663: 25], [1664: 405].

52 "Jácaras" en los mss., que aparecen publicadas como poesía satírica en la ed. de Blecua [1999] o que éste considera romances (POC, 854). 


\subsection{Las cañas que jugó Su Majestad cuando vino el príncipe de Gales}

(POC, 677): "Contando estaba las cañas..."

MANUSCRITOS

BNE, ms. 3940, f. 63r.

Ms. de Rodríguez Moñino, f. 114r.

BMP, ms. 152, f. 124v.

IMPRESOS

Parnaso [Madrid, 1648: 368]; [Zaragoza, 1649: 265].

Romances varios [1643: 427]; [1648: 62]; [1664: 433].

8.3. Boda y acompañamiento del campo (POC, 683): "Don Repollo y doña Berza..."

\section{MANUSCRITOS}

BNE, ms. 2100. Poesías varias manuscriptas compuestas por diferentes autores. ff. 469r-470r: Jácara ridícula a las bodas de don Repollo y doña Berza. Cfr. Pérez Cuenca [1997] lo califica, al igual que Blecua, de romance.

Ms. CLXI de la Biblioteca de la Hispanic Society (Nueva York). Romances de D. Antonio de Mendoza. El poema 683 figura incompleto, con la nota "Véase lo demás en el Parnaso de Quevedo, cuyo es este romance". Ms. 3920. Tejuelo: Parnaso español 10. Antología con poemas de A. Hurtado de Mendoza, Céspedes, Miguel Cejudo, Góngora y otros. Letras distintas del siglo XVII, ff. 262-264.

IMPRESOS

Parnaso [Madrid, 1648: 486]; [Zaragoza, 1649: 381]. 
Primavera y flor de romances, de Arias Pérez (Madrid, 1621, p. 46).

\subsection{Segunda parte de "Marica en el Hospital" y primera en lo} ingenioso (POC, 695): "A Marica la Chupona..."

MANUSCRITO

BNE, ms. 3884. Poesías varias. Tomo I, f. 313.

IMPRESO

Parnaso [Madrid, 1648: 599]; [Zaragoza, 1649: 491].

8.5. Los borrachos (POC, 697): "Gobernando están el mundo..."

MANUSCRITOS

Cancionero de 1628, f. 407.

BNE, ms. 3885. Poesías varias castellanas. Tomo $2^{\circ}$, ff. 283-287.

IMPRESO

Parnaso [Madrid, 1648: 508]; [Zaragoza, 1649: 403].

8.6. (POC, 753) "Hagamos cuenta con pago..."

Señala Blecua [1999: 920]: "En el ms. "Del mismo. Otra." Pero no se trata de una jácara, sino del romance "Villodres con Guiràndaina" (Parnaso, 601), retocado según confiesa González Salas." Pérez Cuenca [1997], probablemente confundida por el ms., lo califica de jácara. De igual modo, procede John M. Hill en su estudio "Una jácara de Quevedo" [1928].

MANUSCRITOS

BNE, ms. 3797. [Poesías varias], ff. 239v-242. Cfr. Pérez Cuenca [1997].

${ }^{53}$ Ha de distinguirse del baile de título homónimo (POC, 873). 
BNE, ms. 3879. Cancionero, ff. 397r-399v.

8.7. La toma de Valles Ronces (POC, pp. 1273-1279): "Mala la hubisteis, franceses..."

Blecua lo publica en un Apéndice de su POC [1999: 1273]: "en tres mss. de la época (dos de don A. Rodríguez-Moñino y el XCIV de la BHSA, de NY, núm. 44) figura a nombre de Díaz Plantel." Sin embargo, por una anónima Relación de hacia 1636 se sabe que, además de la carta a Luis XIII, Quevedo escribió una jácara contra los franceses. Publicado por Janer [BAE, LXIX: 528-542].

MANUSCRITOS

BNE, ms. 3797. [Poesías varias], ff. 242r-245r. Cfr. Pérez Cuenca [1997].

BNE, ms. 3879. Cancionero, ff. 400r-402v. Presenta una ligera variante:

"Mala la hubisteis francés..."

BNE, ms. 4.066. [Poesías varias], ff. 2 y ss. Cfr. Blecua [1999: 1279].

RAE, ms. 29. [Poesías varias], ff. 2 y ss. Cfr. Blecua [1999: 1279].

\section{JÁCARAS: NUEVAS ATRIBUCIONES}

9.1. A los amores del rey don Rodrigo y la Cava. "Dos serafines hermosos..." 
MANUSCRITO

Biblioteca de la Universidad de Coimbra, ms. 324. Copia del siglo XVII, ff. $92 v-94 r$.

\section{BAILES DE ATRIBUCIÓN SEGURA}

10.1. Los valientes y tomajonas (POC, 865): "Todo se lo muque el tiempo..."Según Blecua [1999: 1177], es posterior a 1616, "por las alusiones a los bailes derivados del Escarramán".

MANUSCRITOS

BNE, ms. 3700. Poesías diversas, ff. 155r-156r.

BNE, ms. 3940. Obras de Quevedo. ff. 107r-111v.

IMPRESOS

Parnaso [Madrid, 1648: 374]; [Zaragoza, 1649: 272].

Romances varios [1643: 43], [1655: 46], [1663:74], [1664: 67].

Hill [1945: 236-237].

10.2. Las valentonas, y destreza (POC, 866): "Helas, helas por do vienen..."

MANUSCRITOS

BNE, ms. 3700. Poesías diversas, ff. 144-145.

BNE, ms. 3796. Tejuelo: Poesías manuescritas 2. Letras de distintas manos del siglo XVII, ff. 171r-172r. 
BNE, ms. 4117 [Papeles varios de poesía, prosa y teatro]. Letra del siglo XVII, ff. 287r-288r.

BNE, ms. 3940. Obras de Quevedo. f, 104v-107r.

BNE, ms. 14070/1. [Poesía], f. 1 (sin foliación, ms. sin encuadernar).

CXCV de la Biblioteca de la Hispanic Society (Nueva York). Baile de las valentonas y destreza, de Quevedo. Letra del primer tercio del siglo XVII, 4 pp. Cfr. Blecua [1999: I, 34].

IMPRESOS

Parnaso [Madrid, 1648: 377]; [Zaragoza, 1649: 274].

Romances varios [1643: 30], [1655:33], [1663:82], [1664: 35].

Hill [1945: 237].

10.3. Los galeotes (POC, 867): "Juan Redondo está en gurapas..." MANUSCRITOS

BNE, ms. 3940. Obras de Quevedo, f, 200. "Juan Redondo está en gurapa..." Cfr. Buendía [1960: 1145].

Ms. de la Biblioteca de Antonio Rodríguez Moñino, f. 134v.

IMPRESOS

Parnaso [Madrid, 1648: 380]; [Zaragoza, 1649: 276].

Romances varios [1663: 87].

10.4. Los sopones de Salamanca (POC, 868): "Un licenciado fregón..." MANUSCRITOS

BNE, ms. 3940. Obras de Quevedo, ff. 204r-205r.

Ms. de la Biblioteca de Antonio Rodríguez Moñino, f. 186. 
IMPRESOS

Parnaso [Madrid, 1648: 383]; [Zaragoza, 1649: 278].

Romances varios [1655: 464], [1663: 94], [1664: 460].

10.5. Cortes de los bailes (POC, 869): "Hoy la trompeta del juicio..." MANUSCRITO

Ms. de la Biblioteca de Antonio Rodríguez Moñino, f. 191.

IMPRESOS

Parnaso [Madrid, 1648: 385]; [Zaragoza, 1649: 280].

Romances varios [1663: 99].

10.6. Las sacadoras (POC, 870): "En los bailes de esta casa..."

MANUSCRITO

BNE, ms. 3700. Poesías diver., ff. 211v.-213.

Parnaso [Madrid, 1648: 388]; [Zaragoza, 1649: 282].

Romances varios [1663: 105].

10.7. Los nadadores (POC, 871): "El que cumple lo que manda..." IMPRESOS

Parnaso [Madrid, 1648: 390]; [Zaragoza, 1649: 284].

Romances varios [1663: 109].

10.8. Boda de pordioseros (POC, 872): "A las bodas de Merlo..."

A propósito de la tradición textual de este texto, véase el artículo de J.M. Blecua [1965: 78-97]. 


\section{MANUSCRITOS}

Ms. de la Biblioteca de Antonio Rodríguez Moñino, f. 159v.

BNE, ms. 3797, Poesías manuescritas 3, f. 289v. Ofrece la variante "A las bodas alegres..."

BNE, ms. 3940. Obras de Quevedo, ff. 134-136. Ofrece la variante "A las bodas alegres..."

BNE, ms. 4123. Bailes de Bernardo. Colección reunida por Bernardo López del Campo en el siglo XVII, ff. 65r-67r. En el ms. aparecen partituras, formas de baile y cambios de escena.

\section{IMPRESOS}

Parnaso [Madrid, 1648: 392]; [Zaragoza, 1649: 286].

Romances varios [1663: 115].

Verdores/ del Parnaso/ en veinte y seis entre-/ meses, bayles, y sainetes,/ de diversos autores./ Dedicados/ a Don Christoval de/ Ponte Llarena Xuarez y Fonseca, Maes-/ tre de Campo de la Milicia de la Islal de Tenerife./ Con privilegio./ En Madrid: por Domingo García Morrás, Im-/ pressor del Estado Eclesiastico de la Coro-/na de Castilla, y León, año/ de 1668. A costa de Domingo de Palacio y Villegas, vendesel en su casa frontero del Colegio de Atocha. Cfr. la edición de Rafael Benítez Clarós: Verdores del Parnaso. Madrid: CSIC, Instituto Miguel de Cervantes, 1969, pp. 159-166.

10.9. Los borrachos (POC, 873): "Echando chispas de vino..." IMPRESOS

Parnaso [Madrid, 1648: 394]; [Zaragoza, 1649: 288]. 
Romances varios [1663: 120].

10. 10. Las estafadoras (POC, 874): "Allá va con un sombrero..." MANUSCRITO

BNE, ms. 3940. Obras de Quevedo, ff. 239-240. Cfr. Buendía [1960: 1146]

IMPRESOS

Parnaso [Madrid, 1648: 396]; [Zaragoza, 1649: 289].

Romances varios [1655: 475], [1663:124], [1664: 473].

\section{BAILES POR CONSIGNAR}

\section{1. "Picarilla, Picarilla..."}

MANUSCRITO

BNE, ms. 17683. Tejuelo: Bailes. Con el sello de Pascual de Gayangos. Copias del XVII y XVIII en diferentes letras, ff. 56r- 57v.

11.2. Comedia de las dependencias de España. "Que predica mi musa ha muchos años..."

MANUSCRITO

BNE, ms. 17683. Tejuelo: Bailes. Con el sello de Pascual de Gayangos. Copias del XVII y XVIII en diferentes letras, ff. 8-9v. 


\section{EL CORPUS TEXTUAL: NÓMINA Y CRONOLOGÍA}

El catálogo de los testimonios manuscritos e impresos de Quevedo permite establecer una nómina de su obra dramática. Para datar los textos, en un principio opté por el método que S.G. Morley y C. Bruerton [1968] utilizaron para fechar el teatro de Lope de Vega, basado en criterios métricos. Este tipo de análisis permite establecer criterios de atribución y fijar las líneas de mutación y evolución de estilo del autor. ${ }^{54}$

No obstante, el corpus dramático disponible, sobre todo en el caso de las comedias (la mayoría inacabadas y de atribución por consignar), resulta demasiado escueto como para establecer conclusiones. Por ello, acudí a otros criterios internos de las obras -alusiones históricas o biográficas, indicios de representación- para fijar una cronología aproximada de las mismas.

\section{Comedias}

\subsection{Conservadas}

La mayoría de la crítica considera como limitados los aciertos de Quevedo en el terreno de la comedia. ¿Acaso su inclusión en la historiografía teatral se debe más a la fama del autor como genio lírico,

\footnotetext{
${ }^{54}$ Cfr. C.H. Rose [1991: 125-137], concretamente su artículo "On atributtion”.
} 
satírico y burlesco que al valor intrínseco de sus comedias? ${ }^{55}$ La nómina disponible es todavía muy reducida como para emitir este tipo de juicios de valor. El carácter palatino y por encargo de esta clase de obras condiciona su argumento, circunscrito a una realidad sociopolítica dominante y a un tono encomiástico poco enaltecido por el gusto estético contemporáneo.

Tan sólo contamos con una comedia acabada de la que Quevedo es autor indiscutible: Cómo ha de ser el privado. Aureliano Fernández Guerra, en su epístola inserta en el Catálogo de Barrera y Leirado [1860], daba noticia de un manuscrito del segundo tercio del siglo XVII que se había incluido en la colección de Ambrosio de la Cuesta y Saavedra y que, más tarde, fue incorporado a la biblioteca de Bartolomé José Gallardo. Éste lo anotó de su letra y se lo prestó a un sobrino suyo. Casi siete décadas después, el códice se localizó en la Biblioteca Menéndez Pelayo de Santander. El célebre manuscrito 108 fue editado por Miguel Artigas en la "Biblioteca selecta de Clásicos Españoles" de la RAE [1927].

Cómo ha de ser el privado constituye una tendenciosa apología del conde Duque de Olivares y, si bien su valor dramático es cuestionable, resulta interesante como documento historiográfico. ${ }^{56} \mathrm{Si}$ Fernández Guerra consideraba que la obra había de ser compuesta poco antes de 1628, Elliot ${ }^{57}$ la sitúa en 1629, rectificando, a su vez, la proposición de Artigas

\footnotetext{
55 Así lo afirma Cotarelo Valledor [1945].

56 Cfr. Luciana Gentilli [2004]. También véase S. Hernández Araico [1999: 201-234], R.
} Lida [1980: 159-179] y R. Iglesias [2005: 267-298].

${ }^{57}$ Cfr. J. H. Elliot [1982: 235] "the Infanta María was in fact married by proxy to the King of Hungary on 25 april 1629, and Quevedo may well have written the play for a palace performance during the marriage festivities." 


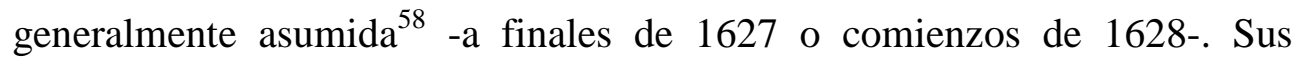
criterios de datación remiten a un hecho histórico: el matrimonio de la infanta María con el rey de Hungría, motivo que aparece en la comedia, fue en abril de 1629 .

En cuanto a si la comedia fue o no representada, hallamos diferentes pareceres. Armando Cotarelo [1945: 66] cree que no hay indicios de representación, "ni acaso haya subido nunca a la escena, pues los sucesos le quitaron actualidad prontamente y las persecuciones del autor enfriarían sus entusiasmos por ella y por el laudado". Sin embargo, consideramos, al igual que Elliot, que se pudo interpretar durante las nupcias de la Infanta. Tiene todos los números de ser una comedia por encargo. La obra debía responder a las feroces críticas contra el gobierno de Olivares y su manipulación del rey.

Cómo ha de ser el privado, a pesar de no aparecer en el catálogo de Shergold y Varey de representaciones palatinas entre 1603 y 1699, pudo tener impacto teatral dentro del espacio cortesano. ${ }^{59}$ La comedia se incluyó dentro de una lista de obras interpretadas en 1624, citada por Merimée. Desde la edición de Artigas [1927], se ha postulado que se representó en esa fecha y que fue años más tarde reelaborada. ${ }^{60}$

${ }^{58}$ Cfr. Urrutia [1982: 175], que da por hecho que la comedia fue redactada en 1627.

${ }^{59}$ Cfr. Susana Hernández Araico [1999: 462-469].

${ }^{60}$ Afirma Ignacio Arellano [1995: 435] que "es posible que el poeta rehiciera algunos pasajes: hay otras alusiones (al fracaso de los proyectos matrimoniales de la infanta con el Príncipe de Gales, etc.) que en 1628 serían ya pasadas y que más bien corresponden a 162324, fecha de una probable primera redacción." 
Pero Vázquez de Escamilla, por otra parte, es una comedia inacabada. También figura en el ms. 108 de la BMP de Santander, y fue editada por Miguel Artigas. Se define como "Representación española" y de ella sólo aparece el principio del primer acto, el fragmento correspondiente a una jácara inicial y una breve escena amorosa petrarquista. En el ms. se dice que el autor no la continuó.

Bajo circunstancias similares, hallamos el Fragmento de comedia, de la que tan sólo se conservan unas redondillas que apuntan hacia el tema de las preocupaciones matrimoniales.

Ambos textos dramáticos inacabados son demasiado escuetos como para establecer una datación convincente. No obstante, creo que pueden perfectamente situarse entre 1623 y 1628, durante el segundo periodo cortesano más claro de Quevedo, en el que nuestro autor estaba "integrado en el mundo de la urbe y el de la Corte", según nota Jauralde [1999: 490].

\subsection{Perdidas}

El abad don Juan Antonio de Tarsia, en la Biografía de nuestro autor (Madrid, 1663), afirma cómo Quevedo dejó una memoria autógrafa de sus papeles extraviados, entre los que se cifraban "algunas comedias de las cuales dos, viviendo el autor, se representaron con aplauso de todos".

En colaboración con Antonio Hurtado de Mendoza y Mateo Montero, Quevedo escribió una comedia de título desconocido mencionada en Avisos manuscritos archivados en la BNE y recogidos por Casiano Pellicer [ed. 
1975] en su Tratado histórico sobre el origen y progreso de la comedia y el histrionismo en España. Fue escrita por encargo del marqués de Eliche y de Toral, yerno del Conde-Duque. Se representó el 9 de junio de 1625 en el Real Palacio, en ocasión del cumpleaños de la reina Isabel de Borbón. ${ }^{61} \mathrm{La}$ interpretaron los ayudas de Cámara. La obra, según señala Pellicer, estaba llena de "muy donosos chistes", calificación que tal vez denote su carácter burlesco. $^{62}$

También sabemos, por el Tratado de Pellicer, que Quien más miente, medra más se estrenó en los jardines del Conde de Monterrey. Quevedo y Hurtado de Mendoza la compusieron en un solo día. Se estrenó en junio de 1631 para festejar la noche de San Juan. ${ }^{63}$ Según Mesonero Romanos, ${ }^{64}$ esta comedia pudo ser reelaborada en Los empeños del mentir de Antonio Hurtado de Mendoza, que se publicó en la colección Flor de las mejores doce comedias de los mayores ingenios de España (Madrid, 1662). ${ }^{65}$ Fernando Doménech [2002: 61 y ss.] ha respaldado esta hipótesis.

\footnotetext{
${ }^{61}$ Cfr. Barrera y Leirado [1860:313].

${ }^{62}$ Cfr. M. Vitse [1990: I, 595].

${ }^{63}$ A pesar de que en muchos catálogos se cita que el ms. 18717 de e la BNE existe una noticia de la representación de esta comedia en 1631, no logré encontrarla in situ. ¿Acaso se ha extraviado?

${ }^{64}$ Cfr. A. Hurtado de Mendoza, Los empeños del mentir, en Dramáticos contemporáneos a Lope de Vega. [1881]. Véase también la edición modernizada de Fernando Doménech, a propósito del estreno de la obra por la compañía José Estruch-RESAD en el XXIV Festival de Almagro (10 de julio de 2001): A. Hurtado de Mendoza y F. de Quevedo, Los empeños del mentir [2002].

${ }^{65}$ Véase el Catálogo de Barrera y Leirado [1860: 313].
} 


\subsection{ESPURIAS}

Si bien las piezas dramáticas atribuidas que hemos citado en nuestro Catálogo bibliográfico del teatro de Quevedo deben ser minuciosamente estudiadas para demostrar o rebatir la autoría de don Francisco, las que mentamos a continuación están fuera de toda duda y se pueden desechar definitivamente de la nómina, aunque anteriormente se vieron incluidas en ella.

Bien haya quien a los suyos parece (1622) es la comedia que, en cuanto a autoría, ha levantado más polémica. La confusión se produjo porque aparece inserta en el mismo códice manuscrito que Cómo ha de ser el privado, Pero Vázquez de Escamilla y el Fragmento. ${ }^{66}$ Se halla, concretamente, en los ff. 71r-137r ["Hacia esta parte cayó..."] del ms. 108 de la BMP.

El principal argumento para considerar que esta comedia no es de don Francisco es que, además de estar atribuida a un tal don Cernúsculo de Guzmán, al final de la misma se lee: "Acabóse en Toledo a 24 días del mes de abril de mil seiscientos y veintidós años. Don Luis Cernúsculo de Guzmán." Así lo señala el Catálogo de Barrera, a instancias de la carta de Fernández Guerra. ${ }^{67}$ La obra, de considerable estilo lopesco, no pudo ser

${ }^{66}$ Cfr. Madroñal [1991].

${ }^{67}$ Fernández Guerra [cfr. Barrera y Leirado, 1860: 313] argumenta lo siguiente: "Grande contradicción ofrece esta fecha, y el verse incluida la comedia en el libro como de Quevedo. Si es aquella exacta, hay que adicionar el catálogo de los autores dramáticos con el nombre de un nuevo poeta, desconocido hasta ahora, a no suponer que este autor sea don Luis de Guzmán, a quien se atribuye El feudo de las cien Doncellas. El día 24 de abril hallábase en Villanueva de los Infantes Quevedo, teniendo la población por cárcel; y tan 
escrita en 1622 por Quevedo, dado que el autor estaba preso y gravemente enfermo en Villanueva de los Infantes.

Miguel Artigas [1927: 117-230], sin embargo, editó Bien haya quien a los suyos parece como de Quevedo. En su "Introducción", contradice los argumentos del Catálogo de Barrera y considera que Cernúsculo no es más que un pseudónimo de don Francisco. Dado que el ms. señala que la comedia está escrita en Toledo, Artigas cree que Quevedo pudo desasirse de su destierro carcelario en Villanueva de los Infantes y hacer una escapada a esta ciudad para sus negocios. El crítico justifica el estilo lopesco aludiendo a la amistad y buena correspondencia existente entre el Fénix y Quevedo. Señala vetas satírico-burlescas propias del mismo en los parlamentos de Merlín y múltiples concordancias con los Sueños. ${ }^{68}$

falto de salud que se temía por su vida. Mal pudo concluir, pues, en Toledo ninguna obra. Además, el estilo de la presente corresponde a la escuela de Lope de Vega, y desdice de los varios que tuvo nuestro don Francisco. Hay rasgos, sin embargo, y caracteres en la comedia muy recomendables. Sirvan de muestra los propósitos del criado Merlín para hacer figura en la corte (...). No obstante lo que va manifestando acerca de esta pieza dramática, debemos recordar que el códice donde se baila, se compone todo de obras inéditas de Quevedo, y advertir al mismo tiempo que el biógrafo Tarsia indicó haber sido representadas con grande aplauso dos de sus comedias en vida del eminente escritor." A su vez, señala Armando Cotarelo [1945: 69]: "Pieza en tres actos, contenida en el manuscrito de Gallardo, donde están las anteriores, por lo cual fue publicada por Artigas como de D. Francisco, según entendía también D. Aureliano. Pero no tiene nada de nuestro polígrafo. Está firmada en Toledo, a 24 de abril de 1522, por Don Luis Cernúsculo de Guzmán, poeta de quien dió noticias Ramírez de Arellano en el Boletín de la Real Academia de Bellas Artes y Ciencias históricas de Toledo (octubre de 1919)."

${ }^{68}$ Cfr. Miguel Artigas [1927: LIII-LXVII]. 
Blecua [1981:14], por suerte, nos saca de dudas. Reconoce el refinado sentido crítico de don Aureliano y añade a sus premisas la noticia de la existencia real de Cernúsculo de Guzmán, que descartaría definitivamente esta comedia de la nómina dramática de don Francisco. ${ }^{69}$

Asimismo, son obras espurias El mejor Rey de Borgoña, de don Juan de Quevedo y Arjona, atribuida a don Francisco en el texto original de la Biblioteca de Osuna y que posee otro testimonio, esta vez con el nombre verdadero del autor, en la BNE; y El castigo de la culpa, asignada por don Basilio Sebastián Castellanos (Obras de Quevedo, VI, 355), probablemente por confusión con la comedia Hacer gloria de la culpa, del mentado Quevedo de Arjona.

Cotarelo Valledor también atribuye a nuestro autor El retraído, sátira dramática no representable de Juan de Jáuregui, donde éste hace una escenificación jocosa de La cuna y la sepultura (1634) de Quevedo. Es curioso cómo durante un tiempo algunos eruditos pudieron pensar que don Francisco se parodiaba a sí mismo con esta obrilla, firmada por el pseudónimo $D$. Claudo, que es una alusión a nuestro autor y significa etimológicamente "cojo". ${ }^{70}$

69 "Aunque don Aureliano ignoraba la existencia real de Cernúsculo de Guzmán, afinó su sentido crítico para rechazar esa comedia." Para conocer más datos acerca del autor, véase A. Madroñal Durán [1991: 183-194].

${ }^{70}$ Cfr. J. Matas Caballero, Juan de Jáuregui. Poesía y poética [1990]. 


\subsection{NUEVAS ATRIBUCIONES}

En la búsqueda directa de los testimonios, se presentaron algunas novedades inéditas. Germán Vega, descubridor de La privanza desleal y voluntad por la fama, ${ }^{71}$ fue muy amable al indicarme la signatura del impreso de la comedia, ubicada en cajas sin catalogar de la BNE.

Me extrañó que no hubiera publicado la comedia: tras leerla, supe por qué. De escaso valor literario, afronta el tema del valimiento desde una perspectiva muy poco quevedesca. La incluí en la edición de Teatro inédito atribuido a Quevedo por mantener cierto rigor científico y porque tal vez su escritura despersonalizada se deba a su carácter por encargo o a una posible coautoría.

Es una comedia en verdad sui generis: el tema de la privanza se ve desplazado por una compleja maraña de triángulos amorosos expresados en una mal llevada imaginería petrarquista. Aunque la temática es poco ortodoxa, el encorsetamiento lingüístico de sus personajes no muestra, ni por asomo, la grandeza verbal de don Francisco. La comedia, que ya aparece en los índices de Fajardo y de Durán, probablemente sea anterior a 1625.

Por otra parte, en el fondo Sedó del IT figura una comedia inédita y nunca recogida en la nómina de la obra dramática de nuestro autor: la Comedia famosa del galán fantasma (ms. de la vitrina A, Estante 5), cuya copia manuscrita es de 1637 y que se representó hacia 1640. La comedia, cribada por el célebre censor Navarro de Espinosa, tiene múltiples borrones

\footnotetext{
${ }^{71}$ Véase su reseña del descubrimiento: Germán Vega [1993:109-121].
} 
y pasajes tachados y el ductus de tres copistas distintos del siglo XVII. Es una clásica comedia de enredo que entraña, sin embargo, una pequeña peculiaridad: el gracioso tiene una dicción sumamente quevedesca, un protagonismo superior al de los arquetípicos criados de comedia. Al final de la obra, como aconsejaba doña Fáfula a su marido comediante en $E l$ sueño de la muerte, sale soltero, contraviniendo al tópico de los desenlaces en boda.

No ha sido publicada hasta ahora por dos motivos: primero, porque cuando Blecua editó el teatro de Quevedo, este manuscrito pertenecía a la biblioteca privada de Arturo Sedó (y, pese a que consultó sus fondos, probablemente no contaba con la misma libertad investigadora que ofrece una biblioteca pública) y debido a un error de catalogación, a todas luces inducido por el título, que se presta a confusión con el Entremés del marido pantasma e incluso hace pensar en la comedia homónima de Calderón, cuyo contenido es claramente distinto. Hay algo que nos induce a pensar que debería circular una versión impresa de la obra, dado que "famosa" era el calificativo que se le daba a toda comedia que llegaba a imprimirse, tuviera o no éxito. ${ }^{72}$ Sea como fuere, no hemos conseguido dar con esa publicación. ¿Fue acaso objetivo de la Inquisición por su ataque jocoso a la institución del matrimonio en boca del pícaro Gorrión? ¿Podría corresponderse con la comedia sin título y perdida de 1625 a la que se alude en el Catálogo de Barrera? Más adelante, analizaremos esta posibilidad.

\footnotetext{
${ }^{72}$ Cfr. Lola Josa en su edición de El burlador de Sevilla y convidado de piedra [2003: 109].
} 


\section{EL TEATRO BREVE}

El teatro breve de Quevedo comparte con su poesía satírica el estilo impetuoso y desaforado, la agudeza conceptista y la frescura popular. Sus entremeses, comedias burlescas, jácaras y bailes constituyen un retablo de figuras grotescas tópicas en la literatura festiva, auténticos cuadros costumbristas que con artificio carnavalesco caricaturizan la bajeza moral de fantoches y pícaros. ${ }^{73}$

\subsection{ENTREMESES}

Se han conservado los siguientes entremeses de segura atribución: Niño y Peralvillo de Madrid, La Ropavejera, El marido pantasma, La venta, El marión y El zurdo alanceador (también titulado Los enfadosos). Blecua acepta con mayor reserva Los refranes del viejo celoso, de ascendencia cervantina y prefigurador de la mojiganga. A ellos, añade Sabor de Cortázar [1987: 155] El caballero de la Tenaza, que Blecua considera espurio. Bergman [1975: 376-397] señala, a su vez, lo arbitrario y caprichoso que ha resultado considerar el entremés de Las sombras como una refundición de Los refranes del viejo celoso, tratándose a todas luces de una obra anterior, más primitiva, clara dramatización del Sueño de la muerte de Quevedo. La autora retoma las reservas de Blecua y lanza como hipótesis que Los

\footnotetext{
${ }^{73}$ Cfr. E. Cotarelo y Mori [2000], G. Mancini [1955].
} 
refranes pertenece a la pluma de Quiñones de Benavente, el autor entremesil que ha investigado con más tesón.

El bibliófilo Crosby [1937] consideró en su día que los manuscritos que antaño fueron de su propiedad y que vendió en 1981 a la Hispanic Society, testimonios únicos de Los refranes del viejo celoso y El hospital de los malcasados, eran autógrafos. No obstante, tras analizar las copias digitalizadas de los mismos y cotejarla con otros autógrafos del autor, creo que, definitivamente, no son originales de la mano de don Francisco, según ya sospechó Blecua.

A la lista deben añadirse los entremeses que Eugenio Asensio [1965: 259264] encontró en el manuscrito de la Biblioteca Pública de Évora (Cod. CXIV/1-3) y cuya trascripción editó como apéndice de su estudio sobre el teatro breve barroco Itinerario del entremés. Nos referimos a Doña Bárbara, Diego Moreno, La destreza, La polilla de Madrid y La vieja Muñatones.

Los tradicionalmente calificados como entremeses apócrifos -El muerto, el médico y Las sombras- aparecen en Entremeses nuevos de diversos autores, libro impreso por Francisco Ropero (Alcalá de Henares, 1643). Estos, junto con La endemoniada fingida y chistes de Bacallao, de todavía más confusa procedencia, hallaron cabida en la Biblioteca de Autores Españoles, de Rivadeneira [1953: III, 501:525], pero no en El Parnaso Español ni Las tres musas últimas castellanas.

A los antedichos entremeses se suman otros tantos perdidos. Caraquí me voy aparece mentado en el Tribunal de la justa venganza y caracterizado 
como "friísimo". ${ }^{74}$ Fue bastante célebre, según denota el poema Letra de donaire acomodada al estribillo, el cual cantaba una dama con mucha gracia de los Favores de las musas (Milán, 1631) de Francisco Medrano:

\footnotetext{
Caraquí, caraquí, caracoles

que la vida mata de amores.

Caraquí que sale el alba,

pues es el alba Leonor,

a quien una y otra flor

con las aves hace salva.

De entre la hiedra y la malva

salid a ver su beldad,

y en su esplendor admirad

cifrado el sol en dos soles.

Caraquí, caraquí caracoles,

que la vida mata de amores.
}

También es probable que dicho estribillo, aducido por Felicidad Buendía $^{75}$, se inspirase en un cantarcillo popular. La esperanza de encontrar este entremés extraviado se afianza en el hallazgo de Asensio. Recordemos que veinte años antes de su Itinerario del entremés, Armando Cotarelo [1945: 72] daba como perdido un entremés "con nombre o asunto de Diego Moreno, según pudiera deducirse de la alusión, algo oscura, inserta al final del Sueño de la muerte" y que Asensio logró encontrar en el manuscrito evorense.

\footnotetext{
${ }^{74}$ Cfr. Barrera y Leirado [1860], Blecua [1981: 10].

${ }^{75}$ Cit. de Buendía [1960: 1359].
} 
Dentro de la nómina de entremeses perdidos, por último, quisiera aludir a un supuesto documento que ha dado más de un quebradero de cabeza a los investigadores. Nos referimos al Códice Candamo, un sospechoso manuscrito londinense que aparece citado en el Catálogo [1860] de Barrera y Leirado. En éste, figuraría un entremés inédito de Quevedo titulado Los enjuagues de Lavapiés. Las dudas aparecen cuando corroboramos que lo menciona Cotarelo y Mori en sus anotaciones sobre "Bibliografía. Notas" del teatro de Quevedo, en el ms. 47178 del IT de Barcelona.

¿Dónde encontrar el Códice Candamo?¿Cómo ubicar esta hipotética pieza inédita? Con esta cuestión en ciernes, escribí un correo a Pablo Jauralde Pou que, diligente, me expuso lo que se sabe del asunto y su hipótesis al respecto. $^{76}$

Según Jauralde, el Códice Candamo fue un invento de Castellanos, en el siglo XIX. Existe una caja en la BNE con sus papeles, que examinó y analizó Isabel Pérez Cuenca (cfr. Edad de Oro, XIII, 1994). De estos documentos se deduce que él había visto un manuscrito con cosas de Quevedo y que dicho manuscrito había terminado en Londres, que por su poseedor se llamaba "de Candamo" (estamos a mediados del siglo XIX). Pero todas las noticias que Castellanos dice haber leído en ese manuscrito resultan casi siempre falsas, lo que es fácil de demostrar en la mayoría de los casos. Por esta razón, Jauralde deduce que este códice, del que no existe ninguna otra noticia y que nadie ha visto nunca, fue una ficción de Castellanos, que tenía una cierta propensión a inventarse datos eruditos que

\footnotetext{
${ }^{76}$ Los datos que menciono a continuación, proceden de un correo que me escribió Pablo Jauralde el 19 de enero de 2009.
} 
él pensaba que nadie iba a saber encontrar nunca. Por aquella época, Gayangos era el agente de la British Library en España y compraba muchas cosas para llevarlas allá; pero Gayangos tampoco supo nunca nada de ese códice. $^{77}$

Efectivamente, Isabel Pérez Cuenca catalogó y analizó los papeles de este curioso erudito del XIX, que entremezcla datos auténticos con supercherías de su propia invención. Sorprende, en la actualidad, el escaso rigor científico sobre el que se han sustentado muchas de las ediciones y estudios literarios anteriores a la segunda mitad del siglo XX. De ahí la importancia de que el futuro investigador no dude en revisar los datos aducidos por sus predecesores.

Grosso modo, podemos situar los entremeses de Quevedo entre la producción dramática menor de Cervantes y la de Quiñones de Benavente. Antes del descubrimiento de las composiciones en prosa, Astrana Marín [1932] escalonaba las piezas entre 1619 (El caballero de la Tenaza) y 1624 (Los refranes del viejo celoso), basándose tan sólo en alusiones internas. No obstante, en su biografía La vida turbulenta de Quevedo [1998: 358-359], rectifica lo caprichoso de su datación y señala que la obra dramática de don Francisco se inició con las jácaras y tomó consistencia en 1624 con la

${ }^{77}$ Cfr. Jauralde [1999: 187n, 338n]. 
composición de una comedia por encargo, a lo que siguieron otras jácaras, diálogos y entremeses de ascendencia cervantina.

Sólo de dos entremeses se pueden conjeturar fechas aproximadas: el Niño y Peralvillo de Madrid y El zurdo alanceador.

En el Niño y Peralvillo de Madrid, los fragmentos alusivos a la representación del Anticristo, la comedia de Juan Ruiz de Alarcón, inducen a Cotarelo Valledor a datar el entremés sobre 1618:

Hay en la obrilla una acerada burla al estreno del Anticristo, comedia de Alarcón, silbada por la ruindad de sus émulos. En el mismo pasaje se recuerda la aventura del "autor" Diego Vallejo, quien, debiendo volar por una maroma, no se atrevió a hacerlo y voló por él Luisa de Robles, con mucha destreza. Estos detalles fechan el entremés en 1618.

Diego Vallejo fue padre de Manuel Vallejo, "autor de título" y comediante notable. Luisa de Robles tuvo novelesca historia no bien esclarecida. Parece que, casada con Juan de Labadía y después con el famoso Alonso de Olmedo, regresó su primer marido, que se daba por muerto, deshaciéndose el segundo matrimonio. Era buena actriz y figuró en varias compañías. [1945: 75-76]

Asensio [1965: 233-234], sin embargo, la sitúa en torno a 1622, dado que el recuerdo del Anticristo duró más de un año (y no será la única pulla quevedesca hacia Alarcón) y porque en dicha fecha se separaron los dos hermanos Juan Bautista y Juan Jerónimo Valenciano, como remarcan los versos siguientes: 


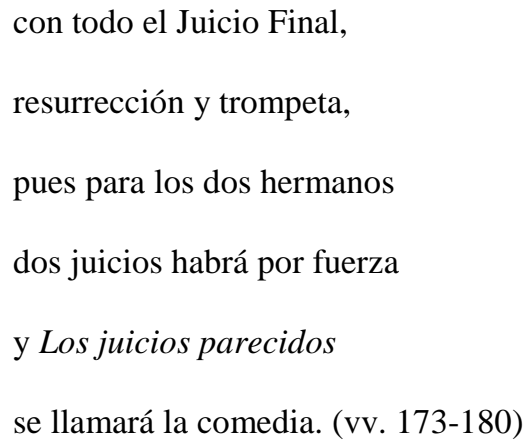

Entre los nombres de los actores expuestos al escarnio en el rollo del Peralvillo destaca Cosme Pérez, in situ denominado Cosme-Alvillo, el futuro y célebre Juan Rana. Al parecer, en 1622 figuraba en la compañía de Juan Bautista y representó La nueva victoria de don Gonzalo de Córdoba de Lope. En el reparto, asimismo, aparecen Manuela y Ana, que hacia el desenlace del entremés importunan al Niño.

Sobre El zurdo alanceador, sabemos que lo representó Amarilis en Sevilla, en 1624. Esta fecha coincide con una expedición de Felipe IV a Andalucía, entre cuya comitiva figuraba nuestro Quevedo.

En el margen izquierdo del entremés de La polilla de Madrid reproducido en el ms. de Évora aparece el nombre de los actores de la compañía Morales Medrano, de cuya nómina formaban parte en 1624, que representaron a los dos protagonistas: Francisco Robles con el papel de Carralero e Isabel Ana como Elena. Este hecho nos induce a datar el entremés sobre dicho año.

Por otra parte, Astrana Marín fecha arbitrariamente el entremés de $L a$ venta en 1622. Armando Cotarelo [1945:78] retoma su datación, si bien aludiendo a circunstancias de representación: "El autor Guevara aquí citado puede ser Juan de Guevara o Pedro Cerezo de Guevara, recitantes por los 
años 1614-16, aunque no consta que ninguno formase compañía. Suponesele de 1622." Asensio considera que la técnica refleja la transición del paso al verso, dado que todavía el verso es uniforme pese a las convenciones lopescas. Asimismo, sostiene que la alusión a la compañía de Guevara situaría la fecha entre 1616 y $1619 .^{78}$

Ni la cronología ni la influencia de Cervantes, pese a las reminiscencias de Los refranes del viejo celoso, satisfacen a Asensio [1965: 198], que aporta nuevos entremeses a la nómina y, por lo tanto, dilata el arco de la creación dramática breve de don Francisco. Éste propone nuevos criterios para fechar: a las alusiones internas añade datos históricos de representación y la fecha límite del entremés en prosa, desaparecido entre 1618 y 1620 . El crítico considera que los textos dramáticos de Quevedo pueden datarse entre 1613 y 1631. Durante estos años, entre los 33 y los 51 de vida de nuestro autor, éste publicó el Buscón, la primera parte de la Política de Dios, los Sueños y La cuna y la sepultura, entre otras obras.

Los cinco entremeses escritos en prosa pueden fecharse entre 1606 y 1613 (Doña Bárbara, Diego Moreno -con sus respectivas segundas partes- y La vieja Muñatones) y, los compuestos en verso (el resto), entre $1623 \mathrm{y}$ 1627, periodo que precede a la composición de los entremeses de Quiñones de Benavente, como notó agudamente Eugenio Asensio [1965], desmintiendo la tesis de Armando Cotarelo [1945].

Blecua [1981] fecha los entremeses amparándose en las conjeturas de Asensio. Jauralde [1999: 490-491] matiza que los límites de ambos

${ }^{78}$ Cfr. C. Pérez Pastor [1901: 160], F. Rodríguez Marín [1914: 339-340]; Varey y Shergold [1985]. 
periodos de composición entremesil están acotados por dos circunstancias de la vida de Quevedo: el viaje a Italia de 1613, con el consiguiente inicio de su periodo diplomático; y 1627-1628, cuando don Francisco se enmaraña en grandes polémicas políticas y literarias.

\subsection{JÁCARAS}

Las jácaras son composiciones que, sujetas siempre al orden lógico de planteamiento, nudo y desenlace, consisten en una narración lineal de sucesos relacionados con el mundo de la corrupción o del hampa. Quevedo ha sido tradicionalmente considerado el artífice de este género literario y uno de los modelos principales de las composiciones de raigambre germanesca, ${ }^{79}$ tras el notable éxito mediático que ganó su Jácara de Escarramán (POC, 849), que hacia el año 1613 ya circulaba como pliego suelto, según un antiguo impreso que, al parecer, figuraba en la biblioteca de don Luis Valdés. ${ }^{80}$

En 1636, se publica la primera edición zaragozana de la Primavera y flor de los mejores romances del licenciado Pedro Arias Pérez, que incluye la jácara Añasco el de Talavera (POC, 857). ${ }^{81}$

\footnotetext{
${ }^{79}$ Así lo constata la edición de John M. Hill [1945], que ofrece variantes de las jácaras 849 $855,857,861,862,865$ y 866 .

${ }^{80}$ Véase Astrana Marín [1932: 215]. Blecua [1999: I, 40] asegura no haberlo encontrado.

81 Según ha documentado Chevalier [1992: 141].
} 
A su vez, cinco años antes de la muerte del escritor, se editan cuatro jácaras suyas (POC: 855, 856, 857, 861) en la colección de Romances varios de 1640, entre unas dieciséis de Jerónimo de Cáncer y Velasco. ${ }^{82}$

Tres años más tarde, en la antología de 1643, además de los mentados títulos, se imprime la pareja de jácaras de corte epistolar entre el bravo Lampuga y su coima la Perala (POC: 851, 852).

En los Romances varios de 1648, a las ya citadas cuatro jácaras que aparecían en todas las colecciones (POC: $855,856,857,861)$, se suma la célebre Jácara de Escarramán (POC, 849), que principia la narración de las hazañas del más célebre jayán quevedesco.

El influjo de este tipo de poesía satírica se incrementa tras la edición póstuma del Parnaso por parte de González de Salas en 1648, que publica las jácaras 850-862. Éstas se reeditan en la edición zaragozana de 1649. A lo largo del siglo XVII, las colecciones de Romances varios continúan atesorando un notable éxito editorial: en las de 1655 y 1663 ya aparecen 14 jácaras -de la 849 a la 862- que respetan el orden que les dio Salas en el Parnaso. En la edición de 1664 no se incluyen, sin embargo, las jácaras 851, 852 y 861.

Pero esta difusión a través del Parnaso y de los Romances varios no tiene por qué significar que las jácaras de Quevedo tuvieran un particular éxito editorial, dado que no ocupan en la producción impresa un lugar tan destacado como las Obras (1651) de Cáncer y Velasco, las Poesías varias

\footnotetext{
${ }^{82}$ A pesar de que la edición zaragozana de 1640 es la primera conservada, Chevalier considera que la primera edición de esta colección de romances sale, verosímilmente a la luz, en 1635 o 1636.
} 
(1654) de Alfay, o una serie de pliegos sueltos que se imprimen entre 1650 y 1660. En efecto, en la antología de Alfay no se incluye ninguna jácara de Quevedo, ni en los pliegos sueltos jacarandos que estudia J. M. Hill y que compila en su volumen de Poesías germanescas.

Las obras de mayor calidad literaria no son forzosamente las que más lectores tienen. Las jácaras de Quevedo cuentan con las mismas ediciones que otras composiciones tan mediocres como Cante la fama mi nombre (Romances varios, $\left.\mathrm{n}^{\circ} 1\right)$ o Cercado de belleguines (Romances varios, $\mathrm{n}^{\circ}$ 16). ${ }^{83}$ Ignoramos hasta qué punto han sido perseguidas y censuradas las jácaras de don Francisco respecto de otras piezas de menor repercusión literaria.

Los testimonios manuscritos de las jácaras son ingratos para el investigador que, al igual que los bailes, suelen aparecer anónimas en anárquicas misceláneas, con multiplicidad de variantes.

Gracias al ms. 3700 de la BNE, hemos recuperado la Jácara de la venta (POC, 863), que no aparece en las ediciones impresas. El ms. 3773, posterior a 1638 como implica la trascripción del certamen del Buen Retiro, recoge cinco jácaras más (POC: $851,852,854,855,856) .{ }^{84}$ El ms. 3795, primer tomo de Poesías manuescritas de Tejuelo, contiene las jácaras 849 y
\end{abstract}

\footnotetext{
${ }^{83}$ Como bien nota Chevalier [1992: 142].

${ }^{84}$ El códice no contiene los poemas 854, 857 y 858. Corregimos el error de Blecua [1999: I, 5], que por falta de revisión repite M.J. Alonso [2005: 219]. Cfr. Pérez Cuenca [1997].
} 
857; el ms. 3797, tercer tomo de la misma serie, las composiciones 861,862 y $858 .{ }^{85}$ El ms. 3940, los poemas $849-852,856-857$. Son, además, abundantes los códices que presentan una sola jácara de Quevedo: en la miscelánea 3811 figura, a título de romance, la jácara 856; en el ms. 3884 de la BNE, entre versos de diferentes autores, se incluye la 861; en los mss. 3920 y 19387, la 849; en el 17717, la 857.

Más testimonios de jácaras únicas aparecen en los mss. de la Biblioteca Menéndez Pelayo de Santander. En el célebre ms. 108 -códice único de las comedias de Quevedo- encontramos la jácara 864, que también se incluye en el ms. 142 y en un ms. de la biblioteca particular de don Luis Valdés (una copia de Gallardo, probablemente del ms. 108). En el ms. 152, asimismo, entre obras de Villamediana, Lope de Vega y Baltasar de Zúñiga, al igual que en el ms. de la biblioteca particular de Rodríguez Moñino ${ }^{86}$, se incluye la jácara 857. En la Biblioteca de la Hispanic Society de Nueva York hallamos, también aislados, el poema 856 (ms. XVI) y el 861 (ms. LXXXIV).

Con todo, hay un pequeño inconveniente a la hora de fijar la nómina de las jácaras de Quevedo, y tiene que ver con la delimitación del género al que pertenecen. Algunos testimonios incluyen composiciones denominadas "xácaras" y, en cambio, Blecua no las editó como tales, sino como romances satíricos. Este es el caso del poema Las cañas que jugó su Majestad cuando vino el Príncipe de Gales (POC, 677), que aparece como jácara XVI en el

\footnotetext{
${ }^{85}$ No hay rastro del poema 860 en dicho manuscrito. Es, pues, otro error de Blecua [1999:

I, 6]. Cfr. Pérez Cuenca [1997].

${ }^{86}$ Cfr. Blecua [1999: I, 35].
} 
Parnaso; la composición Boda y acompañamiento de campo (POC, 683), que figura en el ms. 2100 de la BNE como "jácara ridícula"; el romance Segunda parte de "Marica en el Hospital" y primera en lo ingenioso (POC, 695) , Los borrachos (POC, 697) y el romance que empieza "Hagamos cuenta con pago" (POC, 753). Mención aparte merece La toma de Valles Ronces, que Blecua publicó en un apéndice de su edición. ${ }^{87} \mathrm{La}$ composición, atribuida en tres mss. (dos de don A. Rodríguez-Moñino y el XCIV de la BHSA, de NY, núm. 44) a un tal Díez Plantel, tiene como epígrafe "Jácara al mal francés". Blecua está convencido de la paternidad quevedesca de esta composición, ante todo por las confluencias temáticas y retóricas con el resto de su obra, que fue a todas luces cantada y recitada por la calle.

La cronología de las jácaras sólo puede fijarse de una manera difusa. ${ }^{88} \mathrm{La}$ composición 849 es anterior a 1612, dado que en este año ya estaba transfigurada "a lo divino" y, en 1613, circula en forma de pliego suelto. ${ }^{89}$ La respuesta de la Méndez $(P O C, 850)$, acaso por su contigüidad temática respecto de la anterior, podría situarse sobre las mismas fechas.

Acerca de la versión del poema 849 del ms. 19387 existe una interesante aproximación textual de Margarita Peña [1992]. La autora señala que este códice, titulado "Cartapacio de diferentes versos a diversos asuntos por el

\footnotetext{
${ }^{87}$ Cfr. Blecua [1999: III, 455-493].

${ }^{88}$ Cfr. M.J. Alonso [2005: 219-221].

${ }^{89}$ Sobre las recreaciones de la figura de Escarramán, véase el monográfico La tradición escarramanesca en el teatro del Siglo de Oro de E. Pinto [2005].
} 
año 1598 y los siguientes", pudo haber sido compilado en tierra americana por Mateo Rosas de Oquendo, aventurero, criado de virrey y escritor que se ha considerado uno de los primeros mexicanos. La presencia de la jácara en el mentado manuscrito, le induce a la siguiente reflexión cronológica:

¿habrá traído Oquendo consigo la jácara cuando se embarcó, antes de 1598, para América? Esta suposición cae por sí sola en primera instancia. Astrana Marín ubica la fecha de composición de lo que él llama "celebérrima jácara" entre 1611 y 1612 [...] Así, se plantean dos hipótesis respecto a las condiciones en que el poema pasó a formar parte del manuscrito: una que la jácara haya atravesado el océano apenas salida de la pluma de Quevedo para encontrar su lugar en el cartapacio de Oquendo; otra, que la última parte del citado cancionero se haya integrado en España, asimilando, así, la exitosa composición de Quevedo. [1992: 52]

La celebridad de la jácara en las Indias puede inducirse, además, del pasaje del entremés del Rufián viudo de Cervantes donde, a propósito de Escarramán, se dice "han pasado a las indias tus palmeos". 90

Para la jácara 854 , la datación se fija como posterior a 1607, dado que alude al empresario Pablo Charquías y ese es el año en que montó el negocio de abastecimiento de nieve en Madrid: ${ }^{91}$

\section{A la rubia de aventuras,}

la que se peina bochornos, de cuyas manos Charquías llena de nieve sus pozos. (vv. 17-20)

\footnotetext{
${ }^{90}$ Véase la ed. de Miguel Herrero García [1952: 53].

${ }^{91}$ Cfr. Blecua [1999: 291], Crosby [1967: 107-108].
} 
La jácara 856, puesto que alude en algunas de sus variantes a las Soledades de Góngora (mss. 3940, 3773, 3811 de la BNE y XVI de la BHSA), ha de ser posterior a 1613, época en la que empezó a circular la primera de las dos que don Luis llegó a componer. El autor alude a ellas en singular-Soledad-, y el hecho de que todavía no estuviera escrita la segunda de las Soledades, nos hace redundar en esta fecha. También será, asimismo, posterior al 4 de febrero de 1623, año en que Felipe IV prohibió la existencia de mancebías o casas públicas en las ciudades y villas del reino, porque los siguientes vv. aluden a su cierre:

\author{
A las hembras de la caja, \\ si con la expulsión fatal \\ la desventurada corte \\ no ha acabado de enviudar. (vv. 177-180)
}

La jácara 857 cuenta con el mismo dato para ser fechada: va precedida por el epígrafe Sentimiento de un jaque por ver cerrada la mancebía y versa sobre la melancolía del jaque al ver "cerrada la manfla,/ con telaraña el postigo" (vv. 37-38).

Otro dato poco preciso sirve para situar en el tiempo la jácara 858: la presencia del tabernero Juan Lepre, que tal vez falleció el 23 de diciembre de 1634, según una nota que pasó Asenjo Barbieri a Janer. ${ }^{92}$

Tan sólo cabe añadir que las jácaras 851, 852, 854, 855, 856, 857 y 858 se recogieron en el ms. 3773 de la BNE, que es posterior a 1638 por copiar

\footnotetext{
${ }^{92}$ Cfr. Blecua [1999: III, 328].
} 
el certamen del Buen Retiro. Por lo tanto, todas ellas fueron compuestas con anterioridad a esta fecha límite.

\subsection{BAILES}

En la primera edición del Parnaso (1648) se publican casi todos los bailes hasta hoy atribuidos a Quevedo (POC: 865-874). Estos vuelven a imprimirse en 1649. Los dos primeros bailes aparecen, asimismo, en Romances varios (1643), editado en Zaragoza por Pedro Lanaja.

La colección de romances de 1655 incluye los bailes 865, 866, 868 y 874; repertorio que se repite en la selección de 1664. La impresión zaragozana de 1663 recoge todas las composiciones citadas excepto el Baile de los pordioseros (POC, 872). Este baile aquí excluido, curiosamente, es el único que se compila en los Verdores del Parnaso de $1668 .{ }^{93}$

En el ms. 3700 de la BNE figuran los bailes 865, 866 y 870. En el ms. 3796, segundo tomo de Poesías manuescritas [sic.] de Tejero, reaparece el 866; y en el ms. 3797, tercer volumen de la misma serie, figura el poema 872, si bien con notables variantes. En el ms. 3940 de la BNE se hallan los bailes $865-868,872$ y 874 . En el códice 4117 , junto con poemas de Cairasco, Góngora, Lope y el Conde de Salinas, aparece el baile 866. Y en

${ }^{93}$ Sobre la transmisión textual de este baile, es indispensable el artículo que publicó Blecua [1965: 79-97] en la Revista Hispánica Moderna, que ejemplifica las múltiples variantes a las que está sometida este tipo de literatura. 
el hermoso ms. 4123, que contiene exclusivamente Bailes de Bernardo, junto con algunas partituras musicales, figura el baile 872 .

Ya en la Biblioteca de la Hispanic Society, aparece como pieza única de unos pliegos sueltos el baile de Las valentonas, y destreza (POC, 866), junto con algunas indicaciones en cifra para los músicos. En el ms. de la Biblioteca de Rodríguez Moñino figuran los bailes 867-869 y 872 .

La fecha de composición de los bailes parece posterior a la de las jácaras, dado que no figuran en los testimonios más tempranos de la poesía de Quevedo y a menudo hacen referencia a personajes o motivos de las mismas. Así pues, los bailes 865 y 867 son posteriores a 1613, porque mencionan a Escarramán como a un jaque anciano "con sus canas,/ con sus nietos y biznietos" (vv. 98-99). Lo mismo sucede con el baile 869, donde encontramos intertextualidades con las jácaras 849 y 863: funde pasajes del intercambio epistolar entre Escarramán y la Méndez y modifica el arranque de la Jácara de la venta. Y también el baile 870 alude a este jayán ya decadente:

Allá voy con baile nuevo,

$$
\begin{aligned}
& \text { que Escarramán y los Bravos, } \\
& \text { la Corruja y la Carrasca } \\
& \text { ponen miedo a los ancianos. (vv. 37-40) }
\end{aligned}
$$

Así pues, las alusiones a personajes jacarandos son la principal guía para fechar los bailes más conocidos de Quevedo, cuya compleja fijación textual ha delimitado un corpus no mucho más extenso que el publicado por 
González de Salas en su primera edición del Parnaso, concretamente en la sección de la Musa V.

\subsection{TESTIMONIOS NOVEDOSOS}

El catálogo de Isabel Pérez Cuenca me llevó a los manuscritos de dos comedias burlescas atribuidas a Quevedo, El premio de la hermosura (BNE, ms. 15288) y ¡Qué villano es el amor! (BNE, ms. 15070) de la BNE. ${ }^{94}$

Astrana Marín ${ }^{95}$ desechaba la autoría de la primera alegando que no era otra que la homónima de Lope, publicada en la XVI parte de sus comedias. Probablemente, no llegó a leer el manuscrito, porque si lo hubiera cotejado con la comedia del Fénix habría visto que son obras completamente

${ }^{94}$ Recordemos que la comedia burlesca La Infanta Palancona, tradicionalmente tildada de entremés, había sido falsamente atribuida a Quevedo, aunque en verdad procede de la pluma de Félix Persio, Bertiso. Cfr. Rosa Navarro [2003: 101-115].

95 Respecto a la edición de Astrana Marín, señala Blecua [1999: I, XXXI], cuyas observaciones secundamos: "don Luis Valdés, heredero de don Aureliano Fernández Guerra, puso todos los papeles a disposición de don Luis Astrana Marín, quien publicó las Obras completas de Quevedo en 1932 (Edit. Aguilar, Madrid), reimpresa numerosas veces. Esta edición, tan tendenciosa desde la portada, en la que se dice que publica los textos genuinos del autor, descubiertos y clasificados [...] con más de doscientas producciones inéditas del príncipe del ingenio y numerosos documentos y pormenores desconocidos, dista enormemente de ser una edición crítica. Es obra de un aficionado, y con suerte, llena de errores de todo tipo, con auténticos inéditos y otros que lo son en colección, confundiendo muchas veces los manuscritos y editando otros a través de copias, como sucede con el mejor, el 108 de la Biblioteca de Menéndez y Pelayo [...]." 
diferentes. A pesar de que el manuscrito que se conserva tiene letra del siglo XVIII, por su temática y usos lingüísticos podría ser del XVII. Pertenece a la tradición lucianesca de la parodia de los dioses olímpicos y confluye temática y retóricamente con la obra satírica de Quevedo.

Respecto a la comedia inacabada ¡Qué villano es el amor!, Astrana Marín también descartó la autoría quevedesca alegando que la obra, por estar escrita con letra del siglo XVIII, no pertenecía al barroco español. Encontré, por suerte, en el Fondo Sedó del IT una copia del ms. de la BNE (ms. 47.184) anotado por Cotarelo y Mori. Éste, uno de los mayores estudiosos y compiladores del teatro breve del barroco ${ }^{96}$, decía en una nota a lápiz: "por los retrúecanos puede muy bien ser de Quevedo. Que pertenece al siglo XVII no cabe duda."

¡Qué villano es el amor! volvería a aparecer más adelante. En la Biblioteca Nacional de Lisboa había consultado el catálogo de Miranda, que fue una magnífica guía. La autora lamentaba que los hispanistas del Siglo de Oro apenas hubieran aprovechado el filón de las bibliotecas lusitanas, nación que en vida de Quevedo estuvo anexionada a España. En el vecino Portugal, mientras consultaba un códice manuscrito que contenía poesías de Quevedo (el ms. 324 de la Universidad de Coimbra), di con un romance titulado Jácara/ A los amores del rey Rodrigo y la Cava, sin autor explícito pero contiguo a unos poemas de Quevedo. La temática coincidía con la subversión del tópico morisco de la comedia burlesca antes citada. Por eso y

${ }^{96}$ Cfr. Cotarelo y Mori [1991]. Es el antologador de la relevante Colección de loas, entremeses, jácaras y bailes. 
por su belleza popular (algo intrínseco al romance) estuve leyendo con ociosidad desinteresada hasta que di con una estrofa que me sobrecogió:

\author{
De verse de un Rey gozada \\ quedó la niña entonada, \\ mas fuerza será que amanse \\ cuando mueve su rigor. \\ ¡Qué villano es el amor! \\ Líbrenos Dios que se canse. (vv. 242-247)
}

El romance y la comedia burlesca entrañan cierta relación o referente común, de eso no cabe duda. Ver si el romance es un fragmento de la comedia inacabada o una obrilla independiente está todavía por consignar.

En ocasiones, como corrobora La toma de Valles Ronces, hay composiciones que en el siglo XVII se denominan "jácaras” pero que, en rigor, no son sino romances. Estas piezas desplazan su asunto criminal hacia otro tipo de personajes, no necesariamente jaques o jayanes, que a juicio del autor ejecutan acciones inmorales o blasfemas. Así sucede en el mentado romance A los amores del rey don Rodrigo y la Cava, donde el monarca figura como impúdico ultrajador de la princesa mora.

A su vez, hay dos jácaras que versan sobre la figura de Escarramán y que atribuimos a Quevedo en este monográfico. La primera, es otra Respuesta que hemos ubicado en el ms. 3795 de la BNE, una variante de la jácara 850. Ignoramos si la lima es obra del propio Quevedo -una versión posterior- o si acaso es producto de la trasmisión oral, que suprime algunos pasajes e incorpora otros nuevos. En segundo lugar, sospechamos que el mismo 
autor, cuya obra redunda en intertextualidades, pudo hacer una versión a lo divino de su jácara de Escarramán $(P O C, 879)$, que hemos hallado en el ms. 19387 de la BNE, contigua a sus poesías. Recordemos que el códice 19387 contiene un buen número de poemas anónimos junto con otros de Mateo Rosas de Oquendo, Cristóbal Flores de Alderete, Alonso Álvarez de Soria, Cervantes, Lope de Vega y Quevedo. Margarita Peña, sin embargo, baraja la posibilidad de que esta divinización del jayán sea obra del Fénix:

Aparece, asimismo, en el cancionero, un "Escarramán a lo divino", romance anónimo, testimonio de las transformaciones que, determinadas por su popularidad y buena fortuna, experimentó el poema de Quevedo. Aún cuando éste no es el momento para especular sobre la posible autoría del romance, cabría mencionar el hecho de que se ha señalado a Lope de Vega como uno de los que jugaron con el paso "a lo divino" de la jácara quevediana. En la edición de las Obras completas, de Quevedo, Felicidad Buendía cita, en nota a pie de página, los dos primeros versos de dos romances "a lo divino" sobre el tema, obra de Lope, que aunque no concuerdan con los primeros versos del romance del "Escarramán" en nuestro cartapacio, se integran a la familia de escarramanes divinizados que andan dispersos en diferentes manuscritos. [Margarita Peña, 1992: 49]

Por otra parte, en el ms. 17683 de la BNE encontramos dos bailes atribuidos a Quevedo: el que se inicia "Picarilla, picarilla..." y la Comedia de las dependencias de España, que no se incluyen en la edición de Blecua. Analizaremos estas dos obrillas más adelante.

Finalmente, la sorprendente similitud del nombre de un pretendido dramaturgo aurisecular al que sólo se le atribuyen dos entremeses, Miguel de Mulsa, con el pseudónimo de juventud de Quevedo, Miguel de Mussa, 
me llevó a localizar estas dos piezas de tema disparatado, picante y con chispazos satíricos: el Entremesico del Hurto del nene y el Entremés de las verdades del Zonzo. Ambos pertenecieron a la biblioteca de Osuna y se ubican en la BNE. Hay, sin embargo, copias de los mismos con algunas anotaciones de Fernández Guerra y Cotarelo en el Fondo Sedó del IT de Barcelona. Veremos pros y contras de estas posibles atribuciones en el apartado correspondiente.

\section{3. ¿TRADUCCIONES DE TEATRO GRECOLATINO?}

Aunque despunte ante todo por su obra original, Francisco de Quevedo era un traductor considerable. Excelente en latín, bastante bueno en griego, intentó dominar el hebreo y estaba familiarizado con el francés y el italiano. Entre las obras que tradujo encontramos las Lágrimas de Jeremías castellanas (del hebreo), el Anacreón castellano (del griego), las Noventa epístolas de Séneca (del latín), el Rómulo de Malvezzi (del italiano) o la Introducción a la vida devota de Francisco de Sales (del francés). Incluso se ha localizado una traducción de las poesías de Ausiàs March (del catalán). ${ }^{97}$

Como ávido lector y filólogo humanista, leyó diversas obras de teatro. Así lo demuestran los apuntes de su letra a una traducción latina de la Retórica de Aristóteles, entre los que figuran abundantes comentarios sobre

${ }^{97}$ Véase Martí de Riquer, Traducciones castellanas de Ausiàs March en la Edad de Oro [1946: 427 y ss.]. 
los genios de la escena griega. Además, hemos localizado notas autógrafas de Quevedo sobre las comedias de Plauto ${ }^{98}$ y el Eunuco de Terencio.

En todo caso, González de Salas, en su opúsculo Nueva idea de la tragedia antigua, ofrece una particular panorámica de obras teatrales que a todas luces conocía Quevedo. En sus "Preliminares" al Parnaso, cita también a algunos autores trágicos como Melanippides Melio, las odas líricas danzadas de Píndaro, las comedias de Aristófanes, Terencio y Plauto, la Medea, el Hipólito y ante todo Las troyanas de Séneca. ${ }^{99}$ No se conserva, sin embargo, ninguno de estos fragmentos traducidos. Esperemos que aparezcan con el tiempo.

${ }^{98}$ Real Academia de la Historia (Madrid), Ms. 9-805, f. 143r-v. Autógrafo. El documento es inédito y aparece junto al mejor testimonio, autógrafo, de La España defendida. También hemos encontrado algunas traducciones de Plauto en el ms. 3.708 de la BNE, que contiene poesías varias de Quevedo, aunque no sabemos si éstas pertenecen a la pluma de nuestro autor.

${ }^{99}$ Las troyanas es la obra que González Salas edita al final de su Nueva idea de la tragedia antigua. 
Capítulo II

QUEVEDO Y EL TEATRO CORTESANO

$-125-$ 
- 126 - 


\section{VERICUETOS DE UN POLÍGRAFO}

\section{RETRATO DE UN PERSONAJE}

Iconográficamente, no tiene nada que envidiar a Chaplin. Dibújense unos quevedos, una media melena ondulante y un bigotillo espigado. Nadie dudará en reconocerle. Hasta circulan chistes que llevan su nombre. La relación entre Quevedo y las artes escénicas podría tratarse desde muchas perspectivas distintas.

Pensemos, de entrada, en su aspecto pintoresco y contestatario, harto explotado en comedias al uso del teatro romántico: ${ }^{1}$ el bigotudo de ancha frente, zambo y semijorobado, miope y adicto al tabaco. Trazos únicos que, junto con las onduladas greñas negras, se pincelan en el célebre retrato ancestralmente atribuido a Velázquez, pero también a su suegro y maestro Juan Van Der Hamen. ${ }^{2}$ Se le ve, en este retrato y en el misterioso busto que se conserva en la BNE, de semblante poco agraciado, excesivamente cargado de espaldas, de "cuerpo abultado", con brochazos bermejos en el cabello, zambo y miope a tal punto de legar su apellido a los anteojos que llevaba. $^{3}$

\footnotetext{
1 Para el lector curioso, hemos compilado bibliografía sobre "Quevedo, personaje teatral”. Cfr. Alonso Cortés [1929], Garner [1905] y García Valdés [2004].

2 La célebre pintura del autor aparecía en un suplemento del Babelia como obra de Juan van der Hamen. Cfr. Francisco Calvo Serraller, "Van der Hamen completo", Babelia ( El país), sábado 29 de octubre de 2005.

3 Cfr. Reyes Dávila [1981:11].
} 
Sus detractores se afanaron en adjetivarlo gordo y desaliñado, aunque excesivamente pulido en su vejez. Él resolvió llevar estas pequeñas deformaciones con ostentación y osada galanura: fumador empedernido, enormes anteojos, vestimenta oscura, joroba, abundante cabellera.

Los más crueles adversarios, como Juan de Jáuregui en su comedia $E l$ Retraído (1635), sátira teatral que atentaba contra La cuna y la sepultura, recuerdan sus vicios de la carne y la bebida, su rondar por tabernas y prostíbulos. $^{4}$ Con poca originalidad, bombardean su figura con composiciones recargadas de retruécanos, calambures y poliptotos.

Pero Quevedo supo reírse de sí mismo y convertirse en un divertimento literario a través de jocosos autorretratos. Es mítico el fragmento del Memorial pidiendo plaza en una Academia, compuesto entre 1601 y 1606, donde se proclama a sí mismo hijo de sus obras y padrastro de las ajenas, cofrade de la Carcajada y de la Risa y hombre de bien nacido para mal. ${ }^{5} \mathrm{Y}$ también se describe del siguiente modo:

ordenado de corona, pero no de vida; que es de buen entendimiento pero no de buena memoria; que es corto de vista, como de ventura; hombre dado al diablo y prestado al mundo y encomendado a la carne, rasgado de ojos y de conciencia; negro de cabello y de dicha; largo de frente y de razones; quebrado de color y de piernas; blanco de cara y de todo, falto de pies y de juicio, mozo amostachado y

4 Cfr. Jauralde Pou [1999: 885-898]. Cita los dos sonetos anónimos que figuran en el ms.3920 de la BNE.

5 Quevedo se mofa de sí mismo en diversas composiciones satíricas. Véanse, según la numeración de José Manuel Blecua, los romances 211, 235, 237, 732, 772 y 774. El autor también alude jocosamente a su cojera en la Carta de las calidades de un casamiento. 
diestro en jugar a las armas, a los naipes y a otros juegos; y poeta sobre todo, con perdón, descompuesto componedor de coplas [BAE, I: 473a].

Prefirió en el Sueño del infierno, como Maquiavelo, una vez asumida su conciencia de irremediable pecador, conversar sobre política con los autores paganos del averno dantesco que aburrirse con los santos y beatos del paraíso. 6

Arquitecto de las galerías del alma y ávido lector nocturno, estuvo, sin embargo, habituado a los motivos del teatro y la fiesta pública, y esgrimió su credo político y religioso como bandera de su pensamiento humanista.

Tuvo poderosos protectores y enconados adversarios; de allí que alternara aposentos en cárcel y palacio. Es sumamente difícil fijar su residencia porque, afanoso de la chispa de la conversación -tan notable en su teatro satírico-, prefirió posadas y casas ajenas a un inmueble propio, siquiera en Madrid, a excepción de su señorío manchego en la Torre de Juan Abad, retiro en el que pasó los últimos años de su vida solitaria.

\section{ENTRE LA CALLE Y LA ALCOBA PALACIEGA}

Una compleja y dilatada literatura ${ }^{7}$ ha inundado la biografía de Quevedo. Fue un hombre acostumbrado al ritmo religioso y cortesano que había pautado su educación más temprana. De cuna esclarecida aunque no

\footnotetext{
6 Cfr. Maurizio Viroli, La sonrisa de Maquiavelo [2002:15].

7 Véase Borges [1952].
} 
rica, usó lengua y espada con destreza sin par, y sus maestros fueron la cátedra y la calle.

Don Francisco fue a todas luces un humanista, políglota del saber arcano y curioso impertinente de los quehaceres de sus coetáneos. Los anales de la posteridad lo han retratado, sin embargo, no tan genial como Cervantes, ni tan astuto medrador como Lope.

Conocedor de caballerizos, maestresalas, guardadamas y aposentadores, ¿cómo no iba a escribir sobre la sociedad cortesana y de su reverso, la incipiente picaresca? Su versatilidad de polígrafo y su visión poliédrica de la realidad le permitirían tratar el asunto desde diversas ópticas y con el uso de técnicas expresivas diferentes.

Ambición, envidia y lisonja ${ }^{8}$, los móviles y pecados de una sociedad jerarquizada, quedarían retratados a través de su fuerza verbal, que trasciende las particularidades de cada género.

La relación de Quevedo con la cúpula palaciega estaba impregnada del empaque de la reverencia y del halago a los que debían adscribirse los poetas y artistas cortesanos. ${ }^{9}$ La sumisión, el vasallaje y la reverencia eran

${ }^{8}$ Cfr. Juan de Mora [1589: f. 2v]. En Virtud militante, Quevedo calificaría a la envidia de "primera peste del mundo".

9 Así lo admite en Su espada por Santiago: "Yo conozco cuánta obligación tenemos los vasallos de vuestra Magestad a obedecer rendidamente las señas de vuestra voluntad, a seguir vuestras órdenes, a reverenciar en todo vuestras acciones, aún a costa de nuestra propia dignidad." [BAE, 1951: 427]. 
naturales en un ambiente en que la vida siempre giraba en torno a las circunstancias de la familia real. ${ }^{10}$

No obstante, nuestro autor fue más allá de la aquiescencia del régimen monárquico. Por ello podemos contrastar la ortodoxa comedia Cómo ha de ser el privado con la doctrina que contienen otras obras suyas. ${ }^{11}$

Don Francisco no es un autor que se preste a la lectura unívoca de su obra. La genialidad nunca es parca en matices. Como bien expresó Claudio Guillén, supera las posibilidades y fuerzas de la crítica: Quevedo es un enigma literario.

La fuerza de su pluma le valió la gloria del Parnaso cervantino ${ }^{12}$ pero, como a todos los talantes intrincados, también le llevó a la prisión, el destierro y la muerte.

Madrid, entre 1580 y 1645, no sólo era la corte, sino también una ciudad conventual. ${ }^{13}$ En este mundo abreviado y "emulación del paraíso", ${ }^{14}$

${ }^{10}$ Así lo ilustran algunas obras plenamente cortesanas como la comedia por encargo Cómo ha de ser el privado (1629).

${ }^{11}$ En el opúsculo satírico Discurso de todos los diablos (1628), desde la perspectiva de diversos condenados, formula juicios peligrosamente despectivos contra el monarca. De igual modo, en la comedia atribuida La privanza desleal y voluntad por la fama, se cuestiona la autoridad de un rey tirano que finalmente es destronado por su valido. Como apunta en Virtud militante, "los reyes son en la tierra retratos de Cristo" [1985: 106]. Por ello, Quevedo amenaza a los déspotas con la ira divina en su Política de Dios, como lo hiciera Juvenal en sus sátiras.

${ }^{12}$ Cfr. La edición de Vicente Gaos [2005: 78,79]

${ }^{13}$ Así lo expresa Jauralde Pou [1999:29]. Hemos recurrido a su Biografía como fuente valiosísima de los datos más relevantes que nutren el presente capítulo.

${ }^{14}$ Quevedo, Cómo ha de ser el privado (II, 43). 
transcurrió gran parte de su vida. Allí conoció las controversias del género que gozó de mayor proyección social durante el siglo XVII. Un género que también le perteneció, a pesar de que, como a Cervantes, tengamos que devolvérselo siglos más tarde.

\section{LAS FIESTAS OFICIALES DE LA MONARQUÍA}

El teatro de Quevedo está íntimamente ligado al mundo cortesano. Y el espectáculo dramático aurisecular va unido a la fiesta, al fasto público o privado, religioso o profano, supeditado al calendario litúrgico o a las variopintas celebraciones nobiliarias.

Durante el Siglo de Oro, la fiesta adquiere una dimensión teatral nueva. Está relacionada con una visión del poder. Inunda las calles de imaginativos decorados urbanos que, como en Los Sueños, albergan imágenes cifradas, artificios lúdicos que distraen al pueblo de las adversidades, como decía amargamente Barrionuevo. ${ }^{15}$

La espectacularidad impregna la vida pública y hasta los más livianos acontecimientos de la cotidianidad monárquica y su entorno: coronaciones, bautismos, bodas, pompas fúnebres, triunfos bélicos, inauguraciones arquitectónicas o beatificaciones. La corte traduce sus relaciones políticas y sociales y las exhibe con diferentes códigos lingüísticos: la música, la danza, la pintura, la literatura y la arquitectura efímera.

\footnotetext{
${ }^{15}$ Cfr. Barrionuevo [1968-1969: II, 51].
} 
La fiesta barroca, de la que Quevedo fue activo espectador y participante, generó toda una literatura que pervive gracias a su difusión impresa, a través de las Relaciones de Sucesos, que es el protoperiodismo aurisecular. Hubo abundantes certámenes y justas poéticas aparejados a festejos, que contaron con cronistas de prestigio: sabemos, por ejemplo, que Lope de Vega fue secretario de las celebraciones por la beatificación de San Isidro (1620) y de San Ignacio de Loyola (1622).

Los artistas de relieve aprovechaban el filón de las festividades cortesanas para poner su creatividad al servicio de la organización y difusión de estos acontecimientos. Pedro de Herrera fue el relator oficial de los festejos de Lerma de 1617; Ruiz de Alarcón, con la colaboración de Mira de Amescua y por orden del Duque de Cea, relató el recibimiento en Madrid del Príncipe de Gales en 1623.

Más allá del modelo de fiesta carnavalesca y popular que estudió Bajtín, Quevedo participó de la fiesta oficial, organizada por los mandatarios y con fines propagandísticos. Fue espectador del boato y la exageración: arcos triunfales, mecanismos de maquinaria aérea (nubes, granadas, globos), altares, carros y danzas, iluminación y fuegos artificiales, naumaquias, torneos, encamisadas, máscaras, banquetes, espectáculos de fieras y ostentosos autos sacramentales para el día del Corpus y su Octava.

La fiesta del Siglo de Oro, en definitiva, era vasta y polifónica. Desplegaba con insigne plasticidad una compleja red de espectáculos que invadía múltiples espacios.

Recordemos, sin embargo, que Quevedo también vivió en aquella España opresiva que hacía un espectáculo de las ejecuciones públicas de 
mujeres, herejes y homosexuales; una España que publica índices expurgatorios y condena a muerte a los que importan libros extranjeros sin licencia real (1558); la España que prohíbe la publicación de comedias y novelas (1625-1635) y exacerba el espíritu de sus talentos con sus ambiciones desmedidas y una caída estruendosa. ${ }^{16}$

Don Francisco, como dijo Neruda, "lo vio todo en su siglo". Es testigo de una época. Va de las posadas a los pasillos de la corte de Madrid, de la Torre de Juan Abad a los palacios italianos. Para él, como para Job, la vida del hombre es milicia en la tierra.

${ }^{16}$ Cfr. Mario Campaña [2003:12]. 


\section{BAJO EL REINADO DE FELIPE II (1580-1598)}

\section{LAS PARADOJAS DE UN REY MELANCÓLICO}

El año en que nació Quevedo se cerraron los corrales de comedias de Madrid. Precisamente, cuando el autor italiano Alberto Nasselli, alias Ganassa, había formado compañía en la capital. ${ }^{17}$ ¿Podían tolerarse las inmorales representaciones teatrales si la reina Ana, cuarta mujer de Felipe II, había muerto meses después de dar a luz a la Infanta María? El teatro dependía de los avatares cortesanos y la monarquía estaba de luto.

Se ha especulado mucho sobre el desagrado personal de Felipe II hacia las manifestaciones escénicas. ${ }^{18}$ Sin embargo, durante su reinado, se generó un caldo de cultivo que alentó la posterior eclosión del teatro barroco. Había, de hecho, una práctica escénica cortesana de teatro privado y fasto ceremonial, cuyos orígenes se remontaban a las justas, representaciones y torneos de la Edad Media.

Bajo el mandato de Felipe II, se consolida la escena teatral barroca. Se forman las primeras compañías de actores profesionales. Se gestan los

${ }^{17}$ En pos del éxito del autor italiano, se asentaron otras compañías dell'arte en la Península. Sobre la compañía de Ganassa, véase el artículo de Carmen Sanz Ayán y Bernardo J.García García, "El oficio de representar en España y la influencia de la comedia dell'arte (15671587)" [1995: 475-500].

${ }^{18}$ Véanse los artículos de Carmen Sanz Ayán, "Felipe II y los orígenes del teatro barroco" [1999] y de Teresa Ferrer Valls, "Bucolismo y teatralidad cortesana bajo el reinado de Felipe II", editado en las actas del Congreso Felipe II (1597-1598). Europa y la Monarquía Católica [1998: 133-143]. 
corrales de la Cruz y del Príncipe en Madrid, la casa de la Olivera en Valencia, los corrales de San Juan y Doña Elvira en Sevilla. Estos corrales emergentes eran edificios vinculados a cofradías de la caridad que convirtieron la actividad teatral en un modo de autofinanciación.

Los dramaturgos de la década de los ochenta orientan su producción hacia un teatro trágico, de contenido moral, que utiliza recursos senequistas, en cuya órbita Cervantes hace sus primeros pinitos como autor teatral. Se afianzan, en particular, dos subgéneros: el auto sacramental, alentado por la relevancia que la Contrarreforma confiere al misterio eucarístico; y los pasos, que adquieren autonomía en la pluma de Lope de Rueda, siendo embriones del entremés barroco.

Claro que, cuando el río suena, agua lleva. El rey, proverbialmente tildado de hermético y melancólico, secundaba la admonición del Padre Rivadeneyra que, en su Tratado de la Tribulación de 1589, atacaba el desarrollo del teatro comercial:

Porque el medio más eficaz que algunos toman para engañar y disimular sus penas es entretenerse con farsas y representaciones, así por el gusto que hallan en ellas, como porque realmente se divierten más y la novedad y variedad de las cosas que se representan suspenden los males y no los deja pensar en ellos; y veo que, de poco acá, se ha introducido y extendido mucho esta manera de entretenimiento y recreación, y aun que se representan algunas veces por hombres y mujercillas perdidas, cosas indignas de la excelencia y honestidad cristiana $(\ldots)^{19}$

${ }^{19}$ Cfr. Cotarelo y Mori, Bibliografía sobre las controversias de la licitud del teatro (Madrid, 1904). Seguimos la edición facsímil de Granada [1997: 522-523]. 
Durante la década de los ochenta, los asuntos públicos eran objeto del arbitrio real. La familia de Quevedo servía en Palacio, y no era ajena a los mandatos y prohibiciones de la monarquía. ${ }^{20}$

Don Francisco conoció el entorno que más tarde afloraría en su obra dramática costumbrista. Respiró la servidumbre y la etiqueta de sus moradores, paradigmas de "sangre, lustre, hacienda y persona". ${ }^{21}$ Participó de los festejos del Corpus de la plaza de Santa María. Acudió a los patios convertidos en las antesalas de las audiencias, llenas de los paniaguados y pretendientes que afloran en La hora de todos y en El infierno enmendado. Estaba acostumbrado a los sastres y comerciantes que habían desfilado ante su padre, escribano de cámara, que inventariaba los trajes y enseres de la cámara real. Paseó por los jardines que descendían hacia la vega de la Casa de Campo, evocados alguna vez en su poesía, y que deja de visitar cuando se construye el Retiro. E, incluso, como Velázquez, atisbó a la realeza desde el otro lado del tapiz: la intimidad de los monarcas le era revelada por su abuela, dueña de retrete. Conoció los engranajes de la máquina del Estado y formó parte de la urdimbre de relaciones familiares y amistosas que se tejían en torno a su elite. ${ }^{22}$

Los ojos de Quevedo contemplaron las estancias vedadas para el pueblo llano. Huérfano de padre a muy corta edad y, tras ello, único varón de su

${ }^{20}$ En la Corte trabajaba la familia de don Francisco, particularmente sus abuelos maternos, cuya actividad administraba el bureo, órgano en el que se dirimían los asuntos internos de los criados y oficiales palaciegos.

${ }^{21}$ Cfr. Discursos de don Antonio Hurtado de Mendoza, edición de E. Rodríguez [1959: 159].

${ }^{22}$ Cfr. Jauralde [1999: 65-88]. 
familia nuclear, se crió en un ambiente pacato y femenino. Su madre propició su formación intelectual, y su abuela, además de buscarle ayo y preceptor, le puso a estudiar con los jesuitas, que impulsaron un tipo de teatro edificante, ajeno a las frivolidades, de raíz culta y académica.

\section{EL TEATRO ESCOLAR DE JESUITAS}

Como Lope de Vega o Calderón de la Barca, Quevedo se formó como alumno de los jesuitas en el Colegio Imperial de Madrid. ${ }^{23} \mathrm{Su}$ cultura tiene una sólida base de humanismo cristiano, aderezada por un profundo conocimiento de la literatura patrística. El estudio del latín se amparaba en el Arte de Nebrija, refundido por el padre Juan Luis de la Cerda.

Probablemente, el joven Quevedo conoció la obra del padre Pedro Pablo Acevedo, uno de los defensores del teatro escolar latino del siglo XVI. Más predicador que dramaturgo, concebía el teatro como un sermón disfrazado, un género idóneo para plasmar ejemplos morales. Este uso literario ya lo recomendaban las poéticas de Aristóteles, Quintiliano, Cicerón y los preceptistas medievales.

El primitivo drama litúrgico se había impregnado de elementos profanos. Las universidades acogieron representaciones más desenfadadas, influidas por los juegos de escarnio, la fiesta del obispillo y otras de naturaleza semejante.

\footnotetext{
${ }^{23}$ Hay, asimismo, indicios de que Cervantes estudió con los jesuitas en Sevilla, o en otro colegio de la Compañía.
} 
La Compañía de Jesús, desde su creación el 27 de septiembre de 1540, se había convertido en un eficaz instrumento de la Contrarreforma. Su índole misionera la orientaba hacia la formación de jóvenes. Incorporaba en su método pedagógico la difusión de un teatro de impronta clásica y de apostolado con fines literarios y pastorales.

El teatro jesuítico heredaba de la tradición medieval su vinculación a la liturgia, engrosada por el legado cultural latino. Los modelos clásicos de referencia eran las tragedias de Séneca, las comedias de Plauto y, con mayor reticencia, las de Terencio. ${ }^{24}$ Como veremos más adelante, nos han llegado documentos que cercioran el influjo de esta impronta clásica en la formación intelectual de Quevedo. ${ }^{25}$

${ }^{24}$ A principios del siglo XVII, se contabilizaban unas cinco ediciones de Terencio, autor que no se reedita a partir de la tercera década del mismo siglo. Recordemos el juicio negativo de Quevedo a propósito de la traducción de Pedro Simón Abril: "Las comedias de Terencio/ Abril en España vierte,/ mas con tal oscuridad/ que más que Abril es Diciembre." Entre otros eclesiásticos, San Agustín, San Gregorio, Juan de Ávila y Martín de Azpilcueta habían condenado a Terencio. El padre jesuita Bonifacio denostaba las obras del autor latino, que tildaba de provocativas. Sus objeciones eran más temáticas que estéticas, como apunta la siguiente carta: "No sin razón prohibió nuestro Ignacio que leyésemos a Terencio. La Compañía arroja de sus casas todos aquellos autores cuya doctrina es sospechosa, o cuyo lenguaje es lascivo, para que no se manche la pureza ni reciba menoscabo alguno la religión. Por eso no pueden entrar en nuestras casas Erasmo ni Terencio, porque el primero es poco sincero con la fe, y el segundo es enemigo tanto más peligroso de la castidad cuanto mayor es el número de sus partidarios." Terencio había sido, en cambio, un comediógrafo alabado por Erasmo y recomendado en su lectura. Véase, al respecto, el estudio de Jesús Menéndez Peláez: Los Jesuitas y el Teatro en el Siglo de Oro [1995: 35].

${ }^{25}$ Véase el capítulo IX. 
Los dramaturgos del teatro jesuítico eran profesores de Retórica que no solían destinar sus obras a la publicación. Su escritura, más pragmática que inspirada, no buscaba la gloria personal, permanecía a menudo en el anonimato. El repertorio de personajes estaba condicionado por su representabilidad a cargo de un gran número de estudiantes actores.

Dentro de la comedia jesuítica, además, se intercalaban otras piezas teatrales breves y jocosas. La praefatio jocularis y la actio intercalaris (inspiradas en los coros clásicos y que desembocarían más adelante en las jácaras, loas, entremeses y bailes), motivaban al espectador y rebajaban la tensión dramática. La música, instrumental o coral, elemento característico del teatro profano, es frecuente en estas representaciones intermedias.

Algunos jesuitas, sin embargo, consideraban que el teatro rezumaba un espíritu más mundano que religioso. Esta objeción ya había sido planteada por los clásicos de la patrística: Tertuliano, Taciano, San Agustín, San Jerónimo, Santo Tomás de Aquino.

En el manual pedagógico de Pedro López de Montoya - Libro de la buena educación y enseñanza de los nobles (1595)-, al igual que en múltiples lugares de la obra del Padre Mariana, se mostraban unas pautas de educación que, si bien eran partidarias de la enseñanza de la Gramática, Historia y Retórica a partir de los clásicos grecolatinos, apartaban a los niños de las comedias y los cantares. ${ }^{26}$ ¿Cuál era el motivo de semejante reticencia?

\footnotetext{
${ }^{26}$ Pedro López de Montoya [1595: f. 37 y ss. y 39 y ss.].
} 
Las controversias sobre la licitud del teatro en el Siglo de Oro $^{27}$ se debieron a que, según los acérrimos moralistas, este espectáculo público podía pervertir la virtud del auditorio y acrecentar la soberbia del dramaturgo.

El máximo contacto que podía tener Quevedo con el teatro en su niñez era la composición de exercitaciones a propósito de rudimentarias comedias latinas con moraleja, ejercicios académicos basados en el émulo de los recursos literarios y disquisiciones filosóficas sobre las comedias de Séneca, Plauto y Terencio. El andamiaje intelectual que hemos descrito, más enfocado hacia la práctica del sermón, la poesía y la prosa doctrinal, pretendía proyectar al alumnado hacia los estudios de Teología. ${ }^{28}$

\section{MALANDANZAS CON COMEDIANTES}

En otoño de 1596, Quevedo inicia sus estudios de Arte en la Universidad de Alcalá de Henares, donde Arias Montano había sido catedrático de Retórica. Alcanza el grado de bachiller en 1600. Por aquel entonces, se enreda en algunas malandanzas con el Duque de Osuna, que vive unos

\footnotetext{
${ }^{27}$ Véase Cotarelo y Mori [1904].

${ }^{28}$ Quevedo, más tarde, en La cuna y la sepultura (1635) y en la Defensa de Epicuro (1635) recuerda la enseñanza vana de demostraciones y silogismos y hace gala, como el filósofo griego, del desprecio hacia la paideia.
} 
amoríos ilícitos con la hija de Salcedo, un autor de comedias. El teatro aparece en la vida de Quevedo como enjundia perniciosa. ${ }^{29}$

Las aventurillas juveniles de Quevedo con el Duque de Osuna terminan en algún duelo que probablemente les impulsó a huir a Sevilla. Este viaje puede explicar las múltiples alusiones al hampa sevillana en algunas de sus obras - el Buscón, las Capitulaciones de la vida de la corte- y, desde luego, en sus entremeses. ${ }^{30}$

En noviembre de 1600, nuestro autor se matricula de nuevo en Alcalá para estudiar Teología. El plan de estudios incluye lecturas de Aristóteles, en ocasiones comentadas por Santo Tomás o Domingo de Soto. Don Francisco estudia al estagirita con dedicación filológica y reflexiona sobre su concepción del teatro clásico. ${ }^{31}$

En las librerías de Alcalá, Quevedo pudo leer otra obra teatral de poderoso influjo en sus entremeses: La Celestina. Si es que no la había leído antes: ésta había sido editada en 1586 por Juan Gracián y en 1591 y 1594 por Hernán Ramírez. Hubo otras publicaciones dramáticas de actualidad, como las tragedias de Gabriel Lasso de la Vega y traducciones de las comedias de Terencio.

${ }^{29}$ Quizá por ello, los detractores de El tribunal de la justa venganza lo tildarán más adelante de estudiante "capigorrón" y pendenciero. Cfr. Jauralde [1999: 95].

${ }^{30}$ Quevedo fue perseguido por la justicia y, gracias a la intervención de la Duquesa de Lerma, salvó la vida. Sólo sufrió una prisión atenuada, de la que se redimió al alcanzar la mayoría de edad de aquella época, los veinticinco años. Cfr. Jauralde [1999: 108].

${ }^{31}$ Conocemos, como veremos más adelante, sus anotaciones a la edición latina de la Retórica de Hermolao Bárbaro, donde son profusas las alusiones a los mecanismos y peculiaridades perlocutivas de los grandes dramaturgos griegos. 
Durante esta época estudiantil de Quevedo, los viajes entre la Universidad Complutense y la corte madrileña son frecuentes, con parada de rigor en la venta de Viveros, que aparecerá recreada en El Buscón y en el entremés de La venta. ${ }^{32}$

Cuando, por mediación del Duque de Lerma, la corte se traslada a Valladolid, Quevedo se inscribe en su universidad para proseguir con sus estudios teológicos. ${ }^{33}$ Se matricula en otoño de 1602. Profundiza en la Biblia y los libros de sentencias, se proyecta hacia las humanidades y se forma sólidamente como filólogo.

En 1598, poco antes de su muerte, el rey Felipe II suspendió las representaciones palatinas a raíz de la muerte de su hija Catalina. Vivió el calvario de una enfermedad que sumergió a la corte en un ambiente profundamente religioso. Los sermones públicos sustituyeron a las bambalinas. Quevedo pudo asistir a los que dieron Luis Montesino o Fray Lucas de Montoya en la Universidad de Alcalá tras la muerte del rey. ${ }^{34}$

\footnotetext{
${ }^{32}$ Cfr. Jauralde [1999: 119].

${ }^{33}$ Creemos que Quevedo se licenció en Teología, a pesar de que la crítica haya dudado al respecto por el escarceo de algunos documentos que lo acrediten. En efecto, no consta su nombre en los expedientes universitarios. Sin embargo, sí que se incluye en papeles de obtención de cátedras y oposiciones, para las que ser licenciado era conditio sine qua non.

${ }^{34}$ De los últimos años del reinado de Felipe II, Quevedo atesora, al principio, buenos recuerdos, como emergerán en Grandes anales: un monarca espléndido y magnífico, sin codicia, justiciero, piadoso, gentil con sus vasallos y temible para sus enemigos. Este juicio positivo continuará en el romance 800 (1605) y en el Discurso de privanzas. No obstante, ya en El chitón de las tarabillas (1630) Quevedo aludirá a este soberano en un tono irónico y negativo.
} 
El cambio de monarquía, como suele suceder, influyó en la dinámica del teatro. Tras la subida al trono de Felipe III, menguó la censura real sobre los espectáculos públicos. 


\section{LA MONARQUÍA DE FELIPE III (1598- 1621)}

\section{LA LIBERALIZACIÓN DE LAS COSTUMBRES}

El fallecimiento de Felipe II el 2 de mayo de 1598 liberaliza oficialmente las costumbres. El cambio de poder beneficia a la familia de Quevedo. Tras la entronización del joven Felipe III, el duque de Lerma ejerce como su valido. Este privado favorece particularmente la fastuosidad, el ceremonial, el derroche y la frivolidad. Bajo su tutela se representan múltiples obras teatrales, adscritas a celebraciones especiales.

El drama cortesano propiamente dicho inicia su andadura en España. La reina es una gran aficionada al teatro. Las representaciones particulares de la Corona desbordan los aposentos regios. ${ }^{35}$ ¿Qué podemos aducir si hasta se sabe que el futuro monarca Felipe IV fue destetado sobre un escenario ${ }^{36}$

${ }^{35}$ Cfr. Melveena McKendrick [1994: 224]: "Al principio, se levantaba de vez en cuando un escenario provisional en alguna de las calles del Alcázar para públicos más numerosos. Luego, en 1606, el rey y la reina asistieron a dos obras en la Casa del Tesoro, cercana al Alcázar, donde tenía un aposento el Duque de Lerma, y al año siguiente uno de los patios de este edificio fue convertido en una réplica de los teatros públicos para permitir que la familia real viera comedias en las auténticas condiciones de corral: un paso significativo en la integración del teatro en vida de la corte."

${ }^{36}$ Y Melveena McKendrick [1994: 225] añade la siguiente anécdota: "el teatro constituiría durante toda su vida una pasión que no se vio afectada por la desagradable experiencia que tuvo a los nueve años, cuando hacía el papel de Cupido en una Comedia de la Corte: el balanceo del carro en que salió a escena, combinado sin duda con la emoción, le hizo vomitar dos veces en presencia del augusto público." 
Quevedo escribe en esta época sobre figuras en falsete. Recrea el retablo humano de las Capitulaciones de la vida de la corte, que más adelante afloraría en sus primeros entremeses en prosa. También escribe las Premáticas, un Memorial pidiendo plaza en una Academia y el Origen y definición de la necedad. ${ }^{37}$

Don Francisco, además, admira y lee a Justo Lipsio, ${ }^{38}$ que en sus Políticas adoctrina a príncipes y validos. Degusta el prólogo de Bernardino de Mendoza a la primera versión española, que dedica la obra a la nobleza porque no comprende el latín. Con empacho cortesano, en los primeros Sueños, traba la crítica a los oficios con el retablo del mundo mercantil urbano que recreará en sus entremeses en prosa.

Sobre las mismas fechas, el autor se enemista con uno de los personajes más corruptos del reinado de Felipe III, don Rodrigo Calderón, Marqués de Siete Iglesias, ajusticiado públicamente por ser un valido poco virtuoso. Un personaje que reaparecerá en la comedia Cómo ha de ser el privado como un mal ejemplo a evitar.

${ }^{37}$ La obra de Quevedo difícilmente puede desasirse del apego por la cultura establecida. Sus primeros poemas circunstanciales están dedicados al círculo del Duque de Lerma y a su protectora, doña Catalina de la Cerda, que fallece el 2 de junio de 1603. Sus primeros juguetes buscan el apoyo de los grandes mecenas del momento. Ello explicaría que tanto el Sueño del Juicio, que circuló manuscrito antes de 1605, disponga de testimonios manuscritos dedicados, indistintamente, al Duque de Lerma y al Conde de Lemos. Cfr. Jauralde [1999: 134].

${ }^{38}$ La correspondencia entre Quevedo y Justo Lipsio ya se da a finales de 1604. Ambos traban una amistad filológica. Conforme al credo político del humanista holandés, Quevedo escribirá más adelante la comedia Cómo ha de ser el privado. 
El 9 de abril de 1609, Felipe III ordena la expulsión de los moriscos. ${ }^{39}$ Sea como fuere, este acontecimiento influyó en la fecunda afición de los ingenios por el cultivo de composiciones para las fiestas de moros y cristianos. La comedia burlesca inédita y atribuida ;Qué villano es el amor! bien pudiera ser una pequeña muestra de un género que, según sospechamos, cultivó Quevedo, a pesar de que apenas nos hayan llegado testimonios.

\section{UNA SOCIEDAD CORRUPTA}

A mediados de noviembre de 1609, se celebran en Madrid las fiestas por la beatificación de San Ignacio. Es un mes de regocijos en la corte, de caro espectáculo bambalinesco. El padre Mariana, que Quevedo conoce en Toledo probablemente a través de Tomás Tamayo de Vargas, es encarcelado por denunciar la corrupción cortesana: la malversación de fondos, la venta de cargos y la debilidad del monarca (jugador de naipes, como el propio Duque de Lerma). ${ }^{40}$

La sociedad frívola se enmascara con la circulación de premáticas hipócritas que pretenden gobernar minucias de las costumbres y protocolos.

${ }^{39}$ La postura de Quevedo al respecto, como frente a tantos otros asuntos, no deja de ser paradójica. Mientras que en el Chitón de las tarabillas (1630) criticará abiertamente esta medida, en la Execración de los judíos (1633) se mostrará partidario. Y, en la postrera disquisición sobre el tema, en la sátira menipea La hora de todos (capítulo XIX), el problema morisco volverá a plantearse desde perspectivas divergentes.

${ }^{40}$ Cfr. Jauralde [1999: 221-258]. 
En esa misma época, Quevedo, antes del 21 de marzo, destinó una chria o alabanza retórica a El buen repúblico (Salamanca, 1611) del célebre poeta y cómico Agustín de Rojas Villandrando. Consciente de las circunstancias palaciegas, eleva la obra a la categoría de utopía social: en esta nueva suerte de República platónica, "si de buenos ciudadanos será la más perfecta, modelo es el que saca a luz para gobernarse el más desconcertado" [1951: III, 479].

Don Francisco se conduele de la soledad de la corte madrileña tras su traslado a Valladolid. Hacia 1611, ya empiezan a circular algunas jácaras suyas manuscritas, fruto del clima de esparcimiento cortesano. Este subgénero poético, derivado del romance, era una forma burlesca de sátira social. La famosa Jácara de Escarramán $(P O C, 849)$ era muy conocida en 1612 y, poco más tarde, figuraba impresa en pliegos sueltos, y "vuelta a lo divino". Pero, sobre todo, se representaba en los corrales: era un elemento más de la tarde de fiesta.

Durante estos mismos años, bajo el influjo de Cervantes, Quevedo redacta sus primeros entremeses en prosa: Bárbara (en su primera y segunda parte), Diego Moreno y La vieja Muñatones.

Loas, jácaras, entremeses... ¿Qué otros subgéneros teatrales son los más corrientes durante este periodo? El drama alegórico es efímero en España, dado que la muerte de la reina en 1611 supone el fin de las representaciones en presencia del rey durante un par de años. Por estas fechas, además, los dramaturgos siguen cultivando el género autóctono, la comedia. Esta modalidad teatral, flexible y proteica, se acomodaba con facilidad a las exigencias del teatro cortesano. 


\section{ITALIA, CUNA DEL HUMANISMO}

Ya en la segunda década del siglo XVII, Quevedo destina gran parte de su energía a la política. Le nombran secretario del Duque de Osuna, a quien acompaña a Italia. $^{41}$ Allí vivirá entre 1613 y 1618. ${ }^{42}$ Este cargo, lógicamente, le priva de asistir a las fiestas de octubre de 1614 en Lerma que, como nota Lope en una Relación, se nutrió de variadas representaciones teatrales. ${ }^{43}$ Éste representó, por cierto, El premio de la hermosura, una comedia de título homónimo a otra atribuida a Quevedo que hemos rescatado recientemente. Con motivo de esta obra lopesca, se construyó un proscenio al aire libre con varios escenarios simultáneos a la orilla del río, que también formaba parte del decorado. ${ }^{44}$

${ }^{41}$ Durante el Siglo de Oro, Italia fue destino de muchos artistas españoles vinculados al poder político. Se sentía como territorio de la Corona, a diferencia de Flandes, que era considerada tierra de herejes y extranjeros. Su virreinato más preciado era el de Nápoles. No era casual que allí se hubiera formado el Conde-Duque de Olivares, futuro valido de Felipe IV. Fue refugio de surtidos aventureros y literatos. Allí viajaron servidores de la monarquía española, hombres de armas y de letras como Garcilaso, Cetina, Figueroa, Villamediana o Cervantes. Y también pintores como Velázquez o Ribera.

${ }^{42}$ Tarsia, tal vez para darle un cariz heroico a nuestro escritor, dice que don Francisco fue allí por un lance de capa y espada.

43 Así figura, por ejemplo, en el ms. 3700 de la BNE, f. 38-40v.

${ }^{44}$ Melveena McKendrick [1994: 225-226] no escatima la descripción de detalles técnicos de la tramoya de El premio de la hermosura de Lope: "Éste incluía varios senderos, dos montañas, una cueva y un templo móviles, un palacio, un segundo templo y un castillo encantado, todo profusamente adornado; embarrancado sobre una roca del río, había un barco lo bastante grande para acoger a treinta personas; un mecanismo para hacer nubes y 
Italia gozaba de un clima cultural muy rico. Cuna de la comedia del arte, sus compañías teatrales estaban muy cotizadas en Europa. Su influjo había posibilitado la comercialización, el desarrollo urbano del teatro y la tecnificación de la puesta en escena.

Don Francisco estuvo en Sicilia entre 1613 y $1615 .^{45}$ Así lo testimonia Cervantes en su Adjunta al Parnaso, que contemplaba con nostalgia cómo sus colegas literatos repetían los viajes de su juventud. Quevedo conoció allí a Antonio Amico (1568-1641), un historiador panormitano que le regaló un ejemplar de las Tragedias de Séneca. ${ }^{46}$ También entabló relación con el dramaturgo más famoso de la isla, Ortensio Scammaca (1562-1648), de la Compañía de Jesús, autor de tragedias sacras que solían representarse en el teatro del Spasimo. Quevedo se rodeó de un grupo erudito de Palermo, constituido por intelectuales políglotas e historiadores. ${ }^{47}$

En agosto de 1615, el parlamento siciliano designa a don Francisco el cargo de embajador. Intenta llegar a España atravesando los Pirineos. Durante el periplo es encarcelado tres días por los hugonotes, después en Tolouse, y otras tres veces más antes de llegar a Salas. Su objetivo es Burgos, donde se encontraban el monarca español y el Duque de Uceda, con

un telón de fondo tapaban el río cuando era necesario. Todo estaba cubierto con un toldo de lona, y había vestuarios, talleres, y una sala de tramoyas." Del texto publicado de El premio de la hermosura se induce que esta obra fue modificada con posterioridad, al parecer para su representación el los corrales.

45 Así lo postula Jauralde [1999: 309].

${ }^{46}$ Se ha ubicado en la Biblioteca del Escorial, aunque no hemos logrado localizarlo.

${ }^{47}$ En la Biblioteca Comunal de Palermo, a parte de una traducción de los Sueños, tan sólo se ha encontrado un Discurso de privanzas. Cfr. Jauralde [1999: 313]. 
motivo de unas fiestas reales. Estos festejos, no exentos de representaciones palatinas, celebraban los mutuos casamientos de España y Francia. Quevedo no pudo acudir: cayó enfermo tras la que será, sin duda, su estancia más prolongada en el suelo francés.

Entre 1616 y 1618, Quevedo reside en Nápoles, coincidiendo con la posesión del Virreinato por parte del Duque de Osuna. Vive en el palacio real napolitano: un relevante centro artístico y cultural donde se celebran fastuosas fiestas del Corpus, obras teatrales, juegos de cañas y reuniones académicas. ${ }^{48}$ Con todo, durante este periodo escasea su producción literaria (a lo más disponemos de su correspondencia epistolar): el autor opta por dar la imagen pública del diplomático flamante.

¿Podría don Francisco componer durante su estancia en Nápoles algunos de sus más celebres entremeses como entretenimiento de sus quehaceres diplomáticos? No disponemos de datos suficientes para afirmarlo. ${ }^{49}$

La práctica y experiencia adquirida en asuntos del virrey se hace patente en la composición de opúsculos de carácter político, que el autor escribe a

${ }^{48}$ Alessandro Martinengo [1983: 173-179], en su estudio La astrología en la obra de Quevedo incluye un apartado sobre la biblioteca de Quevedo y sus lecturas italianas, ante todo, astrológicas y alquímicas. Durante su estancia en la corte napolitana se le apodaba, al parecer, "il nigromante".

${ }^{49}$ Si Eugenio Asensio situaba algunos de sus entremeses más famosos como anteriores a 1618, Jauralde [1999: 373] considera que su posición política podía verse afectada por la composición de estos cuadros grotescos. En todo caso, no se muestra muy partidario de fechar estos entremeses en la época napolitana de Quevedo. 
partir de $1621 .^{50}$ Ese mismo año, Felipe III obtiene una dispensa especial para que dos compañías aunadas representaran comedias durante la Cuaresma, con la finalidad de entretener al Maréchal de Bassompierre durante su visita.

Quevedo es testigo de la corrupción y de la lucha de poder que hacia finales del reinado de Felipe III mantuvieron Osuna, Lerma y Uceda. ${ }^{51}$ Las cartas que envió a su señor fueron más tarde utilizadas en su contra en el proceso que se le abrió al Duque hacia 1621. Quevedo fue desterrado y preso, primero en Uclés y después en la Torre de Juan Abad por haber sido su agente hasta 1619, fecha en que fue destituido. Este servicio le privaba de ocupar cualquier otro cargo de poder. Por ello, Quevedo buscó en el teatro político un medio que le permitiera medrar en el ámbito cortesano. ${ }^{52}$

Efectivamente, con los corrales, los autos sacramentales, el drama jesuita y las representaciones palatinas, el teatro era fundamental en la vida urbana española. Quienes se oponían a su espectáculo tenían graves problemas para suprimir durante mucho tiempo las representaciones en los locales públicos.

\footnotetext{
${ }^{50}$ Estos tratados, además de la comedia Cómo ha de ser el privado, son: Política de Dios, Carta del Rey don Fernando el Católico, Grandes anales de quince días, Mundo caduco y desvaríos de la edad, Lince de Italia, Memorial por el patronato de Santiago, Su espada por Santiago, El chitón de las Tarabillas, Carta a Luis XIII, Visita y anatomía de la cabeza del Cardenal Richeleu, La rebelión de Barcelona, Marco Bruto o el Panegírico a la majestad del rey nuestro señor don Felipe IV en la caída del Conde-Duque.

${ }^{51}$ El Duque de Osuna, por ejemplo, le envió a la corte en 1615 para sobornar con regalos a quienes le habían asegurado el virreinato de Nápoles.

${ }^{52}$ Véase Lía Schwartz [2006: 13].
} 


\section{EL ESPLENDOR DEL TEATRO CORTESANO}

Pronto el Duque de Osuna encuentra a Quevedo desapacible para sus negocios, y conviene destituirle por Luis de Córdoba. El escritor regresa a Madrid el 28 de junio de 1619. Allí recibe la noticia de la detención de uno de sus enemigos acérrimos, Rodrigo Calderón (personaje que cita en la comedia Cómo ha de ser el privado), el 20 de febrero de 1619.

Don Francisco recobra el pulso literario y participa de las polémicas intelectuales. Junto con otros escritores como Tomás Tamayo de Vargas, Paravicino, Lucas de Montoya, Luis Tribaldos de Toledo, Jiménez Patón o Vicente Mariner, defiende la comedia nueva de Lope de Vega. La mayoría de partidarios del Fénix también será simpatizante de las composiciones de Quevedo. $^{53}$

Es una época de esplendor teatral cortesano, que recibe un soberbio estímulo por parte de la nobleza y del mecenazgo real. La demanda de representaciones cortesanas orienta al teatro en una dirección que, ya en el reinado siguiente, conducirá a un florecimiento y profesionalización de la farándula palatina.

Don Francisco no es ajeno al espectáculo público. El personaje teatral más celebrado por nuestro autor es la atractiva actriz María de Córdoba, conocida con el sobrenombre de Amarilis, famosa desde su papel en Las paredes oyen (1617) de Alarcón. Ésta, además de representar, más adelante, en Sevilla, el entremés quevedesco de El zurdo alanceador (también

\footnotetext{
${ }^{53}$ Jiménez Patón, por ejemplo, en su Mercurius Trimegistus (1621) cita versos de Quevedo.
} 
denominado Los enfadosos), es la musa que inspira el siguiente romance halagador:

La belleza de aventuras,

aquella hermosura andante,

la Caballera del Febo,

toda rayos y celajes;

ojos de la Ardiente Espada,

pues mira con dos Roldanes;

don Rosicler sus mejillas,

don Florisel su semblante;

doña Nueve de la Fama,

si dejan que se desate;

$\mathrm{y}$, en soltando sus faciones,

allá van los Doce Pares;

la que en un golpe de vista

no hay gigantón que no parte,

pensamiento que no ruede,

espíritu que no encante;

la que deshace los tuertos,

y la que los ciegos hace,

siendo de Cupido y Venus

epílogo de hijo y madre;

para quien son los pastores,

Fiera-Giles, Fiera-Brases;

Amadís para ninguno,

para todos Durandarte;

mienten, pues, los romances,

que Amarilis la llaman, si no entienden 
Desde su regreso a Madrid, Quevedo comienza la redacción de su Política de Dios. El escritor es un desengañado de los ministros y privados que rodearon a Felipe III. Los avatares ideológicos de esta obra, reaparecerán en su teatro político. ${ }^{55}$

\section{El DUQUE DE OSUNA: ESCÁNDALO Y FARÁNDULA}

El 23 de agosto de 1620, Quevedo compra una casa en la calle del Niño de Madrid, situada en el barrio de los comediantes. El Duque de Osuna regresa a la corte el 10 de octubre del mismo año. El reencuentro le vale el destierro a nuestro autor. Como explicaría más tarde en Lince de Italia, no escatimaron en fiestas sonadas, muy a menudo en compañía de gente de teatro.

Osuna era un hombre temperamental y extrovertido, espontáneo, improvisador, mordaz. Su comportamiento fue considerado a menudo poco

54 "Hallóse ansí imperfecto en un borrador", señala González de Salas. Nos referimos a los tres últimos versos, que no cuadran con la métrica del romance.

${ }^{55}$ Sigue la tradición del Speculum principes que se remonta al De Regimine principium de Santo Tomás y pasa por la cuentística medieval y referentes de categoría como el Institutio principis Christiani (1516) y el Enquiridion militis christiani de Erasmo, el Príncipe de Maquiavelo, el libro IV de Il cortesano de Castiglione, los diálogos XIX y XX de la Linguae Latina exercitatio de Luis Vives o el difundido Relox de príncipes de Fray Antonio de Guevara. 
político, persiguió con avidez la popularidad. Sus apariciones públicas no estaban exentas de gestos demagógicos y actitudes histriónicas. Se sabe que, antes de su regreso a España, Quevedo había acompañado al Virrey de Nápoles a sus visitas a las cárceles. ${ }^{56}$

En el códice AA., $n^{\circ} 7$ tabla 3 de la Biblioteca Colombina se conserva una carta anónima sin lugar de 1621, que narra el aposentamiento del Duque de Osuna "en uno de los corrales de comedias". La epístola denota los devaneos del noble con la célebre actriz Amarilis, en compañía de nuestro Quevedo:

Sólo diré a Vuestra Majestad lo que ha pasado esta semana con el Duque de Osuna y por su respeto con otras personas. Envió pedir un día de los de ella un aposento en uno de los dos corrales de comedias, y, por estar todos dados, le enviaron a decir que no le había, con lo cual envió los capitanes que aquí tiene, que se apoderasen de todos y no dejasen ocupar ninguno, como lo hicieron: y para dar calor a ello se fue allá en comiendo, y los fue ocupando con diversas mujeres y otras gentes como quiso. [...] Aquella tarde dicen que salió muy brava una farsanta que llaman Amarilis, a quien dicen que festejaba el Duque, y que en muy pocos días le había dado muchos dineros y vestidos, a hacer un paso a caballo, y que llevaba un jaez que el Gran Turco había enviado al Duque; y que en la comedia había de todo. Ha habido gran grita y bulla, que junto con lo de los aposentos dio campanada. [...] También han echado de aquí a Don Francisco de Quevedo, a quien envió de Nápoles por embajador con un presente porque le dieran el hábito de Santiago [...] [Krzysztof Sliwa, 2005: 300-301]

\footnotetext{
${ }^{56}$ Sobre este personaje, véase el capítulo de Alessandro Martinengo "El Duque de Osuna, entre Nápoles y Venecia", incluido en su estudio Quevedo: Fronteras de la filología [2006: 65-74].
} 
El Duque de Osuna, como todos sus coetáneos, quedó encandilado por la bella actriz Amarilis, que hasta Lope de Vega describe embelesado en sus cartas al Duque de Sessa. La afición del noble al mundo de la farándula sumergió a Quevedo en su medio.

En efecto, don Francisco incluye en sus sátiras personales un Diálogo entre Morales y Jusepa, que había sido honrada cuando moza y vieja dio en mala mujer (POC, 847). El poema alude a la famosa pareja de representantes, que contrajeron matrimonio en 1602 y que, más adelante, incluyeron a su propia hija en los números. Es un jocoso muestrario de la decadencia física y moral de la actriz, que en 1618 recibió un premio de 300 escudos por su buena actuación. La sarcástica composición recurre a temas predilectos de la risa entremesil: la cornudería y el mal envejecer. Quevedo propone chistes onomásticos a propósito de los apellidos de los comediantes. Sobre Jusepa, la voz de Respuesta dice: "Temo que hasta aquí fue Vaca/ y que agora lo estará" (vv. 23-24). Sobre Morales, la Pregunta final señala la evolución del autor hacia el medro, su segundo apellido: "Hasta aquí he sido Morales; / desde aquí seré Medrano" (vv. 39-40).

Sea como fuere, la relación entre el Duque de Osuna y Quevedo fue una amistad peligrosa que le valió el segundo destierro, en enero de 1622. Se sabe que don Francisco escribió una extensa biografía de don Pedro TéllezGirón que nunca se ha llegado a editar: los Dichos y hechos del duque de Osuna en Flandes, España, Nápoles y Sicilia. Este manuscrito inédito se halla en un archivo nobiliario de complicado acceso. Tal vez, si alguna vez ve la luz, logremos extraer más datos sobre la relación de don Francisco con el teatro. 


\section{FELIPE IV Y EL TEATRO POLÍTICO CORTESANO (1621- 1627)}

\section{EL CAMBIO DE LA CÚPULA DE PODER}

Tras la muerte de Felipe III, el 21 de marzo de 1621, acaecen toda una serie de acontecimientos históricos que Quevedo narra con veracidad de cronista en sus Grandes anales de quince dias. ${ }^{57}$

Siete días después de la muerte del monarca, se detiene al Duque de Osuna. Es inevitable que, meses más tarde, el 20 de junio de 1621, la Junta que encausaba al Grande de España consultara al nuevo rey sobre la culpabilidad de Quevedo por asistirle a las fiestas y gastos con lisonja. El destierro en la Torre de Juan Abad no durará más de un año, sin embargo.

Con el ascenso al trono de Felipe IV, aumenta la actividad dramática en la corte. Compañías de actores profesionales actúan regularmente en palacio y, durante un tiempo, prosiguen los espectáculos interpretados por aficionados.

En 1622, el rey solicita que se construya un corral de comedias dentro del palacio, pero el Ayuntamiento de Madrid, probablemente preocupado por las consecuencias que este tipo de teatro podía tener para los locales públicos, parece no atender la propuesta.

${ }^{57}$ Esta obra se interrumpe por causas de fuerza mayor, tras su destierro a la Torre de Juan Abad, cuando se aparta del escenario de los hechos. Años más tarde, Quevedo rememora estos primeros años del reinado en su comedia Cómo ha de ser el privado. La realidad, sin embargo, se distorsiona bastante en esta obra cortesana, compuesta para ser representada en Palacio. 
Al margen de los escritos políticos, hacia 1622 corren nuevas obrillas festivas de Quevedo por la corte. Desde 1620 circulaban las Cartas del Caballero de la Tenaza, que pudieran inspirar el entremés de título homónimo, que Blecua tildó de apócrifo.

Durante estos años, Quevedo sigue con su costumbre de hospedarse en posadas, donde le gustaba platicar con los eventuales viajeros y personajes de a pie.

Se produce, además, un hito en la evolución del espectáculo cortesano: con tres brillantes representaciones de aficionados en el palacio de verano de Aranjuez, emergen entretenimientos calificados de invenciones y no de comedias. ${ }^{58}$ En esta clase de obras, el montaje y la escenografía desplazan el protagonismo de la palabra: el ingeniero jefe de las fortificaciones del reino de Nápoles, Julio César Fontana, estuvo a cargo de la compleja maquinaria de La gloria de Niquea, del Conde de Villamediana. Las otras dos obras que se representaron en Aranjuez fueron Querer por sólo querer de Antonio Hurtado de Mendoza y El vellocino de oro de Lope de Vega. Naturalmente, don Francisco tuvo noticia de estas invenciones. .

\section{SUCESOS DE 1623}

El año 1623 es significativo por varios motivos. Velázquez entra en la corte con sus refinados pinceles. ¿Fue este pintor genial o acaso su suegro y maestro Juan Van Der Hamen quien inmortalizará la imagen más difundida

\footnotetext{
${ }^{58}$ Cfr. Melveena McKendrick [1994: 227].
} 
de don Francisco? Es un retrato omnipresente, desde luego, que ayudará a la cristalización del escritor como personaje literario y, por ende, dramático. Velázquez, en todo caso, como pintor oficial de la corte, fue un interesante referente para la dramaturgia auricular que, en sus galerías de personajes, bebe de la plasticidad pictórica.

En 1623, el salón del Alcázar se utilizaba con tanta asiduidad para la representación que se le llamaba salón de comedias. Se convirtió en el centro de las actividades dramáticas. ${ }^{59}$ Durante el Carnaval, las cuatro compañías que trabajaban en Madrid fueron contratadas para representar entremeses, loas, jácaras y bailes. La corte gozó de una parodia improvisada, que interpretaron diferentes poetas y cortesanos, entre ellos Alarcón y Vélez de Guevara.

Asimismo, el 17 de marzo, el príncipe de Gales, dispuesto a “enamorarse" de la Infanta María de Austria, llama de incógnito a la puerta del embajador inglés de Madrid, el Conde de Bristol. España e Inglaterra pretenden un enlace amistoso, alternativo a un temido encuentro militar por la crispada política centroeuropea. ${ }^{60}$

${ }^{59}$ Cfr. Melveena McKendrick [1994: 228]: "La afición de la reina al drama desde luego no disminuyó: entre el 5 de octubre de 1622 y el 8 de febrero de 1623 se organizaron no menos de cuarenta y cinco particulares, de al menos una docena de dramaturgos, la mayor parte de los cuales escribían para los corrales, por cinco compañías distintas en las habitaciones de la reina, siendo los domingos, los jueves y los festivos cuando en principio había teatro en el Alcázar."

${ }^{60}$ A la controversia del english match se suma el dilema ideológico: se llegaron a reunir cuarenta teólogos para discutir hasta qué punto era viable casar a una princesa católica con un príncipe "hereje". 
Cuando la noticia se hace pública, el Conde-Duque de Olivares prepara unos fastuosos festejos de bienvenida, entre los que se incluyen un banquete ofrecido por el Conde de Monterrey, dos corridas de toros en la plaza mayor y juegos de cañas. El 21 de agosto, el pueblo recibe con sorna todo este boato e impostura, pero disfruta de la fiesta que se le regala. El cronista oficial del evento, el célebre dramaturgo Ruiz de Alarcón, recibe pullas por doquier. $^{61}$

Las redondillas de don Francisco A Vallejo, cuando no quiso en una comedia bajar en la nube, y bajó su mujer, Luisa de Robles (POC, 848) se burlan de la cobardía del actor ante una escena de acción teatral representada en 1623. El rubor del comediante contrasta con el ímpetu de su mujer:

\author{
Quien no cayó en la tramoya \\ que andaba sin enviudar, \\ bien se pudiera fiar \\ aun del caballo de Troya. \\ Sin duda fue carnicero \\ quien el pasillo enmendó, \\ pues que la carne bajó \\ porque no subió el carnero. \\ Mostró Luisa su osadía, \\ pues subió para enseñar \\ en el aire a descargar \\ a la nube en que venía. ${ }^{62}$
}

${ }^{61}$ Quevedo también describirá satíricamente estos festejos en los romances 677 y 723.

${ }^{62}$ José Manuel Blecua [1999: 1115] sostiene que el actor que protagoniza el poema puede aludir a Manuel Vallejo, solicitado comediante aurisecular que no estaba casado con Luisa 
Finalmente, con la venida del Príncipe de Gales, hubo "mucho ruido y pocas nueces": ruido que llegó a parodiarse hasta el agotamiento. Quevedo hizo de este asunto una trama secundaria de la comedia Cómo ha de ser el privado.

Entre 1623 y 1628, según traduce su teatro político, Quevedo se alinea con el programa reformista de Olivares, como plasmarán en su modalidad poética el Sermón estoico y la Epístola satírica y censoria.

\section{EXPEDICIONES Y ENTREMESES}

En febrero de 1624, el monarca parte hacia Andalucía por diversos motivos estratégicos. Quevedo le acompaña en la comitiva, al servicio del Almirante de Castilla. La fatigosa expedición se convierte en una auténtica odisea, aunque goza de descansos ociosos. Como la representación, los días 16 y 17 de febrero, del entremés El zurdo alanceador en Sevilla, que tenía un papel para la célebre actriz Amarilis.

Otro de los entremeses del autor pudo representarse el jueves 14 de marzo, después de que el rey matara un jabalí en Doñana, en el Palacio de Lomo el Grullo, o bien en situación parecida -como condimento a la representación de varias comedias- el siguiente fin de semana (del 16 al 18

de Robles, sino con María Riquelme, también de renombre teatral. Ignora si coincide con el Vallejo que estrenó la comedia de Ruiz de Alarcón El Anticristo el 12 de diciembre de 1623 y que se atemorizó en una escena de vuelo del segundo acto, dejando que Luisa de Robles lo hiciera en su lugar. 
de marzo) en la casa de campo o el palacio del Duque de Medina Sidonia en el coto de su mujer, Doña Ana. ${ }^{63}$

La representación de los entremeses en verso de Quevedo coincide con este segundo periodo cortesano (1623-28). ${ }^{64}$ Durante esta época se representan los entremeses de El Marión, El marido pantasma, La venta, El Niño y Peralvillo de Madrid, La destreza, La Polilla de Madrid, La ropavejera y Los refranes del viejo celoso.

\section{UNA COMEDIA PARA EL CUMPLEAÑOS DE LA REINA}

Después de la rendición de Bredá el 15 de junio de 1625, que Velázquez retrató en Las lanzas, la corte se viste de fiesta y jolgorio. A los motivos de celebración se añaden el aniversario de la reina (con una fiesta de toros y cañas en la Priora), la canonización de Isabel de Portugal y la recuperación de Brasil por la armada de Fadrique de Toledo.

Por estas fechas, Quevedo participa en la composición de una comedia escrita a tres manos, junto con Mateo Montero y Antonio Hurtado de Mendoza. Se representa el 9 de julio con motivo del cumpleaños de la soberana. Cada uno de los dramaturgos escribe un acto. Es una comedia de título desconocido, que se ha perdido, según la crítica. ¿Podría tratarse de $E l$ galán fantasma, la comedia manuscrita con tres tipos de letra diferentes que

\footnotetext{
${ }^{63}$ Cfr. Jauralde [1999: 480].

${ }^{64}$ El primer periodo cortesano suele situarse entre 1606 y 1613, que coincide con la época de las primeras jácaras, bailes y entremeses en prosa de Quevedo.
} 
he hallado en el Fondo Sedó del IT? Dejaremos este asunto para más adelante.

Quevedo, durante estos años, también participa de algunas fiestas literarias para el divertimento cortesano, que organiza el alegre Marqués de Velada, el protector del poeta, prematuramente fallecido, Anastasio Pantaleón de Ribera (1600-1629).

En el romance 688, nuestro autor alude a Cosme Lotti, célebre escenógrafo de origen italiano y constructor del "teatro a máquina". Tuvo un notable impacto como procurador de los más arcanos "efectos especiales" de la escena:

\author{
Con bullicios, Cosme Loti \\ de tramoyas, subo y bajo, \\ y en remolinos del cuerpo \\ mil veces mudo el teatro. (vv. 53-56)
}

El ingeniero hidráulico toscano, a petición de Olivares, había llegado de Italia para construir fuentes y riegos automáticos para jardines. Pronto se convirtió en diseñador de escenografías y de una maquinaria escénica sumamente imaginativa, que lo convirtió en jefe de los tramoyistas de la corte. El poema de Quevedo tal vez aluda a la representación de La selva sin amor de Lope de Vega, el 18 de diciembre de 1627, que fue escenificada en presencia del rey, la reina y la hermana del monarca, la Infanta María, en el salón de comedias de palacio. La llegada de Cosme Lotti supuso un gran avance en la sofisticación de los efectos teatrales. 
De 1627 podría ser el romance que sirve de loa (POC, 768) a Amores y celos hacen discretos de Tirso de Molina, impresa ese mismo año, aunque la compañía de Valdés ya la había representado en Sevilla, en 1615. Se escenificó en una fiesta y fue recitada por una célebre actriz que llamaban Roma, vestida con traje de hombre. Esta loa está relacionada con el romance 787, que imita muchos de sus versos. Con toda seguridad, durante las horas muertas de los ocios nobiliarios, se escenificaron algunos entremeses de Quevedo difíciles de fechar. ${ }^{65}$

${ }^{65}$ Cfr. Jauralde [1999: 504]. 


\section{BAJO EL ÍNDICE DE LIBROS PROHIBIDOS (1627-1632)}

\section{Censura y destierro}

A comienzos de 1627, se había reglamentado la composición del Índice de libros prohibidos, en el que habían colaborado el Padre Pineda y Pedro Pacheco, que no mantenían una relación demasiado cordial con nuestro autor. ${ }^{66}$ Quevedo no podrá evitar su inclusión como autor damnatus de segunda clase, categoría que censuraba una parte de su producción literaria (y no toda entera, por suerte, como sucedía con los autores damnificados de primer orden, cuyo nombre ya era sinónimo de herejía). Este hecho perjudicó, naturalmente, a su teatro. Y, a todas luces, ha cambiado el rumbo de la historia literaria. ¿Cuántas obras maravillosas murieron en el fuego inquisitorial?

El Índice de libros prohibidos, con el pretexto de la limpieza moral de una época, ha sido uno de los mayores atentados contra la libertad de expresión. Los filólogos al uso nunca dejaremos de escandalizarnos y de recriminar unas medidas que han reducido considerablemente el patrimonio cultural de una de las épocas más fecundas de nuestra literatura. Fruto de sus medidas prohibitivas, se vieron afectados muchos hombres célebres de la farándula, como el representante de Granada Mateo Lisón de Biedma, que fue inmediatamente desterrado.

${ }^{66}$ El padre Pineda tuvo una escabrosa relación con Quevedo. Ambos se censuraron mutuamente, aunque don Francisco en su Respuesta no fue más allá del terreno estéticoliterario, claro está. Jauralde [1999: 520-527] profundiza en esta relación. 
A partir del 13 de junio de 1627, se dicta una célebre premática sobre libros y publicaciones, que deja sin novedades teatrales a las prensas durante diez años.

En abril de 1628, muy arbitrariamente, destierran a Quevedo a la Torre de Juan Abad. Han advertido que su Política de Dios contiene malas opiniones del gobierno. Don Francisco no dispone de mecenas; su aislamiento es entre amistoso y disciplente. El Conde-Duque de Olivares ni siquiera ha leído la dedicatoria a Su espada por Santiago, un memorial que despertó polémica.

Nuestro autor vive en el retiro la publicación de El zurdo alanceador, impreso en Segovia en 1628. Pretende recuperar el favor real en su otro memorial Lince de Italia y zahorí español, donde no sólo alude a la política italiana, sino también al panorama diplomático español. Ignoramos si la obrilla fue a parar a manos del monarca. Lo que sí sabemos es que el 29 de diciembre de 1628, le escribe el Cardenal Gabriel Tejo, Presidente del Consejo Real, para que regrese a la corte.

Entre 1627 y 1632, fecha de la nueva publicación del Índice de libros prohibidos, Quevedo, para curarse en salud, se autodenuncia. Reniega de las obras impresas que circulan a su nombre sin su previa autorización y modifica el texto de su último libro, el Discurso de todos los diablos, con la finalidad de protegerse y de limpiar su imagen pública. El miedo a la censura puede explicar, entonces, su extraña gloria parcial. Podemos horrorizarnos ante una censura tan atroz que induce, de antemano, a la autocensura de los creadores. 
En el Índice de Zapata de 1632, Quevedo vuelve a aparecer como autor de segunda clase. Don Francisco está bien acompañado: Pellicer, Montalbán, Cervantes, Pero de Mexía, Vicente Espinel, Diego Niseno... grandes intelectuales y escritores de su tiempo, mentes muy lúcidas. ${ }^{67}$

Hacia 1632, aparece la carta del padre Andrés Mendo que hemos trascrito en el primer capítulo, preguntándose si podrá conservar el ingenioso y entretenido entremés de El zurdo alanceador.

El Chitón de las Taravillas, que circulaba anónimo, también cifraría entre las obras censuradas. En este punto, el investigador fabula y se pregunta de qué modo pudo Quevedo desasirse de las garras de la censura. Sin duda, en lo que a nuestro objeto de estudio se refiere, deben de conservarse obras dramáticas suyas bajo el anonimato o pseudónimos difíciles de desenmascarar. Queda mucho trabajo por hacer.

\section{TEATRO PANFLETARIO}

Tras su regreso a Madrid, Quevedo asume el rol de cerebro propagandístico de la política del Conde-Duque. La economía española anda en crisis: en agosto de 1628, ha aparecido la premática de la devaluación de la moneda de vellón, tema que emergerá en el baile inédito y atribuido Comedia de las dependencias de España, cuyo enigma desvelaremos más adelante. En esa línea deben interpretarse el romance

${ }^{67}$ A propósito de este asunto, véase el artículo de Asensio "Censura inquisitorial de libros en los siglos XVI y XVII. Fluctuaciones. Decadencia.”, en El libro antiguo español [1986]. 
Fiesta de toros, literal y alegórica (POC, 752), El chitón de las Taravillas y la pieza dramática Cómo ha de ser el privado. De la misma época es la comedia Pero Vázquez de Escamilla, de la que sólo se conserva un fragmento de la jornada primera. Quevedo ejerce, asimismo, de filólogo, y publica las poesías de Fray Luis y Francisco de Torre.

El 12 de octubre de 1629, hay fiesta de cañas y de toros en la Plaza Mayor de Madrid. Se festeja la boda de la Infanta María con el rey de Hungría, tras el fiasco de su enlace con el Príncipe de Gales. Una semana más tarde, el 17 de octubre de 1629, se celebra el nacimiento del Príncipe Baltasar Carlos. Se le bautiza el 4 de noviembre. El 21 de noviembre, el Duque de Medina de las Torres organiza una grandiosa máscara. Y hay celebraciones de toros y cañas el 12 de diciembre. ${ }^{68}$ Inferimos que, en el marco de estas fiestas, tuvo cabida la representación de alguna de las comedias de Quevedo. ${ }^{69}$

Sobre estas fechas, nuestro escritor emprende un viaje a Toledo en pleno invierno: quiere saldar la publicación de los Juguetes y atender asuntos de la Torre de Juan Abad. En una carta al canónigo toledano Alonso Mesía, del 7 de diciembre de 1629 , relata su intrincado viaje, donde las ventas, tema de uno de sus entremeses, son refugio indispensable para el viajero y a la vez constituyen una metáfora de nuestro paso por el mundo. ${ }^{70}$

\footnotetext{
${ }^{68}$ Cfr. Jauralde [1999: 594].

${ }^{69}$ Elliott [1982: 235], de hecho, postula la representación de Cómo ha de ser el privado para estas fechas.

${ }^{70}$ Krzysztof Sliwa [2005: 450].
} 
En 1630, el monarca Felipe IV se desplaza a Zaragoza con su comitiva. Pudo haber algún tipo de trato entre editores aragoneses y alguien del séquito que llevara manuscritos de Quevedo. Del 29 de abril, precisamente, es la aprobación de la Doctrina moral, por Pedro Vergés.

El absentismo del monarca en Madrid hace que Quevedo se replantee su relación con Olivares, cuyo gobierno recibe críticas llenas de crispación. El valido se sirve de la pluma de los ingenios para defender su prestigio. Por ello, nuestro autor publica anónimamente - para no exponerse a la censura inquisitorial- El chitón de las Taravillas. Los argumentos, sin embargo, no serían del todo del agrado de Olivares, que prohíbe la circulación del libelo. Lope de Vega, desconociendo la autoría del mismo, le escribe al Duque de Sesa que es "lo más satírico y venenoso que se ha visto desde el principio del mundo." 71 También Salazar y Antonio Hurtado de Mendoza editan unos discursos panfletarios a favor del privado.

En septiembre de 1630, Quevedo inicia su correspondencia epistolar con quien será su nuevo protector: el Duque de Medinaceli. Don Francisco le ayudará a formar su biblioteca. Su amistad estará cimentada en la avidez intelectual del inquieto y joven mecenas. Durante estas fechas, respaldado por este aliento propicio, don Francisco vuelve a dedicarse a tareas filológicas: traduce el Rómulo del noble boloñés Virgilio Malvezzi y escribe los preliminares a la Comedia Eufrosina, traducida por el capitán don Fernando de Ballesteros y Saavedra.

\footnotetext{
${ }^{71}$ Cartas, ed. Nicolás Marín [1985: 284].
} 


\title{
3. LA NOCHE DE SAN JUAN DE 1631
}

Quevedo disfrutó de una tranquila velada la noche de San Juan de 1631. ${ }^{72}$ Se deleitó en una fiesta llena de regocijos, que celebró en sus jardines el Conde de Monterrey, cuñado de Olivares. En los cenadores del Duque de Maqueda, vecinos al Prado, se representó una comedia que hoy se ha perdido. Esta obra, compuesta entre Quevedo y Antonio Hurtado de Mendoza, se llamaba Quien más miente, medra más.

La representación de la comedia corrió a cargo de la compañía de Manuel Vallejo. Éste era un excelente cómico y "autor" de título, uno de los pioneros de la Cofradía de la Novena. Estaba casado con la virtuosa actriz María de Riquelme, que interpretó la loa.

Durante el mismo festejo, se representaron la comedia de Lope La noche de San Juan -compuesta en tres días- y tres bailes de Quiñones de Benavente. El Fénix versifica acerca de la comedia compuesta por sus colegas:

\author{
Representará Vallejo \\ una comedia en que ha escrito \\ don Francisco de Quevedo \\ los dos actos que serán \\ el primero y el tercero, \\ porque el segundo que abraza \\ los dos, dicen que ha compuesto \\ don Antonio de Mendoza $[\ldots]^{73}$
}

\footnotetext{
${ }^{72}$ Así lo describe una Relación que cita Casiano Pellicer [1975] en su Tratado histórico sobre el origen y progresos de la comedia.

${ }^{73}$ Véase la edición de Anita K. Stoll, La noche de San Juan [1988: 44].
} 
La obra de Quevedo y Hurtado de Mendoza aparece en una Relación de Pellicer como "poblada de las agudezas y galanterías cortesanas de don Francisco", muy sazonada de chistes, de manera poco común en las comedias ordinarias. ${ }^{74}$

Las damas, espectadoras de los lances y chanzas hacia el género femenino y la institución del matrimonio, decidieron vengarse del autor casándole por mediación del Conde de Medinaceli. Con toda seguridad, el matrimonio de Quevedo no sería oficial, sino jocoso, dado que las malogradas y tardías nupcias de nuestro autor se celebraron en $16344^{75}$

Las comedias de este día de San Juan fueron dirigidas por el Duque de Medina de las Torres. El superintendente de las obras de palacio, el Marqués Juan Bautista, supervisó la construcción de los escenarios y los decorados. No sabemos si Cosme Lotti participó en estas representaciones, pero sí se ha documentado que lo hizo al año siguiente, con Júpiter vengado de Diego Jiménez de Enciso, en el Alcázar, y dos comedias de capa y espada, una del Príncipe de Esquilache y otra de Antonio Hurtado de Mendoza. $^{76}$

\footnotetext{
${ }^{74}$ Cfr. Germán Vega [1993: 115].

${ }^{75}$ Véase A. Cotarelo [1945: 58].

${ }^{76}$ Cfr. Melveena McKendrick [1994: 231].
} 


\section{Poemas de Circunstancias}

La Plaza Mayor de Madrid era el nuevo centro de eventos de la corte. Menguaba la celebridad de la estrecha plazuela de Santa María y la del Salvador aunque, por su refinada modernidad, no atraía demasiado la barahúnda del gentío. Esa zona, desde su reciente inauguración, había sido teatro de fiestas y de ejecuciones públicas. El contraste no deja de ser curioso: el mismo lugar que albergaba el regocijo del baile, el espectáculo y la galanura, había exhibido públicamente la condena a muerte del Marqués de Siete Iglesias.

El 7 se julio de 1631, se incendia gran parte de la Plaza Mayor de Madrid, y las llamas tardan tres días en sofocarse. Quevedo fue testigo de este accidente catastrófico. Su soneto Al incendio de la plaza de Madrid, en que se abrasó todo un lado de cuatro (POC, 101) interpreta el acontecimiento como una lección para los madrileños, fruto de la divina Providencia:

Cuando la Providencia es artillero,

no yerra la señal la puntería;

de cuatro lados la centella envía

al que de azufre ardiente fue minero.

El teatro, a las fiestas lisonjero

donde el ocio alojaba su alegría,

cayó, borrando con el humo el día,

y fue remedio al fuego compañero.

El viento que negaba julio ardiente

a la respiración, le dio a la brasa, 
tal, que en diciembre pudo ser valiente.

Brasero es tanta hacienda y tanta casa;

más agua da la vista que la fuente;

logro será, si escarmentado pasa.

La tragedia se repite unas semanas más tarde. El 28 de agosto de 1631, un falso rumor de incendio provoca una avalancha multitudinaria durante una corrida de toros, que se cobra la vida de varios. Don Francisco, apenado, refiere en otro soneto $(P O C, 129)$ que la "fatal suerte" es fruto de la voluntad divina:

¿Quién duda en ser avisos soberanos, aunque el vulgo los tenga por antojos, con que el cielo el rigor de sus enojos severo ostenta entre temores vanos? (vv. 5-8)

Por fortuna, Quevedo no sólo escribió a los supuestos castigos divinos del teatro. También participó en poemas lisonjeros a las proezas públicas de la familia real. En la fiesta venatoria del 14 de octubre del mismo año, después de una pelea de fieras (muy al estilo del circo romano, todo hay que decirlo), el monarca remató el espectáculo matando a un toro de un tiro certero. La anécdota inspiró el ingenio de muchos poetas, que vieron en la circunstancia una ocasión de oro para ganarse el favor real.

Don Francisco escribió un romance $(P O C, 767)$ y dos sonetos $(P O C$, 221, 222) a la "mucha muerte en poco plomo" (POC, 767, v. 195) que, de la mano de Felipe IV, hizo desaparecer al toro exhausto. Estos poemas, compilados con composiciones de otros autores, fueron acogidos en un 
libro de aclamaciones poéticas, el Anfiteatro de Felipe el Grande, en el que también colaboraron, por cierto, Lope y Calderón.

\section{El Distanciamiento del CONDE-DUQue}

Hacia 1632, la ideología de Quevedo y su deseo de ascenso cortesano no encontraban vías de reconciliación. Su nuevo y joven protector, el Duque de Medinaceli, sobrino del Duque de Lerma, se alineaba con los nobles que se mantenían al margen del aparato oficial. El Conde-Duque, por otra parte, había sido negligente en el marco de su política diplomática y económica: había trapicheado con judíos y se había burlado, en fin, de la autoridad del monarca durante su ausencia de la corte madrileña. Era fácil profetizar su caída.

Don Francisco se inclina hacia un latente antiolivarismo. En su Execración contra judíos, elogia a la Inquisición que con su "mano derecha y sagrada" condena a los herejes, con los que precisamente había tratado el valido. Entre el 7 y el 19 de marzo se celebra la solemne Jura del Príncipe Baltasar Carlos y el escritor compone unas octavas reales $(P O C, 235)$ que glorifican al monarca, donde el privado ya no es centro del panegírico.

El 12 de abril de 1632, la comitiva real - el monarca, los infantes y el propio Olivares- se dirige a los reinos de Valencia, Cataluña y Aragón para recibir donativos. En Madrid quedan al frente del gobierno la Reina y Luis García de Haro, ayudados por una junta escogida por Olivares. Quevedo, en un romance $(P O C, 681)$ dirigido al Conde de Sástago, miembro de la 
expedición, retrata el gobierno endeble de la capital, incapaz de regular el libertinaje y los escándalos en corrales de comedias.

\section{UNA BODA AGRIDULCE}

En 1632, Quevedo se convierte en el protagonista de un episodio que tuvo su contrapartida teatral, siglos más tarde: un matrimonio frustrante, de conveniencia. Ha sido mucha la presión cortesana para que el misógino por antonomasia se case. Sobre todo, hay una confabulación de las damas cortesanas. Prueba de ello, es el fruto de una de las últimas travesuras literarias de Quevedo: la epístola jocosa (oficialmente conocida como la Carta sobre las calidades del casamiento) sobre las virtudes que habrá de atesorar su futura esposa. En ella deja clara su postura: "He sido malo por muchos caminos, y habiendo dejado de ser malo, no soy bueno, porque he dejado el mal de cansado, y no de arrepentido." ${ }^{77}$

Sobre la misma fecha, cabe situar el romance La vida poltrona (POC, 773) donde hay una incipiente defensa de la soltería, sinónimo de libertad y autorrealización:

Dicen que me case;

digo que no quiero,

y que por lamerme

he de ser buey suelto. (vv. 53-56)

${ }^{77}$ Transcribo de la copia manuscrita de la Biblioteca de Catalunya: ms. 3619, f. 265 r. 
El 31 de enero de 1632, el Duque de Medinaceli extiende los poderes para otorgar las capitulaciones para el casamiento de Quevedo con la viuda cincuentona Esperanza de Mendoza, señora de Cetina. El fallecimiento de la hermana de Quevedo probablemente retarda la boda, que no se celebra hasta el 26 de febrero de 1634. Fue un corto y nada apasionado matrimonio de conveniencia: Esperanza murió apenas unos años más tarde en su villa, en $1642 .^{78}$

78 Dice Jauralde [1999: 672]: "Pocos son los datos biográficos que nos acerquen a los días de la boda de Quevedo en Aragón, aunque me consta que existe documentación inédita e iconográfica, en aquellos lugares, que algún día ilustrara las circunstancias, pero que yo no he alcanzado a ver." 


\section{EL DESENGAÑo ESTOICO (1633-1645)}

\section{El BUen Retiro}

A finales de 1633, con la inauguración del Palacio del Buen Retiro, la corte se viste de sus mejores galas. Quevedo, según se ha documentado, ${ }^{79}$ asistió a una de sus numerosas fiestas, el 5 de diciembre. Según narra Lope de Vega, cronista oficial de los acontecimientos, don Francisco pudo ver la clásica corrida de toros (en la que participaron ocho aristócratas, en comitiva de Olivares), una justa que llegó a protagonizar el mismísimo monarca y, claro está, la representación de una comedia por dos compañías de representantes, a la que siguió un banquete. Nuestro autor llega a escribir un soneto de circunstancias en alabanza del rey, el que empieza "Aquella frente augusta que corona..." (POC, 229). ${ }^{80}$

Quevedo, sin embargo, pronto se desliga del boato del Retiro para recluirse en su señorío manchego, como clara oposición al régimen olivarista. En una carta escrita desde la Torre de Juan Abad a Sancho de Sandoval [2005: 504], alude a la redacción de una obra propia en la que ha trabajado valientemente, denominada Theatro de la Historia, "obra grande, política y ética, con erudición sabrosa, por tener veras importantes, todas de novedad, asistidas de donaire bienquisto de lo sagrado del tratado".

\footnotetext{
${ }^{79}$ Cfr. Jauralde [1999: 664].

${ }^{80}$ Durante las mismas fechas, se celebra la reforma de otro paraje real, el Palacio de los Duques de Lerma, que se inaugura con sus correspondientes celebraciones, al que Quevedo dedicará otro soneto $(P O C, 225)$.
} 
Actualmente, sin embargo, carecemos de testimonios manuscritos o impresos de dicha composición. ${ }^{81}$

El autor, sin embargo, estaría al tanto de la inauguración teatral del lago del Retiro el 2 de julio de 1635, en la que Calderón de la Barca y Cosme Lotti colaboraron artísticamente con un montaje extraordinario que se elevaba sobre el agua. La obra era El mayor encanto amor, y dramatizaba la leyenda de Circe, cuya representación duró seis horas.

La creación del Buen Retiro unió al público de a pie con el palatino. Se transformó en el centro de las diversiones cortesanas a gran escala, porque permitía montajes lujosos y experimentales.

\section{EL DILEMA MORAL}

Quevedo, en sí mismo, era un espectáculo ambulante, pródigo en escenificaciones de taberna. Una enigmática carta de 1635 desvela el "aplauso que del vulgo" lograba don Francisco, erigido como personaje dramático con su "grave teatro". El punto de vista del autor anónimo de la epístola es el de un enemigo suyo. Juzga moralmente a un personaje obcecado en la provocación:

El diligentísimo correo se entró en un bodegón, en quien una inclusa puerta daba tránsito a la taberna de mayor aprobación y más asistida de los poco paniegos y con exceso vinosos: grave teatro, tan antiguo como propio, donde los discursos de este

${ }^{81}$ Para Pablo Jauralde [1999: 690] este título podría aludir a La hora de todos y la Fortuna con seso. 
infeliz autor (don Francisco de Quevedo) van siempre a parar y tienen común y agradable acogida, y en quien los hombres más distraídos y con abominación desechados por vil escoria de la república, celebran sus escritos, admiran sus frialdades, hiperbolizan sus desvergüenzas, ponderan sus viles y bufonescos gracejos, repiten con risadas bacanales sus malicias, hacen suma alabanza de sus deshonestidades, califican sus atrevimientos contra lo divino y humano, y entre tahada y tahada y el déjala vuizé vezir, lo vitorean por el antiguo congregante de la glotonería, y aclaman por oficial insigne del trago... [Krzysztof Sliwa, 2005: 555].

Sobre las mismas fechas, otros documentos apuntan que Quevedo repudiaba la masificación popular de los eventos teatrales, sobre todo el escándalo de los mosqueteros. Las representaciones abundaban en la corte, había diversiones burlescas en los días festivos y cada vez los montajes eran más profesionales. Tras la muerte de Lope de Vega en agosto de 1635, dramaturgos como Calderón, Rojas Zorrilla, Quiñones de Benavente, Vélez de Guevara y Antonio Coello mostraban sus invenciones en noches de San Juan y Martes de Carnaval, a menudo respaldados por las maquinarias escénicas del ingeniero toscano Cosme Lotti.

Don Francisco, sin embargo, vive más ajeno que nunca a estos espectáculos. En ello se traduce su versión de la Doctrina de Epicteto, que en su capítulo XXXV señala que "No se han de frecuentar los teatros de las comedias, y si se oyere alguna, ha de ser con modestia y silencio, sin alabanza ni vituperio":

No frecuentes comedias, ni teatros, donde la mocedad antes alcanza escándalo, que ejemplo y enseñanza. 
Mas, si en ellos entrares,

entiendan todos de una misma suerte,

que quieres sólo a ti satisfacerte:

Quiero decir, que quieras

que en lo que la comedia sucediere

sea como su autor lo dispusiere,

que venza quien la fábula ordenare,

que obedezca la copla en el sentido,

a lo que el consonante la forzare,

que el indigno de amar goce admitido,

que venza quien la fábula quisiere,

que se logre la treta

que imaginó el poeta,

y que muera el valiente

cuando lo ordene el trágico accidente,

o el fin de la batalla,

trata de oírla, deja el disputalla;

que si así te compones con la gente,

serás sabio, y oyente.

No des voces, palmadas, ni te rías, vituperes, ni alabes

la copla humilde, ni los versos graves:

y de lo que has oído y lo que has visto,

tu semblante podrá salir bien quisto.

Y acabada la farsa,

no censures la traza, ni los versos,

pues ya fuese confusa, o poco tersos,

para tu corrección nada aprovecha,

y mostrarás envidia, y no doctrina,

y antes parecerá por tu cuidado 
El credo del pasaje concuerda con las polémicas moralistas, oscilantes entre lo lícito y lo ilícito, que Quevedo respiró durante su vida. Distingamos, sin embargo, entre el dicho y el hecho. Por algo don Francisco dijo de sí mismo que era hombre de bien, nacido para mal. Quizá los teatros eran cuadras de pecado, pero nuestro autor las había frecuentado sin remordimientos.

\section{EL DESPRECIO A LAS VANIDADES DEL TEATRO}

Entre 1639 y 1641, se renovó y reamuebló el gran Salón del Alcázar, donde residía la familia real gran parte del tiempo. Se restauró el techo con molduras de oro y pasó a llamarse el Salón Dorado. Se construyó un escenario bajo desmontable, también dorado, con telón frontal y decorado con perspectiva.

El espectáculo incluía a la familia real, que se ubicaba bajo el dosel y frente al escenario para tener una vista privilegiada de la representación. Su entrada y su salida se asistía con boato y solemnidades, en un ceremonial que convertía a la monarquía en otro centro de atención, además de la comedia representada.

El Coliseo disponía de un escenario algo más elevado, pero la presencia del rey y la reina en sendos tronos los seguía colmando de protagonismo. Los escenarios con proscenio del Salón Dorado y el Coliseo procuraban una 
experiencia teatral distinta a la de los corrales: el público era pasivo y estático y permanecía en silencio.

Con todo, la década de los 40 no fue especialmente prolífica teatralmente. La sublevación de Cataluña y la guerra con Portugal acallaron los festejos cortesanos, aunque siguió habiendo particulares. Olivares, el gran instigador y apasionado del teatro cortesano, fue destituido en 1643 . Cosme Lotti falleció ese mismo año. Y, al perecer la reina al año siguiente, cesaron los particulares y se cerraron los corrales por un tiempo. El teatro no se revitalizó hasta la década de los cincuenta.

Pero, ¿qué es de Quevedo, mientras tanto? Son los últimos años de su vida y está completamente ensimismado.

La invidiosa murmuración es la carcoma con la que han sido perseguidos todos los grandes. Sapientes abscondunt scientiam. (Los sabios esconden su sabiduría.) No puede ser sabio quien no es verdaderamente humilde. Ningún estudio conseguirá descifrar los grandes misterios de la vida. Como afirma don Francisco en el capítulo IV de La cuna y la sepultura:

¿Quién te dio a ti cuidado de las estrellas y puso a tu cargo sus caminos? ¿Para qué gastas tu vida en acechar curioso sus jornadas? Deja el cuidado a la providencia de Dios y a la ley que las gobierna, en cuya obediencia trabajan día y noche, que por más que te fatigues en entender los secretos del cielo no has de saber más de lo que tú inventares y soñares, disponiendo las cosas para entenderlas, y nunca las entenderás cómo están dispuestas, por más que estudies. [1951: II, 90.] 
Quevedo se refugiaría en este tópico de la Stoa como gesto de hastío. Reconoce, como el enciclopédico Fausto, los límites cognoscitivos del ser humano. Para él, la paz de la conciencia sólo puede tener cabida en el cobijo de la fe religiosa.

En una carta a Sancho de Sandoval, Quevedo expresa su deseo de irse a La Torre a pasar unos días. El motivo es el escándalo por "un enjambre de putos" que ha ensuciado más todavía la reputación cortesana. El escarnio aglomera a decenas de implicados, entre los que figura el célebre cómico Juan Rana.

Hacia 1637, Quevedo aboga por la meditación que se aleja de la risa. Desdeñoso de los torneos, las fiestas y las vanidades del teatro, redacta la segunda parte de la Política de Dios. Esta vez no escatima en ataques al privado, insiste en la funcionalidad de su escritura: Yo escribo para ser medicina y no entretenimiento. ¿Qué diferencia con respecto a la alabanza característica de las comedias por encargo!

Don Francisco se afianza en un estilo grave y de tono sermonal, parapetado en textos bíblicos. El rey debe asumir su papel y no delegar funciones. El valido, entonces, queda arrinconado en su urgente necesidad de extinción.

Durante los últimos años de su vida, Quevedo expresa su desprecio hacia los festejos reales en el Buen Retiro. Para él son distracciones artísticas de poca monta. No participa de la plantilla de ingenios que se entretiene componiendo juguetes para la monarquía y su entorno. Su sana repulsa hacia esta actividad bufonesca del escritor explica la ausencia de su nombre 
entre los de Vélez de Guevara, Antonio de Mendoza, Francisco de Calatayud o Rioja.

En sus epístolas a Sancho de Sandoval, sale a relucir su hartazgo de la sortija y faquín del Buen Retiro. Es cuando enferma del cáncer de pecho que acabará con su vida. La repulsa de los espectáculos palaciegos no deja de albergar cierta coherencia con la doctrina de los ars moriendi de patrón estoico.

Poco a poco, nos adentramos en una trayectoria intelectual más preocupada por retomar el camino de la virtud. Es la época del Marco Bruto, inspirado en las Vidas paralelas y las Moralia de Plutarco (que se publican hacia 1644), del Job, de La providencia de Dios, de La caída para levantarse de San Pablo, del panfleto político contra la rebelión de Cataluña. También es cuando Quevedo es apresado en San Marcos de León, cuando se llevan sus baúles y se pierden muchos de sus escritos dramáticos. En 1639 es arrestado por alta traición, por orden del monarca Felipe IV, bajo la acusación de ser espía de los franceses. Esta denuncia nunca se probó, ni don Francisco siquiera alude a ella en ningún documento, pero le valió cinco años de condena.

La noche del sábado 17 de enero de 1643 el monarca destituye al CondeDuque de Olivares, para regocijo público. Tras su tardía liberación de la cárcel de San Marcos (probablemente hacia junio del mismo año), Quevedo se reencuentra con su viejo amigo y mecenas el Duque de Medinaceli.

A partir de ese momento, don Francisco se relaciona de otro modo con la corte. Es significativo que no escriba nada cuando muere la Reina Isabel de Borbón el 6 de octubre de 1644: ni un solo poema de circunstancias. 
Quevedo podrá ver el fin del Conde-Duque de Olivares, que fallece en Toro el 21 de julio de 1645, apenas unos días antes de su muerte, el 8 de septiembre de 1645 .

Aquí termina la vida de Quevedo. Pero no acaba, por supuesto, la trayectoria de su obra dramática, cuyos documentos circulan constantemente. Ars longa, vita brevis. En definitiva, durante el apogeo teatral cortesano, "el escritor no fue del todo ajeno al espectáculo público de moda". ${ }^{82}$ Así lo hemos certificado con el rastreo de su visión de autores y obras dramáticas, ingenieros, público y representantes, cada uno de los engranajes que constituyen este arte colectivo, el teatro, tan distante de la “conversación con los difuntos" de la lectura solitaria.

${ }^{82}$ Como señala Jauralde Pou [1999: 394-395]. 


\section{Capítulo III}

\section{ENTRE COMEDIAS Y DRAMATURGOS}




$$
\text { - } 188 \text { - }
$$




\section{LA COLABORACIÓN TEATRAL EN PALACIO}

\section{CONDICIONES DE LA OBRA POR ENCARGO}

La relación de Quevedo con las musas del teatro (Melpómene, Talía, Terpsícore) estuvo pautada por la impostura de la corte madrileña. La realeza dispuso a su capricho la permisividad o prohibición de los espectáculos públicos. ${ }^{1}$

Don Francisco creció en un ambiente donde la farándula era tachada de inmoral y, a su vez, consumida como ocio cortesano. Estas circunstancias condicionaron la composición de comedias, jácaras, bailes y entremeses.

El teatro de Quevedo se ve ampliamente difuminado por varios factores que pueden hacer enormemente difíciles las conjeturas de atribución. En primera instancia, la temática de su teatro serio está supeditada a una determinada circunstancia cortesana. En segundo lugar, el carácter "por encargo" de estas obras implica cierta premura de composición, de improvisada apelación a los tópicos dramáticos y la falta de pulimento literario. $\mathrm{Y}$, ¿qué decir de lo que supone atribuir una obra que pertenece a dos o tres ingenios distintos? ¿Cómo distinguir la escritura de uno y otro, cuando seguramente procuraron la homogeneización de su propio estilo en

1 No es algo excepcional, desde luego. La historia de la literatura está repleta de casos similares. La elite social critica un arte que se convierte en su bien de consumo. Asume una doble moral. El dramaturgo, entonces, sigue siendo un bufón del medievo, un orfebre de la palabra por encargo. Deberá franquear la censura y halagar a la cúpula del poder. Gozará de menos libertad que el artífice de otros géneros literarios, porque el teatro no deja de ser un espectáculo. 
pro del mensaje propagandístico cortesano? Lo más común, sin embargo, era que cada uno escribiera un acto por separado: juntos pero no revueltos. Después, por lógica, harían una presurosa puesta en común para que el conjunto no desafinara.

Quevedo colaboró con otros ingenios en la elaboración de obras teatrales para eventos cortesanos. Confeccionó comedias por encargo con Antonio Hurtado de Mendoza y Mateo Montero, que compartieron con él las peculiares circunstancias de la vida palaciega bajo el reinado de Felipe IV.

\section{EL "ANTICOJO" Y EL "DISCRETO DE PALACIO"}

La amistad entre Quevedo y Antonio Hurtado de Mendoza ha sido estudiada por la crítica con la intención de dilucidar entre atribuciones equivocadas. $^{2}$

Durante la época de la corte vallisoletana, probablemente ambos coincidieron en su condición de escritores e hidalgos montañeses procedentes de casas nobles de Santander, y su relación se mantuvo hasta la muerte de Hurtado de Mendoza, en 1644.

Ambos recibieron el mismo tipo de formación intelectual. ${ }^{3}$ Hurtado de Mendoza se relacionó desde muy temprano con la corte y participó en las fiestas del Duque de Lerma de 1617, donde estrenó el entremés $E l$

2 Cfr. Ignacio Aguilera [1945: 494-523]; García de Enterría [1988: 199-213].

${ }^{3}$ Fue, precisamente, en una academia donde se conocieron Quevedo y el Duque de Osuna. Probablemente así lo hicieron también Hurtado de Mendoza y el Conde Duque de Olivares, de quien fue secretario. 
examinador Miser Palomo. ${ }^{4}$ Tras la subida al trono de Felipe IV y la privanza de Olivares, se determinó su ascenso: en 1621 fue nombrado Secretario de la Cámara Real y en 1623 ingresó en la Orden de Calatrava.

Quevedo y Hurtado de Mendoza escribieron un soneto arraigado en el mismo endecasílabo inicial: "Estas son y serán las postreras". Don Francisco incluye este verso en su poema 473 (POC) y Mendoza en su obra Querer por sólo querer (1622). ${ }^{5}$

También ambos coincidieron en la escritura de un epitafio en honor de don Rodrigo Calderón, ajusticiado en octubre de 1621, motivo que aparece en la comedia Cómo ha de ser el privado. Quevedo escribió el jocoso epitafio A don Rodrigo Calderón, marqués de siete iglesias, que murió degollado en pública plaza (POC, 811), en el que denuncia la hipocresía de los poetas que, como "cocodrilos descubiertos" (v. 13), lloran por la muerte de los que se comieron vivos. Hurtado de Mendoza, en cambio, escribe un

4 Así lo nota el biógrafo de Antonio Hurtado de Mendoza Gareth A. Davies [1971]. El Examinador Miser Palomo es un entremés muy alabado por Cotarelo Mori [1911].

5 Querer por sólo querer se representó en 1622 para celebrar el cumpleaños de la reina. El espectáculo volvió a representarse un año más tarde, como particular, por una compañía de profesionales. El montaje contaba con complejos efectos. Cfr. Melveena McKendrick [1994: 228]: "entre estos se contaba un castillo que se elevaba y descendía sobre la escena y se abría para mostrar a la princesa cubierta de flores, un gigante negro que echaba fuego por la boca y salía de un salto de las fauces de una serpiente, Marte montado en un carro tirado por leones y portando una lanza llameante, y Diana surgiendo de la tierra en un trono." Esta invención dramática guarda similitudes con los célebres versos de "Amor constante más allá de la muerte" (POC, 472), que a su vez se pueden contrastar con el soneto "A un amor secreto" de Mendoza. Cfr. García de Enterría [1988: 200-201]. 
escueto epitafio ("Yace aquí la esclarecida"), fundamentado en un juego antitético de conceptos. $^{6}$

Ante los feroces ataques políticos que sufría el Conde-Duque, Quevedo y Hurtado de Mendoza escribieron diversos panfletos apologéticos. Don Francisco redactó El chitón de las tarabillas (1630), que se publicó bajo el anonimato. Ha de relacionarse con el Papel que don Antonio de Mendoza, escribiendo al Conde Duque cuando estaba en lo ardiente de su valimiento, discurre sobre un libro que salió impreso sin autor. Los dos escritos siguen las mismas pautas: el revisionismo histórico de la monarquía española y la definición de las principales virtudes del valido (desinterés, falta de ambición, recato, estoicismo). El tono de Hurtado de Mendoza, sin embargo, es de mayor confianza y no se ensaña en el vapuleo de los enemigos de la privanza. Quevedo fue un escritor más atrabiliario, ácido y mordaz en todas sus críticas.

Abundan noticias sobre la colaboración teatral entre Quevedo y Hurtado de Mendoza, pese a que carecemos de los textos, hoy perdidos. Ambos trabajaron para encargos de la corte, si bien, como señala García Enterría [1988: 202-203] "la nunca desmentida fidelidad del poeta cortesano Hurtado de Mendoza poco tuvo que ver con el apoyo que como escritor prestó Quevedo a la corte sólo en circunstancias y momentos muy precisos". Asimismo, como desvela la correspondencia epistolar entre ambos, mantuvieron una entrañable amistad. Se conserva una hermosa carta de Quevedo a su amigo, escrita hacia 1632: con un estremecedor tono

\footnotetext{
6 Véase la edición de Benítez Claros [1947].
} 
intimista, el autor reflexiona sobre la inexorabilidad de la muerte y la contrapartida filosófica de este sino aciago, que hace del mundo un teatro. ${ }^{7}$

Recordemos, en todo caso, que a Hurtado de Mendoza se le conocía como "el Discreto de Palacio" y "el Aseado lego". Las comedias palatinas solían ser sencillas, de capa y espada, donde el sentido de la moderación prevalecía por encima de los extremos lances de honor o las modas del momento. ${ }^{8}$ Las jácaras de Hurtado de Mendoza están influenciadas por las producciones dramáticas breves de Quevedo, ante todo por su Escarramán. ${ }^{9}$

Se sabe, según notábamos, de una comedia de título desconocido escrita en 1625 entre ellos y Mateo Montero: un trabajo repartido equitativamente, dado que cada uno escribió un acto.

Por otra parte, en 1631, la comedia perdida Quien más miente, medra más fue representada durante la noche de San Juan, también fruto de los dos ingenios. Veremos, más adelante, cómo tal vez fue reversionada en Los empeños del mentir, de Antonio Hurtado de Mendoza.

\section{Algunos datos sobre Mateo Montero}

Poco se sabe de la vida de Mateo Montero. La mayoría de datos acerca de este dramaturgo asentado en la corte, proceden del Catálogo de Barrera y Leyrado [1860].

\footnotetext{
7 Cfr. Krzysztof Sliwa [2005: 475].

8 Cfr. Arellano [1995: 419-420].

9 Cfr. García de Enterría [1988: 209].
} 
Mateo Montero, a inicios del siglo XVII, fue criado de don Juan Alfonso Enríquez de Cabrera, almirante de Castilla. Más tarde, ejerció como integrante gentil de la Cámara Real y, después, como mayordomo mayor de Felipe IV.

Uno de los escasos documentos que se conservan sobre sus trabajos en la corte es una carta de Francisco de Quevedo al Marqués de Velada, escrita el 17 de febrero de 1624 en Andújar, donde cuenta el viaje a Andalucía con el rey Felipe IV. Nuestro autor alude a la compañía de su íntimo amigo y colaborador, al que cita en dos ocasiones:

Del Condado pasamos a Linares, jornada para el cielo, y camino de salvación, estrecho y lleno de trabajos y miserias. Íbamos en el coche juntos don Enrique y yo, y Mateo Montero y don Gaspar de Tebes, con diez mulas; y en anocheciendo, en una cuesta que tienen los de Linares para cazar acémilas y coches, nos quedamos atollados. No hubo locura que febrero no ejecutase con nosotros [...]

¿Y vernos ayer a Mateo Montero y a mí, estar asistiendo de responso al entierro de nuestro coche; venirnos de peregrinos de media legua, él riéndose de verme cojear, pidiendo bueyes para sacar una pierna, y yo decirle a él, al bajar un cerrito, llevase la panza en sus manos a la silla de la Reina? [Krysztof Sliwa, 2005: 357$358]$.

Según ya hemos indicado, en los Avisos manuscritos de Pellicer consta cómo el 9 de julio de 1625, con motivo de los festejos de la reina Isabel, se representó una comedia de título desconocido, que había escrito Mateo Montero, en colaboración con Quevedo y Hurtado de Mendoza, por encargo del Marqués de Eliche y Toral. 
Tan sólo reunimos un par de datos más acerca de la vida de este autor. Baena, en su Diccionario de ilustres matritenses, alude a Román Montero de Espinosa, poeta y militar de mediados del siglo XVII, probablemente su hijo. ${ }^{10}$ Asimismo, Pedro de Herrera, en su Relación de las fiestas de Lerma, redactada en 1618, menciona a Mateo Montero como actor de la comedia de Luis Vélez de Guevara El Caballero del Sol, un "hidalgo principal cortesano" que probablemente servía al Conde de Saldaña durante aquel tiempo. $^{11}$

${ }^{10}$ La alusión figura en el Catálogo [1860] de Barrera y Leyrado.

${ }^{11}$ Cfr. B.N.E. R-15880. Pedro de Herrera, Translación del santísimo sacramento a la iglesia colegial de San Pedro de la Villa de Lerma, Madrid, Juan de la Cuesta, 1618. 


\section{DRAMATURgos LAUREADOS}

\section{JORGE FERREIRA DE VASCONCELloS Y SU COMEDIa EUFRosina}

¿Qué relación mantuvo Quevedo con otros dramaturgos más consolidados? Algunos de los más eminentes lo laurearon, entre ellos Lope de Vega, Cervantes, Claramonte e incluso Montalbán.

En La Perinola, por cierto, don Francisco deja las comedias a Lope, Luis Vélez y Calderón de la Barca. También gustó del teatro de Agustín de Rojas, Tirso de Molina y Cervantes. Pero, sobre todo, alabó la traducción de la portuguesa Comedia Eufrosina y la producción dramática de su admirado Lope.

Quevedo escribió su mayor apología al género dramático en una carta a los lectores de la comedia Eufrosina traducida de lengua portuguesa en castellana por el capitán D. Fernando de Ballesteros y Saavedra (Madrid, 1631). La obra, compuesta por Jorge Ferreira de Vasconcellos, se imprimió el 22 de enero de 1555 en la imprenta de Joan Barreira, de la Universidad de Coimbra. Se reeditó el mismo año en esta bella ciudad portuguesa. Tuvo dos publicaciones más en Évora en 1561 y 1566 (esta última, secundada por el español Andrés de Burgos, "impresor e caualeiro da casa do cardeal iffante").

La Comedia Eufrosina, como bien indica el documentado estudio de Eugenio Asensio, ${ }^{12}$ se ha parangonado con la Celestina y se cotejaba durante los siglos XVI y XVII con las comedias de Terencio. Con una

\footnotetext{
${ }^{12}$ Véase el prólogo a su edición de 1951.
} 
aparente falta de unidad y personajes arquetípicos del Renacimiento, su temática se decanta por una historia de amor honesto que contrasta con el amor lascivo, hilvanada sobre ejemplos morales y sazonada con la vivacidad de los refranes, chistes y tonadillas populares.

En la reseña, Quevedo ensalza los méritos de dicha composición y, apelando a una epístola de Séneca, transmite su ideal ciceroniano de la comedia como imitación de la vida, espejo de costumbres e imagen de la verdad, donde la mala acción recibe su castigo y la virtud se alaba:

Mañosamente debajo del nombre de comedia enseña a vivir bien, moral y políticamente, acreditando las virtudes y disfamando los vicios con tanto deleite como utilidad; entreteniendo igualmente al que reprende y al que alienta: extraña habilidad de pluma, que sabe sin escándalo ser apacible y provechosa condición, que deben tener estas composiciones. Así lo juzgó Séneca (epist. 115). Refiere que en una tragedia de Eurípides, Belerofonte, que era la persona que hablaba, dijo tales palabras: "Deja que me llamen maldito, como me llamen rico; pues todos preguntamos si uno es rico, no es bueno. No preguntan por qué y de dónde; sino cuánta hacienda posee: en toda parte es cada uno tanto como tiene. Preguntas, ¿qué cosa nos está mal tener? Respondo que nada. Y quiero vivir rico, y si soy pobre, morirme: bien muere quien muriendo gana algo. Si en la cara de Venus resplandece cosa como la riqueza y el oro, con razón enamora a los hombres y a los dioses." En acabando de pronunciar estas palabras postreras, todo el pueblo se levantó con ímpetu a apedrear al representante y a los versos; hasta que Eurípides mismo se levantó entre todos, pidiendo que aguardasen a ver qué fin tenía en la tragedia este idólatra del oro. Oyéronle, y Belerofonte en la fábula tenía el castigo que merecía su insolencia." 
Hasta aquí son palabras de Séneca, que aprobando la buena composición y ejemplar de Eurípides, previno desde entonces aplauso y alabanza a nuestra Eufrosina, donde están distribuidas las ruinas y las afrentas sobre los vicios, y los premios sobre las virtudes y méritos. No quede sin alabanza aquel vulgo que se amotinó en el teatro contra la insolencia de las palabras, cuando no se lee de los jueces y magistrados algún enojo." [1951: II, 492]

Don Francisco ensalza el potencial moralizador del teatro y su relevancia social, dado que constituye todo un ocio cortesano. En definitiva, apela a su preeminencia como alimento espiritual. Cree que es una buena vía para instruir a los jóvenes aristócratas. Elogia los modelos de virtud insertos en las comedias palatinas.

\section{TODO LO BUENO "ES DE LOPE"}

El Fénix de los Ingenios, al que Cervantes llamó "monstruo de naturaleza" y Vélez de Guevara "prodigioso monumento español y nuevo Tostado $^{13}$ en verso", era uno de los espectáculos de Madrid. Su retrato decoraba los muros de los palacios y de las casas humildes. Sus contemporáneos llegaron a utilizar su nombre como sinónimo de cosa buena, de buena calidad. Así lo expresa Cervantes en su entremés La guarda cuidadosa diciendo que "son de Lope las cosas que son o parecen

\footnotetext{
${ }^{13}$ Alonso Tostado, también llamado Alonso del Madrigal y el Abulense, escribió unos 70225 pliegos. Su nombre se utilizaba en el siglo XVII para designar una obra prolífica.
} 
buenas". Y, precisamente, Quevedo reitera: "Pues ha de ser de Lope lo que es bueno/ en cualquier persona, en cualquier trato."14

Don Francisco aludió a él en tono jocoso en el Buscón, y en el entremés del Niño y Peralvillo de Madrid jugó con el lenguaje apodándole "Lope de Vergas", como probable guiño al donjuanismo de Lope, que tenía, además de una facilidad inusual para escribir, un éxito notable con las damas. Pero sólo eran guiños literarios sin malicia.

En un soneto contra don Francisco, Góngora llegó a acusarle de ser un émulo del "terenciano Lope". ${ }^{15}$ El Fénix, en verdad, fue una de las debilidades de Quevedo. Compartieron credo estético. La admiración de don Francisco hacia este autor queda plasmada en el soneto A Lope (POC, 284).

A su vez, en un fragmento de la carta de Lope al licenciado Diego de Colmenares de Segovia, escrita en 1624, apreciamos que el célebre dramaturgo, como Quevedo, tiene la necesidad de enriquecer sus creaciones con la retórica del discurso, las fuentes grecolatinas, sagradas y humanas, y el afán historiográfico:

Pero quien siente que no tiene fundamento [la poesía] en la retórica, ¿qué respuesta merece? O no entiende que le tocan las mismas obligaciones que al historiador, fuera de la verdad, o poca erudición muestra quien esto ignora; estando todos los retóricos llenos de ejemplos de poetas, como verá mejor Vuestra Excelencia, si don Francisco de Quevedo prosigue un Discurso que dejó

\footnotetext{
${ }^{14}$ Cfr. Néstor Luján, Madrid de los últimos Austrias [1989:120].

${ }^{15}$ Los versos injuriosos de don Luis son los que siguen: “¿No imitaréis al terenciano Lope,/ que al de Belerofonte cada día/ sobre zuecos de cómica poesía/ se calza espuelas y le da un galope?" Véase la edición de Ciplijauskaité [1992: 275].
} 
comenzado: ingenio verdaderamente insigne, y tan adornado de letras griegas y latinas, sagradas y humanas, que para alabarle más, quisiera conocerle menos... . [Krzysztof Sliwa, 2005: 360]

Lope de Vega elogió tempranamente a Quevedo al enviarle La hermosura de Angélica (Madrid: 1602) e integró al joven poeta en la nómina de escritores matritenses. Le dedica el soneto 128 de sus Rimas, compuesto hacia 1600-1601, cuando Quevedo estaba estudiando en Valladolid:

Vos de Pisuerga, nuevamente Anfriso, vivís, claro Francisco, las riberas, las plantas atrayendo, que ligeras huyeron dél, con vuestro dulce aviso.

Yo, triste, en vez de Dafne, a Cipariso tuerço en la frente, y playas estrangeras, a vista de las ánglicas vanderas, donde Carlos tomó su empresa, piso.

Vos, coronado de la excelsa planta por quien suspira el sol, no veis, Francisco, si canta la sirena o Circe encanta.

Y yo, sin mí y son vos, atado a un risco, no aviendo hurtado al sol la llama santa, sustento de mi sangre un basilisco. ${ }^{16}$

\footnotetext{
${ }^{16}$ Véase la Edición crítica de las Rimas de Lope de Vega, a cargo de Felipe B. Pedraza Jiménez [1993: I, 465-467].
} 
Por ello, don Francisco escribe uno de los poemas preliminares de $E l$ peregrino en su patria (1604). En Jerusalén conquistada (Madrid, 1609), Lope vuelve a elogiar la tarea literaria de Quevedo. Ambos, de hecho, habían colaborado con sendos sonetos en los preliminares de Siglo de Oro en las selvas de Erifile (Madrid, 1608), de Bernardo de Balbuena.

Otro dato curioso: se inscribieron como esclavos del Santísimo Sacramento en el oratorio de la calle Olivar de Madrid, de donde también fueron miembros Salas Barbadillo, Espinel, Cervantes y Paravicino. ${ }^{17}$

En la sexta epístola de Circe, con otras rimas y prosas (1625) de Lope, dirigida a Lorenzo Van der Hammen de León, se alude a su "común amigo" don Francisco. ${ }^{18}$ Los lazos de amistad y admiración mutua son constantes: Lope también lo elogiará en la silva VII de El laurel de Apolo, en 1629.

Sabemos, asimismo, que ambos participaron en las fiestas organizadas por el valido en honor a los reyes en 1631, cuando Quevedo compone junto con Antonio Hurtado de Mendoza Quien más miente, medra más.

En 1632, Lope imprime en Madrid La Dorotea, celestinesca como La Eufrosina. Quevedo, en los preliminares de la comedia portuguesa, incluye un corto laudo destinado a su buen amigo:

Con grande gloria de la virtud y buen ejemplo, se han escrito en España con nombre de comedias (fuera de las fábulas), historias y vidas, que a la virtud y al valor enseñan y mueven con más fuerza que otra alguna cosa; como se ve con admiración en las de Lope de Vega Carpio, tan dignas de alabanza en el estilo y

\footnotetext{
${ }^{17}$ Cfr. Jauralde [1999:207].

${ }^{18}$ Esta relación amistosa se afianza si consideramos que Quevedo escribió los preliminares de Don Philipe el prudente de Van der Hammen.
} 
dulzura, afectos y sentencia, como de espanto por el número demasiado para un siglo de ingenios, cuanto más para uno solo. A quien en esto siguen dichosamente muchos que hoy escriben este entretenimiento decente a soberanas ocupaciones; que el ocio de los reyes tiene estatutos de majestad, y no debe admitir alivio que no sea calificado.

Por esto tiene lugar en los oídos de los príncipes éste de las comedias, a quien han dado su atención, contra la prolijidad de los cuidados, los más y mejores monarcas del mundo; sin que a esto ofenda lo que algunos malician para reprobar los ingenios que dichosamente se ocupan en esta composición; ni en el entretenimiento que ofrece, gustoso, docto, ejemplar y limosnero, por el socorro frecuente con que alimenta los espíritus." [1951: II, 492]

\section{Quevedo afianzó su relación literaria con Lope mediante su} correspondencia literaria ${ }^{19}$ y su aprobación a las Rimas del licenciado Tomé de Burguillos (Madrid, 1634):

escrito con donaires, sumamente entretenido, sin culpar la gracia en malicia, ni mancharla con el asco de palabras viles; hazaña de que hasta agora no he visto que puedan blasonar otras sales sino estas. El estilo es (no solo decente, sino raro, en que la lengua castellana presume vitorias de la latina) bien parecido al que solamente ha florecido sin espinas en los escritos de frey Lope Félix de Vega Carpio, cuyo nombre ha sido universalmente proverbio de todo lo bueno; prerrogativa que no ha concedido la fama a otro nombre. Son burlas que de tal suerte saben ser doctas y provechosas, que enseñan con el entretenimiento, y entretienen con la enseñanza; y tales, que he podido lograr la alabanza en ellas, no ejercitar la censura. No hay palabra que disuene a la verdad católica, ni palabra que no se encamine a alentar las

${ }^{19}$ En un par de cartas al Duque de Sessa (las 61 y 91), Lope alude a este verso picante de Quevedo: "Las, Dios nos libre, faldas levantadas". Cfr. la ed. de Nicolás Marín [1985: 176, $214]$. 
buenas costumbres: méritos que granjean la licencia que se pide para que la imprenta la reparta. [1951: II, 496-499]

En las Rimas a Tomé Burguillos, por cierto, Lope le ha dedicado un soneto a Quevedo:

\author{
Para cortar la pluma en un profundo \\ ideal concepto y trasladarle en rima, \\ hallé, peregrinando el patrio clima, \\ que érades vos lo más sutil del mundo.
}

Atento os miro, y tan valiente infundo

alma al ingenio, al instrumento prima,

que a escribir, a cantar, a ser me anima

de vuestro claro sol Faetón segundo.

Para alabaros hoy, pedíle al coro

de Apolo, si es que tanto emprender puedo,

permitiese mi pluma a su tesoro;

y respondiome con respeto y miedo:

-"Burguillos, si queréis teñirla en oro,

bañalda en el ingenio de Quevedo." ${ }^{20}$

Ambos coincidirán en la inauguración de las fiestas del Buen Retiro, en diciembre de 1632, cuando Lope ya era un anciano.

Su entrañable simpatía no quedaría empañada, si quiera, por el enfrentamiento de Quevedo con uno de los incondicionales defensores del

${ }^{20}$ Cfr. Lope de Vega, Obras poéticas. Edición, introducción y notas de José Manuel Blecua [1983: 1424]. 
Fénix, Pérez de Montalbán, que publicó su polémica obrilla Para todos en 1633.

El 19 de mayo de 1635, en uno de sus últimos contactos con el dramaturgo (que moriría el 27 de agosto, en Madrid), Quevedo aprueba la Veinte y una parte verdadera de las comedias de... Félix Lope de Vega Carpio. $^{21}$ El autor admira estas composiciones llenas "de muy honesta enseñanza y otros tantos ejemplos, elegantes y entretenidos para la advertencia moral." 22

${ }^{21}$ Las comedias son: La bella Aurora; Hay verdades en el amor; La boba para los otros y discreta para sí; La noche de San Juan; El castigo sin venganza; Los bandos de Sena; El mejor alcalde, el rey; El premio del bien hablar; La vitoria de la honra; El piadoso aragonés; Los Tellos de Meneses; Por la puente, Juana.

${ }^{22}$ Cfr. Quevedo [1951: II, 500]. 


\section{CONTROVERSIAS LITERARIAS}

\section{Un COMBATE DE ESGRIMA CON PACHECO de NARVÁEZ}

Quevedo también era un espadachín miope y fantaseador. Hacia 1608 se enfrenta por primera vez a Luis Pacheco de Narváez en casa del Conde de Miranda. No se trata de un mero incidente, sino del origen de una enemistad perpetrada por ambas partes. Esta mutua animadversión fue plasmada en diversos escritos y se prolongó durante tres décadas. Sólo tuvo fin tras la muerte de Pacheco de Narváez en 1640, mientras Quevedo afrontaba la dura reclusión en San Marcos de León. ${ }^{23}$

Luis Pacheco de Narváez había cobrado fama como teórico del esgrima, de cuyos tratados don Francisco se mofaba. ${ }^{24}$ Durante su estancia en el archipiélago canario redactó su Libro de las grandezas de la espada. Se trasladó a Madrid con el manuscrito de la obra en 1599 y, tras la asunción

${ }^{23}$ Acerca de esta relación virulenta personal y literaria véase el artículo de Aurelio Valladares Reguero, "La sátira quevedesca contra Luis Pacheco de Narváez" [2001: 165194].

${ }^{24}$ Sobre la esgrima filosófica hay un curioso artículo de Joan Perucho, "Filosofía de l'espasa", en Histories apòcrifes [Barcelona: Edicions 62, 1974, p. 162]: "El mètode de Pacheco va tenir un gran èxit entre les classes il-lustrades, i tothom es batia seguint les figures geomètriques preestablertes, sumant, restant i multiplicant a consciència en els assalts, observant amb escrupolositat l'ángulo recto, base científica primordial de l'esgrima filosófica, fins que seguint l'ordre natural de les coses $-\mathrm{i}$ donades la naturalesa i l'enveja humanes- li van sortir a Pacheco detractors innúmers. (...) A Pacheco, tanmateix, el tret de gràcia l'hi va donar Quevedo en retratar un culte espadatxí filosòfic enfrontant-se a un altre purament intuïtiu i ignorant." 
de varios riesgos económicos, la publicó en 1600 con un gran número de poemas laudatorios. Así se ganaba la fama en la corte.

La publicación de la segunda obra de Pacheco de Narváez, Las cien conclusiones o formas de saber de la verdadera destreza (Madrid: Luis Sánchez, 1608) es la que motiva el célebre altercado entre ambos ingenios. ${ }^{25}$ Así lo narra el primer biógrafo de Quevedo, Pablo Antonio de Tarsia:

Hallóse don Francisco en un concurso de los mayores Señores de la Corte en casa del Presidente de Castilla, donde se arguyó sobre las cien conclusiones de la destreza de las armas, que sacó don Luis Pacheco de Narváez, Maestro, que fue del Rey nuestro Señor en esta profesión, y mayor en los Reinos de España; y después de haber discurrido algunos, e impugnado las conclusiones, salió Don Francisco contradiciendo la que en un género de acometimiento decía no haber reparo ni defensa; y para la prueba, convidó al Maestro, a que tomase con él la espada; el cual, aunque no rehusaba, alegando que la Academia se había juntado para pelear con la razón, y no con la espada, obligáronle sin embargo los Señores a salir con ella, y al primer encuentro le dio don Francisco en la cabeza, derribándole el sombrero. Retiróse el Narváez algo enojado del suceso; y don Francisco, para sazonar la fiesta, dijo: "Probó muy bien el señor D. Luis Pacheco la verdad de su conclusión, que a haber reparo en este acometimiento no le pegara yo." [1663: 59-60].

\footnotetext{
${ }^{25}$ Luis Pacheco de Narváez fue un escritor prolífico en su temática. Otras obras destacables son Compendio de la filosofía y destreza de las armas, de Jerónimo de Carranza (Madrid, Luis Sánchez, 1612); Modo fácil y nuevo para examinarse los maestros en la destreza de las armas (Madrid, Luis Sánchez, 1625); Engaño y desengaño de los errores que se han querido introducir en la destreza de las armas (Madrid, Pedro Tazo, 1639) y Nueva ciencia y filosofía de la destreza de las armas, su teórica y práctica (Madrid, Melchor Sánchez, 1672).
} 
Se ha postulado, por la alusión a un maestro de esgrima en El sueño del juicio final (anterior a 1608), que esta enemistad tuvo su origen antes del famoso incidente del derribo del sombrero. El diestro del relato, sin embargo, no tiene por qué corresponder con ningún personaje histórico concreto. ${ }^{26}$ Quevedo se mofa particularmente de la destreza primitiva $o$ vulgar, en contraposición a la destreza verdadera, que se fundamentaba en términos matemáticos y que era, precisamente, la que abanderaba el esgrimista baezano.

Pacheco de Narváez arremete contra Quevedo en su Memorial... denunciando al Tribunal de la Inquisición ciertas obras políticas y satíricomorales de Don Francisco de Quevedo. ${ }^{27}$ Se jacta, más adelante, de ser coautor de El Tribunal de la justa venganza (1635), donde Quevedo recibe toda una serie de títulos jocosos: Maestro de Errores, Doctor en Desvergüenzas, Licenciado en Bufonerías, Bachiller en Suciedades, Catedrático de Vicios y Protodiablo entre los Hombres.

Entre el 18 y el 25 de octubre de 1636, don Luis es apresado por componer una comedia en prosa satírica contra Quevedo. La noticia de este

\footnotetext{
${ }^{26}$ Así lo cree Ignacio Arellano en su artículo "El diestro del Juicio Final de Quevedo, y su identidad", en Busquemos otros montes y otros río. Estudios de literatura española del Siglo de Oro dedicados a Elías L. Rivers [1992: 11-17].

${ }^{27}$ Este libelo que atenta contra la Política de Dios, el Buscón y los Sueños se ha conservado gracias a un manuscrito autógrafo, redactado hacia 1630, que fue adquirido en 1859 por Fernández-Guerra. Por su gentileza lo publicó por primera vez Menéndez Pelayo y, más adelante, Astrana Marín. Se ha contemplado la posibilidad de que esta obra se redactara con la colaboración de Diego Niseno y Pérez de Montalbán.
} 
hecho se conserva en un escrito anónimo publicado por Antonio Rodríguez Villa ${ }^{28}$ que relata lo acaecido en Madrid. Según el documento, el Maestro de armas se sentía enamorado de su obra, y aún bajo la amenaza de ser encarcelado, no quiso desmentir su autoría:

Don Luis de Narváez está preso muy estrecha y apretadamente por haber compuesto y dado a la estampa una comedia en prosa, que es una sátira muy atroz y continuo sarcasmo contra don Francisco de Quevedo, y aunque pudiera muy bien don Luis haber excusado esta pesadumbre, porque se ofrecían otros a quienes poder atribuir y achacar este escrito, no quiso, porfiando que él era autor y no otro ninguno, enamorado de su obra, al modo de un padre que quiere y estima a su hijo. Créese que es don Francisco quien debajo de cuerda le ha hecho prender, si bien él lo niega fuertemente, y animoso jura que en saliendo don Luis de la cárcel, salga cuando saliere, le ha de desafiar luego y matarle en el desafío, por muy gran maestro de esgrima que sea don Luis... [Krzysztof Sliwa, 2005: 572]

No se sabe nada de esta comedia. Por la fecha, algunos investigadores creen que tal vez aluda a El tribunal de la justa venganza. Pero este texto no es estrictamente una comedia. Sería más lógico pensar que tiene relación con los Peregrinos discursos y tardes bien empleadas que se conserva en un manuscrito de 1640 , pero que podría haber sido redactado con anterioridad. El encarcelamiento de Pacheco de Narváez explicaría que, pese a contar con algunas aprobaciones para su publicación, ésta no se llevara a cabo.

${ }^{28}$ Este texto ha sido compilado por diversos estudiosos de la obra epistolar de Quevedo. Cito de la edición de Sliwa. No obstante, véase Antonio Rodríguez Villa, La Corte y la Monarquía en los años de 1636 y 1637. Madrid: Luis Navarro Editor, 1886, pp. 57-58. 
Los Peregrinos discursos están redactados en forma de diálogo, tal vez por ello se le podía haber denominado "comedia en prosa" en la noticia anónima. Se estructura en torno a la conversación que mantienen unos peregrinos que regresan de Santiago de Compostela hacia Madrid. Durante cinco jornadas, debaten estos cinco viajeros oriundos de diferentes puntos de la península (un sacerdote, un jurista, un humanista, un soldado y un cortesano) y dos ermitaños expertos en derecho civil y canónico. Refutan, entre varias obras de Quevedo, los fundamentos teológicos de la Política de Dios. La temática, si consideramos la ortodoxia religiosa del libro de Quevedo y el hecho de que se le indisponga con el rey Felipe IV y Olivares, puede explicar la prisión de Pacheco de Narváez. ${ }^{29}$

El encontronazo con el Maestro mayor de las armas es significativo en la obra satírica de Quevedo que, a diferencia de su contrincante, abre fuego en todos los campos de batalla dialécticos y no sólo le ataca en aspectos doctrinales. En El Buscón (I, II) y en La hora de todos (XXXV, "El Gran Turco") don Francisco se mofa de la doctrina matemática que Pacheco de Narváez aplica a la esgrima en el Libro de las grandezas de la espada (1600). En las octavas del Poema heroico de las necedades y locuras de Orlando (POC, 875), que se ha fechado entre 1626 y 1628, lo califica de “más infame que azote de verdugo,/ un maestro de esgrima que enseñaba/ nueva destreza, a güevo y a mendrugo.” La crítica antipachequista rebasa lo

\footnotetext{
${ }^{29}$ Acerca de esta obra, véase el artículo de Aurelio Valladares Reguero "Peregrinos discursos y tardes bien empleadas: una obra desconocida de Pacheco de Nárvaez contra la Política de Dios de Quevedo." La Perinola 1 (1997): 237-56. Este mismo autor ha editado el ms. Cfr. Pacheco de Narváez, Luis (1999), Peregrinos discursos y tardes bien empleadas, ed. de Aurelio Valladares Reguero, Pamplona: Eunsa.
} 
intelectual y se recrea en la falacia ad hominem: Narváez se convierte en “don Hez”. En el contexto paródico de los héroes del ciclo carolingio, Quevedo le trata de jaque cornudo.

Pero, ante todo, nos interesa la crítica satírica a Narváez en el ámbito dramático. En el baile de Las valentonas y destreza (POC, 866), Quevedo improvisa una grotesca escuela de esgrima "en el Corral de las armas". Allí se parodia la teoría de la destreza de las armas a través de la fraseología típica de los tratados del maestro (expresiones como "por línea recta", “destreza verdadera" o "cuarto círculo"). Las protagonistas son mujeres, en una notable inversión de sexos propia del tópico del mundo al revés. Y, si además notamos la presencia del espadachín Santurde, alter ego de Narváez, tenemos un claro ejemplo de degradación del personaje histórico.

En el entremés de La destreza, la doctrina de Pacheco de Narváez también se denigra a través del desfile de "valentonas" de baja estofa que publican sus habilidades en el manejo de armas. Esta escenificación se convierte en el tema central de las dos piezas de teatro breve: Quevedo aprovecha el dinamismo visual de los ejercicios de esgrima entre los actores para denunciar a su enemigo más allá de los selectos lectores cultos, allende los corrales de comedias. 


\section{Pérez de Montalbán, el "LiCenciado libruno"}

¿Pérez de Montalbán? Quevedo le llamó "retacillo de Lope de Vega" cuando compuso contra él La Perinola, crítica feroz hacia el libro misceláneo Para todos (1633), su última obra festiva corta. De malicia refinada, ataca de paso a otros personajes del universo teatral, como Quiñones de Benavente y Salas Barbadillo.

Las pullas de don Francisco relucen en su deslumbrante prosa satírica. Quevedo, en La Perinola, acusa a Montalbán de plagiar y hacer pastiches con la obra del Fénix: "que de cercenaduras de sus comedias se sustentaba, hasta que dio en escribir media con limpio -poeta de la calle de los Negros-, juntándose con otros para hacer pasos a escote..."30

El Para Todos de Montalbán es como un "coche de Madrid a Alcalá, donde se embuten y van juntos dándose hombro con hombro una vieja, una niña y una buscona, y el tratante, y el corchete, y la alcagüeta y el capigorrón. ${ }^{31}$ Esta afluencia de personajes variopintos y revueltos es, por cierto, rasgo común del teatro breve, y no deja de ser sorprendente en una pretendida obra docta.

El libro, "podrido como olla", está confeccionado como un batiburrillo de citas sin ton ni son. Quevedo cree que Montalbán cita sin criterio alguno, evocando los libros que vendiera su padre.

Las décimas finales de la obra $(P O C, 845)$ critican el estilo de "olla podrida" del "licenciado Libruno". Las Redondillas de Don Francisco de

\footnotetext{
${ }^{30}$ Véase la edición de C.C. García Valdés [1993: 472].

${ }^{31}$ Íbid. [1993: 474].
} 
Quevedo contra el doctor Don Juan Pérez de Montalbán (POC, 846) son breves pero arrolladoras:

\author{
Doctor, Don tú te le pones, \\ el Montalbán no le tienes, \\ con que quitado uno y uno \\ sólo te queda Juan Pérez. ${ }^{32}$
}

El hecho de que Diego Niseno se hubiera encargado de aprobar el Para todos de Montalbán, excesivo en sus elogios, dio cuerda al sarcasmo de Quevedo, que tenía varias cuentas pendientes con el cura basilio. Cuando don Francisco había querido publicar sus Juguetes de la niñez (1629), tuvo que vérselas con este gran amigo de Montalbán, de mal genio e ínfulas intelectuales. El censor fue el mismo que aprobó El Polifemo de Góngora y, más adelante, diversas obras teatrales como La primera parte de las comedias (1640) de Rojas Zorrilla, la Flor de sainetes de Francisco Navarrete y varios volúmenes de comedias. Don Francisco pudo sortear su censura acudiendo a su amigo agustino Fray Diego del Campo y el Padre Juan Vélez de Zavala. Asimismo, Diego Niseno había sido uno de los denunciantes a la Inquisición de su Chitón de las taravillas, aunque la obra se hubiera publicado anónima.

Los lances contra Montalbán son incesantes, hasta el punto de haber generado literatura apócrifa atribuida a Quevedo. Tal es el caso de la

\footnotetext{
${ }^{32}$ Tal vez en estos versos Quevedo quisiera aludir a Cosme Pérez, también conocido como Juan Rana, célebre actor cómico. Cotarelo y Mori [1911: CLVII- CLXIII] ha trazado su biografía.
} 
siguiente carta, cuyo verdadero autor es Jerónimo Salas Barbadillo que en Don Diego de Noche dedica estas palabras a "un poeta cómico". El lector podría pensar que, de igual modo, Quevedo equipara las comedias de Montalbán a las corridas de toros e inserta una suerte de descripción costumbrista de los reproches del público descontento. La carta es apócrifa pero verosímil:

Carta/ de Don Francisco de/ Quevedo/ al Dr. Montalbán/ habiéndole silbado/ una comedia, en que/ tenía libradas/ las esperanzas de su fama

Mortales somos todos los hombres (señor Montalbán), y así los poetas cómicos, como los maridos pacientes, están sujetos a silbos: si la comedia tuvo mayor tramoya y se efectuaron mal, culpa es del artífice, a él le silbaron, que no al poeta; no juzgue Vm. a desprecio haberla silbado, sino que se holgaron tanto todos en ella, que la hicieron el mismo tratamiento que a los toros, que es la fiesta más celebrada que tenemos en España. ¿Quién le dijera a Vm. cuando la escribía con tanta confianza, que había de ser una de las comedias al toril, muriendo desjarretada entre silbatos, tenores y tiples? Asegúrole, que tuve por mal agüero el ver para las tramoyas tanta tabla junta, porque me pareció disposición a tablados, y que se podía disculpar él si lo convirtiese en fiesta de toros. Mal aconsejado fue Vm. en llevar a ella música y chirimías, sabiendo que con ellas se hace siempre en la Plaza la señal, con que tocan a desbarrete. Cuando yo vi meter aquel caballo veloz, para echar el reto, temí que había de pasar la comedia tan de carrera como le sucedió, que no fue vista, ni oída. Las mujeres fueron las que empezaron a silbar. Provocados de ellas, dispararon los mosqueteros toda su mosquetería, de modo que la comedia, ya como toro, murió entre silbos, ya como soldado valiente, a mosquetazos. Sedición fue de todo el pueblo, de quien fueron las mujeres capitán: Consuélese Vm. pues en este motín, las que son pies de la República, se hicieron cabeza. Dios guarde a Vm. el 
juicio, digo, que no la vida, que después de semejante suceso, es lo que corre mayor peligro. ${ }^{33}$

La actitud de Montalbán hacia Quevedo era, sin embargo, de respeto y admiración. Alaba, inclusive, la poco reconocida faceta dramática de nuestro autor, cuyas comedias dice que las acierta, como si las escribiera continuamente, tal es su ingenio, de universal, de florido y soberano. En todo caso, este reconocimiento es "de oídas". La crítica de don Francisco también parece algo adyacente: puede derivarse de su enemistad con el Padre Niseno y con el progenitor de Montalbán, el librero Alonso Pérez, que pirateó el Buscón. ${ }^{34}$

La respuesta a la encarnizada diatriba de La Perinola no tardará en llegar. Primero de la pluma del Padre Niseno; después, en algunos libelos de Jáuregui y, finalmente, en la obra colectiva que reunió varios de los más acérrimos enemigos de nuestro autor: en El tribunal de la justa venganza.

El tribunal será una obra meditada, henchida de ira y deseos de venganza, cimentada sobre juicios morales. Orbita sobre citas bíblicas, elaboradas desde un tono eclesiástico propio de la intelectualidad culta del XVII. Analiza la literatura satírica de don Francisco como si se tratara de

${ }^{33}$ Biblioteca Nacional de Lisboa (B.N.L.). Ms. 59,2 (Caixa 59, n²): Obras manuscritas/ de Dn. Francisco de/ Quevedo y Villegas/ Cavallero del orden/ de Santiago./ Las que no se han impreso con las/ suyas, por no ha-/uerse obtenido licencia para ello. f. 87r-89r. Ortografía y letra del siglo XVII excepto la primera página, de letra moderna, 101f. Cf. Miranda [1988: 88]. Es Felicidad Buendía [1960: 1363] la que, a propósito de los múltiples testimonios de esta carta apócrifa atribuida a Quevedo, desvela su autoría real.

34 Cfr. Jauralde Pou [1999: 647]. 
doctrina. Entre los insultos a Quevedo resaltamos el de "legítimo entremesista", regocijado en el ambiente de bodegones y tabernas. Censuran el aplauso del vulgo, al que agrada con un estilo bajo, rufianesco, “envejecido en hablar suciedades". 35

La enemistad fue tan acérrima que, incluso, Quevedo hubo de sentirse aludido en junio de 1639, por el Elogio evangélico funeral al fallecimiento del Doctor Juan Pérez de Montalbán, escrito por Diego Niseno.

\section{JÁUREGUI Y EL RETRAÍDO}

En 1635, Jáuregui escribe El Retraído, comedia de mofa de La cuna y la sepultura. En ella, variopintos personajes (Platón, Plutarco, Aristóteles, la Cuna, la Sepultura) parodian el contenido del libro de Quevedo. Escarmentado por las pullas de La Perinola, el autor de la densa y poco agraciada versión de la Farsalia de Lucano, compuso esta comedia para denunciar una supuesta incompetencia teológica de don Francisco. También le contradirá públicamente en un Memorial al Rey Nuestro Señor, donde ridiculiza su formación cultural y conocimientos humanísticos.

Una carta al Duque de Medinaceli, fechada del 24 de noviembre de 1636, nos hace sospechar que Quevedo escribió una réplica teatral a El Retraído y que pretendió camuflar bajo la autoría de su mecenas y la de su testaferro, don Alonso Mejía de Leiva:

\footnotetext{
${ }^{35}$ Cfr. A. Marín [1945: 1255].
} 
Presto, me escribe don Alonso, remitirá a Vuestra Excelencia la tercera jornada, y creo todo lo enriquecerá vuestra Excelencia y lo mejorará, pues no siendo nada difícil sino el lugar de Job, Vuestra Excelencia lo tenía entendido como yo lo llevaba respondido. Verá Vuestra Excelencia en esas dos jornadas, segunda y tercera, cosas notables de la desvergonzada ignorancia de aquel hombre, y sin réplica ni respuesta alguna. Ni puede llegar la abominación al lugar donde hace decir a Aristóteles que Cristo fue su discípulo; mas aplíquele un lugar del Evangelio a la letra. [Krzysztof Sliwa, 2005: 573].

La alusión a El Retraído está clara por las fechas de composición de la obra dramática en respuesta y por la referencia a un Aristóteles que dice que "Cristo fue su discípulo".

¿Por qué no tenemos noticias de esta obra? ¿Acaso debía figurar bajo la autoría del Conde de Medinaceli o la de don Alonso Mejía de Leiva, para que el prestigio de Quevedo fuera aparentemente defendido por otra pluma? Algo nos hace sospechar que hubo un pacto entre el joven mecenas, don Alonso y nuestro autor. A don Francisco no le importaba deshacerse del mérito de componer una comedia cuya única función era ser la respuesta literaria a una crítica. No hemos logrado dar con este documento, sin embargo. Pero dejamos un interrogante abierto.

\section{Ruiz de Alarcón, "CORCOVILla"}

La parodia de los dramaturgos ficticios de la prosa satírica de Quevedo tiene su parangón en la realidad. Así le ocurrió con Mira de Amescua, al que llama "Mira de Mosca" en el Niño y Peralvillo de Madrid y, sobre todo, con 
el "corcovilla" Juan Ruiz de Alarcón, cuyo infeliz Antecristo ridiculiza nuestro autor en el mentado entremés.

Contra Alarcón, don Francisco escribió la décima A un poeta corcovado que se valió de trabajos ajenos de varios ingenios (POC, 842), donde emerge la denuncia del plagio en sus composiciones:

\author{
Yo vi la segunda parte \\ de don Miguel de Vanegas, \\ escrita por don Talegas \\ por una y por otra parte. \\ No tiene cosa con arte; \\ y así no queda obligado \\ el señor Adelantado \\ por carta tan singular, \\ sino a volverle a quitar \\ el dinero que le ha dado.
}

La respuesta satírica al Elogio descriptivo a las fiestas que su Majestad del Rey Filipo IV hizo por su persona en Madrid a 21 de agosto de 1623 [...] de Ruiz de Alarcón promovió irónicas décimas de otros escritores. El mentado Miguel de Venegas es autor de otra Relación apologética centrada en idéntico motivo. El "Adelantado" aludido, en este caso, se corresponde con Francisco Gómez Sandoval y Padilla, el Duque de Cea. El poema citado refleja una mofa oportunista que fue colectivizada.

Las afrentas líricas de Quevedo a menudo salían de parámetros anecdóticos y entonces podían ser aterradoramente directas. Así lo muestra la Sátira contra don Juan de Alarcón (POC, 843), donde el "corcovilla" es 
tachado de "poeta juanetes" y "letrado codillo". La pulla se focaliza en sus defectos físicos (la joroba, el desaliño y mal olor) y académicos (la ignorancia pedantesca):

\author{
¿Quién del Derecho aprendió \\ a párrafo y no a letrado? \\ ¿Quién, en coma consultado, \\ de tilde se graduó? \\ ¿Quién como lego aprendió \\ la doctrina y la cartilla? \\ Corcovilla. (vv. 72-78)
}

Quevedo utilizaba su mordacidad como eficiente herramienta filológica. Escribió un Comento contra setenta y tres estancias que don Juan de Alarcón ha escrito a las fiestas de los conciertos hechos con el Príncipe de Gales y la Señora Infanta María (1623):

Esto es desatino; que no hay elogio descriptivo, como no hay hombre y caballo, ni tragicomedia, por ser de diferente especie; y aun en el estilo ha de haber diferencia en el elogio que es alabanza, y en la narración de unas fiestas; porque tres estilos hay ínfimos: el primero es doctrinal, el segundo, descriptivo y el tercero laudatorio: y uniendo y confundiéndolos, vino a formar un monstruo. [Cfr. Astrana Marín, 1945: 758b]

La crítica se justifica en tanto que Alarcón mezcla los tres estilos ínfimos: el doctrinal, el descriptivo y el laudatorio. Estos tres, confundidos, quebrantan el decoro literario y vienen a engendrar el monstruo. 
Tal y como revela su correspondencia con Justo Lipsio, nuestro autor tenía graves preocupaciones intelectuales y un sinfín de propósitos humanísticos, a los que urgía la destrucción de la literatura apócrifa, lo que, a su parecer, era "mala literatura".

\section{Y GóNGORA... No TAN LEJOS DE QUEVEDO}

Góngora no era un poeta memo al que flagelar, y menos para Quevedo. Han corrido ríos de tinta sobre una encarnizada enemistad, personal y literaria, de dos autores que la historia de la literatura ha tratado injustamente como antagonistas. ¿No es ya el momento de despojarse de los maniqueísmos estéticos? ¿No existe el conceptismo de las letrillas de Góngora y el culteranismo de los sonetos metafísicos Quevedo? Trivializaremos, entonces, la magnitud de la tragedia. Y veremos, por cierto, lo cerca que estuvieron en su concepción del teatro.

Pero, ¿cómo desmentir algo en lo que insisten todos los manuales al uso? Hay sólo una vía posible. La búsqueda de testimonios solventes que ilustren los vínculos que hubo entre estos dos grandes ingenios del XVII.

Han sido, precisamente, algunos gongoristas los que, alarmados por la falta de evidencias documentales, se han replanteado las verdaderas fallas y vericuetos de su relación. ${ }^{36}$ Últimamente, han aparecido esclarecedores

\footnotetext{
${ }^{36}$ Cfr. Ha insistido, por ejemplo, Amelia de Paz [1999: 42]: "llama la atención, por ejemplo, que se haya hecho de Quevedo, y no de Lope de Vega, el gran enemigo de Góngora, cuando Lope, coetáneo estricto de Don Luis, fue su verdadero rival." La ed. de
} 
artículos que desmienten esta visión romántica y sin medias tintas del quehacer poético aurisecular. Además de las sospechosas omisiones de Tarsia (1663) -que sí nota, en cambio, las polémicas quevedianas con Morovelli -, existe, de hecho, un testimonio de Francisco Manuel de Melo, gran amigo de don Francisco, que probaría la estima literaria de nuestro autor hacia don Luis. Pone en boca de Quevedo las siguientes palabras:

Torno a dizer que não fui amigo desse zote [Góngora], mas que do seu alto engenho não vi outro mais afeiçoado. Todos os que em seus dias e depois deles versificamos temos tomado seu estilo como traslado do Palatino, Barata ou Morante, para ver se podíamos escrever, imitando aquella alteza, que juntamente é majestade. Poucos o conseguiram, precepitados, como demónios, do resplandor às trevas; donde disseram muitos malintencionados que este engenho viera para maior dano que proveito do mundo, pondo sòmente os olhos nos desbaratados, e não nos instruídos. [1959: II, 109]

Según este documento, Quevedo jamás se declaró amigo de Góngora, es cierto, pero lo llegó a considerar un maestro. Y más, teniendo en cuenta que

Las Soledades de Robert Jammes [1994: 92]: “curiosamente, cuando uno hace balance de sus panfletos antigongorinos o anticultistas (La aguja de navegar cultos, de 1625; un pasaje del Discurso de todos los diablos, de 1627; La culta latiniparla, de 1629, y un corto episodio de La hora de todos, de hacia 1633-1635), excluyendo las mediocres poesías antigongorinas que le atribuyen sin fundamento verdadero, Quevedo no aparece como uno de los adversarios más encarnizados de la "nueva poesía": sus sátiras de los poetas cultos (no menciona casi nunca a Góngora) vienen siempre mezcladas con otros temas misóginos, sobre todo- que desvirtúan su impacto. Finalmente, el único texto donde expresa de modo serio e indiscutible su reprobación del estilo gongorino es el prefacio (redactado en 1629) a su edición de las poesías de Fray Luis de León”. 
don Luis era unos veinte años mayor y que, por tanto, era hombre de otra generación. ¿Debemos, entonces, dar una dimensión personal a las chanzas satíricas que intercambiaron ambos autores?

En el epistolario de Góngora no hay ni rastro de Quevedo. En el de don Francisco, tampoco. ${ }^{37}$ ¿No es sorprendente?¿Se habrá visto odio tan poco obsesivo? Pero, ¿qué sucede con el cruce de sátiras volanderas que todos conocemos?

De los cuatrocientos dieciocho poemas auténticos de Góngora y el más de medio centenar de probable atribución, sólo dos sonetos están irrefutablemente compuestos contra Quevedo: Anacreonte español, no hay quien os tope (Millé LXII) y Cierto poeta, en forma peregrina (Millé LXXV).$^{38}$ Estas dos composiciones no habrían de ubicarse, sin embargo, dentro de las sátiras personales, dado que no traspasan la inventio de la tópica burlesca. Góngora en ellas satiriza de manera poco drástica contra un Quevedo que no traduce demasiado bien del griego, su proverbial cojera que también aparece en el Parnaso cervantino- y los juegos paronomásicos con la bebida. Nada comparable con sus fieras invectivas contra Lope.

${ }^{37}$ En la edición de Krzysztof Sliwa [2005: 856] sólo hay tres someras alusiones notificadas en el índice de nombres, todas ellas pertenecientes al intercambio epistolar de Lope de Vega.

${ }^{38}$ Como veremos más adelante, no está claro el destinatario de "Musa que sopla y no inspira” (Millé XXII), porque todavía no se ha desvelado que Miguel Musa fuera un certero pseudónimo de Quevedo, como postuló por primera vez Artigas en Don Luis de Góngora y Argote. Biografía y estudio crítico [1925: 90], basándose en el epígrafe de un manuscrito que fue de la propiedad de Foulché-Delbosc. Cfr. Amelia de Paz [1999: 33]. 
¿Y las sátiras antigongorinas de Quevedo? Pues bien: resulta que la mayoría cuenta con un solo testimonio manuscrito y sin una clara atribución al autor. De las dieciocho sátiras atribuidas, diez (POC, 832-837; 839-841) aparecen sin autor en el ms. 108 de la Biblioteca Menéndez Pelayo de Santander. Asimismo, el único testimonio del 830 (el ms. 3795 de la BNE) tampoco figura atribuido a Quevedo. Por otra parte, lo único que queda es un poema de atribución segura $(P O C, 825)$, cuatro probables composiciones, distanciadas por un lapso temporal de más de veinte años $(P O C, 826,829,831$ y 838) y otras dos (POC, 827 y 828) dudosas por razones de estilo. ${ }^{39}$

Consideramos necesarios estos preámbulos para establecer qué relación dramática tuvieron Góngora y Quevedo. Don Luis conoció a nuestro autor desde su primer encuentro en Valladolid en 1603. También cultivó el teatro, si bien ha tenido escasa resonancia. ${ }^{40}$ Su relación con las tablas se remonta a su más tierna edad: sabemos que hospedaba en su casa cordobesa a los cómicos itinerantes y asistía a numerosas representaciones de comedias. Asimismo, hacia 1609, es probable que tuviera algún vínculo con compañías que interpretaban autos sacramentales. Algunas de sus letrillas religiosas fueron representadas por actores.

Góngora, al igual que Quevedo, escribió sonetos satíricos a propósito de actores conocidos. Jusepa Vaca, actriz frecuentemente citada en las epístolas entre Lope de Vega y el Duque de Sessa, fue satirizada en su soneto $A$

\footnotetext{
${ }^{39}$ Véase el análisis de Amelia de Paz [1999: 38-42]

${ }^{40}$ Sobre la enemistad de ambos escritores, véase el capítulo "Góngora y Quevedo" que P. Jauralde Pou incluye en la biografía de Quevedo [1999: 899-924].
} 
Jusepa Vaca, farsanta (Millé, LXXIX). Es sorprende la coincidencia temática con el diálogo quevedesco $(P O C, 847)$, sobre todo la insistencia en el libertinaje sexual de la actriz, patente en los dos últimos tercetos, y la incipiente cornudería de su marido, el actor Juan de Morales Medrano:

\footnotetext{
No llames castidad la que forzada

hipócrita virtud se representa,

saliendo con su capa disfrazada.

Jusepa, no eres casta; que si alienta

contraria fuerza a tu virtud cansada,

es vicio la virtud cuando es violenta.
}

También compuso un soneto satírico contra Pedro de Valdés, director de una compañía de cómicos, y su mujer, Jerónima de Burgos (Millé, LXVII). Si bien esta composición es algo oscura, el primer terceto alude inequívocamente a los cuernos de Valdés:

Yo soy de parecer, Anteón mío,

que pues la vuelta ignoro, y Baltasara

se fue a ermitañear, ¿qué es lo que aguardo?

Acteón, el cazador transmutado en ciervo por Diana, era una tópica alusión a los cornudos. No nos sorprende, entonces, que Quevedo tenga un soneto (POC, 593) en el que se alude a la misma poco honrosa condición de Valdés, en el primer cuarteto: 
no piense que ha de ser solo el cornudo.

Valdés lo pretendió, mas nunca pudo

restañarle los cuernos a Cabrera.

Asimismo, al igual que Quevedo (en el entremés del Niño y peralvillo de Madrid) y otros ingenios, don Luis compuso un soneto contra Vallejo (Millé, LXXX), porque en una representación del Antecristo de Alarcón no se atrevió a efectuar unas acrobacias:

\footnotetext{
Quedando con tal peso en la cabeza, bien las tramoyas rehusó Vallejo, que ser venado y no llegar a viejo repugna a leyes de naturaleza.

Ningún ciervo de Dios, según se reza, pisó jurisdicciones de vencejo; volar, a sólo un ángel lo aconsejo, que aun de Roble supone ligereza.
}

Al céfiro no crea más ocioso toro, si ya no fuese más alado, que el evangelista glorïoso.

"No hay elemento como el empedrado", dijo; y así el teatro numeroso volar no vio esta vez al buey barbado.

Esta circunstancia aparece en una carta que escribió el 19 de diciembre de 1623:

La comedia, digo el Antechristo de don Juan de Alarcón, se estrenó el miércoles pasado. Echáronselo a perder aquel día con cierta redomilla que enterraron en medio 
del patio, de olor tan infernal que desmayó a muchos de los que no podían salirse tan aprisa. Don Miguel de Cárdenas hizo diligencias, y a voces invió un recado al Vicario para que prendiese a Lope de Vega y a Mira de Mescua, que soltaron el domingo pasado, porque prendieron a Juan Pablo Rizo, en cuyo poder se encontraron materiales de la confesión. [Millé, $\mathrm{n}^{\mathrm{o}}$ 108]

El valor de Góngora como dramaturgo ha sido ensalzado por Robert Jammes [1984], el primero en realizar una edición moderna de Las firmezas de Isabela, El doctor Carlino, la Comedia venatoria y el entremés apócrifo de La destrucción de Troya. Jammes justifica el rechazo de una obra dramática que contravenía los presupuestos lopescos del Arte nuevo y que reivindicaba los referentes tradicionales del teatro antiguo español.

El teatro de Góngora se equipara al de Quevedo en lo que atañe a la intensidad verbal del discurso en detrimento de la acción dramática. Una fórmula ciertamente alejada del entramado comercial y llano - ese hablar en necio para agradar al vulgo- de la comedia nueva de Lope. Ambos concebían el lenguaje como entidad autónoma edificadora de realidades poéticas. Hallamos, por tanto, estatismo y pirotecnia lingüística en el teatro de dos autores que la reciente historia literaria ha querido contraponer como la noche y el día de la literatura aurisecular. 


\section{LAS HUELLAS DE QUEVEDO EN EL TEATRO}

\section{EN LA COMEDIA AURISECULAR}

Si bien apenas tenemos noticia del influjo del Quevedo comediógrafo en el teatro serio del siglo XVII, Chevalier en su estudio Quevedo y su tiempo [1992:197-198] ensalza la relevancia de las esporádicas influencias de la prosa de don Francisco que emergen en la comedia aurisecular.

Personajes y aguafuertes de los Sueños reviven en Semejante a sí mismo (acto III) de Ruiz Alarcón, donde se retoma la heterogénea olla podrida de figuras del Juicio. Tirso evocó en Quien da fuego, da dos veces (jornada III) a los infernales sastres y pasteleros que pueblan los Sueños. Calderón revivió en Lances de amor y fortuna el pasaje de la criada crédula ante las alarmas de un poeta eufórico que figura en el Buscón.

Toda la comedia del Siglo de Oro se ve constantemente salpicada por chistes o equívocos quevedescos, sobre todo en boca de los graciosos, como Tristán de No hay vida como la honra de Montalbán, Clarín de La vida es sueño de Calderón, el Chichón de Darlo todo y no dar nada o Alejo de Lances de amor y fortuna.

Asimismo, Chevalier [1992: 198] considera a Lope "imitador de la agudeza verbal quevediana" y justifica su influencia citando pasajes dramáticos del Fénix de los Ingenios: Amar sin saber a quién (1616-1623), La malcasada (1610-1615) y La carbonera (1623-1626) atesoran múltiples ecos del Buscón. A su vez, romances quevedescos recogidos en el Cancionero de 1628 rebrotan en Las bizarrías de Belisa (1634). 
Con todo, no hemos de olvidar la relevancia de las sartas de equívocos de la Premática del Tiempo retomados en las comedias lopescas, ni la siembra de neologismos jocosos y voces germanescas típicamente quevedescas en comedias de Tirso, Calderón, Rojas Zorrilla, Moreto y Francisco de Leiva.

El polígrafo y humanista dejó la huella de su notable personalidad literaria en todos los géneros que se cultivaron durante el fértil Siglo de Oro de las letras españolas. ${ }^{41}$

\section{INNOVACIONES QUEVEDESCAS DEL ENTREMÉS}

Quevedo compuso entremeses originales, entregó a los cómicos un variopinto almacén de tipos y figuras y utilizó una ejemplar técnica literaria en la pintura del antihéroe. Fue maestro del teatro breve barroco, incluso a través de materiales satíricos procedentes de su poesía, los Sueños y otros juguetes no dramáticos. Desde un ángulo inesperado, claro predecesor del esperpento, supo reflejar temas universales ya presentes en la satura latina: el rostro y la máscara, los antagonismos sexuales, gozos y sombras del amor, los avatares del poderoso caballero don Dinero. Topoi que, vehiculados en arabescos de ingeniosidades y frescos parlamentos de personajes arquetípicos, desvelan a Quevedo como escritor del teatro de la conciencia. Porque "perseguía la ingeniosidad con tanto celo como la verdad." ${ }^{42}$

\footnotetext{
${ }^{41}$ Este complejo rastreo exige un estudio riguroso todavía por elaborar.

${ }^{42}$ Como señala Asensio [1965:189].
} 
Uno de los mayores logros de Quevedo estriba en "el realce festivo de la actuación ágilmente eficaz de la mujer" ${ }^{43}$, después retomado por Quiñones de Benavente con ufanía mimética. Sus entremeses están poblados por pícaras y avispadas mujeres, ambientados con tonos extravagantes e hiperbólicos, fantasías y ensueños, capaces de despertar una sonora carcajada, no exenta de complicidad despotricadora.

No obstante, no es concluyente el cotejo entre el lindo, el hablador y el valentón de la prosa quevedesca con las mismas figuras que emergen en los entremeses de Salas Barbadillo y Castillo Solórzano. ${ }^{44}$

El teatro breve quevediano destinado a palacio pudo inspirar algunos de los entremeses de Hurtado de Mendoza, como El examinador Miser Palomo. ${ }^{45}$ Este fue representado el 10 de octubre de 1617, junto con $E l$ caballero del sol de Vélez de Guevara, en ocasión de las fiestas con que el Duque de Lerma homenajeó a la corte de Felipe III. Su protagonista alude a un personaje popular celebrado en una letrilla de Quevedo: "Yo me soy el rey Palomo/ yo me lo guiso, yo me lo como" (POC, 644). El entremés de Hurtado de Mendoza es el primero en publicarse solo y marca, para muchos teóricos teatrales, el paso definitivo de la prosa al verso de este subgénero dramático.

\footnotetext{
${ }^{43}$ Véase S. Hernández Araico [2004: 230].

44 No hemos de olvidar las matizaciones de Chevalier [1988: 155; 1992: 221] respecto a la herencia de tipos entremesiles de Quevedo. A su vez, a propósito del entremés de $E l$ caballero de la Tenaza, descartado por Blecua del corpus entremesil de nuestro autor [1981:IV, 14-15] y que para García Valdés queda todavía por consignar [1985: 35], es indudable que su protagonista pertenece a las Cartas del caballero de la Tenaza.

${ }^{45}$ Cfr. S. Hernández Araico [2004: 212].
} 
Pero el éxito de Quevedo no se reduce a la invención de tipos. ${ }^{46}$ Sus entremeses plasman la hipocresía de los valores ensalzados en la comedia, las seductoras máscaras femeninas, encubridoras de una atroz avaricia, el matrimonio como elenco de ridículos fingimientos, el mundo como retablo de bajezas morales, el hombre como pamplinas estafado en su cornudería y desvalijamiento pecuniario.

\section{MAESTRO DEL "PONTÍFICE DE LOS BAILES Y ENTREMESES"}

La celebridad de Quiñones de Benavente, Lope de Vega del entremés, eclipsó la fama del Quevedo dramaturgo, a pesar de que el autor de Jocoseria compuso su obra a todas luces con posterioridad. ${ }^{47}$

${ }^{46}$ Como señala Susana Hernández Araico [2004: 203], "el logro entremesil quevedesco consiste en una construcción dramática risible muy especialmente barroca donde destaca el artificio teatral mismo."

47 Así lo nota Asensio en su Itinerario del entremés [1965]. Sin embargo, Armando Cotarelo [1945: 46] había erróneamente considerado que Quevedo, "en el teatro menor barroco, sigue los derroteros marcados por Quiñones de Benavente, no sin cierta originalidad". Astrana Marín [1943: 555] define a Quiñones como "plagiario constante de nuestro escritor." A lo largo de nuestro estudio entremesil, hemos topado con múltiples reelaboraciones del ingenio quevedesco por parte del "pontífice de los bailes y entremeses" que, por granjearse el favor de la mosquetería y la cazuela y eclipsar su obra dramática, mereció la animadversión de Quevedo. Sin embargo, compartimos el criterio de Abraham Madroñal y Hannah E. Bergman [1993: 21].: "Quiñones no es un plagiario, sí un hábil dramatizador de motivos anteriores que puede tomar tanto de un texto en prosa como de un entremés, ya sea de Cervantes, Quevedo u otro". 
Señalemos algunas coincidencias biográficas. Quiñones de Benavente nace en Toledo solo un año después de don Francisco, en 1581. Ambos son clérigos de primeras órdenes: Quiñones se ordena en $1598^{48}$ y Quevedo, entre 1606 y $1607 .{ }^{49}$ Coinciden en el ambiente cortesano madrileño hacia 1617, cuando Quiñones abandona su ciudad natal. ${ }^{50}$ Medrano, en su obra Favores de las musas (Milán, 1631), los sitúa como compañeros de Academia por aquel entonces.

Los autores, asimismo, comparten amistades de célebres autores dramáticos coetáneos. Mateo Montero, amigo y colaborador teatral de Quevedo, había asistido con Benavente a la Academia toledana de Fuensalida, centro al que también concurría el camarada común José de Valdivielso, que en un principio tuvo buena relación con Quevedo, a pesar de que más tarde sería atacado en la Perinola. Ambos conocen al entremesista Gaspar de Barrionuevo y a don Antonio Hurtado de Mendoza, insigne poeta cortesano. ${ }^{51}$

No obstante, discreparon en cuanto a Juan Pérez de Montalbán, que alababa a Quiñones en su Para Todos. Quevedo, como es sabido, le crucificó en la Perinola (1632).

${ }^{48}$ Cf. BNE, ms. 3.825. F. 42: Memoria de las personas que en la c[iuda]d de Toledo ordenó el S[eñor] obispo de Salona, a siete días del mes de marzo de 1598. Señala "Luis de Benauente, [hijo] de Christóbal de Benavente y Luisa Ana, de Toledo".

${ }^{49}$ Según Astrana [1945:126].

${ }^{50}$ Cf. A. Madroñal [1993: 17]. Asimismo, M. Chevalier dedica un capítulo a la relación entre Quevedo y Quiñones en la obra Quevedo y su tiempo: la agudeza verbal. [1992: 220226]

${ }^{51}$ Cf. I. Aguilera [1945: 494- 523], Gareth A. Davies [1971]. 
Si la producción dramática entremesil de Quevedo se extiende entre 1613 y 1631, aproximadamente, la etapa de mayor esplendor creativo de Quiñones se cifra entre 1620 y $1630 .^{52}$

La compilación de la obra de Quiñones, Jocosería, se publica en 1645 a cargo de su amigo don Manuel Antonio de Vargas, el mismo año de la muerte de Quevedo. El epígrafe, Burlas veras, o reprehensión moral y festiva de los desórdenes públicos marca los mismos ideales que la comedia antigua, de "reformar, riendo, las costumbres". Este propósito coincide plenamente con la obra entremesil de Quevedo.

Ambos autores compartieron su desdén hacia la poesía culterana, el ataque a Juan Ruiz de Alarcón y semejantes temas satíricos. Sus entremeses retratan tipos moralmente defectuosos, aunque de leves pecados. ${ }^{53}$ Reflejan las necedades humanas aplastándolas con la carcajada catártica.

Las pidonas de Quevedo reaparecen en los entremeses de Quiñones La capeadora y El talego, con sus respectivas segundas partes, que podrían inspirarse en las Cartas del caballero de la Tenaza. La agudeza verbal de $E l$ zurdo alanceador hizo que Quiñones de Benavente tomara prestadas algunas expresiones en El guardainfante y el tema del afeminamiento

52 A lo que Abraham Madroñal [1993: 18] señala: “Quevedo, también autor de estas piececillas, debió empezar a sentir cierto recelo ante aquel poeta que tenía la osadía de inventar una lengua cuando le venía en gana, que utilizaba los mismos procedimientos humorísticos, basados en la dislocación conceptista, y que a veces utilizaba también para sus gracias textos anteriores, incluso del mismo don Francisco."

${ }^{53}$ Señala Bergman [1968:14] a propósito de Benavente: "No son grandes pecadores dignos de castigos trascendentales el tahur, la alcahueta, la cortesana (...), sino gentuza que se merece prosaicamente la cárcel, azotes, hospital". 
masculino en pro del interés creado en Los muertos vivos y en Turrada. El marión como personaje fue retomado por Quiñones en una obra homónima y multiplicó a los mozos afeminados en Los mariones. ${ }^{54}$

No obstante, Quevedo procuró marcar sus diferencias con el entremesista. No comparte con él los tintes risueños, ni posee la misma veta fantástica de los entremeses cantados de Quiñones. Recordemos que éste incluye personajes alegóricos y hace hablar hasta a animales y objetos inanimados, como sucede en el parlamento de las calles de El casamiento de la Calle Mayor con el Prado Viejo.

Don Francisco critica en la Perinola el populacherismo de Quiñones de Benavente y el uso del lenguaje lúdico -propio de los zarambeques o baile de negros-:

Benavente diciendo a Quintiliano que se haga allá a puras matracas, que no cabe y no le deja a puros burungongoros, mongorros, chongorros, lugar para media declamación. [1981: 177-179].

El célebre entremesista responde a los vituperios en el Entremés del Murmurador, cuando se le reprocha a un personaje cortesano la crítica a mujeres y médicos.

Quiñones utilizó a Quevedo como fuente argumental de muchos de sus entremeses. ${ }^{55}$ La inspiración del entremés cantado La verdad de Quiñones

\footnotetext{
${ }^{54}$ Los mariones como recreación de una obra ajena se estudia en Bergman [1972: 91-95].

${ }^{55}$ Cfr. Cotarelo [1911: 593]. A propósito de reminiscencias de textos quevedescos en prosa, señala Hannah. E. Bergman la deuda del entremés Las civilidades con el Cuento de cuentos de Quevedo en su estudio "Para la fecha de Las civilidades" [1956: 187-193] . En "Jácara
} 
en el Mundo por de dentro de Quevedo se hace patente en los siguientes versos:

JOSEFA LOBACO- Hoy se te ha ofrecido

tan lindo encuentro,

ya parece que veo

lograr un deseo,

si no es que me arrojo

pidiendo un antojo:

que no me desdeñes,

y el mundo me enseñes

todo por de dentro.

LUISA- ¡Ay quién le viera!

¡Jesús!, ¡quién le viera!

por saber si es verdad o mentira

lo que de ordinario en el mundo se mira,

o si es por de dentro

lo que es por de fuera.

LAS DOS- ¡Ay, quién le viera!

Jesús, quién le viera, etc.

FRUTOS- Hembras, por curiosidad,

hombres, porque la Verdad

desnuda os sale al encuentro

venid a ver el mundo por de dentro. (vv. 23-43)

que se cantó en la compañía de Bartolomé Romero", Pedro Real dice en su último parlamento "Todo eso es cuento de cuentos" [1968: 140]. El Libro de todas las cosas ve reproducidos algunos de sus chistes en El abadejillo: "-La mejor señal de agua (...)/ - Es el no haber para vino" y en El remediador: "-Para no llegar a vieja,/ ¿qué remedio podré hallar?- Que la maten cuando moza." 
Quiñones incluye versos conocidos de don Francisco -sobre todo de jácaras y romances suyos- en su obra dramática. Así pues, en la Loa que representó Antonio de Prado, encontramos una parodia de la jácara de Quevedo Relación que hace un jaque de sí y otros (POC, 856): "zampuzado en un banasto/ nos tiene tu autoridad" (vv. 187-188) ${ }^{56}$ y otra del romance Descubre Manzanares secretos de los que en él se bañan (POC, 719): "Manzanares, Manzanares,/ arroyo aprendiz de río" (vv. 227-228) ${ }^{57}$ En el entremés cantado Los planetas, aparece aludida la citadísima jácara Carta de Escamarrán a la Méndez (POC, 849): "Ya está metido en la trena/ tu querido Escamarrán" (vv. 15-16) ${ }^{58}$, que vuelve a aparecer parodiada en Don Gaiferos: "No más. Vencido me han/ tus lágrimas de azafrán,/ y por sacarte de pena,/ ya está metido en Sansueña/ tu querido Escamarrán." 59

Bergman no duda en aventurar una hipótesis que pretende perpetuar las similitudes entre los dos entremesistas: Quevedo sería autor de Las sombras, entremés hasta ahora encajonado en el limbo de lo espurio, y Quiñones habría realizado una dramatización del Sueño de la muerte en el entremés Los refranes del viejo celoso. De todos modos, la aventurada conjetura denota el poderoso influjo que nuestro autor tuvo sobre el más célebre

\footnotetext{
${ }^{56}$ El inicio de la jácara de Quevedo dice "Zampuzado en un banasto/ me tiene su majestad" (vv. 1-2).

${ }^{57}$ Esta vez, los versos coinciden del todo con el inicio del romance de Quevedo.

${ }^{58}$ El inicio de la jácara de Quevedo dista un poco de los versos citados: "Ya está guardado en la trena/ tu querido Escamarrán". La cursiva es nuestra.

${ }^{59}$ Cf. Cotarelo [1911: 612].
} 
entremesista del siglo XVII, hecho que bastaría para afianzar su relevancia como dramaturgo. ${ }^{60}$

\section{LA IMPRONTA DE LAS JÁCARAS DE QUEVEDO}

Las jácaras de Quevedo, a pesar de que su difusión impresa fuera más o menos corriente, son las que mayor resonancia consiguen entre sus coetáneos poetas, novelistas y dramaturgos. ${ }^{61}$ Todo ello, hasta el punto de borrar de un plumazo la tradición germanesca anterior, que empieza a despuntar con la poesía de Rodrigo de Reinosa. ${ }^{62}$

Para lectores e ingenios del barroco, Quevedo será el principal artífice de las jácaras. Este género, lejos de encontrar en nuestro autor su principio de degeneración ${ }^{63}$, se desarrolla y populariza: alcanza su apogeo estético, genera una plantilla de personajes recurrentes y se fija en un léxico - la jerigonza o lengua de germanía- que le es propio.

${ }^{60}$ Así lo afirma Bergman [1975: 390]: "Benavente debía de ser un gran admirador de Quevedo. Su temperamento era menos acerbo, y por ello su sátira es más suave, pero los objetos de la sátira suelen ser los mismos. Muestra un interés especial por los modos de expresión, fijando su atención ya en la jerigonza de los précieux, ya en otras idiosincrasias lingüísticas, ya en el habla vulgar. “

${ }^{61}$ Cfr. Chevalier [1992: 143].

${ }^{62}$ De acuerdo con Felipe B. Pedraza [2006: 78], puso los cimientos de la jácara al reflejar el mundo criminal y prostibulario en sus composiciones líricas.

${ }^{63}$ Cfr. Alonso Hernández [1989: 622]. 
La jácara, tras la impronta de Quevedo, salta al teatro, y es admirada por grandes ingenios de las tablas, como Quiñones de Benavente, Salas Barbadillo, Luis Vélez de Guevara o Calderón. Se integra en las comedias, o da origen a algunas de ellas, como sucede con Pero Vázquez de Escamilla de Quevedo o Añasco el de Talavera, de Cubillo de Aragón. Se inserta dentro de algunos pasajes de las comedias de Rojas Zorrilla como No hay ser padre siendo rey, El caín de Cataluña, El más impropio verdugo o El catalán Serrallonga. ${ }^{64}$ Por ello, González de Salas en sus preliminares al Parnaso afirma que Quevedo es el "primero descubridor" del género, pese a que hoy en día reconocemos la presencia de múltiples antecedentes.

La Carta de Escarramán a la Méndez (POC, 849), la Respuesta de la Méndez a Escarramán (POC, 850) y Testamento que hizo Escarramán editado en un pliego suelto barcelonés de 1613- constituyen los pilares de una larga tradición de alusiones escarramanescas. En 1613, el jesuita Pedro Juan Ferrer escribe en su Tratado de comedias (publicado en Barcelona, en 1618):

agora corren por esta ciudad unas canciones que llaman Escarramán, que en el teatro las han representado con tanta torpeza, que aun los aficionados a las comedias se escandalizan de ellas y muchos por no oírlas se salían del teatro. [Cotareo y Mori, 1904: 353b].

El jaque Escarramán se volvió a lo divino. Se documenta en una obra de Gabriel Serato, Relación verdadera que se sacó del libro donde están los milagros de nuestra Señora de la Caridad de San Lúcar de Barrameda

${ }^{64}$ Cfr. Felipe B. Pedraza [2006: 84]. 
(Málaga, 1612). ${ }^{65}$ Hay diversos manuscritos con estas versiones divinizadas, como el Romance de Escarramán a lo divino que figura en el ms. 19387 de la BNE; el del ms. 4154 (f. 265v.) y el del ms. 3895 (f. 140). Aparece como tal en El rufián viudo llamado Trampagos (1611-13), entremés cervantino: ${ }^{66}$

$\begin{array}{ll}\text { REPULIDA } & \text { Hante vuelto divino. ¿Qué más quieres? } \\ \text { CHIQUIZNAQUE } & \text { Cántante por las plazas, por las calles. } \\ & \text { Báilante en los teatros y en las casas. }\end{array}$

[1952: 52, 53]

La alusión final de La cueva de Salamanca también se apoya en la jácara de Quevedo:

$\begin{array}{ll}\text { CRISTINA } & \text { Basta; ¿que también los diablos son poetas? } \\ \text { BARBERO } & \text { Y aun todos los poetas son diablos. } \\ \text { PANCRACIO } & \text { Dígame, señor mío, pues los diablos lo saben } \\ & \text { todo, ¿dónde se inventaron todos esos bailes } \\ & \text { de las Zarabandas, Zambapalo y Dello me } \\ & \text { pesa, con el famoso del nuevo Escamarrán? } \\ \text { BARBERO } & \text { ¿A dónde? En el infierno; allí tuvieron su } \\ & \text { origen y principio. [1952: 212]. }\end{array}$

Escarramán llega a lexicalizarse en un adjetivo. Cervantes lo utiliza en el entremés de La Cueva de Salamanca: "Pues en verdad que tengo yo mis puntas y collar escarramanesco..." [1952: 212]. En el capítulo V del libro

\footnotetext{
${ }^{65}$ Véase Elena di Pinto [2003: 385].

${ }^{66}$ Cfr. Asensio [1965: 103-105].
} 
IV de Los trabajos de Persiles y Sigismunda, se inserta una carta de Bartolomé que es una original recreación de la jácara. ${ }^{67}$

En la comedia de Lope ¿De cuándo acá nos vino?(1612-1614) aparece un personaje que canta "lo de Escarramán". Este autor incluyó un Romance de Escarramán, vuelto a lo divino ("Ya está metido en prisiones/ alma, Jesús, tu galán") en la Segunda parte del desengaño del hombre (Salamanca, 1613; reimpreso en Madrid, en 1615). En el auto de La puente del mundo, la loa no es más que otra versión a lo divino, que se inicia "Ya está cifrado en la forma/ tu querido y santo Isaac". El Fénix también incluirá la venta del pliego de Escarramán en la comedia lopesca Al pasar del arroyo (1616). En agosto de 1617, en una carta dirigida al duque de Sessa escribe: "pienso que estoy en la capilla, como Escarramán".

La flor y nata literaria quedó fascinada por este jayán que protagoniza la pareja de jácaras epistolares de Quevedo: Góngora, en el romance Al pie de un álamo negro (1614), alude al "cantado Escarramán". También aparece en el Quijote (1614) de Avellaneda y en un soneto de fray Bernardo de Cárdenas (1616). Incluso protagoniza una comedia de Salas Barbadillo (El gallardo Escarramán, 1620). Sus versos aparecen reformulados en obras dramáticas de Alarcón, Quiñones de Benavente, Tirso, Rojas Zorrilla y otros.

Predominaron, sin embargo, las malas imitaciones de las jácaras de Quevedo, romances de estilo tremendista y de nulo valor estético. ${ }^{68}$ La plaga

\footnotetext{
${ }^{67}$ Véase la glosa de Felipe B. Pedraza [2006: 86- 88].

${ }^{68}$ M Cruz García Enterría en su estudio Sociedad y poesía de cordel en el barroco [1973] las documenta prolijamente.
} 
de estas versiones inmundas rebasó la publicación de los pliegos sueltos y se trasladó, incluso, a los libros: invitó a disolverse, sin pena ni gloria, a este género dinamizado por don Francisco. La jácara naufragó, ya del todo, en el siglo XIX.

\section{Más ALlá de LA Literatura}

El teatro siempre ha fascinado a los amantes de la palabra. El novelista, el poeta lírico o el compositor de lances épicos atesoran éxitos remotos e invisibles. Su placer y su gloria son íntimos o participan de círculos cerrados, se paladean en el retiro silencioso de la torre de marfil y en el forcejeo solitario con la pluma. Su espacio de representación es el libro.

El dramaturgo, en cambio, escribe para una puesta en escena y unos actores que modularán la palabra en un recitado. El verbo, vuelto conjuro, tiene efectos inmediatos sobre el auditorio.

El teatro no sólo es literatura. Porque se parece demasiado a la realidad, aunque ésta sea una realidad fingida, ensayada, artificial. Es un género literario que, por su visualidad y dinamismo, ostenta un insigne alcance social. Genera opinión pública, colectiviza sentimientos, potencia la disolución del yo en la escena representada. Si la composición es efectiva, "posee" al espectador en una genuina catarsis.

El dramaturgo, mientras sea espectador de su propia obra, podrá soñarse dios de las figuras que ha dotado de habla. Catará en persona los halagos del triunfo y las mieles del aplauso. Como dijo Cervantes en la Adjunta al 
Parnaso, "es cosa de grandísimo gusto y de no menos importancia ver salir mucha gente de la comedia, todos contentos, y estar el poeta que la compuso, a la puerta del teatro, recibiendo el parabién de todos." Quevedo no pudo sustraerse de esta labor tan laureada. ${ }^{69}$ En ella vertió su enorme capacidad de expresión, su imitación de tonos y la asunción de campos léxicos. Peligrosos y delincuentes son los hombres que tienen el corazón charlatán y muda la lengua. $^{70}$

${ }^{69}$ Así lo señalaba Armando Cotarelo Valledor [1945: 41-42] al inicio de su conferencia El teatro de Quevedo.

${ }^{70}$ Cfr. Providencia de Dios [1951, II, 192 b]. 


\section{Capítulo IV}

EL QUEVEDO COMEDIÓGRAFO 


\section{- 242 -}




\section{TEATRO Y POLÍTICA}

\section{DOCUMENTOS Y MONUMENTOS}

El valor de las creaciones artísticas no siempre debe medirse con la misma vara, porque hay "monumentos" y "documentos". ${ }^{1}$ Las comedias de privanza de Quevedo, al margen de su calidad literaria, pueden ser estudiadas como "documentos", dado que nos ayudan a entender aspectos de la vida política y social del siglo XVII. Reflejan algunas preocupaciones individuales de nuestro autor, así como el curioso papel que le tocó ejercer en la corte de Felipe IV.

El teatro áureo operó como instrumento político-social, "en apoyo de la sociedad configurada según el orden monárquico-señorial". ${ }^{2} \mathrm{Su}$ finalidad ética, incluso en asuntos religiosos, estaba subordinada a la socialización de un sistema de convenciones. Las comedias cortesanas robustecían la ideología colectiva y la acción sobre las masas. Liberaban las tensiones entre autoridad y rebeldía, podían incorporar una ideología conservadora y conformista. ${ }^{3}$ Esta concepción del teatro quizá trataba de compensar su otra

\footnotetext{
1 Véase Panofsky [1983: 26-27].

2 Maravall [1990:19]

3 A propósito de nuestro autor, nota Maravall [1990:20]: "Es curioso advertir, entre otros matices, la ausencia de sátira en el teatro -justamente en el ámbito de una literatura que produce casos como el de Quevedo-".
} 
función, más lúdica y festiva, vertida en jácaras, bailes, entremeses y comedias burlescas, que no siempre secundaba el poder establecido. ${ }^{4}$

A pesar de que el teatro áureo ejerciera el rol de mass media, no podemos afirmar que un personaje tan controvertido como Quevedo arrinconara del todo su honda preocupación humanística, que se filtró, en mayor o menor medida, en su obra dramática seria. El panegírico del poder no neutralizó las ideas políticas de nuestro autor. Retomó el ejercicio erasmiano del Speculum principis del Enquiridion, preexistente en el modelo homónimo de Epicteto. Quevedo permaneció, sin embargo, en "el imposible equilibrio entre el encomio cortesano y la reprimenda política". 5

Don Francisco simpatizó con el modelo que Baltasar de Céspedes ejemplificaba en El discurso de las letras humanas, llamado el humanista. ${ }^{6}$ Siguió la impronta de aquellos filólogos eruditos y prudentes que, como Montaigne y Justo Lipsio, defendían un ideario que conjugaba la ética y la política. Un paradigma que, según el parecer de todos ellos, debían emular las nuevas monarquías absolutas. ${ }^{7}$

4 Sólo así se explica la primera orden de cierre de los teatros públicos en España en 1598. Cfr. Ferrer Valls [2004: 15].

5 Como desarrolla Rafael Iglesias [2005: 267-298] en un artículo a propósito de Cómo ha de ser el privado.

${ }^{6}$ Hemos consultado la edición de P. Gregorio de Andrés [1965].

7 A propósito de ello, Fernández Guerra [1946: I, XXII y ss.], en el "Discurso preliminar a las Obras de Francisco de Quevedo, afirmaba: "Quien afrontaba la colosal empresa de reformar las costumbres y la gobernación de la monarquía en los reinados del tercero y cuarto Filipo, debía de ser por necesidad político profundo, teólogo, asceta, moralista, filósofo, y lo que parece un delirio: poeta." 
Don Francisco vivió en la Europa fanática de las guerras de religión, habitó en el tiempo traumático de un cambio de era. Su avistamiento de la realidad fue desde el observatorio privilegiado de la nobleza. Criado en palacio, había convivido con la corte, había conocido tres monarcas diferentes y tenía conciencia de pertenecer a la cúpula palaciega. Ese sentimiento de pertenencia a la elite fue, a todas luces, el que le impulsó a preocuparse por asuntos de gobierno.

Quevedo, aunque a veces escribió lejos del mundanal ruido, jamás convirtió su Torre de Juan Abad en una Torre de Marfil. Hasta su adscripción a la filosofía estoica estuvo condicionada por las circunstancias políticas. Incluso en prisión, seguía leyendo con asiduidad las Relaciones de Sucesos. ${ }^{8}$ Quería estar bien enterado de todo cuanto sucedía en el país.

En todo caso, el autor de La España defendida- cuya redacción ya inició en 1609- ${ }^{9}$ empleó su erudición humanista como instrumento de patriotismo. Así lo avalan, bajo rótulos heterogéneos, diversos tratados que fueron fruto de su pluma ${ }^{10}$ : la Carta del rey don Fernando el Católico (1621), Grandes anales de quince días (1621), Mundo caduco y desvaríos de la edad (1623), El chitón de las taravillas (impresa en 1630), Carta a Luis XIII (impresa en 1635), Visita y anatomía de la cabeza del Cardenal Richeleu (1635), Breve compendio de los servicios de don Francisco Gómez de Sandoval (1636),

8 Véase el Boletín Oficial de Relaciones de Sucesos (BORESU) on line: http://rosalia.dc.fi.udc.es/BORESU/

9 Cfr. Roncero López [2000], que mediante el análisis de La España defendida y los Grandes anales de quince días afianza el perfil humanístico de Quevedo, su rigor como filólogo e historiador.

${ }^{10}$ Véase la edición de A. Rey [2005: III]. 
Respuesta al manifiesto del duque de Berganza (1641), La rebelión de Barcelona (1641) y el Panegírico a la majestad del rey nuestro señor don Felipe IV (1643). Todos estos opúsculos confluyen como testimonios políticos de sucesos polémicos comprendidos entre 1621 y 1643: los años del valimiento de Olivares y la primera etapa del reinado de Felipe IV. Son exponentes de las contradicciones ideológicas del autor respecto al declive de la monarquía.

Quevedo, atento lector de las Políticas (Leiden, 1589) de Justo Lipsio ${ }^{11}$, traducidas al español por Bernardino de Mendoza, coincidirá en la visión ciceroniana de la historia como magistra vitae -tal y como se explicita en De oratore-, una ética de inspiración estoica, teñida de escepticismo y orientada hacia el tacitismo. ${ }^{12}$

En una carta al insigne humanista holandés, del 22 de noviembre de 1604, don Francisco expresa los motivos de su zozobra intelectual. Desprecia, por cierto, la traducción de las Políticas de Bernardino de Mendoza:

¿Qué puedo decirte acerca de España sin que me tiemble la voz? Vosotros sois presa de la guerra. Nosotros lo somos del ocio y la ignorancia. Allí se consumen nuestros soldados y nuestras riquezas. Aquí nos consumimos nosotros, y aunque no falta quienes dan consejos, faltan quienes los lleven a cabo. Los más prestigiosos varones caminan aquí con paso vacilante, pero tenemos que consolarnos. Hágase la voluntad del poderoso Júpiter. Tradujo tu Política a nuestra lengua materna

\footnotetext{
${ }^{11}$ Cfr. Justo Lipsio [1997].

${ }^{12}$ Justo Lipsio editó de Tácito De Constancia (1583), las Políticas (1589) y De militia romana $(1595)$.
} 
Bernardino de Mendoza, ciego como Tiresias, ciego como Argos. [Krzysztof Sliwa, 2005: 126].

No es de extrañar que Lope, en el Laurel de Apolo calificase a Quevedo de "Lipsio de España en prosa y Juvenal en verso". Sus intereses radican en continuar la obra de su maestro: reivindicar a Homero y Epicuro (contra las disquisiciones de Escalígero), cristianizar a los estoicos, conciliar la Biblia con los sabrosos frutos de los autores paganos y, ante todo, orientar hacia la virtud la política monárquica. ${ }^{13}$

La historiografía quevedesca no sólo se ceñía a los datos aportados por las Relaciones de Sucesos, sino que se nutrió de reminiscencias a historiadores clásicos, con moldes tan característicos del humanismo como el encomio y el panegírico, en la modalidad de las Gesta Ferdinandi regis (1495-6) de Lorenzo Valla. Quevedo ubicó en el armazón de la historia sus meditaciones morales y políticas, recurriendo a menudo al acerbo de tesis providencialistas que predominaron en comentarios y exposiciones auriseculares. ${ }^{14}$ Don Francisco volcó estos conceptos en la composición de su teatro palatino.

13 Javier Peña y Modesto Santos sintetizan esta afinidad en los siguientes parámetros: "La amistad entre Lipsio y Quevedo quizá haya que cifrarla en la afinidad de sentimientos. Quevedo recurre a Lipsio para que corrija sus trabajos: "Yo remitiré mis trabajos a vuestra merced, y vuestra merced lo corregirá con benevolencia." Sin duda su mejor lazo de unión fue el amor a los clásicos y el afecto que ambos sintieron por los estoicos.” [1997: XLXLI].

${ }^{14}$ Como nota Alfonso Rey [2005: 20]. 


\section{EL CONDE-DUQUE DE OLIVARES Y LAS COMEDIAS POR ENCARGO}

Las comedias de privanza auriseculares eran aquellas que tenían como protagonista a la figura del valido o que tocaban el tema del valimiento. Quevedo cultivó este subgénero dramático: pertenecen a esta clase Cómo ha de ser el privado y la atribuida La privanza desleal y voluntad por la fama. $^{15}$ Estas obras teatrales están en implícita relación con la representación del poder. ${ }^{16}$ Sus tópicos y temas literarios recurrentes -la envidia en los personajes antagónicos, el menosprecio nobiliario, los cambios caprichosos de la Fortuna- habitan el espacio cortesano. Dentro de este ámbito de dominio político, el aristócrata se siente obligado a conseguir el favor de la monarquía para consolidar o mejorar su estatus social. ${ }^{17}$

La sociedad cortesana pugna por penetrar el magnético círculo que rodea al monarca y sus decisiones políticas. El rey ocupa una posición central o nuclear y sus favoritos son los dispensadores de su patronazgo. Como la caprichosa Fortuna, el monarca regala mercedes, títulos, cargos, rentas y

\footnotetext{
${ }^{15}$ Cfr. Urrutia [1982: 176 y ss.]

${ }^{16}$ Tras la muerte de Felipe II, la figura del privado adquiere grandes dimensiones políticas, que aparecerán reflejadas en este subgénero dramático. Lope de Vega, con Los Guzmanes de Toral, ${ }^{\square}$ es pionero del ciclo de este tipo de comedias. Luego florecen en la pluma de autores como Salustio del Poyo, Tirso de Molina, Guillén de Castro, Mira de Amescua, Pérez de Montalbán o Ruiz de Alarcón. También en el Vélez de Guevara de A lo que obliga el rey, o el Calderón de Saber del bien y el mal. Cfr. Ignacio Arellano [2001: 94] a propósito de Tirso.

${ }^{17}$ Sobre el tema de la privanza, véase J. Gutiérrez [1975], L. Caparrós Esperante [1987], L. Bradner [1971] y R.R. MacCurdy [1978].
} 
mayorazgos que después, con la misma facilidad, puede arrebatar a sus ministros. $^{18}$

Este tipo de comedias se ajustaba a la defensa de un sistema de poder. Ofrecía modelos de comportamiento adecuados para que el espectador se integrara de manera correcta en la sociedad. Se sustentaba en una serie de mitos asesorados por un trasfondo ideológico que establecía las pautas de conducta mediante un mecanismo coactivo, necesario para restituir el orden social cuando éste había sido violado.

Un personaje histórico concreto viene a nuestra mente cuando meditamos sobre las relaciones entre Quevedo, el teatro y la política: el Conde-Duque de Olivares. El Marqués de Valisero de Cómo ha de ser el privado es el anagrama de su nombre. ${ }^{19}$

La relación entre el Conde-Duque y Quevedo se extiende desde el 5 de abril de $1621^{20}$, fecha de la primera carta entre ambos, hasta el 7 de diciembre de 1639, día nefasto en el que Quevedo es prendido y encerrado en el convento de San Marcos de León. ${ }^{21}$

\footnotetext{
${ }^{18}$ Cfr. Norbert Elias [1993:60].

${ }^{19}$ Señala Armando Cotarelo [1945: 63]: "la obra presenta a Olivares como modelo de validos, celoso, trabajador, desinteresado, asequible, vigilante y devoto de las personas reales."

${ }^{20}$ En la relación quevedesca de las bodas de la Reina de Francia, del 21 de noviembre de 1615 aparece, de hecho, la primera alusión al Conde-Duque, el cual hizo su aparición con "un par de poetas sobre apuesta, amenazando con su relación" [2005: 187].

${ }^{21}$ Véase G. Marañón [1972: 126].
} 
Si ubicamos las comedias de Quevedo en esos años de correspondencia y amistad con Olivares, su significado propagandístico se esclarece. ${ }^{22} \mathrm{La}$ primera carta, en la que Quevedo pide la libertad al Conde-Duque y en la que, sea de paso, le envía la Política de Dios (Zaragoza, 1626), ya contiene valiosas reflexiones sobre el valimiento "ni celoso, ni desinteresado":

Al Conde-Duque, gran Canciller, mi señor, don Gaspar de Guzmán, Conde de Olivares, sumilier de Corps y caballerizo mayor de Su Majestad.

Enviándole la Política de Dios y gobierno de Cristo.

Excelentísimo señor:

Dar a leer a Vuestra Excelencia este libro, es la mejor diligencia que puede hacer el conocimiento de su integridad, para darse por entendido del cuidado con que asiste al Rey nuestro señor, en valimiento ni celoso ni interesado. Supo este libro tener oyentes y hoy sabe escogerlos; y animoso a Vuestra Excelencia hace lisonja nunca vista, solo con no recatarle severo verdades desapacibles a otro espíritu menos generoso: pues han hecho fineza tan estorbada con Vuestra Excelencia, que no han escarmentado, cuando sospechas de haberlas imaginado tuvieron resabios de delito, y fue culpa el intento aun no amanecido. Lea Vuestra Excelencia lo que ejecuta, y habrá sido más hazañoso que bien afortunado en ser lector de advertimientos que le son alabanza y no amenaza. Deseo a Vuestra Excelencia vida y salud, para que Su Majestad tenga descanso, y felicidad sus reinos.

Preso en mi villa de Juan Abad, a 5 de abril, 1621.

Don Francisco de Quevedo Villegas. [Krzysztof Sliwa, 2005: 302]

Esta epístola es un reclamo de profundis, con deseos puros colmados de esperanza. Don Gaspar de Guzmán no habrá de temer palabras de reproche

\footnotetext{
${ }^{22}$ Cfr. Jorge Urrutia [1982: 175]
} 
o de recelo. Las "duras verdades" de Quevedo se traducirán en palabras amables para el valido. ${ }^{23}$

En 1624, Quevedo escribe la célebre Epístola al Conde de Olivares. Hacia $1629,{ }^{24}$ redacta Cómo ha de ser el privado, cuyos principios se repiten en El Chitón de las Taravillas, panfleto olivarista que data del mismo año. También por encargo del valido se escribe Quien más miente, medra más en 1631 que, a pesar de no tratar el tema de la privanza, se inicia con una loa laudatoria al privado, una lisonja mal disimulada por nuestro poeta. $^{25}$

Ignoramos si estas comedias de privanza nacen por deseo espontáneo del autor. No son fruto de su libre inspiración, sino de encargos con un afán de alabanza. ${ }^{26}$ Estas piezas palatinas de Quevedo han sido atendidas como paradigmas de una literatura panfletaria, tendenciosa y por encargo, que genera la impresión de "una pluma inhábil para el teatro serio" e incluso cierta "reacción de antipatía en el lector". ${ }^{27}$ Pero dentro de las restricciones de este tipo de literatura, Quevedo procuró exponer dramáticamente los avatares de sus ideales políticos.

\footnotetext{
${ }^{23}$ Raimundo Lida [1958: 149]

${ }^{24}$ Aceptamos la postulación de Elliott [1982: 235].

${ }^{25}$ Así leemos en el Tratado de Casiano Pellicer: "María Riquelme, insigne comedianta [...], dio en breves coplas la enhorabuena a los reyes, y extrañando que se hallase en diversiones el Conde-Duque, a quien suponía todo ocupado en el continuo despacho de los graves e inmensos negocios de la Monarquía, pidió que se la diese testimonio por donde constase que se hallaba presente a aquella diversión." [1975: 127]

${ }^{26}$ Urrutia [1982: 176]

${ }^{27}$ Cfr. Raimundo Lida [1980: 160] y Gregorio Marañón [1972: 126].
} 
Cuando en 1643 acontece la caída, Quevedo se apresurará a escribir un Panegírico a la Majestad del Rey nuestro señor Felipe $I V .^{28}$ Las Sagradas Escrituras servirán como parangón y consuelo: Si Cristo escogió doce discípulos, entre ellos, Pedro le negó tres veces, le dudó Tomás, le vendió Judas y todos le abandonaron en el momento de su crucifixión; por lo tanto, ¿qué clase de confianza merece un privado? Así lo señala Raimundo Lida [1958: 156]: “A la pregunta de cómo ha de ser el privado, Quevedo responde ahora simple y amargamente: Lo mejor es que el privado no sea."

\section{LA PRIVANZA Y EL PENSAMIENTO POLÍTICO DE QUEVEDO}

El planteamiento político que cristaliza en Cómo ha de ser el privado está glosado en otros libros del mismo autor. El polígrafo suele concebir su obra como un todo orgánico. Los asuntos, en el fondo, se verán vertidos en diferentes moldes de composición. La originalidad de las ideas no será tan relevante como la forma de expresarlas.

La preocupación de Quevedo por los tratados de regimine principium se inspira en su vivencia personal de las galanuras, intrigas y entresijos de la corte. Su visión particular de esta temática se disemina en sus versos y su prosa. La especulación sobre las cualidades que ha de poseer el perfecto valido es un leitmotiv del Discurso de privanzas, ${ }^{29}$ la Política de Dios y

\footnotetext{
${ }^{28}$ Véase la edición de Alfonso Rey [2005].

${ }^{29}$ Cfr. R. Lida [1958: 149-156]. Al respecto, Urrutia [1982: 181] señalaba la presencia de un texto hallado en una biblioteca italiana que coincide en gran medida con la comedia y
} 
gobierno de Cristo $^{30}$ e, incluso, del jocoso Discurso de todos los diablos. Quevedo, bajo diferentes vías compositivas, se ampara en modelos teológicos y conecta oblicuamente con el tacitismo.

La temática reaparece, esporádicamente, en algunos pasajes de Grandes anales, Lince de Italia, El chitón de las taravillas, Execración contra los judíos, Visita y anatomía de la cabeza del Cardenal Richelieu y la Relación en que se declaran las trazas de Francia. Aflora, incluso, en la obra poética del autor. Véase, por ejemplo, el romance Fiesta de toros, literal y alegórica (POC, 752), retrato halagüeño del quehacer burocrático del Conde-Duque de Olivares. La literatura, entonces, es un calidoscopio.

\subsection{DEFINICIÓN DEL PRIVADO}

Al inicio del Discurso de privanzas, el primer opúsculo político del autor, se define el valimiento como "un amor o afición, entre muchos sujetos, determinada a uno". ${ }^{31}$ Existen privanzas que responden a la

que estaba trabajando el Dr. Sarazeno, de la State University of New York: "Ignoro si pudiera ser otra versión del Discurso de las privanzas, del que como se sabe se conserva un manuscrito en la Biblioteca Comunal de Palermo."

${ }^{30}$ Según ya han notado M. Somers [1956: 261-268], R. Lida [1958: 149-156], J. Urrutia [1982: 176] y J.H. Elliot [1982: 234-238].

${ }^{31}$ Cfr. Eva María Díaz Martínez [2000: 197]. Esta obra fue en un principio considerada espuria, por haber sido incluida notablemente modificada por Valladares Sotomayor en el Semanario Erudito. Es un ensayo sobre los modos de gobernar, el primer asomo político de Quevedo. En Política de Dios encontrará un tono sermonario más efectivo. 
inclinación natural -la virtud o el vicio del monarca- y otras que, enmascaradas por la hipocresía, son endulcoradas por falsas adulaciones y lisonjas. Si bien estas últimas nunca pueden ser perdurables, las primeras sí. $^{32}$ La naturaleza, aunque sea viciosa, puede ser enmendada por el arrepentimiento.

En el Discurso de todos los diablos, Quevedo describe al privado como el filósofo, historiador, general o cónsul que goza de la confianza del rey. Emerge el paradigma por antonomasia, la sufrida privanza de Séneca para con el tirano Nerón, ante lo que Satanás hace mofa evidente:

\footnotetext{
¿Ahora sabes- dijo Satanás- que la privanza es tropezón, y todo príncipe zancadilla? ¿Que los tiranos lo aborrecen todo: a lo bueno porque no es malo y a lo malo porque no es peor?¿Qué privado han hecho que no le hayan precipitado? ¿Qué digo? Acuérdeseos de la emblema de la esponja: todos sois esponjas de los príncipes. Dejan os chupar hasta que estáis hinchados, y luego os exprimen y sacan zumo para sí. [2003: II, 514]
}

Séneca constituye el ejemplo de privado virtuoso del tirano. La privanza debe fundarse en su inclinación a la virtud, como demostró con acciones, vida y palabras el admirado filósofo latino. Como expresa Quevedo en la Política de Dios, si el rey ha de imitar a Cristo, el valido ha de seguir el modelo de San Juan Bautista.

\footnotetext{
${ }^{32}$ Quevedo las ejemplifica aludiendo a los validos de Nerón: "como se ve en los privados de Nerón, que así mató los malos como los buenos; estos no porque eran buenos, sino porque no convenían con su natural; y aquellos, aunque convenían con su natural, porque eran malos, que fue sólo en los que estuvo disculpada su crueldad." [2000: 197]
} 
En Cómo ha de ser el privado, como su propio título apostilla, Quevedo ofrece una definición del valido. Si la mayoría de comedias de privanza pretendían dilucidar este tema partiendo de modelos históricos cercanos, el enfoque es distinto en Quevedo, que defiende la figura de un valido virtuoso. $^{33}$

La comedia que nos ocupa inspira algunos de sus motivos en Los Guzmanes de Toral de Lope de Vega. ${ }^{34}$ Esta obra, bajo el subtítulo Cómo ha de usarse el bien y ha de prevenirse el mal, presenta el valimiento como un estado sometido a los cambios de la Fortuna, donde el "bien" equivale al favor del monarca y el "mal" a la caída. Ambas comedias están encaminadas a mostrar la concepción ideal del valido, el cual carece de antagonista explícito, al contrario de lo que era común en los dramas de privanza. $^{35}$

${ }^{33}$ Cfr. Urrutia [1982: 177]: "Frente a un subgénero que procura dilucidar el grave problema de la privanza que tanta importancia tiene en la España del siglo XVII, buscando generalmente modelos de comportamiento de la historia, Quevedo pretende defender la persona de un privado preciso, presentándolo como dechado de perfecciones."

${ }^{34}$ Así lo señala Urrutia [1982: 185]: Por ejemplo, la huella de Los Guzmanes de Toral, de Lope de Vega, se aprecia tanto en el momento de la elección del valido, como en la insistencia en la pobreza de sus trajes y de su aliento. Pero si el subgénero de la comedia de privanza suele ilustrar el tema de la ascensión y la caída, de la fortuna y la desgracia (como, por ejemplo, en No hay dicha ni desdicha hasta la muerte, de Mira de Amescua, o en Ganar amigos, de Ruiz de Alarcón), Quevedo prescinde del pasado de su personaje y, más que idealizarlo, parece querer negar acusaciones muy concretas que se le hacían al CondeDuque.

${ }^{35}$ Véase Teresa Ferrer Valls [2004: 15-30]. 
Al principio de Cómo ha de ser el privado el soberano solicita a sus allegados que le definan su ideal de perfecto valido. Uno destaca la vigilancia; otro, la fidelidad; y, el Marqués de Valisero, el desinterés. Éste ofrece la mejor definición, que le supondrá la asunción del puesto:

\author{
Virtudes son el cuidado \\ y la verdad del prudente: \\ pero yo fuera eminente \\ en ser desinteresado. (I, vv. 149-152)
}

Cuidado, verdad, prudencia y, ante todo, desinterés, son los principales ingredientes de la virtud para el privado. Esta tétrada de valores evitará su ociosidad, negligencia y corrupción.

\title{
3.2. LOS PELIGROS DEL VALIMIENTO
}

En el segundo capítulo del Discurso de privanzas, Quevedo se pregunta sobre la peligrosidad del valimiento. Apelando a la admonición bíblica "Maldito sea el hombre que se fía de otro"-, nuestro autor considera que el rey nunca debe fundar sus decisiones en su privado, dado que, de lo contrario, caería como la estatua de Nabuco, que tras tantos metales preciosos y resistentes en la cabeza y tronco, se desplomó en el suelo por los pies de barro. Ésa fue la virtud de Job: no achacar a Dios los motivos de su desgracia (el derrumbamiento de su casa, la hacienda quemada, la familia 
destruida), sino apelar a los desvaríos de la Fortuna y a su propia humanidad.

Quevedo cree que el fundamento de la privanza ha de ser la conciencia de la debilidad humana y de sus errores, la aceptación de que todo hombre es susceptible al engaño y la traición. Ilustró esta convicción con el ejemplo del "cardenal de Richeleu" "36, enfatizada en su Visita y anatomía. De su cabeza realiza un controvertido análisis médico para comprender por qué está "mordido de animal venenoso", dado que "escrito lo tienen en toda su persona los dientes de la envidia que le roe y masca las mismas entrañas". ${ }^{37}$ En el soneto Figurada contraposición de dos valimientos (POC, 228) y Parenética alegoría (POC, 230), de hecho, Quevedo avisa al "decimotercio rey", Luis XIII, sobre el peligro de confiar en su favorito:

¡Oh, muy cristiano rey!, en gloria tanta,

ya el azote de Dios tienes encima: mira que el Cardenal se te levanta, (vv. 12-14)

Richelieu se enfrentó a Olivares en 1635, fecha en la que estalló una guerra de manifiestos y panfletos entre ambos países. La Carta al serenísimo, muy alto, y muy poderoso Luis XIII, rey cristianísimo de Francia, fue un probable encargo del valido español a nuestro autor. La epístola alude a la misma traición potencial de Richelieu:

\footnotetext{
${ }^{36}$ Richeleu, en vez de Richelieu, es como Quevedo le llama, en consciente parodia del francés. De igual modo, dirá "Monsur" en su Visita y anotomía de la cabeza del cardenal Armando de Richeleu [2005: 317].

${ }^{37}$ Véase Quevedo [2005: 327].
} 
todos los vuestros [...] quisiesen asegurarse y asegurarnos de tan abominable traición contra vuestra corona y descendencia y sucesión, si Dios os la diere como él desea, o la de vuestra sangre, en aquellos príncipes a quien por ella perteneciere legítimamente. [2005: 300]

El cardenal francés, que "ha estudiado en los cartapacios de Lucifer", 38 es otro ejemplo más de la reflexión teórica sobre el privado que Quevedo deposita en el Discurso de privanzas. El monarca, en definitiva, jamás deberá confiar un alto cargo a quien tenga comportamientos de dudosa virtud. El valido habrá de tener un fondo puro, limpio de todo pecado.

\subsection{LA RELACIÓN CON EL MONARCA}

Dios tuvo un privado, Luzbel, que acabó traicionándole. Jesucristo, en cambio, contó con San Juan Bautista, que le estimuló y animó: así lo expresa Quevedo en el tercer capítulo del Discurso de privanzas. La misma consideración emergerá en la Política de Dios y gobierno de Cristo, donde don Francisco compara al monarca con el sol y al valido con la luna, satélite que se alimenta de la luz del poder:

Así han de ser el privado y el rey; que como la luna se esconde delante del Sol y tanto más luce con sus mismos rayos cuanto más se aparta dél, el privado ha de esconderse delante del príncipe, no ha de competir con él en luz. [1932: II, 1394]

${ }^{38}$ Quevedo [2005: 343]. 
La imagen tópica del soberano como sol que esparce su luz en su reino reincidirá al inicio de Cómo ha de ser el privado y en el Panegírico a la majestad del rey nuestro señor don Felipe IV, donde Quevedo le llama "sol clarísimo". ${ }^{39}$ También en la Política de Dios (II, 13), el autor contempla al monarca como "una estrella del cielo, que alumbra la tierra, norte de los súbditos, con cuya luz e influencia viven." 40

En el primer acto de Cómo ha de ser el privado, don Fernando de Nápoles es coronado rey. ${ }^{41}$ La identificación del monarca de la comedia con el soberano español (el personaje histórico real) se evidencia en el siguiente pasaje, donde Quevedo se permite hacer un somero juego lingüístico:

\author{
Cuando el pueblo te miró \\ debajo del palio entrar \\ entre tu pueblo a reinar, \\ tantas veces te aclamó \\ que, como son $\mathrm{F}$ y E \\ el principio de tu nombre, \\ no se oía en ningún hombre \\ sino Fe, todo era Fe. (I, vv. 29-36)
}

\footnotetext{
${ }^{39}$ Quevedo [2005: 483].

${ }^{40}$ Saavedra y Fajardo [1999: 294] en sus Empresas políticas denomina a los príncipes “los planetas de la tierra, las lunas en las cuales substituye sus rayos aquel divino Sol de justicia para el gobierno temporal”. Este tópico ya aparece en la Moralia de Plutarco: el monarca es similar a los dioses, cuyas imágenes quedan representadas en el sol y la luna.

41 Felipe III había fallecido el 31 de marzo y Felipe IV había sido proclamado monarca el 4 de mayo de 1621, cuando se alzó el pendón real en la Plaza Mayor, la Plaza de la Villa y el Convento de las Descalzas. Cfr. Lisón Tolosana [1991: 161].
} 
Además de constituir las primeras dos letras del nombre del rey, la cualidad emblemática de la monarquía es la fe.

Tres cortesanos dan su enhorabuena al soberano y reflexionan acerca del sobrenombre más adecuado para el mismo. Dudan entre Santo o Prudente, pero el rey escoge el de Justiciero.

Don Fernando alude a la ejecución de Rodrigo Calderón. Ésta ocurrió históricamente algunos meses después de la entronización del Felipe IV. Quevedo quebranta la fidelidad histórica para ofrecer dentro de su comedia un exemplo de las consecuencias nefastas del abuso de poder y la deslealtad al monarca.

A instancias del Conde-Duque, el Conde de Sartabal es agregado al despacho. Bajo el pretexto de la inscripción programada para la estatua del rey difunto (don Juan en la comedia) expone su concepción del valido:

\footnotetext{
Es un ministro de ley,

es un brazo, un instrumento

por donde pasa el aliento

a la voluntad del rey.

$[\ldots]$

Al ministro singular, aunque pueda aconsejar, no le toca decidir. (I, vv. 253-264)
}

La falta de don Juan había sido "haberse sujetado/ con extremo a su privado" (vv. 245-246). En esta primera escena, Quevedo pretende recordarle al monarca sus deberes. Sabía que el valido procuraría 
imponérsele. No obstante, en la segunda y la tercera parte se reiterarán el desinterés y filantropía de Valisero, el valido ejemplar.

Como expresa Violín, el gracioso de la comedia, el privado ha de asumir culpas poco gratas, es el chivo expiatorio que purgará todos los flancos problemáticos del país:

\author{
Si no hay pan, tiene el Valido \\ la culpa (abrásele un rayo) \\ porque no llovió por mayo, \\ porque por mayo ha llovido. \\ Si está sin tratos la tierra, \\ el Privado lo ha causado, \\ si hay paz es mandria el Privado, \\ es un violento si hay guerra. (I, vv. 369-376)
}

Con estos versos, Quevedo tal vez pretendía responder a los que acusaban a don Gaspar de manipular al joven rey casado. El valido deberá remitirse constantemente al monarca.

El privado, asimismo, asume como propias las faltas del rey. Valisero, ante un individuo que tacha al monarca de injusto, exige que las injurias se dirijan hacia su persona:

Es

vuesamerced atrevido;

diga de mí cuanto mal

quisiere y cualquier defecto,

pues hay tantos, y el respeto

a la persona Real 
debido no se le pierda,

que a no estar en este puesto

no me viera tan modesto. (III, vv. 345-352)

Por otra parte, al valido "aunque puede aconsejar,/ no le toca decidir." (I, vv. 263-264). Como dice Serafina al Rey:

\author{
El mismo Marqués me ha dicho \\ que a él no toca el despacho \\ de ningún negocio. (I, vv. 895-897)
}

Los privados han de escarmentar a los aduladores y advertir a los

monarcas de sus desórdenes internos. Por ello, el Marqués de Valisero disuade al monarca de su pasión ilícita hacia Serafina. Sin embargo, no habrá de extenderse más allá de lo que le permiten sus cargos. Tendrá que anteponer el favor a los méritos, y el trabajo a las negociaciones.

\title{
3.4. LA ENVIDIA, ENEMIGA DEL VALIDO
}

La envidia, primera peste del mundo, será el mayor peligro al que el privado deberá enfrentarse. Quevedo reflexiona sobre ella en Virtud militante y Las cuatro fantasmas del mundo, obra que dedicó a su amigo el inquisidor Pedro Pacheco. Don Francisco parafrasea a Pedro Crisólogo cuando la define como el más antiguo de todos los vicios y "vientre de los pecados": 
La invidia está flaca porque muerde, i no come: suzédela lo que al perro que rrabia. No ai cosa buena en que no hinque sus dientes i ninguna cosa buena la entra de los dientes adentro. No ai imbidioso que confiese que lo es i que no se quexe de que le invidian. No quiere ser lo que es, i quiere que los otros sean lo que no son. [1985: 78]

No obstante, si el privado es honesto, sólo atraerá hacia sí las envidias más mezquinas, porque la virtud siempre es deseable. El valido, como dice el capítulo IV del Discurso de privanzas, es un intermediario entre el monarca y el pueblo -como ya señalaba la poética metáfora de la luna-, hombre atlántico en cuya espalda reposa la voluntad del rey y el peso de la República.

Sobre si el valido ha de ser rico o pobre, Quevedo considera, al igual que Séneca en De vita beata, que la pobreza no es patrimonio exclusivo de los pordioseros:

la miseria del mendigo y del necesitado igualmente es del pobre y del rico: del pobre para sufrirla, del rico para remediarla [1932: II, 1395].

Por lo tanto, el privado ha de ser poderoso, porque en lo elevado también mora lo paupérrimo, al igual que Dios, como dice el salmo $(138,6)$, "estando en lo alto, mira lo humilde en el cielo y en la tierra".

Don Francisco distingue entre los aduladores y los amigos verdaderos. Los traidores son la principal amenaza de la monarquía. El peligro de los enemigos es que la mayor parte de las veces están encubiertos en la propia casa. El privado habrá de discernir entre los rivales públicos y los secretos. 
Quevedo, a su vez, hace una curiosa reflexión sobre cómo uno puede sacar provecho de sus enemigos, dado que hacen cuidadosos y cuerdos a los hombres, les incitan a ser mejores en las tensiones competitivas y son espejo de uno mismo. Induce a amar a los rivales, a sentir lástima por ellos y a no magnificar las tensiones.

En Cómo ha de ser el privado, don Francisco defiende los valores netamente estoicos, de "Séneca español" del valido. Este estoicismo es necesario para afrontar los inconvenientes que entraña el cargo: las "invidias y quejas" del "teatro del mundo".

\subsection{CONTRA LA TIRANÍA}

Quevedo contradice los postulados de El príncipe de Maquiavelo. Esta orientación le distanciaba un poco de Justo Lipsio, que en sus Políticas sostenía un maquiavelismo moderado. En el capítulo VIII del Discurso de privanzas, nuestro autor cree que al pueblo no debe quitársele la hacienda mediante ruines impuestos y vasallajes:

Así que, contra Maquiavelo, tenemos probado para nuestro intento que no ha de hacer un rey o privado cosa que escandalice al pueblo, ni le tenga temeroso, antes, como digo, ha de asegurarle y hacerse no señor, sino compañero de todos. [1932: II, 1404]

Como reza Cómo ha de ser el privado, la mayor virtud del valido es el desinterés y, su mayor peligro, las ambiciones desmedidas, análogas al 
destino del cohete, que después de los deslumbrantes fuegos artificiales cae de manera fulminante:

La privanza tiránica es semejante al cohete, pues resplandece como el sol al subir y, llegando al cielo, parece estrella, llévase tras si los ojos de todos. Lo mismo que le sube, que es la pólvora, eso le va disponiendo para que caiga escuro en humo y hecho ceniza. [1932: II, 1407-1408]

Y si don Francisco arremete contra la privanza tiránica, también desaprueba a los déspotas como Nerón o Calígula. Considera que el príncipe ejemplar, como Dios, puede ser a la vez temido y amado. Es loable en un monarca el desprecio de la ira y las crueldades: debería aprender de la abeja, que picando una sola vez muere. Un príncipe que abunda en arbitrariedades es tan reprehensible como el médico que procura muertes. Por ello, el privado ha de ser virtuoso y moderar al rey en sus excesos. 


\section{CÓMO HA DE SER EL PRIVADO: UNA PIEZA DESDRAMATIZADA}

\section{ESTATISMO TEATRAL}

La trama de Cómo ha de ser el privado es fácil de resumir, porque apenas domina la acción sobre el mensaje moral de la obra. Es una comedia muy poco lopesca, en este sentido: recordemos que el Fénix defendía en su Arte nиеvo las composiciones ricas en intrigas, tensiones, clímax y pasión, un dinamismo indispensable para la catarsis del espectador.

Tras cada personaje y lugar de esta comedia se reconoce un modelo. Nápoles representa Madrid. El rey Felipe IV es Fernando. La Infanta doña Margarita encarna a doña María, la ilustre hermana del monarca español. Ésta estuvo a punto de contraer matrimonio con el Príncipe de Gales, aspirante, en la comedia, al trono de Dinamarca. El enlace de boda queda, sin embargo, algo desfigurado por la rivalidad del Príncipe de Transilvania, que en la comedia representa al Rey de Hungría. Por lo demás, el Duque de Sartabal enmascara a don Baltasar de Zúñiga, tío del Conde-Duque. ${ }^{42}$ Olivares eclipsa a las demás figuras. Su presencia adquiere un protagonismo abrumador. Quevedo consigue fijar en éste la imagen neoestoica que el Conde-Duque anhelaba proyectar de sí mismo. ${ }^{43}$ Asimismo, en la comedia

\footnotetext{
${ }^{42}$ Como señala Armando Cotarelo [1945: 59].

${ }^{43}$ Como asegura Elliott [1982: 237; 1986: 281]. El crítico desarrolla, de hecho, el título "The New Spanish Seneca" para una sección de su estudio del Count-Duke.
} 
no aparece ningún personaje que represente a los infantes hermanos del rey, a quienes Olivares deseaba ningunear. ${ }^{44}$

Cómo ha de ser el privado desarrolla motivos poco aptos para las tablas: la glorificación de Olivares como ejemplo del valido perfecto, el matrimonio frustrado del príncipe de Gales y la Infanta Doña María ${ }^{45}$ y la fidelidad amorosa del monarca.

Quevedo no logra organizar una trama y provocar un conflicto para poner a prueba la valía del privado (¿es “un tipo absurdo por su inutilidad”? ¿sus cualidades reposan en la retórica y no en las acciones?). ${ }^{46}$ No elogiará al rey a través de la exaltación de una heroicidad. La comedia carecerá del suspense dramático a la manera lopesca. La virtud real residirá en su inmovilismo, la resistencia estoica ante la corrupción y el adulterio.

Sin embargo, el estatismo dramático, la ausencia de lances del acaso y reveses de la Fortuna y el enaltecimiento formulario de los poderosos (condiciones sine qua non de una comedia palaciega por encargo) no han de juzgarse peyorativamente. La paralización escénica puede inducir a la intensidad dramática y actúa como premisa de la alabanza del Estado y la represión erótica. Para no caer en el juicio anacrónico, se ha de contextualizar la irradiación del poder en los personajes y su proyección visual en el decorado palatino. ${ }^{47}$

${ }^{44}$ Hume [1907: 172-179; 183-186] y Elliott [185-186; 313; 317-318] escriben acerca de la amenaza política que Olivares notaba en Carlos y el cardenal infante.

${ }^{45}$ Son el príncipe de Dinamarca y Doña Margarita, respectivamente, en la comedia. Véase Eugenio Asensio [1965: 196].

${ }^{46}$ Cfr. Urrutia [1982: 181].

${ }^{47}$ Susana Hernández Araico [1999:461]. 
Entonces, ¿cómo calificar Cómo ha de ser el privado? ¿Se trata de una comedia mediocre, de mero interés historiográfico $?^{48}$ ¿Consiste en un simple ensalzamiento del valido? ${ }^{49}$ ¿Un trabajo “descaradamente propagandístico”? ${ }^{50}$ ¿Hay quizás una sutil crítica a la corte filípica en el asunto, dada la disparidad entre los elogios de la comedia y la situación político-social de la España del momento $?^{51}$

Cómo ha de ser el privado es un documento historiográfico valioso y significativo en el contexto político en el que se compuso. El autor de los Grandes Anales de Quince Días, con rigor de cronista, sacrifica la imaginación al servicio de lo visto y oído. Tiene un doble propósito: ético y político. ${ }^{52}$ Pero el teatro palatino de Quevedo también debe ser atendido

\footnotetext{
${ }^{48}$ Artigas [1932: 50-51].

${ }^{49}$ Manuel Urí [1998:13].

${ }^{50}$ Elliott [1982: 241].

51 Jauralde [1999: 586-587].
}

52 Aubrey Bell, en su reseña a la edición del Teatro inédito de Quevedo de Miguel Artigas [1927], no duda en negar el genio dramático de nuestro autor, cuyo mérito siempre relega a otros matices compositivos: "It is right that anything still in manuscript from the pen of a genius so various and extraordinary should be published. It cannot be said that Quevedo's genius was dramatic. It was forcible and and many-sided, but it was always momentarily one-sided and overbalanced. It might seem as impossible for him to write a really dramatic play for a fencer to be at once himself and his opponent." [1928: 208-209]. Comparten esta opinión sobre la inhabilidad de la pluma de Quevedo para el teatro serio otros autores como Cotarelo Valledor [1911: 98], Astrana Marín [1945: 360], Urrutia [1982: 174] y, por supuesto, Raimundo Lida [1958: 150]. Todos ellos refuerzan su opinión apelando a sus ataques satíricos a la farándula y carátula. Germán Vega [1993: 119], si bien no desmiente lo que achaca la crítica anterior, no duda en, al menos, realzar la relevancia del valor historiográfico de la comedia quevedesca: "la originalidad del planteamiento quevediano no 
como "monumento". Es una manifestación artística en su integridad, deudora de una tradición literaria.

El principal motivo por el que se ha menospreciado el teatro serio de Quevedo deriva de la falta de acción dramática. La teatralización del estatismo, sin embargo, no carece de intensidad y es la fórmula adecuada para reflejar el estrecho vínculo de Quevedo con el Estado y su defensa del estoicismo de la monarquía ante las posibles tentativas de corrupción.

La no acción, teñida de la filosofía neoestoica, también ha de tener su validez teatral y su impacto visual en el espectador. Nos hallamos ante escenas de contención más visuales que literarias, que debemos ubicar en el escenario palatino y la suntuosidad de su rico decorado. ${ }^{53}$

\section{ACCIONES DRAMÁTICAS TRUNCADAS}

Cómo ha de ser el privado se sustenta sobre tres acciones dramáticas fallidas. La acción principal es, como apostilla el título de la obra, la descripción del valido perfecto, que arranca desde el primer acto. Las dos acciones secundarias -el matrimonio de la Infanta y los devaneos amorosos del monarca- se resuelven desde el principio y abaten la expectación con su previsibilidad. Por encima del suspense, Quevedo atiende a una interpretación ética de la historia. La acción principal queda lastrada por el

se fragua en los criterios poéticos o dramáticos adoptados, sino en la intervención de factores extraliterarios".

${ }^{53}$ Susana Hernández Araico [1999:261] respalda el valor documental de Cómo ha de ser el privado sin, por ello, negar sus méritos literarios. 
peso y la gravedad doctrinal, más aptos para el género ensayístico que para las tablas. 54

Este planteamiento dramático supone un problema: el rey ha quedado relegado a un segundo plano en detrimento del consejero. ${ }^{55}$ Tal protagonismo desequilibrado pretende solucionarse a través de una definición atroz del privado como satélite del rey solar, parapeto de los errores de la corona:

\author{
no es otra cosa el Privado \\ que un sujeto, en quien la gente \\ culpe cualquier accidente \\ o suceso no acertado. (I, vv. 181-184)
}

La mayoría de la crítica tampoco cree acertado el motivo de las nupcias frustradas entre la Infanta María con el príncipe de Gales, las fiestas de boato cortesano en torno al "English Match". El valido, tras una reflexión sobre el marido perfecto, afirma que la Infanta sólo podrá contraer matrimonio con un católico, lo que implica desestimar al ficticio rey de Dinamarca. De este modo queda acallado el suspense dramático, desaparece la sorpresa y la intriga argumental. En esta trama de la comedia, Quevedo

\footnotetext{
${ }^{54}$ Raimundo Lida lo afirma con mayor rotundidad: "Teatro pasivo, de figuras de palo y de discursos igualmente inertes" [1958: 152]; al igual que Armando Cotarelo [1945: 65]:

"Dada su índole, ofrece poco interés dramático y acción floja y diluida."

${ }^{55}$ Urrutia [1982: 179].
} 
aborda con ortodoxia las diferencias religiosas que distanciaron a ambas monarquías. $^{56}$

El príncipe de Dinamarca aparece inesperadamente en la Corte española y se convierte en centro de deliciosas atenciones, vanas a la postre. Se describen los festejos celebrados a su llegada y su desairosa retirada. También se alude a la agresión de los daneses a Taranto ("que por la semejanza del terreno/ llaman el Cádiz de este mar Tirreno"), que enmascara la incursión de los ingleses al puerto andaluz en 1625. Quedan ofuscadas las esperanzas políticas de muchos. Retirado el pretendiente de Gales, el aparente embajador de Transilvania pide la mano de la Infanta, con previo consentimiento del rey.

En la trama argumental de las nupcias frustradas entre la Infanta y el Príncipe de Gales existe una teatralidad retórica, impactante en la imaginación del espectador. La venida del insigne sajón promovió los festejos más impresionantes del reinado de Felipe IV, más excelsos incluso que los de la propia boda de la Infanta. ${ }^{57}$

${ }^{56}$ Como señala Armando Cotarelo [1945:60], "hace notar Quevedo la nobleza y lealtad del Rey y del valido, que tropezaron, como es cierto, con la cuestión religiosa y con la poca franqueza del príncipe." Así lo ilustra el parlamento de Valisero (I, vv. 762 -804); la Infanta estará de acuerdo con las palabras del valido: "¿Yo tengo de ser esposa/ yo tengo de dar la mano/ a hombre de otra religión?/ Cierto, señor, que me espanto/ que tu Majestad lo escuche." (I, vv. 809- 813). Los versos citados concuerdan con la plegaria del monarca para que la solución de los conflictos matrimoniales sea ventajosa para la situación política del país (I, vv. 837-856).

57 Cfr. Susana Hernández Araico [1999: 466]: "La teatralidad retórica en torno a la entrada del príncipe de Gales y la visual, aunque mucho más modesta en torno al matrimonio de la 
A los ejes temáticos mentados, hemos de añadir el del galanteo y discreteo del rey con Serafina. ${ }^{58}$ Este furor debe ser moderado por la ratio, como ilustraba Séneca en los exempla de sus Tragedias ${ }^{59}$. El estatismo elogioso de la monarquía, impulsado por el comportamiento estoico de Olivares, tiene su proyección en el refreno erótico del rey.

La consigna interior del monarca -"Venzamos, razón, venzamos"invierte los parámetros del calderoniano "soñemos, alma, soñemos." ${ }^{60}$ Este motivo constituye un asunto teatral aparente, apocado y tímido, puesto que rápidamente el monarca se domina a sí mismo tras consultar al valido ("No hizo más Alejandro/ vencedor soy de mí mismo", vv. 1131-1132 ). ${ }^{61}$ Pero consideremos el impacto dramático de los dos sonetos amorosos contiguos

infanta con el heredero imperial, sin duda constituye una de las metas de impacto espectacular más logradas del texto de Quevedo.”

${ }^{58}$ Recordemos que, en la obra, tan sólo se alude a la Reina en una ocasión, definiéndola como "la flor más soberana". La flaqueza real de Cómo ha de ser el privado está documentada. A finales de los 1620, Felipe IV mantuvo una relación ilícita con la actriz apodada "la Calderona", de quien tuvo un hijo, seis meses antes del parto de Baltasar Carlos, en octubre de 1629. La Calderona se recluyó en un convento después del reconocimiento de su hijo, que más tarde sería celebrado como Juan José de Austria. Pero la alusión a Serafina también puede esconder otros referentes. Doña María Enríquez era una hermosísima dama de la reina Isabel de Borbón. Quevedo la admiraba por sus quehaceres literarios y políticos. En abril de 1622 le dedica el Sueño de la muerte. Se lo envía por carta, dado que esperaba su actuación para que se le cancelase el destierro.

${ }^{59}$ Cfr. Séneca [1997 y 1999].

${ }^{60}$ Como nota Raimundo Lida [1958: 152].

${ }^{61}$ Así opina Armando Cotarelo [1945: 65]. 
que se insertan en esta trama escénica, "o sea, una inmovilización de los personajes proyectada con tensión excepcional." ${ }^{62}$

\section{LA LÍRICA ENTREVISTA}

El rey consulta con su privado acerca de sus impulsos eróticos irracionales, y el valido propugna la represión de lo ilícito. Inmediatamente después, en una lírica entrevista, hallamos dos sonetos amorosos a la petrarquesca, donde el monarca y Serafina, en un tenso estatismo cargado de pasión (anulada por la conveniencia racional), no sólo establecen un acuerdo entre dos amantes defraudados.

El soneto no aparece como soliloquio destinado a la resolución de un problema, como formulaba Lope en su Arte nuevo de hacer comedias. En las dos composiciones consecutivas se alcanza un clímax dramático:

\footnotetext{
REY- Si viste verdes montes coronados

de guirnaldas, de nubes y de velos;

si viste las campanas de los cielos,

si viste las esferas de los prados,

y el mar verde y azul, con matizados

colores, de esperanza y de celos:

ya has visto por iguales paralelos

lo inmenso de mi amor, y mis cuidados.

Dirás que es corto amor, pues ha cabido

en breve corazón, que hermosa estrella
}

${ }^{62}$ Véase Susana Hernández Araico [1999: 461]. 
pulsando resplandores singulares,

un átomo de luz no ha parecido,

llega cerca y verás que una centella

es mayor que los montes y los mares. (III, vv. 808-821)

La indecisión del monarca queda reprimida en favor de una casta relación que en la comedia se denomina "amistad" y que la dama le ofrece en un soneto:

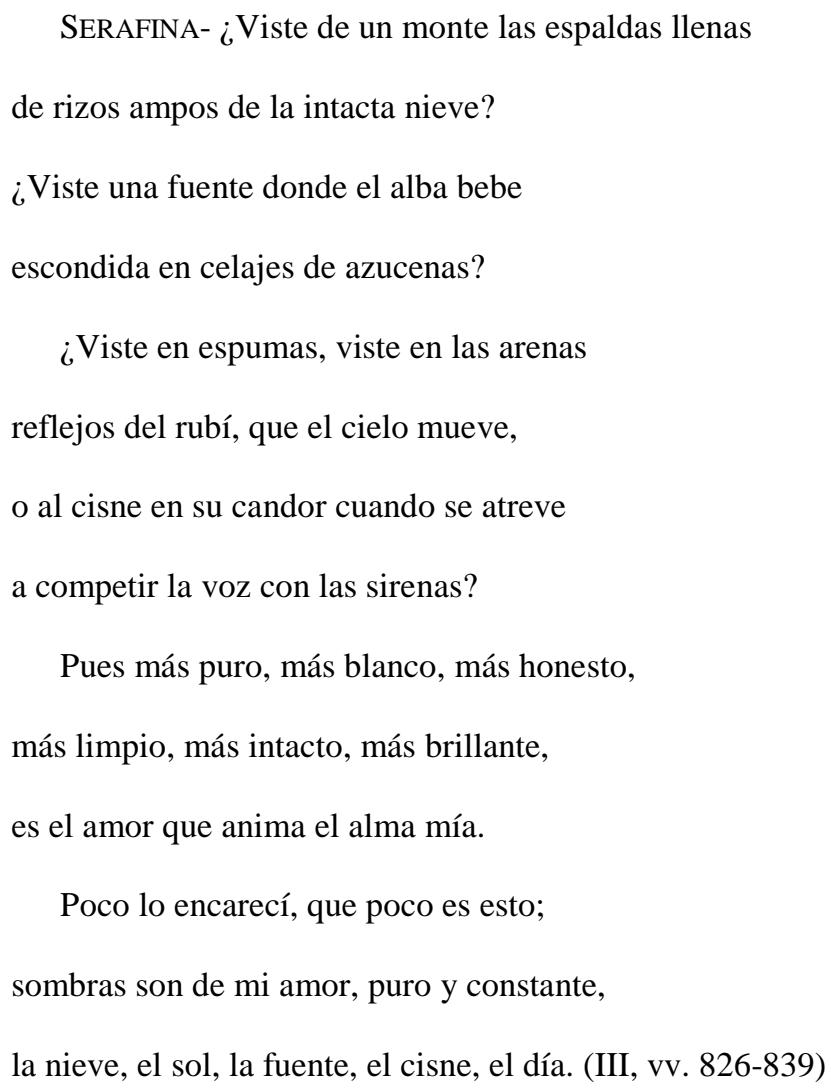

La represión amorosa se trasmuta en estatismo paisajista. El soneto de Serafina, a través de la nieve, la fuente, la espuma y arena, apaga el incendio del corazón del rey, el "átomo de luz". La acción se suspende en la mirada de los personajes, y su forzado quietismo exige un paladar más poético que dramático. Para la mayoría de la crítica, sin embargo, en esta trama 
argumental la emoción tampoco subyace, porque la renuncia del monarca ante la tentación ya queda avisada al principio:

\author{
Príncipe, la festejé; \\ Rey he de vencerme a mí; \\ no quiero que el galanteo \\ aumente la inclinación \\ la inclinación la afición, \\ y la afición al deseo. (I, vv. 484- 489)
}

La pasión reprimida es, en todo caso, una beneficiosa prevención de las murmuraciones y la deshonra, porque la dama aparece sin ninguna ubicación familiar en la comedia, sin la protección de su padre en la corte. Sin embargo, ¿podía el público estremecerse ante la contención del monarca frente al pecado?

\title{
4. NEOESTOICISMO
}

Cuando Quevedo se acerca al discurso moral, pierde fuerza dramática y capacidad figurativa. En este caso, asume una posición radicalmente distinta a la del escritor jocoso, de burlas y veras. El tono grave y escéptico de Cómo ha de ser el privado desenmascara su filiación a la doctrina neoestoica.

El 12 de noviembre de 1612 había enviado a Tomás Tamayo de Vargas, traductor de las obras filosóficas de Justo Lipsio, el Nombre, origen, intento, recomendación y descendencia de la doctrina estoica, que publicará en 
1635 con el Epicteto, el seudo-Phocílides y la Defensa de Epicuro. Don Francisco viste al Marqués de Valisero con las tesis estoicas que contienen estas obrillas. El valido perfecto es autosuficiente ante la adversidad y de ánimo imperturbable. Estos principios están emparentados con la valentía cristiana, que Quevedo considera derivados del libro sagrado de Job.

Los textos de Job encuentran su correlato en los del Manual de Epicteto y los de Séneca. Quevedo, al cristianizar a los clásicos del estoicismo, sigue los pasos de Justo Lipsio. En su Doctrina estoica, sin embargo, la exposición apasionada de esta manera de vivir no está exenta de pinceladas propias de su poesía:

vivir con el cuerpo, mas no para el cuerpo: contar por vida la buena, no la larga; no por muchos años, sino por inculpables. (...) Vivían para morir y como quien vive muriendo. Acordábanse del mucho tiempo en que no fueron; sabían que hacía poco tiempo que eran. Vían que era poco y para poco tiempo, y creían que cada hora era posible que no fuesen. No despreciaban la muerte, porque la tenían por el último bien de la naturaleza; no la temían porque la juzgaban descanso y forzosa. [1958: 973b]

Quevedo defiende el temperamento estoico contra las críticas de Plutarco, que lo tildaba de apático o insensible. Las mismas ideas aparecen plasmadas en su vertiente lírica en el Heráclito cristiano:

\footnotetext{
Nace el hombre sujeto a la Fortuna, y en naciendo comienza la jornada desde la tierna cuna a la tumba enlutada
} 
y las más veces suele un breve paso

distar aqueste oriente de su ocaso (POC, 21, vv. 11-16)

El aciago fallecimiento del hijo del valido en Cómo ha de ser el privado es un trasunto de la muerte de la Marquesa de Eliche, hija única de Olivares que murió en 1627. ¿Cómo debe reaccionar un padre ante la pérdida de su única descendencia? Marco Aurelio, en sus Meditaciones, expresaba:

\footnotetext{
"Al besar a tu hijo", decía Epicteto, "debes decirte: Mañana tal vez muera." "Eso es mal presagio". "Ningún mal presagio", contestó," sino la constatación de un hecho natural, o también es mal presagio haber segado las espigas." [1995:205].
}

Las catástrofes naturales no dependen del ánimo ni la voluntad del valido, sino que son lances de la Fortuna. El destino nefasto no le hace suspender sus quehaceres, sino que le reafirma en su depuración de las ambiciones.

La muerte es un horizonte existencial, reverso de la vida. El valido perfecto debe conocer su fin, para relativizar el papel que le ha tocado en el gran teatro del mundo. El que, por el contrario, atesore su cargo con soberbia, tarde o temprano habrá de escarmentar. ${ }^{63}$

El privado ideal, en resumen, es incorruptible. ¿Y qué habrá de hacer el valido frente a la rueda de la Fortuna? Quevedo, en el capítulo V del Discurso de privanzas, cita a Séneca: "Que la fortuna es como el vidrio, que

${ }^{63}$ Así lo insinúa Quevedo en La cuna y la sepultura: ¿¿Es tuya la voluntad de tu rey? Privado eres, a ti miran todos, de ti penden los negocios. ¿Dichoso te sueñas por eso?: pues despierta y mira cómo lo han pasado otros que en el mundo lo han sido. Habla con sus fines y verás que escarmientan y no incitan." [1951: II. 84ª] 
cuando más reluce, es más fácil de quebrar". El autor recomienda una prudencia estoica, que muy bien podría ampararse en el Enquiridion de Epicteto o en las Cartas a Lucilio de Séneca, el valido de Nerón. 


\section{COMEDIAS PERDIDAS E INCOMPLETAS}

\section{El autoplagio en Pero VÁzquez de ESCAMILLa ${ }^{64}$}

El segundo cuadro de la comedia inacabada Pero Vázquez de Escamilla está destinado a denunciar la moda culterana. En silva de consonantes ${ }^{65}$, Don Pedro, afectado galán, declama palabras de amor a Doña Ana, elocuente ejemplo de culta latiniparla. Hasta ahora, nadie ha notado que el inicio del parlamento del personaje es una variante de la canción quevedesca Llama a Aminta al campo en amoroso desafío (POC, 389), que también figuró en la Segunda parte de las flores de poetas ilustres de Juan Antonio Calderón [1611: 226 y ss.], si bien en versión distinta.

¿Quevedo reutilizó pasajes de su obra poética para su teatro? ¿O acaso fue al revés? Cotejamos la canción con el papel del galán de comedia. Subrayamos las variantes de ambos textos:

${ }^{64}$ Esta comedia incompleta atesora una jácara inicial que analizaremos, por afinidad, en el capítulo que dedicamos al teatro breve.

${ }^{65}$ Cfr. Jauralde Pou [1999: 238]: "En algunos manuscritos se llama "silva", pero son estancias de doce versos." Nosotros, no obstante, optamos por la designación tradicional que también consideramos válida. 
Pues quita Primavera al tiempo el ceño

y el verano risueño

restituye a la tierra sus colores,

y donde vimos nieve vemos flores,

y las plantas vestidas

gozan las verdes vidas,

dando, a la voz del pájaro pintado,

las ramas sombras y silencio el prado,

$\underline{\text { sal, doña Ana, que quiero }}$

que, viéndote primero,

agradezca sus flores este llano

más a tu blando pie que no al verano.

$\underline{\text { Sal, por verte, a el espejo de esta fuente: }}$

pues, suelta la corriente

del cautiverio líquido del frío,

perdiendo el nombre aumenta el suyo el río.

Las aguas que han pasado

verás por este prado

llorar no haber visto, con tristeza;

mas en las que mirares tu belleza

verás alegre risa

y cómo las dan prisa,

mormurando la suerte a las primeras,

por poderte gozar las venideras.

Si te detiene el sol ardiente y puro,

$\underline{\text { sal, }}$ que yo te aseguro

que, si te ofende, le has de vencer luego,

porque pelea con luz y tú con fuego;

mas si gustas de sombra,

en esta verde alfombra

una vid tiene un olmo muy espeso

(no sé si diga que abrazado o preso),

y a las sombras de sus ramas

les darán nuestras ramas,

ya les digan abrazos o prisiones,

invidia al olmo y a la vid pasiones.
Pues quita al año Primavera el ceño

y el verano risueño

restituye a la tierra sus colores

y en donde vimos nieve vemos flores,

y las plantas vestidas

gozan las verdes vidas,

dando, a la voz del pájaro pintado,

las ramas sombras y silencio el prado,

ven, Aminta, que quiero

que, viéndote primero,

agradezca sus flores este llano

más a tu blanco pie que no al verano.

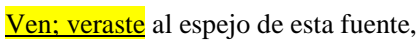

pues, suelta la corriente

del cautiverio líquido del frío,

perdiendo el nombre, aumenta el suyo al río.

Las aguas que han pasado

oirás por este prado

llorar no haberte visto, con tristeza;

mas en las que mirares tu belleza,

verás alegre risa,

y cómo las dan prisa,

murmurando su suerte a las primeras,

por poderte gozar las venideras.

Si te detiene el sol ardiente y puro,

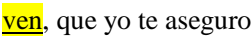

que, si te ofende, le has de vencer luego,

pues se vale él de luz y tú de fuego;

mas si gustas de sombra,

en esta verde alfombra

una vid tiene un olmo muy espeso

(no sé si diga que abrazado o preso)

y a sombra de sus ramas

le darán nuestras llamas,

ya los digan abrazos o prisiones,

invidia al olmo y a la vid pasiones. 
$\underline{\text { Sal, }}$ que te aguardan ya los ruiseñores,

$\mathrm{y}$ los tonos mejores,

porque los oigas tú, dulce tirana,

los dejan de cantar a la mañana.

Tendremos invidiosas

las tórtolas dichosas,

pues viéndonos de gloria y gusto ricos,

imitarán los labios con los picos.

Aprenderemos dellas

soledad y querellas,

y, en pago, aprenderán de nuestros lazos

su voz requiebros y su pluma abrazos.

¡Ay! Si vinieses ya, ¡qué tiernamente

a el ruido de esta fuente

gastáramos recíprocos acentos

en suspiros de amor y sentimientos!

$\underline{Y}$ tantos te diría

que los igualaría

a las rosas que viste en ese suelo

y a las estrellas que nos muestra el cielo.

$\underline{\text { Sal, y saldrá a porfía }}$

el día antes del día;

que bien puedes tener, bella tirana,

por aprendiz de luz a la mañana.

Halláraos aquí la blanca aurora

riendo, cuando llora:

la noche alegre, cuando en cielo y tierra

tantos ojos abrirá como en sí cierra.

$\underline{\text { Hurta el sol a tu ceño }}$

el ser del mundo dueño;

amanezcan los rayos a el abismo

y amanezcan tus ojos a el sol mismo;

que de producir flores

y de inventar colores,

$\underline{\text { si en esta soledad salieres antes, }}$

los abriles tendrás por platicantes.

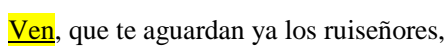

y los tonos mejores,

porque los oigas tú, dulce tirana,

los dejan de cantar a la mañana.

Tendremos invidiosas

las tórtolas mimosas

pues, viéndonos de gloria y gusto ricos,

imitarán los labios con los picos:

aprenderemos dellas

soledad y querellas,

y, en pago, aprenderán de nuestros lazos

su voz requiebros y su pluma abrazos.

¡Ay, si llegases ya, qué tiernamente,

al ruido de esta fuente,

gastáramos las horas y los vientos,

en suspiros y músicos acentos!

$\underline{\text { Tu aliento bebería }}$

$\underline{\text { en ardiente porfía }}$

que igualase las flores de este suelo

y las estrellas con que alumbra el cielo,

y sellaría en tus ojos,

soberbios despojos,

y en tus mejillas sin igual, tan bellas,

$\underline{\text { sin prado, flores, y sin cielo, estrellas. }}$

Halláranos aquí la blanca Aurora

riendo, cuando llora;

la noche, alegres, cuando en cielo y tierra

tantos ojos nos abre como cierra.

Fuéramos cada instante

nueva amada y amante:

y ansí tendría en firmeza tan crecida

la muerte estorbo y suspensión la vida;

y vieran nuestras bocas,

en ramos de estas rocas,

ya las aves consortes, ya las viudas,

más elocuentes ser cuando más mudas. 
Además de los versos finales completamente distintos, la mayor diferencia entre ambos textos es el nombre de las amadas: Ana, de la pieza teatral, frente a Aminta de la canción. Acerca de este último pseudónimo amoroso femenino, señala Jauralde que es posible vincularlo a la etapa siciliana de Quevedo (entre 1613 y 1616):

Cercanos a su estancia siciliana situaría a todos los poemas en los que se nombra a Aminta como amada, lo que ya ocurría en algunas de las silvas recogidas por Calderón de 1611. El recuerdo de Aminta permanece en alguno de los poemas autógrafos del manuscrito de Nápoles, incluso en algunos que ya se habían publicado en aquella antología, que Quevedo sigue retocando durante estos años. [1999: 331]

Aminta aparece como musa poética en los poemas 305, 306, 308, 312, 343, 383, 389, 393, 399, 400, 404 y 414 (POC). Tal vez Quevedo, teniendo el esbozo de su obra teatral no terminada, quiso al menos reaprovechar alguno de los fragmentos del borrador de la comedia, que publicó en la Segunda parte de las Flores ilustres, en 1611. Ello nos permitiría fechar la comedia incompleta Pero Vázquez de Escamilla como anterior a 1611. Esta fecha coincide con la que, según Jauralde [1999: 490], sería la primera fase dramática de Quevedo, entre 1606 y 1613, cuando escribe sus primeras jácaras y entremeses, "probablemente algunos de los que están en prosa y muestran cierta cercanía al tema y estilo con el Buscón y los primeros Sueños."

$\mathrm{Si}$, por el contrario, el poema fuera anterior a su reaprovechamiento en la pieza teatral, Quevedo acudiría al mismo recurso que le invita a reutilizar alguno de sus bailes más célebres en sus entremeses. Pero Vázquez de 
Escamilla sería, por lo tanto, una comedia posterior a 1611, fecha que la aproxima a Cómo ha de ser el privado (1628) y a la madurez de su obra dramática, segundo periodo teatral que Jauralde [1999: 490] fecha entre 1623 y 1628.

Tal vez sea más coherente pensar en la segunda hipótesis, con la finalidad de aproximar Pero Vázquez de Quevedo al resto de sus comedias conocidas. Quizá el autor, ante la premura de un encargo palatino, se vio obligado a incluir uno de sus poemas más célebres que, por aquel entonces, ya circulaba impreso.

\section{UN BREVE FRAGMENTO DE COMEDIA}

En el ms. 108 figuran once redondillas de una escena de comedia anotada en el reverso de una carta. Aureliano Fernández Guerra, a través del Catálogo de Barrera y Leirado [1860] las califica de "preciosísimas redondillas, ricas en sal ática y rebosando en conocimiento del corazón humano". El insuficiente fragmento del que disponemos nos presenta a don Juan y el recién casado don Rodrigo, que entablan un diálogo acerca de los riesgos que comportan las nupcias.

Como señala Armando Cotarelo [1945: 69]: "Posiblemente la comedia tiraría contra el matrimonio." La temática del hastío del casado es recurrente en nuestro autor. El miedo a la boda es el hilo conductor del entremés del Marido Pantasma y de las discrepancias vitales entre Gorrión y su amo Jacinto en la comedia atribuida El galán fantasma. 


\title{
3. LA RECONSTRUCCIÓN DE QUIEN MÁS MIENTE, MEDRA MÁS
}

\subsection{UNA NUEVA HIPÓTESIS}

Se tiene noticia, por las Relaciones de Pellicer, de dos comedias perdidas de Quevedo. De la de 1625 no sabemos ni el título. De la representada en 1631, Quien más miente, medra más, sospechamos que fue tal vez reelaborada en Los empeños del mentir de Antonio Hurtado de Mendoza. ${ }^{66}$ Lope de Vega aportaba los siguientes datos sobre esta comedia en La noche de San Juan (1631), que fue representada el mismo día:

\author{
Una comedia, en que ha escrito \\ don Francisco de Quevedo \\ los dos actos, que serán \\ el primero y el tercero, \\ porque el segundo, que abraza
}

\footnotetext{
${ }^{66}$ Así lo supusieron Ticknor en su Historia de la literatura y Mesonero Romanos en su edición de Dramáticos contemporáneos a Lope. Armando Cotarelo [1945: 58] plantea su desacuerdo al respecto: "No lo parece, por no guardar semejanza con el estilo quevedesco, por expresarse en ella corresponder a un autor solo, por tener alusiones a sucesos ocurridos en 1633 y 1634 (batalla de Nordlingen) y por no haberse, acaso, puesto en escena hasta 1637." Davies [1971:275], experto en la vida y obra de Hurtado de Mendoza, considera que Los empeños del mentir y Quien más miente, medra más son obras distintas, pese a que hayan tratado temas comunes y reelaborado las mismas fuentes. Acerca de la autoría, sostiene Doménech [2002:57] que la construcción ejemplar de la comedia Los empeños del mentir induce a pensar que si, efectivamente, fue obra de dos ingenios, probablemente tenían la idea muy madurada para conseguir el perfecto engranaje de la comedia.
} 


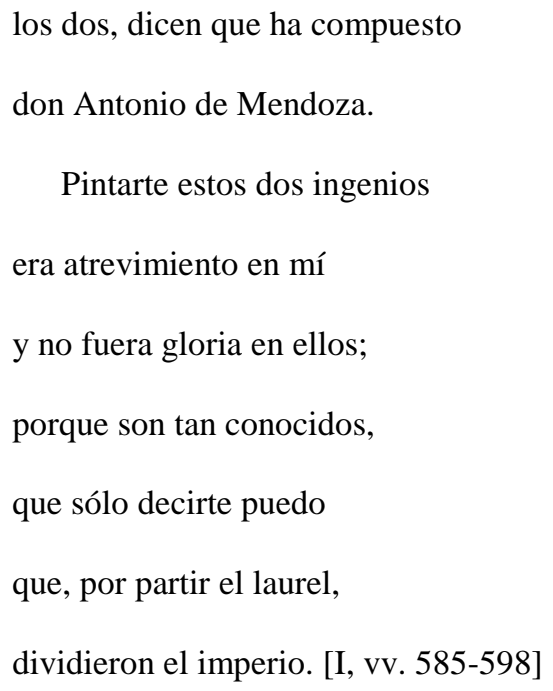

Curiosamente, la crítica apenas ha relacionado la comedia perdida con la Loa para la comedia "Más medra quien miente más" que se hizo en el Buen retiro, el día de San Pedro de 1634, únicamente atribuida a Hurtado de Mendoza, que nos induce a creer que la obra fue representada de nuevo, tal vez reversionada por éste, en 1634.

El lugar de representación de la loa citada parece coincidir con lo que se induce del tercer acto de Los empeños del mentir: ¿la comedia se escribió para una representación en el Palacio del Buen Retiro para conmemorar la victoria de Nordlingen del 5 y 6 de septiembre de 1634? El siguiente pasaje metateatral del inicio de la comedia puede ayudarnos la reconstruir la historia:

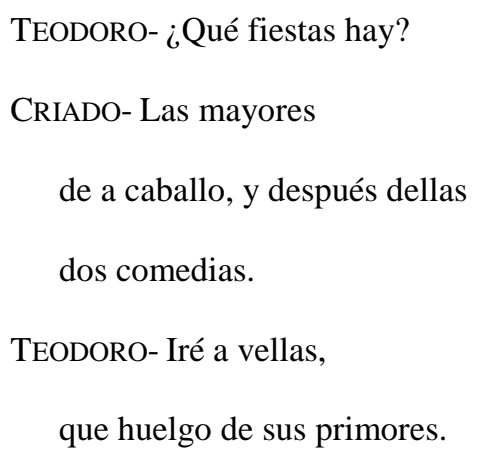




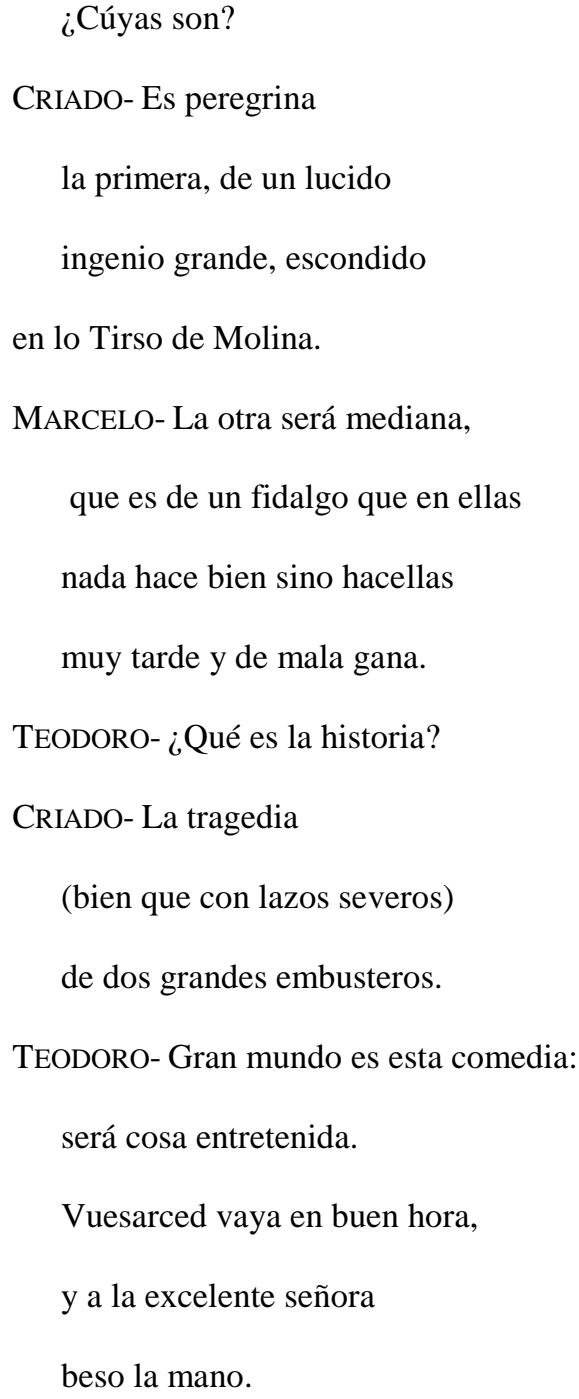

Esta segunda comedia escrita por un hidalgo alude a Los empeños del mentir, cuyo asunto es el que se describe: "la tragedia [...] de dos grandes embusteros". Observamos una sustitución del Lope de Vega de 1631 por un Tirso de Molina de 1634.

Probablemente Hurtado de Mendoza arregló Quien más miente, medra más en ocasión de las fiestas del Buen Retiro de 1634, sin la colaboración de Quevedo, y lo hizo tan apresuradamente que en Los empeños del mentir quedan rastros de la obra anterior, pistas para reconstruir la comedia perdida que nos interesa. 
La incoherencia textual clave es la continua alusión a un bandolero catalán: Quien más miente, medra más debió de ser una relación de bandoleros, subgénero de gran actualidad en 1631 y patente en obras como El rufián dichoso, de Cervantes. ${ }^{67}$

\subsection{LA ESTÉTICA DE LA MENTIRA}

En 1652 se publicó en Madrid Los empeños del mentir, "Comedia famosa de Hurtado de Mendoza", en la Flor de las mejores doce comedias de los mayores ingenios de España (f.43r-84r). El motor de dicha comedia, muy quevedesco, es el tema del embuste, que aflora en el soneto Valimiento de la mentira (POC, 579):

\footnotetext{
Mal oficio es mentir, pero abrigado; eso tiene de sastre la mentira, que viste al que la dice; y aún si aspira a puesto el mentiroso, es bien premiado.

Pues la verdad amarga, tal bocado mi boca escupa con enojo y ira; y ayuno, el verdadero, que suspira, invidie mi pellejo bien curado.

Yo trocaré mentiras a dineros, que las mentiras ya quebrantan peñas;
}

${ }^{67}$ Sobre estas pesquisas, Doménech [2002] se atreve a reconstruir la obra, focalizándola en la relación del bandolero. 


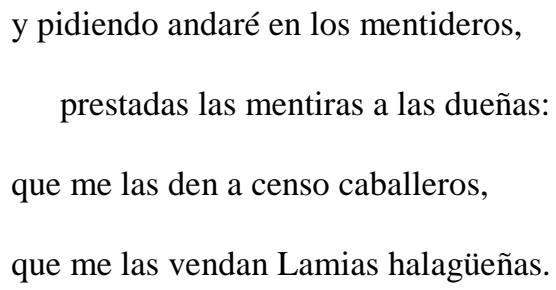

Este tópico universal fomenta la anagnórisis cómica en la escena. La treta de suplantación de personalidades ya está presente en el Anfitrión, el Pseudolus y el Mercator de Plauto, obras que Quevedo conocía bien. Como en el Tartuffe de Molière, Eros desvela el misterio de la personalidad del personaje. En El astrólogo fingido de Calderón y su respectiva adaptación de Corneille, vemos la misma propuesta cercana a la mentira metateatral, asunto que, en dimensiones más reducidas, se entrevé en entremeses como La Polilla de Madrid o Los refranes del viejo celoso. Igualmente, encontramos afinidades con La verdad sospechosa de Ruiz de Alarcón, en donde existe una reflexión implícita sobre la complejidad de la mentira.

El espacio urbano, Madrid, actúa como epítome de todas las ciudades, por encima de Menfis y Babilona. ${ }^{68}$ El procedimiento comparativo nos recuerda al mecanismo apologético de La España defendida de Quevedo.

En la primera escena, los pícaros Marcelo y Teodoro, bajo la intención de medrar, expresan su deseo de tomar un oficio "entre noble y mecánico", el de embusteros mejor que el de escuderos: ambos vocablos, a pesar de la

${ }^{68}$ Cree Doménech [2002: 69-70] que en Quien más miente, medra más "la descripción inicial de Madrid era mucho más breve que la que aparece en Los empeños, y que faltaba toda la descripción del Buen Retiro, si bien es posible que estuviera en su lugar una descripción del Prado". 
proximidad fonética, distan en sus significados, separan al humilde hombre de bien del pícaro antihéroe (vv. 72-75).

La primera táctica para ascender socialmente es la mentira: sustituyen sus botas por unas espuelas para fingir que poseen un caballo. Teodoro propone a Marcelo un contrato teatral: "jurarás cuantas cosas yo mintiere" (v. 90). Ante lo que éste acepta: "haré verdad las cosas que tú sueñas/ y mentiré por señas" (vv. 95-96).

Los antihéroes, a continuación, presencian una disputa entre tres rufianes que atacan a un solo hombre, don Diego. La caracterización del personaje, montañés, hidalgo, criado en Madrid y aficionado al naipe, no deja de resultarnos digna de jácara quevedesca.

Don Diego, conforme a los patrones de la comedia de enredo, es hermano de una bella mujer casadera que espera paciente a su prometido italiano. Entonces surge la siguiente treta, asimilación metateatral de una segunda identidad: Marcelo suplanta a don Luis de Vivero, futuro esposo de doña Elvira de Guzmán. La dinámica de la mentira se acelera: Marcelo, tildado en la obra de protoembustero, inventa nuevos episodios y Teodoro complementa los embustes. En los apartes, el espectador comprende la confabulación de ambos. No obstante, la grosería y torpeza de Marcelo desencantan a la dama.

En el segundo acto, encontramos otro grado de mentira: Teodoro, loco de amor, sustituye a Marcelo en su interpretación de Luis de Vivero. La mentira posibilita el tópico del mundo al revés, el trueque de amos y criados, mecanismo que, por ejemplo, también aparece en Donde hay agravios no hay celos, de Rojas Zorrilla. Al final del acto, Teodoro alude al 
lema de la obra perdida: "que tú agora medres más,/ si yo no sé mentir menos" (vv. 754-755). Sobre el embuste se introduce la siguiente reflexión existencial:

\author{
Embusteros de sí mismos \\ son todos, moral me vuelvo. \\ ¿Qué no engaña aún en nosotros \\ dentro de nosotros mesmos? \\ ¿Quién no se miente a sí mismo \\ sangre, discreción y esfuerzo? \\ Y, ¿qué es mentir a los otros, \\ si yo a mí propio me miento? (vv. 772-776).
}

La mecánica de la mentira va in crescendo: no cesa cuando Elvira descubre que tampoco Teodoro es su futuro marido. Entonces, se improvisa otro ardid: Marcelo, siguiendo las pautas de la commedia dell'arte, se hace pasar por el Conde Fabio de Bitoldo. Pretende doblegar la avaricia de Elvira y de Teresa, su criada, a través de la ostentación de nobleza y dinero.

En la lógica anagnórisis final, aparece el verdadero don Luis, al que encarcelan los pícaros acusándole de bandolero. Pero la firmeza de la verdad del italiano ayuda a que los descubran. Sin embargo, éste los perdona y parten los dos hacia Flandes para incorporarse al ejército.

Los empeños del mentir, en definitiva, se caracteriza por la hibridación de pícaros personajes entremesiles y afamados nobles de porte cortesano. ${ }^{69}$ Por

${ }^{69}$ Fernando Doménech [2002: 60] se pregunta "cómo vería la Corte una comedia en donde los bobos dignos de ser engañados son una familia que se llama Guzmán, como el CondeDuque, aunque no es improbable que la alta nobleza la viese como una sátira de los 
los temas y expresiones quevedescos de la comedia, la hipótesis de Doménech puede ser válida: Los empeños del mentir del "Discreto de Palacio" podría ser una reelaboración de la comedia perdida Quien más miente, medra más (1631), de la que Quevedo escribió dos actos. Así lo corrobora la existencia de una Loa para la comedia "Más medra quien miente más" de Antonio Hurtado de Mendoza, representada en el Buen Retiro en 1634, año que, precisamente, coincide con el que conjetura Davies para la interpretación de Los empeños del mentir, con motivo de la celebración de la batalla de Nordlingen.

hidalguillos que merodeaban alrededor de los grandes recordándoles continuamente su apellido". 


\section{COMEDIAS INÉDITAS ATRIBUIDAS A QUEVEDO}

\section{LA PRIVANZA DESLEAL Y VOLUNTAD POR LA FAMA}

\subsection{AlgunOS DATOS Bibliográficos}

La correcta catalogación de una biblioteca repercute indudablemente en el estudio de sus documentos. El investigador, si no tiene acceso a buenos repertorios actualizados, ha de resolver enigmas bibliográficos incurriendo en una suerte de "arqueología" de los catálogos.

Tal ha sido la labor de Germán Vega, que en 1993 resolvió el misterioso vacío de la Privanza desleal y voluntad por la fama, una obra dramática atribuida a Quevedo que se reputaba por perdida.

A fechas de hoy, la comedia no aparece todavía en los ficheros de la BNE, que en 1863 adquirió los fondos bibliográficos de Agustín Durán. Éste había sido director de la célebre biblioteca estatal entre 1854 y $1861 .^{70}$ Entre sus aportaciones personales a la institución, figuraba este único ejemplar impreso de la obra.

Antes de que la BNE heredara esta publicación del siglo XVII, Aureliano Fernández Guerra había aludido en el Catálogo de la Barrera [1860] a la Privanza desleal con las siguientes referencias a sus antiguos propietarios:

\footnotetext{
${ }^{70}$ Sabemos, sin embargo, que actualmente hay un equipo en la BNE solventando estas lagunas de catalogación. Aguardamos que cuando el lector lea estas páginas, la signatura de La privanza desleal ya sea la definitiva.
} 
Citada anónima en el índice de Fajardo. Con referencia al de la colección que fue del Conde de Saceda, se atribuye a Quevedo en el catálogo del señor Durán, quien añade por nota: "Es parte de un libro que no conozco", refiriéndose al ejemplar impreso que posee. [1860: 309].

Estos datos, como decíamos, no han sido revisados hasta 1993. Incluso J. M. Blecua [1981], el mejor editor del teatro de Quevedo, en la introducción del volumen IV de la Obra poética, cita la comedia en la casilla 35 de su listado bibliográfico, pero no añade ni modifica los datos del Catálogo.

Fue Germán Vega el que en su artículo "La privanza desleal y voluntad por la fama: el encuentro, al fin, con una comedia perdida atribuida a Francisco de Quevedo", publicado en Manuscrt. cao V (1993), dio con la obra perdida consultando los repertorios bibliográficos de la $\mathrm{BNE},{ }^{71}$ bajo la guía de los índices citados por Fernández Guerra.

El índice de Fajardo asigna el título de nuestra obra a una comedia anónima que posee "el librero de la Red de San Luis, Moreno". ${ }^{72}$ Germán Vega da con otra mención entre las existencias de los Herederos de Medel del Castillo en $1735^{73}$, aunque no lo especifique don Aureliano. La fuente principal de éste se halla en el ms. 21.423/1: “Anón[imo]. Quevedo (D. Fran[cis]co de)", f. 95v, donde aparece la citada colección del duque de Saceda. ${ }^{74}$

\footnotetext{
${ }^{71}$ Cfr. M. Sánchez Mariana [1989: 233-258].

${ }^{72}$ BNE, ms. 14.706. Títulos de todas las comedias que en verso español y portugués se han impreso hasta el año de 1716. Madrid, 1717, f. 43r.

${ }^{73}$ Cfr. la edición de J.M.Hill [1929: 144-369].

${ }^{74}$ Señala, al respecto, Germán Vega [1993: 111]: “La primera palabra lleva una “o” encima y la segunda "Saceda". Se trata de claves, cuyo significado se desvela en un doble folio
} 
Se puede complementar la información bibliográfica consultando el ms. 14.690, Catálogo de las comedias impresas en $4^{\circ}$ sueltas anteriores a 1750 que existen en la biblioteca de Don Agustín Durán. ${ }^{75}$ Recuérdese, no obstante, que la comedia impresa no aparece en el inventario de $1865 .^{76}$

Germán Vega, sin embargo, no facilitaba en su artículo la signatura del impreso. Sólo especificaba que éste se hallaba en "cajas sin catalogar" de la BNE. Tuve que moverme para conseguirlo. En verdad, estaba en sus manos que yo pudiera acceder a esta información. Le escribí un correo electrónico, que él respondió muy amablemente el 3 de abril de 2006:

no debe de estar aún registrado en su catálogo público, aunque sí que tiene signatura, porque fueron dándolas cuando yo trabajé con ese fondo sin catalogar. He mirado en el listado que hice entonces para ver si me daba una pista de la que puede tener hoy. Casi con toda seguridad es T-55293-21. Pídela y dime si es así.

inserto al comienzo del manuscrito con este encabezamiento: "cualquier título o Autor que tenga uno de estos signos... es equivalente a decir que el libro o documento a que corresponde el signo se ha tomado la noticia que ahí consta". Según esto, "o" correspondería al Índice de Fajardo y "Saceda" al "Yndice [manuscrito] de la Colección del Conde de Saceda". Completa la noticia: "S[uel]ta es parte de un libro que no conozco".

${ }^{75}$ La comedia concuerda con la alusión de Fernández-Guerra en el catálogo. Aparece, como descubre Germán Vega [1993: 112], “calificada como de "Ideas” y encabezada con la fórmula: "Anónima $=$ se dice de Quevedo $\left(D\right.$. Fran $\left.{ }^{\mathrm{co}}\right)$. Cierran la escueta noticia los datos del impreso que posee el coleccionista: "Sin A[ño] ni L[ugar]= Edi[ció]n del 17 de un L $\{\mathrm{i}] \mathrm{b}[\mathrm{r}] \mathrm{o}$ q[ue] no conozco".”

76 “Inventario de la librería que fue del excelentísimo Señor don Agustín Durán comprada por el Gobierno de S.M. con destino a la Biblioteca Nacional en virtud del real orden fecha en 27 de junio de 1863”, en Memoria remitida al Excmo. Sr. Ministro de Fomento (1865), pp. $30-114$. 
Y así era. Le agradecí profundamente su ayuda. Al cabo de unos días viajé a Madrid, y pude leer y transcribir el enigmático impreso.

\subsection{EXTRAVAGANCIAS ARGUMENTALES}

Tras las pesquisas bibliográficas, sin embargo, llega la lectura desconcertante del impreso que explicaría, quizá, las omisiones de Durán y Fernández Guerra. La privanza desleal apenas guarda relación con las obras dramáticas de Quevedo que aparecen en el ms. 108 de la BMP de Santander.

La comedia está dividida en tres actos, término que también designa los tres tramos que dividen Cómo ha de ser el privado. Como obra palaciega, su representación está destinada a círculos restringidos. Está ubicada en un espacio y un tiempo lejanos, sus dramatis personae son arquetipos de alto rango nobiliario y, a su vez, se caracteriza por ser profusa en alusiones mitológicas, bíblicas e históricas, aunque de poca gravedad filológica y menguado ingenio intelectivo.

Parece compuesta con cierta presteza, hecho que apunta a su probable escritura por encargo, pese a que esta vez, a la inversa de las comedias perdidas de 1625 y 1631, parece fruto de una sola pluma. Esa premura podría explicar las notables deficiencias dramáticas que incurren en la comedia, el tono bajo y poco decoroso para personajes elevados, que se desgranan en diálogos y monólogos inconsistentes.

Pese a que se ensarta en la cadena subgenérica de la privanza, la obra incide en extravagancias varias que la distancian de lo canónico. El privado 
sigue un esquema argumental poco común: después de su caída como valido, es ascendido nuevamente, esta vez como rey. La idea del monarca tirano sólo puede tener en la imaginería de Quevedo cierto parangón con el ejemplo clásico del arbitrario Nerón, que condenó a muerte a su sabio valido, Séneca.

El abatimiento del privado se debe a la enajenación amorosa, no a la envidia y ambición de otros nobles antagonistas. Si el Marqués de Valisero de Cómo ha de ser el privado atemperaba la inclinación del monarca hacia una relación extraconyugal, el conde Albano es una suerte de Lancelot enamorado de su reina Ginebra. ${ }^{77}$

\section{3. ¿UNA COMEDIA PALATINA DE ENREDO?}

El antiguo reino de Lidia enmarca la acción principal de La privanza desleal, apenas pautada por acontecimientos militares y políticos. La

\footnotetext{
${ }^{77}$ Según nota Germán Vega [1993: 119]: “Así, el esquema ascenso-caída-ascenso que nuestra comedia traza no se plantea en ninguna de las piezas pertenecientes al ciclo que conozco. También suponen un llamativo boquete de fuga del cerco genérico los factores que impulsan el abatimiento del protagonista, que, como ya apunté, no son la envidia ni la ambición, sino el amor y la enajenación. Sin embargo, desde el punto de vista de la privanza, son aún mayores las diferencias que tiene con la única comedia conocida y aceptada de Quevedo. Los dos pilares de ésta -el ensalzamiento de un privado concreto y la doctrina política- para nada se dejan ver en los niveles comprensibles de nuestro drama, sin recurrir a arcanos sentidos, cuya clase no consigo entrever."
} 
privanza tan sólo actúa como telón de fondo de una múltiple y desconcertante madeja de triángulos amorosos.

Se concatenan los tópicos petrarquistas y las pasiones paralelas. Esta composición teatral constituye un híbrido entre el drama del valimiento y la comedia de enredo. Cupido ha penetrado en la corte de Lidia y ha convertido la obra dramática en una colmena de nobles enajenados por el amor.

Si esta obra fuera efectivamente de Quevedo, ¿cómo la fecharíamos? Sabemos que don Francisco leyó el Tratatto dell'Amore humano del italiano Flaminio Nobili ${ }^{78}$ hacia 1634 . Durante esos años, empieza a madurar su cancionero a Lisi, que contiene ese famoso soneto, Amor constante más allá de la muerte (Dámaso Alonso lo calificó como el más bello soneto de la literatura española). Nada comparable, por cierto, a los versos amorosos de esta comedia que, para Germán Vega, podría ser anterior a 1625.

El nudo principal de la trama de relaciones es el protagonizado por el Conde Albano que, ensalzado al inicio de la obra como favorito del rey, será durante los dos primeros actos víctima de una atronadora caída, que no tendrá relación con los comunes desmanes de la Fortuna.

La envidia de los cortesanos tan sólo surge en la escena inicial y queda en murmuraciones y críticas sin peso dramático. Tampoco su ambición de ascenso -a pesar de que se lo reproche Lisandro al inicio de la comedia- es un móvil de la deslealtad y el declive, signos únicamente ocasionados por su pasión hacia la Reina Cleonarda, esposa de Minandro.

\footnotetext{
${ }^{78}$ Se trata del ms. add. 12108 de la British Library.
} 
El monarca descubre la infidelidad al final del segundo acto. El Conde Albano se libra de la condena de muerte huyendo de prisión y recluyéndose en la vida pastoril. Una guerra desatada le permitirá penetrar de nuevo en el mundo cortesano a través de las armas. Tras los desatinos tiránicos de Minandro y el rapto de la Reina Cleonarda, tomará protagonismo en la victoria final. Finalmente, tras la muerte del monarca, Albano desposará a Cleonarda y accederá a la corona del reino de Lidia.

Los amores del resto de nobles constituirán la trama subsidiaria, urdimbre de enamoramientos correspondidos o desafortunados. El caballero Rosicleo, de entrada frívolo ante los sentimentalismos, será el más solicitado al comienzo de la obra y recobrará paulatinamente la esperanza en el amor. Doblemente reclamado por Anarda (la Princesa de Asiria) y Mayor (la Duquesa de Calabria), deberá enfrentarse a los ataques celosos de Lisandro, Evandro y César, los galanes inicialmente desdeñados de la comedia. Sus delirios serán, al principio, para la princesa de Asiria. No obstante, las resoluciones finales serán las siguientes: Rosicleo se casará con Mayor y, Evandro, con Anarda. Los caballeros que se quedan sin dama accederán a títulos y galones: Albano hará a Lisandro almirante y, a César, marqués de Esmirna.

Una última nota se nos revela al final de la obra: “Aquí se acaba, senado,/ la privanza desleal" (vv. 2778-2779). Recordemos que en el Buscón [2005: II, 118], Pablos se mofaba de las comedias que llaman a la gente "senado". Con todo, don Francisco solía burlarse de los tópicos que él mismo utilizaba. 
¿Acaso la presente comedia constituye un eco del pensamiento político de Quevedo? La relación con su ideario no está clara, al contrario de lo que sucede con Cómo ha de ser el privado. Reincide, asimismo, en todos los tópicos que había criticado en su obra satírica en prosa. Apreciaríamos, con todo, cierta coherencia con la condena a los malos reyes y tiranos, sentenciados al infierno en el primero de sus Sueños.

El autor sólo muestra su pasión por el ejercicio retórico en parcas ocasiones, cuyos guiños conceptistas no están a la altura del gran troquelador del lenguaje, se ciñen tan sólo a algunos poco sorpresivos juegos onomásticos y paronomásicos. Tales deficiencias sólo pueden explicarse si las relacionamos con el contexto de una comedia por encargo. Queda encorsetada la originalidad y libertad creativa del escritor por las convenciones de un auditorio restringido y la premura de la inmediatez productiva. ¿En qué medida puede traslucirse el genio literario de Quevedo en una obra limitada por semejantes circunstancias? Germán Vega [1993: 121] concluye al respecto: la comedia, "en su desmayada calidad artística no podrá ayudar a Quevedo, ni a ningún otro escritor, a avanzar en los repechos del Parnaso." 


\section{EL GALÁN FANTASMA}

\section{1. UN MANUSCRITO ESCONDIDO}

En el Fondo Sedó de la Biblioteca del Institut del Teatre figura una comedia manuscrita e inédita atribuida a Quevedo que hasta ahora ha sido desatendida por la crítica. Se conserva en muy mal estado por el desgaste natural del uso (tiene anotaciones del autor de comedias o de los mismos actores) y por los despiadados estragos de la censura. Cada acto está escrito con una letra distinta (el tercero, según se puede deducir por el seseo ortográfico, es fruto de un copista andaluz).

Como dice el lema de todo bibliotecario, "un libro mal catalogado es un libro perdido". La obra aparece catalogada como entremés, hecho que ha valido la confusión con el entremés del Marido Pantasma. Su título -El galán fantasma- coincide, además, con la célebre producción calderoniana, cuyos argumentos son, sin embargo, distintos.

El manuscrito de la obra atribuida a Quevedo nos ofrece algunos datos fiables para fechar la comedia. En el f. 3r observamos escrito con tinta tenue el año "1637", que coincide probablemente con la fecha de la copia manuscrita. En el f. 66r, aparecen tres censuras que confirman que esta obra fue representada, como mínimo, en tres ciudades españolas: Madrid y Valencia, en 1640, y Zaragoza, en 1642.

Por otra parte, al final de la comedia leemos una variante que no puede pasar inadvertida, en la que un tal Felisardo se declara autor del texto. ¿Nos 
encontraremos ante un pseudónimo de Quevedo? ¿Como "Acnoste"79 en la dedicatoria de Visita y Anotomía de la cabeza del cardenal Armando de Richeleu o el "Licenciado Todo Lo Sabe" en El Chitón de las Taravillas? Este nombre propio no aparece en el Diccionario de seudónimos literarios españoles de Rogers y Lafuente [1977], ni tampoco en la adición de Amancio Lavandeiro Fernández [1983]. Puesto que este dato no nos confiere indicios de autoría suficientes, hemos de focalizar la investigación hacia aspectos de carácter lingüístico y temático insertos dentro de la propia obra literaria.

Nos preguntamos si acaso la comedia fue aquella hasta ahora perdida, de título desconocido, que se representó en 1625 con motivo del cumpleaños de Isabel de Borbón y que se denominó llena de "muy donosos chistes". El hecho de que en la copia manuscrita se le llame comedia famosa implica que la obra había sido impresa y que el original podía ser perfectamente de unos años antes. Al lado de los dramatis personae tal vez figure el nombre de los actores:

$\begin{array}{ll}\text { Don Fernando }+ \text { autor } & \text { Aurora }+ \text { an } \\ \text { Don Jaçinto }+ \text { fran }^{\text {co }} & \text { Doña Veatriz }+ \text { Ysabel } \\ \text { Don Veltran }+ & \text { Luçia } \\ \text { Gorrion lacayo }+ \text { ant }^{\text {o }} & \text { Lucreçia criada } \\ \text { Fabio criado }+ & \text { Celia }\end{array}$

79 "Acnoste" es, de hecho, el pseudónimo con el que se firmó la Satyre Ménipée de la Vertu du Catholicon d'Espagne et de la Tenue des États de Paris (1593). 
Observamos en esta comedia vetas líricas similares a la poesía amorosa de nuestro autor y, ante todo, la ruptura del tópico del final en boda. La fecha estimada de composición coincide con la madurez literaria de nuestro autor y su vinculación a la corte (etapa que va emparejada con su producción teatral por encargo) y, sobre todo, disponemos del manuscrito del Institut del Teatre que atribuye la comedia a nuestro autor. (A pesar de que en la portada del mismo sólo se lee la abreviatura Fco. de Que. )

Nos hallamos, en todo caso, ante una comedia inédita que fue como mínimo tres veces representada en vida de Quevedo y que posee notable valor literario en sí misma.

\subsection{ESTRAgOS DE LA CENSURA}

La comedia que nos ocupa es, de momento, un testimonio único cuya trascripción se ve enormemente dificultada. En el trascurso de la edición del texto, se me ocurrió que si la reflectología infrarroja, por ejemplo, que recientemente se utiliza en obras pictóricas para mostrar los primeros esbozos de un cuadro (algo que se está experimentando en el Museo del Prado) se aplicara a los mss. teatrales censurados, podríamos elaborar ediciones más fidedignas, ver detrás de la mancha de tinta. Versos dormidos en el sueño de los justos podrían reaparecer. Esta tecnología podría asistir al limitado ojo humano y revolucionar disciplinas de estudio literario como la ecdótica o la variantística. Gracias al Galán fantasma, imaginé una herramienta filológica cuya viabilidad estoy valorando actualmente con el 
asesoramiento del CSIC, dado que una inversión de ese tipo ha de resultar rentable.

La censura de El galán fantasma explica las abundantes tachaduras y modificaciones del texto dramático, que han dificultado notablemente la trascripción del mismo:

He visto esta comedia y puede representarse en Madrid. 12 de enero de 1640. Juan Navarro de Espinosa.

Por orden de Vs. el señor Vicario General he visto esta comedia y en ella no hay cosa contraria a nuestra Santa Fe Católica ni buenas costumbres, y así puede Vs. servirse en dar licencia que piden para que se represente. Hecho en Valencia, en el Convento de Nuestra Señora del Remedio, Orden de la Santísima Trinidad. A 16 de octubre de 1640 .

Fr. Juan B ${ }^{\mathrm{a}}$ Palacio, cualificador del Sto Oficio.

Puede representarse en Zaragoza. 13 de enero de 1642. El Dr. Peyron. ${ }^{80}$

¿Qué conocemos de las plumas que acribillaron este infeliz manuscrito teatral, de difícil trascripción?

${ }^{80}$ No obstante, las múltiples supresiones y anotaciones de la comedia no sólo se deben a la intervención de dichos censores sino que, como nota José M. Ruano de la Haza [1989: 202], "no será posible establecer con certeza si el pasaje analizado fue tachado y suprimido por el censor o por el autor o copista. Sin embargo, el contenido escabroso o doctrinalmente sospechoso [...] nos hace intuir en cada caso la intervención del censor." Curiosamente, en su artículo "Dos censores de comedias de mediados del siglo XVII", alude a dos de los tres censores que nos ocupan: Fray Juan Bautista de Palacio y Navarro de Espinosa. 
La censura de Fray Juan Bautista de Palacio -de octubre de 1640coincide con la plantilla típica utilizada, como muestra la última hoja del ms. 16.720 de la BNE (El bastardo de Castilla, de Álvaro Cubillo de Aragón), firmada el 2 de abril de $1641 .{ }^{81}$ Dudamos de que sus tachones hayan interferido demasiado en el texto, dado que por sus comentarios difícilmente leía las obras.

De mayor interés parece la figura de Navarro de Espinosa ${ }^{82}$, fiscal matritense de comedias que escudriñaba minuciosamente las piezas dramáticas que censuraba. ${ }^{83}$

${ }^{81}$ Ruano de la Haza [1989: 203] considera que este censor apenas leía las obras, apelando a otras siete censuras suyas presentes en la BNE y elaboradas en Valencia entre 1641 y 1644: Amar como se ha de amar, de Lope de Vega (ms. 16.552); El mejor esposo san José, de Guillén de Castro (ms. 16.830); A un tiempo rey y vasallo, de Luis Belmonte Bermúdez (ms. Res. 113) y El Purgatorio de san Patricio, de Calderón (ms. Res. 89).

${ }^{82}$ Las comedias censuradas por Juan Navarro de Espinosa de la BNE son, cronológicamente, las siguientes: en 1638, El español Juan de Urbina de Manuel González (ms. 15.493); en 1640, La aurora del sol divino de Francisco Jiménez Sedeño (ms. 16.621) y Celos, industria y amor de Cristóbal de Monroy (ms. 15.517); en 1641, De la abarca a la corona de tres ingenios (ms. 15.544), El acierto en el engaño y robador de su honra de Luis de Belmonte (ms. 15.009), Casarse sin hablarse, de Luis Belmonte Bermúdez (ms. 15.527), El mártir de Madrid, de Mira de Amescua (ms. Res. 107) y El bastardo de Castilla, de Cubillo de Aragón (ms. 16.720); en 1642, El águila del agua, de Luis Vélez de Guevara (ms. Res. 111), La luna de Florencia, de autor anónimo (ms. 16.173), A un tiempo rey y vasallo, de Luis de Belmonte (ms. Res. 113) y El secreto a voces de Calderón (Ms. Res. 117); en 1643, Lo que pasa en un mesón de Cristóbal Monroy y Silva, copiada por Domingo de la Vega (ms. 16.556) y El negro Serafín, de Luis Vélez de Guevara (ms. 17.317); en 1644, Troya abrasada de Zabaleta y Calderón (Ms. Res. 78); en 1646, Los Esforcias de Milán, de Martínez de Meneses (ms. 17.144); en 1649, Las narices, entremés 
Sorprendentemente, en un ms. que fue de la propiedad de Aureliano Fernández Guerra (ms. 61.567 del Institut del Teatre de Barcelona) hemos encontrado un entremés suelto atribuido a este mismo autor, titulado $\mathrm{La}$ Celestina. Entremés Famoso. Este censor, claro está, era también dramaturgo y poeta, por lo que se tomaba la licencia de corregir versos. Hay reseñados algunos aspectos de su obra y biografía en el Catálogo de Barrera y Leyrado [1860].

A continuación de la censura de Navarro de Espinosa a La aurora del sol divino de Francisco Jiménez Sedeño (ms. 16.621 de la BNE) hallamos otra que nos resultará familiar:

Con las Advertencias enmiendas y reparos de Navarro de espinosa doctamente advertidas se puede representar en Çaraga 28 de diciembre 1640. el dr. Peyreny. [1989: 205]

Efectivamente, observamos que el censor de Zaragoza es Peyron (Ruano de la Haza transcribe Peyreny), el tercero de la comedia que nos ocupa, que seguía los pasos de Navarro de Espinosa. ¿Qué sabemos de él? En el Catálogo [1860] de Barrera y Leirado aparece registrado un erudito aragonés llamado don Martín Peyron y Queralt, nacido en Zaragoza a principios del siglo XVII, licenciado en 1631 y después denominado anónimo (ms. Res. 144); en 1650, El príncipe perseguido de Belmonte y otros ingenios (ms. Res. 81); en 1652, El Purgatorio de san Patricio de Calderón (ms. Res. 89); y, en 1655, También tiene el sol menguante, de Luis Vélez de Guevara (ms. 15.568).

${ }^{83}$ Ruano de la Haza, en este caso, reproduce diez censuras que preceden y siguen las medidas prohibitivas y cierre de los teatros entre 1646 y 1649. 
"doctor". Sin embargo, también se aduce que murió violentamente en 1641, por lo que, lamentablemente, las fechas no cuadran.

Las censuras coinciden en gran medida con los criterios prescriptivos de las comedias que Ruano de la Haza escruta de la BNE a propósito de Navarro de Espinosa [1989: 228]. Encontramos eliminados múltiples pasajes afrentosos contra mujeres y santos, sentimientos contrarios al catolicismo como la muerte por amor y el suicidio, disquisiciones pseudoteológicas sobre el alma como las de los tópicos petrarquistas más trillados, alusiones mitológicas ostensiblemente paganas, pasajes sensuales, irrespetuosos con jerarquías sociales o eclesiásticas y juramentos. Parece, en definitiva, que la criba no se remite sólo al ámbito ideológico, sino también al estético. ${ }^{84}$

\subsection{LA OBRA HOMÓNIMA DE CALDERÓN}

Es preciso establecer las similitudes y diferencias entre la comedia que nos ocupa y la que pertenece a Calderón de la Barca, que fue representada en el Palacio Real y, al parecer, se compuso hacia 1635 y dos años más tarde era impresa. Philipe Quinault, en 1659, escribió una imitación, Le

\footnotetext{
${ }^{84}$ A pesar de que no existe una historia completa de la censura de las obras dramáticas del Siglo de Oro, a propósito de la misma, se pueden consultar A. Márquez [1980], E. Cotarelo y Mori [1904], R. Hornedo [1980: 340], J.C.L. Metford [1951], J.E. Varey y N.D. Shergold [1960: 286-325], A. Rumeu de las Armas [1940] y J.M. Rozas [1979: 149-161].
} 
fantôme amoureux, pero ni su fecha de composición ni su texto tampoco coinciden con la obra que nos ocupa. ${ }^{85}$

La obra homónima atribuida a Quevedo posee una estructura argumental y unos personajes dramáticos similares a los de la obra calderoniana: dos galanes -don Fernando y don Jacinto- y sus respectivas damas - Aurora y Laura -, el padre autoritario de Aurora, vigía de su honra -don Beltrán- y los criados -Fabio, Lucía, Celia, Lucrecia y Gorrión-. ¿La pieza atribuida a Quevedo es anterior? Las fechas de composición de ambas parecen próximas.

Observamos en ambas comedias procedimientos tópicos de la comedia de enredo: el ardid del disfraz fantasmagórico o la aparición de ultratumba, escotillones y escondrijos, misteriosos apagones de luz, tensión amorosa, celos, confusión y, por último, la aclaración del misterio, una comprensión piadosa del amor humano y doble boda con felicidad para todos. Sin embargo, el desarrollo de la obra atribuida a Quevedo es distinto y dispone de un gracioso, Gorrión, mucho más avispado y definido.

\subsection{EL ARGUMENTO DE AMOR}

El galán fantasma no escapa de las lides comunes de la comedia de enredo: el amor con aspiraciones matrimoniales es el motor que impulsa a los personajes a esconderse y reaparecer, el hilo conductor de la trama. Los

\footnotetext{
${ }^{85}$ Véase Manuel Couvreur, "La presencia de España en el teatro", en La historia de España en la literatura francesa: una fascinación. Madrid: Castalia, 2002, p. 222.
} 
parlamentos de los protagonistas son equiparables a las composiciones líricas de Quevedo escritas en estilo elevado y de amor purus - el registro exaltado que postulaba la imitación de la Eneida, de acuerdo con la teoría de los tres estilos (o rota virgiliana)-, y destacan por su agudeza e ingenio, nociones que integraban las bases filosóficas del arte de la dificultad que caracterizó al barroco español. El artificio reside en manipular las metáforas fosilizadas procedentes del petrarquismo y en hacer de ellas construcciones destinadas a provocar una chispa de asombro en el intelecto, una voluntad de juego lingüístico que deriva de la tradición trovadoresca y que se ha denominado conceptismo. ${ }^{86}$

El artificio será aplicado a lo que Herrera denomina "argumento de amor" que protagoniza una dama bella y cruel, cuya hermosura se pondera sobre todo en la descripción del rostro (descriptio puellae). En El galán fantasma el nombre de la dama protagonista, Aurora, dará todo el juego lírico que le negará su apellido, Mendoza (v.175). Al inicio de la primera jornada, don Jacinto explica cómo el retrato de su futura esposa le inspiró los siguientes versos:

\footnotetext{
Copia del sol, en tanto que homicida, es de mi ser el tuyo inanimado, ni muero del ardor de enamorado ni vivo de los riesgos de tu vida.
}

\footnotetext{
${ }^{86}$ En esta línea, la poesía amorosa de Quevedo es una continuación de los elementos corteses presentes en cancioneros o antologías del siglo $\mathrm{XV}$, algunas de las cuales fueron recogidas en el Cancionero general (1511) de Hernando del Castillo [1987].
} 
En tus mismos ardores fenecida

quieres morir, efímera del prado;

toma para tu riesgo y mi cuidado

de las muchas que prendes, una vida.

Prueba a vivir, verás lo que te cuesta

si no te vales tú, copia del cielo:

déjate a ti, por darte a ti las palmas.

Pero, cómo el temor dudas apuesta,

en faltarte la vida en tu desvelo,

cuando tienen tus ojos tantas almas. (vv. 235-248).

El acto de escritura se inserta como acción dramática. En el primer cuarteto, emerge la imagen de la dama solar como tributo neoplatónico. El retrato es una copia: pervive, por tanto, el dualismo platónico, el ideal y su reproducción mundana. El soneto se ampara en la creencia filosófica de que la dama priva del alma a sus pretendientes siendo homicida, conforme a lo que exponía Marsilio Ficino en De amore:

aquel que ama a otro y no es amado por él no vive en ninguna parte. Y por esto el amante que no es amado está muerto completamente. Y no resucita jamás, si la indignación no le reanima. Pero cuando el amado corresponde en el amor, el amante vive al menos en él. Y así se produce ciertamente un hecho admirable. [2001:42]

El soneto 307 de Quevedo también se relaciona con el motivo del retrato. Plantea la dificultad de reproducir la belleza de la amada, siendo el espejo el único capaz de aproximarse a ella: 
Podráos él retratar sin luz impropia,

siendo vos de vos propia, en el espejo,

original, pintor, pincel y copia. (vv. 12-14).

No obstante, el soneto 348 hace más evidente su relación con el motivo de la copia celestial, tal y como reza su extenso título, Habiendo llamado a su zagala Aurora, pide a la del cielo que se detenga para ver en ella el retrato de su misma zagala. En este caso, preexisten dos Auroras, la macro y la microcósmica:

Tú, princesa bellísima del día, de las sombras nocturnas triunfadora, oro risueño y púrpura pintora, del aire melancólico alegría; pues del sol que te sigue y que te envía eres flagrante y rica embajadora; pues por ennoblecerte llamé Aurora la hermosa sin igual zagala mía,

ya que la noche me privó de vella, y esquiva mis dos ojos, pïadosa, entreténme su imagen en tu estrella.

Niégale al sol las horas; no invidiosa su llama, que tus luces atropella, esconde en ti su ardiente nieve y rosa.

La siguiente escena de intensidad lírica que acontece en $E l$ galán fantasma se inicia cuando Fernando explica a su amigo reencontrado, don Jacinto, el incidente de honor que le impulsó a matar en Flandes a don 
Diego, el hermano de Aurora. El principio de su relato, abundante en hipérbatos y alusiones culteranas, muestra semejanzas muy manifiestas con el inicio de las Soledades de Góngora:

Era ya el sol por estaciones de oro huésped un mes de aquel fenicio toro que animado bajel, galera breve, fugitivo surcó montes de nieve: rompía para dar una librea, los condados de rosas a Amaltea.

Nunca mayo heredó tantos pensiles y lloraba el aurora sobre abriles, era la pompa de la primavera y la ocasión de mis disgustos era. Andaba, en parte, menos bravo Marte y entraba Venus en aquella parte una lóbrega noche, que en lo adusto apuestas atrevió con mi disgusto.

Echó ceñuda o trémula las llaves, Jacinto, al día, y las nocturnas aves, con tardo vuelo y canto pavorido dejaban soñolientas aquel nido que en su preñez sombría las niega a los escrúpulos del día.

Volaban, sombras, las infaustas aves y con gemidos graves nadaba el viento el búho soñoliento dormitando en los piélagos de viento; ladraba el can atento e importuno 
las sentidas pisadas de ninguno;

el aire, blandamente, se quejaba

y el pájaro, doméstico, cantaba. (vv. 311-338)

Este fragmento, apreciado en su contexto, no es en absoluto una parodia, sino una imitación. ¿Es imposible que Quevedo emulara a Góngora, cuando la historia literaria se ha empeñado en enemistarlos? Ya hemos señalado con anterioridad que, en ocasiones, hemos de desmentir a prioris poco documentados.

Nos sorprende la amplitud de este pasaje descriptivo, la enorme extensión de los parlamentos de don Fernando, cuya prolijidad será extremada en su última intervención, con más lirismo que valor dramático.

Lágrimas de amor perotiniano $-\mathrm{o}$ aljófar, como dice la metáforamanarán de los personajes contrariados y enloquecidos por Eros, dado que gran parte de la comedia se sustenta sobre una dialéctica amorosa que irá tomando diferentes disfraces retóricos: la metáfora de la roca frente a las olas del mar (vv. 662-701), el oxímoron en el dilema del honor y la pasión (vv.720-723), la hipérbole en la desesperación e invocación del cese del deseo (vv. 738-746) e incluso, una acalorada discusión incentivada por celos poco fundados. Este último motivo está precedido por un soneto de don Fernando tras la visita de don Jacinto con el misterioso retrato de su hermana, Beatriz. Sus palabras le delimitan dentro de un cerco asfixiante que le niega el libre albedrío:

Tan vivo estoy del sentimiento mío, tanto a la pena estoy acompañado 


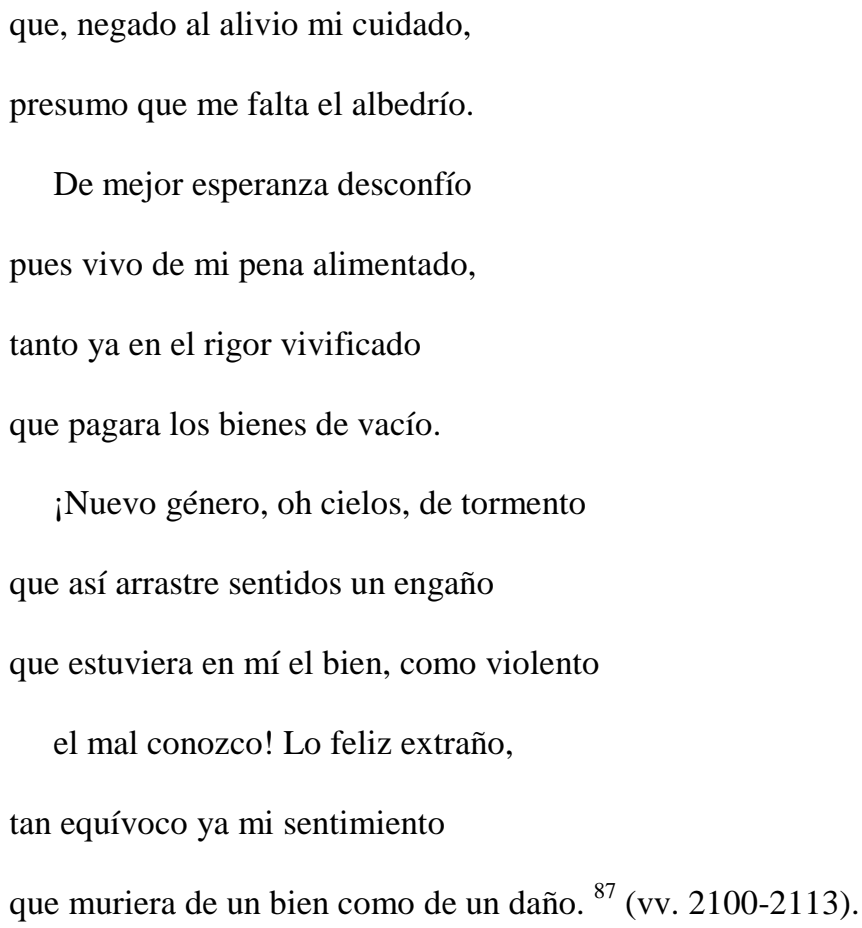

Como hemos podido apreciar, los pasajes alusivos al amor y a sus secuelas son abundantes y, por no incurrir en repeticiones, no me detendré más en ellos.

\subsection{EL PÍCARO GORRIÓN}

El galán fantasma tiene, a mi entender, una especial particularidad, porque uno de sus dramatis personae constituye una auténtica bomba de relojería. Parodia todas las circunstancias ridículas y contradictorias que viven sus amos, impulsados por una pasión cegadora. Nos referimos al curioso protagonismo de Gorrión, un gracioso más peculiar y combativo que

${ }^{87}$ El tema debió de parecer heterodoxo a Navarro de Espinosa, que censuró el soneto sin piedad. 
los habituales, antagónico al resto de los personajes y a todos los tópicos de la comedia al uso. Su nombre, de entrada, parece poco quevedesco. Pero, ¿qué ocurriría si El galán fantasma se tratara de una obra escrita entre tres ingenios distintos, como la comedia perdida de 1625 ? En este caso, el nombre del gracioso podría haber sido propuesto por Mateo Montero o Hurtado de Mendoza. La posible coautoría de esta comedia dificulta muchísimo nuestras pesquisas.

La relación entre amos y criados de El galán fantasma nos hace comprender las fuentes fundamentales de las tensiones y divergencias de intereses de la sociedad del siglo XVII. La inclusión de pícaros y graciosos en las obras teatrales obedecen a las posibilidades integradoras que estas figuras ofrecían en las tablas, a pesar de la visión subversiva de estos estratos en la esfera de las relaciones individuales. La diferencia de sangre entre nobles y pícaros explicaba las intrincadas diferencias en su escala de valores. $^{88}$

El pícaro es la vena satírica de la comedia, el espíritu de contradicción, el desengaño del ideal. Aunque Gorrión, a diferencia de Pablos, ha renunciado a llevar una vida de buscón:

\footnotetext{
Y si la verdad se apoya, nunca fui buscón, de mío, y estoy mal con las busconas porque lo son solamente. (vv. 2481-2484)
}

\footnotetext{
${ }^{88}$ Cfr. Maravall [1990: 121].
} 
Su principal obsesión -sumamente quevedesca- es rehusar el matrimonio, actitud que caracteriza a los personajes entremesiles de nuestro autor. $\mathrm{Al}$ inicio de la comedia, reprehende a su amo y le muestra clara y abiertamente su visión de estar casado, en absoluto halagüeña, apelando a la sabiduría de los romances populares:

(...) yo no sé en Dios y en mi alma

con qué conciencia, a qué efecto

va por sus pasos contados

un hombre a su casamiento.

Ochenta leguas y más

sin haber perdido el seso,

porque aunque es boda y la boda

suele ser fiesta y contento,

este contento, esta fiesta,

en que hay cenas y en que hay juegos

es para quien entra y sale

no para quien queda dentro.

Religioso de marido,

ya posdata de soltero,

saliendo voy del discurso

mas vuélvome a meter dentro,

que ha de quedar apurada

esta materia si puedo.

[...] Si te habías de casar,

¿no era mejor en tu pueblo,

donde conoces lo malo,

donde no ignoras lo bueno,

dando un buen día a tu casa, 


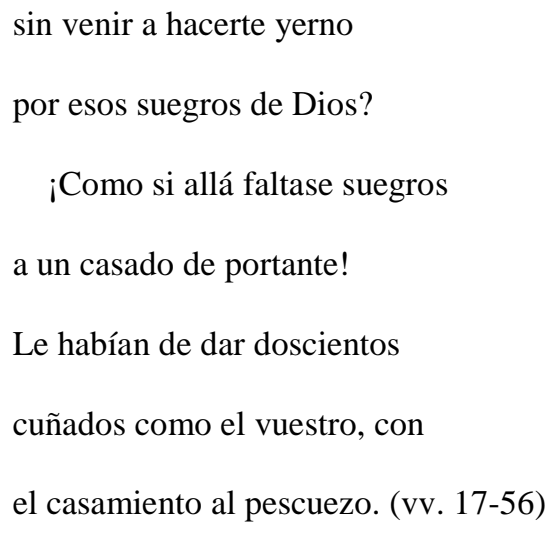

El gracioso desdeña los idealismos y "tormentos del cerebro" de su amo pero es, en cambio, el que alimenta fundamentalmente el título de la comedia, el que da credibilidad a los fantasmas que moran su enigmático cuarto, el que se cree descomulgado cuando aparece Beatriz con la intención de ver a su amado Jacinto. Es consciente de su condición de lacayo, de "limpión de zapatos"; no obstante, se mantiene firme en sus convicciones. Ni siendo pagado por su amo, consentiría en casarse, como asegura en el monólogo de apertura del segundo acto:

Aquí de Dios, que haya hombres de amor tan mal inclinado que lo pongan en casarle (sin temor de un suegro) cuando tiemblo yo con todo el cuerpo (¡sí, por Dios!) de imaginarlo y soy quien soy, y un figura quiere meterse a casado, mire en qué extremo lo pongo que si me dijesen "tu amo te ha de dar una librea 


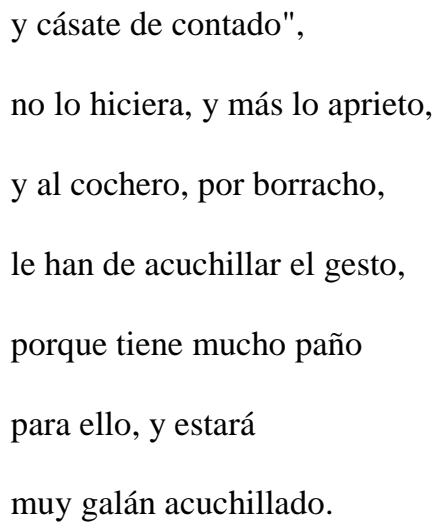

Como se evidencia al inicio del tercer acto, los cuidados de Gorrión serán distintos a los de su amo. Su motor vital no persigue las bodas y amores, sino que su guía principal es el reloj del hambre y del sueño:

$$
\text { De noche, }
$$

éste es el reloj más cierto.

También de día hay relojes

infusos en las entrañas:

porque, como es mundo el hombre, no hay alhaja que no tenga.

$\mathrm{Al}$ amanecer, dispone

la hambre que sean las nueve

para almorzar, y las doce

cuando hay gana de comer,

aunque salga el sol entonces. (vv. 2207-2217) 
Por último, si la obra fuera de Quevedo, el autor se habría obedecido a sí mismo. Gorrión se rebela al final de la comedia y determina no casarse, como había recomendado doña Fáfula a su marido comediógrafo en $E l$ sueño de la muerte:

en una comedia, porque no se casasen todos, le pedí que el lacayo, queriéndole casar su señor con la criada, no quisiese casarse ni hubiese remedio, siquiera porque saliere un lacayo soltero. [2003: I, 452]

En El galán fantasma, en definitiva, sí que hallamos algunas agudezas y retruécanos de ingenio notable, ante todo condensados en los parlamentos del gracioso Gorrión, personaje coherente con las obsesiones satíricas de Quevedo. 
Capítulo V

LOS ENTREMESES DE QUEVEDO 
- 320 - 


\section{NOTA PREVIA}

\section{Características del entreméS}

El entremés es un subgénero dramático muy versátil, que permite muchas posibilidades de composición. Gracias a esta cualidad, tuvo una exitosa acogida entre el público aurisecular. ${ }^{1}$ Surge como herencia de la tradición cómica que se remontaría a los juegos de escarnio medievales, prohibidos en la Iglesia por las Siete partidas de Alfonso $X,^{2}$ y también bebe de la influencia de la commedia dell' arte. Frente a la "comedia nueva" expuesta en el Arte nиevo lopesco, queda muchas veces reconocido como "comedia antigua".

En el Diccionario de Autoridades, el entremés corrobora su versatilidad: es una "representación breve, jocosa y burlesca, la cual se entremete de ordinario entre una jornada y otra de la comedia, para mayor variedad, o para divertir y alegrar al auditorio". Esta definición amplía y matiza, con todo, la ofrecida en el Tesoro de Covarrubias, que subraya sus características fundamentales: la brevedad, su carácter lúdico y su intención

1 Sentaurens [1983: 71-72], aunque centrado en los escenarios teatrales sevillanos, alude a la relevancia que el entremés tuvo en su época: "Esta particular importancia del entremés queda aseverada, en el plano cuantitativo, por el hecho de que las compañías cómicas contratadas para los corrales [...] suelen presentar un repertorio en que los entremeses son dos veces más numerosos que las comedias; y en el plano cualitativo por el hecho de que la obligación de estrenar obras nuevas, de capital importancia para el éxito comercial de las representaciones, también se aplica a los bailes y entremeses."

2 Cfr. La ley XXXV (I, VI) de Las siete partidas, de Alfonso X [1983:181]. 
satírica; rasgos que se avenían muy bien con la vena literaria de don Francisco.

Emilio Cotarelo Mori [1911] en su Colección de entremeses, loas, bailes, jácaras y mojigangas es el primero en inventariar pacientemente lo más representativo del género en un proyecto que, pese a todo, no logró terminar. El teatro breve de Quevedo se quedó en sus borradores manuscritos. $^{3}$

William S. Jack [1923] nota en el entremés una raíz alegórico-religiosa que relaciona con la del auto, si bien ésta se centra en los bajos fondos de la sociedad y la reprehensión del pecado mediante su exhibición grotesca. Heidenreich [1962], por su parte, analiza los tipos y mecanismos humorísticos del teatro breve.

Hannah E. Bergman [1965], a partir del estudio de la obra dramática de Quiñones de Benavente, intenta establecer una diferenciación morfológica de las diversas manifestaciones del género entremesil. En múltiples ocasiones, saca a colación el teatro de Quevedo, como referente de cotejo.

Pero es Eugenio Asensio [1965: 15] quien en su Itinerario del entremés aporta nuevos datos diacrónicos sobre los orígenes del entremés, "esqueje desgajado de la comedia por Lope de Rueda." Remarca su matriz festiva, el significado de la farsa, la carnavalización y su permisividad moral. Y, sobre todo, remarca por primera vez el valor literario de los entremeses de Quevedo y publica los cinco inéditos que encontró en el ms. de Évora.

3 Entre sus múltiples borradores, hemos encontrado en la Biblioteca del Institut del Teatre ediciones manuscritas que tenía preparadas de comedias burlescas, jácaras y bailes de Quevedo y que nos han sido sumamente útiles en la preparación de nuestra edición de teatro breve inédito y atribuido. 


\section{Criterios de Clasificación}

Los entremeses de Quevedo se resisten a una distribución sistemática.

Sus finales admiten mucha variedad: pueden alternar canto, baile o palos. ${ }^{4}$ Su temática abarca en gran medida las obsesiones satíricas de su autor. ¿Qué esquemas de clasificación ha ofrecido la crítica?

Armando Cotarelo [1945: 71] diferencia entre los entremeses misóginos (destinados a denunciar la avaricia femenina) y los destinados a la descripción de figuras:

Cuatro, El caballero de la tenaza, El niño, El marido pantasma y aun Los refranes del viejo celoso, van en contra de las mujeres y sus astucias para ganar a los hombres, bordoncillo habitual en Quevedo. Otros dos, El hospital de los malcasados y El zurdo alanceador, corresponden al recurso tópico en estas piezas de representar variedad de tipos escogidos, pero encuadrados en un marco común, tal que El hospital de los podridos, anónimo; El tribunal de los majaderos, El busca oficios, El cocinero de amor, El caballero bailarín y El comisario de Salas Barbadillo; El comisario de figuras y El casamentero, de Castillo Solórzano; El examinador de Miser Palomo (dos partes), de Mendoza, y otros posteriores, como La plaza del Retiro, anónimo, Las malcontentas, Las civilidades, El murmurador y El Martinillo (dos partes), todos de Benavente; El juez de los impertinentes, de Navarrete y Ribera, y hasta algunos sainetes de D. Ramón de la Cruz. El marión, de resbaladizo asunto, debió de alcanzar gran éxito, pues tuvo segunda parte.

4 Véase Armando Cotarelo [1945: 70-71]. Bergman se mostrará en desacuerdo con éste respecto al final "con palos", que Quevedo criticó en sus comentarios burlescos acerca del teatro. 
El enfoque de Asensio [1965] es de índole textual, de crítica externa. Se rige por la confusa cronología de publicación y divide su análisis entre los entremeses certeros, espurios y perdidos. Esta división le permite una gran libertad expositiva.

Celina Sabor de Cortázar [1987: 156], asimismo, propone un esquema de agrupación fundamentado en criterios temáticos, formales y técnicos:

\section{LOS CONTENIDOS}

1.1. Los temas

1.1.1 El Dinero (La vieja Muñatones, El Caballero Tenaza, El niño y Peralvillo de Madrid)

1.1.2. El matrimonio (El marido pantasma)

1.1.3. El mundo al revés (El Marión)

1.2. Las figuras

1.2.1. El cornudo (Diego Moreno)

1.2.2. Otras figuras (El zurdo alanceador).

\section{LAS FORMAS}

2.1. La creación idiomática (La venta, El zurdo alanceador, El marido fantasma)

\section{LAS TÉCNICAS}

3.1. Desrealización y deshumanización (La ropavejera)

Los ítems aludidos, sin embargo, están interrelacionados en todos los entremeses y son extensibles a la obra satírica de Quevedo. Así sucede con el tópico del mundo al revés ${ }^{5}$, la preponderancia del Poderoso Caballero ${ }^{6}$ y

\footnotetext{
${ }^{5}$ Cfr. C. Vaíllo [1982].

${ }^{6}$ Cfr. E. Alarcos García [1965: 443-472], que analiza el papel del dinero a lo largo de todas las obras de Quevedo.
} 
la crítica contra el matrimonio. Observamos que, por ejemplo, la figura de Diego Moreno -dispuesta en otro apartado- se deriva del desposorio insatisfecho. Lo mismo sucede con la parodia idiomática y las técnicas de caricaturización y degradación, a las que se exponen todas las figuras. ${ }^{7}$

Los criterios de clasificación de los entremeses de Quevedo deben ser considerados como pautas del orden expositivo. La literatura, en ocasiones, se resiente ante los propósitos sistematizadores de la filología. Particularmente, he optado por un análisis temático de los entremeses de Quevedo que aglutinara los criterios de Cotarelo, Asensio y Sabor de Cortázar. He distribuido los entremeses atribuidos a Quevedo del siguiente modo, en función del motivo principal de cada uno de ellos:

I. El arte de desplumar femenino: El niño y Peralvillo de Madrid, La polilla de Madrid, La destreza, La Vieja Muñatones, La ropavejera, el entremés atribuido El caballero de la Tenaza.

II. Una crítica al matrimonio: Doña Bárbara, Diego Moreno, El marión, El marido Pantasma, los entremeses atribuidos El hospital de los malcasados, Los refranes del viejo celoso.

III. El entremés de figuras: los entremeses atribuidos Los refranes del viejo celoso y Las sombras; La venta; El zurdo alanceador.

Finalmente, he destinado el último apartado al estudio de dos entremeses firmados por un tal Miguel de Mulsa (nombre parecido al que durante muchos años se ha considerado uno de los pseudónimos vallisoletanos de Quevedo: Miguel de Mussa), cuyos testimonios manuscritos se datan hacia 1620 y que formaron parte de la Biblioteca de Osuna.

\footnotetext{
7 Conforme apunta el estudio de Alarcos García [1955: 3-38].
} 


\section{EL ARTE DE DESPLUMAR FEMENINO}

Las mujeres son pidonas, pedidoras o pedigüeñas, salteadoras, tomajonas, tomonas o tomascas: todas ellas feligresas de su patrono Santo Tomé, jocoso equívoco que juega con el nombre del santo y el pretérito de "tomar". El léxico abarca una amplia gama sinonímica: saben trasquilar, desollar, pelar, rapar, hacer cuartos. Sus exigencias en la sonsaca son ilimitadas, no dependen de su edad o aspecto físico. Jóvenes y ancianas son artistas del pedir: las más novicias explotan su lozanía y poder de seducción, las vetulas acuden a sus conocimientos de alcahuetería, nigromancia y cirugía estética. Si los hombres son los paganos y dátiles - los que pagan, los que dan-, ellas son las quitanas y quítales. ${ }^{8}$

Quevedo celebra en su teatro breve a la mujer ingeniosa y audaz. Recupera de la tradición la sátira contra mulieres, también presente en la Celestina y la prosa picaresca. ${ }^{9}$ La mujer de los entremeses resulta mucho más relevante que en la comedia: rehuye la cándida pasividad de la virtud en pro de artimañas e intereses propios que, de no ser reivindicados, frustrarían sus ambiciones materiales. ${ }^{10}$

\footnotetext{
8 Cfr. Alarcos García [2004: 12-13].

9 Huerta Calvo [1983: 33-36].

${ }^{10}$ Como indica J. Huerta Calvo [1988:118-121]: "Hay toda una femineidad que no es feminista, o lo que se entiende modernamente como feminismo, pero que está latente en el género y es evidente." Con ello no queremos decir, sin embargo, que don Francisco vincule la avaricia exclusivamente a las mujeres, dado que en ambos géneros son considerables los estragos del Poderoso Caballero. De hecho, en términos políticos, nuestro autor consideraba en sus anotaciones a la Retórica [1547:49] aristotélica que la codicia tributaria
} 
La etopeya de la amada que había fijado el petrarquismo se desmorona ante la obsesión monetaria de la mujer. Así lo ilustra el siguiente Diálogo de galán y dama desdeñosa (POC, 586):

GALÁN: ¿Qué quieres más de un hombre?

DAMA: Más dinero,

y el oro en bolsa, y no en cabellos rojos. [...]

GALÁN: Róbame el pecho.

DAMA: Más valdrá una tienda. [ ...]

GALÁN: Muérome, pues.

DAMA: Pues mándame tu hacienda.

La avaricia femenina es un lugar común de la poesía satírica de Quevedo, que confluye temática y retóricamente con sus entremeses. Este asunto se articula en el soneto Procura también persuadir aquí a una pedidora perdurable la dotrina del trueco de las personas (POC, 563), cuyo sujeto poético, para guardar su bolsa, pretende enseñarle a una pidona que es posible el "taz a taz", esto es, la permuta:

\author{
Es lenguaje de pollos y de establo \\ “tengamos y tengamos"; y "lo cierto \\ es lo de taz a taz", si yo le entablo. (vv. 9-11)
}

puede llegar a arruinar un país. Bien lo explica una fábula de Esopo [1547:228]: “[...] enseñó Esopo con la fábula del que tenía una gallina que le ponía cada día un huevo de oro, y pareciéndole que pues ponía cada día un huevo de oro tendría en el cuerpo mucho oro, por no aguardar poco a poco y tomarlo de una vez la mató y se quedó sin huevo de oro y sin gallina." Más adelante, en las mismas notas y para indagar en la fuerza de las riquezas, Quevedo aludirá a la paradoja de Simónides, que viendo a los sabios por las puertas de los ricos, señalará que éstas "no son otra cosa sino dichosa locura". 
A su vez, en el romance A una dama que pedía joyas, diciéndola que en sus partes y hermosura estaba junto un tesoro, donde era fuerza buscar lo que pedía (POC, 789), el yo poético, como el Licenciado Vidriera cervantino, se burla de los tópicos petrarquistas que establecían que los cabellos de la dama eran de oro; los labios, de coral; la lengua, de ámbar; los dientes, de perlas; y el pecho, de diamantes.

Con porte lucianesco, en el soneto A Apolo siguiendo a Dafne (POC, 536), Quevedo traslada la misma situación al panteón griego. Tan siquiera Júpiter escapa al capricho pecuniario femenino; para conseguir el favor de Dánae ha de convertirse en lluvia de oro:

\footnotetext{
Volviose en bolsa Júpiter severo; levantose las faldas la doncella por recogerle en lluvia de dinero. (vv. 9-11)
}

También, en el romance Encarece la hermosura de una moza con varios ejemplos, aventajándola a todos (POC, 682), los amores mitológicos aparecen con disfraz burlesco y diseminados en chistes: Hércules, Yole y Deyamira (vv. 97-157); Apolo y Dafne (vv. 169-180); Júpiter con sus múltiples relaciones con Dánae (vv. 189-204), Leda (vv. 205-208), Ío (vv. 209-212), Europa (vv. 221-264) y Pasífae (vv. 265-268), junto con el Juicio de Paris (vv. 277 y ss.). ${ }^{11}$

Las mujeres de los entremeses de don Francisco son aquellas que sermoneadores y moralistas criticaron desde la intolerancia teatral, juzgándolas de incitadoras de la lascivia y equiparándolas al mismísimo

\footnotetext{
${ }^{11}$ A propósito del romance 683, véase A. Martinengo [2005: 113-124].
} 
diablo. ${ }^{12} \mathrm{Al}$ contrario que el prototipo de mujer entremesil cervantina, más dada a placeres que a joyas, nuestro autor recreará "mujeres de uña, como sortijas", y "damas barberas que saben rapar". ${ }^{13}$ Como dice Quevedo en el último terceto de Admirable enseñanza del pedir (POC, 61):

\footnotetext{
Mas si el pedir es fuerza no excusada, quiero pedirme a mí que nadie pida, primero que pedir a nadie nada. (vv. 12-14).
}

La venalidad y la codicia marcan al personaje femenino de los entremeses de Quevedo. ${ }^{14}$ Aparece en El Niño y Peralvillo de Madrid, que advierte de los intereses materiales de las mujeres de la Corte, es el motor de la farsa del entremés de La polilla de Madrid, emerge en las posturas de la esgrima de La destreza y en el materialismo desbordado de las celestinescas Ropavejera y La vieja Muñatones.

El tópico de la pidona alimentará, incluso, el duelo de sexos entre doña Anzuelo y don Tenaza, sea o no apócrifo el entremés que recrea la relación entre ambos personajes.

\footnotetext{
${ }^{12}$ Este "amor venal" expresado en la pareja antagónica avaro-pidona es el que Mas [1957: 150] ha definido como "thème majeur de la satire de Quevedo." La tomajona abundará en los entremeses en general, como se ve en La buscona, de Navarrete y Ribera, y en Don Gaiferos y las busconas de Madrid, Don Pegote y La pedidora, de Calderón de la Barca.

${ }^{13}$ Las expresiones proceden del parlamento inicial de Don Beltrán en el Entremés de Diego Moreno. Véase el apartado "Ad dulcem pecuniam!” del estudio de I. Arellano "Cómico y femenil bureo" [1983: 33].

${ }^{14}$ Cfr. F. C. R. Maldonado [1974: 11-12].
} 


\section{LA AVARICIA CORTESANA EN EL NIÑO Y PERALVILLO DE MADRID}

El entremés del Niño y Peralvillo de Madrid constituye una "repulsa de busconas y pedigüeñas." ${ }^{15}$ Integra, a su vez, el tópico del menosprecio de la Corte, que ya aparece implícito en el soneto Despídese de la ambición de la Corte (POC, 572). Quevedo matiza que es en tal choza donde oye el dácala, es decir, la petición de dinero:

\footnotetext{
Ya dije a los palacios: "Adiós, choza".

Cualquiera pretensión tengo por maza;

oigo el dácala y siento el embaraza,

y solamente el libre humor me goza. (vv. 5-8)
}

Como en un paródico cuento de hadas, el Niño abandona su hogar, sin dejar de atender los consejos de su madre. ¿Cuál habrá de ser el foco principal de su atención? No fiarse de las pidonas de la Corte. La avaricia de las cortesanas se relaciona con la temática del romance Instrucción y documentos para el noviciado de la Corte (POC, 726), que consiste en una retahíla de consejos para el joven Perico:

A la Corte vas, Perico;

niño, a la corte te llevan

tu mocedad y tus pies:

Dios de su mano te tenga.

Fiado vas en tu talle, caudal haces de tus piernas;

${ }^{15}$ Cfr. Cotarelo Valledor [1945: 74]. 


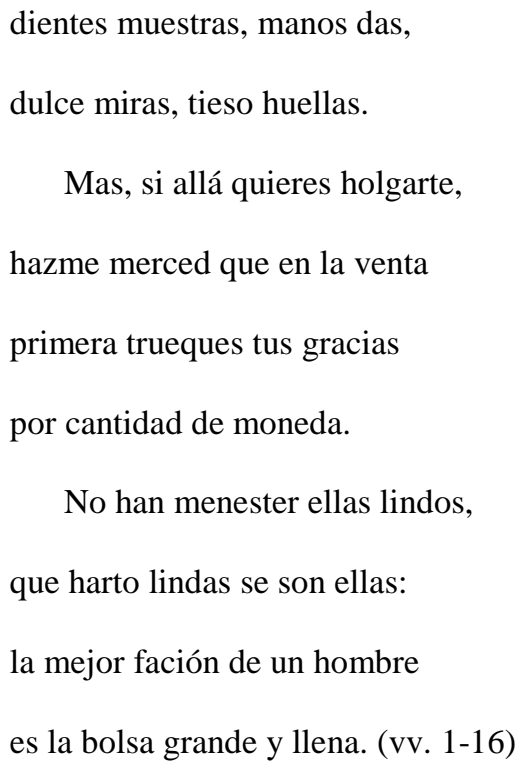

Se ha postulado que el Niño que protagoniza el entremés no es sino un viejo que se finge como tal, por analogía a las múltiples niñas viejas que protagonizan algunos poemas de Quevedo, empecinadas en maquillarse para encubrir los desperfectos del paso del tiempo. ${ }^{16}$ Don Francisco reformula en clave satírica el tópico del puer-senex: el anciano, como un grotesco Fausto, aspira a conseguir el vigor físico del joven. No me parece una hipótesis descabellada, después de leer el poema que dedicó a un viejo teñido ( $P O C$, 632).

A pesar de que no se brindan indicaciones escénicas, imaginamos que la acción del entremés sucede de camino a la Corte. ${ }^{17}$ El Niño emprende su viaje y se encuentra con el amolador Juan Francés, que le explica los seis enigmas plásticos del Peralvillo de Madrid. Esta literatura visual de fuerte impacto moralizante puede vincularse con la tradición emblemática de

\footnotetext{
${ }^{16}$ Alonso Hernández [2001:44].

${ }^{17}$ Como indica Celina Sabor de Cortázar [1987: 158].
} 
Alciato. Como La Polilla de Madrid, nos hallamos ante el motivo del teatro dentro del teatro, esta vez inserto en el monólogo de un hábil rapsoda.

Las acotaciones escénicas, contraviniendo a la práctica general, están impregnadas de la técnica del retrato compuesto. Quevedo traslada a la escritura el efecto pictórico de los cuadros de Arcimboldo. Nuestro autor, si bien alejado del sabroso realismo cervantino, atina en su desbordante imaginación y su capacidad para dramatizar visiones y corporizar conceptos ingeniosos. $^{18}$

Juan Francés suple el rol moralizador de la madre del Niño. Los pliegos sueltos hablan del Peralvillo, lugar en el que yacían expuestos los convictos de la justicia. Por él desfilarán varios ajusticiados, que dialogarán con el amolador explicando el motivo de su desgracia: la codicia femenina.

Simbólicamente, las víctimas de las mujeres son representadas a través de los atributos que han sido la causa de su asableamiento: Alonso-Alvillo, por vestidos; Diego-Alvillo, por comidas; Cosme-Alvillo, por pleitos; Antonio-Alvillo, por comedias. Todos ellos se ven traspasados por estos objetos, como los condenados en el verdadero Peralvillo según las disposiciones de la Santa Hermandad:

\footnotetext{
Y de este Peralvillo que ahora lloras

los cuadrilleros son estas señoras,

que con daca buídas

y tomas penetrantes,

si no los asaetean,

los ajoyan y piden y tiendean. (vv. 91-96)
}

${ }^{18}$ Cfr. C. Sabor de Cortázar [1987: 159]. 
Tras el parlamento de los reos, se descubrirá un monedero vacío encima de unos huesos del difunto. Es la bolsicalavera, cuyo destino es el hurto perpetuo de las pidonas en el infierno:

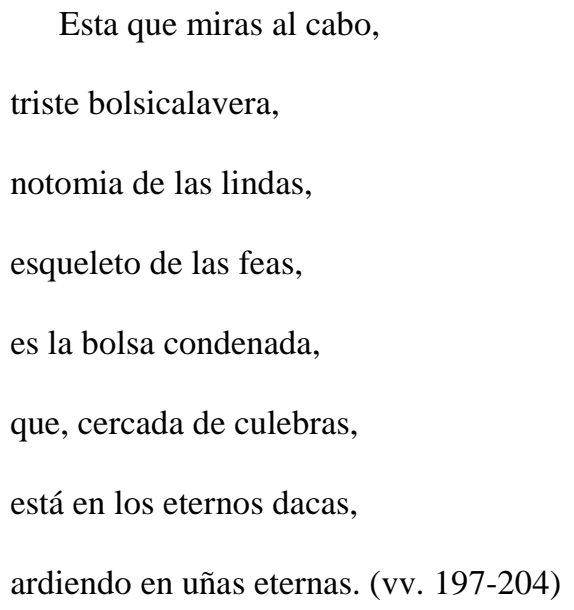

Al final del entremés, se cumplen los pronósticos sobre la picardía femenina. El Niño, una vez en Madrid, se ve abordado por tres mujeres que le requieren la bolsa. Se niega como bien aleccionado, declarándose el Santo Niño de la "Guarda" (no de "la Guardia") en graciosa paronomasia. El canto final, remedo de nana entonado por las damas, es clara síntesis de la situación:

Pues que da en no darnos

este muchacho,

bien será que le demos

todas al diablo.

Niño de mis ojos,

haz cuando lloras,

para ti pucheros,

para mí ollas. (vv. 243-250) 


\section{LA PICARESCA FEMENINA EN LA POLILLA DE MADRID}

La polilla de Madrid entabla claras similitudes con la novela picaresca de heroína femenina La hija de la Celestina (1612) de Salas Barbadillo. En este entremés, una pidona profesional se rodea de parientes y rufianes a los que otorga los papeles de amas, dueñas y criadas de una falsa representación. El objetivo es atraer a ricos caballeros a los que desvalijar la bolsa.

La Pava invita a su casa a los más adinerados de sus pretendientes para asistir a la presunta comedia El robo de Elena. Se introduce el teatro dentro del teatro como reto del barroco conceptista. Este recurso ya había sido experimentado por algunos dramaturgos, como Tirso de Molina en El vergonzoso de palacio.

Después de haber efectuado el robo, la estafadora huye junto con toda la compañía. Los caballeros esperan a que se desarrolle la comedia; no advierten que ésta ya ha tenido lugar y que ellos han sido sus protagonistas.

El robo de Elena es un título que permite la dilogía conceptista. Produce el engaño de sus asistentes, que relacionan el rótulo de la representación con el tema mitológico del rapto de Elena. La ambigüedad reside en la preposición "de": Elena no es el objeto directo, sino el sujeto del robo.

Se ha postulado que el romance Hagamos cuenta con pago (POC, 753) alberga coincidencias temáticas con la historia de Elena, constituyendo una posible continuación del entremés. ${ }^{19}$ Particularmente, tan sólo he notado

\footnotetext{
${ }^{19}$ Cfr. Asensio [1965: 220].
} 
coincidencia en el nombre de algunos personajes que Quevedo relaciona con el mundo canallesco, y que son frecuentes en su poesía. ${ }^{20}$

Lo grotesco aparece como desencadenante de lo verídico. La gradación cómica del entremés, en todo caso, es descendente o anticlímax, rasgo que caracteriza la obra quevedesca de los últimos años. ${ }^{21}$

\section{LA herencia de la Celestina}

La Celestina es una figura esencial para las referencias literarias del teatro satírico aurisecular. Quevedo, como muchos de sus coetáneos, retrató a la malvada vieja decrépita, cuya tradición literaria parte de la hechicera de los clásicos grecolatinos, halla su representante en la figura de la trotaconventos medieval (presente en el Libro de buen amor del Arcipreste de Hita) y llega a la cumbre del protagonismo en La tragicomedia de Calixto y Melibea de Fernando de Rojas. Quevedo, de hecho, escribió unas redondillas A Celestina $(P O C, 804)$ donde señalaba que ésta:

\footnotetext{
No quiso en el cielo entrar

a gozar de las estrellas,

por no estar entre doncellas

que no pudiese manchar (vv. 5-8).
}

${ }^{20}$ Villodres, por ejemplo, reaparece en los poemas 690, 855 y 865; Mondoñedo, en el poema 873. Es más, en el romance 753 , no se alude a la Chirinos ni a la Pava, y ambas se nombran en la jácara 849. Ésta última, a su vez, se menciona en el poema 866.

${ }^{21}$ Asensio [1965: 221] insiste en este "final como caída", en contraste con la comicidad in crescendo de los primerizos entremeses en prosa. 
La alcahueta hace pócimas y remienda cuerpos en los entremeses de $L a$ ropavejera ${ }^{22}$ y La vieja Muñatones ${ }^{23}$ y es la vetula aleccionadora de La destreza. Se trata de un personaje común en la obra satírica de Quevedo. En El discurso de todos los diablos, el autor nos ofrece una sugerente descripción:

sobreescrito de Bercebús, pinta de satanases, recovera de condenaciones, encañutadora de personas y enflautadora de miembros, encuadernadora de vicios, endilgadora de pecados, guisandera de los placeres, lucero de los diablos mundanos. [2003: II, 546]

Retahíla de pullas que se mantiene en La fortuna con seso:

Abuela, endilgadora de refocilos, engarzadora de cuerpos, eslabonadora de gentes, enflautadora de personas, tejedora de caras, has de advertir que somos mozas para vendernos a la pobre barbada y a los cazasiglos; gasta esta munición en dueñas, que son mayas de los difuntos y mariposas del "aquí yace". [2003: II, 650].

En múltiples ocasiones, Quevedo equipara la dueña a la alcahueta. La convierte en una vieja codiciosa que aglutina todos los defectos femeninos. El Epitafio de una dueña, que idea también puede ser de todas $(P O C, 521)$ concentra en el "pequeño y perpetuo espacio" del soneto todos los escarnios

\footnotetext{
${ }^{22}$ Véase I. Arellano y C. C. García Valdés [2001: 25-37].

${ }^{23}$ Jesús G. Maestro [2001: 83] ha identificado a la "puta vieja", cuyos antecedentes son la trotaconventos de El libro de buen amor o la comadre de Bath en The Canterbury Tales, con el personaje nihilista que "desmitifica el triunfo del ser humano basado en el uso fraudulento de la virtud y la dignidad".
} 
posibles -fealdad, alcahuetería, necedad, bajeza moral-, hasta motejar a la dueña de "mula de alquiler", metáfora de meretriz. Esta crítica a las dueñas era común en la literatura coetánea: ya se puede apreciar, por ejemplo, en $E l$ Quijote (I, XXXI). Para Cervantes, las dueñas representaban el lado femenino del hidalguismo.

En el entremés de Diego Moreno, la dueña Gutiérrez, de hecho, aparece como consejera de los amores adúlteros de doña Justa. No en vano, por sus parlamentos, el Licenciado la llamará sanguijuela de bolsas. Así alecciona a su allegada sobre la sonsaca:

Hija, ya que estamos solas, oye una lición. Y es que tú no has de desechar ripio. De cada uno toma lo que te diere, así del carnicero carne, como del especiero especias, del confitero dulces, del mercader vestidos, del sastre hechuras, del zapatero servillas, del señor joyas, del ginovés dineros, del letrado regalos, del médico curas, del alguacil amparo, del caballero oro, del hidalgo plata y del oficial cascajo. Sólo has de huir de valientes que te regalarán con estocadas y te darán en votos y juros lo que no has menester en censos; de apartarte de los músicos, porque ya no se come con pasos de garganta, sino con qué tener que pasar por ella. ¿Pues poetas? Gente apestada: con un soneto te harán pago si los quieres y con una sátira si los dejas. [1965: 264-265]

Por otra parte, Quevedo versifica frecuentemente sobre los artificios de la vetula para ostentar juventud, como sucede en el soneto Encarece los años de una vieja niña $(P O C, 512){ }^{24}$

${ }^{24}$ Sobre el retrato degradante de la vieja, véanse los poemas 549, 551, 618, 708, 762 y 778. Sobre el tópico de la niña-vieja, véanse, además, las poesías 569, 575 y 702. 
La trotaconventos, a su vez, es la remendona que pretende reparar los estragos del tiempo en el cuerpo de los cortesanos. En la Sátira a una dama (POC, 640), don Francisco aludía a los virgos inhallables o contrahechos de las doncellas, motivo que se mantiene en el poema Riesgos del matrimonio en los ruines casados (POC, 639, vv. 236-237) y en el romance Los santeros y santeras manifiestan sus interiores (POC, 705, vv. 61-64).

La Madre Monda, la Ropavejera y la Vieja Muñatones son ancianas celestinescas. De inextinguible codicia, son hipócritas y alcahuetas. Su rapacidad y avidez monetaria las convierte en inmorales pedagogas: conciben el amor como mercancía y enseñan a sus pupilas el arte de sablear.

\subsection{Pidonas y eSgrimistas en La DestreZa}

En La destreza, Quevedo incluye a la alcahueta como personaje y ejemplifica el arte pedigüeño mediante la metáfora de la esgrima, que representa la estilización del robo. La Madre Monda, matrona meretriz y segunda Muñatones, alecciona a dos daifas - Mari Pitorra y la Chillona, dos tipos teatrales de "marimachos"- sobre el arte de pedir con embestidas de espada ropera. ${ }^{25}$

\footnotetext{
${ }^{25}$ Véase la edición facsímil de la HSA de la obra de Nicolás Tamariz, Cartilla y luz de la verdadera destreza sacada de los escritos de D. Luis Pacheco y Narváez (Sevilla, 1696). La espada ropera fue de uso típico en el arte de la esgrima aurisecular.
} 
El entremés le sirvió a Quevedo para burlar una vez más a su enemigo Luis Pacheco de Narváez, escritor de varios manuales de esgrima, como el Libro de las grandezas de la espada (Madrid, 1600) y Las cien conclusiones o formas de saber la verdadera destreza (Madrid, 1608). El término destreza solía aplicarse al estudio de la esgrima, que incluía cálculos geométricos y matemáticos, en contraposición a la fuerza. La sátira contra el célebre espadachín asentado en la corte ya aparece en El Buscón.

El deber de la vetula para con sus discípulas es adoctrinar sobre las artes secretas para descalabrar al género humano mediante todas las prácticas de la alcahuetería. Así lo expresa el soneto Hechicera antigua que deja sus herramientas a otra reciente (POC, 541), composición poética en la que la anciana bruja deja en herencia sus ungüentos mágicos a su aprendiza, y en el romance Lición de una tía a una muchacha, y ella muestra cómo la aprende (POC, 722), donde se reproduce íntegro el Alcorán de "Mariquita/ quitapesares/ digo quitapesos/ de a ocho reales" (vv.85-88).

La metáfora de la esgrima en el arte de pedir es sumamente hermética para el lector contemporáneo. ${ }^{26}$ No obstante, Quevedo ve en el baile con posturas de esgrima una estética seductora para la representación del duelo de los sexos, recurso que también utiliza en el baile Las valentonas y destreza $\left(\right.$ POC, 866),${ }^{27}$ donde alude a "la destreza verdadera" y la "herida [...] de la faltriquera".

A modo de loa entremesada, la obra se inicia con un encomio de tres compañías: la de Juan de Morales Medrano, Antonio de Prado y Cristóbal

\footnotetext{
${ }^{26}$ Así lo considera Asensio [1965: 220].

${ }^{27}$ Astrana Marín [1932: 578 ] lo denomina "Baile de las armas".
} 
de Avendaño. Las dos primeras representaron en Madrid los autos de 1623 y 1624 por encargo municipal. Avendaño actuaba en la Corte durante el mismo periodo. ${ }^{28}$ Asensio supone que La destreza fue representada por la compañía de Prado, dado que la Pitorra la menciona tras el elogio inicial.

En el entremés de La destreza, la familia de bailes viejos aparecen personificados como descendientes de personajes del hampa. Incluye un baile final que González Salas había publicado de manera independiente en el Parnaso con el nombre de Las estafadoras (POC, 874). En el texto que descubrió Asensio en el manuscrito de Évora sólo hay una cuarteta añadida. La pidona en La destreza, como denota el gracioso baile, "va con pasos de pasión/ de crucificar amantes,/ y con donaires sayones/ que los dineros taladren" (vv. 197-200). Habría sido fascinante acudir a la representación de esta obrilla, ser testigo de la coreografía de estas mujeres esgrimistas del dinero, artistas de la sonsaca.

\subsection{LA ROPAVEJERA}

El entremés de La ropavejera apareció inserto en Las tres musas últimas castellanas, a modo de la segunda parte de Los enfadosos. La "ropavejera" era tendera de harapos viejos: su fama de timadora la incorporó al retablo de tópicos de la sátira. ${ }^{29}$ En El sueño de la muerte, por ejemplo, Quevedo

\footnotetext{
${ }^{28}$ Cfr. C. Pérez Pastor [1901: 196, 206-207]. H. A. Rennert [1909]

${ }^{29}$ Señala Armando Cotarelo [1945: 76] que es una "burla de la vanidad y la coquetería."
} 
calificaba a los roperos de "sastres a Dios y a la ventura y ladrones a diablos y desgracia". ${ }^{30}$

Complemento preposicional incluido, la "ropavejera de la vida" ${ }^{31}$ vende "retacillos de persona". Es la versión celestinesca de la cirugía estética actual: zurcidora de arrugas de viejos, remendona de pieles desgastadas por los años, "calcetera del mundo todo/ pues los cuerpos humanos son de punto" (vv.9-10). Esta vetula tiñe las canas con fustán (como en POC, 697, vv. 77-80), realiza ortodoncias y remiendos vaginales, alisamientos de caras e incluso recomposiciones de rostros.

El entremés se divide en dos partes. En la primera, la Ropavejera atiende sucesivamente a varios clientes, entre los que se cifran dos hombres y tres mujeres que acuden a su tienda en busca de ungüentos, postizos y parches fisonómicos para reparar los deterioros de la vejez. La segunda parte está constituida por el baile final, que constituye una sátira contra los bailes viejos.

El desfile de ancianos es contemplado por el ojo examinador de Rastrojo que, pese a sus agudas críticas, también terminará remendado. La Ropavejera le mostrará las proezas de su oficio. Apelará metateatralmente a la cazuela del teatro. Desde el inicio del entremés, la vetula ficcionaliza a los espectadores, los convierte en sus clientes. Es un recurso espléndido que amplía los límites de la representación más allá del escenario:

ROPAVEJERA- ¿Veis aquella cazuela?

RASTROJO- Muy bien.

\footnotetext{
${ }^{30}$ Quevedo [2003: 433].

${ }^{31}$ Cfr. A. Cotarelo [1945: 76].
} 


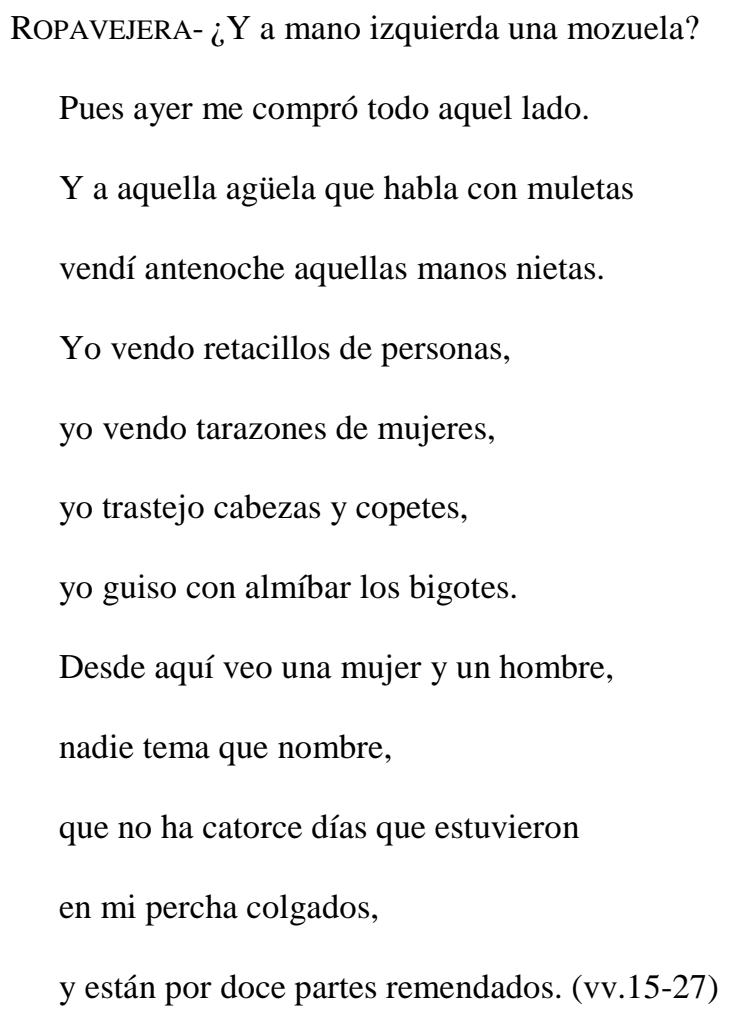

La anciana habla con muletas, porque ni tiene dientes ni muelas suficientes: Quevedo utiliza esta aguda metonimia para caracterizar su dicción. Otro rasgo relevante son sus manos nietas, es decir, unas manos seniles restituidas con cosméticos. La jocosa adjetivación del sustantivo también figura en el entremés de Los enfadosos, aunque a propósito del rostro: "porque hay vieja orejón encarrujada/ que se viste de noche, muy secreta,/ sobre caraza agüela, cara nieta" (vv. 57-59). Está en la línea, por cierto, de llamar viejas a las niñas de los ojos.

Los afeites se guisan como la comida. Así figura en el poema 692: "Bigotes que amortajaron/ el blanco lienzo los días/ el escabeche los cubre/ pero no los resucita" (vv. 27-30). También en La fortuna con seso aparece una anciana que "estaba guisándose las cejas con humo, como chorizos" [2003: II, 616]. 
Después del muestreo del trabajo de la Ropavejera a costa de la imaginaria clientela que se improvisa entre el público, se inicia el desfile de los clientes-actores del entremés, enjuiciados por el testigo Rastrojo: doña Sancha, don Crisóstomo, la dueña Godínez, don Ortega y doña Ana.

Doña Sancha adquiere una dentadura "que no ha servido sino en una boda", dientes de alquiler como lo eran las mulas, metáfora que solía utilizar Quevedo para aludir a las prostitutas.

Don Crisóstomo precisa de dos piernas nuevas ${ }^{32}$ y de tinte para barbas y cabellos. Luego solicita mójili, ungüento para teñir las "barbas de leche" (cuyas canas son susceptibles de ser "ordeñadas"), que por su semejanza con ajilimójili estimamos como metáfora culinaria.

La dueña Godínez aspira al matrimonio y para ello se dispone a recobrar la juventud. Las acotaciones la caracterizan con el prototípico vestido de dueña: largas tocas que asoman por debajo del manto de anascote, confeccionado con una suerte de tela de lana con el que también se elaboraban los hábitos monacales. ${ }^{33}$

\footnotetext{
${ }^{32}$ El repuesto de las piernas, que al parecer ya procedían "de casa" pero habían salido deterioradas, también figura en el romance "Lindo gusto tiene el tiempo" (POC, 757): "Y tiene por pasatiempo/ al más preciado de gambas/ calzarle sobre juanetes/ la lapidosa podagra" (vv. 80-83).

${ }^{33}$ Recordemos que las dueñas son uno de los tipos satíricos preferidos de Quevedo. El Sueño del infierno las moteja de "ranas del infierno" [2003: 303], a las que acusa de alcahuetas, charlatanas, feas, arrugadas, lascivas y embusteras. Estos atributos peyorativos persisten en el pasaje dedicado a la dueña Quintañona en el Sueño de la muerte y en el que comparte con el entremetido y el soplón en el Discurso de todos los diablos. A su vez, la dueña aparece retratada en los poemas 521, 536, 564, 579 y 713. Este último la describe del
} 
La Godínez "de cáscara de nuez tiene el pellejo" (v. 58), imagen que designa las arrugas de la ancianidad y que reaparece en los poemas 739 ("A pesar del artificio,/ el padre Matusalén/ ha introducido en su cara/ mucha cáscara de nuez"; vv. 5-8) y 748 ("frente cáscara de nuez,/ que ha profesado de jimio", vv. 45-46). Para restituir la niñez del rostro, la Ropavejera hervirá su cara en dos lejías, en la caldera de Pero Botero, nombre folclórico del diablo.

El arrebozado Ortega, el impotente de "voz sin criadillas" (esto es, de capón), solicita aparentar virilidad. Para restaurar su cara lampiña, pedirá clavillo y bozo (barba y bigote) de Meléndez, la famosa familia de pañeros segovianos. ${ }^{34}$ La anciana prosigue con el guiño metateatral y le envía al vestuario de los gallos, donde presuntamente adquirirá los complementos de su hombría.

Por último, doña Ana, vergonzosamente tapada con abanico, achaca a la melancolía sus arrugas y pérdida de los dientes, y exige una remodelación completa de la cara. Pide a la Ropavejera la mayor discreción y miente aduciendo que sólo tiene 22 años. Quevedo insiste en las justificaciones y falsedades de las viejas para no reconocer los estragos de la edad en sus cuerpos. ${ }^{35}$

siguiente modo: "una de aquestas que enviudan/ y en un animal se vuelven/ que ni es carne ni pescado,/ dueña, en buena hora se miente." (vv. 9-12)

${ }^{34}$ Cfr. Arellano [1987].

35 Así lo expone en el Libro de todas las cosas [1993: 427-428]: "Unas viejas en duda, que se usan, que se toman de los años como del vino, y andan diciendo que la falta de dientes es corrimiento, y que las arrugas son herencia, y las canas disgustos, y los achaques pegados, y por no parecer huérfanas de la edad llaman mal de madre el que es mal de agüela." Al 
Doña Ana, con encubrimiento eufemístico, llamará "corrimientos" a las "arrugas" (vv. 92-95) y justificará sus ajadas manos por un sufrido mal de ojo. La Ropavejera concluye que las mujeres nunca reconocerán que envejecen:

En las mujeres siempre son los años

buenos, justos y santos inocentes,

pues en cana, ni arruga, ni quijada,

no tuvieron jamás culpa de nada. (vv. 103-197)

La humanidad aparece representada en el entremés de La ropavejera como carnalidad y putrefacción. Quevedo cultiva la técnica del retrato compuesto donde cada uno de los órganos, como en las teorías genéticas de Empédocles, aparecen cambiados de lugar y sin interconexión. El recurso reaparece en el Sueño del Juicio final, cuando los difuntos buscan sus miembros y facciones para reconstruirse tras la resurrección. Todos los personajes del desfile, haciendo alarde de hipocresía, requieren la perdida belleza corporal, buscan la hermosura mundana, tan distante de la perfección moral. Existen otros entremeses de asunto similar como $\mathrm{El}$ remendón de la naturaleza de Salas Barbadillo y el Barbador, de Castillo Solórzano.

igual que en el Sueño del infierno [2003: 305-306]: "Muchas [viejas] han venido acá muy arrugadas y canas y sin diente ni muela, y ninguna ha venido cansada de vivir. Y otra cosa más graciosa, que si os informáis dellas, ninguna vieja hay en el infierno, porque la que está calva y sin muelas, arrugada y lagañosa de pura edad y de puro vieja, dice que el cabello se le cayó de una enfermedad, que los dientes y muelas se le cayeron de comer dulce, que está jilbada de un golpe, y no confesará que son años si pensare remozar por confesarlo." 
Al final del entremés de La ropavejera suenan las guitarras y Rastrojo incita a la Ropavejera a que remiende también "tonos y voces" (v. 118). En el epílogo, los músicos solicitan a la Ropavejera que repare los bailes viejos, como el Rastro,

Zarabanda, Pironda, la Chacona,

Corruja y Vaquería;

y los bailes aquí: Carretería,

¡Ay, ay!, Rastrojo, Escamarrán, Santurde. (vv. 130-133)

Así pues, esta reparación de danzares viejos tendría su equivalente con el remiendo de cuerpos mustios. Aparecen los bailarines y la anciana les va limpiando la cara con un paño, "como a retablos".

\subsection{LA VIEJA MUÑATONES}

La vieja Muñatones enseña a sus pupilas las nueve mil y seiscientas maneras de pedir. ${ }^{36} \mathrm{Su}$ oficio consiste en proporcionar meretrices y filtros $\operatorname{amorosos}^{37}$, por ello la llaman conchabadora, organista de placeres o juntona. También vende afeites ${ }^{38}$ y realiza pequeñas intervenciones de cirugía estética, por lo que se la tilda de encuadernadora, masecoral de

\footnotetext{
${ }^{36}$ Cfr. Asensio [1965: 290].

${ }^{37}$ Sobre la figura de la alcahueta destacan las siguientes composiciones satíricas: 541, 621, 713, 725, 809 (POC).

${ }^{38}$ A propósito de los afeites, véanse los poemas 553, 566, 575, 597 y 632 (POC).
} 
cuerpos humanos, trasponedora de personas y enflautadora de gentes. ${ }^{39}$ Es otra recreación de la alcahueta celestinesca.

La presencia de un Túmulo escrito a la vieja Muñatones en el ms. 108 de la Biblioteca Menéndez Pelayo (f. 161v) y editado por Blecua $(P O C, 598)$ indujo a Asensio [1965:215] a pensar que se trataba de un personaje real castigado por la Inquisición. En el soneto fúnebre, la vieja es "vianda maldita" incluso para los gusanos. Se le acusa de sodomía, brujería encorozada y luteranismo. ${ }^{40}$ La cruz y el agua bendita, elementos rituales de la fe cristiana, no deben malgastarse en su figura. Quevedo la acusa en el primer terceto de pidona ("dio a los hombres en la bolsa guerra") y de meretriz hechicera ("paz a los cabrones en el rabo"); el último terceto, revela su nombre y su condena inquisitorial.

El apellido Muñatón se aplicó durante el Siglo de Oro a los profesionales de la hechicería. En su edición del Buscón, Aureliano Fernández Guerra añade "Muñatones, la de Salamanca" a la presencia de la Vidaña de Alcalá y la Planosa de Burgos, castigadas en 1616 por la Inquisición. ${ }^{41}$ La sobrina de Don Quijote, asimismo, justifica la desaparición de la biblioteca de su tío aludiendo a las malas artes de un brujo llamado "el sabio Muñatón". ${ }^{4}$

\footnotetext{
${ }^{39}$ Cfr. Asensio [1965: 291].

${ }^{40}$ Por asimilación de la heterodoxia, Quevedo relacionaba a Lutero con la blasfemia imperdonable. Otras referencias a Lutero las hallamos en los poemas 59, 264, 527, 580, 586, 598, 639, 640, 720, 729, 749, 860, de POC.

${ }^{41}$ Esta alusión no coincide con la edición de Américo Castro [1927: 243], que se limita al siguiente pasaje: "Citaba a la Vidaña, su concurrente en Alcalá, y a la Placiosa, en Burgos, mujeres de todo embuste" Nótese que el autor lee "Placiosa" en lugar de "Planosa".

${ }^{42}$ Cfr. Miguel de Cervantes [1994: I, 151].
} 
Creemos que otro romance de Quevedo, no citado por la crítica, narra la historia de la vieja Muñatones: es el Suceso que, aunque parece de conseja, fue verdadero $(P O C, 774)$. El poema alude a su condición de calcetera y a su posterior ajusticiamiento. Los versos están escritos con notable sabor popular y tienen la estructura del prototípico cuento infantil sobre la bruja malvada. El autor matiza que sus tretas van más allá de las de la Celestina:

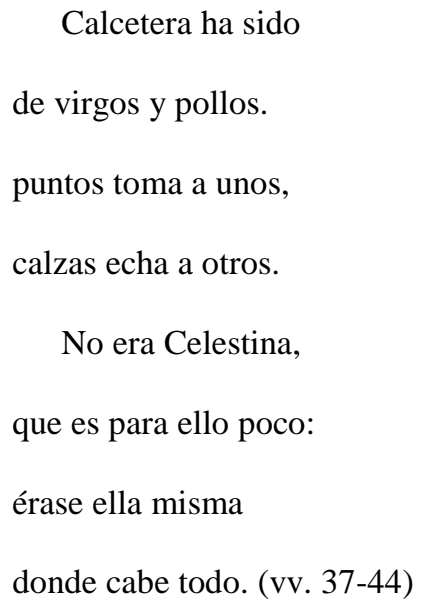

En el ars amandi burlesco de Quevedo, el amor es una mercancía que se compra con dinero. Más que seducir, las daifas ejercen su arte de pedir. En el entremés de La Vieja Muñatones, las escenas se desarrollan con la metáfora de la danza como telón de fondo, de claras reminiscencias carnavalescas. La reducción del arte pedigüeño a reglas de baile es una invención jocosa que probablemente tuvo más significado en el siglo XVII que para nosotros. ${ }^{43}$

La madre Muñatones, caracterizada como las dueñas "con tocas y sombrerillo y báculo y antojos y rosario" enseña a sus discípulas Cristina y Berenguela que el mayor bien del mundo es el dinero:

\footnotetext{
${ }^{43}$ Como señala Asensio [1965:217].
} 
El mejor aire es el que trae el dinero hacia acá. Los brazos se han de alargar todo lo que fuere necesario para llegar a las faldriqueras. Vuestros cruzados han de ser portugueses, vuestras floretas flores nuevas, vuestras mudanzas del que entretiene al que regala, del que promete al que envía, del gracioso al mercader; vuestros pasos hacia el dinero, y bailar sobre mi alma pecadora. [1965: 289]

El entremés fundamenta su acción en un desfile de clientes asiduos de la alcahueta.

Cardoso, un viajero de Sevilla recién llegado a Madrid, acompañado por un guía oriundo de la capital, Pereda, es voyeur de la situación y la juzga moralmente. Se lamenta de la venalidad amorosa y de que las damas sólo aspiren a tener "sangre de bolsa" y no galanteos.

Pereda es una especie de Pármeno en el entremés, tal y como se percibe su afecto familiar por la alcahueta: "Madre, ¿no me abraza?” [1965: 289].

Don Toribio es uno de los asiduos. La vieja Muñatones le aconseja que corteje a criadas y que deje a un lado altas pretensiones, demasiado caras para su bolsillo. Por su talante puede ser "pregonero o aguador" como lo es el Lazarillo al final de su medro picaresco.

Llega la justicia, representada en un alguacil. La anciana cita a Fray Luis de León para disimular sus malas artes con buena doctrina cristiana. Ante lo que el Escribano apunta que "es la vieja entre diablo y zorra" [1965: 293]. Las mozas, para entretener al guro, terminan bailando al son de una melodía que alude al arte de la sonsaca: 


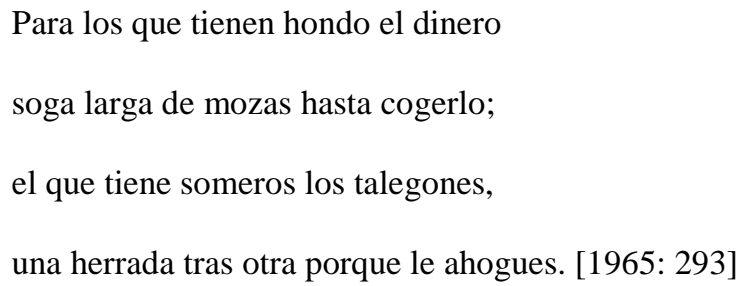

Así reaparece la Celestina entre las figuras entremesiles de Quevedo: recomponiendo cuerpos envejecidos o maltrechos, haciendo bolsa del pavor ante la decrepitud física, el cese de la juventud y de la belleza, amparándose en la hipocresía, la tercería, la astucia y el robo para medrar con tiento.

\section{El DUELO DE SEXOS EN El CABALLERO DE LA TENAZA}

Apócrifo o no, El caballero de la Tenaza está relacionado con la crítica a las mujeres abocadas ad dulcem pecuniam. ${ }^{44}$ Hay quien lo define como una "lanzada a las ninfas de petitoria."45

La obrilla recrea las tensiones monetarias entre Doña Anzuelo, arquetipo de pidona, y Don Tenaza, el caballero agarrado. En las tempranas Cartas del Caballero de la Tenaza, su más directa fuente literaria (1600- 1606), quedaba reflejada esta tensión entre los sexos.

El entremés El caballero de la Tenaza, en el que "Quevedo se plagia a sí mismo", ${ }^{46}$ ha sido desestimado de la nómina por José Manuel Blecua:

\footnotetext{
${ }^{44}$ Astrana Marín publicó como de Quevedo el entremés homónimo, a partir del impreso sin autor, a costa de Antonio Ribero Rodríguez Flor de entremeses y sainetes de diferentes autores (Madrid, 1657).

${ }^{45}$ Armando Cotarelo [1945: 72].
} 
El asunto, la sátira de las mujeres pedigüeñas y el título podría pertenecerle, pero ni el desarrollo ni la falta de gracia, ni la lengua ni el estilo coinciden con lo que sabemos, y muy bien, de don Francisco. [1981: 14].

Estos argumentos contradicen al juicio de Asensio [1965: 234], que alude a la reimpresión del entremés por Menéndez Pelayo [1903] y a la proverbial identificación entre Quevedo y su personaje: "Lego soy pero en Tenaza/ muy vuestro hermano carnal". ${ }^{47}$ Acerca de la fecha y los diversos datos de representación, Asensio nos brinda la información más valiosa:

Astrana, él sabrá por qué, coloca la obra en 1619. Lo cierto es que Bezón, el famoso gracioso rival de Cosme Pérez, cuyo nombre el amanuense ha deslizado una vez en el papel de Tenaza, no asoma en nuestros documentos hasta 1622, cuando con su mujer Ana de Peralta ingresa en la compañía de Hernán Sánchez de Vargas. Si le hemos de dar un plazo para escalar la primacía de la graciosidad, podemos conjeturar que el entremés se representó hacia 1624. La creciente importancia del romance y el baile aconseja no adelantar mucho la fecha." [1965: 235]

Sea como fuere, el entremés espurio presenta a Don Tenaza con el "brazo desencajado" por los tirones interesados de Doña Anzuelo. Ambos se saben

${ }^{46}$ Según Celina Sabor de Cortázar [1987: 158].

${ }^{47}$ Asimismo, Bergman [1965: 277], en su estudio Luis Quiñones de Benavente y sus entremeses, dice "no me atrevería a negar terminantemente esta atribución (generalmente aceptada), pero conste que la versificación ingeniosa y el alto porcentaje de rima en las silvas (93'8) desdicen de la práctica quevediana en los entremeses incluidos en las Tres musas últimas.” 
carnaza del infierno, sus atenciones se fijan en el "Malo del dinero", identificado con una suerte de diablo.

Don Tenaza pide a la encubierta "pedigüeña vergonzante" que se destape, puesto que quiere verla "sin nube, cortinaje ni antipara". Ella, con devaneo seductor, le pregunta cómo juzga su lozano aspecto físico ("¿Soy fea?") y, a continuación, se descubre, ante lo que él responde con un piropo contra voluntad ("Bonitamente lo pelea"). Luego ella le solicita la sortija que lleva en el dedo, y éste no la suelta.

Las figuras que protagonizan el entremés se hallan definidas por sus respectivos nombres. No dudan en glosarlo, sin perder la sutilidad metafórica:

\author{
ANZUELO.- Si no le pesca mi anzuelo, \\ no me llamen buena pesca. \\ TENAZA.- Si blanca diese Tenaza, \\ atenaceado muera. [1932: 561]
}

Ambos reclutan a más miembros de sus respectivos sexos, que ellos capitanean. Generan sendos ejércitos: hombres y mujeres quedan enfrentados. Esta guerra igualitaria se manifiesta en la repetición y paralelismo de situaciones, recurso cómico por antonomasia. El quorum se incrementa en el disparatado torneo de los sexos.

Don Tenaza relata las vicisitudes del hombre, siempre ligadas a los innumerables gastos de la vida familiar. A lo que doña Anzuelo responde quejándose de las congojas de parir. De nuevo, ambos se definen a través de 
cómicos estereotipos: ellas quieren pedir doblones y ellos reventar a palos. Ellas solicitan la bolsa y ellos niegan y encumbran el donaire.

Transformada la contienda en baile, todo termina con una amena dialéctica de sexos, una jocosa copla a dos voces en la que cada uno reafirma su naturaleza, como reza el estribillo:

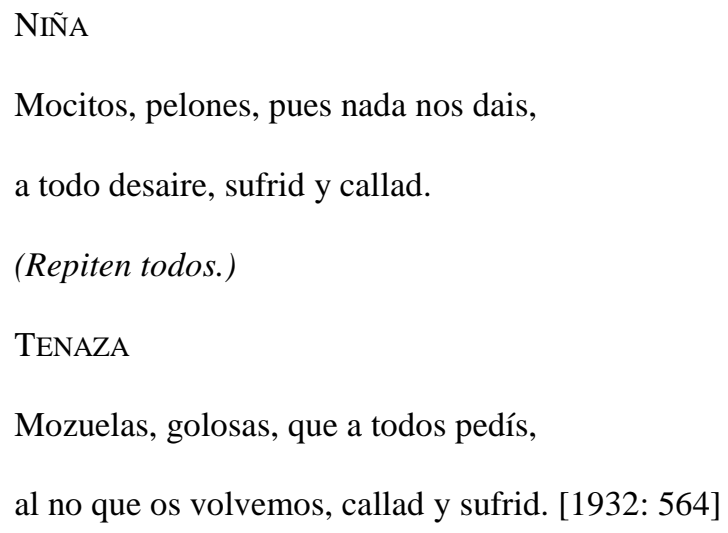

La postura del galán de bolsillo recatado es la manifestada en el romance Dificultades suyas en el dar (POC, 656), cuyo protagonista condensa en la última estrofa el eterno retorno de Don Tenaza y Doña Anzuelo: "Primero del prometer/ que del pecar me arrepiento:/ todo loco con su tema:/ tú Dacas, y yo No tengo" (vv. 37-40).

Del mismo modo, el romance Quejas del abuso de dar a las mujeres $(P O C, 706)$ cifra el apuro de los varones ante las insistentes rapiñas de las damas que sonsacan amparándose en su poder seductor:

\footnotetext{
aquesos diez mandamientos

(que así las manos se llaman)

de ejecución contra bolsas,

de apremio contra las arcas;
} 


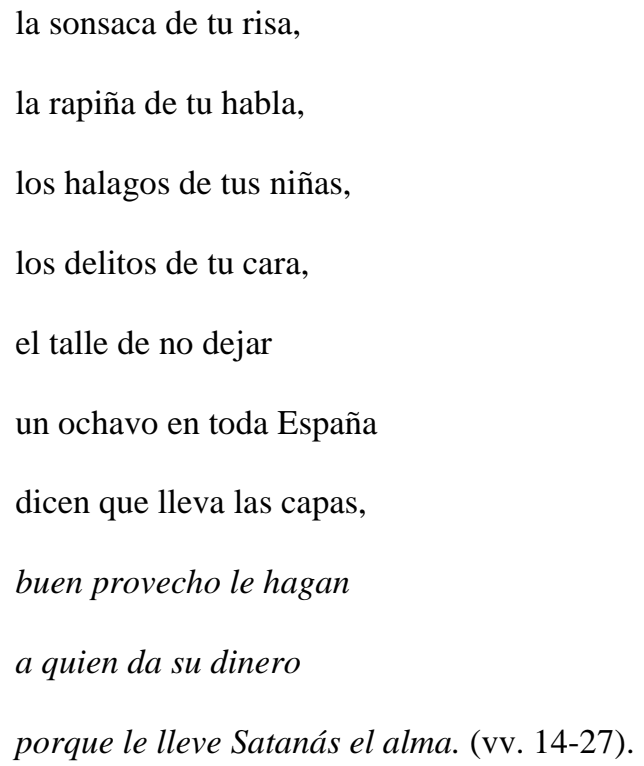

En definitiva, a pesar de que el entremés del Caballero de la Tenaza ha sido calificado de espurio por Blecua, contemplamos en éste la clara reproducción de los roles de los protagonistas de las Cartas del Caballero de la Tenaza. Si bien no disponemos de pruebas fehacientes para demostrar su autoría quevedesca, argüimos las múltiples coincidencias entre este entremés y el resto de la obra satírica de don Francisco. 


\section{UNA CRÍTICA AL MATRIMONIO}

Casarse es la extremaunción de las pedidoras, la aspiración total de las sonsacadoras quevedescas. La burla contra la institución del matrimonio, ya presente en la satura VI de Juvenal, ${ }^{48}$ es otra vertiente más de la tópica misoginia, y trata de los desastres del hombre casado.

Quevedo, mediante una jocosa y falsa etimología popular, apostilla que el significante de la palabra comienza en matri, "madre" (en alusión a la suegra), y termina en monio, "demonio". Porque casarse es condenarse a las tretas y chanzas de la mujer lúbrica, despótica y avariciosa. A su disposición desfilan calzonazos, maridillos cornudos y mariones.

Del desposorio se derivan otros tipos afectados por la amoralidad del enlace hipócrita: el marido tiranizado por la suegra, el prematuramente hastiado y el vejete casado con la niña. Satélites funestos circundan estos matrimonios desafortunados: la alcahueta, la dueña o el casamentero.

En el Sueño del infierno, Quevedo dice que "un mal casado tiene en su mujer toda la herramienta necesaria para mártir, y ellos y ellas, a veces, el infierno portátil" [2003: I, 285]. Este infierno portátil actúa como contexto de fingimientos ridículos y acontecimientos disonantes como el adulterio, la homosexualidad o la impotencia senil. ${ }^{49}$ Quevedo analiza esta cuestión en el soneto Hastío de un casado al tercero día (POC, 517), donde se alude al

\footnotetext{
${ }^{48}$ A propósito de la crítica al matrimonio en los satíricos latinos, cfr. Sánchez Alonso [2004: 115-121].

${ }^{49}$ Cfr. A. Mas [1957]; I. Arellano [1984].
} 
acelerado envejecimiento y devastadora monotonía de la vida conyugal, dado que "mujer que dura un mes, se vuelve plaga".

En Casamiento ridículo (POC, 518), nuestro poeta alude al tema del desposorio infortunado entre Dorotea y Jorge, prototipo de maridillo sufrido que terminará "hecho tiesto de cuernos el cogote".

Y, ante todo, en el último poema incluido en la Musa VI del Parnaso: Riesgos del matrimonio en los ruines casados (POC, 639), se prefiere la muerte a la boda, que se identifica irremisiblemente con el suicidio: "a los hombres que están desesperados/ cásalos en lugar de darles sogas:/ morirán poco menos que ahorcados" (vv. 42-5). A todas luces, Quevedo se adscribe a la tradición misógina medieval, que bebía de las prevenciones bíblicas contra la mujer adúltera.

Por suerte, según veremos, los infortunados esposos pueden enviudar. Descansarán de los sinsabores de la vida matrimonial una vez hayan muerto sus respectivos cónyuges. Esa conclusión es la que alcanza Muñoz, que en El marido pantasma aparece en "negro descanso" y "dulcísimo capuz". La viudez hipócrita, motivo tópico de la literatura satírica, también se expresa en las "bravas tocas de viudas" que llevan Justa y la dueña Gutiérrez de la segunda parte de Diego Moreno.

\section{LOS ARDIDES DE DOÑA BÁRBARA}

Impregnado de recursos similares a los de la commedia dell'arte, obrilla in crescendo en mímica y movimiento, Doña Bárbara es el entremés más 
antiguo de Quevedo y el más próximo a la tradición misógina: versa sobre los múltiples engaños conyugales de la mujer y su triunfo final.

La escena se sitúa en Sevilla, "emporio del comercio y el hampa."50 Intervienen en ella personajes heterogéneos de diversas procedencias. Unos son italianos, caracterizados por su español macarrónico y sus nombres: Octavio, Julio y Ascanio. Otros son porteños, como Silva, el capitán, y Truchado, el amigo de indianos. Y todos pretenden a Bárbara, la daifa del cornudo jayán Hartacho, que aún no se ha casado con ella. ${ }^{51}$

El nombre de la protagonista tal vez sea una voluntaria feminización del decurión Bárbaro que, en un cuento inserto en el Asno de oro de Apuleyo, tiene a la mujer encerrada como en una cárcel y, cuando descubre más tarde la infidelidad de su esposa con su criado, ata a su esclavo desleal como a un reo y exhibe su vergüenza públicamente por toda la ciudad.

Al inicio de la composición, Hartacho dice a Bárbara: "hasta enterrarme, puede muy bien decir" [1965: 339]. Es el cornudo en potencia, "marido en nombre, y en acción difunto" (v.11) que se describe en el soneto $590 .^{52}$ Coincide con el prototípico esposo cartujo, tal y como denota su reiterada frase "con aquesto me tapa la boca".

Doña Bárbara, cuyas costumbres hacen honor a su nombre, acudirá a la treta del embarazo fingido para conseguir regalos y dinero de sus pretendientes, haciéndoles creer que son los padres:

\footnotetext{
${ }^{50}$ Cfr. Asensio [1965:201].

${ }^{51}$ En este entremés, Quevedo, como Torres Naharro, caracterizará la mezcolanza lingüística en los parlamentos de personajes de diversas procedencias.

${ }^{52}$ Sobre la cornudería, véase POC: 555, 556, 592, 593.
} 
[...] y cada uno piensa que es sólo él el querido. Y a estos, cuando se fueron, les di a entender que quedaba preñada, que soy gran mujer de fingir vómitos, que me toman desmayos, y quitárseme la gana de comer, antojárseme de lo uno y de lo otro. Y ahora les he dado con el hijo en las barbas. [1965: 340]

El fingimiento de la preñez para obtener regalos de los amantes también figura en el entremés de Diego Moreno, donde doña Justa amenaza y achanta a los hombres exclamando “¡Ay, Jesús, que estoy preñada y malpariré!". Quiñones de Benavente utiliza el mismo recurso en $L a$ antojadiza. $^{53}$

La paternidad fraudulenta urdida por la avaricia femenina ya aparecía como motivo anecdótico en el Guzmán de Alfarache (I, 2) y en el anónimo entremés en prosa editado por Cotarelo ( $\mathrm{n}^{\mathrm{o}}$ 16), titulado La mamola, que confluye en muchos aspectos con esta obrilla. Doña Bárbara multiplica su comicidad a través de la repetición de frases y situaciones. Al morisco de $L a$ mamola le sustituye el italiano; al gracioso Lorenzo, la dueña infernal. ${ }^{54}$

Bárbara, astuta y embaucadora, no dejará que ninguno de sus pretendientes -incluido el rufián Hartacho- estorben sus nupcias con el músico italiano. Todos asistirán al baile final Cucambé que el amor me ha preso, donde Bárbara descubre jocosamente su amoralidad diciendo: "Es propio de las mujeres/ no guardar a nadie fe." [1965: 351]

\footnotetext{
${ }^{53}$ Cfr. Huerta Calvo [1995: 70-71].

${ }^{54}$ Cfr. Amédée Mas [1957: 63-68].
} 
En la segunda parte del entremés Dona Bárbara, más original, Quevedo presenta a la protagonista viuda, con tocas negras y vestida de verde por dentro. Su equívoco disfraz es una caracterización sintomática de su hipocresía.

La viuda hipócrita es una figura seductora para el imaginario satírico de Quevedo. Prueba de ello es su aparición en El mundo por de dentro, donde el narrador homodiegético, acompañado por el viejo Desengaño, asiste a un entierro y se compadece de una enlutada plañidera. El Desengaño le abre los ojos para que sepa captar la verdad profunda, que nada tiene que ver con las apariencias:

Oye; verás esta viuda, que por defuera tiene un cuerpo de responsos, cómo por de dentro tiene un ánima de aleluyas; las tocas negras y los pensamientos verdes. [2003: I, 374].

Octavio, el marido indiano de doña Bárbara, en verdad ha fingido su muerte -un naufragio en su viaje a Florida- para probar la lealtad de su mujer. Reaparecen los antiguos pretendientes: Hartacho, que ha mejorado su estatus económico, y Ascanio, el italiano que regresa de Nápoles cargado de oro. Hartacho aspira a casarse con Bárbara, pero es plantado por segunda vez ("Dos veces me ha engañado y me engañará ciento"). Ascanio, arquetipo del celoso, termina compuesto y sin novia. A todo ello, Octavio certifica la infidelidad de su esposa. Finalmente, al son de una canción, variante de Hucholó, los músicos exaltan los toros y cuernos del primer amor. 
Los viajes de indianos y los maridos resucitados, el triunfo de la mujer pecadora y la reiteración de recursos cómicos son un claro legado de la commedia dell' arte. ${ }^{55} \mathrm{~A}$ su vez, en el entremés hallamos constantes quevedescas como la pintura de la dueña ávida, la lucha de sexos en la que el hombre tiene las de perder y una jerga semiitalianizante imposible. ${ }^{56}$

\section{DiEGo MoRENO O EL "CORNUdO CARTUJO"}

En el entremés de Diego Moreno se repiten los esquemas y tipos femeninos que aparecen en Doña Bárbara. En la primera parte, Justa, aconsejada por la dueña Gutiérrez, en una relación análoga a la de Bárbara con la dueña Álvarez, conseguirá el dinero de tres pretendientes. En la segunda parte, también viuda, escogerá entre sus solicitantes al celoso Diego Verdugo que, como el italiano Ascanio, será conocedor de las tretas de su amada, escamoteará a los otros galanes e impondrá un nuevo orden en su casa.

Diego Moreno es el nombre propio del sufrido descrito en Vida de la corte, paradigma de la cornudería consentida. Deben notarse las

\footnotetext{
${ }^{55}$ K. M. Lea [1934: I, 194].

${ }^{56}$ Recordemos, por cierto, que don Francisco estuvo en Italia varios años, al servicio del Duque de Osuna. A esta mezcolanza babélica alude Quevedo en la España defendida [1945: I, 281]: "porque, si se hablara el portugués o el italiano puro, fuera dificultoso y cómo burlar, no entendiéndolo nadie". Torres Naharro ya había utilizado este recurso.
} 
connotaciones del apellido del protagonista, que vendría a significar “marrano, judío converso o judaizante". 57

El cornudo irrumpe en la escena con gestos y silencios que comunican no verbalmente su presencia. En la primera parte, le vemos sorteando las injurias que le impulsarían a generar demostraciones de honor. En la segunda, mediante las quejas de la viuda consolable, comprendemos su pertenencia al arquetipo de marido manso. Esta figura emerge en El alguacil endemoniado, paciente y calzonazos:

\footnotetext{
Abajo, en un apartado muy sucio lleno de mondaduras de rastro (quiero decir cuernos) están los que acá llamamos cornudos; gente que aun en el infierno no pierde la paciencia, que como la llevan hecha a prueba de la mala mujer que han tenido ninguna cosa los espanta. $[O C P, 2003: 262] .{ }^{58}$
}

El marido consentido podría ser víctima de un estoicismo atroz. Su filosofía de la pasividad confluye con la carta XCVI de Séneca a Lucilio, titulada "Necesidad de la resignación":

$\mathrm{Si}$ quieres que te diga la verdad, no creo que exista para el hombre otra calamidad sino la de pensar que existe en el mundo alguna cosa que para él es una calamidad. El día que ya no pueda soportar una cosa cualquiera, ya ni a mí mismo podré soportarme. (...) he procurado acostumbrarme de tal manera a todo aquello que es gravoso y adverso, que no obedezco a Dios, antes bien, consiento lo que me envía; le sigo por voluntad, no por necesidad. [1985: 336]

\footnotetext{
${ }^{57}$ Como indica F. Arranz Lago [2005: 209].

${ }^{58}$ Cfr. Arellano [1984:66-72], Mas [1957:114-120], Nolting-Hauff [1974:158].
} 
El estatus del cornudo ha cambiado con los tiempos. Ahora constituye un oficio más que exige una formación y un aprendizaje:

En mi tiempo hacía tanto ruido un marido postizo que se vendía el mundo por uno y no se hallaba; ahora se casan por suficiencia y se ponen a maridos como a sastres y escribientes, y hay platicantes de cornudo y aprendices de maridería, y anda el negocio de suerte que, si volviera al mundo (con ser el propio Diego Moreno) a ser cornudo, me pusiera a platicante y aprendiz delante del acatamiento de los que peinan Medellín y barban de cabrío. [2003: I, 464].

El sufrido entra en casa tosiendo para hacer acto de presencia y sus movimientos son tan intencionadamente pausados que mujer y amante encuentran subterfugios para encubrir su adulterio. Estos avisos del maridillo también son patentes en las Premáticas y aranceles generales, donde se ve obligado a "ir hablando recio" antes de entrar en su morada. En El mundo por de dentro, tiene "un esquilón por tos, que se oye a seis calles". A su vez, en el romance Alega un marido sufrido sus títulos en competencia de otro (POC, 760), se ufana de sus méritos diciendo: "¿Abro la puerta sin toser/ y sin decir "Yo soy c'abro"?" (vv. 65-66). Su silencio ante los evidentes devaneos de su esposa le valen el título de marido cartujo.

No considero, como Asensio [1959: 397-412], que la figura no tuviera apenas predecesores y que estos se limitaran al rufián bravo patente en la Celestina y Lope de Rueda. Consideramos que el cornudo manso ya es un tópico de la sátira menipea, presente en las historias de adulterio del libro XI del Asno de oro de Apuleyo, donde el amante se esconde en algún lugar afín a la profesión del esposo. En el cuento de la mujer del artesano, el querido 
de la adúltera se mete en un tonel -quizá relacionado metafóricamente con el útero de la mujer- para escapar de las sospechas del cornudo. Y resulta más cercano todavía a Diego Moreno el molinero consentido de Apuleyo, que Boccaccio recreó en la narración décima de la quinta jornada del Decamerón. Si buscamos referentes españoles, también podríamos aludir a Lázaro de Tormes, el Guzmán de Alfarache o al marido de la actriz que Pablos pretende gozar en el Buscón.

El entremés de Diego Moreno parodia elementos de la comedia al uso. ${ }^{59}$ Se ampara en la mofa explícita al tema de la honra. Perfila un honor invertido o inexistente. Veamos un ejemplo. Hay una escena en la que Diego Moreno encuentra una espada que ha dejado olvidada un amante de su esposa la noche anterior. La fémina se ha dado cuenta y pide consejo al ama Gutiérrez, que le insta a engañar al marido haciéndole creer que es suya. Pues bien, existe un pasaje de notable semejanza en El médico de su honra de Calderón de la Barca, que es una refundición de la comedia homónima de Lope de Vega. Pero Quevedo invierte los roles: el marido manso no quiere enterarse de su honra manchada.

El protagonista de Diego Moreno actúa como contrafigura de los maridos calderonianos. Quevedo, para retratarlo, se vale del encomio adoxográfico o paradójico, recurso consistente en adular lo aparentemente indeseable, ${ }^{60}$ dado que el maridillo sufrido puede vivir a costa de los amantes de su esposa, como ya habían comprobado Lázaro de Tormes y Guzmán de Alfarache.

\footnotetext{
${ }^{59}$ Como señala José Amezcua [1981: 24].

${ }^{60}$ Cfr. Rodrigo Cacho Casal [2003: 103-227].
} 
Las ventajas del cornudo serán revisadas en el soneto titulado Un casado se ríe del adúltero que le paga el gozar con susto lo que a él le sobra (POC, 555). El tema aparece, asimismo, en la Sátira a un amigo suyo (POC, 641), que elogia al "cornudo de bien" a través de una serie de correspondencias entre cuernos reales y metafóricos, mediante grotescas asociaciones a la cornamenta de ciertos animales, los signos del Zodiaco, la luna, el unicornio, los tinteros (fabricados con cuerno en el siglo XVII) o el mito de Acteón, ${ }^{61}$ personaje mitológico que se metamorfoseó en ciervo por espiar a Diana mientras ésta se bañaba.

Quevedo abundó en juegos de palabras a propósito de la cornamenta, como sucede en el soneto A un hombre llamado Diego, que casaron con una mala mujer llamada Juana (POC, 615), donde la mayoría de los versos aluden fonéticamente a la palabra cuerno. A su vez, nuestro autor utiliza "Cornelio" como nombre del marido sufrido en la segunda parte de Doña Bárbara y al inicio del romance Documentos de un marido antiguo a otro moderno $(P O C, 721)$.

El cornudo consentido suele ser víctima de subterfugios femeninos. Doña Justa se sirve del ardid del embarazo fingido para detener los afanes inquisidores de su infortunado esposo. En la segunda parte, esta mujer liviana, ya viuda, se casa con Diego Verdugo, personaje que actuará conforme a su apellido, "no ya como demiurgo burlón y sarcástico, sino como juez escarmentador."

\footnotetext{
${ }^{61}$ A este mito, Quevedo dedica el soneto Significa el mal que entra a la alma por los ojos con la fábula de Acteón (POC, 346).

${ }^{62}$ Cfr. Javier Huerta Calvo [1995: 91].
} 
Quevedo tenía presente el refrán "Dios que me guarde a mi Diego Moreno/ que nunca me dijo ni malo ni bueno" ${ }^{63}$, que glosa satíricamente en el Sueño de la muerte:

Mi mujer era una picaronaza, y ella me disfamaba, porque dio en decir "Dios me le guarde al mi Diego Moreno, que nunca me dijo malo ni bueno", y miente la bellaca, que yo dije malo y bueno ducientas veces. Y si está el remedio en eso, a los cabronazos que hay agora en el mundo decildes que se anden diciendo malo y bueno a sus mujeres, a ver si les desmocharán las testas y si podrán restañar el flujo del hueso. Lo otro, yo dicen que no dije malo ni bueno; y es tan al revés que viendo entrar en mi casa poetas decía "¡malo!", y en viendo salir ginoveses decía "¡bueno!", si vía con mi mujer galancetes decía "¡malo!"; si vía mercaderes decía "¡bueno!"; si topaba en mi escalera valientes decía "jremalo!"; si encontraba obligados y tratantes decía "¡rebueno!" ¿Pues qué más bueno y malo había de decir? [2003: I, 463]

${ }^{63}$ Este estribillo de la memoria popular fue recogido en El truhanesco (1573) de Juan Timoneda. En el primer cantar se le retrata como personaje manso burlado por su mujer infiel que, harta de los juicios ajenos, denuncia la hipocresía general, dado que nadie escapa al vicio de la lujuria: "Todos blasonan/ de Diego Moreno/ y nadie no pone/ la mano en su seno". El truhanesco inspiró el Coloquio séptimo de Jonás Profeta (publicada en México, 1616) del dramaturgo Fernán González de Eslava, donde reaparece el personaje. También se le menciona en una composición de la Flor de varios romances (Huesca, 1589): "Nacido le ha un hijo ajeno,/ carillo, a Diego Moreno" y en las Obras de diversos de la BNE (ms. 3.924). A su vez, una de las imitaciones más destacables de la estampa de Diego Moreno fue la de Alonso Jerónimo de Salas Barbadillo en El sagaz Estacio, marido examinado (Madrid, 1620). La viuda hipócrita, por otra parte, figura también en la obra calderoniana El pésame de la viuda, donde se recrea a doña Justa y su comida funeral. 
En el mismo Sueño de la muerte, el protagonista es perseguido por nuestro personaje de "honras títires", que pretende golpearle. Cuando éste pregunta: "¿Qué le he hecho yo?", aquél responde con sorna vengativa:

- Entremés- dijo tan presto Diego Moreno-. ¿Yo soy cabrón y otras bellaquerías que compusiste a él semejantes? ¿No hay otros Morenos de quien echar la mano? ¿No sabías que todos los Morenos, aunque se llamen Joanes, en casándose se vuelven Diegos y que el color de los más maridos es moreno? ¿Qué he hecho yo que no hayan hecho otros mucho más? ¿Acabóse en mí el cuerno? ¿Levánteme yo a mayores con la cornamenta? ¿Encareciéndose por mi muerte los cabos de cuchillos y los tinteros? ¿Pues qué los ha movido a traerme por tablados? Yo fui marido de tomo y lomo, porque tomaba y engordaba; siete durmientes era con los ricos y grulla con los pobres; poco malicioso, lo que podía echar a la bolsa no lo echaba a mala parte. [2003: I, 461-463]

En el romance Marido que busca acomodo y hace relación de sus propiedades $(P O C, 716)$ también se cita al cornudo por antonomasia: "Si hiciérades oración/ por un marido del Soto/ no os lo deparara el Rastro/ más Diego ni menos hosco" (vv. 61-64).

En todo caso, Quevedo explicita que su época es la del cuerno, como aflora en su composición La vida poltrona (POC, 773):

\footnotetext{
De la edad de oro gozaron sus cuerpos; pasó la de plata, pasó la de hierro y para nosotros vino la del cuerno,
} 
rica de ganados

y Diegos Morenos. (vv. 21-28)

Nuestro autor le dijo a su personaje: "Al mundo voy sólo a escribir entremeses de tu vida". Asensio [1965:214] se pregunta al respecto si el entremés perdido Caraquí me voy, cuyo título parece ser una eufemística alusión a los cuernos del caracol, pertenece a esta rama de la literatura de cornudos. Para saberlo, habremos de encontrar algún día esta obrilla extraviada.

\section{EL INTERCAMBIO DE ROLES EN EL MARIÓN}

El abreviado mundo subvertido del entremés muestra su faceta más ridícula en El marión. ${ }^{64}$ El tópico del mundo al revés, ya presente en el motivo central de La fortuna con seso, se despoja de trascendencia olímpica y persigue la sencilla carcajada.

El entremés consiste en un "vejamen de mancebos barbilindos y maridos pusilánimes". ${ }^{65}$ Constituye una parodia de la comedia de capa y espada,

${ }^{64}$ Este entremés nos ha llegado a través de un ms. de texto corrompido perteneciente a la colección Sedó del Institut del Teatre de Barcelona. Sabemos, asimismo, que fue impreso suelto por Francisco Juan de Velasco (Cádiz, 1646) y por Astrana Marín, según el ejemplar del impreso hallado en la librería de Fernández Guerra. Armando Cotarelo, sin ofrecer ninguna justificación, data la obrilla en 1623, ateniéndose a la arbitraria fecha que expone Astrana Marín.

${ }^{65}$ Cfr. Armando Cotarelo [1945: 79]. 
donde los sexos invierten sus roles. La bufonada está trabada sobre un disparate: el galán obra como dama y viceversa.

El carnavalesco motivo de la inversión de los sexos actúa como otra cara de la moneda de aquellas comedias en las que la mujer se disfrazaba de hombre para recuperar su honestidad perdida. De temática similar sería la anónima Mojiganga del Mundo al Revés, obrilla compuesta a finales del siglo XVII, donde lo grotesco de la forma mitiga la salacidad de la temática.

Más que una sátira contra el hombre homosexual, ${ }^{66}$ El marión constituye un juguete literario, en el que los prototípicos comportamientos masculinos aparecen esta vez insertos en la mujer y viceversa. ${ }^{67}$ El tema de la pérdida de las virtudes viriles es una constante en Quevedo, como ilustra su Epístola satírica y censoria al Conde-Duque de Olivares (1624), donde pide a Don Gaspar de Guzmán que reprima su afeminado afán de galas y perfumes cortesanos y evoca la gallardía de los rudos soldados que forjaron el esplendor del imperio español.

${ }^{66}$ Véase Asensio [1965: 232]. Cfr. El epitafio A un bujarrón (POC, 637).

${ }^{67}$ Debemos reiterar, sin embargo, que Ursula K. Heise [1992: 363] señala que los archivos de la Inquisición de la Corona de Aragón recogían que entre 1570 y 1630 se ejecutaron a 187 personas en Zaragoza, 156 en Valencia y 102 en Barcelona por actos homosexuales; y en la Corona de Castilla, estimaron que en Madrid la cifra oscilaba entre 100 y 150 ejecuciones entre 1575 y 1640 y en Sevilla unas 100 entre 1575 y 1620 . Sabemos que Quevedo tuvo noticia de varios de estos ajusticiamientos: el 5 de diciembre de 1622, por ejemplo, se quema a cinco jóvenes acusados de homosexualidad: un bufón, un esclavo mulato, dos criados del Conde de Villamediana y un paje del Duque de Alba. Cfr. Jauralde [1999: 457]. 
El pisaverde don Constanzo, cuyo nombre es una masculinización de "Constanza", representa el motivo de la belle sans merci del amor cortés. ${ }^{68}$ El personaje asume dos papeles: el de doncello y malmaridado, atributos enfatizados respectivamente en la primera y segunda parte del entremés.

En la primera parte, en una escena de calle y ventana, don Constanzo es galanteado por tres pretendientas marimachos -doña María, Bernarda y doña Teresa- que le rondan, le cantan canciones amorosas para conquistarlo y se baten en duelo por él. El marión se ve obligado a rechazar sus requiebros y regalos. Aquí se evidencia la inversión de papeles del motivo del galán enamorado que comparece junto a la reja de la amada y rivaliza con otros aspirantes (un tópico que figura, por ejemplo, en El caballero de Olmedo de Lope de Vega).

El afectado intenta pacificar la trifulca y todos los concurrentes son sorprendidos por su autoritario padre, esbozo paródico de los vigías paternos del pudor de sus hijas en las comedias de capa y espada. Tras las tensiones propias del honor, el entremés termina en un jocoso baile.

La segunda parte es una escena de interior. En ella se refleja la problemática de la mujer casada, pero a través de una burlona inversión de roles. Don Constanzo ha contraído matrimonio y se convierte en un abnegado de su esposa doña María, que le maltrata física y psicológicamente. La dulzura del amor se ha trastocado en un encierro doméstico, en un martirio de imperativos sexistas, golpes e incluso amenazas de devolución a la casa paterna. Mientras tanto, doña María

${ }^{68}$ Cfr. José Amezcua [1981: 22]. 
callejea como un jaranero y gasta la dote de su esposo en juegos de azar y borracheras. Así sintetiza el pobre marión su desdicha matrimonial:

Tiene una condición más que tirana.

¿Yo poderme asomar a la ventana?

¿Yo visitar? ¿Yo ver amigos, fiesta,

guerras? ¿Yo ver comedia?

No tengo más holgura conocida

que estar en un rincón toda mi vida. (vv. 50-55)

Aunque, alarmados por el ruido de la reyerta, le consuelen los vecinos, don Constanzo está perdido. Llega una amiga de doña María a buscarla. Ésta se dispone a partir sin prescindir de la espada, el manto, el broquel y la linterna, que solicita a su criada: advierte que llegará tarde. El marión se quedará hilando en la rueca mansamente. Reaparece el jaleo, entran los músicos y de nuevo termina Constanzo protagonizando un baile grotesco, por órdenes de la mujer, mientras ella sale de casa llevándose el anillo del marido para jugarlo. ${ }^{69}$ Él, que cree estar preñado, asiente ante las órdenes de su esposa dominante y responde, con un acusado síndrome de Estocolmo: "Es muy justo/ obedecerla en todo y darle gusto" (vv. 89-90).

La inversión de roles en El marión no sólo se ciñe a los comportamientos y acciones de los personajes, sino que es también extensible al espacio

\footnotetext{
${ }^{69}$ La proyección de esta obra resultaría polémica e inoportuna en la actualidad, cuando se está gestando una paulatina conciencia sobre la violencia de género.
} 
dramático. El adentro, la casa, es el receptáculo femenino en las comedias ${ }^{70}$, como sucede en El castigo sin venganza de Lope o La dama duende de Calderón, y en El marión es el lugar de don Constanzo. El afuera, la calle, constituye el terreno masculino por excelencia y esta vez configura el ámbito de las damas: por ello doña Juana en Don Gil de las Calzas verdes de Tirso de Molina y Rosaura en La vida es sueño de Calderón han de vestirse de hombres para vengar su honra y andar por los caminos.

Quiñones de Benavente tiene una obrilla homónima que, sin embargo, poco coincide con la de Quevedo. ${ }^{71}$ El entremés, en cambio, ha sido estudiado en contraste y parangón con Los mariones del mismo autor, sin duda redactado a vista del quevedesco. ${ }^{72}$ Las diferencias y confluencias entre ambos han sido notadas unánimemente por la crítica. ${ }^{73}$

${ }^{70}$ Como ha notado José Amezcua [1981:22]. El crítico alude a algunos refranes y expresiones como la denominación de "mujer de la calle" a la prostituta o "La mujer, en su casa y con la pata quebrada".

${ }^{71}$ Cfr. Armando Cotarelo [1945: 79].

${ }^{72}$ Pablo Restrepo-Gautier [1998: 331-343] indaga en la figura del marión y se pregunta si este personaje travestido es un producto subversivo o acaso conservador para los patrones morales de la sociedad filípica. Para solventar la duda, indaga en las raíces de la comicidad. Apoyándose en los argumentos de Judith Butler, autora del estudio de enfoque feminista Gender Trouble: Feminism and the Subversion of Identity ${ }^{\square}$, sostiene que el travestismo es una parodia de la concepción del género, pero no forzosamente una subversión.

${ }^{73}$ Cotarelo y Mori [1911: LXXIV] sostiene que Benavente sustituyó "la acritud brutal o amargura sarcástica de los rasgos satíricos por una ironía mansa, una burla decorosa, amable y transigente, que recrean el espíritu y excitan suavemente la risa". Hannah E. Bergman [1972:100] también ha insistido en la violencia de Quevedo en el trato del tópico del mundo al revés, frente al humor menos dañino para la sensibilidad de Quiñones. 
El motivo ofrece en Quevedo y Quiñones tratos divergentes, su risa obedece a talantes distintos. Quevedo problematiza la inversión sexual, mientras que Quiñones no lo hace. Las diferencias entre ambos estriban básicamente en que en Quevedo es más acusado el influjo de lo carnavalesco, en tanto que Quiñones opta por un humor decoroso.

En Los mariones, el número de galanes se dobla. Los hermanos Estefanío y Quiterio, en el marco de la noche de San Juan, son pretendidos por dos damas, Francisca y María. Cuando éstas ofrecen sendos regalos a sus enamorados, Estefanío se finge recatado al aceptar el presente. Finalmente lo toma, sin embargo, y así revela su afeminada codicia. En El marión de Quevedo, la escena del obsequio opera con otro tipo de risa, una risa verbal. Don Constanzo no acepta el regalo alegando su temor al embarazo indeseado, evidente disparate en boca de un hombre:

no es bien que tomen los doncellos; que suelen sucederles mil desgracias.

Que uno conozco yo que apenas vía, no digo el sol, pero la luz del día, y porque recibió un cierto presente, de una mujer en pretendelle loca, está con la barriga hasta la boca. (vv. 38-44)

Armando Cotarelo [1945: 79] señalaba, al respecto, que Quiñones había mejorado el entremés dentro de lo espinoso y templado las grotescas exageraciones del genio madrileño. Y, del mismo modo, Asensio [1965: 232] considera que Benavente "rebaja el tono grotesco" de nuestro autor. 
A su vez, en las escenas de las pruebas de castidad, podemos ver cómo la osadía de Quevedo supera la de Quiñones. En El marión, el padre de Constanzo, sujetando a su hijo del brazo, le pregunta si le han mancillado la honra. Ante la negativa del mozo, el progenitor le pide pruebas, a lo que don Constanzo solicita que lo mire una comadre, esto es, que alguien le inspeccione el virgo, como solía hacerse con las doncellas. El marión asume convencionalismos que son inaplicables a su sexo: sería motivo de sonantes carcajadas entre el público. En Los mariones, en cambio, don Quiterio y don Estefanío no proponen esta obscena comprobación para corroborar su honra. Reivindican su honor verbalmente. Benavente procura evitar la tosquedad escatológica:

\footnotetext{
No me perdone Dios, señora madre,

si aunque estamos con ellas yo y mi hermano, han llegado a tocarnos ni una mano, porque antes, mirando nuestras famas, han estado las dos como unas damas. [1911: 597] ${ }^{74}$
}

Quiñones emula a Quevedo en elementos temáticos, no léxicos. La brusquedad expresiva de don Francisco es fruto del influjo carnavalesco. Ambos comparten referentes literarios y sociales comunes, como el temor a la autoridad paterna, la defensa de la honra, la obsesión por la belleza femenina o la reiteración de la sexualidad invertida. Pero mientras Quiñones incluye a la madre como figura de autoridad e introduce una boda de criados como elemento paródico de la comedia de capa y espada, Quevedo

\footnotetext{
${ }^{74}$ Cito por la edición de Cotarelo Mori [1911].
} 
desatiende estos factores y se centra en el desarrollo de la parodia de los sexos.

Si Quiñones de Benavente opta por una inversión sexual completa, Quevedo nos avecina a una trasmutación parcial. El marión de Quevedo conserva ciertos rasgos masculinos: no se maquilla, al contrario que don Estefanío y don Quiterio, ni tiene rizos en el cabello. Constanzo constituye un híbrido, un nuevo ente que plantea un cuestionamiento ontológico.

La risa jovial de Quiñones dista muchísimo de la risa desestructuradora y agresiva de Quevedo. Nuestro autor lleva la comicidad a niveles del lenguaje de plaza de mercado, practica una mayor libertad ideológica que la profesada en la comedia, aunque tengamos que pensar en la "libertad estrechamente vigilada" del entremés. ${ }^{75}$

\section{EL MARIDO PANTASMA O EL TEMOR DE ENYERNAR}

El marido pantasma fue publicado en 1643 en el Ramillete de Valencia y compilado en Las tres musas últimas (1670) con texto de mayor calidad. Fascinante por su mezcla de sátira y visión, contiene un enfoque onírico que Quevedo lleva a su culminación en los Sueños, el Discurso de todos los diablos y La fortuna con seso.

Muñoz, al igual que Panurge en el Tiers livre de Rabelais, con quien comparó a Quevedo el censor fray Juan Ponce de León, ${ }^{76}$ se siente inseguro

\footnotetext{
${ }^{75}$ Cf. C. Chaudadis [1980: 165-173].

${ }^{76}$ Véase la publicación de Astrana Marín [1945: I, 657].
} 
ante el matrimonio. Viene a "ponerse a oficio" (v.5), ${ }^{77}$ porque don Francisco concibe el maridaje como una profesión de estatutos bien definidos. ${ }^{78}$

La cornamenta ya aparece retratada en el "guarnecido frontispicio" de Muñoz, en probable alusión burlesca al sombrero con cuernos visibles que, en la puesta en escena, podría formar parte del vestuario del personaje. ${ }^{79}$

Si bien la mujer es la principal carga del matrimonio, la acompañan otros personajes funestos. Muñoz vacila en tomar mujer por el temor de ser "enyernado". La suegra se lleva en dote (POC, 518, v.14), es inmortal (POC, 525, v.14; 700 -primer romance-, v. 42) y más temible que el diablo.

Muñoz quiere casarse con una mujer sin madre, tías, amigas, vecinas, visitas, ni escenarios de galanteos y enredos ("sin coches y sin Prado"). ${ }^{80} \mathrm{Su}$

${ }^{77}$ Sigo la edición de I. Arellano y C.C. García Valdés [1997].

${ }^{78}$ Encontramos referentes de este cometido social en los poemas Doctrina de marido paciente (POC, 715), Marido que busca acomodo y hace relación de sus propiedades (POC, 716), Documentos de un marido antiguo a otro moderno (POC, 721) y Alega un marido sufrido sus títulos en competencia del otro (POC, 760). En El siglo del cuerno [1993: 308-309; 313] se define al marido como "el mejor oficio que hay en la república, teniendo por acompañado el ser cornudo", cuyo puesto debería conseguirse por oposiciones o cátedra. La Premática del tiempo [1993: 225] subraya, de hecho, la necesidad de superar una suerte de pruebas de acceso: "ordenamos que se haga oficio y que nadie sea admitido a él sin examen y aprobación." Según sugiere el protagonista del soneto 612, el marido sufrido es digno de ser canonizado, y hará milagros si consigue mantener la fidelidad de su esposa.

${ }^{79}$ Cfr. I. Arellano; C.C. García Valdés [1997: 47].

${ }^{80}$ Recordemos que los paseos al Prado y los coches eran espacios idóneos para los usos amorosos. Así figuraba en numerosos entremeses, comedias de capa y espada y en la literatura costumbrista aurisecular. Cfr. Herrero [1963:190-193], donde se documenta la relevancia literaria de estos lugares. 
amigo Mendoza le pregunta al respecto dónde podría encontrar mujer sin madre. Luego reflexiona y añade: "Vusté perdió linda ocasión en Eva". Porque Eva es la única mujer sin madre, nacida directamente de una costilla, según reza el Génesis bíblico.

Muñoz relata en silva de consonantes que prefiere la culebra tentadora del paraíso a la suegra, por varias razones que no vacila en aducir:

\author{
A sí propia se arrastra la culebra, \\ mas la madre, mirad si es diferente, \\ arrastra al que la tiene yernalmente. \\ Item más, la culebra se hace roscas, \\ mas de cualquier moscatel que asome, \\ la madre se las pide y se las come. \\ Item más, la culebra da manzana; \\ la madre pide toda fruta humana. \\ Item más, que da silvos la culebra, \\ y la madraza, llena de veneno, \\ si arrugó el propio, desolló el ajeno. \\ Item más, la culebra sabe mucho; \\ y las madres y viejas que celebras \\ dicen que saben más que las culebras. (vv. 32-48)
}

La equiparación de la suegra al mismísimo diablo -como hay Fragelum demonum existe, también el Fragelum suegrorum- se erige como ejemplo paradigmático de parodia idiomática. Quevedo arranca la carcajada mediante jocosos equívocos. 
Como señala el soneto 699, la mayor dicha de Adán fue no tener suegra. El chiste sobre Eva es de carácter tradicional, ${ }^{81}$ y reaparece en las Cartas del Caballero de la Tenaza: "Soy amigo de huérfanas y a Adán no le invidio otra cosa sino que tuvo mujer sin madre, que quiero más tratar con la culebra y con el diablo" [1993: 297]. En esta obra satírica, también se corea la preocupación quevedesca por la adquisición de madres, tías y vecinas a costa de las nupcias:

mientras tuve qué dar y me duró el granillo, el tiempo fue pecador, no hubo vecinas, tu maldita y descomulgada tía que agora gruñe de día y de noche, entonces de día me comía y de noche me cenaba, y con aquellos dos colmillos, que sirven de muletas a sus quijadas, pedía casi tanto como tú con más dientes que treinta mastines. ¿Qué diré de la bendita de tu hermana? Que, en viéndome, se volvía campana: no se le oía otra cosa que dan, dan. [1993: 287-288]

El hastío del esposo frente a la familia de la mujer es un tópico quevedesco que se extiende a las Capitulaciones matrimoniales: "Los defectos insufribles son: Lo primero, que no traiga consigo padre, madre, hermanos ni parientes" [1993: 252].

Madres, suegras y tías constituyen, asimismo, un chilindrón de viejas, ferocísima metáfora apositiva: Quevedo utiliza el vocablo aplicado a la tríada de los naipes -sota, caballo y rey- y lo extiende al campo semántico de los parentescos familiares.

Las presiones del hombre desposado, sin embargo, no se limitan a la parentela de la presunta esposa. Se amplían a los casorios por embarazo ("a

\footnotetext{
${ }^{81}$ Como bien ha señalado Chevalier [1976: 35].
} 
pares las futuras sucesiones"), que entrañan la doncellez como ficción, y a los posibles "lugartenientes de casado", los sustitutos del marido en caso de baja laboral. Como rezan las mismas Capitulaciones:

[...] si (lo que Dios no quiera ni permita) las enfermedades y indisposiciones del marido le hicieren incapaz del ejercicio del matrimonio, la novia puede nombrar al teniente, con tal que no sea estudiante, ni soldado, ni poeta, ni músico. [1993: 255]

El diálogo entre los dos amigos, Mendoza y Muñoz, introduce a los dos personajes que reaparecerán más tarde: Oromasia y Lobón. Mendoza, a pesar de todas las prevenciones de su amigo casamentero, logra encontrar a una mujer -Oromasia- que reúne las características exigidas:

\footnotetext{
Aquí hay una mujer, que no se sabe

quién es, ni se conoce

padre, ni madre, ni pariente suyo,

que no trata con nadie, y tiene hacienda,

y no hay en este pueblo quien la entienda,

y todo lo trabuca. (vv. 70-75)
}

Pero Muñoz teme tanto a las nupcias que prefiere aguardar al testimonio de su amigo Lobón, que prometió casarse antes que él para relatarle "lo que padece y pasa/ el hombre que se casa" (v. 86). Se pregunta, además, si no será apresurado contraer matrimonio con una mujer cuya madre sólo lleva un año enterrada, porque "Diez años dura el tufo de una madre" (v.95). Después, con exageración eclesiástica, dirige al todopoderoso una jocosa plegaria en la que ruega el alejamiento de las viejas. Su oración emula el 
pasaje bíblico del Libro de Daniel en que Susana es rescatada por intervención divina de los ancianos que la acosaban en los baños.

Se duerme Muñoz, parodia de un motivo frecuente en las comedias de capa y espada. Quevedo es consciente de la sobreconocida técnica de suspense dramático y no duda en colocar el comentario metateatral en boca del soñoliento personaje: "que al entremés ninguna ley le quita/ lo de sueño me ha dado y visioncita" (v. 109).

En sueños, como profetizan los versos, se le aparece el camarada Lobón, auténtico marido fantasma. Está apenado por la carga familiar de su esposa (suegros, casamentero y dueña), que no cesan de reclamarle "coche y calle". El infortunado hasta suegras tiene las voces -obsérvese la adjetivación del sustantivo- y con fatalidad sinestésica "encalabrina con hedor de yerno". Él se autodefine cachimarido, como cachidiablo, que en el Diccionario de Autoridades se define como "El que se viste de botarga o diablillo". Es peor que fantasma: es "hombre marido" (v. 116) que debió de tomar algún antídoto o triaca contra las viejas. Muñoz se enternece y su amigo Lobón le pide que le saque de la suegra que padece. La razón la esgrime Quevedo en un paralelismo que entraña juego lingüístico: "Sacar de suegras es sacar de penas" (v. 166).

Tras la onírica visión, Muñoz teme que se le "yerne el alma" (v.172). Quevedo trastoca el valor morfológico de los parentescos, que no duda en convertir en adjetivos e incluso verbos conjugados, en función de la necesidad satírica.

Aparece, a continuación, el personaje femenino ya anunciado: Doña Oromasia, que se retrata a sí misma mediante una vivaracha etopeya. 
Curioso nombre de pidona: véase el compuesto de "oro" y el sufijo "masia", quizá relacionado con el adverbio de cantidad "más". Al principio del entremés, Mendoza realizaba un similar juego de palabras a partir del nombre propio de Muñoz: "el mu le basta y todo el ñoz le sobra" (v.9).

Las razones que Oromasia aduce con "hambre canina de marido" para consagrarse como media naranja de Muñoz son, por lo demás, grotescas e hiperbólicas. Como "echada a la piedra", esto es, huérfana de padre y madre, es calva de amigos y familiares, poco melindrosa -hasta podría llevar ratones como pendientes y convivir con arañas como perros-, recogida -con el sentido de promiscuidad sexual- y, aunque parezca paradójico, doncella y viuda a la vez:

\footnotetext{
Son maridos en letras que he tenido

cédulas son de casamiento todas;

a las comedias puedo prestar bodas;

diecisiete maridos he amagado,

pero ningún marido he madurado.

Cansada de casada y de vïuda,

por ser lo que mejor hoy traga el mundo,

me he vuelto a ser doncella pro secundo

y para la segunda vez casada,

aún me queda doncella reservada;

soy y seré doncella, sin ser rubia. (vv. 206-216)
}

En múltiples pasajes de los Sueños, encontramos alusiones similares al tópico del final de dobles nupcias en las comedias. Oromasia ostenta multiplicidad de bodas y de doncelleces. Su virginidad se ve perpetuamente 
restaurada por fingimientos hipócritas o remiendos de ropavejeras. Esta burla a las falsas doncellas también aparece en el El zurdo alanceador, donde la pidona ha sido "cien doncellas en diez años" (v. 246). Al mismo tema aluden las Cartas del caballero de la Tenaza:

Linda cosa $[\ldots]$ hacerse doncella de entre manos no siéndolo de entrepiernas. Donaire has tenido; no he visto virgen postiza tan graciosa. Dime, ¿cuántas veces puedes ser doncella en este mundo? Una mujer a quien, me dicen, han pagado el virgo décimo cuarto, y que el último está de puntillas sobre un peinado [...]. Doncella de siete y llevar, si fueras en tiempo de Almanzor (pregunta a tu abuela quien es este moro, que es docta en Hametes) contigo sola se pudiera abreviar el número de las cien doncellas que le pagaba Mauregato: que, si en dos años has sido catorce veces doncella, en ocho fueras ocho mil. [1993: 299-300]

Muñoz, asustado por la doncella lluvia y desengañado de mollera por la visión descasadera, se dispone a renunciar al matrimonio. Arguye que los malos casados habrían de tener redentores, como los había de los cautivos que penaban en las prisiones del norte de África. De nuevo, la misma idea figura en las Cartas del caballero de la Tenaza:

Y porque no me suceda lo que sucede a los que se casan, no quiero tener quien me suceda; y perseveraré en este humor, hasta que haya órdenes de redimir casados como cautivos. [1993: 292]

Pero vuelve a aparecer Lobón vestido de luto y con una sonrisa en los labios, que hace recapacitar al soltero. En contraste con la escena anterior, está alegre y aconseja a su camarada que siga adelante con la boda para poder apreciar la guinda del matrimonio, el maravilloso placer de enviudar: 


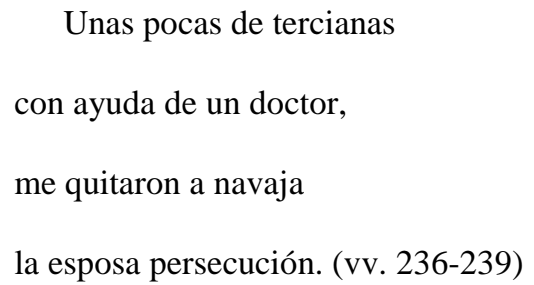

Nótese, a propósito del fragmento citado, que los médicos son siempre para Quevedo ineludibles matasanos. Así pues, el tópico de la viuda de lágrimas de cocodrilo se traslada de nuevo a los hombres. La tensión cómica, amparada por la ingeniosidad verbal de Quevedo, va in crescendo hasta desembocar en el cinismo final. La pieza termina con un jocoso dúo musical en el que hombres y mujeres, a través de la música y el baile, se incitan a casarse para después enterrar al cónyuge. Todo, al son de un popular estribillo afianzado en un quiasmo que ensalza el valor de lo visto con los propios ojos, esto es, de la experiencia: "Yo que lo vi, que lo sé, que lo digo;/ yo que lo vi, que lo digo, lo sé.” (vv. 284-285)

\section{LOS MALMARIDADOS DE DOS FALSOS AUTÓGRAFOS}

Aureliano Fernández Guerra, en la epístola incluida en el Catálogo de La Barrera [1860], afirmaba poseer los autógrafos de dos piezas inéditas de Quevedo: Los refranes del viejo celoso y El hospital de los mal casados. Fueron editados por Astrana [1932] y estudiados por el bibliófilo Crosby [1967], que en 1981 los vendió a la Hispanic Society of America. La crítica ha desestimado la validez de estos autógrafos desprovistos del título o la firma de su autor. Por ello, Blecua [1981: 10, 12] deshecha la autoría de 
Quevedo de El hospital y acepta con reservas Los refranes. Como señala Crosby:

si se probara un día que cierto manuscrito tenido por autógrafo no lo es, surgiría implícito el problema de la atribución de la obra misma, pues habría que buscar otros criterios para establecerla de nuevo. [1967: 73]

El hecho de que estas atribuciones descansaran tan sólo en el supuesto carácter autógrafo de los manuscritos ha generado una nueva incertidumbre crítica de atribuciones. Veremos, en adelante, qué confluencias temáticas, estilísticas y verbales pueden dilucidar la paternidad quevedesca de ambas obrillas.

\subsection{EL HOSPITAL DE LOS MALCASADOS}

El hospital de los malcasados versa sobre el tema de los malmaridados. Estos enfermos del matrimonio están ingresados en un grotesco centro médico donde un pillastre recomienda medicamentos inventados. El tema coincide con el que rige el entremés cervantino El juez de los divorcios.

En la escena inicial, don Embuste explica a doña Aldonza la dinámica de un pretendido centro para matrimonios mal avenidos. Es el cebo del timo:

Yo me voy a curar de malcasado, que estoy hasta los huesos apestado, si se quiere curar, venga conmigo. (vv.12-14) 
En una época en la que todavía no existen los asesores matrimoniales, los timadores se aprovechan de las desavenencias conyugales para sacar su provecho. Estos inconvenientes, como hemos visto, son repetidos hasta la saciedad en la obra burlesca de Quevedo.

Los malmaridados tienen "abrasadas sus carnes y comidas/ de cuñados, de suegras y de tías" (vv. 50-51). El pánico ante los familiares de los esposos ya emergía, según hemos citado, en el entremés del Marido Pantasma, las Capitulaciones matrimoniales o Las Cartas del caballero de la Tenaza.

Desfila una clientela perturbada, que sufre las consecuencias de las nupcias contraídas con viejos; bodas que son fruto de la lujuria, la avaricia y los intereses creados. Invierno de maridos y primavera de las mozas: es el mismo problema de Mariana y el Vejete con el que está casada, personajes del entremés cervantino El juez de los divorcios.

En cuanto llama la justicia a la puerta, en un ademán de teatro dentro del teatro -al igual que en la Polilla de Madrid-, los enfermos representan una comedia sobre la degollación de los Inocentes. Se aturden el alguacil y el escribano -figuras que también aparecen al final del entremés de La vieja Muñatones- y dos niños surgidos de la nada les propinan con matapecados.

El hospital de los malcasados es un entremés breve y de asunto quevedesco. Trata los tópicos ya comentados sobre los matrimonios desiguales, la infidelidad y las tretas de los pícaros para conseguir dinero. Por la calidad y lenguaje, la obrilla podría pertenecer a nuestro autor. Sin embargo, el único testimonio manuscrito del texto y la falta de confluencias estilísticas determinantes no dan pruebas fehacientes de esa autoría. 


\subsection{LOS REFRANES DEL VIEJO CELOSO}

A propósito de Los refranes del viejo celoso, Bergman [1975: 376-397] no ha dudado en lanzar una nueva hipótesis: el entremés de Las sombras tendría que regresar a la nómina de obrillas teatrales quevedescas y dejar que Los refranes suscribiera su adhesión a la obra dramática de Quiñones de Benavente.

Se compaginan dos asuntos diversos en esta obrilla teatral. El primero se inscribe en la tradición del adulterio literario, en que la malcasada se evade de las penurias de su infortunado matrimonio acogiendo a un amante entre sus sábanas. El segundo es un desfile de personajes folclóricos, prefigurador de la mojiganga.

El motivo de la malmaridada, relacionado con el ataque a las hipocresías matrimoniales, nos remite al entremés de El viejo celoso cervantino. La deuda con esta obrilla queda patente en el título, porque la alusión a los celos en Los refranes es muy efímera. ${ }^{82}$

Los refranes se centra en los devaneos de "una cierta casadita casquivana con el sopista Rincón". ${ }^{83}$ El Vejete cornudo y pedantesco regresa antes de hora y ella, llamada irónicamente Justa, como la protagonista de Diego Moreno, con gracia y picardía, finge sacarle una paja del ojo para que pueda escaquearse el amante capigorrón sin ser visto.

El recurso satírico de distraer al cornudo para que el amante se dé a la fuga ya aparece en las Tesmoforias de Aristófanes. Los subterfugios

\footnotetext{
${ }^{82}$ Como ya ha mencionado A. Mas [1957: 105- 106].

${ }^{83}$ Cfr. Armando Cotarelo [1945:80].
} 
cómicos, sean del ámbito que fueren, son muy comunes en la literatura entremesil: en El borracho de Benavente, por ejemplo, un pícaro explica cómo cinco soldados sacaron a una dama de un pozo mientras se hace con la bolsa de su interlocutor. En El avantal, del mismo autor, encontramos un pasaje similar.

La mujer joven enumera los lastres desagradables de la vejez. En Los refranes, el Vejete está "echo de barro", es "depósito de tos y del catarro,/ alma de hueso que por miserable/ penando está en braguero perdurable,/ todo refranes como el dueño güeros" (vv. 90-94). En El viejo celoso cervantino:

¡Jesús y mal del viejo! Toda la noche: "Daca el orinal; levántate, Cristinica, y caliéntame unos paños, que me muero de la ijada: dame aquellos juncos, que me fatiga la piedra"...¡Pux, pux, pux, viejo clueco, tan potroso como celoso, y el más celoso del mundo! [1952: 218-219]

Pero si el asunto de Los refranes se inspira probablemente en El viejo celoso cervantino, ofrece, sin embargo, un enfoque distinto. El motivo del matrimonio desigual es nuevamente un pretexto para retratar otra tipología de cornudo: el anciano pedante desplazado por el joven dinámico, ingenioso y vitalista.

El entremés se inicia con una burla de la "Flérida para mí dulce y sabrosa" de Garcilaso. ${ }^{84}$ El amor petrarquista invierte sus valores de pureza

${ }^{84}$ Quevedo parodió a Garcilaso como epítome del culteranismo. Recordemos cuando, por ejemplo, el autor compró la casa en la que vivía Góngora y quemó unos versos de Garcilaso para "desgongorizar" la vivienda. 
en los cortejos apicarados de Rincón. Esta parodia estilística aparece, según aduce Bergman, en diversos entremeses de Quiñones de Benavente: Los gorrones, La hechicera, La muestra de los carros, El ángulo y Las alforjas.

En otras composiciones entremesiles, como El cesto y el sacristán, de Francisco de Castro (Cómico festejo, Madrid, 1742); La capa y las figuras y Los linajudos, anónimos; o La burla de Pantoja, de Moreto, encontramos ecos del asunto del matrimonio entre el viejo y la malmaridada adúltera.

Los argumentos aducidos no aportan pruebas suficientes que justifiquen la autoridad quevedesca de este entremés, una vez desacreditado el carácter autógrafo del ms. conservado. No obstante, apelaremos a esta obrilla en el siguiente apartado, relacionado con el entremés de figuras y el desfile de personajes folclóricos, un tema que abordó Quevedo en el Sueño de la muerte. 


\section{EL ENTREMÉS DE FIGURAS}

Quevedo encontró en el entremés el campo apropiado para explotar una de sus venas geniales: la representación de la sociedad degradada de manera caricaturesca e hilarante. Para ello, se amparó en dos herramientas fundamentales en la construcción de lo grotesco: el retrato y la creación idiomática.

Uno de los mayores logros de don Francisco fue la composición de figuras. ${ }^{85}$ En la Premática del tiempo, parodia de las ordenanzas de la época, don Francisco ofrece una definición particular del término:

Item, porque piensan los astrólogos, poetas y retóricos que sólo ellos saben alzar figuras para escurecer sus enredos, declaramos que sean tenidos por figuras los que a nadie quitan la gorra, y más si es de puro arrogantes; los que dicen mal de todo, hablan adrede descuidos ignorantes, para dar a entender están divertidos en negocios; los que no teniendo hacienda blasonan de gastadores; los que en tiempo de lodos pisan menudico, saludan a cuantas mujeres encuentran, aunque sean viejas y feas; los que a las mañanas hacen traer el rosario al criado, y andan toda la tarde enfrenados con el palillo y al tiempo de hablar, por el embarazo de la madera, babean y rocían las barbas de los circunstantes. Asimismo declaramos por figuras a todos los viejos que se remozan y dan en requebrar, ordenando que, pues siendo viejos se hacen niños, no les dejen salir de casa si no es con ayo. Y, finalmente, declaramos por figuras a todas las mujeres que, siendo hermosas o ya viejas, se pintan y, generalmente, a todas las viudas que dan en lavar ropa blanca, aunque sea a gente grave y de autoridad. Y mandamos sean comprehendidas con éstas y tenidas

${ }^{85}$ Así lo nota Melchora Romanos [1982: 903-911]. No compartimos, con todo, su parecer respecto a la pretendida lejanía entre la figura de la tradición latino-cristiana que analiza Auerbach [1959] y su manifestación alrededor de 1600. 
por figuras descorteses [...] las mujeres que el día que van en coche, y más si es prestado, desconocen a quien más las conoce, dándose más a conocer con eso. [Arellano ed., 2003: 64-65]

En su temprana obra festiva, Quevedo ejerce sus dotes de caricaturista. Vida de la Corte, que Astrana Marín data hacia 1599 y que Mérimée lleva hasta 1603-1604, traza en cuatro apartados un cuadro burlesco de las figuras o personajes arquetípicos cortesanos, paradigmas de la hipocresía, objetos del chiste y la denuncia. Los clasifica en naturales (cojos, concorvados, calvos...), artificiales (galanes o semicaballeros sin hacienda), lindas (figuras ligeramente esbozadas, una suerte de apéndice de las artificiales) y los valientes de embeleco. Quevedo sigue con un catálogo de flores o trampas de juego: gariteros o tahúres, estafadores y cornudos que actúan como personificación de la mentira. Las flores, por cuestiones de ritmo y enfoque, trascienden el modelo de descripción picaresca de Mateo Alemán.

En lo que concierne a su dimensión moral, podemos perfectamente emparentar las figuras de Quevedo con las del Antiguo Testamento y los Padres de la Iglesia. ${ }^{86}$ La amoralidad de las figurillas es aparente: su conducta es invertida, representativa de un mundo al revés de lo que debería ser. $^{87}$

En un tono deliberadamente festivo y ceñido a la breve extensión característica del género entremesil, nuestro autor cultivó el denominado

\footnotetext{
${ }^{86}$ Véase el estudio de S. López Poza [1992].

${ }^{87}$ En ello somos conscientes de discrepar con algunas facciones de la crítica, empecinadas en considerar el entremés como un género amoral, en el que impera el desorden, la reyerta y la batahola. Cfr. C. Sabor de Cortázar [1987: 154].
} 
"entremés de figuras", cuyo auge se extiende a partir de la segunda década del siglo XVII. A partir de dicho periodo, el argumento del entremés se debilita para dar lugar al desfile de personajes estereotipados.

Los oficios y estados tipifican la descripción de vicios y virtudes. Quevedo, tal y como indicaría en su España defendida, bebe de modelos inmarcesibles como la Celestina y el Lazarillo, de los que los entremeses Diego Moreno y La vieja Muñatones aparecen impregnados.

También es destacable la influencia de los Caracteres de Teofrasto en la galería de retratos quevedescos. ${ }^{88}$ Don Francisco, sin embargo, se diferencia de Teofrasto en el énfasis descriptivo, cuya textura o trama matiza mediante recursos implícitamente manieristas: equívocos, imágenes, hipérboles y la técnica impresionista de descuartizar el cuerpo y descomponerlo en posturas y actitudes.

De manera similar a como operaba Arcimboldo (1530-1593) en sus composiciones pictóricas, ${ }^{89}$ Quevedo muestra la escisión de un todo

${ }^{88}$ La obra de Teofrasto fue impresa y latinizada por Pirkheimer (1527) y también traducida por Casaubon (1592). El tributo en Quevedo al autor clásico fue, con todo, menor que el de Ben Jonson y la Bruyère. Quevedo únicamente imitó a Teofrastro en la proyección del hombre urbano sobre el telón de la sátira y el cuadro costumbrista. No obstante, así nacieron las figuras que aparecen descritas en Vida de la Corte, hecho que autoriza a Asensio [1965:183] para calificar a nuestro autor de "Teofrasto del hampa cortesana". ${ }^{\square}$ No en vano, filólogos como Alfonso de Palencia (1490) ${ }^{\square}$ en su Universal vocabulario y Rodrigo Fernández de Santa Ella en su Vocabularium ecclesiasticum (1550) equipararon carácter a figura.

${ }^{89}$ Véase M. Levisi [1968:217-235], donde establece una correlación entre las figuras compuestas en Arcimboldo y Quevedo. Véase también el estudio de F. Würtenberger [1964] que alude a la práctica manierista del "despedazamiento" (Zerstükkelung) y la 
orgánico perpetrada por la corrupción de lo mundano. Sus mecanismos descriptivos consisten en la yuxtaposición de rasgos aislados, se fragmentan en "pequeñas imágenes independientes en las que cobra gran relieve la expresividad de los gestos y de las actitudes, o la enumeración de la vestimenta." ${ }^{90} \mathrm{El}$ desfile de tipos es natural en la obra satírica de nuestro autor: así sucede en los Sueños, La fortuna con seso o El discurso de todos los diablos.

No podemos desdeñar la etimología de la palabra figura: ésta procede del verbo latino fingere, esto es, "fingir". Explicaría la vinculación entre máscara y figura que encontramos en la Premática de Aranceles generales:

los que, llevando máscara de matachines o semejantes figuras, van por de dentro de ellas haciendo gestos como si real y verdaderamente les pareciese que son vistos hacerlos por de fuera, no lo siendo; y [con los que], [contrahaciendo] o cortando con algunas malas tijeras o trabajando con otro algún instrumento, tuercen la boca o sacan la lengua o hacen visajes tales. [Arellano ed., 2003: 45]

Esta proximidad permite relacionar el muestrario de figuras falsas con la tradición carnavalesca, como comentaremos a propósito de Los refranes del viejo celoso. El teatro breve a menudo se inspira en sus "fiestas de locos", los precarios reyes del gallo y el lúdico intercambio entre el príncipe y el mendigo. $^{91}$

\footnotetext{
"desmedida reificación" (Verdinglichung) a propósito de la técnica compositiva de Arcimboldo. Cfr. Asensio [1965:190].

${ }^{90}$ Cfr. M. Romanos [1982: 910].

${ }^{91}$ Tal y como lo ha planteado E. Cros [1975] a propósito del Buscón.
} 
Quevedo esboza una gran variedad de personajes, oficios y costumbres morales. Los dispone en secuencias deshilvanadas y los ubica en una sucesión lineal como la de los bajorrelieves. Así los descubriremos en el entremés costumbrista de La venta y en el juicio moral del entremés de $E l$ zurdo alanceador.

\section{UNA VISITA DE LOS CHISTES}

El segundo argumento de Los refranes del viejo celoso consiste en otorgar realidad corporal a tipos imaginarios o figurillas folclóricas que son de uso común en el refranero y cancioncillas populares. Este asunto se inspira en el Sueño de la muerte (1621-1622), obra quevedesca cuya esencia queda plasmada en su título alternativo: La visita de los chistes. A medida que el vejete vaya aludiendo casualmente a ciertos personajes de la imaginería popular, estos comparecerán de mala gana para castigar al pedantón por su sabiduría de refranero.

El amante Rincón reaparece de mágico para encantar a Justa -nombre irónico- y juega a disfrazarse para mofarse del viejo marido cuando éste regresa a casa para descubrirlos in fraganti, en una situación de ecos bocaccianos. Encarna un personaje del folclore cada vez que el vejete lo menta en un refrán, a modo de mascarada, arremetiendo contra el anciano y reprendiéndole por su pedantería y malas acciones.

Así, desfilarán Calaínos, “de francés y a lo gracioso”; Villadiego, con las "calzas atacadas"; Juan de la Encina, "con ramas de encina cubierto"; Perico 
el de los Palotes, "cargado de ellos"; Maricastaña, disfrazada "de dueña", la dueña Quintañona, "con un rosario al cuello, con muletas"; el Rey que rabió, "amortajada la cara blanquizca"; Marta, con sus pollos; el Otro, discriminando "necedades, boberías"; el Rey Perico, criticando eruditos a la violeta; y Pero Grullo, harto de escuchar "estornudar basiliscos". Y todos arremeterán con matapecados contra el Viejo por haberlos nombrado.

Cuando el vejete alude al Rey Perico, éste aparece en un tribunal con las demás figurillas. El monarca imaginario encarga a Pero Grullo la condena del imputado por "hablador a lo antiguo". Cuando este desfile de personajes - precedente de la mojiganga- finaliza, Justa desaparece en compañía del Rey Perico (Rincón disfrazado) mientras el vejete es aporreado con el arcaico matapecados, instrumento carnavalesco consistente en una vejiga inflada rellena de piedras.

Bajo el influjo del teatro de títeres de cachiporra, son lugar común los finales con palos, que Quevedo condenó explícitamente en diversas ocasiones, también en el Sueño de la muerte. El matapecados estaba asociado al loco o al simple, se vinculaba a excéntricos personajes teatrales como los zanni de la comedia dell' arte. El vejiguero, mojigón, moharracho o botarga, como también se le denominaba, aparece ya mentado en $E l$ Quijote (II, 11) cuando Cervantes describe a los cómicos que van en el carro de Las cortes de la muerte. Este instrumento de jocoso escarnio sólo aparece en dos entremeses alguna vez atribuidos a Quevedo: Los refranes del viejo celoso y El hospital de los malcasados.

De los diez personajes folclóricos que aparecen en Los refranes del viejo celoso, nueve ya figuran en el Sueño de la muerte: todos excepto 
Maricastaña. Ambas obras coinciden en la apelación a santos imaginarios como recurso cómico derivado del teatro renacentista. La intervención de Juan del Encina es, además, muy similar. También hay diferencias: observamos un cambio en el orden de aparición de las figuras. El Rey que Rabió y el Rey Perico se desplazan hacia el final del entremés. Los parlamentos de estos y los de Pero Grullo y Calaínos son completamente distintos. La queja del Otro presenta una formulación nueva.

Los interlocutores de Los refranes del viejo celoso, salvo Perico el de los Palotes, reaparecen en el entremés de Las sombras, que se imprimió bajo la autoría de Quevedo en Entremeses nuevos, de diversos autores, para honesta recreación (Alcalá de Henares, 1643). ${ }^{92}$ Esta atribución fue aceptada durante mucho tiempo. Fernández Guerra, por ejemplo, lo considera auténtico, según queda plasmado en el Catálogo [1860] de Barrera y Leirado. Más adelante, E. Cotarelo y Mori [1911: lxxii] lo califica de "delicioso juguete" relacionado con La visita de los chistes.

\footnotetext{
${ }^{92}$ Sólo tras la aparición del supuesto autógrafo de Los refranes, tal y como nota Bergman [1975: 377], empiezan las incertidumbres. Así, Astrana Marín [1932: 555] dirá de Las sombras: "Esta obrita se ha reimpreso siempre entre las producciones genuinas de don Francisco; empero su estilo difiere tanto del de Quevedo, como concuerda (tiene todo su corte y sabor) con el de Quiñones de Benavente, plagiario constante de nuestro satírico". Después, en la línea de las pesquisas de esta autoridad quevedista, Armando Cotarelo [1945: 81] califica Las sombras de "arreglo de la segunda parte" de Los refranes, al igual que Guido Mancini [1955: 57], Felicidad Buendía [1965: 364] y Asensio [1965], que prescinde de analizarlo al considerarlo una mera refundición.
} 
Las sombras es un entremés estructuralmente más primitivo que Los refranes, cuya idea básica es la materialización de entes folclóricos. ${ }^{93}$ Respecto a su fuente principal, el Sueño de la muerte, varía la nómina, orden y parlamento de los personajes. Se prescinde del Marqués de Villena, Pero Grullo y Diego Moreno, figuras relevantes en el Sueño. Pocos segundos median entre la entrada y salida de Encina, la dueña Quintañona, don Diego de Noche y doña Fáfula. Se agrega el Bobo de Coria; personajes antes pasajeros como Maricastaña y Mata se imbrican con extensas disertaciones. El orden de aparición sólo se mantiene respecto al Rey que Rabió y el Rey Perico. Guarda similitudes relevantes con las quejas del Otro y el Rey que Rabió. Suprime, en cambio, el extenso parlamento de Juan del Encina y distribuye ideas centrales del mismo entre otros interlocutores como Calaínos, el Bobo de Coria y Maricastaña. Otras modificaciones relevantes se dan en la protesta de Villadiego y el discurso del Rey Perico, que poco tiene que ver con el del Sueño.

En Las sombras, la trama argumental se centra en un gracioso que, aquejado de la manía de citar frases proverbiales, es escarmentado por las mentadas figurillas de refrán. Éstas, por arte de magia, aparecen después de que su nombre sea pronunciado y lo aleccionan a base de "golpes, torniscones y sopapos". La obrilla, por lo tanto, elimina la interpretación política y metafísica del Sueño de la muerte, centrándose tan sólo en una doble sátira lingüística y social.

\footnotetext{
${ }^{93}$ Hannah Bergman [1975: 376-397] procede con un cotejo de ambos entremeses para llegar a conclusiones críticas determinantes.
} 
La relación entre Las sombras y Los refranes del viejo celoso no sólo se reduce a la dramatización de una fuente común en prosa. Coinciden en construir una sátira lingüística sobre el habla tópica mediante la encarnación de personajes folclóricos. ${ }^{94}$ No obstante, si bien el protagonista de Las sombras promete reformar sus costumbres, el matapecados es la manera abrupta de terminar Los refranes. La pronunciación del nombre como conjuro mágico confluye en ambas obrillas. Guardan notables similitudes la presentación del Rey Perico (sea en su trono -Las sombras- o en un tribunal -Los refranes-), la descripción de Calaínos y la identificación del artículo pronominal "las de Villadiego" con sus calzas.

Asumidas estas concordancias, nos preguntamos: ¿Qué entremés es anterior? Ni las fechas de impresión (Las sombras en 1643 y, Los refranes del viejo celoso, publicado por primera vez por Astrana Marín en 1932), ni las conjeturadas dataciones de composición ofrecen pistas suficientes. Sólo podemos comprobar la mayor sencillez argumental de Las sombras, pero, como señalaba Crosby [1967: 78], no constituye una prueba fehaciente. Ante semejante carencia de datos filológicos, Bergman desglosa una pista cronológica:

Las calzas atacadas fueron prohibidas por premática en septiembre de 1622. [...] La prohición tuvo efecto, según se puede comprobar por los retratos de la época. Por tan precisa alusión a la actualidad sugiero que Las sombras debió de escribirse muy poco después del Sueño, obra que el autor (a no ser Quevedo mismo) conocería por alguno de los manuscritos que tanta circulación tuvieron. [1975: 386]

\footnotetext{
${ }^{94}$ Cfr. Bergman [1975: 384-386].
} 
Por ello, como postula Bergman, tal vez Las sombras sea anterior a Los refranes y no una mera refundición o plagio, sino la dramatización de un texto satírico en prosa. Su inspiración en el Sueño de la muerte sería más inmediata y se daría en asuntos más nucleares, como la relación entre el desfile de personajes folclóricos con las artes mágicas del Nigromántico, que en Los Refranes se circunscribe solamente al ámbito doméstico de los malcasados y a la presentación como "mágico" de un amante pícaro.

Calderón en Las carnestolendas, entremés inspirado en Los refranes que compuso seguramente después de 1638, continuará este desfile entremesil de entes folclóricos. En el marco de las costumbres tradicionales del Carnaval, un anciano reprime a sus hijas vivarachas que pretenden celebrarlo con una comedia casera. El entremés incluye elementos de impacto escénico, como una burda comilona, una borrachera fingida que permite al galán llevarse a las hijas del viejo, el guiño al actor Antonio de Prado y a los tipos cómicos tradicionales del teatro (el vejete, el negro, el borracho) y, por último, una mojiganga con música y baile donde todos los personajes del entremés se metamorfosean en las aludidas figurillas del folclore: el Rey que Rabió, Marta, Perico el de los Palotes, Maricastaña, la Dama Quintañona y un Hermafrodita, una curiosa fusión de hombre y mujer. Los parlamentos de estos seres proverbiales, que el vejete llama "antiguallas", "sombras" y "fantasmas" no son referencias textuales de Los refranes ni Las sombras; el entremés sí que toma, en cambio, pasajes de La maestra de gracias de Luis Belmonte - escrito hacia 1635- y El borracho de Quiñones de Benavente -impreso en Jocosería (1645)-. 
También el entremés calderoniano Las jácaras, de notables semejanzas a Las sombras, pertenece al ciclo de entremeses derivados del Sueño de la mиеrte. El gracioso introduce varias personas en la morada del vejete para socorrer a su hija en el oscuro vicio de cantar jácaras. Cada vez que la joven empieza las letrillas de sus canciones, se materializan los rufianes más temibles. Calderón retoma la técnica de curar los vicios dando entidad corporal a los personajes de la fantasía popular.

En conclusión, como apunta Aurora Egido [1978:197] a propósito del Buscón, en los entremeses de Quevedo "el efecto visual del saltimbanqui debe producirlo la palabra sola, y Quevedo la maneja con la misma técnica con que manejaría un muñeco de guante." Los títeres entremesiles matan a la autoridad para renovarla: son reyes de Carnaval, coronados y sucesivamente destituidos de su efímero trono. ${ }^{95}$

\section{LA VENTA COMO ESCENARIO COSTUMBRISTA}

El entremés de La venta, que fue impreso como anónimo en la segunda parte de las comedias de Tirso de Molina, aparece compilado en Las tres musas últimas castellanas (1670) por Aldrete. El hecho de que el sobrino de Quevedo lo reconociera como auténtico es un factor que abona su autenticidad. A ello, debemos añadir la presencia de la jácara final, legítima

\footnotetext{
${ }^{95}$ Sobre la relación entre el carnaval y los entremeses de Quevedo, véase Alonso Hernández [1999] y [2001].
} 
de nuestro autor, que en el manuscrito evorense aparece con variantes de escaso valor.

La obrilla traza un cuadro costumbrista ${ }^{96}$ de las ventas españolas del siglo XVII, lugar común de la novela picaresca, a la par que instaura la alegoría del mesón del mundo. ${ }^{97}$ Venteros rapaces y hospederías precarias llegaron a constituir un tópico en la literatura.

La picaresca rebosa en escenas ambientadas en ventas, que son las universidades del mundo. Así lo ilustra la escena del mesón de Cantillana en el Guzmán de Alfarache (I, 6) y el capítulo intitulado "Del mesonero consejero" de La pícara Justina (I, 3). En el Buscón (I, 4) se alude a "la maldita venta de Viveros", entre Madrid y Alcalá, donde se hospedan Pablos y Diego. Hallamos una venta homónima en El rufián dichoso de

${ }^{96}$ Armando Cotarelo [1945:77] especifica que es una obrilla "contra los figoneros, mesoneros, hosteleros y demás congéneres, a los cuales nuestro autor hace arder en los Infiernos." Para Asensio [1965: 365], "La venta es la única pieza de Quevedo esencialmente costumbrista". Insisten en ello I. Arellano y C.C. García Valdés [2006: 347], que definen el entremés como "un cuadro de costumbres". Susana Hernández Araico [2004: 214], sin embargo, considera que reducir el entremés a una artimaña costumbrista es menospreciar el logro del artilugio dramático.

97 Así define el tópico Antonio Maravall [1986: 319] en su magna obra La cultura del barroco: "casa de locos, mesón del mundo, éste es una "profana hostería del hombre"; en el ir y venir de las gentes que se reúnen en una posada, en la brevedad de su paso por ella, en la variedad y confusión de cuantos pueblan aquélla, en las mentiras y engaños de que está llena, en su desorden, la imagen viene a ser muy convenientemente adecuada para darnos la versión del mundo en que nuestra existencia se contiene." 
Cervantes, situada en Toledo. ¿Y acaso no es célebre el mesón en el que ordenan caballero a Don Quijote (I, 2) $?^{98}$

La letrilla satírica 647, expone la metáfora del mundo como venta, donde sólo prospera el que roba a tiempo:

\footnotetext{
Toda la vida es hurtar, no es el ser ladrón afrenta, que como este mundo es venta, en él es propio robar. (vv. 1-4)
}

Curiosamente, al igual que en el entremés de La venta, este poema juega paronomásicamente con los apellidos Hurtado y Guevara (vv. 19 y 26). De igual modo, en el Sueño del infierno, subyace el tópico de la venta del mundo.

La venta del entremés de Quevedo queda de camino hacia Granada. ${ }^{99}$ Probablemente la Jácara de la venta (POC, 863), con su reiterativo estribillo ("¡Urruá, urruá, que en la venta está!"), podría haber acompañado a esta pieza de teatro breve en otro intervalo de alguna comedia. ${ }^{100}$

El trasfondo moral rebasa la anécdota mediante las canciones de la moza Grajal y la santurronería del ventero hipócrita, Corneja, "casamentero de estómagos y gatos". La animalización de los personajes está patente en sus

${ }^{98} \mathrm{Al}$ respecto, observa Huerta Calvo [1985: 163]: "El espacio de la venta viene a caracterizar numerosas obras literarias de los Siglos de Oro, y también diversos géneros asociados al cronotopo novelesco del camino: la novela picaresca, el Quijote, los entremeses."

${ }^{99}$ Según notan I. Arellano y C.C. García Valdés [2006: 347].

${ }^{100}$ Así lo postula S. Hernández Araico [2004: 215]. 
nombres. Al inicio del entremés, Grajal canta unas seguidillas en las que retrata la avaricia del vejete ventero. Corneja aparece con un rosario, objeto que utiliza Quevedo, como otros autores de su época, para caracterizar a los hipócritas: con la misma funcionalidad figura en La vieja Muñatones y en el Buscón [2005: 33]: "traía un rosario al cuello siempre, tan grande, que era más barato traer un haz de leña a cuestas".

La moza de la venta nota que el ventero "hasta el nombre le tiene/ de malas aves" (vv.4-5). La corneja era, de hecho, un ave que auguraba buena o mala suerte en función de si aparecía a la derecha o la izquierda del camino.

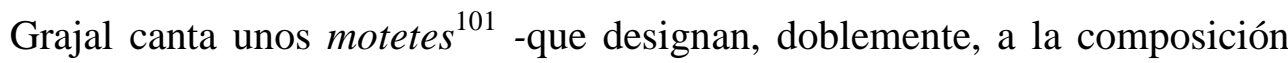
breve musical y al "denuesto, baldón"- en los que equipara a su amo a un gato, voz que en germanía aludía a los ladrones:

\footnotetext{
Quien temiere ratones

venga a esta casa,

donde el huésped los guisa

como los caza.

Zape aquí, zape allí, zape allá, que en la venta está, que en la venta está. (vv. 17-22)
}

Notamos cómo Quevedo recurre a la expresión zape, que servía para despachar a los gatos. El estribillo es similar al de la Jácara de la venta. El ventero rapaz envía a guisar a Grajal "lo que sabe mal a quien lo come" (v.

${ }^{101}$ Señala Armando Cotarelo [1945: 77]: "La moza de una venta descubre en sus cantos los gatuperios culinarios del ventero, adobador de gatos, burros, lechuzas, grajos, picazas, ratones y otras alimañas". 
37) y a "barrer las bolsas y regar el vino" (v.42). A lo que ella responde con un insulto todavía mayor:

\author{
Ventero murió mi padre, \\ Satanás se lo llevó \\ porque no piense el infierno \\ que hubo solo un mal ladrón. (v.44-47)
}

La alusión se ubica en la línea antisemita: el ventero podría ser uno de los ladrones que fueron crucificados con Jesucristo, esto es, un judío. A continuación, el prototípico estudiante de entremés con más hambre que dinero, ya recogido en La cueva de Salamanca de Cervantes, apoya a Grajal en la retahíla de pullas sobre los malos guisos de la venta. Corneja no acepta demasiado bien las críticas y envía al estudiante a hacer otros discursos en tierra de moros (v.77), a lo que el joven responde: ¿Eso pasa?/ Yo vendré a discurrir a aquesta casa" (vv. 78-79).

Grajal relata mordazmente la comida de unos arrieros. Su parlamento está repleto de alusiones tópicas contra ventas y venteros: harapos en vez de manteles, el vino pasado, aguado y avinagrado -vino de retorno- y una morcilla que más parece maleta que pellejo. Los comensales son minuciosamente descritos. Los arrieros ebrios, sentados "en arpón" (v. 103), como los protagonistas del romance Los borrachos (POC, 697, v. 9), comen con pose y gesto característico: el mascador de montante, con las dos manos (como se cogería el montante, la espada grande de esgrima utilizada para separar contendientes); el comedor con pujo, cuya expresión facial recuerda 
a los quehaceres de retrete, y el mascujador contemplativo, que come "con dedos clericales/ del cabritillo de diez y seis años" (v. 120).

La moza de la venta, a su vez, protagoniza una breve parodia amorosa, donde algunos tópicos del petrarquismo y del amor neoplatónico se someten a la voluntad lúdica de Quevedo. La moza es un "lindo torbellino" y "tempestad de hermosura" (vv. 151-152) y, por ello, su pretendiente, el mozo de mulas, invoca a Santa Bárbara, protectora de los rayos y tormentas. Los espirtos neoplatónicos de la mirada de la joven han impreso la imagen amada en el alma del galán ("me has clavado la vista hasta las cachas", v. 159). No obstante, los cabellos de Grajal, red amorosa en el tópico petrarquista, no dispone de más plazas ("no me cabe un alma más en mi cabello", v. 163), y menos para los requerimientos de un mozo de mulas, de escasas remuneraciones capitales ("no hay para alfileres/ en cuatro eternidades de alquileres", vv. 171-172). El final del galanteo es muy risible: los ojos de la dama son médicos en lo asesinos y Grajal, con escabroso humor negro, insinúa que con el cadáver del enamorado Corneja podrá aumentar los platos del menú:

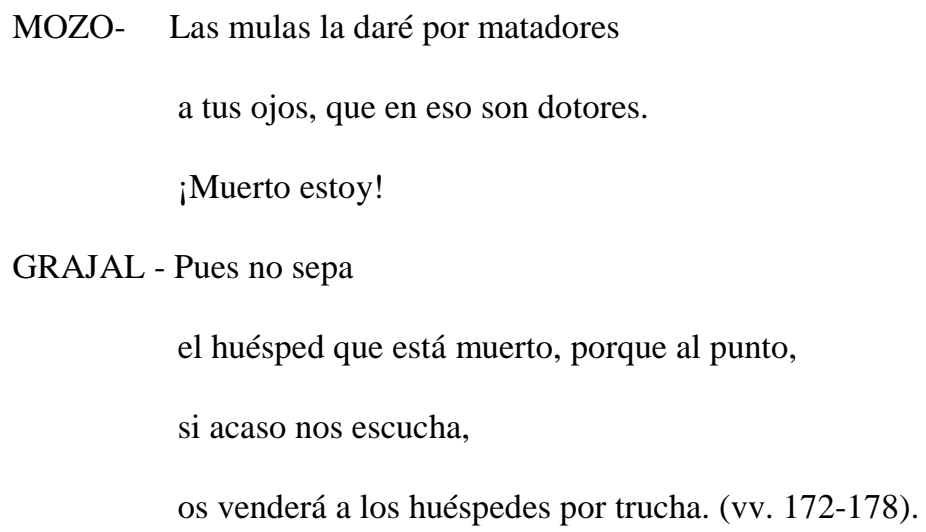


Pero analicemos otro pasaje del entremés. El estudiante protesta por lo caro del servicio, y moteja al ventero de sisón. Este chiste tópico ya estaba presente en el Sueño del infierno cuando Quevedo encuentra a Judas, despensero de los apóstoles y patrón de los mismos:

vi que la pena de los despenseros era que, como a Titio le come un buitre las entrañas, a ellos se las descarnaban dos aves que llaman sisones, y un diablo decía a voces de rato en rato:

-Sisones son despenseros y los despenseros sisones. [2003: I, 315]

El zipizape es inminente. La llegada de la compañía de Guevara en una "linda bocanada de personas" sirve para finalizar el juguete literario. La compañía marcha a Granada a representar una obra y se detiene de camino. Moza y ventero siguen siendo ladrones de sus clientes, como denotan los siguientes juegos con apellidos:

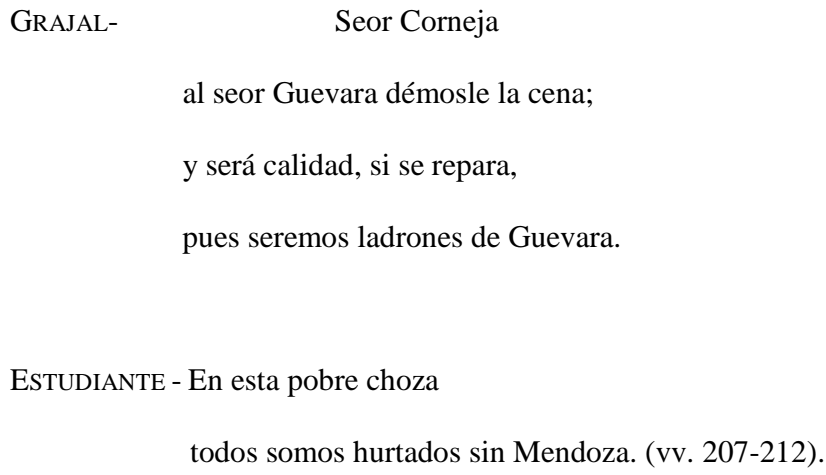

Como decíamos a propósito de la letrilla 647, Quevedo fue aficionado a estos juegos lingüísticos a partir de nombres propios, hecho que 
probablemente podía tener su eco gracioso en el contexto palaciego y en presencia de los personajes mentados. ${ }^{102}$

El desenlace de la obra con los primeros cuatro versos de la jácara de Quevedo Carta de la Perala a Lampuga, su bravo (POC, 851) sirve para evadir el final "a palos", criticado por Quevedo en multitud de ocasiones. El canto y la danza epigonal, prototípicos de los entremeses cervantinos, actúan como restauradores del orden.

\section{UN JUICIO MORAL REPRESENTADO EN EL ZURDO ALANCEADOR}

El zurdo alanceador, entremés que en el ms. de Évora mantiene el genuino título de Los enfadosos, avala su autenticidad en una carta autógrafa del Padre Andrés Mendo, escrita en Salamanca y con fecha del 20 de noviembre de 1632, en la que pregunta si esta obrilla está o no prohibida por la Inquisición.

La composición pertenece al subgénero de entremeses a examen, impulsado por El examinador Miser Palomo (1617) de Antonio Hurtado de Mendoza. En esta clase de piezas dramáticas, una serie de figuras con

${ }^{102}$ Para S. Hernández Araico [2004: 216]. la pulla podría encubrir una alusión a Vélez de Guevara: "El juego de palabras parece mofa de una especie de robo o hurto por parte de Guevara a Mendoza o a otros por parte de los cómicos, incluso de los espectadores. La alusión a "ladrón de Guevara", por otro lado, bien pudiera ser una burla hacia Vélez de Guevara mismo, ya que en las fiestas de Lerma y en alguna otra, Vélez de Guevara, además de dramaturgo, habría tenido que hacerlas de director de su comedia y quizá hasta de actor." 
defectos físicos y psíquicos desfilan ante un juez o examinador que los evalúa moralmente, como si se hallasen frente a un Juicio Final microcósmico.

El entremés presenta el juicio de una pareja de hombres y de mujeres. Estas figuras tipifican los vicios cortesanos: hallamos el caballero remedón don González, la celestinesca doña Lorenza, la pidona doña Luisa y el calvo Carasa. Con la enumeración de acciones y ademanes que ya ejerciera Teofrasto, Quevedo hace hincapié en el contraste entre los dos varones. Observamos cómo, en ocasiones, los personajes esbozados en las obras festivas no dramáticas de Quevedo se redondean en el entremés mediante una plástica amplificatio.

Las repercusiones del personaje celestinesco - en este caso doña Lorenza-, ya las hemos notado a propósito de los entremeses de La destreza, La ropavejera y La vieja Muñatones.

La manoseadora aparece retratada en el Libro de todas las cosas y otras muchas más, paródico tratado de fisonomía, adivinación y supersticiones. Este esbozo se desarrolla en el Buscón y luego se incorpora como minucia en el retrato de la mujer hermosa de El mundo por de dentro. ${ }^{103}$ Finalmente, estas descripciones se redifunden en el autorretrato de Luisa, pidona obsesiva que desfila junto con otros personajes en El zurdo alanceador:

\footnotetext{
Han dado en enfadarse unos mozuelos

destos que para el gasto me dan celos

de que yo saque a pasear mis manos
}

${ }^{103}$ Véase el análisis expositivo de estas prefiguraciones de la manoseadora en Asensio [1965: 191]. 


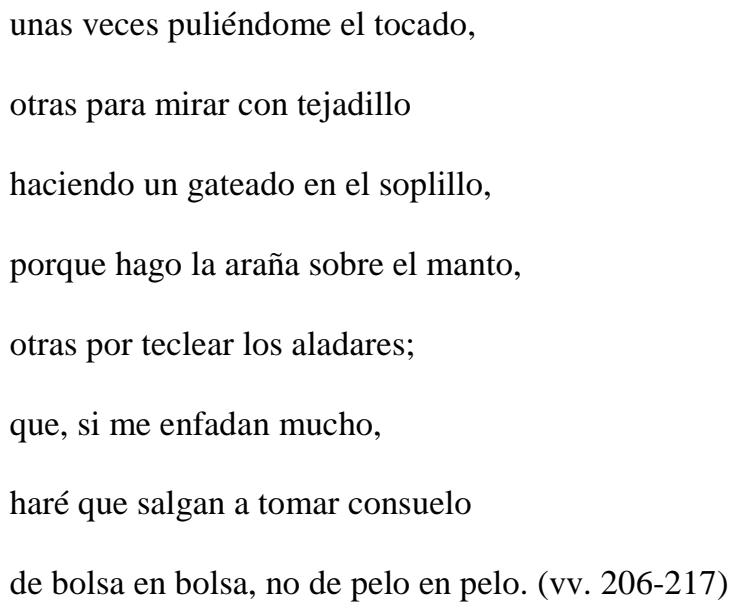

El semicaballero o falso aristócrata, caricatura común en la obra satírica de Quevedo, figura en El libro de todas las cosas como "toreador sin desgracia ni gasto" de "caballo prestado" y después se cifra en el retrato de Don González de El zurdo alanceador, que "caballerea" por la calle y tiene notables habilidades taurinas.

Carasa, que en un principio parece un personaje testigo del juicio, pasa a ser uno de los juzgados por su condición de calvo de "gorra perdurable" y "bonete sempiterno", porque no obedece a las reglas de cortesía de la sombrerada. ${ }^{104}$ Don González, en cambio, se deshace en saludos y halagos en el paseo madrileño a fin de ostentar amistades e influencias inexistentes.

El tópico de la calvicie concretado en la figura de Carasa entronca con el soneto burlesco Calvo que se disimula con no ser cortés (POC, 528), donde el hecho de no quitarse el sombrero también supondría una posible alusión a prácticas homosexuales. ${ }^{105}$ Este tipo de sátira, común en la cultura occidental - ya presente en el mimos falakrós de los griegos- prosigue en

${ }^{104}$ Sobre la relevancia de la sombrerada en usos cortesanos, véase Rodríguez Villa [1886: 92-93].

${ }^{105}$ Véase Rodrigo Cacho [2003: 265]. 
los endecasílabos de Calvo que no quiere encabellarse (POC, 527), donde, probablemente, "encabellarse" se relaciona con el coito -en este caso, en alusión al vello púbico- y se juega jocosamente con la palabra "Calvino", que reconvierte su significado de nombre propio para ser un mero diminutivo de "calvo". También en el romance Varios linajes de calvas $(P O C, 703)$ emerge la idea del calvo como hombre invertido, que ostenta un degradante paralelismo entre la cara y el trasero ("Háseme vuelto la cabeza nalga") y, a su vez, se especifica una tipología de calva mapamundi: "Hay calvas de mapamundi, /que con mil líneas se cruzan,/con zonas y paralelos/ de carreras que las surcan" (vv. 37-40). La misma represalia contra los calvos emerge en La fortuna con seso y la hora de todos [2003: II, 614]: “A los calvos se les huyeron las cabelleras con los sombreros en grupa y quedaron melones con bigotes, con una cortesía de memento homo".

La deshilvanada estructura de El zurdo alanceador consiste en una superposición de cuadros a través de los cuales se proyectan las figuras. Su logro es fundamentalmente lingüístico. ${ }^{106}$

Quevedo acuña el neologismo "encalvar", que quiere decir "casarse con un calvo". El matrimonio puede impregnar de palabras nuevas a los contrayentes. Como sucedía con el ya citado "enyernar" de El marido pantasma, don Francisco crea este neologismo mediante la prefijación " en" y la conversión del adjetivo sustantivado en verbo de la primera conjugación. Sucede algo similar en pasajes del Discurso de todos los

\footnotetext{
${ }^{106}$ Con todo, como ha señalado C. Sabor de Cortázar [1987: 165], en El zurdo alanceador "es la palabra la que crea realidad, el espacio escénico y sus personajes."
} 
diablos, donde los diablos "diablan" y las dueñas "dueñan". ${ }^{107}$ Siempre nos sorprende Quevedo, ávido prestidigitador del lenguaje, ventrílocuo y titiritero de los arquetipos de la humanidad.

${ }^{107}$ Como ya nota Asensio [1965: 240]. 


\section{V. ¿Miguel De Mussa o Miguel De Mulsa?}

\section{UNA HIPÓTESIS RAZONABLE}

El teatro es el género peor conservado del Siglo de Oro. Ya hemos señalado el lamentable estado en el que nos han llegado muchos de sus textos: algunos se destruían después de las representaciones, otros eran mal trascritos por copistas o memorillas y, los más, eran recortados y brutalmente intervenidos por oficiantes de la Inquisición.

El teatro, sobre todo su vertiente cómica, sufrió con creces la polémica que surgió sobre su licitud moral. Muchos escritores no lo consideraron a la hora de reconocer los hijos legítimos de su producción literaria. Lo corroboramos cuando releemos la lista de libros autorizados que don Francisco confecciona para que nadie sospeche de falsas atribuciones o ardides de libreros, en la que da prioridad a sus traducciones y obras teológico-morales. ${ }^{108}$

Muchas piezas dramáticas auriseculares se editaron bajo el anonimato o fueron firmadas con pseudónimos con la finalidad de proteger al autor de posibles represalias de la censura. Esta certeza, por el escaso corpus teatral que se ha conservado de Quevedo, me indujo a rastrear nuevas atribuciones tanteando obrillas que pudieran componerse bajo otro nombre.

Aureliano Fernández Guerra anotó en un manuscrito que pertenece al Institut del Teatre de Barcelona un listado de las obras teatrales que formaron parte de la Biblioteca de Osuna, entre cuyos propietarios destaca

\footnotetext{
${ }^{108}$ Véase Krzysztof Sliwa [2005: 790].
} 
particularmente Guzmán Pérez Girón, que había sido protector, amigo y confidente de Quevedo (que llegó a servirle en Italia, como ya hemos notado). Entre ellas, hay tres entremeses atribuidos a un tal Miguel de Mulsa: Las verdades del Zonzo, Entremesico del hurto del Nene y La Perendeca.

A raíz de este dato, nos preguntamos si el pretendido dramaturgo (de escasísima obra atribuida) pudiera ser en verdad el mismo que Miguel de Mussa, pseudónimo literario que enmascararía, según algunas hipótesis, a Quevedo durante su estancia en Valladolid.

\section{2. ¿UN PSEUDÓNIMO DE JUVENTUD?}

Discernir entre los pseudónimos que utilizó Quevedo es harto complicado, y más teniendo en cuenta con qué facilidad se deshacía de ellos. La crítica ha postulado que Quevedo utilizó el pseudónimo Miguel Mussa en su juventud para satirizar contra Góngora. ${ }^{109}$ Don Francisco lo utilizaría entre 1601 y 1605, durante su época vallisoletana (que coincidió con el traslado de la corte a Valladolid). ${ }^{110}$ Esta suposición se plantea por primera vez en un estudio de Miguel Artigas, Don Luis de Góngora y

${ }^{109}$ Cfr. Fernández Guerra [1897: 126-128], Astrana Marín [1932: 1097] y Antonio Carreira, en Criticón, 56 (1992: 7-20).

110 Según Blecua [1991: 581]. 
Argote. Biografía y estudio crítico [1925: 90], y se basa en el epígrafe de un manuscrito que fue de la propiedad de Foulché-Delbosc. ${ }^{111}$

Se cree que la letrilla burlesca que escribió Góngora sobre el Esgueva (“¿Qué lleva el señor Esgueva?”) originó una réplica habitualmente atribuida a Quevedo, quien se ocultaría bajo el pseudónimo de Miguel Mussa. Se trata del poema Ya que coplas componéis (POC, 826), cuya edición basa Blecua en el ms. 3917 de la $\mathrm{BNE}^{112}$ donde, por cierto, no figura ninguna alusión a Miguel Mussa. Para muchos gongoristas, que desconfían de la paternidad quevedesca de estas piezas, el contenido de estas décimas es soez y maldiciente. Baste la última para ilustrar esta poco elegante y escatológica arremetida contra Góngora:

\footnotetext{
Yo, por mí, no pongo duda

en que las coplas pasadas,

según están de cagadas,

las hicisteis con ayuda.

Más valdrá que tengáis muda

la lengua en las suciedades;

dejad las ventosidades:

mirad que sois en tal caso

albañal por do el Parnaso

purga sus bascosidades. (vv. 81-90)
}

${ }^{111}$ Concretamente, el VE, f. 110. Véase su edición de las Obras poéticas de don Luis de Góngora [1921: III, n 477].

${ }^{112}$ Véase la descripción de Pérez Cuenca [1997]. 
A esta réplica, Góngora escribiría las décimas de "Musa que sopla y no inspira." Este poema, para muchos, alude inequívocamente a Quevedo, lo satiriza por su actuación con unos criados del embajador francés.

Sea como fuere, en el catálogo de Simón Díaz [1992], la única entrada que aparece bajo el nombre de Miguel de Mussa es la de un soneto (POC, 614) que sólo documenta el ms. 3700 de la BNE. Este soneto burlesco recrea la temática de la niña pedigüeña, tópico satírico al que don Francisco fue aficionado, pero no aporta muchos más datos respecto de su autor, excepto que frecuenta la rima aguda.

Lo que parece certero es que Góngora identificó a Miguel de Mussa como uno de sus enemigos, y que lo relaciona con Quevedo. No hay, sin embargo, mucha más información sobre este pretendido pseudónimo literario. ${ }^{113}$ No obstante, nos parece harto sospechoso que, sobre los mismos

${ }^{113}$ Curiosamente, la investigación sobre este supuesto mote de juventud apenas cuenta con bibliografía particular. Hay, de hecho, más comento sobre este punto entre los destacados gongoristas. Robert Jammes [1994: 676-677] , de hecho, cuestiona la autoría de las poesías satíricas atribuidas a Quevedo contra Góngora, sobre todo las que van contra el Polifemo y Las Soledades y sugiere que algunos poemas tradicionalmente atribuidos a nuestro autor podrían ser en verdad artificio de González de Salas: "Me extraña que nadie ponga en duda la legitimidad de estas atribuciones, fundadas en la autoridad de un solo manuscrito: salvo una o dos excepciones, son poesías mal escritas, pesadas y totalmente desprovistas de gracia; se diría que el autor trató de disimular su falta de talento detrás de un cúmulo de groserías y ataques personales: todo esto- aunque pueda parecer quevedesco- no basta para hacer poesía de Quevedo.” 
años, existiera un poeta vallisoletano llamado Miguel Mulsa. ${ }^{114}$ Hay muchas similitudes gráficas entre uno y otro nombre, y más si recordamos la particular "s" alargada que aparece en la escritura del XVII, ya sea manuscrita o impresa. Fuera Mulsa o Mussa, creímos conveniente localizar esos documentos con el fin de estudiarlos y sacar conclusiones.

\section{Dos entremeses de Miguel de Mulsa}

Miguel de Mulsa aparece en el Catálogo [1860] de Barrera y Leirado, que le atribuye los mismos entremeses que aparecen en las notas de Aureliano Fernández Guerra. Cotarelo y Mori en su Colección de entremeses [1911: LXXII] dice:

A Miguel de Mulsa pertenecen el entremés Las verdades del Zonzo, autógrafo fechado en 1620, en la Biblioteca Nacional; es una graciosa invectiva contra la liviandad femenina; pero el Entremesico del hurto del Nene es un conjunto de despropósitos urdidos sólo para hacer reír; en realidad forman una mojiganga. Es también autógrafo.

Barrera atribuye a Mulsa un entremés de La Perendeca, que supone autógrafo, existente en la Biblioteca de Osuna. Pero como no ha pasado a la Biblioteca Nacional con los dos anteriores, como debía, es probable que sea error suyo y confusión con el que con más probabilidad se atribuye a Moreto en el tomo titulado Tardes apacibles (Madrid, 1663, 8º́, pág. 128).

${ }^{114}$ Dice Antonio Carreira [1998: 419] en nota a pie al respecto: "Como simple curiosidad, anotemos que un Miguel de Mulsa colabora en la Floresta Espiritual, del bachiller Mateo Fernández Navarro (Toledo: Thomás de Guzmán, que sea en gloria, 1613, f. 194).” 
En vista de esta información, nos encaminamos a la Biblioteca Nacional de Madrid, donde pudimos comprobar la ausencia del supuesto autógrafo de La Perendeca, que ha sido atribuido a Moreto por su versión impresa en Tardes apacibles. ${ }^{115}$ Asimismo, este entremés figura en el códice que fuera propiedad de Aureliano Fernández Guerra: en el ms. 61564 del Institut del Teatre de Barcelona, aparece ya atribuido a Moreto; este ejemplar de $L a$ Perendeca sí que está escrito con letra del siglo XVII y, en todo caso, no aparece en él bajo ningún concepto el nombre de Miguel de Mulsa.

Los otros dos entremeses atribuidos, El hurto del nene y Las verdades del Zonzo, todavía no están incluidos en el índice de manuscritos ni en la web de la BNE, ${ }^{116}$ pero gracias a Paz y Mélia [1937: nº1727 y 3763] logramos dar con sus signaturas:

1727- Hurto (El) del Nene

Entremés de Miguel de Mulsa

E. Cer. Válgante doce diablos por caballo.

A. Porque visten a costa de sus personas.

(5 hoj., $4^{\circ}$. Autógrafo y con firma. Tachada la fecha. Pasta. (O.)- 14.780. (p. 258)

3763- Verdades (Las) del Zonzo.

Entremés de Miguel de Mulsa

E. To. Tú de Bruto, mi bien, tú apazguatado.

A. pues a voces lo dicen los doce naipes.

115 Véase la edición de María-Luisa Lobato [2003].

${ }^{116}$ Seguramente esta labor ya estará consumada en el momento de publicación del presente trabajo, dado que actualmente hay un grupo de catalogadores que, coordinados por Pablo Moíño Sánchez, están llevando a cabo este trabajo tan necesario. 
Ambos entremeses, que parecen fruto de la misma pluma, son reputados por autógrafos en todos los catálogos. En la primera página aparece una fecha de composición: 1620. Están firmados por Miguel de Mulsa, pero la letra de la firma es harto distinta de la del texto, por lo que pensamos que probablemente no sean autógrafos como se cree. ¿Acaso el corpus textual tiene la letra de un escriba y la firma es del autor? Porque sí que hay similitud entre la firma de estas composiciones y letra de don Francisco de Quevedo.

Estos dos entremeses presentan, sin embargo, un importante inconveniente a la hora de formular una posible atribución a don Francisco: contienen versos hipermétricos y su rima no obedece a patrones homogéneos. ¿Podemos pensar que estos entremeses encajan perfectamente con un periodo de transición entre la escritura del entremés en prosa y la del entremés íntegramente en verso?¿Se puede atribuir la hipermétrica a un error de un mal copista?

Los tachones son del mismo autor, o del escriba al que le dicta el autor original. No hay rastros de censura en los textos. Eso indica que se tratan de manuscritos originales, hecho que explicaría el poco pulimento de algunas estrofas. Se trata de una primera fase de escritura. Los versos podrían limarse pero el asunto de los entremeses se comunica de manera clara y emergen algunos chispazos conceptistas. Pero analicémoslos uno a uno. Veamos confluencias y desavenencias entre estos dos entremeses y la obra satírica de Quevedo. 


\subsection{EL ENTREMESICO FAMOSO DE LAS VERDADES DEL ZONZO}

Como ya hemos señalado, esta composición figura en tres testimonios distintos: el antiquior es el ms. 15.269 de la BNE, con letra del siglo XVII y firmado por Miguel de Mulsa. Después, tenemos dos copias de este ejemplar en la Biblioteca del Institut del Teatre (Barcelona), el ms. 61.566, con la letra de Aureliano Fernández Guerra, ${ }^{117}$ y el ms. 46998, trascrito por Cotarelo y Mori. ${ }^{118}$ Ambos eruditos, sin duda, tenían preparadas sendas ediciones que jamás llegaron a publicarse.

De que este "entremesico" iba a ser representado, no cabe duda. Recordemos que así lo señalaba la apostilla "famoso". Entre los dramatis personae, además, figuran dos actores célebres de la época: María de Alcaraz, con el papel de Torbellina, y Cristóbal de León, que interpretaría al mismísimo Perotudo del Zonzo. Al final de la obrilla también se destaca a la actriz Isabel "sola": ¿Alude a la actriz y dama cortesana Isabel de Mendoza, conocida como "Isabelona"? No tenemos suficientes datos para esclarecerlo.

La temática del entremés abarca una retahíla de tópicos burlescos, muy frecuentes en la imaginería quevedesca: la liviandad femenina, la cornudería y el deseo de enviudar del malcasado. En lo que a esto último respecta, mantiene muchas similitudes con el entremés del Marido Pantasma. Como

${ }^{117}$ El ms. 61.566 pertenece a un volumen titulado Teatro antiguo Español: 92. BAI-ENTMOG. (mss. 61.528-61.568): "Entremeses, mojigangas, bailes, jácaras, manuscritos copias manuscritos originales u rápidos juicios, con noticias curiosas de puño y letra de D. Aureliano Fernández Guerra.”

118 El entremés está reencuadernado con otras piezas antiguas de teatro breve, en un volumen titulado Entremeses varios A-M. Varios autores. (mss. 46.965- 46.999). 
indican las notas autógrafas de Don Aureliano en el manuscrito de su propiedad:

El estilo de las verdades del Zonzo es muy parecido al de los entremeses de Cervantes (...). El argumento de la piececita tiene la índole de los rasgos de Quevedo. Cuadro importante para juzgar de la moralidad de aquella época.

De hecho, el ilustre quevedista indicará con un asterisco tres pasajes del entremés que le recuerdan a Cervantes: el uso de la expresión enterneraros (v. 78) con el significado de "hacer a uno cornudo", el pasaje del cortejo del mesonero a Torbellina (vv. 82-92) y la alusión al poder de los dineros, "que ablandan penas" (v. 113).

Cotarelo también incluyó unas anotaciones a lápiz en el borrador de la edición, que a todas luces tenía preparada para su Colección de loas, entremeses, jácaras y bailes (1911):

Buen entremés intencionado contra la liviandad femenina. Lo mismo en este que en el otro suyo titulado El hurto del nene no suele seguir Mulsa una norma regular en lo concerniente a la rima, a lo mejor abandona la consonante y escribe en verso libre para volver luego a tomar aquella cuando le parece.

Esta falta de regularidad métrica será, como veremos, uno de los inconvenientes a la hora de determinar la paternidad quevedesca del entremés.

La trama es la que sigue: Torbellina, pícara criada de mesón (un contexto que Quevedo había recreado en el entremés de La Venta), tiene una discusión conyugal con su marido, Perotudo del Zonzo, que aspira a ser 
"ladrón jubilado y recoleto" (v. 11). Éste le pide que le dé algo de dinero y, ante su negativa, le hiere con la daga. Alarmado por el escándalo, sale el mesonero, que reprende su conducta de malcasados y les obliga a darse un abrazo. El mesonero, sin embargo, desea a Torbellina, que cederá a su galanteo de buenas a primeras. Cuando Perotudo, escondido detrás de una cortina, sea espectador del cortejo, consciente de sus cuernos, encerrará a su mujer, la atará de pies y manos y le rapará la cabeza. Mientras le salen los cuernos, dictará a un Escribano sus "verdades": una enumeración de tópicos misóginos sobre el casamiento y la naturaleza de la mujer. Todo ello, hasta que alguien irrumpa en su discurso y le comunique la muerte de su esposa. Entonces saltará y, feliz de enviudar, se pondrá a bailar a ritmo de una canción.

Nos llama la atención, de entrada, el nombre del protagonista: Perotudo del Zonzo. Perotudo es el apelativo de un jaque famoso en la literatura hampesca. En la antología de Juan Hidalgo, el primer romance se llama Perotudo, y nos cuenta la vida de este rufián. En esta composición, Méndez, por cierto, aparece como una de las marcas (prostitutas) de su propiedad. Ello explica que el personaje reaparezca en la famosa jácara de Escarramán de Quevedo en los términos que siguen:

\footnotetext{
Sobre el pagar la patente

nos venimos a encontrar yo y Perotudo el de Burgos: acabóse la amistad.

Hizo en mi cabeza tantos un jarro, que fue orinal,
} 
y yo con medio cuchillo

le trinché medio quijar. (POC, 849 , vv. 41-48)

La relación del protagonista del entremés con el mundo rufianesco queda explícita en el entremés a través de algunas alusiones:

De valientes de viento me he librado

y quiero aquí, en estado más perfecto,

ser ladrón jubilado y recoleto. (vv. 9-11)

Torbellina, más que esposa, parece una marca. Ambos han decidido cambiar de vida, por ello la pícara empieza a trabajar de criada en un mesón. Él pretende vivir de su sueldo, y le exige el dinero a punta de daga:

Perotudo- Daca luego el dinero, o con la daga...

TORBELLINA- ¿Tú sabes lo que has dicho, gran perdido?

¿Daguita contra mí, que soy tu hacienda? (vv. 19-21)

Por otra parte, el adjetivo zonzo, según el Diccionario Etimológico de Corominas-Pascual, es un americanismo que se documenta por primera vez hacia la segunda década del siglo XVII y, por lo tanto, presenta una gran novedad en este entremés. Se utiliza con el mismo significado que tonto: alude a una persona sosa, lenta, sin gracia. Existe un entremés, titulado $E l$ rollo y atribuido a Luis de Belmonte Bermúdez, publicado por primera vez en el impreso en Entremeses nuеvos (Zaragoza, 1640), cuyo protagonista lleva el mismo nombre. Adelaida Cortijo Ocaña, en el estudio específico que dedica a esta obrilla, señala, al respecto: 
El entremés El Rollo se basa en una anécdota mínima. La Mujer, joven y atractiva, está casada con Zonzo, marido ignorante y bobalicón. Quiere salir a divertirse una noche de fiesta (¿de Carnaval?) para encontrarse con su enamorado. Ante la negativa del marido urde una treta para vengarse de él. Se llevará la cena al rollo de la villa. Su enamorado, el Barbero, se disfrazará de Rollo y así podrán encontrarse a salvo los dos amantes. La artimaña se complica cuando el vejete Guadarrama, que está enamorado de la Mujer, acude también al Rollo, aunque dispuesto a ahorcarse en él por despecho, pues la Mujer no corresponde a su amor. (...) Al fin el Zonzo echa a correr asustado y la mujer se deja caer en brazos del marido.

El tema general es el del engaño de las mujeres, de frecuente aparición en entremeses y heredero de las tradiciones de los fabliaux medievales. En él aparece la figura del marido burlado, ignorante y zafio: Zonzo, heredero de la figura de Diego Moreno en los dos entremeses de este título de Quevedo. [2005: 145]

El argumento de El rollo, en verdad, recuerda a Los refranes del viejo celoso en lo que atañe a la transmutación carnavalesca del amante de la Mujer. Asimismo, nos sorprenden las similitudes entre el Zonzo y Diego Moreno: ambos son personajes cornudos, si bien con un pequeño matiz. En tanto que Diego Moreno consiente la infidelidad de su mujer, el Zonzo de Belmonte Bermúdez opone resistencia, a pesar de que su corta inteligencia no le impide que sea burlado. Así es, por cierto, el protagonista del Entremesico de las Verdades del Zonzo:

\footnotetext{
que tengo miedo al coco de la honra

y para ser sufrido valgo poco. (vv. 106-107)
} 
Son profusas las alusiones a los cuernos a partir de la entrada en escena del mesonero:

\author{
Dios sea en mi cabeza, y en mis sienes \\ toda la Trenidad, porque casado \\ podré, sin ser moneda, ser cornado. (vv. 79-81)
}

El uso jocoso a la palabra cornado, como "moneda antigua de poco valor" y "cornudo", reaparece en algunos poemas de Quevedo:

\author{
El cura, que es Cornejo, escribió el nombre \\ con tintero de cuerno, y él le ha dado \\ un cornado, que es todo lo que pudo. (POC, 615, vv. 9-1)
}

¡Triste de tu velado, que, entre tanto doblón, se ve cornado! (POC, 623, vv. 31-32)

\title{
(...) que case con bendición
}

la blanca con el cornado, sin que venga dispensado

el parentesco de Roma, con su pan se lo coma. (POC, 645 , vv. 24-28)

\section{(...) y por tener un cornado}

casaron a este moreno. (POC, 698, vv. 31-32).

Otras referencias grotescas a los cuernos del Entremesico famoso de las verdades del Zonzo abarcan desde el uso burlesco de topónimos ("Sin ser de Toro, en Toro habré nacido!", v. 93), las comparaciones risibles (“y me duelen las sienes, como cuando/ le duelen las encías a algún niño", vv. 
123,124 ), metonimias curiosas ("No quepo por la puerta, que el cabello /se me ha vuelto de alambre", v. 129) y la creación idiomática ("enterneraros", v. 78).

Lingüísticamente, además, el texto abunda en recursos idiomáticos muy quevedescos: la incrustación burlesca y chocarrera de voces latinas ("Pues si en ella castigas morietur/ y en manos de ella mantienes perecetur.", vv. 2223) o el neologismo arbobolas, formado a través de la sincopación de dos lexemas:

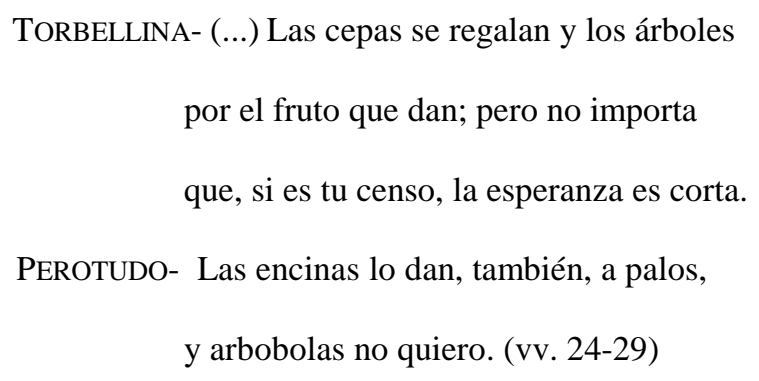

La obrilla aglutina otras obsesiones satíricas de Quevedo, como el deseo de enviudar del malcasado -presente en El marido pantasma-, la crítica misógina al matrimonio en el dictamen de las verdades del Zonzo al Escriba o la chanza contra las viejas. Asimismo, el baile final incluirá una burla a las damas de la Corte, muy en la línea del Niño y Peralvillo de Madrid:

\footnotetext{
Si te casas, Perico,

no sea en la Corte

porque van las doncellas

pagado el porte. (vv. 186-189)
} 
En las coplas finales, se citará a un personaje que protagoniza otros versos de nuestro autor, "un Pedro de Soria/ que es matasiete" (vv. 197,198):

Tu donaire es de la hampa,

tu mirar es de la hoja,

tus ojos en matar hombres

son dos Pericos de Soria. (POC, 860, vv. 77-80)

¡Quién vio a Perico de Soria,

sastre de vidas humanas,

matar con un agujón

más hombres que el beber agua! (POC, 865, vv.53-56)

En resumen, el Entremesico famoso de las verdades del Zonzo, por su fecha, ubicación, temática y confluencias con el resto de la obra satírica de Quevedo, podría ser del autor. No obstante, tenemos un gran inconveniente a la hora de cercionarnos de su paternidad: la hipermetría.

\subsection{EL ENTREMESICO DEL HURTO DEL NENE}

El ms. antiquior del Entremesico del Hurto del Nene (ms. 14.780 de la BNE), al igual que el anterior, tiene letra del siglo XVII y perteneció a la Biblioteca de Osuna. Se ha reputado por autógrafo pero diferimos de ello: la letra de la firma y la del corpus textual son harto distintas. 
El mentado testimonio también fue copiado por Aureliano Fernández Guerra y reencuadernado junto con otros entremeses pertenecientes a la Biblioteca de Osuna en un volumen titulado Teatro antiguo Español: 92. BAI-ENT-MOG. En la primera hoja contiene las siguientes anotaciones del erudito filólogo:

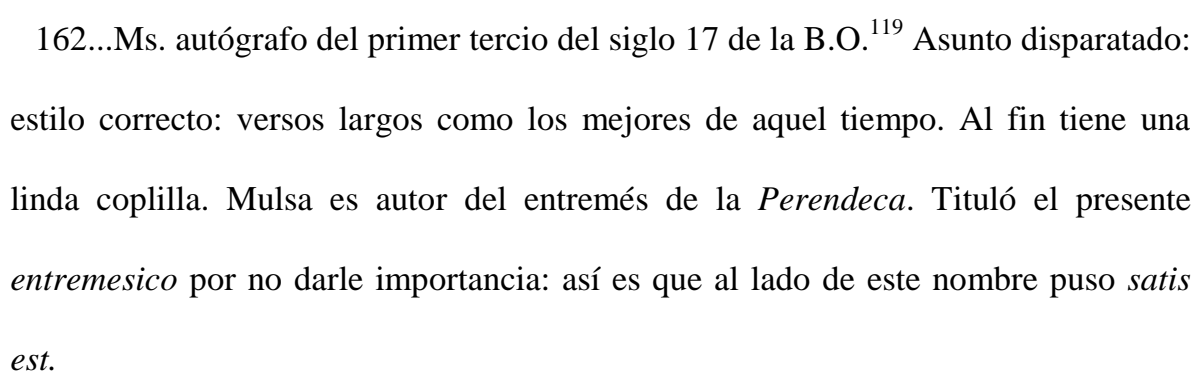

Cotarelo y Mori procedió de manera similar y copió de su puño y letra el mentado manuscrito. Esta copia está reencuadernada con otras piezas antiguas de teatro breve, en un volumen titulado Entremeses varios A-M. Varios autores. En la primera hoja, tiene las siguientes anotaciones de Cotarelo: “Conjunto de despropósitos unidos sólo para hacer reír. Es una verdadera mojiganga."

La obrilla versa sobre un asunto disparatado: la picardía de unos jayanes que quieren secuestrar a un bebé enorme y desgarbado, fruto de un embarazo prodigioso.

La escena se inicia con unos jaques muertos de hambre -Lanzón, Cermeño y Tarugo- que, hartos de naipes, alguaciles y fregonas, deciden raptar al Nene, una suerte de monstruo hijo de un mono, un oso o una palma que, según ellos, puede ser un buen partido como bufón del príncipe. La

119 B.O.: Biblioteca de Osuna. 
historia de este niño sobrenatural probablemente era la simiente de un cuento popular:

\author{
al fin, un monstruo, porque en una isla \\ de una tormenta que anegó una nave \\ arribó una mujer en una tabla \\ donde estuvo dos años regalada \\ de un monazo tan grande como un hombre. (vv. 42-46).
}

Más adelante, Tarugo recurrirá a otra narración para explicar el origen de esta criatura grotesca y peluda:

\author{
TARUGO- Este princeso que digo \\ (escucha, que hay que escuchar) \\ dicen que le parió una palma.
}

\author{
NotomiA- ¿Cómo le pudo engendrar? \\ TARUGO- Dicen que durmió con ella \\ una noche de San Blas \\ un oso y quedó preñada, \\ y no es patraña, es verdad, \\ que Dioscórides y Plinio \\ de este árbol y este animal \\ este gran secreto escriben \\ y, si lo leen, lo verán. (vv. 86-97)
}

Si bien no hemos localizado cuentos similares en las antologías al uso de

Soons [1976], Chevalier [1978] o Hernández Valcárcel [2002], los 
embarazos prodigiosos eran un tema bastante trillado en la literatura áurea, siendo noticia de algunos sorprendentes titulares de las Relaciones de Sucesos. ${ }^{120}$

La aparición del Nene es el motivo cómico por antonomasia del entremés. El aspecto de este personaje seguramente produjo la carcajada del público: barbudo y enorme, balbuciente y con babero, con una Comadre que cuenta a Notomia delicias de sus tragaderas pantagruélicas:

\author{
COMADRE- Anoche se cenó cincuenta rábanos \\ y un caldero de migas, y de vaca \\ siete manos fiambres.
}

Notomia- ¿ ¿Tanto engulle?

COMADRE- Ahora acaba de merendar tres panes, y un azumbre de miel, y medio queso, y luego le veréis con cuánta gracia entra pidiendo papa: ¡Ah, nene mío! (vv. 61-67)

Las tretas de los tres bravos para hacerse con este curioso ejemplar serán dignas de mojiganga. Primero, se harán pasar por lacayos del rey turco. Uno de ellos, Cermeño, disfrazado de preñada, amenazará con malparir si no le entregan a la criatura:

¡Mira que malparirá

esta turca que es su suegra! (vv. 113-114)

\footnotetext{
${ }^{120}$ Véase H. Ettinghausen [1995].
} 
Recordemos el motivo de la embarazada que amenaza con malparir si se le lleva la contraria es un recurso que Quevedo utiliza en la primera parte del entremés de Doña Bárbara y en el de Diego Moreno, bajo la expresión “¡Ay, Jesús, que estoy preñada y malpariré!” 121

Después, los truhanes se hacen pasar por músicos que desfilan en una comitiva. La Comadre gritará al ver que el Nene ha desaparecido de su lado. Los malhechores, de nuevo, fingiéndose astrólogos, simularán una ceremonia esotérica para su reaparición:

TARUGO-
Muestre y ponga
esa mano al Oriente uñas arriba,
y esotra garra, como que es araña,
la boca tuerza hacia el oído derecho
y diga guate guite y haga un bufe
(Diga ella lo que él dijere.)
y alce luego los ojos mientras miro
si los planetas la merienda acaban.
Ya Venus se retira con Saturno,
Marte pide un caballo y una pica,
y a metellos en paz el Sol se aplica. (vv. 185-194)

Sabemos que han sido varias las parodias quevedescas de la astrología, fundadas en un conocimiento profundo que tuvo el autor de la materia, adquirido, ante todo, durante su estancia en Italia. ${ }^{122}$ Los astrólogos desfilan, por ejemplo, entre los pecadores del Sueño del Infierno.

\footnotetext{
${ }^{121}$ Cfr. Arellano [1983: 11].

${ }^{122}$ Véase, al respecto, el estudio de A. Martinengo [1983].
} 
Finalmente, el Nene emergerá cantando y bailando una graciosa coplilla. Ésta recoge el famoso estribillo popular "Madrugabalo el aldeana,/ y ¡cómo lo madrugaba!", que procede de un antiguo villancico que recoge Correas en su Diccionario de refranes. También aparece en otras composiciones conocidas, como el Cancionero de Horozco ( $\left.\mathrm{n}^{\circ} 268\right)$, El villano en su rincón de Lope o el Cancionero de Jerónimo de Barrionuevo (BNE, ms. 3736). ${ }^{123}$

El lector del entremés puede notar algunas expresiones que encajarían con la imaginería quevedesca: a saber, los truhanes hastiados y sin dinero, en la escena inicial, presentan más enfado con los naipes que si fueran suegras (v. 14-15), reniegan sobre su hambre alguacilada (v. 16) y tienen de sastres las conciencias (v. 23). El Nene que pretenden raptar es hijo de una tal Lindona de Gazpirrio, mujer del extranjero Pierres Verga: recordemos que Quevedo había aludido jocosamente a un tal "Lope de Vergas" en su entremés de El niño y Peralvillo de Madrid.

Una última nota nos llama la atención: en el ms. original se indica que el entremés se escribe en Madrid, en la década de los años veinte. Por esa época, sabemos que Quevedo está instalado en la capital: el 23 de agosto de 1620, había comprado una casa en la calle del Niño, situada en el barrio de los comediantes.

${ }^{123}$ Véase Margit Frenk, Corpus de la antigua lírica popular hispánica: siglo XV a XVII. Madrid: Castalia, 1987, p. 527. Cfr. el artículo de José Manuel Pedrosa, "Flor de canciones tradicionales inéditas de los Siglos de Oro: el Cancionero de Jerónimo de Barrionuevo (BNM Ms. 3736) y otros manuscritos madrileños”, Revista de Filología Románica 11-12 (1994-1995). Servicio de Publicaciones. Univ. complutense. Madrid. También on-line: http://revistas.ucm.es/fll/0212999x/articulos/RFRM9495110309A.PDF 
¿Son suficientes estos datos para esclarecer la paternidad quevedesca? Porque de nuevo nos encontramos ante la desconcertante hipermetría. ¿Qué otro corpus atribuido a Miguel de Mulsa figura en los anaqueles de las bibliotecas?¿Puede ofrecernos esta información alguna que otra pista?

En el catálogo de Simón Díaz [1992], aparte de los dos entremeses que hemos analizado, se hace alusión a dos composiciones poéticas impresas atribuidas a Miguel de Mulsa: un romance y unas octavas. ${ }^{124}$ Estos dos poemas mediocres difícilmente son de la pluma de don Francisco. Tampoco guardan, sin embargo, demasiadas similitudes con el Entremesico de las

${ }^{124}$ El romance “Al nombre del niño grande...", incluido en dos antologías de temática espiritual, trata jocosamente la alabanza del niño Jesús. Sin embargo, hay varios motivos que nos inducen a rechazar la autoría quevedesca de este romance. En primer lugar, chirrían algunos versos esdrújulos que no acaban de cuadrar la rima (“del famoso Aristóteles”, v.2; o "del templo echó con cólera", v.16) y vocablos que jamás utilizó don Francisco en su poesía ("gentalla", "agradación”). Por otra parte, las fechas no acaban de cuadrar. Según Blecua, Quevedo utilizaría el pseudónimo Miguel de Mussa durante su época vallisoletana y en 1613, cuando se imprime por primera vez el poema en la Floresta espiritual, se encontraba en Sicilia, sirviendo al Duque de Osuna. Don Francisco también estaba en Italia, por cierto, cuando se publicaron en Valladolid las octavas atribuidas a Miguel de Mulsa. Es extraño que Quevedo compusiera una alabanza a Santa Teresa, con claras resonancias gongorinas, en fechas tan tardías. Como máxime, la podía haber loado en su juventud y por respeto a la vida conventual de su hermana María, que fallece en Madrid el 16 de abril de 1605, probablemente víctima de la epidemia del tifus. Recordemos que, con motivo de los enfrentamientos que suscitó el patronazgo de Santiago, don Francisco puso en peligro su estatus político al mantener su oposición a la elección de santa Teresa como patrona de España en favor de Santiago Apóstol, fundamentalmente a través de dos memoriales redactados en 1628: el Memorial en defensa de Santiago, escrito en febrero, y Su espada por Santiago, redactada en mayo. 
verdades del Zonzo ni el Entremesico del Hurto del Nene, que hacen alarde de mayor ingenio.

En resumen, la hipermetría de los dos entremeses analizados es un factor contrario para asegurar su paternidad quevedesca. Pero, sea como fuere, ambas obras nunca han sido editadas en la actualidad, a pesar de que Aureliano Fernández Guerra y Cotarelo Mori tenían sendas publicaciones preparadas.

Salimos de este capítulo con cierto sabor agridulce: no proclamamos con certeza absoluta, como Asensio, dos entremeses inéditos de Quevedo. Desvelamos, sin embargo, dos obrillas sin editar que, por su calidad, son dignas de un estudio filológico más profundo. Lanzamos, como mucho, un pequeño interrogante para futuros investigadores: ¿Es Miguel de Mulsa o Miguel de Mussa un pseudónimo literario de Quevedo o acaso es el nombre de un esporádico y poco prolífico autor vallisoletano?

En todo caso, si Miguel de Mussa fuera el nombre de un escritor de Valladolid, muchos gongoristas tendrían razón a la hora de sospechar sobre la paternidad quevedesca de algunas arremetidas contra Góngora de escasa calidad literaria. 
- 432 - 
Capítulo VI

DOS COMEDIAS BURLESCAS ATRIBUIDAS A QUEVEDO 
- 434 - 


\section{RASGOS DE LA COMEDIA BURLESCA}

La comedia burlesca -también llamada de disparates $\mathrm{y}$, con menor frecuencia, de chanzas o de chistes- es un subgénero dramático aurisecular que debe desmarcarse tanto de la comedia al uso como del entremés. Es una pieza dramática, por lo general, breve. Constituye una parodia carnavalesca de asuntos del teatro serio o tópicos del romancero. ${ }^{1}$

Se han conservado cerca de medio centenar de comedias burlescas, la mitad de ellas anónimas. La nómina es asombrosamente escasa, hecho que confiere valor a las dos comedias burlescas atribuidas a Quevedo conservadas actualmente, que no figuran, por cierto, en el índice bibliográfico de Fréderic Serralta [1980]. ${ }^{2}$ Recordemos, por otra parte, que se había consignado la paternidad quevedesca de la comedia burlesca de $L a$ Infanta Palancona, mal llamada "entremés" en sus testimonios impresos pero que, según anota la crítica actual, es obra del autor Félix Persio Bertiso. $^{3}$

${ }^{1}$ Los estudios de este género recuperado actualmente por la crítica filológica -sobre todo a raíz de las bases asentadas por Fréderic Serralta [1980] en "La comedia burlesca, datos y orientaciones"- son todavía escasos. El GRISO (Grupo de Investigación de Siglo de Oro de la Universidad de Navarra) se ha propuesto la edición completa de estas obrillas bajo el título Comedias burlescas del Siglo de Oro [1999].

2 Recordemos, asimismo, que existen dos comedias de chanzas inspiradas en el más célebre jaque quevedesco: el Escarramán de Moreto y Los celos de Escarramán, anónima.

3 Así lo señala Montaner [1951:103]: "Esta graciosa obrilla, atribuida por Don Aureliano Fernández Guerra y La Barrera a Quevedo, que la compuso según ellos escudado en el pseudónimo de Félix Persio Bertiso es realmente del poeta Don Félix Persio Bertiso". Cotarelo [1911: LXXIII] y Rosa Navarro [2003:101-115] corroboran esta falsa atribución. 
Era frecuente la adopción del título de una obra seria como rótulo de las comedias burlescas. Así sucede con las dos que analizaremos a lo largo de este capítulo. El premio de la hermosura, homónima a una comedia de Lope, parodia asuntos mitológicos y ovidianos. ${ }^{4}$ ¡Qué villano es el amor!, cuyo título coincide con un verso del romance $A$ los amores del rey Rodrigo y la Cava, trata cómicamente motivos del romancero.

La mayoría de las comedias burlescas cuentan con un respaldo tradicional que transgredir. De estructura desorganizada, predomina el triunfo de la incoherencia total, el non sens, el absurdo risible del mundo al revés, que tiene su precedente en las fiestas saturnales de la Antigua Roma.

Las raíces del subgénero se asientan sobre la fusión de dos corrientes: la poesía de disparates - propia de la cultura cómica popular- y la comedia nueva - perteneciente a un ámbito culto-. Existen concomitancias entre la comedia de disparates y la poesía burlesca, concretamente la escatológica, como el uso de la rima aguda (que predomina en algunos poemas de Quevedo). ${ }^{5}$

La presencia musical es, además, muy relevante en estas obrillas. Melodía y ritmo son elementos semiológicos muy efectivos en la representación. Su inclusión deliberada en las comedias burlescas está muy relacionada con la melomanía de Felipe IV.

Rosa Navarro ha publicado poesía inédita de este autor (Sevilla : Diputación Provincial, 1983).

4 Esta comedia burlesca ha sido editada por Alberto Rodríguez [2003].

5 Durante el siglo XVII, por influjo italianizante, la rima aguda fue rechazada en la poesía seria. Véase Francisco Rico, "El destierro del verso agudo", en Homenaje a José Manuel Blecua, Madrid, Gredos, 1983, pp. 525-551. 
¿En qué circunstancias y con qué público solían representarse las comedias de chanzas? Se interpretaban en fiestas cómicas tradicionales, como el Carnestolendas o la verbena de San Juan. También se han documentado en el teatro escolar. Se las adscribe a un público culto de ámbito cortesano, porque no se sabe que tuvieran éxito entre los espectadores de corrales. No obstante, consideramos que este tipo de público menos instruido probablemente tenía conocimientos folclóricos suficientes como para disfrutar de estas representaciones.

El premio de la hermosura y ¡Qué villano es el amor! son dos comedias burlescas que aparecían atribuidas a Quevedo en el Catálogo de Barrera y Leirado [1860]. Más adelante, Astrana Marín desestimó su paternidad aduciendo argumentos poco sólidos. El erudito, en todo caso, era una sola persona que hizo un prodigioso trabajo de compilación y edición de documentos. Lo sorprendente es que la crítica posterior no haya sabido desasirse de sus estimaciones, que han sido acatadas con dogmática y acientífica reverencia. ¿Acaso no es hora de librarnos de esta falacia de autoridad? 


\section{EL PREMIO DE LA HERMOSURA}

Luciano fue el poeta latino capaz de ensalzar a una mosca y de denigrar a los dioses ${ }^{6}$ Aunque en la Vida de San Pablo Apóstol don Francisco le tildó de "descarado ateísta", también compuso sonetos al mosquito y describió una carnavalesca procesión de dioses grecolatinos al inicio de La fortuna con seso y la hora de todos, cuyas fuentes del marco mitológico son las lucianescas Asamblea de los dioses, Zeus trágico, Zeus catequizado y Timón o el misántropo. Los coetáneos de Quevedo notaron este influjo, ya presente en literatos erasmistas. ${ }^{7}$

Pero, ¿a qué viene esta correlación entre don Francisco y Luciano? La comedia burlesca que nos ocupa, El premio de la hermosura, está atribuida a Quevedo y constituye una parodia mitológica. Ambos -el ateo nihilista del siglo II d.C. y el teólogo aurisecular- denunciaron las contradicciones entre las apariencias y la realidad, la vanidad del mundo y la hipocresía social; pero también las pasiones y servidumbres de los dioses paganos, tan

${ }^{6}$ Hay un poema de Quevedo A una mujer flaca $(P O C, 620)$ que dice precisamente así: "Cantó la pulga Ovidio, honor romano,/ y la mosca Luciano [...]" (vv. 7-8). Luciano tenía todos los números para fascinar a Salvador Dalí, cuyo Elogio al insecto publicó como apéndice de su Diario de un genio. Pero, como decía Francisco Umbral [1980: 11], relacionar a Quevedo con el surrealismo "es ejercicio dominical y vago que conviene a la pereza y la brillantez de cualquier ensayista con la tensión baja”.

${ }^{7}$ Véase, acerca del legado de Luciano de Samosata en la literatura española entre 1500 y 1700 el estudio de Vives Coll [1959]. 
viciosos como los mortales. ${ }^{8}$ El teatro satírico de Quevedo, escaso en acotaciones, parece próximo a los diálogos burlescos del escéptico romano. ${ }^{9}$

La comedia satírica en un acto titulada El premio de la hermosura es un claro ejemplo de descripción paródica de las deidades olímpicas. El ms. 15288 de la BNE es el único testimonio manuscrito. La autoría quevedesca de esta obrilla fue desestimada por un débil argumento: en la XVI parte de las comedias de Lope de Vega figura una tragicomedia de título homónimo, cuyo texto, sin embargo, no coincide con la obra que nos ocupa. Así, quedan desautorizadas las poco rigurosas pesquisas de atribución que ha realizado la crítica, que no ha revisado la mentada confusión de Astrana Marín [1932:26].

La comedia lopesca, según una Relación anónima, fue representada durante una fiesta que ofreció el rey viudo don Felipe III, en el parque del Duque de Lerma, el 3 de noviembre de 1614. La única coincidencia temática que guarda con la obra atribuida a Quevedo, con un enfoque y protagonistas distintos, es el motivo del juicio mitológico sobre la dama más bella, esta vez oficiado por Cupido y otorgado a la ninfa Aurora. También

${ }^{8}$ Luciano, además de dejar su huella en la bocacciana Genealogía de los dioses paganos, tuvo influjo directo en algunas de las más celebres obras mitológicas del siglo XVII: la Filosofía secreta de Pérez de Moya y el Teatro de los dioses de la gentilidad de Baltasar de Victoria. Cfr. López Gutiérrez [2002: 200].

9 Como nota Margherita Morreale, Luciano “declamaba sus composiciones en voz alta, llenando así el hueco que había creado en la vida helénica la desaparición del teatro. Nadie podría regatearle el mérito de haber realizado una feliz unión entre el Diálogo y la Comedia." [2004: 224]. 
encontramos una breve alusión al juicio de Paris, cuya función no trasciende la del recurso retórico ornamental:

\author{
(...) que le pusieron a Paris \\ el juicio en contingencia, \\ con más beldad que vio en Troya, \\ en Venus, Juno y Minerva. [1990: III, 1502]
}

Este asunto, aquí citado de paso, será el motivo principal de la comedia burlesca atribuida a Quevedo, que parece una parodia del fin de fiesta Fábula de juicio de Paris, ${ }^{10}$ si bien no se conservan datos sobre su representación.

No olvidemos, sin embargo, que el entremés del Rufián viudo de Cervantes también incluye una leve parodia del juicio de Paris, donde la Repulida, la Pizpita y la Mostrenca pugnan como pretendientas de Trampagos. ${ }^{11}$ Este mismo motivo se trataría más adelante en el baile $E l$ juicio de Paris de Antonio Zamora y la mojiganga La manzana, atribuida a León Merchante. $^{12}$

\footnotetext{
${ }^{10}$ Este fin de fiesta se compuso para la comedia calderoniana El golfo de las sirenas. Se halla en la BNE, ms. 4085. Cfr. Alberto Rodríguez [2003:366].

${ }^{11}$ Las fuentes del motivo clásico tienen sus raíces legendarias en la Guerra de Troya. Homero lo menta de pasada en la Ilíada (XXIV, 25-30) como elemento mítico y familiar. Más tarde, es desarrollado en las Ciprias, una composición perdida que pertenece al ciclo troyano, de la que tan sólo se conservan fragmentos. Ovidio, en las Heroidas (XVI) narra in extenso el juicio de Paris, al igual que Higinio en sus Fábulas (XCII). No obstante, entre todas las fuentes, nos es particularmente próxima la de Luciano, que imagina la escena en sus Diálogos de los dioses (XX).

${ }^{12}$ Cfr. Alberto Rodríguez [2003: 366].
} 
En El premio de la hermosura subyace la descripción burlesca de los dioses mitológicos mediante la técnica del spoudaiogélion. Este mecanismo característico de la sátira menipea entremezclaba registros cultos y vulgares, y en El premio de la hermosura se concreta en una estilización de la lengua de germanía. El tema mitológico asoma en el romance quevedesco Encarece la hermosura de una moza con varios ejemplos, y aventajándola a todos (POC, 682):

\author{
Paris el catarribera \\ que en Ida juzgó a las diosas \\ y dio a Venus la manzana, \\ viendo a Palas en pelota, \\ si te viera, de su pomo, \\ a nadie diera chichota, \\ que a las otras le tirara \\ y a ti te le diera sola. (vv. 277-284).
}

El premio de la hermosura, al igual que ¡Qué villano es el amor! se inicia con el canto de unos músicos, que describen a Júpiter borracho. Éste danzará al son de las coplas en un jocoso baile en el que se dobla, se endereza, da traspieses y vomita (vv. 1-28).

La conducta del padre del Olimpo es la que censura el dios Momo en La asamblea de los dioses de Luciano [1981-1992: III, 201-202], que acusa a Zeus de haberse contaminado de las costumbres de los mortales y de haberse metamorfoseado en vano para capturar sus caprichosos amores. Quevedo, por cierto, se burlaría de las metamorfosis del dios en el poema 682 (vv. 189- 224). 
Este desautorizado Júpiter es el que encabeza La fortuna con seso [2003:

II, 577-579], que aparece como "hecho de hieles", desgañitado y dado a poner "los gritos en la tierra, porque ponerlos en el cielo, donde asiste, no era encarecimiento a propósito".

Quevedo, por cierto, en el prólogo a sus Sueños también mentará a Júpiter a propósito del asno Sileno que le ayudó en su lucha contra los gigantes:

Y guárdense no les suceda a los tales lo que al asno de Sileno, que puso Júpiter entre las estrellas, que por ser ellas tan resplandecientes y claras y él auribus magnis, como advirtió Luciano, descubrió más su disforme fealdad con grande infamia. [2003: I, 207].

En todo caso, se nos retrata a un jerarca pagano que enseña con "su mal ejemplo peores costumbres", como en el Sueño del juicio final, donde este dios emerge del siguiente modo:

vestido de sí mismo, hermoso para los unos y enojado para los otros, el sol y las estrellas colgando de la boca, el viento tullido y mudo, el agua recostada en sus orillas, suspensa la tierra temerosa en sus hijos. [2003: I, 220].

El patriarca duerme la borrachera en un banco, dado que "los sueños dice Homero que son de Júpiter y que él los envía”, como dice Quevedo en el inicio de El sueño del juicio final [2003: I, 209]. Su efebo Ganímedes se acuesta con él, aunque temeroso de sus zorrerías. Tras ello, unas voces despertarán al joven: son las de Venus, Palas y Juno, las tres bellas diosas insistentes en poseer la manzana. La acotación del texto no puede ser más 
cómica, dado que "las tres porfían sobre llevar una fuente de plata con una manzana, pera o pepino de oro”. ¿Una pera o pepino de oro en vez de la manzana?. ${ }^{13}$ La indiferencia ante el aspecto del "premio de la hermosura" incentiva la fuerza cómica del texto dramático.

Mientras Júpiter anda en goliárdicas ensoñaciones sobre el vino, siendo de "muy buena cepa" como el hombre de Sigüenza que inaugura el Cuento de cuentos [2003: I, 44], las tres diosas deciden que él será el juez de su hermosura. A lo que Ganímedes responde que "este caso/ requiere un juez muy despierto,/ y está Júpiter roncando” (vv. 50-52).

Las tres diosas piden al soberano del Olimpo que juzgue su hermosura. Pero él declara no encontrarse en su mejor momento, discurso que remata con un vómito:

\author{
Porque ha de decir \\ quien me la vea en la mano \\ y con vómitos, que todo, \\ peras y vino lo trago. (vv. 69-72)
}

A pesar de que in vino, veritas, Júpiter no es el mejor discernidor. Ante la incertidumbre general, Ganímedes propone que el premio de la belleza se eche a suertes, y Venus protesta por lo de "la ventura de la fea" (v. 81), porque ella es "pasmo de hermosura" (vv. 100-101). Es la misma diosa que en La Fortuna con seso aparece descrita así:

${ }^{13}$ En ¡Qué villano es el amor! hallamos una escena cómica en la que moros y cristianos se van juntos al campo de cacería y comilona y, entre otros manjares, se darán un "hartazgo de pepinos" (v. 391). Más alusiones a los pepinos en POC, 735 (v. 53), 761 (v.43), 770 (v.52), 857 (v. 56). 
haciendo rechinar los coluros con el ruedo del guardainfante, empalagando de faldas a las cinco zonas, a medio afeitar la jeta y el moño que la encorozaba de pelambre la cholla, no bien escaquetado por la prisa. [2003: II, 582]

Palas se encara a Venus aduciendo que "el carro de la hermosura/ todas sabemos untarlo" (vv. 109-110), en alusión a los afeites femeninos. Quevedo, como es bien sabido, satirizó contra los maquillajes. ${ }^{14}$ Don Francisco aspiraba a un ideal de belleza natural, espontánea, como transmite en su romance Retirado de la Corte responde a la carta de un médico (POC, 711):

\author{
Buenas son estas sayazas \\ y estas faldas de cilicio, \\ donde es el gusto más fácil \\ si el deleite menos rico. \\ Las caras saben a caras, \\ los besos saben a hocicos: \\ que besar labios con cera
}

\begin{abstract}
${ }^{14}$ En La fortuna con seso [2003. I, 599], las mujeres afeitadas aparecen junto con los boticarios, gangosos y teñidos como homólogos de la basura, que disfrazan la fealdad con los cosméticos. En el Sueño del infierno [I, 2003: 313] dice a propósito de ello un diablo: "Muchas veces pensáis que gozáis mujeres de otro y no pasáis el adulterio de la cáscara". Estos comportamientos engañosos, enmascaradores de la realidad y símbolos de la hipocresía humana, eran el argumento central de los discursos misóginos grecolatinos clásicos y patrísticos, presentes en epigramas de la Antología griega (XI,68, por ejemplo), Marcial (IV, 93; VI, 93; VII, 13; VIII, 33 y IX, 37) y Juvenal (sátira VI, vv. 460-511) u obras morales como La perfecta casada de Fray Luis (capítulo XI). Cfr. I. Arellano [1984:
\end{abstract} $52-53]$. 
Júpiter, como marca la pauta mitológica, decide llamar a Paris a través del reclamo de un instrumento. El joven acude ipso-facto y, de entrada, cree conveniente que el premio sea para las tres. Éstas no parecen satisfechas con la resolución, por lo que las insta a ver sus gracias. Cada una hará una intervención ingeniosa. La primera será Venus, que satirizará a las feas:

\author{
Para apetecer las feas \\ hermosas han de juzgarse, \\ mucho de píldora tiene \\ quien ha de menester disfraces. \\ Quien a las feas se inclina \\ se califica de orate \\ porque solamente un loco \\ puede apoyar fealdades. \\ Decir que son entendidas \\ es decir un disparate, \\ porque en ellas, ¿cómo puede \\ un buen parecer hallarse? (vv. 154-165)
}

La primera estrofa del romance hace alusión al uso de afeites de las mujeres feas, su belleza disfrazada y engañosa, el equívoco de su apariencia. La segunda apela a la locura como única explicación del amor hacia la fealdad. ${ }^{15}$ En la tercera, Venus ridiculiza el tópico de que las feas son más

${ }^{15}$ Quevedo, como hombre de su tiempo, concibió el amor y la belleza en términos neoplatónicos. En El erótico [1991: 130-131], Plutarco considera que, como dijo Parménides, "Eros es el más antiguo de los trabajos de Afrodita”. Así lo expresa Marsilio 
sabias o entendidas que las mujeres hermosas. Quevedo también disertó satíricamente sobre el dilema entre escoger a una dama culta y fea u otra necia y bella. Así sucede en el romance 740, donde se antepone el placer físico al gozo de orden intelectual:

En vez de una cara hermosa, una noche y una tarde, ¿qué gusto darán a un hombre dos cláusulas elegantes?

¿Qué gracia puede tener mujer con fondos en fraile, que de sermones y chismes sus razonamientos hace?

Quien deja lindas por necias y busca feas que hablen, por sabias coma las zorras, por simples deje las aves.

Filósofos amarillos con barbas de colegiales, o duende dama pretenda, que se escuche y no se halle.

Échese luego a dormir entre bártulos y abades, y amanecerá abrazado de Zenón y de Cleantes;

Ficino [2001: 14-15], en nombre de todos los filósofos: "Cuando decimos amor, entended deseo de belleza. Porque ésta es la definición de amor en todos los filósofos. La belleza es una cierta gracia, que principalmente y la mayoría de las veces nace en la armonía del mayor número de cosas." 
que yo, para mi traer,

en tanto que argumentaren

los cultos con sus arpías,

algo buscaré que palpe.

El tema de la preferencia de la belleza física a la intelectual era común en el discurso popular, que quedó reflejado en cuentos tradicionales y entremeses, como La cueva de Salamanca de Cervantes. ${ }^{16}$ No olvidemos el argumento de La culta latiniparla, catecisma de vocablos para instruir a las mujeres cultas y hembrilatinas, donde Quevedo satiriza contra la pedantería de las mujeres culteranas. El contraste entre mujeres feas y hermosas también puede traslucirse en el siguiente fragmento del Alguacil endemoniado:

- ¿De cuáles se condenan más, feas o hermosas?

- Feas -dijo al instante- seis veces más, porque los pecados para cometerlos no es menester más que admitirlos, y las hermosas, que hallan tantos que las satisfagan el apetito carnal, hártanse y arrepiéntense, pero las feas, como no hallan a nadie, allá se nos van en ayunas y con la misma hambre rogando a los hombres, y después que se usan ojinegras y cariaguileñas hierve el infierno en blancas y rubias y en viejas más que en todo, que de envidia de las mozas, obstinadas, expiran gruñiendo. [2003: I, 269-270]

Tras la intervención de Venus, es el turno de Juno, que describe peyorativamente a las mujeres blancas, bajo el juego conceptista que

${ }^{16}$ También en El jardín de Venus se asientan algunos precedentes de la poesía quevedesca, así como en la Sátira VI de Juvenal, donde se arremete contra las mujeres cultas y habladoras. Cfr. Alzieu, Jammes, Lissorgues [1984: 15]. 
identifica el adjetivo con la moneda de vellón, cuya valía era inferior a la del maravedí:

\author{
Las que por blancas se estiman \\ tengan, tengan, no se ensanchen \\ que la más blanca, los niños \\ saben que un cuarto no vale. \\ Como las blancas son bobas, \\ juzgan favor el desaire, \\ ya naturaleza estiman \\ el que en blanco las dejase. \\ El color las desvanece \\ sin que ninguna repare \\ que no juzga de colores \\ Amor, como ciego nace. \\ Y para que no se engríen \\ blancas y negras ya saben \\ que en el juego de las damas \\ corren parejas iguales. (vv. 170-185)
}

Juno y Venus han sostenido un duelo verbal, cimentado en ingeniosas argumentaciones, muy del gusto de Quevedo. Juno insiste en el tópico de las mujeres blancas como ignorantes, aduce que el amor no juzga colores porque es ciego y emplea una elegante metáfora alusiva al juego de las damas, donde blancas y negras están al mismo nivel. Don Francisco había reflexionado sobre estos asuntos en su Premática que ha de guardar las hermanitas del pecar, hechas por el fiel de las putas: 
Mujer ojinegra o pelinegra, vale un escudo por ser la pimienta del vicio, si es de día; y si es de noche, porque con lo oscuro pierde algo de la vista más que las blancas, se le quite un real [...]. Mujer blanca y rubia, para de camino y por necesidad, vale veinte y cuatro maravedíes y un pan. Y mandamos que ellas ni las cantimploras ni los abanicos no se usen sino el verano, por ser frías y buenas para el tiempo. [1993: 302-303]

El elogio de las damas negras se reservará para la versión del Cantar de los cantares de Salomón (POC, 198: 61-84), donde Quevedo dedica ¡cuatro estrofas! para justificar la hermosura de una mujer de tez morena, notable amplificatio del pasaje bíblico.

Y si Juno y Venus han razonado satíricamente sobre belleza y sabiduría como virtudes femeninas, ¿qué papel queda reservado a Palas? La diosa optará por la acción y danzará con Paris un divertido fandango inspirado por Tersícore, la musa del baile. Pero, finalmente, Paris, conforme marcan las fuentes, dará la manzana a Venus, tal y como ilustra el famoso cuadro de Rubens.

Como conclusión, podemos aducir que esta bella y picante comedia burlesca, El premio de la hermosura, abunda en confluencias verbales y estilísticas con la obra satírica de Quevedo, según hemos cotejado. Heredera de la tradición lucianesca, participa de la parodia de las deidades olímpicas a partir de una jocosa versión del juicio de Paris. Sátira misógina sobre los ardides de la belleza femenina, esta obra versa sobre asuntos cómicos quevedescos como el uso de afeites o el debate sobre la superioridad de las mujeres blancas o negras. La calidad literaria de la obrilla, así como su frescura y fluidez verbal, hacen de esta pieza un gracioso juguete literario que debe ser rescatado del olvido. 


\section{III. ¿QUÉ VILLANO ES EL AMOR!}

¿Qué villano es el amor! es una comedia satírica en un acto que ya figuraba en el Catálogo [1860] de Barrera y Leirado dentro del corpus de piezas dramáticas de Quevedo. Actualmente se han conservado dos manuscritos: el ms. 15.070 de la BNE y el ms. 47.184 de la Biblioteca del Institut del Teatre, que constituye a todas luces una copia del testimonio de la BNE, de puño y letra de Cotarelo y Mori.

Los criterios de desestimación de la obra son contradictorios e insuficientes. Astrana Marín [1932: 26] y Cotalero Valledor [1945:69-70] únicamente se centran en el hecho de que el manuscrito antiquior sea del siglo XVIII para calificar la comedia de obra espuria. Sin embargo, unas cuartillas manuscritas anotadas por Emilio Cotarelo en la portada del segundo testimonio corroboran datos que nos han impulsado a incluir esta obra dentro del corpus dramático atribuido a Quevedo:

\footnotetext{
No es entremés sino un fragmento de una comedia burlesca. Por los equívocos y retruécanos puede muy bien ser de Quevedo. Que pertenece al siglo XVII no cabe duda. Menciona al Conde de Castilla. Debe faltar mucho, pues aun no se adivina un enredo, ni figuran $\mathrm{D}^{\mathrm{a}}$ Ava ni la mora Abdumele. (f.1v)
}

El argumento principal de desestimación de la obra queda en entredicho. Creemos, con Cotarelo y Mori, que la comedia que nos ocupa pertenece al siglo XVII: así lo revela su estilo, el vaciado de fuentes y las referencias históricas y literarias. 
En el ms. 324 de la Biblioteca de la Universidad de Coimbra, ${ }^{17}$ cuyas grafías pertenecen indiscutiblemente a nuestro Siglo de Oro, junto con los poemas de Quevedo que consultó Blecua para su magna edición de la Poesía original completa, encontramos un romance titulado A los amores del Rey Don Rodrigo y la Cava, que tal vez se le pasara por alto porque aparece anónimo. ${ }^{18}$ Ya puede el lector imaginar mi sorpresa, cuando leyendo la hermosa composición, rebosante de erotismo y ardor, llegué a la siguiente estrofa, que justifica el título de la comedia burlesca que nos ocupa:

\author{
De verse de un rey gozada \\ quedó la niña entonada \\ mas fuerza será que amanse \\ cuando mueve su rigor, \\ ¡qué villano es el amor! \\ líbrenos Dios que se canse. (v. 246)
}

Nos preguntamos, vista la evidente relación entre este romance y la comedia burlesca, si ambos se representaron en una misma ocasión o si

\footnotetext{
${ }^{17}$ Fue de suma ayuda encontrar en la Biblioteca Nacional de Lisboa el catálogo de Manuscritos quevedianos en las Bibliotecas portuguesas de Miranda [1988. 87], la cual increpaba -aunque olvidando a Eugenio Asensio, quizá- cómo "hasta ahora, en sus investigaciones, los quevedistas se han desinteresado casi por completo de las bibliotecas portuguesas, olvidando quizás que, entre 1580 y 1640, la Corona de Portugal estuvo unida a la de España."

${ }^{18}$ A pesar de que en un estudio próximo nos centraremos en jácaras, loas y bailes de Quevedo, hemos decidido publicar esta jácara junto con los demás textos inéditos.
} 
acaso el romance constituye el referente de parodia la obrilla. Pero los datos de los que disponemos no son suficientes para solventar estas cuestiones. Por ello nos remitimos a analizar la comedia de chanzas en busca de confluencias temáticas y lingüísticas con el resto de la obra de nuestro autor.

¿Qué villano es el amor! constituye una parodia de las gestas y cruzadas de Fernán González, el primer conde de Castilla, ante todo presentes en el romancero y en el anónimo Poema de Fernán González del Mester de Clerecía. ${ }^{19}$ Este personaje ya aparecía en el romance de Quevedo Pavura de los condes de Carrión (POC, 764), que Crosby cree posterior a 1612, año en que Juan de Escobar publica en Alcalá su Romancero e historial del (...) Cid Ruy Diaz de Vivar. ${ }^{20}$

El núcleo argumental de la comedia burlesca es la concordia carnavalesca entre moros y cristianos representada en una apacible cacería conjunta. Dice Quevedo en El Buscón [2005: 129] que "no hay autor que no

${ }^{19}$ Acerca del romancero de Fernán González, véase Menéndez Pidal [1899. 1: 429-507]. Consúltese, asimismo, el primer canto del anónimo Cantar de Rodrigo [1972: 39-43], donde se narran a la manera juglaresca las hazañas de Fernán González.

${ }^{20}$ En este poema, nuestro autor urde una chanza contra los míticos héroes nacionales, donde se cifran algunos tan aclamados como el Cid y Fernán González. Éste último, espantado por el león que aparece en la mítica escena que denostaba la cobardía de los Infantes de Carrión en el Poema del mío Cid, retrata su propio pavor: "El menor, Fernán González,/ detrás de un escaño a gatas,/por esconderse, abrumó/ sus costillas con las tablas." (vv. 33-36) Unos versos más adelante, de nuevo se lo encuentran ovillado, temeroso ante la fiera, envuelto en su capa ("bohemio"). De entrada nos llama atención la alusión al "ovillo", que emergerá en un refrán popular cantado por los músicos de la comedia que nos ocupa ("Por el hilo se saca el ovillo"): "Y remeciendo el escaño,/ a Fernán González hallan/ devanado en su bohemio,/ hecho ovillo en la botarga." (vv. 61-64). 
escriba comedias, ni representante que no haga su farsa de moros y cristianos". La comedia burlesca ;Qué villano es el amor!, cuyo texto nos ha llegado inacabado, habría tenido muy buena cabida en las célebres Fiestas de Moros y Cristianos ${ }^{21}$ que, sobre todo desde la expulsión de los moriscos de España en 1609, se celebran hasta nuestros días en diversos pueblos españoles. ${ }^{22}$ Este tipo de rituales festivos, exaltadores de la religión católica, constituyen un rejuvenecido y fogoso rescoldo de la cultura popular. ${ }^{23} \mathrm{La}$

${ }^{21}$ Sobre el influjo de los motivos moriscos de la literatura española aurisecular, consúltense Carrasco Urgoiti [1956] y López Baralt [1985].

${ }^{22}$ El discurso explícito de estas celebraciones transmite el poder de la religión oficial. Se inspiran en las cruzadas del siglo XI. El rey Felipe II los convirtió en emblema de sus representaciones palaciegas y durante el siglo XVII fueron cultivados por los más preclaros ingenios. Tales fiestas durante el Siglo de Oro abundaban en representaciones jocosas en las que los participantes se dividían en dos bandos, moros y cristianos, caracterizados con vestimentas del medievo, para rememorar la Reconquista. Florecieron como subgénero teatral en comedias para corrales y autos sacramentales auriseculares, con aportaciones de autores como Lope de Vega, Tirso de Molina, Cervantes, Cubillo de Aragón, Felipe Godínez, Mira de Amescua, Pedro Rosete y Calderón de la Barca. Además, fueron incluidos en las procesiones callejeras del Corpus Christi, donde eran habituales las danzas de moros y cristianos con palos o espadas. Cfr. Demetrio E. Brisset Martín [2001], antropólogo de la Universidad de Málaga.

${ }^{23}$ El teatro de dicha temática, cultivado por Juan de la Cueva y Cervantes, a pesar de ser prelopista, según nota Agustín de Rojas en su "Loa de la comedia" ", apenas ha sido estudiado, y menos aún en su vertiente burlesca. El tema morisco, fecundo en la literatura del siglo XVII, ha sido objeto ante todo de estudios centrados en novelas y el romancero. C.C. García Valdés [1998: 121]. 
comedia burlesca, por cierto, solía incurrir en el juego de unir dos religiones incompatibles, sobre todo el islamismo y el catolicismo. ${ }^{24}$

¡Qué villano es el amor! retoma como personajes a la Infanta Doña Urraca (segunda esposa del Conde), si bien la retrata en una grotesca escena de cortejo, y un repertorio de célebres moros, de los cuales sólo vemos a Fatimán en escena. Abdumele y la Cava, como señalaba Emilio Cotarelo en la citada anotación manuscrita, no llegan a intervenir en la comedia inacabada. Asimismo, el privado del Conde se parece al Sancho cervantino, del que es tocayo. ¿Representa al monarca Sancho I? En este caso, más que probable, los roles jerárquicos, en un desliz tópico del mundo al revés, quedarían intercambiados. ${ }^{25}$ Esta nota de privanza es bastante quevedesca si nos atenemos la relevancia del valimiento en prácticamente todas las obras político-morales de don Francisco.

La comedia burlesca se inicia con la intervención de unos músicos que cantan al paño un romance que explica cómo "el Conde Fernán González/ victorias del moro quiso" e "infelizmente murió" (vv. 6 y 9). Como sucede en el entremés de Los refranes del viejo celoso, el personaje mítico se

${ }^{24}$ Así ocurre en la anónima de tres ingenios El Hamete de Toledo; La renegada de Valladolid de Francisco Antonio de Monteser, Antonio de Solís y Diego de Silva; o la anónima El rey Alfonso el de la mano horadada. A propósito de este motivo, es sumamente clarificadora la lectura del artículo de Fréderic Serralta [1980] "La religión en la comedia burlesca del siglo XVII".

${ }^{25}$ La explicación a esta inversión de papeles nos la ofrece la siguiente nota de H. Salvador Martínez [1991: 14]: “de los cuatro reyes de León que ocuparon el trono en vida de Fernán González, quedaron reducidos a uno: Sancho I el Craso, el más odioso y ridículo de todos ellos por su deformidad física y por haber ido a buscar remedio a Córdoba. Indicio seguro de que este rey era ya el antihéroe elegido por los juglares en su versión épica perdida." 
materializa tras la pronunciación de su nombre propio: emerge como una suerte de fantasmagoría invocada por el romance popular.

Fernán González, junto con su privado Sancho, despierta de su ensueño legendario. Está algo molesto por la burla de las cancioncillas que llevan su sello histórico. El gracioso privado le recomienda que recobre la paciencia perdida con una misa a San Antonio, unas lavativas y un puchero limpio. Los músicos retoman su cantarela con el fastidioso estribillo y el Conde los empuja a empellones para que no prosigan. Ellos se justifican alegando que son meros peleles de la letra impresa. Este argumento templa al Conde que, con vanidad y orgullo, reafirma sus proezas, dado que "quien sustituye en la fama/ la vida, mal ha podido morir infeliz, pues ya/ se inmortaliza en los siglos" (vv. 39-42)

Fernán González aduce con sorna que no es lo mismo una muerte gloriosa que una muerte con credo: sus hazañas le inmortalizan en la fama, al revés que lo que procura el fallecimiento en suplicio de pícaros y ahorcados. ${ }^{26}$ Dicha afirmación pone en evidencia al Conde, un embravecido miles gloriosus, y contradice el tópico horaciano de la muerte que iguala a reyes y pordioseros.

El Conde, en una paródica fórmula juglaresca, pide a los músicos que escuchen "con los oídos" (v.60) su versión de los hechos. Empieza

\footnotetext{
${ }^{26}$ Acerca de las ejecuciones públicas, véase el parecer de Quevedo en una carta cuyo destinatario se ignora (se barajan las posibilidades del presidente de Castilla don Francisco de Contreras o a Gaspar de Guzmán, gran canciller y Conde-Duque de Olivares), compuesta el 9 de julio de 1624. Cfr. Krzysztof Sliwa [2005: 362].
} 
aludiendo a su padre Garci Fernández, que en verdad se llamaba Gonzalo, ${ }^{27}$ y hace un guiño al espectador de la época al indicar que no ha de "traer al cuello/ la cláusula del bautismo"(vv. 65-66): la autojustificación se debe a que los romances juglarescos solían dar a los héroes orígenes ilegítimos. Fernán González, por lo tanto, se muestra graciosamente dubitativo ante su origen bastardo. Explica, en fin, que su padre había tenido pendencias con los moros y cómo, paradójicamente, promueve una guerra preventiva. ${ }^{28}$

En este punto se despliega una ingeniosa sátira armada de equívocos conceptistas contra los acontecimientos bélicos. El nutrido ejército está constituido por "falsos amigos": artilleros para que mueran a tiros, pordioseros de San Antón como "bocas de fuego" y "diez mil niños de teta" para la infantería. Luego carga tres burros con prostitutas, a lo que aduce Sancho que "para no faltar caballos/ lindísimo fue el arbitrio" (vv. 99-100). Leemos implícita la quevedesca identificación de la meretriz con la "mula de alquiler" (POC, 521, v.12). El ingenio va in crescendo.

El campo de batalla está revestido de boticarios que "mataban a puros botes" (v.105). Estos, junto con los barberos y médicos, son proverbialmente vituperados por Quevedo en sus oficios curativos. Según aparece en el Sueño del Juicio Final, el médico “como con el diablo tiene/

\footnotetext{
${ }^{27}$ La alusión es, por tanto, errónea. Garci Fernández fue el hijo de Fernán González, según narra el Cantar de Rodrigo: “Un hijo tenía el conde, Garci Fernández llamado” [1972: 43]. Los padres del Conde fueron Gonzalo Fernández y Muñadona o Muña. Cfr. H. Salvador Martínez [1991: 11].

${ }^{28}$ Nos resulta sumamente actual esa burla que hace el autor de la comedia acerca de las “guerras preventivas". Lamentablemente, la literatura suele ser una prueba irrefutable de los eternos retornos de la historia.
} 
con el boticario hecho/ pacto explícito de purgas" (POC, 735, vv.45-47). Los matasanos aparecen en el Sueño del infierno, donde se nos ofrece una detallada descripción del contenido de sus ungüentos mortíferos:

Estos tales boticarios, de la agua turbia, que no clara, hacen oro, y de los palos; oro hacen de las moscas, del estiércol; oro hacen de las arañas, de los alacranes y sapos, y oro hacen del papel, pues venden hasta el papel en que dan el ungüento. [2003: I, 308]. ${ }^{29}$

El ambiente bélico lo animan ante todo los soplones, "abanicos del infierno", que en El discurso de todos los diablos [2003: II, 491, 509] tienen la doble función de atizar el fuego y de acusar a los pecadores ante Lucifer.

La guerra que desencadenó el padre de Fernán González, según señala el grotesco personaje, "pareció día de Juicio" (v. 126) y ciertamente alberga semejanzas con el caótico Sueño quevedesco. Su padre "echó con todos los diablos/ número casi infinito de moros" (vv. 138-139), ante lo que Almanzor se da a la huida. Cuando el Conde lo alcanza, deja de darle muerte porque el fugitivo lo embauca con conceptos religiosos que no acaba de entender, como la excomunión. Decide, entonces, echar un sueño y, en cuanto cae dormido, aparecen emboscados dos tercios del ejército morisco tras unos espinos, todos ellos sastres, que bajo la consigna "tijeretas" le propician una paliza de muerte. Reconocemos la misma expresión aplicada a los sastres en el entremés del Niño y Peralvillo de Madrid, cuando Juan

\footnotetext{
${ }^{29}$ Para la figura del boticario y la tradición satírica véase Nolthing- Hauff [1974: 127-130] y Chevalier [1982: 41-42].
} 
Francés describe la poca fortuna de Alonso-Alvillo, que "sale atravesado de varas de medir, medidas de sastre y tijeretas":

\author{
Éste que, vareteado, \\ diciendo está "Tijeretas" \\ pasado de parte a parte \\ de varas y de tijeras. (vv. 96-100)
}

Como expresa la siguiente letrilla satírica $(P O C, 645)$ :

\footnotetext{
Que el sastre que nos desuella

haga con gran sentimiento,

en la uña el testamento

de lo que agarró con ella;

que deba tanto a su estrella,

que las faltas de sus obras

sean para su casa sobras,

mientras la muerte no asoma,

con su pan se lo coma. (vv. 38-46)
}

La antipatía hacia los sastres es común en la sátira de Quevedo contra los oficios. En el Sueño del Juicio [2003: I, 218] se hace patente en tanto que se les considera "ladrones". En el Alguacil endemoniado [2003: I, 218] se dice que tienen "posesión de hurtar". Hasta en el Sueño de la muerte [2003: I, 410] un cadáver impaciente increpa: “A quién no matarán las mentiras y largas de los sastres y hurtos??30

\footnotetext{
${ }^{30}$ Sobre los sastres como tipo satírico, consúltese Chevalier [1982: 96-106].
} 
Fernán González acaba su narración juglaresca y entonces Sancho le pregunta si le apetece tomar dos huevos sorbidos, ante lo que el Conde responde: "Déjalos hasta que compre/ la Bula de Laticinios" (v. 220). Huevos y bulas reaparecen en el soneto quevedesco titulado Que la pobreza es medicina barata y descuido seguro de peligros (POC, 588):

\author{
Cenas matan los hombres; yo no ceno; \\ ni ladrón ni heredero me atribula; \\ güevos me dan sufragio de la bula, \\ mas no la bula sin sufragio ajeno. (vv. $5-8)^{31}$
}

Fernán González pregunta a los músicos qué murmuraciones corren sobre él. Responden enigmáticamente: "Que temblar harás/ al deformar" (vv. 226-227). Al transcribir esta última palabra vacilé por su confuso significado (¿deformar o reformar?), pero el ductus es clarísimo en los dos testimonios manuscritos de la comedia. ¿Qué quiere decir semejante respuesta? Interpretamos que se trata de un anticipo de lo que sucederá a continuación en la comedia. En adelante, Fernán González “deformará” la realidad, pondrá el mundo al revés. ${ }^{32}$

Ante la perplejidad del Conde, Sancho amenaza con quemar inquisitorialmente los libros impresos que no le retraten como es debido. A

${ }^{31}$ Otros poemas que aluden a las bulas en $P O C: 620,645,763,785,863$ y 872 . La crítica a las bulas fue foco de las reformas erasmistas, que quedaron patentes en escenas literarias de denuncia como la aparición del buldero entre el desfile de ánimas del Diálogo de Mercurio y Carón, de Alfonso de Valdés.

${ }^{32}$ A propósito de este tópico literario específicamente aplicado a la literatura de Quevedo, véase Carlos Vaíllo [1982: 364-393]. 
continuación, hacen acto de presencia dos damas: la histórica Infanta doña Urraca y una tal Aldonza, que presenta algunas similitudes con su tocaya del Quijote cervantino. Este segundo cuadro constituirá una parodia burlesca de la tópica descriptio puellae y de las comedias al uso. Asistimos a un grotesco parlamento amoroso entre dos parejas de diferente categoría social: el Conde y su legendaria segunda esposa doña Urraca y su privado Sancho y la dama Aldonza.

El Conde, de finura segoviana como el pícaro Pablos, juzga las rosadas mejillas de doña Urraca aptas para beber vino con ellas; las cejas como el "arco de Cristo" (v.246), monumental puerta de entrada a la ciudad de Cáceres; los ojos "suelen echarse a dormir" (v. 251), esto es, bizquean o padecen alguna suerte de ptosis parpadal; el cabello se sostiene hueco "sin los moldes de los rizos" (v. 258: esto es, la Infanta está medio calva) y sus manos, en tremendo juego conceptista, no valen ni dos pitos ni un ochavo, porque son dos blancas (v. 265), moneda que, en tiempos de Alfonso XI, equivalía a un tercio del valor de un maravedí.

Doña Urraca le devuelve las gracias y el Conde dice estar tan ancho que habrá de ponerse guardainfante, la pieza de vestir femenina que se utilizaba para ahuecar las faldas. ${ }^{33}$ El lector sonríe al comprobar el doble sentido de la palabra: ¿acaso lo que en verdad precisa es un guarda infanta para prevenirse de doña Urraca? Una parodia lingüística similar se nos ofrece en

${ }^{33}$ Tal y como ilustra el poema Una figura de guedejas se motilla en ocasión de una premática (POC, 689), en una premática del 13 de abril de 1639 se prohibía su uso en las mujeres, al igual que las guedejas -o cabellos largos- en los hombres. 
el romance quevedesco Alega un marido sufrido sus títulos en competencia de otro $(P O C, 760)$ :

\author{
vio en el estrado su hembra \\ con guardainfante plenario \\ de los que llaman las ingles \\ guarda infantes y caballos. (vv. 25-29)
}

La primera pareja queda en segundo plano y la atención dramática se focaliza en Aldonza y Sancho, que equivaldrían a los criados enamorados de las comedias de enredo. Sancho no "retrata" mujeres, porque nació de tabardillo, enfermedad que hacía aflorar manchas -en ocasiones de colores vivos- en la piel. La dama, con gracia, apela al refranero -el "evangelio chico"- y le incita a que imite al Conde en su composición de "retraticos", porque en casa de tamborilero, todos son bailadores. Él prueba a describirla: es cabal porque tiene cinco sentidos y su rostro de encaje en nada debe envidiar a las puntillas de Flandes. Sancho, entusiasmado, pide a los músicos que canten el viejo refrán, "por el hilo se saca el ovillo”. Urraca critica el proverbio y el Conde se despide de ella alegando que ha quedado con el hijo de Almanzor para irse a cazar. Ella lamenta que vaya con moros y llora, aunque como dice el dicho popular, cuanto más lloras, menos meas, y así lo asume la propia doña Urraca:

\footnotetext{
que atado tengo el ombligo

y de mear me lo ahorro

el llanto que no reprimo. (vv. 351-354)
} 
Sancho y Aldonza se despiden con más tino, razonando acerca de las "tres potencias del marido": voluntad, memoria y entendimiento. Recordemos que ser marido, para Quevedo, es un oficio de estatutos bien definidos y, ante todo, una condición del ser humano. Aldonza confiesa a Sancho sus impulsos de convertirse al islam, pero promete reprimirlos en favor de su nueva relación. Esta confidencia haría reír al público ortodoxo de la comedia burlesca que, como vemos, aglutina un sinfín de despropósitos para provocar la risa.

El siguiente cuadro ahonda en las relaciones entre moros y cristianos. El Rey católico y Fatimán, el hijo de Almanzor, confirman las "venganzas olvidadas/ para dejar las paces ajustadas" (vv. 368-369). El Rey se jacta de ser un hombre de pocos ruidos, con aspiraciones hedonistas: cacerías en el bosque y buenos yantares. Con la música de clarines y tambores de guerra, Fernán González, Sancho, el Rey y Fatimán se disponen a cocinar juntos unos conejos de caza para que la alegría se imponga y puedan saborear la dulzura de la paz, como cantan los músicos disfrazados de cazadores:

\footnotetext{
Los fieles y los paganos

ya desmienten el refrán,

pues tienen paz cuando están

como moros y cristianos. (vv. 444- 447)
}

Dado que la "caza es viva imagen de la guerra" (v. 476), moros y cristianos deciden constituir un ejército para cazar conejos y después darse una buena comilona juntos. Los gritos y los tiros de arcabuz de esta escena contrastan notablemente con el siguiente cuadro, donde ambas damas 
interpretan una jocosa parodia del petrarquismo y del amor neoplatónico. ${ }^{34}$ Aldonza reelabora el tópico motivo de los ojos como soles y doña Urraca se quema y consume por los celos. Por desgracia, en este punto se interrumpe la escritura del testimonio antiquior y, por tanto de la copia que hizo Cotarelo y Mori.

La comedia burlesca ¡Qué villano es el amor!, a pesar de presentarse inacabada, es una obrilla digna de publicarse e, incluso, de adaptarse para ser representada. Ofrece una jocosa concordia entre moros y cristianos, desmitifica motivos romanceriles, hace una crítica grotesca contra los oficios y se mofa del código petrarquista. Al igual que El premio de la hermosura, ofrece numerosas concomitancias verbales, temáticas $\mathrm{y}$ estilísticas con la obra satírica de Quevedo.

${ }^{34}$ Para comprender la visión neoplatónica del amor, véanse los Diálogos de amor de León Hebreo [1993], el libro IV de El Cortesano de Castiglione [2003: 49-73] y Los asolanos de Pietro Bembo [1990]. 
- 464 - 
Capítulo VII

JÁCARAS Y BAILES

- $465-$ 
- 466 - 


\section{Al COMPÁS DE TERPSíCORE}

Quevedo escribió cerca de medio centenar de romances calificados como jácaras o bailes. Son de difícil datación, porque la mayoría aparecen anónimos en romanceros tardíos, de mediados del siglo XVII. Comparten muchos elementos temáticos con el resto de la obra festiva del autor, particularmente de la picaresca y de los entremeses. Acogen con ironía asuntos propios de la marginación social y de la delincuencia.

González de Salas, el editor de la poesía de Quevedo, aglutina sus bailes y jácaras bajo el epígrafe de la musa V, Terpsícore. ${ }^{1}$ En la elaboración del Parnaso español (1648), procede con una estructuración temática de los poemas. Pedro Aldrete, el sobrino de don Francisco, continuará con este criterio en la edición de Las Tres Musas Últimas Castellanas (1670). Salas destaca las cualidades de las composiciones incluidas en este apartado del Parnaso:

A esta Musa, digo, nombrada Terpsícore, asignamos con singularidad las poesías destinadas a la música de la voz y a los compases y medidas también de los bailes armoniosos. [1991: I, 124]

Terpsícore, en contraposición a la musa Erato, es la que a través del canto combate la tristeza y eleva el ánimo. De hecho, su etimología significa "que deleita con los coros". El delectare de la musa se correlaciona con su descripción física:

1 La descripción iconográfica de este personaje mitológico está inspirada en la Oda Ístmica II de Píndaro (de una Terpsícore ambiciosa). Cfr. Píndaro, Odas y fragmentos [1995: 6-12]. 
una moza elegante, de espíritu alentado y hermoso, que con la airosa acción de su movimiento, ansí en los pies, con la postura de baile, como en las manos, ocupadas en tocar un instrumento de cuerdas, significan cuidadosamente medir, en un mismo tiempo, a la consonancia de su cítara, los compases de su voz y de sus mudanzas. [1991: I, 124]. ${ }^{2}$

Secundados por esta "moza elegante", las jácaras y los bailes dramáticos de Quevedo comparten algunas características: transmisión oral, popularidad, puesta en escena y vinculación a dos ingredientes básicos, la música y la danza. Suscitan los recursos más originales de la inventiva de don Francisco, que fantasea lingüísticamente y aborda la jerga de la marginalidad para recrear la literatura germanesca.

Las jácaras y los bailes dramáticos son composiciones osadas y fruto de la eclosión expresiva de Quevedo: el autor se inspira en un léxico, estilo y personajes propios del mundo hampesco, descompone las mudanzas de las danzas tradicionales y las acerca a la obscenidad, como en los hyporchemata griegos. $^{3}$ Salas disculpará esta labor equiparando la obra de Quevedo a la de Catulo y Marcial: la crítica del pecado parte de una intención moral, ésa es la esencia de la sátira.

2 Esta prosopografía coincide con la que ofrece Cesare Ripa en su Iconología (1593), que a su vez se inspiró en la descripción de Virgilio en De Musis. Véase M. J. Alonso Veloso [2005: 30].

3 Cfr. M⿻a J. Alonso Veloso [2005: 16]. 


\section{LAS JÁCARAS DE QUEVEDO}

\section{UN NUEVO GÉNERO DRAMÁTICO}

La palabra jácara en un principio sirvió para designar a un grupo de jaques (así se documenta en el siglo XVI). ${ }^{4}$ Ya en el siglo XVII, se usó para aludir al lenguaje de estos valentones y, también, a sus hechos, aventuras y ademanes. Por extensión, según señala el Diccionario de Autoridades, pasó a denominarse así al romance de tono alegre que narra en jerga de germanía hechos de la vida rufianesca. Las jácaras son, entonces, composiciones voceadas por la plebe ínfima y, a su vez, hablas urbanas de los propios pícaros.

La adscripción de la jácara al canto callejero y nocturno ha merecido otras acepciones, como la de la molestia y el enfado que provocan estas cantarelas populares con contenidos picantes y palabras soeces. Su carácter musical también se ha prestado a confusión con ciertos bailes como el rastro, la zarrabanda y la tarraga. ${ }^{5}$

Quevedo describe las peculiaridades de la jácara en dos de sus composiciones (POC, 854, 855). En el poema 854, A una dama señora, hermosa por lo rubio, ${ }^{6}$ el autor destaca su tono apicarado y su narratividad adornada de apodos y chirigotas:

\footnotetext{
4 Cfr. Cotarelo y Mori [1991: I, CCLXXIV].

5 Cfr. Maria José Ruiz Mayordomo [2003: 283-307].

6 Como señala J.M. Blecua [1999: 1137]: “No es propiamente una jácara, como verá el lector, pero González Salas la incluye en ese grupo."
} 
Allá vas, jacarandina

apicarada de tonos,

donde los motes y chistes

navega el Amor el golfo. ( vv 1-4)

El contenido estará siempre relacionado con la "vida y milagros" de jaques o personajes amorales y pecadores, contraejemplos biográficos, hagiografías invertidas.

Asimismo, Quevedo destaca el carácter musical de la jácara. Así lo ilustra el principio del romance 855, Vida y Milagros de Montilla, donde el jayán Montilla canta su propia historia en falsete, mientras marca unos ritmos con las manos:

\footnotetext{
Montilla en el primer banco

arrempuja el primer gonce

al escritorio de chusma,

al vasar de los ladrones,

tocando con la cadena

la jaracandina a coces,

y punteando a palmadas

con los dedos en el roble,

imitando con la voz

cuando se despega, al odre,

dijo con mucha tajada

y en un falsete de arrope. (vv. 17-28)
}

Las jácaras de Quevedo, carentes de estribillo, se diferencian aún bastante de los entremeses y los bailes dramáticos. Esta distinción apenas 
puede delimitarse en otros dramaturgos como Quiñones de Benavente, Jerónimo de Cáncer o Calderón, que homogeneizan los distintos subgéneros del teatro breve.

¿Dónde ubicamos a la jácara, en la lírica o el teatro? Actualmente, se concibe como una pieza dramática que solía representarse, como los bailes y entremeses, en los entreactos de la función. Todo ello, a pesar de que el Diccionario de Autoridades ${ }^{7}$ no la vincule a la escena y que se haya relacionado con la poesía dialogada de cancionero.

La crítica ha considerado a Rodrigo de $\operatorname{Reinosa}^{8}$ creador de la lírica germanesca, en concreto del prototipo de rufián. Este autor de principios del siglo XVI expone una rufianesca en la que el valentón exalta la relación con su manceba, así como las bravuconadas y pendencias entre jayanes. No obstante, como Álvaro de Solano, todavía adolece de cierta inestabilidad métrica en su manera de componer: no se inclina hacia el romance que caracteriza las jácaras del siglo XVII. Habrá, con todo, ecos temáticos de sus composiciones en algunas jácaras de Quevedo. ${ }^{9}$

El interés por el mundo del hampa y su reflejo literario se recoge en los Romances de germanía (Sebastián de Cormellas, Barcelona, 1609) de Juan Hidalgo, primer estadio de la jácara, que contienen un "vocabulario al cabo". La intencionalidad del compilador es estrictamente lingüística y nada

\footnotetext{
7 Según nota Felipe B. Pedraza [2006: 78].

8 Sobre este autor, véase la edición de María Inés Chamorro Fernández [1988] y el estudio y edición de José M. Cabrales Arteaga [1980].

9 Alonso Veloso [2005: 100-103] coteja estas similitudes.
} 
teatral: transmitir unos textos escritos en una jerga, cuya complejidad se glosa en un amplio apéndice de voces. ${ }^{10}$

¿La vinculación de la jácara al espectáculo teatral es incuestionable? Todas las jácaras, métricamente, pueden calificarse de romances. ${ }^{11}$ No obstante, el empleo de las voces de germanía y su ocasional estructura dialogada convierten estos romances en el recital de bravos, rufianes y ladrones. A partir de las jácaras de Quevedo, ante todo con la refundición de la Carta de Escarramán a la Méndez, éstas adquieren una dimensión dramática. Quevedo, entonces, tal y como expresó Salas, fue pionero y primero descubridor de un género nuevo.

\section{LA EDICIÓN DE GONZÁLEZ SALAS}

Bajo el rótulo de jácaras, González de Salas publicó varios poemas en su edición del Parnaso Español (1648). Como ya hemos explicitado, el motivo fundamental de estas composiciones es el mundo del hampa, protagonizado por la camarilla de la delincuencia: valentones, ladrones, rufianes, coimas y criados de mancebías. En la dedicatoria de la musa V, Terpsícore, Salas alude a este nuevo género en los siguientes términos:

[...] un género de poesías ha de comprehender raro, singular y desemparentado de cuantos en lengua alguna, antigua o vulgar, hoy puedan, a lo que yo alcanzo,

\footnotetext{
${ }^{10}$ Tal y como indica Alonso Hernández [1989: 610].

${ }^{11}$ Cfr. García Enterría [1973: 148] y Hill [1949: ix].
} 
ofrecerse a la estudiosa diligencia. Jácaras se apellidan estas que digo. [Blecua, 1999: I, 126]

González de Salas manifiesta asombro ante un género radicalmente nuevo que, a su parecer, carecía de modelos clásicos o contemporáneos. Según señala el erudito, las jácaras son composiciones elegantes, con garbo y donaire, escritas en jerigonza, xargon (como dirían los franceses) o germanía, por su bárbaro origen:

Tiene nuestra lengua española muy varias especies, que dialectos llaman los griegos, y algunas no poco ridículas y bárbaras; y entre las que lo son no sé si podrá reputar por primera la que vulgarmente llaman jerigonza, que siendo este apellido tan genérico contiene la habla de los gitanos y otras que los muchachos fingen o inventan, denota también aquella que los rufianes han compuesto para entenderse entre sí, sin que los otros los entiendan. Xargon dicen los franceses, y curiosos y atentos más a nosotros que nosotros mismos, nos han dado de ese lenguaje copiosos diccionarios. Germanía la llaman también sus profesores, teniendo uno y otro nombre bárbaro origen, como era fuerza, que no de otra suerte lo fuesen sus inventores, aunque a mí me agradan poco los que les fingen nuestros eruditos. [1999: I, 126-127].

Para el humanista, las composiciones de Quevedo son, además, de distinta índole a las que circulaban con anterioridad:

Muchas jácaras rudas y desabridas le habían precedido entre la torpeza del vulgo; pero de las ingeniosas y de donairosa propriedad y capricho, él fue el primero descubridor sin duda; y como imagino, el Escarramán, la que al nuevo sabor y cultura dio al principio. [1999: I, 127]. 
Advierte González de Salas que, si bien las jácaras son un género vulgar, Quevedo les confiere ingenio literario y que, por lo tanto, es el descubridor de este nuevo talante. Las osadas palabras del editor no han sido bien entendidas por parte de la crítica. Cotarelo y Mori, por ejemplo, desmiente este comentario, sin atender al hecho de que Quevedo es el que asienta el género de la jácara y le confiere un calibre teatral:

Engañóse Salas; porque muchísimos años antes del Escarramán de Quevedo, se habían compuesto los tres primeros romances compilados por J. Hidalgo, que por su lenguaje y estilo están diciendo ser de mediados del siglo XVI y también anteriores son los otros ocho que añadió el mismo Hidalgo y todos los cuales son artísticos y tan buenos como el de Quevedo. Uno de ellos tiene fecha de 1570, año en que Quevedo no había nacido. [...] Los romances que bautizó Don Giuseppe Antonio González de Salas con el nombre de jácaras son 15, y lo mismo pudo llamárselo a ortas 20 o más composiciones semejantes. Quevedo no usó la voz jácara para estas obras. [1911: CCLXXIX].

Como ya hemos señalado, los romances de la antología de Hidalgo profundizan ante todo en el uso de términos de germanía, en tanto que Quevedo va más allá de la mera acumulación de voces en jerigonza y las maneja en juegos de ingenio y agudeza verbal, propiciándoles una dimensión distinta, acentuando sus rasgos más teatrales (esto es, las partes bailadas y los diálogos). Entonces, tal vez, Quevedo es el que entierra el género y lo hace renacer, desnaturalizando su lenguaje. 


\section{VIDA Y MILAGROS DEL JAQUE}

La etimología de la voz jaque es harto curiosa: el Diccionario de Corominas-Pascual la relaciona con el étimo árabe sâh que significa "rey en el juego de ajedrez". Es sinónimo de valiente o bravo. Jayán, del árabe haiyán, tiene el significado original de "vivo, animoso, fuerte". Aunque en las novelas de caballerías -como se consigna en el Amadís de Gaula (IV, 47)- pasó a definir a un pendenciero injusto y cruel, Quevedo lo reviste de un matiz satírico lejanamente emparentado con el miles gloriosus de la comedia latina y el rufián de los Pasos de Lope de Rueda.

Existe una jerarquía de maleantes, aunque los términos se utilicen a menudo como sinónimos: en el estrato más bajo está el mandil o trainel, a menudo criado de las prostitutas; en segundo lugar, el rufián propiamente dicho y, después, el jaque, valiente o bravo. A este le sigue el jaque-rufián y el más poderoso de los criminales, que es, sin duda, el jayán.

Madrid es la urbe por excelencia y el jaque -como el bandolero en el medio rural-, más allá de representar el desorden civil, actúa como el elemento contracultural. La diferencia más relevante entre el jaque y el bandolero es, no obstante, que el primero merece un tratamiento interno y no externo: sus hazañas son narradas desde dentro y en su propia jerga.

En este sentido, las jácaras pueden clasificarse en función de cómo se presenta el relato de las aventuras del jaque: a través de la forma epistolar (POC, 849-852), mediante un narrador heterodiegético que introduce los diálogos de los jayanes (POC, 855, 857, 858, 861-864) o a partir de la relación biográfica en primera persona (POC, 853, 856, 860). 
Por otra parte, los primeros versos de la jácara 853 nos revelan cómo son los jaques: suelen vivir de la espada, son cobardes, borrachos, paladines del hampa, proxenetas, pendencieros y charlatanes; en general, gente de mala vida:

\footnotetext{
Mancebitos de la carda,

los que vivís de la hoja,

como gusanos de seda

tejiendo la cárcel propria,

cuya azumbre es la Colada,

cuya camisa, Tizona;

Rodriguitos de Vivar

por conejos, no por obras;

jayanes de arredro vayas,

cuya sed a todas horas

se calza, de vino añejo,

sin ir de camino, botas;

paladines de la heria,

aventureros de trongas,

que, sin ser margen de libro,

andáis cargados de cotas,

maullones de faldriqueras,

cuyos ratones son bolsas

si el zape aquí del verdugo

no os va cantando la solfa;

matadores como triunfos,

gente de la vida hosca,

más pendencieros que suegras,

más habladores que monjas;
} 


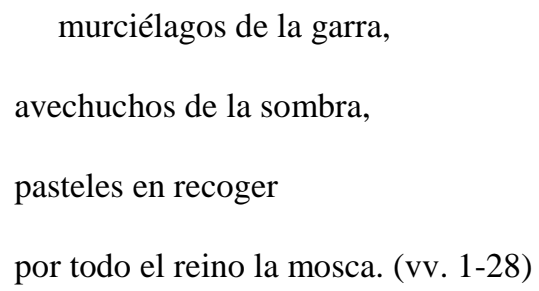

Como cuenta Montilla (POC, 855), los jayanes se inician en la delincuencia desde su más tierna infancia, tejen su propia cárcel y son condenados a galeras.

Los personajes del mundo rufianesco frecuentan tabernas, burdeles, prisiones, galeras y salas de tortura. Estos espacios decadentes son, en ocasiones, los verdaderos protagonistas de las jácaras. La trena, la bayuca, el calabozo: son realidades semánticas que nos transportan a una pesadilla de inframundo.

Las jácaras hacen referencia inequívoca al amor como intercambio mercantil y relación interesada entre los jayanes y sus izas. En los poemas 857 y 864 los rufianes añoran los prostíbulos, paraderos del vicio, a los que no pueden acudir tras el cierre de las mancebías por real decreto de Felipe IV, el 4 de febrero de 1623.

Las coimas de las jácaras de Quevedo se describen paródicamente con expresiones tópicas del petrarquismo. ${ }^{12}$ En los textos conservados de don Francisco, nunca se menciona si son víctimas de malos tratos físicos de los rufianes o condenadas a galeras: como máximo, reciben azotes por sus robos. Recordemos que estas agresiones eran un tópico de la literatura picaresca: en el cervantino Rinconete y Cortadillo, por ejemplo, el rufián Repolido da una gran paliza a su iza, la Cariharta.

\footnotetext{
${ }^{12}$ Véanse las jácaras 853 (vv. 57-60) y 854 (vv. 41-52).
} 
La embriaguez de los jayanes, su afición a las tabernas, ayuda a caricaturizarlos: quedan "vueltos ojos de gallo/ los ojos amodorridos,/ acostados en el sorbo,/ ya ballesteros, ya bizcos" (POC, 857: vv. 33-36). La borrachera acostumbra a ser el colofón de toda pendencia. Los jaques suelen ir "a la ermita de San Sorbo/ en el altar de San Trago" (POC, 861: vv. 115116). El vino es el gran consuelo del galeote:

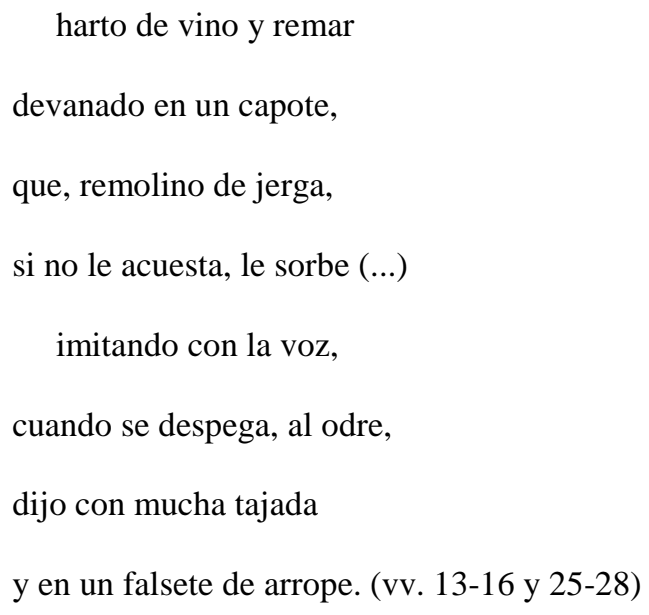

Muchas jácaras parten de la estancia en la cárcel como escenario propicio para que el jayán rememore (en forma de monólogo, diálogo o narración epistolar) su historial delictivo. El ejemplo más emblemático es el de la Carta de Escarramán a la Méndez (POC, 849), que comienza:

\footnotetext{
Ya está guardado en la trena

tu querido Escamarrán, que unos alfileres vivos me prendieron sin pensar. (vv. 1-4)
}

Así sucede en Zampuzado en un banasto (POC, 856), que confina a su protagonista en una cárcel de Sevilla. Las prisiones son, asimismo, las 
mejores escuelas, a las que los jaques acuden a aprender las artes de su oficio, como nota Lampuga en la jácara 852:

\author{
Letrado de las sardinas \\ no atiendo sino a bogar \\ gradüado por la cárcel \\ maldita universidad. (vv. 65-68)
}

Las galeras, "la casa de las sardinas", suelen ser otro escenario habitual. Montilla, en la jácara 855, parte de su condición de galeote para explicar su vida pendenciera a los otros reclusos: como no ha muerto ajusticiado, continuará con sus andanzas en cuanto haya cumplido condena, sin arrepentimiento alguno.

Luciferinos, arrogantes, desafortunados: los jaques son maleantes terribles, ladrones, ángeles caídos. Son, asimismo, conocedores de su propia intrahistoria. Cuando un rufián pondera su valentía suele enumerar las hazañas de una retahíla de jayanes afamados precedentes. En esta línea, el baile Los valientes y tomajonas (POC, 865) engrandece a los jaques ajusticiados a manos del verdugo: todos están ubicados en una ciudad del mapa español, son muchos y muy afamados. La justicia ha acelerado su muerte; sus vidas, duras y lacrimógenas, han ahogado las penas en el vino.

No es de extrañar que el público se regodeara escuchando las desgracias de Escarramán, Cardenoso, Cañamar, Perotudo, etcétera, o viendo la recreación de sus ejecuciones y autos de fe, cuando acudía ufano al ajusticiamiento de herejes y criminales. ¿Cómo podía ser, entonces, extraño, que se bailara al son de prendimientos y homicidios? 


\section{MARTIRIO Y ESTOICISMO. RELACIÓN CON LA NOVELA PICARESCA}

El jaque es más criminal que el pícaro, menos ruidoso y alegre. La jácara y la novela picaresca parten, sin embargo, de un particular subrayado de la dignidad de los delincuentes, dotados de una resistencia estoica ante las adversidades, de una capacidad cristiana para soportar el exacerbado dolor del castigo. La recreación literaria de este motivo fue también predilección de Cervantes: es el mismo aplomo de los galeotes del Quijote (I, 22), el pintoresco universo de la marginalidad que aparece en La gitanilla y, ante todo, en Rinconete y Cortadillo.

La jácara está, asimismo, prefigurada en el Buscón. En fechas próximas a las andanzas de don Quijote, esta novela picaresca emerge en el mundo germanesco y apunta tópicos jacarandos, como la exaltación irónica de la destreza del verdugo en su profesión ("vérsele hacer daba gana a uno de dejarse ahorcar") o la entereza del padre de Pablos al morir ahorcado ("quedó con una gravedad que no había más que pedir"). Quevedo recurre en el Buscón al argot específico de los delitos y penas; el protagonista, de hecho, se jacta de estudiar jacarandina y de ser rabí de otros rufianes. Don Francisco, a su vez, trae a colación personajes legendarios de jácara, como Pero Vázquez de Escamilla, al que Quevedo Domingo Tiznado, Gayón, o Alonso Álvarez de Soria. ${ }^{13}$

Las jácaras narran con carisma las acciones delictivas de los jayanes, las pendencias, la pasión por la bebida y el juego, sus historias de amor prostibulario, sus penalidades en prisión y su condena a galeras o la horca,

\footnotetext{
${ }^{13}$ Cfr. Felipe B. Pedraza [2006: 81].
} 
donde terminaban los más. También esbozan algunas críticas a la justicia, por aquel entonces, cruel, precipitada, incompetente, con falta de argumentación en su proceder, dictadora de arbitrarias sentencias irrevocables. A pesar de que los crímenes y las leyes fueran claros, los castigos siempre eran desequilibrados. ${ }^{14}$

Escarramán y compañía son bravos, pero más aún lo es la gura, la autoridad, los alfileres que sujetan sin piedad. Basta acudir a la Nueva o Novísima Recopilación para apreciar cómo se computaban los delitos, a la vista de si se producían o no dentro de la corte. Léase la premática de 1552:

Mandamos a todas las justicias de nuestros reynos que, los ladrones que conforme a las leyes de nuestros reynos deben ser condenados con pena de azotes, de aquí adelante la pena sea que los traigan a la vergüenza, y que sirvan quatro años en nuestras galeras por la primera vez, y por la segunda le den cien azotes y sirva perpetuamente en las dichas galeras, siendo mayores de edad, y por la segunda vez le sean dados doscientos azotes y sirva perpetuamente en dichas galeras. ${ }^{15}$

Este decreto se reforma en la premática de 1566, donde se amplían las penas y se reduce la mayoría de edad, de veinte años a diecisiete:

Por quanto en la precedente pragmática de veinte y cinco de noviembre de 1552 se ordena y manda, que los ladrones, que conforme a las leyes de estos reynos habían de ser condenados en pena de azotes, por la primera vez, fuesen condenados en quatro años de galeras y vergüenza pública, siendo el hurto hecho fuera de Corte, y siendo en Corte, ocho, mandamos que los quatro años sean y se entiendan seis, y

\footnotetext{
${ }^{14}$ Cfr. Herrera Puga [1971: 334].

${ }^{15}$ Cfr. M. Martínez Alcubilla [1885, vol. II, p. 1871b. (Lib. XII, tit. XIV, ley I)].
} 
los dichos ocho diez, y que en el dicho caso sean condenados por el dicho tiempo en el dicho servicio de galeras; lo qual se entienda y execute, no embargante que los dichos ladrones no hayan la edad de los veinte años, como en la dicha pragmática se dice, siendo de tal disposición y calidad, que puedan servir en las dichas galeras, y habiendo a lo menos diez y siete años. ${ }^{16}$

Pese a que estas premáticas son anteriores al nacimiento de Quevedo, se mantienen durante su vida con muy pocas modificaciones. Don Francisco, que elogiaba el quehacer de los mandatarios, no llega a poner en duda el papel de la justicia y el proceder del Santo Oficio, al menos en su correspondencia oficial. Con todo, se conserva una carta que escribió al presidente de Castilla don Francisco de Contreras o quizás al Conde-Duque de Olivares, que data del 9 de julio de 1624, donde expone la necesidad de excusar la publicidad de los castigos de los reos. Para el autor, hacer de la ejecución un espectáculo público, glorifica y hace mártir al hereje:

Los castigos todos son justos, y todos son pocos: en esto convenimos. Resta mirar con qué modo harán el efecto que se desea; siendo el principal extirpar y extinguir con el ejemplo semejantes ofensas, y lo que es peor, la intención disimulada de establecer con las cenizas de estos malditos sus errores, procurando copiar esta diligencia de los tormentos de los santos mártires, que por el cuchillo y la llama fortalecieron la verdad apostólica romana. Y es cierto que estos tales herejes temerarios, inducidos de la persuasión de los predicantes, con el nombre y la veneración de la posteridad que les prometen, ambiciosos de la adoración que niegan y de los altares que profanan, dan por pasados los años que les pueden quedar de vida, y tienen por logro lo que pierden [...]

\footnotetext{
${ }^{16}$ Véase la nota anterior.
} 
Y siendo esto así verdad, parece medicina segura y descansada burlarles esta diligencia con que el Santo Oficio de la Inquisición a todo hombre que vivo e impertinente se deja quemar, le queme vivo con el propio secreto que le prende. $\mathrm{Y}$ no será menos útil este silencio que aquel, pues el primero aseguró la prisión, y el segundo el acierto del castigo, pues con esto descaecerá su vanidad, y el arrepentimiento tendrá menos que vencer para reducirlos, y los novatores tendrán más corto blasón de los que, siendo demonios, llaman mártires. [Krzysztof Sliwa, 2005: 363].

Para nuestro autor era un peligro moral que el condenado a muerte fuese ajusticiado públicamente. Quevedo creía conveniente silenciar el castigo, para que el vulgo no hiciera mártires a los pecadores. Uno de los rasgos característicos de los jayanes es, precisamente, el orgullo de su vida delictiva, que es ponderada como una hazaña. Nos parece significativo que Gorgolla, el jayán de la jácara titulada Postrimerías de un rufián (POC, 862), descarte el arrepentimiento de sus actos criminales:

\footnotetext{
A niños de la doctrina

no pienso pagar la solfa:

música que no he de oúlla, que la pague quien la oiga. (vv. 85-88)
}

Las jácaras de Quevedo, a diferencia de las poesías germanescas recogidas por Hill, no abundan en referencias explícitas a la muerte de los rufianes en la horca. ¿No parece un dato significativo si lo relacionamos con la epístola citada?

Por ello, no es sorprendente que Escarramán devenga un Cristo martirizado en los romances "a lo divino", como en aquel que figura 
anónimo en el ms. 19.387 de la BNE, f. 200 v. ${ }^{17}$ Esta pieza, compuesta a imitación de la Carta de Escarramán a la Méndez (POC, 849), trata el tema de la pasión de Cristo y su crucifixión en términos similares a los de las penalidades y castigos que reciben los bravos.

La moral de los delincuentes que protagonizan las jácaras podría situarse entre el neoestoicismo y la sofística ${ }^{18}$, lleva a la práctica el relativismo y es una honda encarnación del substine et abstine. Bajo la travesura verbal y la pirotecnia ingeniosa, palpita un escepticismo irónico que reviste a los criminales con una notable capacidad de aceptación de su fatum o destino. El detrito de la marginalidad social puede trascenderse en su resignación cristiana del dolor y convertirse en un trágico paradigma de heroísmo, dignidad y solidaridad. Esta gravedad y orgullo del rufián es la que, en adelante, posibilitó que el esquema de la jácara quevedesca se trasvasara a los más nobles objetos: la divinidad, el santoral, la realeza o la política. ${ }^{19}$

Si la aristocracia del pobre se mide con el filo de su lenguaje, el jaque, como el sofista, es dueño del arte de defender con ingenio, es capaz de convertir la narración de sus hazañas criminales en una auténtica epopeya. El tópico de la dignidad del ajusticiado ya había emergido en la Celestina, y reaparece en el Guzmán de Alfarache y en el Buscón. El jaque, como el pícaro, es un antihéroe que, con humor patibulario, hilvana en su propia jerga el reverso de la más exaltada epicidad.

\footnotetext{
${ }^{17}$ Véase la edición que incluimos en el Apéndice.

${ }^{18}$ Véase Cristóbal Cuevas García, "Quevedo, entre neoestoicismo y sofística", en Estudios sobre literatura y arte dedicados al profesor Emilio Orozco Díaz. Granada: Universidad, 1979: I, pp. 357-395.

${ }^{19}$ Cfr. Felipe B. Pedraza [2006: 85].
} 


\section{ESCARRAMÁN: EL ALBA DE LA JÁCARA}

A pesar de que la Carta de Escarramán a la Méndez (POC, 849) se documenta hacia 1612, el triunfo del género parece ser más tardío, "no será anterior a la cuarta década del siglo". ${ }^{20}$ Esta jácara tuvo un éxito muy temprano, que se hace patente en sus múltiples imitaciones y parodias. Recordemos que hasta emerge en el entremés cervantino del Rufián viudo. Incluso se ha llegado a postular que Escarramán se tratase de un personaje real. El éxito duró más de medio siglo, debido a la amplitud de sus versiones, aunque la más fiable es la que se incluye en El Parnaso. ${ }^{21}$

¿Qué ingredientes literarios justifican el éxito de esta jácara? Quevedo compone en un lenguaje hampesco exquisito, lleno de chistes y dobles sentidos, las desventuras, trifulcas y amores de un criminal carismático, que en el ajusticiamiento penal de sus delitos asume rasgos del mártir.

La epístola del jayán a su coima relata desgracias propias y ajenas. Le escribe desde la cárcel (trena). Tras una pendencia en una taberna (bayuca), le prenden unos ministros de la justicia (unos alfileres vivos):

\footnotetext{
Ya está guardado en la trena

tu querido Escarramán,

que unos alfileres vivos

me prendieron sin pensar.

Andaba a caza de gangas,

y grillos vine a cazar,
}

\footnotetext{
${ }^{20}$ Según Chevalier [1992: 141].

${ }^{21}$ Cfr. Blecua [1999: 261].
} 


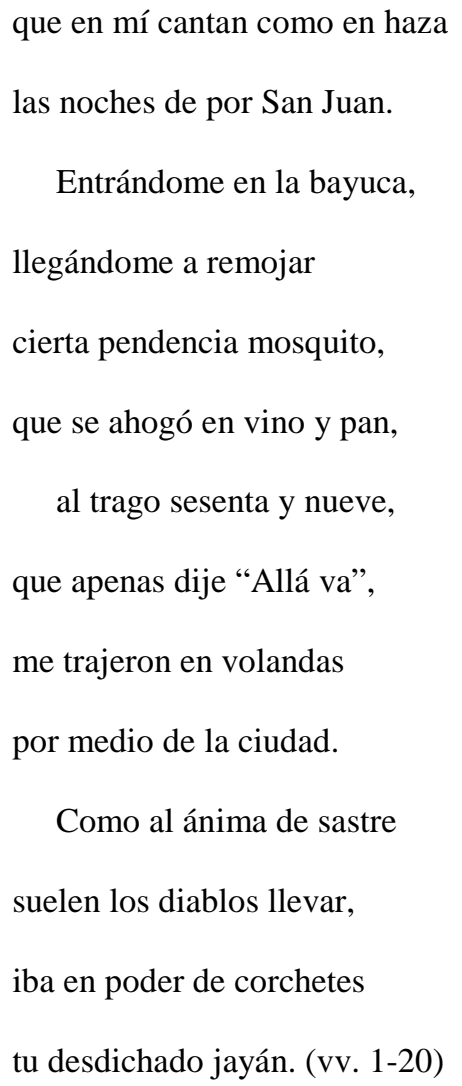

En la cárcel, Escarramán queda en buena compañía. Allí se encuentra con otros godos o principales de su profesión canalla, cuyos destinos no son más agraciados que el suyo. Cardeñoso queda "manco de tocar las cuerdas" (v. 27): la cuerda era una forma de tortura para que los presos confesaran sus crímenes. Remolón es condenado a galeras: "fue hecho cuenta/ de la sarta de la mar" (vv. 29-30): Coscolina, su coima, se va con Cañamar, el caco cerrajero. Lobrezno es ahora un reo de muerte; y Quevedo hace una chistosa asociación de ideas entre la horca y las cadenillas que se solían regalar en el día de santo o cumpleaños: "Dicen que le colgarán/ sin ser día de su santo" (vv. 38-39). Con Pedro Turdo, Escarramán ha tenido una pelea y le ha rajado media mandíbula de una cuchillada.

Los nombres propios de los personajes que cita don Francisco prefiguran futuros arquetipos. Cardeñoso era generalmente relacionado con el criminal 
que no confesaba, mártir por antonomasia. Cañamar tipifica al caco de ganzúa, "hombre que sin ser San Pedro/ tiene la llave universal". Pedro Turdo o Pero Tudo era sinónimo de "ladrón, fullero y valiente". Coscolina, colega de la Méndez, es la mujer pícara y libidinosa, que pasa de un rufián a otro. A menudo los nombres de santos -San Millán, San Juan, San Pedroconviven con familiaridad con los de prostitutas y jayanes.

La jácara proseguirá con una descripción de los castigos y penalidades de Escarramán: un centenar de latigazos (vv. 57-60) y diez años de condena a galeras (vv. 89-96). El jayán pide ayuda a su iza y dice que le encomiende a todos los allegados comunes.

La Respuesta de la Méndez a Escarramán $(P O C, 850)$ es una carta de la coima a su bravo. ${ }^{22}$ Ésta le reprochará su afición a la bebida, causa principal de todos sus males. Por ello, le dirá: "por matar la sed te has muerto" (v.9). La Méndez relativiza los castigos de Escarramán, tanto los azotes como su sino como galeote $\mathrm{y}$, siguiendo la tónica quevedesca de la avaricia femenina, aduce que no tiene nada que darle, más que consejos:

Dices que te contribuya, y es mi desventura tal, que si no te doy consejos, yo no tengo que te dar. (vv. 52)

\footnotetext{
${ }^{22}$ Existe un nuevo testimonio de esta jácara que hasta ahora no había sido registrado. El por qué es simple: el ms. comienza con el verso "Recebí en letra los ciento...” y presenta algunas variantes. Se halla en la BNE, ms. 3795. Poesías manuescritas [sic.] 1, f. 81v.-82.
} 
Muestra su parecer sobre las condenas referidas por Escarramán: siente lástima por Cardeñoso, al revés que por Remolón: al fin y al cabo, en sarta de galeras, "hombre de cuenta será" (v. 76), que era expresión para aludir al personaje de alto rango. La Méndez ha sido testigo de la lujuria de Coscolina y Cañamar, "en cueros por su pecado,/ como Eva por Adán” (vv. 80). Lamenta el ahorcamiento de Lobrezno, por cuya ventura llora su coima Luján.

Por lo demás, la Méndez narra la situación de otros personajes del mundo hampesco: refiere la muerte de Valgarra y los oficios de Cespedosa (ermitaño, esto es, salteador de caminos), Baldorro (mozo de sillas) y Matorral (lacayo). Montúfar, según la iza, ha sido quemado por sodomita; y la Tomás -nombre que alude jocosamente al verbo “tomar", acción típica de las pidonas- ha dejado la prostitución.

La jácara, como podemos comprobar, no sólo narra la vida y milagros de un jayán y su coima. Estos personajes se sienten intrínsecamente ligados a un colectivo, cuyos oficios y castigos narran con prolijidad. El anecdotario narrativo es propio de la épica: Escarramán es un antihéroe que, por los martirios padecidos, terminará divinizado.

Decía Borges que "virtualmente, Quevedo no es inferior a nadie, pero no ha dado con un símbolo que se apodere de la imaginación de la gente."23 Quevedo sí que dio con un personaje que trascendió el quehacer literario de su siglo y que se apoderó de la imaginación popular: Escarramán, el jaque mártir por antonomasia, el antihéroe pendenciero, el trágico enamorado de

\footnotetext{
${ }^{23}$ Cfr. Borges [1998: 62].
} 
su iza, la Méndez. Todo ello, a pesar de que, por motivos diversos, este jayán no brille en nuestros tiempos con la misma intensidad.

\section{Pero VÁzQuez de ESCAMILla : LA JÁCARA EN LA COMEdia}

Quevedo sintió especial atracción por los jaques y figurones de baja estofa, perseguidos por la justicia o por el matrimonio. Los supervivientes de la cotidianidad le permitían explotar su ingenio picaresco. Entre la extensa nómina de los mismos, figura el que fue un corrupto jaque sevillano: Pero Vázquez de Escamilla. El que, según describe Quevedo en su baile Los valientes y tomajonas (POC, 865: vv. 81-84), siendo "blasón de la espada", estuvo hecho de "enfermedad de cordel" y "murió cercado de guardas".

La jácara inicial de Pero Vázquez de Escamilla, fragmento de comedia que ha sido comparado con Rinconete y Cortadillo, se centra en el antihéroe homónimo. Tiene una estructura dialogada, y en ella el jaque relata su vida y milagros. ${ }^{24}$ Quevedo utiliza sus conocimientos de la lengua de germanía para construir juegos conceptistas. ${ }^{25}$ Escamilla, de hecho, aclara a los jóvenes rufianes su dicción germanesca y su costumbre de garlar, esto es, de hablar mucho y sin pausa:

Bien me entenderéis, pues sois

\footnotetext{
${ }^{24}$ Véase Ignacio Arellano [1991: 13].

${ }^{25}$ Para los términos germanescos, hemos consultado el Léxico del marginalismo del Siglo de Oro [1976] de Alonso Hernández.
} 
polluelos de lo germano;

mas yo quiero clarearme,

y entreveréis lo que garlo. (vv. 76-79).

La obra comienza in media res. Pero Vázquez ha sido libertado de galeras por don Juan de Austria, como recompensa a sus proezas bélicas de la batalla de Lepanto. La acción se sitúa en Sevilla: el personaje cruza a nado el Guadalquivir, sorteando los disparos de arcabuz de la justicia. Sale "con la espada en la boca, desnudo, en greguescos de lienzo y muy mojado", acotación impresionista, acaso pre-valleinclanesca. Justo llega a tiempo para apaciguar una pelea de cuatro rufianes (Montes, Tablares, Argomedo y Barco) motivada por "la lujuria".

Los jayanes abandonan las armas para escuchar sus hazañas, relatadas en un elocuente romance de germanía. ${ }^{26}$ Pero Vázquez de Escamilla descubre el motivo de la trifulca, un asunto de faldas ("¿Será requiebro travieso/ por daca y toma putilla?", vv. 62-63): Argomedo y Barco le dan la razón. El jaque propone que para que nadie tenga celos, compartan la bella meretriz entre los cinco. Una vez ganado el respeto, inicia el relato de sus delitos y aventuras de magnate y fugitivo.

Empezará con una tribulación a su maestro, el fullero tramposo que mejor "engiba el cambio", esto es, que recolecta las ganancias del burdel. El

${ }^{26}$ Armando Cotarelo [1945: 67] lo considera "una de las mejores jácaras de Quevedo, que las hizo insuperables." Aubrey Bell [1928: 210], consciente de la maestría quevedesca en la descripción de personajes hampescos, señala que "Quevedo is here in his element; he draws his types of Triana and Seville to the life; we feel at once that this is the Quevedo of the satirical letrillas and jácaras, the bitter author of El Buscón." 
personaje aprovecha acontecimientos multitudinarios como ferias $\mathrm{y}$ ceremonias eclesiásticas para robar discretamente, por ello, "en la bola y salud/ entraba con red de payo" (vv. 74-75). Escamilla enumera todas las variantes de su oficio de ladrón o "gato", según se denomina en lengua germanesca:

\footnotetext{
No vieron cosa sus ojos

que no cogiesen sus manos,

mondador de faltriqueras,

pelliscador en guardado,

gran trasponedor de prendas,

pillador de todo grano,

sacabolsas como muelas,

metededos como gato;

avizor de cualquier presa,

guiñarol, polinche y maco,

demanda para mí mismo,

en todas veredas salto,

gran jugador de la chica,

gran sosquinero de amagos,

y para balcón abierto

hombre de gran garabato;

cierto de ballesta y morro,

hombre de tan lindas manos

que se encuentra con los reyes

y huye con los caballos. (vv. 80-99)
}

El adjetivo guiñarol es voz de germanía que designa a aquél que hace señas con los ojos; el polinche, el que encubre y fía a los ladrones, y maco 
es el astuto bellaco difícil de engañar. Notemos, a su vez, la irónica manera de robar entendida como una "demanda para sí mismo". Escamilla también es ladrón de caminos ("en todas veredas salto", v. 91), hábil en el manejo de la daga ("jugador de la chica", v. 92) y en el golpe o ataque a traición ("sosquinero"). Se califica de "hombre de gran garabato" (v. 95), y en dicha dilogía Quevedo entona un chiste sobre el robo: al ladrón se le llama "mozo de garabato", pero a su vez, el garabato es la herramienta -una suerte de gancho de hierro sujeto a una cuerda- utilizada para robar en las casas por la noche. También es "cierto de ballesta y morro" (v.96), es decir, fullero de los naipes, por lo que, en sagaz juego conceptista, alude a los reyes y caballos de las cartas y de la realidad (su persecución por la justicia real y sus escapadas a caballo por ser cuatrero).

El pasaje que sigue tal vez aluda a su condición de proxeneta, donde "flor de las tías" ha de entenderse en alusión a las "viejas alcahuetas":

Y con la flor de las tías, que son las niñas de antaño, niñeando con las uñas despeloto muchos flancos. (vv. 100-103)

Al igual que se postula en el Entremés de la vieja Muñatones:

CARDOSO- ¿Es alcahueta?

PEREDA- Ya pereció ese nombre, ni hay quien le oiga. No se llaman ya sino tías, madres, amigas, conocidas, comadres, criadas, coches y sillas. [1965: 287] 
Tras la descripción de las mañas del jaque y su heterogénea corrupción ladrón, fullero de los naipes y proxeneta -, Escamilla alude a la persecución de la justicia, del guro. Dos "jueces entregadores" soplan o delatan los desmanes del jayán, hecho que le conduce a ser "penitente de arre" y "disciplinante de asno" (vv. 108-109). Éste era castigo célebre de los delincuentes del Siglo de Oro: los reos, para vergüenza pública, eran azotados por el verdugo en un asno. ${ }^{27}$

Quevedo también juega con todos los integrantes del ritual de penitencia. Los pregoneros recitan a viva voz las supercherías y profanaciones de los presos "diciendo que manda hacer/ el rey, y él está en Palacio" (vv. 114$115)$.

Tras los golpes y cardenales, como clérigo, le rapan pelo y barba y se ordena de remo. Aquí nuestro autor establece una analogía entre la condena de los galeotes y la vida de monje. ${ }^{28}$ También, en un juego léxico similar al anterior, se le llama licenciado en el banasto (v. 123), esto es, licenciado en la cárcel y, aunque provisionalmente rescatado por la Maruja -a todas luces su daifa-, es graduado de colgajo (v. 129), es decir, muerto en la horca o letra de palo, expresión que equivale a vaciar en finibus terrae (v. 128). Sus cofrades -pícaros, rufianes, tahúres y personajes de baja estofa-, finalmente, entierran su cadáver con dignidad.

${ }^{27}$ Los azotes que sufren los criminales son tópico común en las jácaras: así figura en la Carta de Escamarrán a la Méndez (POC, 849: vv. 53- 60), la Respuesta de la Méndez a Escamarrán (POC, 850: vv. 33-36) o la Carta de Perala a Lampuga, su bravo (POC, 851: vv. 71-78).

${ }^{28}$ Alusiones a esta barba sacerdotal de los condenados a galeras encontramos en los poemas 852 (vv. 61-62; 77-84), 867 (vv. 1-2) y 855 (vv. 85-86). 
La primera larga intervención de Escamilla - el homenaje biográfico a su difunto amigo ejemplar- aparece interrumpida por la solicitud del sombrero de Argomedo, porque teme resfriarse ("el sereno me hace daño", v. 149).

Un segundo parlamento de Pero Vázquez se centrará en sus propias hazañas, tras declararse heredero de "las costumbres y las flores" del jayán ahorcado. El relato interesa porque alude a célebres jaques de la literatura aurisecular. ${ }^{29}$ Nadie, hasta entonces, ha conseguido descornarle (desvelar sus trampas): relata su triunfo en Utrera sobre Robles; un desliz en el burdel de Maladros, al que deja moribundo; profundas cuchilladas en la cara (chirlos) a un grupo de tunantes mulatos; altercados con Zaramagullón; persecuciones de la justicia real ("Don Felipe en provisión/ anduvo tras mí dos años", vv. 180-181), el asesinato de cuatro alcaldes y, finalmente, una contienda en un prostíbulo cordobés. De nuevo, Escamilla interrumpe su parlamento para proveerse de la capa de Tablares. Éste protesta aduciendo que es corta, a lo que él le responde que tal vez el corto sea él mismo, "de Duraznos", es decir, tacaño.

En el tercer parlamento, Escamilla explica cómo abandona Córdoba y se instala en Sevilla, donde es jefe fullero del Corral o Patio de los Naranjos de la catedral, frecuente punto de encuentro para la truhanería, según apareció también en la Gatomaquia de Lope de Vega (silva III, vv. 285-286). ${ }^{30}$ El jayán enumera a otros jaques relevantes que le rinden tributo y cuyas bellaquerías dirige: los bribones Gayoso, Tonelero, Bayanduces, Bujarro,

\footnotetext{
${ }^{29}$ Alonso Hernández [1979] los recoge en su estudio El lenguaje de los maleantes españoles de los siglos XVI y XVII.

${ }^{30}$ Cfr. Deleito y Piñuela [1967: 198-199].
} 
Cerbellón, Centellas y Perotudo. También administra el dinero de las coimas: la Pérez, la Pava, la goda (o prostituta de lujo) Coscolina, la Chillona, la Carrasco y la Maldegollada. Pero, como la Fortuna es caprichosa, la justicia sorprende sus trampas y flores:

\author{
Descornáronme la flor \\ los de los ropones largos; \\ acechóme el arco seco; \\ quise avispar otro rancho; \\ metiéronme en la tristeza, \\ juntáronme los pecados. (vv. 240-245)
}

Ante la tortura del potro, Escamilla no quiere revelar su nombre: acude a la fórmula "Iglesia me llamo" (v. 251). Se niega, igualmente, a confesar sus delitos, por lo que lo destierran y condenan a galeras durante seis años. Así describe el suplicio:

\author{
Desterróme el juez y el sepan \\ con las penas del quebranto, \\ a hacer cosquillas al mar, \\ a mecer cunas al charco, \\ y apaleando sardinas \\ he estado en ella seis años. (vv. 228-263)
}

Finalmente, los cuatro jayanes le recuerdan que los ha desnudado -el sombrero y la capa prestados-. El jaque revela su nombre, ante lo que todos responden con reverencia y admiración: sin duda, "Pero Vázquez es el diablo" (v. 303). Dicen que podría haberse ahorrado el relato, porque ya son 
harto conocidas sus aventuras. Cuando termina este primer cuadro, los cinco se disponen a emborracharse juntos y auguran nuevas bravuconerías.

¿Cuándo pudo componerse esta jácara? A juzgar por el fragmento que sigue en la comedia (y según ya hemos analizado en el apartado correspondiente del capítulo IV), parece ser posterior a $1611 .{ }^{31}$ Quevedo compuso esta jácara con una consciente madurez de los fundamentos de este subgénero dramático. El lenguaje utilizado (con el uso ingenioso de los términos de germanía) y la maestría estilística de la pieza denotan que Quevedo se movía en un terreno literario que ya había abordado con anterioridad.

\section{7. ¿SON O NO SON JÁCARAS?}

Uno de los principales problemas de la filología es la delimitación de los géneros. Cuando el investigador del Siglo de Oro se enfrenta a los manuscritos, a menudo se encuentra con composiciones que están bajo el rótulo de jácara, a pesar de que su lenguaje no abunda en germanismos ni los protagonistas son estrictamente jaques. José Manuel Blecua fue consciente de este hecho en su edición de la Poesía Original Completa de Quevedo. Por ello, respecto a la composición A una dama señora, hermosa por lo rubio $(P O C, 854)$, por ejemplo, señala que:

\footnotetext{
${ }^{31}$ Esta hipótesis procede de la atestiguación de que en la comedia inacabada hay un "autoplagio" de una canción a Amarilis.
} 
No es propiamente una jácara, como verá el lector, pero González Salas la incluye en el grupo. Nosotros, por no deshacerlo, la hemos mantenido en este lugar. [1999: 1137].

Otros romances, a pesar de que en los manuscritos aparecen definidos como jácaras, son editados por Blecua en la sección de poesía satírica. Éste es el caso de Las cañas que jugó Su Majestad cuando vino el príncipe de Gales (POC, 677), Boda y acompañamiento del campo (POC, 683), Segunda parte de "Marica en el Hospital" y primera en lo ingenioso (POC, 695), Los borrachos (POC, 697) y "Hagamos cuenta con pago..." (POC, 753).

Mención aparte merecen las dos composiciones atribuidas a Quevedo que trataremos a continuación: la Toma de Valles Ronces y A los amores del Rey Rodrigo y la Cava. Ambas comparten con las jácaras al uso la métrica arromanzada y la narratividad propia de la épica. Sin embargo, estos textos no incluyen un léxico de germanía, ni sus protagonistas son miembros del mundo rufianesco.

\subsection{LA TOMA DE VALLES RONCES}

Quevedo destinó algunos de sus opúsculos a las tensas relaciones políticas entre España y Francia: ante todo, se le han atribuido la Carta al Serenísimo, muy alto y muy poderoso Luis XIII, rey cristianísimo de Francia, que escribiría con motivo de la declaración de guerra del 6 de junio de 1635, y la Visita y anotomía de la cabeza del Cardenal Armando de 
Richelieu, publicada bajo el pseudónimo Acnoste, análisis burlesco del mal francés, personificado en el estudio fisiognómico del cardenal. ${ }^{32}$ Asimismo, por una Relación anónima de hacia 1636, se ha inferido que, hacia 1632, Quevedo había redactado una célebre jácara contra los franceses, escrita en un lenguaje encarnizado:

El señor don Juan de Jáuregui ha sacado un discurso sobre que se ha de hablar y tratar bien de palabras a los enemigos, el cual, dicen, lo han tomado muy mal los superiores. La jácara que ha compuesto el Sr. don Francisco de Quevedo contra los franceses sigue otro estilo, y va con ésta. [Blecua, 1999: 1273] $]^{33}$

Blecua la publica en un Apéndice de su POC [1999: 1.273], a pesar de que "en tres mss. de la época (dos de don A. Rodríguez-Moñino y el XCIV de la HSA, de NY, núm. 44) figura a nombre de Díaz Plantel." Este nombre, sin embargo, podría tratarse de un pseudónimo, ya que el contenido de esta composición implicaría peligros y acusaciones a su autor (no es algo excepcional si consideramos que la Visita y anotomía también fue escrita bajo pseudónimo).

La Toma de Valles Ronces presenta muchas concordancias estilísticas con la obra de Quevedo, sobre todo de tipo sintáctico: abunda en la adjetivación de los sustantivos ("títeres galeones", v. 10; "sopapos escariotes", v. 15) y el uso de frases hechas. En el ámbito léxico, aparece el

\footnotetext{
${ }^{32}$ Véase la edición de ambas obras, respectivamente a cargo de Carmen Peraita y Josette Riandière de la Roche, incluidas en el volumen III de las Obras completas en prosa de Quevedo [2005: 249- 345].

${ }^{33}$ Publicada por Janer [BAE, LXIX: 528-542].
} 
quevedesco uso de la palabra galalón con el significado de "traidor" (v. 28), la parodia de latinismos ("casamentero in utroque", v. 22; "al quodam clérigo pobre" (v. 37) y la agudeza conceptista (en expresiones como, por ejemplo, quiquiriquí sincopado (v. 81) para aludir al duque de Criqué.

En definitiva, La Toma de Valles Ronces es una sátira romanzada que incluye -como las jácaras genuinas- el hacer y deshacer de un sinfín de personajes: si sus protagonistas, en vez de franceses, fueran jayanes, tendría su pase como jácara. Comparte con este género la estructura narrativa y el tono jocoso. No obstante, carece del léxico de germanía y difícilmente llegaría a representarse, dada su temática políticamente escabrosa. Concluimos, por tanto, que no se trata de una jácara específicamente hablando, aunque comparta muchos de sus rasgos. La autoría quevedesca, por otra parte, nos parece incuestionable después de los argumentos de José Manuel Blecua. ${ }^{34}$

\subsection{A LOS AMORES DEL REY RODRIGO Y LA CAVA}

Descubrí un romance tildado de jácara, titulado A los amores del Rey Rodrigo y la Cava, en un volumen que contiene poesías de Quevedo, el ms. 324 de la Universidad de Coimbra. Esta obrilla figura sin título expreso pero aparece contigua a una composición de don Francisco. De notable belleza, uno de sus versos contiene el título de la comedia burlesca atribuida a Quevedo ;Qué villano es el amor!:

\footnotetext{
${ }^{34}$ Blecua ha justificado su atribución. Véase III [1999: 455-61].
} 
De verse de un Rey gozada,

quedó la niña entonada,

más fuerza será que amanse

cuando mueve su rigor:

¡Qué villano es el amor!

Líbrenos Dios que se canse. (vv. 242-247)

Ambos textos entrañan cierta relación o referente común, de eso no cabe duda. ¿Este romance es un fragmento de la comedia inacabada, desgajado por su belleza indiscutible?¿Se trata, por el contrario, de una obrilla independiente? ¿Es el modelo "serio" que parodió la comedia burlesca atribuida a Quevedo? Lo cierto es que hemos descartado que "iqué villano es el amor!" fuera un estribillo conocido de la época, porque no figura en ningún otro texto que conozcamos, aparte del presente romance y la comedia burlesca que analizamos en el capítulo anterior.

La composición que nos ocupa recrea el motivo de uno de los ciclos de romances históricos más célebres: el del rey Rodrigo y la pérdida de España. ${ }^{35}$ Quevedo evoca a este monarca y la Cava en el romance satírico Sábado en Guadalajara (POC, 801), donde hace un juego de palabras con los nombres de estos dos famosos personajes históricos:

${ }^{35}$ Según la leyenda, el último monarca visigodo se sintió atraído por una doncella de la corte, la Cava. Para satisfacer su lujuria, envió al padre de la joven, el Conde don Julián, a Ceuta. Aún así, éste se enteró de la pérdida de la honra de su hija, que en unas versiones aparece violada y, en otras, seducida. Como venganza, contactó con los musulmanes que habían llegado al norte de África, y les propuso la conquista de España. En efecto, en la batalla de Guadalete derrotaron por completo al ejército visigodo. 
Labio de beber a chorro,

que dicen majestad belga,

los que, a pesar de Rodrigo,

llaman cava la taberna. (vv. 5-8).

La lujuria como pecado de los poderosos es un tópico que también emerge en la comedia de Quevedo Cómo ha de ser el privado. En ella, el Rey se siente atraído por una dama que le sedujo en su juventud: el valido tendrá que convencerle para que apacigüe sus pasiones.

El romance $A$ los amores del Rey Rodrigo y la Cava empieza con la descripción de un cuadro idílico. En un locus amoenus, el rey Rodrigo siente lascivia por Florinda y Elvira. El monarca satisface con ellas sus deseos sensuales sin ningún tipo de pudor. El romance describe relaciones sexuales explícitas. Se pondera la liviandad del poderoso, que no es capaz de refrenar el erotismo.

La obrilla prosigue con una descripción de la Cava, cuya extraña beldad cautiva al soberano, como lo hiciera Dafne con Apolo. Se evidencian escenas de violación y forcejeo: la joven se resiste a perder la castidad. Derrama lágrimas por la virtud mancillada y la pérdida de la honra. Después, se serena: desea holgarse y goza del acto sexual. No obstante, tras el letargo amoroso, regresan las lágrimas. Ella está enamorada; él la desdeña: determina aborrecer lo que adora. El amor se convierte en odio: la Cava informa a su padre de la afrenta y clama venganza.

La continuación de la leyenda ya era sabida: cuando un soberano es incapaz de contener su libido, el desliz pone en peligro su fama y su 
mandato. La belleza de la Cava, como la de Helena de Troya, desencadena una guerra.

Este romance, con todo, si bien por el estilo y temática podría pertenecer a Quevedo, tampoco reúne los requisitos fundamentales que lo emparentarían con las jácaras quevedescas al uso. Es un poema narrativo que carece de léxico de germanía. Su protagonista, sin embargo, es un rey, y veíamos que etimológicamente jaque significa monarca en árabe. La jácara, entre la lírica y el teatro, presenta a menudo estas vaguedades.

\section{UNA BREVE VIDA LITERARIA}

Aunque las jácaras dramatizadas surgieron cuando el entremés ya se encontraba en un estadio avanzado, se arraigaron cada vez con más fuerza a la estructura del espectáculo y enriquecieron sus matices expresivos.

La jácara no ocupaba un lugar fijo en la función teatral, ${ }^{36}$ ni tampoco tenía por qué señalar un aparte en la misma: a menudo se interpolaba en el entremés, el baile, la mojiganga o en la comedia (así sucede en Pero Vázquez de Escamilla, como ya hemos apuntado). Se cantaba con una melodía característica y también se solía bailar. El público mostraba tanta afición a las jácaras que a menudo exigía que se representaran antes de terminar la función.

\footnotetext{
${ }^{36}$ El esquema general de la comedia era el siguiente: preliminares (golpes en el tablado, música, etc.), loa, primera parte de la comedia, entremés, jornada segunda de la comedia, baile, tercera jornada de la comedia y mojiganga o fin de fiesta. Cfr. Huerta Calvo [1985: 10].
} 
Con grandes dosis de libertad, la jácara fomenta el deleite artístico y la creación a partir de un material de derribo, la escoria social. Hace del desarraigo, de una particular realidad urbana y de un modo de vida marginal, un motivo literario. El objeto de burla no es simple y unívoco, porque el lector disfruta de una invención en negativo, donde los jayanes más obtusos pueden ser glorificados como en la épica más resoluta.

Bien podría equipararse la intencionalidad de las jácaras de Quevedo a la finalidad de los romances germanescos que, editados por Juan Hidalgo en la edición de Antonio de Sancha (Madrid, 1779), aparecían justificados en el prólogo "Al curioso lector" de la manera siguiente:

\footnotetext{
hechos más para pasar tiempo, que para ofender con ellos el oido del virtuoso. Verdad es que la estrañeza de la lengua, y el mal nombre de los que la usan, eran bastantes causas para condenarla, si no me valiera de mi buen celo, que es advertir della, por el daño que de no saberse resulta. [...] Y desta causa ha procedido mi determinación de hacer manifiesto su escuro lenguaje, que sirve de antídoto contra su veneno, y de contramina y prevención a sus maldades y asechanzas, dándoles ejemplo a ellos mismos con los males fines a los que traen sus viciosos pasos, $\mathrm{y}$ disolutas vidas. [1779: 5-6]
}

El nutrido lenguaje de la jácara, lleno de enriquecedores aromas satíricos y resonancias suburbiales irónicas, justifica que consideremos simplista una interpretación de este género como una crítica del escritor hacia determinados estamentos sociales. Los jayanes se expresan con hipérboles desrealizadoras, narran sus peripecias a través del alambique grotesco. Han de procurar la carcajada del público. Y no sólo eso. Como Cristos azotados 
por la desventura, son mártires de una sociedad que no sabe comprender sus hazañas.

Quevedo se empapa de las formas de vida urbanas. Lleva a su pluma escenas y tipos de la vida pública. Convierte en un espectáculo estrambótico los avatares de una sociedad poco equilibrada. El éxito y la tradicionalización de las jácaras acreditan que don Francisco no fue el único en sentir esta atracción por un género amparado en la decadencia social. El cultivo de la jácara a todas luces le hizo sentir poeta de su tiempo. ${ }^{37}$

Hubo otros "poetas jacarandos" que procuraron imitar a don Francisco. Su inventiva e ingenio, sin embargo, no alcanzaron la belleza estética, la agudeza y la lucidez lingüística de nuestro autor. ${ }^{38}$ Existía, con todo, una diferencia notable entre la inventiva de Quevedo y la de sus seguidores. Así, por ejemplo, Quiñones de Benavente, Calderón de la Barca o Jerónimo de Cáncer (que también compuso jácaras a lo divino) expresaron en la forma y el contenido de sus jácaras la relevante deuda que el género contrajo con la

\footnotetext{
${ }^{37}$ Así lo expresa Jauralde [1999: 268].

${ }^{38}$ Chevalier [1992: 179-180] es drástico en su valoración: "Los poetas jacarandos procuran
} imitar a Quevedo. La intención es plausible. Pero estos fieles imitadores ni siquiera alcanzan el grado de medianos discípulos: sus obritas demuestran poca inventiva y pobre ingenio. Excepción única es la de Jerónimo de Cáncer y Velasco, en cuyas jácaras brilla alguna vez un destello ingenioso. Por regla general, las jácaras "imitadas" de Quevedo no pueden ubicarse bajo el rótulo de la agudeza; merecen plenamente los calificativos de "vulgares" y "plebeyas" que se les ha aplicado. Tienen interés dentro de una historia de la cultura, pero son estéticamente nulas. Hablar de decadencia sería inadecuado; más exacto es decir que las jácaras quevedianas abrieron un paréntesis en la historia del género. En seguida volvieron las aguas de la jácara a correr por el cauce de las coplas de Pedro de Reinosa. La jácara aguda nace y muere con Quevedo." 
representación teatral: respecto de las piezas de Quevedo, notamos una mayor frecuencia del diálogo como marco estructural y del desarrollo del argumento, acotaciones dramáticas, coreografías y un incremento de los personajes; se allana la dificultad lingüística y el aluvión de términos germanescos, las composiciones asumen mayor visualidad y dinamismo escénico.

Hubo otros cultivadores esporádicos de jácaras, como Antonio de Solís, Antonio de Cardona y Francisco de Avellaneda. En ocasiones, esta composición se interpolaba en el entremés, e incluso en los bailes, ya a partir de la segunda mitad del siglo XVII. ${ }^{39}$

La jácara, con todo, tendría una breve vida literaria: ya a finales del siglo XVII, el público empezó a aborrecer la literatura rufianesca. La música y el canto continuaron en la tonadilla, que se perfeccionó ya entrado el siglo XVIII. $^{40}$

\footnotetext{
${ }^{39}$ Según analiza Cotarelo [1911: CCLXXXI- CCLXXXVI].

${ }^{40}$ Cfr. Cotarelo y Mori [1911: CCLXXXVII].
} 


\section{LOS BAILES DE QUEVEDO}

\section{UN CONTEXTO INTRINCADO}

Dice Cervantes, en La Gran Sultana, que "no hay mujer española que no salga/ del vientre de su madre bailadora" (III, vv. 245-246). ${ }^{41}$ Este tópico ha acompañado durante siglos a nuestra cultura. ${ }^{42}$ La entrada del baile en el espectáculo teatral hispánico se atestigua desde sus comienzos, como condimento y sazón de las representaciones.

A principios del Renacimiento, quizá por influjo italiano, ${ }^{43}$ los poetas cultos gustaron de componer obrillas de carácter popular: entre ellos, había músicos y literatos como Juan del Encina, Lucas Fernández, Gil Vicente, Torres Naharro o Lope de Rueda, creadores de fiestas y momos que intercalaron bailes en sus composiciones. ${ }^{44}$

41 Sigo la edición de Florencio Arroyo Sevilla, editada digitalmente en Alicante : Biblioteca Virtual Miguel de Cervantes, 2001.

${ }^{42}$ Merino Quijano [1981: 162] , en su tesis doctoral sobre el baile dramático, destaca este afán natural, motivo de alegría tanto en la aldea como en la corte, como precedente psicológico y social de este género literario.

${ }^{43}$ Cfr. Cacho Palomar [1997: 275]: "Lorenzo el Magnífico creó, a la manera vulgar, sus canti carnascialeschi y sabemos que a muchos humanistas de la Academia florentina les gustaba escuchar las canciones populares.

${ }^{44}$ Los precedentes del baile incluido en obras dramáticas se remontan a la Égloga de Cristino y Febea de Juan del Encina, la primera égloga y la Farsa del nacimiento de Lucas Fernández, los autos de Gil Vicente, la Farsa del juego de cañas de Sánchez de Badajoz o el Coloquio de Timbria de Lope de Rueda. Cfr. Merino Quijano [1981: 160,161]. 
A lo largo del siglo XVI, la corte abrigó coplas, redondillas, folías y villancicos para acompañar las danzas aristocráticas. A mediados de este siglo, surgieron bailes pícaros y lascivos, como la zarabanda y la chacona, que calaron hondo en la urbe.

El baile se extendió hasta entrado el siglo XVII: estaba presente en las comedias, los entremeses, las jácaras, las mojigangas y los fines de fiesta. No cesaron las polémicas al respecto. El Padre Mariana, en el capítulo XII de su reprobación Contra los juegos públicos, titulado "Del baile y canto llamado zarabanda" censuró la representación de esta modalidad, aduciendo que era "tan lascivo en las palabras" y "tan feo en los meneos" que era capaz de corromper aún a las personas más honestas. Para su mayor desasosiego, había penetrado diabólicamente en conventos, iglesias y hasta en las fiestas del Corpus. ${ }^{45}$

El baile se introdujo, en efecto, en los autos sacramentales. A pesar de su irreverencia, eran comunes las escenas en las que aparecían el Papa y cardenales bailando danzas atrevidas. ${ }^{46}$ El dominico Alonso de Ribera se quejaba de ello. Opinaba que los autos del Corpus no habían de estar "envueltos en mil cosas lascivas, claras o disimuladas". ${ }^{47}$

\footnotetext{
${ }^{45}$ En Obras del padre Juan de Mariana [1864: t. XXXI, pp. 432-434].

${ }^{46}$ Recordemos algunos autos anónimos como La fuente de la gracia, el Auto de los desposorios de Isaac. También se baila en el Auto de la oveja perdida de Timoneda. Y en diversos autos de Lope de Vega, como La Maya o El Auto de los Cantares. Cfr. Merino Quijano [1981: 162].

${ }^{47}$ Véase Alonso de Ribera, Historia sacra del Santísimo Sacramento contra las herejías de estos tiempos, VI, 1626, cit. por Cotarelo y Mori en su Bibliografía de las controversias
} [1904: 520]. 
Hay quien cree que la prohibición del teatro en 1598 pudo estar motivada por los bailes nuevos, dado que meses más tarde, en el Memorial a Felipe II, se pide que se restituyan las comedias y las danzas antiguas, que no las modernas. No se hizo caso a la petición: los bailes lascivos decrecieron en las comedias, pero no abandonaron las tablas. Se refugiaron, esta vez, en los entremeses y los bailes de los entreactos.

Quevedo cita en su obra más de sesenta nombres de baile. Muchos de ellos, sin embargo, son inicios de las letras de otros ya conocidos. ${ }^{48}$ El 8 de abril de 1615, la Reformación de comedias del Consejo de Castilla prohibió la representación de "cosas, bailes, ni cantares, ni meneos lascivos ni de mal ejemplo, sino que sean conformes a las danzas y bailes antiguos", así como "todos los bailes de Escarramanes, Chaconas, Zarabandas, Carreterías...". Y más adelante, se añadía: "Que no inventen otros de nuevo semejantes con diferentes nombres". ${ }^{49}$ La naturaleza de esta prohibición implica cómo proliferaron los bailes $\mathrm{y}$, dado su éxito controvertido, cómo intentaron doblegar la censura bajo múltiples tretas. Esto condicionó notablemente la composición de los bailes de Quevedo.

\footnotetext{
${ }^{48}$ Cfr. Cacho Palomar [1997: 281]: "Este fenómeno había ocurrido ya desde el siglo anterior. El nombre del Villano viene del villancico: "Al villano se le dan/ la cebolla con el pan"; las Vacas de "Guárdame las vacas/ carillejo por tu fe/ y un besico te daré"; el Conde Claros del romance "Media noche era por filo/ los gallos querían cantar/ Conde Claros por amores/ no podía reposar" y así también el Rey don Alonso, el Polvico y muchos bailes posteriores."

${ }^{49}$ Según confirma Cotarelo Mori [1911: I, CXC].
} 


\section{GONZÁLEZ SALAS: ORÍGENES Y EVOLUCIÓN DEL BAILE}

El baile como género dramático es un intermedio constituido por cuatro elementos principales: la música, el canto, la letra y, ante todo, el baile (también denominado saltación), que le confiere el nombre. ${ }^{50}$

En los "Preliminares" de la musa V, Terpsícore, de su edición del Parnaso, Salas reflexiona sobre el origen poético de los bailes. Subraya su doble condición como piezas cantadas y bailadas. Su germen está en la Comedia española y su función consiste en divertir de la gravedad de la trama argumental de las comedias, en cuyos entreactos se solían representar:

La parte sola que habemos aquí de calificar con darle noble origen, hallándole muy antiguo, es, conviene a saber, este género de poesías, que con la sentencia, ayudada de la música de la voz, dan alma y vida a las acciones y movimientos todos de los bailes que les corresponden. Elegancia es ésta que digo que adornó nuestro teatro escénico, bien ya después de estar la que se llama Comedia española en alto punto y perfección suma. Distinguía entre los actos suyos para divertir la gravedad de sus acciones, la intermisión de unas representaciones ridículas (que también tienen mucha paridad con algunas de los antiguos), y vulgarmente se dicen entremeses. [1999: I, 127]

Según González Salas, pasajes de Marcial, Catulo, Juvenal y Horacio, entre otros autores, atestiguan la presencia del baile en la antigüedad

${ }^{50}$ Sobre la definición del baile, véanse Cotarelo [1911: CLXIV] y Merino Quijano [1981: $156]$. 
grecolatina. ${ }^{51}$ El erudito compartía estos conocimientos con Quevedo, que, como buen humanista, siempre tuvo presente esta veta clásica, a la que Salas alude:

Tuvieron, digo, los griegos, doctos maestros de las sciencias, bailes con estos tan unos, que cuanto más en ellos mi observación se ocasiona, más el examen de su semejanza me obliga a admiración. [1999: I, 128]

Por otra parte, Cotarelo pretende fijar en la segunda década del siglo XVII la independencia total de los bailes respecto de otros subgéneros dramáticos. Subraya la naturaleza multiforme del baile y lo diferencia del entremés:

Puede ser monologado o dialogado como el entremés, pero siempre es más corto, y la letra, acomodada para el canto, unas veces constituye todo el intermedio y otras sólo una parte. Había, pues, bailes cantados y otros en parte hablados, que se llamaron entremesados. [1911: CLXIV].

El baile es más breve que el entremés y, en cambio, su parte cantada es más extensa que la representada. Hay que distinguirlo del baile entremesado, que muestra narración por medio de unos personajes, y no a

\footnotetext{
${ }^{51}$ Los bailes también se escenifican durante el Medievo, como constatan las Etimologías de San Isidoro. Sobre el baile popular, asimismo, tenemos noticias en las Leyes de la Partida de mediados del siglo XIII y en textos literarios como el Libro de buen amor del Arcipreste de Hita y el Libro de Apolonio. Los antecedentes del baile, de hecho, se remontan a las danzas de la muerte medievales. Sobre la etimología y evolución del baile, véase la tesis doctoral de Merino Quijano [1980: I, 128-173].
} 
través de una música. Su métrica es similar a la de las jácaras: versos octosílabos, que siempre han sido apropiados para ser cantados. Los bailes solían, asimismo, terminar, con una o varias seguidillas.

La historia del baile dependió de la reformulación de sus cuatro componentes: la música, la danza, la letra cantada y la letra hablada. Si en las postrimerías del siglo XVI la relevancia de la música y la danza en el baile es superior a la del texto, los dramaturgos de 1620-1660 aportan mayor brío a su expresividad verbal. A partir de los años 60, con la decadencia del género, el texto pierde de nuevo el brío. El baile, de hecho, fue desapareciendo de las comedias y se trasladó al entremés, hasta que logró constituirse en un género intermedio: el baile dramático o entremesado.

\section{LOS BAILES AL FINAL DE LOS ENTREMESES DE QUEVEDO}

Los entremeses de Quevedo solían terminar en baile. Recordemos que doña Fáfula, la mujer de un comediante en el Sueño de la muerte [2003: I, 453], decía que los personajes de los entremeses, "por escaparse y ser solteros, algunos se acaban en barbería, guitarricas y cántico".

El baile se incorporó en el entremés a medida que se alejaba de la comedia, que fue descartando su inclusión en pro de la búsqueda de personajes de alto rango, asuntos nobles y temas serios. 
En el siglo XVI, aparecen los primeros entremeses que terminan en baile. Pero, sobre todo, emergen a principios del siglo XVII, como evidencia la cláusula de algunos contratos de compañías de representantes. ${ }^{52}$

Cervantes incluye una zarabanda sin letra en El retablo de las Maravillas. En los Alcaldes de Daganzo, aparece un baile a propósito de la intervención de los gitanos. En La guarda cuidadosa, se añade la entrada de los músicos para celebrar el desposorio. Asimismo, al final de El rufián viudo se bailan un paso de la gallarda sin letra; el rastreado, con la letra de un romance que alude a los pasos personajes y su coreografía; y el canario y el villano, sin letra. ${ }^{53}$

En efecto, el baile siguió al entremés a lo largo del XVII: así lo apreciamos en las obras de autores como Castillo Solórzano, Hurtado de Mendoza, Juan de Zabaleta, Francisco Lanini, Quiñones de Benavente o el propio Quevedo.

Repasemos los finales de los entremeses de nuestro autor. Sólo dos de ellos, de atribución dudosa, terminan a la manera antigua, con matapecados: son Los refranes del viejo celoso y El hospital de los malcasados. A su vez, la primera parte del entremés en prosa de Diego Moreno no culmina en baile explícito, que finaliza abruptamente con un parlamento de doña Justa, representativo de su codicia: "Apriétenme la sortija. Y, si hay otra, también, porque estoy preñada y malpariré.” Y, también, La polilla de Madrid, a su

\footnotetext{
${ }^{52}$ Así figura, por ejemplo, en un contrato donde Nicolás de los Ríos en 1603 se concierta con la Cofradía del Rosario de la villa de Fuenlabrada para hacer "un auto con dos entremeses con su música y bailes" y una comedia con su entremés y música y baile”. Cito de Merino Quijano [1981: 163].

${ }^{53}$ Cfr. Querol Gavalda, La música en las obras de Cervantes [1948].
} 
vez, acaba con el parlamento de Mondoñedo a modo de moraleja: el pícaro advierte que "toda niña que se ingiere en robo/ ella es Elena y su galán el robo".

El resto de entremeses de Quevedo sugieren bailes en sus finales. De los escritos en prosa, la segunda parte de Diego Moreno, La vieja Muñatones y la primera y segunda parte del entremés de Doña Bárbara terminan con música en verso, que seguramente se bailaría sobre el escenario.

De los entremeses rimados, La venta culmina con los cuatro primeros versos de la jácara Carta de la Perala a Lampuga, su bravo (POC, 851), que a todas luces se bailaba. La primera parte del entremés de El marión acaba con un baile sin letra. El padre obliga a bailar a don Constanzo:

\author{
PADRE - \\ Pues que bailéis os pido. \\ DON CONSTANZO- ¿Quiere usted que baile, señor padre? \\ PADRE- $\quad$ Baile vuested, señor hijo de puta. \\ Don CONSTANZO- Pues présteme vuested esa gorrilla. \\ (Bailan, con que se da fin a la primera parte.)
}

Y, al final de la segunda parte del mismo entremés, será su esposa, María, la que obligará a su afeminado marido a danzar:

Salen los MúsICOS

HOMBRE-

Los musiquitos.

DON CONSTANZO- ¿YYo he bailar? No, por cierto.

DOÑA MARÍA- $\quad$ Baile agora, porque yo lo mando.

Don Constanzo-

Es muy justo

obedecerla en todo y darle gusto. 
Apócrifo o no, en el entremés de El caballero de la Tenaza hay una picante coreografía interpretada por hombres, capitaneados por don Tenaza, y mujeres, guiadas por doña Anzuelo. Hallamos, incluso, una pequeña acotación coreográfica, cuando interviene la Niña: "Un voladillo, y vuélvense a su lugar".

El niño y Peralvillo de Madrid, si bien no especifica que sus personajes bailen, sí que alude a las vihuelas del final y al canto de las pidonas de una nana paródica.

Al final de La Ropavejera, suenan guitarras y salen músicos, que comparan cantando la vejez de los cuerpos con la de los bailes de antaño:

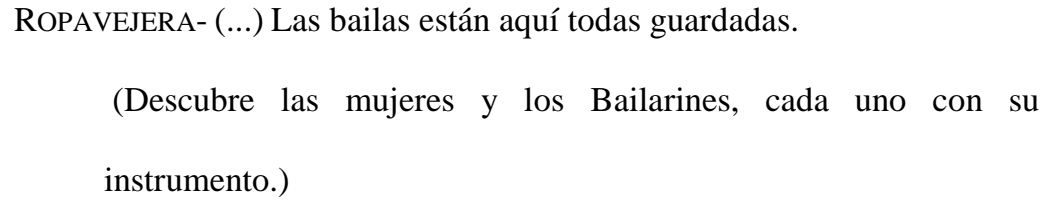

(Va limpiando con un paño las caras a todos, como a retablos, y cantan y bailan lo siguiente:) 
En El marido pantasma, sale al final Mendoza con unas mujeres, y todos cantan y bailan al son de una canción cantada por los músicos y Lobón. El mismo desenlace disparatado culmina con El zurdo alanceador, donde doña Lorenza declara al juez que las mujeres, “enteras y diestras y perfectas/ (...) aun en bailar sabemos tretas”, y desata una picante coreografía femenina.

Sabemos, por último, que el entremés de La destreza acaba con un baile que González Salas publicó en el Parnaso (Madrid, 1648) bajo el título de Las estafadoras (POC, 874).

Por lo general, los bailes con letra insertos al final de los entremeses de Quevedo cortan de forma más o menos tajante con la trama de las composiciones. Don Francisco suele decantarse por el baile adventicio, un pretexto artificial para concluir las piezas.

\section{Clases de baile en el Parnaso}

El baile, como ya hemos señalado, integra cuatro ingredientes esenciales: la recitación, la música, el canto y la danza. A pesar de que el filólogo suele centrarse en la parte literaria, el motor y fin de este intermedio teatral es su parte coreográfica.

Hemos de destacar, de antemano, que existen bailes monologados y bailes dialogados. A menudo, la crítica confunde ambos términos por el hecho de que ambos son escenificados. El baile monologado descansa sobre una letra (una copla, romance, seguidilla...) que acostumbra a tener estribillo y está elaborada por poetas. Esta letra se canta con música de guitarras, 
panderos, sonajas, bandurrias y otros instrumentos y se baila, además, con una determinada coreografía. ${ }^{54} \mathrm{El}$ baile dialogado precisa, además, de la acción de unos personajes que sean portavoces de la letra. ${ }^{55}$

Son, por tanto, distintos los bailes narrativos en los que la letra simplemente es cantada por los músicos y el baile que Quiñones llamó entremés cantado, donde existe un diálogo entre personajes. De los diez bailes de Quevedo que Gonzaléz de Salas publicó en el Parnaso distinguiremos, por tanto, entre los bailes monologados (POC, 865, 868, 873, 874) y los bailes dialogados propiamente dichos (POC, 866, 867, 869, 870, 871, 872), en función de los parámetros señalados.

\section{UNA MÉTRICA VARIABLE}

Los bailes, en general, tienden a plasmar entre dos y seis combinaciones métricas distintas y la longitud de sus pasajes estróficos es muy flexible. Se ha de destacar, sin embargo, la primacía del romance, la seguidilla, los pareados, la redondilla y algunas formas irregulares en su composición estrófica.

\footnotetext{
${ }^{54}$ Véanse los primeros bailes recogidos por Cotarelo y Mori [1911], que reúnen estas características, dado que no contienen la acción de unos personajes: La boda de Foncarral $\left(\mathrm{n}^{\mathrm{o}} 193\right)$, La colmeneruela $\left(\mathrm{n}^{\circ} 194\right)$, Baile Pastoril $\left(\mathrm{n}^{\circ} 196\right)$, Baile curioso y grave $\left(\mathrm{n}^{\circ} 199\right)$, Baile del Duque de Humena ( ${ }^{\circ}$ 201), Baile de D. Jaime ( $\mathrm{n}^{\circ}$ 202), Baile Famoso del Caballero de Olmedo ( $\mathrm{n}^{\circ}$ 203), Baile ( $\left.\mathrm{n}^{\circ} 204\right)$.

${ }^{55}$ Cfr. Gaspar Merino Quijano [1981: 157].
} 
Los bailes monologados de Quevedo son los que presentan mayor similitud con las jácaras. También abundan en alusiones a personajes hampescos y del mundo de la picaresca aurisecular. Nos llama la atención la fluctuación de versos, que no contempla los límites habituales, entre 80 y 160 vv. ${ }^{56}$ Don Francisco, como veremos, compuso bailes de entre 56 y 249 VV.

El baile más extenso es Los valientes y tomajonas (POC, 865), con un total de 249 vv. Es el más próximo temática y estilísticamente a las jácaras. Los primeros 220 versos utilizan la forma estrófica del romance para encumbrar la vida pasada de los jayanes más célebres. La forma de ensartar el recuerdo de estos personajes es la recurrencia al tópico del tempus fugit, la fugacidad de la vida, todavía más breve para los jaques, que mueren prematuramente en manos de sus verdugos. La transición temática hacia el otro motivo del baile, el ansia pecuniaria, implica el cambio estrófico de los últimos versos. En las ocho estrofas finales, Quevedo utiliza la llamada seguidilla compuesta, caracterizada por añadir a una seguidilla simple una segunda parte de tres versos $(5 \mathrm{a} / 7 / 5 \mathrm{a})$.

Los sopones de Salamanca (POC, 868), además de incluir algunos estribillos, inserta redondillas cuando la narración o descripción de los personajes deja paso a sus cantos.

Las estafadoras $(P O C, 874)$ es el baile más breve, cuenta tan sólo con 56 versos. Esta concisión tal vez se deba a su presencia al final del entremés de

\footnotetext{
${ }^{56}$ Según infiere Merino Quijano [1981: 258].
} 
La destreza. ${ }^{57}$ Le sigue en brevedad Los borrachos (POC, 873), con 91 versos. Ambas piezas confirman la tendencia de nuestro autor a combinar el romance con la seguidilla en sus bailes.

En Las valentonas, y destreza (POC, 866) hay una alternancia entre el romance y las seguidillas: el metro más corto, en este caso, no se concentra tan sólo al final del poema.

En el baile de Los galeotes (POC, 867), el romance es predominante en la primera parte, integrada por narración y diálogos. Incluye, a continuación, agrupaciones heptasílabas dispuestas en cuartetas. Esto era corriente en los bailes, estructuras abiertas en las que tiene cabida cualquier estrofa de origen popular. Las últimas nueve estrofas son seguidillas, agrupadas en cuatro, cinco o seis versos. Esta flexibilidad estrófica forma parte de la naturaleza de la seguidilla. El supuesto desorden métrico no hay que asumirlo como anomalía, sino como libertad estilística que se suavizaba con el acompañamiento musical.

En Cortes de los bailes (POC, 869) la seguidilla se inserta como distintivo de la parte narrada y la cantada, al igual que en Las sacadoras (POC, 870). De mayor complejidad es la métrica de Los nadadores (POC, 871), que arranca con cuatro pareados octosílabos y continúa con el romance, que se alterna con un estribillo en forma de seguidilla y varias quintillas.

En Boda de pordioseros (POC, 872), la descripción de las nupcias de Merlo se solventa a través de la forma estrófica del romance. En la segunda

\footnotetext{
${ }^{57}$ En el estudio de la extensión de los bailes de Merino Quijano, éste señala que en el extenso corpus que analiza sólo hay un baile inferior a los 60 vv.
} 
parte, donde se insertan los diálogos de los invitados a la boda y los contrayentes, se introducen versos de diferente medida y combinación estrófica, aunque predomina el endecasílabo. Quevedo utiliza la seguidilla para terminar el baile, dada su idoneidad para ser cantada y bailada.

Los bailes de Quevedo, según vemos, utilizan el romance por su capacidad narrativa y reservan la seguidilla u otras formas tradicionales, como la redondilla, para aquellos pasajes donde la música y el baile cobran especial relevancia. Aunque, de todas estas formas estróficas, la seguidilla ha recibido la calificación de alma mater del baile. ${ }^{58}$

\section{LOS ASUNTOS DE LOS BAILES}

\subsection{EVOLUCIÓN TEMÁTICA. EL MODELO GRIEGO}

Los bailes de Quevedo tratan de manera lúdica asuntos de la sátira social, especialmente de la avaricia femenina y los amoríos interesados. Para ubicar esta temática, hemos de comprender el contexto y evolución temática de los bailes. Recordemos que los primeros versaban sobre la descripción de escenas populares, batallas y asuntos de enredo. Entre 1620 y 1660, estos temas fueron desplazándose en favor del chiste y la galería de

${ }^{58}$ Remito a los estudios de la seguidilla de Correas, El arte de la lengua castellana (1626), en la edición de Alarcos García [1954: 447-448]; Hanssen, "La seguidilla", Anales de la Universidad de Chile, CXXV (1909: 697-796); Henríquez Ureña: "La versificación irregular en la poesía castellana" [1933: 82] y Clarke, "The early seguidilla", Hispanic Review, XII (1944: 218). Cfr. Merino Quijano [1981: 265]. 
oficios: en estos casos, el maestro de bailes contaba con mayor facilidad para disponer mudanzas y lazos. A partir de 1660, el baile juega con la alegoría, lo pastoril, el amor y hasta con los temas de las jácaras. Agotados sus asuntos, empieza la decadencia del género. La muerte de los bailes dramáticos entronca con el nacimiento del sainete de costumbres dieciochesco. ${ }^{59}$

Salas, si bien reconoce el aliento autóctono del baile, ve claras coincidencias entre éste y los hyporchemata griegos. Los argumentos de los bailes de Quevedo son similares a los del mundo clásico. En cierto modo, los bailes pírricos o militares se correlacionan con los que incluyen "valientes o valentones", como sucedería en Los valientes y tomajonas (POC, 865) o Las valentonas, y destreza (POC, 866) y quizás también Los borrachos (POC, 873); los aletes se equiparan a los de "pobres o mendigos" como la Boda de pordioseros (POC, 872); el celeuste, al baile de “galeotes”, al que pertenece, precisamente, Los galeotes (POC, 867). Asimismo, Quevedo se ampara en la auctoritas de los clásicos en la redacción de algunos de sus bailes, como el de Los nadadores (POC, 871), que se fundamenta "en los que Pólux refiere". ${ }^{6}$

Los bailes de don Francisco se asientan en dos filones temáticos indiscutibles: la descripción del mundo hampesco y las alusiones

${ }^{59}$ Cfr. Cotarelo [1911: CCXXVI]. Señala Merino Quijano [1981: 168] al respecto: "Después de una vida zigzagueante fugitiva, en continua búsqueda de sí mismo -que llega en sus postrimetrías a una curiosa amalgama de lo español con lo extranjero -el baile dramático muere hacia el primer tercio del XVIII, con la aparición de los sainetes costumbristas."

${ }^{60}$ Véase M.J. Alonso Veloso [2005: 37]. 
metateatrales a la dinámica de los bailes. Quevedo, en este último punto, aprovecha este subgénero dramático para describir sus tendencias y movimientos.

\subsection{LA DESCRIPCIÓN DEL MUNDO HAMPESCO}

Quevedo trata en sus bailes los asuntos satíricos que son de su preferencia. Entre ellos, la crítica al orden social mediante la descripción del mundo hampesco. En este sentido, son muy similares a las jácaras de nuestro autor. La línea de distinción genérica es muy fina, especialmente en los bailes más narrativos.

En Los valientes y tomajonas (POC, 865), Quevedo parte del tópico del tempus fugit para conferir al baile un enfoque existencial. Enumera a los jayanes más célebres tempranamente fallecidos a manos del verdugo, ${ }^{61} \mathrm{y}$ entronca su muerte con el inexorable paso del tiempo:

Todo se lo muque el tiempo, los años todo lo mascan,

${ }^{61}$ La nómina es muy extensa, a saber: Diego García, Butrón el de Salamanca, la Villodres, Marco Ocaña, Móstoles el de Toledo, Obregón el de Granada, Carrascosa de Alcalá, Gambalúa de Sevilla, Gonzalo Jeñiz, Gayoso, Ahumada, Garcés, Olmedo el de Calatrava, Martín de Santa Engracia, Perico de Soria, Lucas de Burgos, la Chicharra, Tonelero, Afanador de Cabra, Pantoja, Malla, Verenda, Pero Vázquez de Escamilla, Francisco López Labada y, luego, aquellos que son al unísono bailes y valentones, descendientes de Escarramán. 
poco duran los valientes,

mucho el verdugo los gasta. (vv. 1-4)

Tanto los difuntos jaques como el canoso Escarramán, el abuelo y bisabuelo de muchos bailes, han quedado sepultados por el devenir:

\author{
Veis aquí a Escarramán, \\ gotoso y lleno de canas, \\ con sus nietos y biznietos, \\ y su descendencia larga. (vv. 97-101)
}

Este baile comparte algunos rasgos con la descripción narrativa de la vida y milagros de los jaques, corriente en las jácaras más conocidas de Quevedo, como la Carta de Escarramán a la Méndez (POC, 849), la Respuesta de la Méndez a Escarramán (POC, 850), la Carta de la Perala a Lampuga, su bravo (POC, 851), la Respuesta de Lampuga a la Perala (POC, 852) o la Relación que hace un jaque de sí y de otros (POC, 856).

Otros bailes, como Los borrachos (POC, 873), describen y caracterizan el estilo de vida de los jaques. Concretamente, en esta pieza se poetizan sus costumbres etílicas. Los jayanes son asiduos del vino y las tabernas:

Envainan, y en una ermita beben, ya amigos con sorna, su pendencia hecha mosquitos: aquí paz y después gorja. (vv. 33-36) 
Este baile, como sugiere el verso 35, guarda relación con la jácara Pendencia mosquito (POC, 861), donde los bribones acuden "a la ermita de San Sorbo,/ en el altar de San Trago" (vv. 115-116).

Pero no todo iban a ser jaques en la picaresca. Los sopones de Salamanca (POC, 868) es una parodia del estudiante capigorrón, licenciado de capa desgastada y pedante en la miseria, un quidam pauper que se hospeda en una posada. Éste pierde los papeles por una moza inculta, Catalina de Perales, muy parecida a la Grajal del entremés de la Venta, que le canta "muy cicerona" un estribillo sarcástico, con latinismos y mensaje cifrado sobre las condiciones deplorables de la hospedería:

\section{Pulgas me pican;}

el candil está muerto;

ergo sequitur sequitur

que me pican a tiento. (vv. 49-52)

Las estafadoras (POC, 874), asimismo, recurre al tópico de la manoseadora, tan frecuente en Quevedo, como ya vimos a propósito de sus entremeses:

Lleva en sus manos y dedos

a todos los Doce Pares,

Galalones por las uñas, y por la palma, Roldanes. (vv. 21-24)

La codicia femenina y la crítica al matrimonio serán los temas por excelencia de los bailes dramáticos del Parnaso. Al inicio de Las sacadoras $(P O C, 870)$ se aclaran los preceptos de toda pidona: 
En los bailes de esta casa

se advierte a todo cristiano

que han de sacar las mujeres,

que el hombre ha de ser sacado. (vv. 1-4)

En Las valentonas, y destreza (POC, 866), las manoseadoras aparecerán con nombres de baile: la Corruja y la Carrasca. En pasos de esgrima, satirizando a los tratadistas de la época - como Carranza-, se hacen con las bolsas de los hombres. Así lo atestiguará Santurde, otro baile personificado:

\author{
Ángulo agudo es tomar; \\ no tomar, ángulo bestia; \\ quien viene dando, a mi casa \\ se viene por línea recta. (vv. 129-132)
}

Los personajes y el asunto de Los galeotes (POC, 867) son muy similares a los del baile anterior. Esta composición, con todo, aumenta la dimensión dramática de la precedente, e incrementa el número de personajes. Es un baile entremesado más maduro, que incluye hasta acotaciones escénicas con caracterizaciones de vestuario y pequeñas indicaciones coreográficas. Se trata de un collage lingüístico con estribillos de canciones conocidas de la época. En los versos finales hay una asimilación entre los galeotes y los enamorados que reman en un mar de amor: 
como cómitre maldito,

lo primero toma el pito,

que lo primero es pitar. (vv. 83-87)

En Los nadadores (POC, 871), como en Los galeotes (POC, 867), Quevedo utiliza la metáfora acuática. En este caso, no se describe el mundo hampesco, pero sí la sociedad degradada y moralmente laxa de palacio. Y si la corte es mar, el amor cortesano es nadador:

\author{
En el mar de la Corte, \\ en los golfos de chanzas, \\ donde tocas y cintas \\ disimulan escamas, \\ es menester gran cuenta, \\ porque a veces se atascan \\ en enaguas y ovas \\ nadadores de fama. (vv. 13-20)
}

$[\ldots]$

El amor es nadador

desnudo y desnudador.

El amar es, pues, nadar,

desnudar y desnudar. (vv. 69-72)

En Boda de pordioseros (POC, 872), Quevedo fusiona la sátira contra el matrimonio con la crítica a la plebe. Para las bodas de Merlo, se forma un grotesco paripé de indigentes, donde pobres y pobras -“Tendedores de rasa/ bribones de la sopa/ clamistas de la siesta/ y mil zampalimosnas" (vv. 9-12) - acuden a una ceremonia miserable y polifónica, donde se desacralizan los 
sacramentos nupciales, los tópicos de la fidelidad marital y la prosperidad de los novios. El público carcajearía ante este jocoso baile, preludio del esperpento.

La descripción del mundo hampesco, asunto predilecto de los bailes de Quevedo, coincide con las micro-obsesiones que afloran en su obra satírica en general. Imaginemos la letra de estos bailes cantada en conjunción con los movimientos espasmódicos y las coreografías hiperbólicas de las danzas que, lamentablemente, todavía no se han materializado en nuestro siglo. Una representación que, debido al escaso número de acotaciones escénicas, ha de orientarse a través de otras pistas que Quevedo disemina en los mismos bailes.

\subsection{Metateatro}

\subsubsection{LA SÁTIRA DE LAS DANZAS ANTIGUAS}

Durante el siglo XVII, los términos danzar y bailar eran correlativos, pero no sinónimos. Así lo señala González de Salas en su Nueva idea de la tragedia antigua:

Las danzas son de movimientos más mesurados y graves, y en donde no se usa de los brazos sino de los pies solos: los bailes admiten gestos más libres de los brazos y de los pies juntamente. [1778: 171] 
Esta distinción se afianza en el romance Lindo Gusto tiene el tiempo (POC, 757), que se mofa de la fosilización de los movimientos y mudanzas de las danzas antiguas, que han de dar paso a los bailes modernos. En el siguiente pasaje se establece muy bien la diferencia entre unos y otros:

Las fiestas y los saraos

nos los trueca a mojigangas;

y lo que entonces fue culpa,

hoy nos la vende por gracia.

Los maestros de danzar,

con sus calzas atacadas,

yacen por estos rincones

dirigiendo telarañas.

Floretas y cabrïolas

bellacamente lo pasan

después que las castañetas

les armaron zangamangas.

Con un rabel, un barbado

como una dueña danzaba,

y acoceando el Canario,

hacía hablar una sala. (...)

Usábanse reverencias

con una flema muy rancia

$\mathrm{y}$ de gementes et flentes

las veras de la Pavana.

Salía el Pie de gibao,

tras mucha carantamaula,

con más cuenta y más razón

que tratante de la plaza. 
Luego la Danza del peso,

una Alta y otra Baja;

$\mathrm{y}$, con resabios de entierro,

la que dicen De el hacha.

El Conde Claros, que fue

título de las guitarras,

se quedó en las barberías,

con Chaconas, de la gaya.

El Tiempecillo, que vio

en gran crédito las danzas,

pues viene, toma, y ¿qué hace?;

pues darles una carda,

suéltales las Seguidillas,

y a Ejecutor de la vara,

y a la Capona, que en llaves

hecha castradores anda.

De la trena a Escarramán

soltó, sin llegar la pascua;

y al Rastro, donde la carne

se hace, bailando, rajas. (vv. 125-172)

Quevedo, en este pasaje, se posiciona como testigo de un momento clave de renacimiento de un género, el baile teatral. ${ }^{62}$ Las danzas graves y serias pierden escalafón a medida que surgen los bailes populares, alegres y de castañeta. ${ }^{63}$ A pesar de las diatribas que cayeron sobre los bailes modernos,

\footnotetext{
${ }^{62}$ Cfr. Alonso Veloso [2005: 185].

${ }^{63}$ Algunos escritores, nostálgicos de la decencia de las danzas antiguas, escribieron composiciones al respecto, donde se enfrentaban una y otra modalidad de baile. Así, Lope de Vega [1958: 116] en La Dorotea: "Ya se van olvidando los instrumentos nobles como
} 
triunfaron rotundamente durante el siglo XVII: la Folía, la Chacona, la Zarabanda, el Rastro, el Escarramán y otros tantos dominaban la diversión y la fiesta. Entre las danzas, Quevedo cita el Canario: otros autores lo consideran un baile, o el baile que se inventó más tarde.

Mediante la personificación, el Rastro Viejo, la Chacona, el Escarramán, etcétera, son portavoces de la crisis de las danzas antiguas: así sucede en Las cortes de los bailes (POC, 869), Los galeotes $(P O C, 867)$ y en el entremés de La ropavejera. ${ }^{64}$

A algunos bailes, incluso, don Francisco les inventa una genealogía, como sucede en Los valientes y tomajonas (POC, 865), donde el anciano Escarramán, ya "hecho tierra", alude a sus derivados:

las danzas antiguas, con estas acciones gesticulantes y movimientos lascivos de las chaconas, con tanta ofensa de la virtud de la castidad y el decoroso silencio de las damas. ¡Ay de ti, Alemana y Pie de Gibao, que tantos años estuvisteis honrando los saraos!’. La pieza titulada Las fiestas bacanales también es representativa al respecto. Sarao, el protagonista, llama a las danzas antiguas para que se enfrenten a los nuevos bailes. Como dice en su canto inicial: "Míseros bailes del mundo/ que en la infame inundación/ del vino estáis aprendiendo/ esta torpeza veloz,/ yo soy el noble Sarao/ que a poner vengo en razón,/ con mis numerosas naves/ los coros de vuestro error.// Salga la Chacona y salgan/ todos sus compuestos que hoy/ en un torneo defiendo/ la gracia, la discreción,/ la hermosura, los aciertos/ de la Alemana, Alemana de amor." Naturalmente, ganarán los seis bailes modernos a las seis danzas antiguas. Cfr. Cotarelo [1911: CLXVI].

${ }^{64}$ La prosopopeya es un recurso muy utilizado en los bailes. En un romance anónimo de un pliego suelto de 1608 se casan Chacona y Codillo. Asimismo, también hay varios que versan sobre la prisión de Zarabanda. En unas fiestas de Baeza, cuyas composiciones fueron editadas en 1618, aparecen personalizados nueve bailes: Escarramán, Gorrón, Villano, Vaquería, Rastrojo, Juan Redondo, Ay ay ay, Hu-hu y la Gatatumba. Cfr. Cotarelo y Mori [1911: CCL]. 
Veis aquí a Escarramán,

gotoso y lleno de canas,

con sus nietos y biznietos,

y su descendencia larga.

Del primero matrimonio

casó con la Zarabanda,

tuvo al ¡Ay!, ¡Ay!, ;Ay! enfermo,

y a Ejecutor de la vara.

Este, andando unos días

en la Chacona mulata,

tuvo a todo el Rastro viejo

y a los de Vida airada.

El Rastro Viejo casó

con la Pironda, muchacha

de quien nació Juan Redondo,

el de la rucia y la parda.

Juan Redondo fue soltero;

tuvo una hija bastarda,

que llaman la Vaquería,

mujer de buena ganancia.

Por ella de Escarramán

tienen por hembra la casa

las Valientas y Santurde

en el baile de las Armas.

Hecho está tierra el buen viejo,

$\mathrm{y}$, con todo, no se hallan

sin sus bailes sus tablados,

sin sus coplas las guitarras. (vv. 97-124) 
Don Francisco conocía bien canciones como Señor boticario, deme una cala o Ejecutor de la vara. Como veíamos en el baile anterior, Quevedo dice que ese Ejecutor es hijo de Escarramán y Zarabanda. En la Premática y reformación de 1626, se pedía, de hecho "que los barberos no canten todos graves, sino Zarabandas, Chaconas y Ejecutor de la vara." ${ }^{65}$ Ambas letras debían de ser muy célebres. Se cree que hasta llegaron a cantarse en la corte de los Médici. ${ }^{66}$ Don Francisco, en definitiva, teoriza en verso sobre una cuestión candente de su época: cómo los bailes nuevos habían eclipsado las danzas antiguas. Música y literatura se abrazan en sus bailes.

\subsubsection{INSTRUMENTOS MUSICALES, PASOS Y MOVIMIENTOS}

Entre los recursos típicos del baile, destaca la acomodación de la letra a la música para graduar sus compases. Para ello, son frecuentes los estribillos formados por vocablos $\sin$ sentido, la sincopación o la repetición de palabras que por su ritmo acentual dejan entrever los ritmos musicales. La exclamación ;ay!, tan frecuente, no sólo expresa pena o dolor, sino que sirve de apoyatura rítmica. Así, en las seguidillas finales de Los galeotes (POC, 867) de Quevedo:

${ }^{65}$ Cfr. Cacho Palomar [1997: 283]

${ }^{66}$ Cacho Palomar [1997: 283] señala, al respecto: "En Florencia se conservan catorce cancioneros con música española. Cinco de ellos, con encuadernación medicea y con música para guitarra, pertenecen a una misma serie y llevan letras españolas para acompañar pasacalles, folías, zarabandas y chaconas.” Estos códices se ubican en la Biblioteca Riccardiana de Florencia: mss. 2794, 2804, 2551, 2552, 2973-3. 


\author{
¡Ay, que me ahogo, \\ y me matan las velas \\ a puros soplos! \\ ¡Ay, que me aniego. \\ bajelito nuevo, \\ ay que me aniego! (vv. 158-163)
}

En el baile de Las sacadoras (POC, 870) se describen los instrumentos musicales y los pasos de los bailes. Suenan panderos, guitarras y sonajas, que acompañan los conconos, bullidos, pasos de negro, zapateados, brincos y saltos:

\footnotetext{
A sacar parto animosa con mil uñas en dos manos;

empezad, mis castañetas, a requebrar los ochavos.

Ladrad aprisa al dinero, mis gozquecitos de palo, ladrad y morded rabiosos a las bolsas y a los gatos.
}

Doblad por los avarientos, tocá a nublo por bellacos, repicad por dadivosos, tañé a fuego por muchachos.

Dar pasos hacia el dinero es andar en buenos pasos; la mejor vuelta, cadena; brinco de oro, el mejor salto. (...)

No porque salgo después 


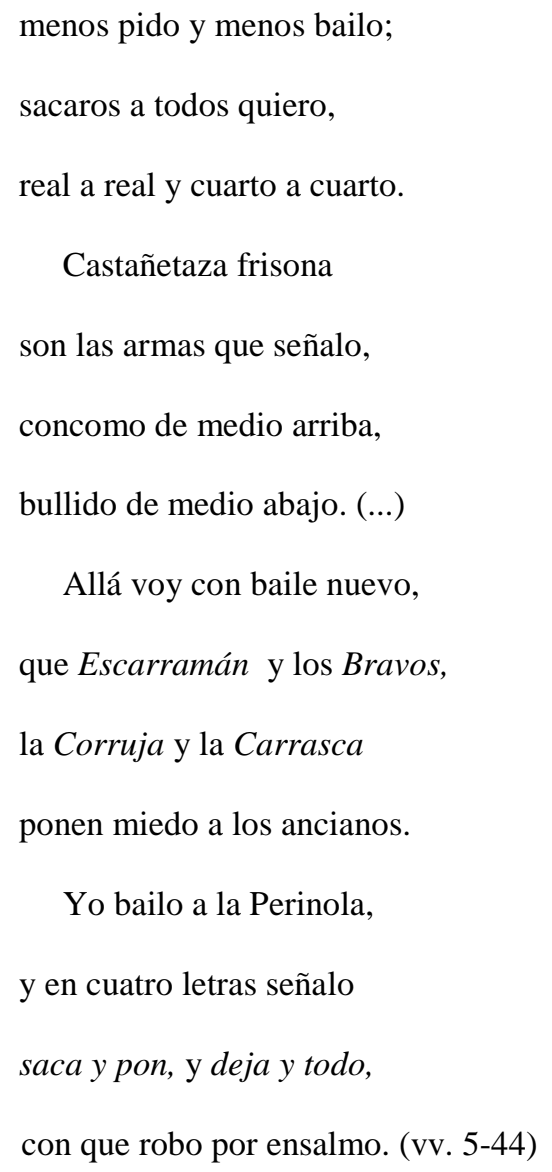

Los pasos de baile serán, en este caso, parte de las artimañas femeninas para robar la bolsa a sus víctimas. Esta jocosa treta de la sonsaca, muy común en Quevedo, es la misma que la de Las valentonas, y destreza (POC, 866), y la que predomina en el entremés de La destreza.

¿Y qué hay de los instrumentos musicales que acompañaban a los bailes? A finales del XVI, la vihuela se sustituye por la guitarra, que siempre había pertenecido al pueblo. Muchos tratados adaptaron a este instrumento piezas de la lírica culta o tradicional que antes se tocaban con vihuela. El barbero, figura tópica de la literatura satírica, a todas horas aparece caracterizado con una guitarra, como en el Sueño de la muerte: 
(...) veo venir gran ruido de guitarras. Alegreme un poco. Tocaban todos pasacalles y vacas.

- ¡Que me maten si no son barberos esos que cantan!

No fue mucha habilidad el acertar, que esta gente tiene pasacalles infusos y guitarra gratisdata. Era de ver puntear a unos y rasgar a otros. Yo decía entre mí:

- Dolor de barba que ensayada en saltarenes se ha de ver rajar y del brazo que ha de recibir una sangría pasada por chaconas y folías. [2003: I, 400] ${ }^{67}$

Por otra parte, según denotan los tratados de música del siglo XVII, como el de Esquivel o las coreografías de Cesare Negri, se distinguía claramente la manera de danzar de los nobles de la del pueblo llano. Las danzas palatinas tenían música muy distinta y no solían ser parejas a la letra de las canciones. En su tiempo de ocio, los señores bailaban con intrincadas mudanzas la gallarda, la pavana o el canario; mientras que los criados cantaban pasacalles carnavalescos y organizaban encamisadas y mojigangas "indecentes": hasta la esclava negra, para jolgorio de todos, bailaba "a lo mandingo" con exuberantes movimientos. ${ }^{68}$ Probablemente, bajo ese influjo, se constituyeron los bailes nuevos.

En la Corte de los bailes (POC, 869), los personalizados Rastro Viejo, Rastrojo, Capona, Escarramán y otros se plantean de dónde sacarán los

${ }^{67}$ En las Premáticas y aranceles generales y en la Premática del tiempo se les deja poner guitarras como anuncios de las barberías. A su vez, en la Conversación de las mulas de unos médicos con la jaca de un barbero (POC, 735), la jaca dice de su amo: "Él estudia en pasacalles/ lo que ejecuta en los miembros/ y en guitarra, y no en cebada,/ me paga mis alimentos." (vv. 117-120)

68 Véase la descripción de las danzas aristocráticas y populares que proporciona Cotarelo [1911: CLXVII- CLXXV]. 
pasos y movimientos. Acuerdan que sean de una espasmódica plasticidad, donde "meneos, ademanes, despachurros/ nuevos de risa y picantes/ con tembladeras de muslos" (vv. 124-126) beben de la heterodoxia y la amoralidad:

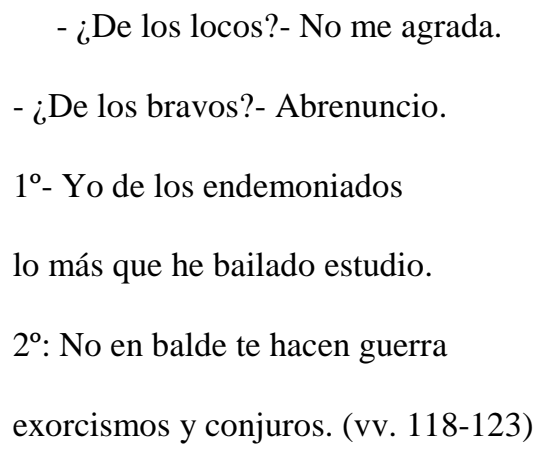

Quevedo es un hábil constructor de escenas a partir de un preciso engranaje verbal. Algunos de sus bailes son verdaderas miniaturas dramáticas. Su imaginación sin trabas es capaz de diseminar un motivo en clave satírica y "hacerlo pepitoria", como diría Cervantes en La Gitanilla. ${ }^{69}$ Ejemplo de ello es la siguiente disquisición sobre las "cosquillas" al final de las Cortes de los bailes (POC, 869). Los músicos cantan al son de los movimientos agitados de la risa, que se parecen a los "meneos" de los bailes modernos:

\footnotetext{
Todo hombre es concebido en cosquilla original: quien no las tiene en los lados, las tiene en el espaldar.

Hay cosquilla cabriola, hay cosquilla mazorral,
}

${ }^{69}$ Cfr. Cervantes [2003: I, 613]: "La señora su vecina la desmenuzaba toda, y hacía pepitoria de todos sus miembros y coyunturas". 
del concomo y del gritillo,

con su poquito de ¡ay!

Hay cosquillas de pellizco

y cosquillas de arañar,

cosquillas de palpadura

y cosquillaza mental.

Hay cosquillones barbados

en hombres de mucha edad

que les están como al diablo

la cruz y el libro misal.

Cosquillas hay marionas

de risa con humedad,

cosquillas envergonzantes,

que andan de noche no más.

Cosquilla se usan postizas,

como pantorrillas ya;

quien de suyo no las tiene,

las compra donde las hay.

Siempre ha tenido Morales

cosquillas en el jugar;

mas la señora Jusepa

no las consintió jamás. (vv. 135-162)

En Las valentonas y destreza $(P O C, 866)$ la letra del baile nos describe o sugiere movimientos coreográficos con pasos de esgrima del mismo:

De verdadera destreza

soy Carranza,

pues con tocas y alfileres

quito espadas. (vv. 93-96). 
Los bailarines aparecen como entes endemoniados de movimientos locos y compulsivos en el baile:

\author{
Una rueda se hicieron: \\ ¿quién duda que de navajas? \\ Los codos tiraron coces; \\ azogáronse las plantas; \\ trastornáronse los cuerpos, \\ desgoznáronse las arcas, \\ los pies se volvieron locos, \\ endiabláronse las plantas. \\ No suenan las castañetas, \\ que, de puro grandes, ladran, \\ mientras al son se concomen, \\ aunque ellos piensan que bailan. (vv. 77-88)
}

Quevedo es consciente de la decadencia moral del baile nuevo, y así se explicita en tono jocoso en el entremés de La Vieja Muñatones:

Pues las mujeres... ¡están apacibles! ¡Fuego, señor Pereda! Como antes iban a la maestra, hoy van las niñas a la castañeta, y en lugar de decillas oraciones dícenlas bailes. [1965: 289]

Estas alusiones a instrumentos, pasos y movimientos dentro de los propios bailes de Quevedo, en todo caso, compensan la falta de indicaciones coreográficas de los textos y pueden aportar pistas para su actual representación. 


\section{LOS PIONEROS DEL BAILE DRAMÁTICO}

Ya hemos señalado que el baile evoluciona como forma de entremés, como sublimación del mismo a partir del canto, la música y las mudanzas, que aparecen como unidad superior integradora. Los bailes dramáticos de Quevedo se presentan todavía de una manera muy embrionaria, dado que la letra acomodaticia, puesta al servicio de las mudanzas, todavía no presenta una complejidad argumental que, al parecer unánime de la crítica, madura y cobra pleno desarrollo con Quiñones de Benavente..$^{70}$

En los bailes de Quevedo predomina la narratividad; en los de Quiñones, el diálogo (por algo los calificaba de entremeses cantados). El primero introduce personajes y retruécanos propios del mundo germanesco, el segundo, de escritura menos ácida y controvertida, procura prescindir de ellos. Además, mientras ignoramos si a ciencia cierta los bailes de Quevedo fueron representados, contamos con múltiples testimonios de bailes entremesados de Quiñones de Benavente, que resucitó en España la ditirámbica imitación. ${ }^{71}$

Hay pocas coincidencias temáticas entre los bailes de Quevedo y Quiñones de Benavente. A lo sumo, el Baile de la Maya de Quiñones tiene leves ecos de la quevedesca avaricia femenina y el Baile de Leganitos presenta algunas similitudes con Las sacadoras (POC, 870). Por lo demás, ni la métrica, ni la descripción de personajes, ni los asuntos coinciden. Ambos, sin embargo, asentaron las bases del baile, que después fue ejercicio

\footnotetext{
${ }^{70}$ Cfr. Merino Quijano [1981: I, 167].

${ }^{71}$ Cfr. Cotarelo [1911: CLXXXVII].
} 
ocasional de la pluma de otros ingenios. ${ }^{72}$ Así, por ejemplo, Matos Fragoso escribirá La boda de pobres bajo el influjo de A las bodas de Merlo (POC, 872) de Quevedo; y el Baile de la Chillona y el Baile de Mellado de Moreto serán protagonizados por izas y rufianes de las jácaras quevedescas. Hay, asimismo, resonancias de nuestro autor en el Baile de la esgrima y Los borrachos de Suárez de Deza, al igual que en el Baile de los galeotes de López de Campo. Por último, no olvidemos que León Marchante escribió ciertos bailes inspirados en jácaras, que muestran la pervivencia de la germanesca en la segunda mitad del siglo XVII. ${ }^{73}$

\section{NUEVAS ATRIBUCIONES}

En la BNE figuran dos bailes manuscritos atribuidos a Quevedo, citados en el Catálogo de Isabel Pérez Cuenca [1997], que todavía no han sido estudiados por la crítica. Se hallan en el ms. 17.683, volumen que compila toda una serie de bailes, copias de los siglos XVII y XVIII en diferentes letras. Era obligatorio analizarlos para ver si nos encontramos frente a

\footnotetext{
${ }^{72}$ Cotarelo [1911: CXCI- CCVII] analiza estos otros autores, entre los que se cifran Jerónimo de Cáncer, Francisco de Navarrete, Matas Fragoso, Moreto, Sebastián de Villaviciosa, Francisco de Avellaneda, Francisco de Monteser, Juan Bautista Diamante, Suárez de Deza, León Marchante, Alonso de Olmedo, Salazar y Torres, Pedro Lanini, Juan Bautista Diamante, Suárez de Deza, León Marchante, Alonso de Olmedo, Salazar y Torres, Francisco de Castro, Francisco Benegas y Luján.

${ }^{73}$ Cfr. Alonso Veloso [2005: 204-208].
} 
piezas de don Francisco o, como suele pasar, hemos de desmentir una atribución errónea.

Los publicamos en el apéndice final: son la Comedia de las dependencias de España y la composición que empieza por el verso “Picarilla, picarilla...". Pero no avanzo nada más. Veamos qué nos deparan estas dos obrillas.

\subsection{LA COMEDIA DE LAS DEPENDENCIAS DE ESPAÑA}

De buenas a primeras, La Comedia de las dependencias de España no parece de don Francisco. No es un baile demasiado logrado, y es polimétrico en algunos pasajes. El olfato filológico, esa herramienta intuitiva tan difícil de justificar y sin valor científico en sí misma, dice que no. Pero tampoco es fácil que, en caso de ser suyo, lo pareciera. La pieza tiene aspecto de ser escrita por encargo y con premura. Para colmo, su cuarta parte, la que trata el tema de la devaluación de la moneda del vellón, dice estar escrita por tres ingenios distintos.

Estructuralmente, la Comedia de las dependencias de España está dividida en cuatro "partes".

La primera, titulada "Las causas de los daños de esta Monarquía" es un soneto que ataca a los doctores como causa de la elevada mortalidad de la población. El autor los considera devotos del diablo, critica las sangrías como método curativo y dice que son más incultos de lo que aparentan ("los 
aforismos de Averroes no saben", v. 12), aunque remiten sus farsas a lo escrito.

La segunda, “Trata del mal presente: cómo se pudiera remediar y el medio que se debe tomar", es otro soneto, que nos puede resultar familiar por la alusión satírica a mujeres que pegan a los hombres en el primer cuarteto. No resulta demasiado agraciado en su lectura, sin embargo.

La tercera, "En que se da un arbitrio para sacar dinero de donde lo hay, y parecerá muy bien a Dios, y a todo el mundo, y se remediarán las cosas", pretende ser un soneto, pero no llega. Le faltaría un verso en la segunda estrofa y otro de ellos es de doce sílabas (v. 37). Nos resulta familiar la expresión "se pasa por lo Hurtado a ser Mendoza" (v. 41). Recordemos que, en el entremés de La venta, Quevedo pone las siguientes palabras en boca del estudiante: "En esta pobre choza/ todos somos Hurtados sin Mendoza." (vv. 210-211).

Después de esta tercera parte, hay una carta intercalada que dirige la obra a "Vuestra Majestad":

[De] sobras tiene la hacienda de Vuestra Majestad todas sus faltas cumplidas, pues ya es de Dios acabe de partir el Desengaño. Y espere Vuestra Majestad en Dios el buen suceso, pues las rogativas de los pobres pueden mucho. Quite Vuestra Majestad a quien quita, pues hurtando al ladrón, gana ya cien días de perdón, y la restitución no le obliga en conciencia, y yo la tomo sobre la mía, que es de teólogo.

Como vemos, en ella se cita al "Desengaño": es un personaje muy quevedesco, presente en las Premáticas del Desengaño a los poetas güeros y en uno de los Sueños. También nos sorprende la preocupación política de 
esta misiva, escrita por alguien que declara tener conciencia "de teólogo". La decadencia económica del Barroco parece anunciarse en esta nota. ¿Está don Francisco detrás de todo esto? No respondamos aún.

Seguimos leyendo. La cuarta parte del baile se titula "De la fúnebre y lastimosa tragedia del cruel martirio del vellón y exaltación de la moneda nueva, jamás vista ni representada. De tres ingenios con Juan Rana (...)”. El tema, dispuesto mediante la intervención de personajes alegóricos, es la devaluación de la moneda de vellón, que Quevedo trató en el polémico Chitón de las Tarabillas. Asimismo, sabemos que el célebre actor Juan Rana, o Cosme Pérez, representó desde principios de siglo hasta $1672 .{ }^{74}$ Hasta aquí, pase. Pero las palabras que epilogan la obrilla, nos sirven para desautorizar la paternidad quevedesca de este baile:

El Pupilo con el Verdugo = Mañana sirvo a Vuestra Merced con esta misma comedia, loas graciosas, entremeses, bailes, apariencias y grandes tramoyas.

El Retiro = Después de mañana convido a Vuestra Merced con el Destierro de la Plata.

El Palacio del Retiro se construyó hacia 1633. El baile, por tanto, a todas luces parece posterior a esta fecha. ¿Qué quiere decir "El Pupilo con el Verdugo"? Esta extraña clave nos revela que Quevedo no pudo ser el autor de esta pieza.

\footnotetext{
${ }^{74}$ Sobre Cósme Pérez, véanse las obras de Francisco Sáez Raposo [2005] y Peter E. Thompson [2006]. También Cotarelo [1911: CLVII- CLXIII] incluye una biografía suya en la introducción de su Colección de entremeses, loas, bailes, jácaras y mojigangas.
} 
Francisco García, alias el Pupilo, tuvo compañía teatral por vez primera en 1648. Francisca Verdugo, una de sus actrices, formó parte de su compañía hasta 1659, fecha en la que pasó a la compañía de Pedro de la Rosa y Diego Osorio. Sin duda, "el Pupilo con el Verdugo" alude a la compañía y a una de sus actrices principales. ${ }^{75}$ Recordemos que estas fechas sitúan la obra fuera del alcance de Quevedo, que falleció en 1645. ¿De quién será, entonces, este baile? Dejamos este asunto para futuras investigaciones. ${ }^{76}$

\section{2. "PiCARILla, PICARILLA..."}

"Picarilla, picarilla..." utiliza el romance como estrofa para ejecutar una jocosa descriptio puellae. No es un baile entremesado propiamente dicho: por la ausencia de personajes, se trata de un baile monologado. José Manuel Blecua no lo incluye en su edición de Poesía Original Completa, y nos sorprende si consideramos que ya apareció publicado por Felicidad Buendía

\footnotetext{
${ }^{75}$ Veáse Varey y Shergold [1985: 408].

${ }^{76}$ Sabemos, por ejemplo, que Agustín Moreto escribió una Loa entremesada para la compañía del Pupilo tal como fue publicado en El teatro menor en la España del siglo XVII: La contribución de Agustín Moreto, University Press of the South, 1998, por Ruth Sánchez Imizcoz. También disponible en la red: http://www.trinity.edu/org/comedia/moreto/Pupilo.html
} 
[1966: II, 359]. ${ }^{77}$ ¿Lo eludió porque lo consideraba espurio? ¿O acaso lo hizo por olvido? Sea como fuere, actualmente, la edición de José Manuel Blecua suele ser la que se utiliza como referencia para los estudios de don Francisco.

Al inicio del baile (vv. 1-8), el yo poético presenta a la dama como una pícara, una mujer que pertenece al mundo hampesco, que combina la belleza con la bellaquería. Al parecer, él la requiere en amores y ella le desdeña, por lo que éste conviene describirla para tener un retrato suyo, de algún modo. A continuación se detallará cómo son su cabello (vv. 9- 24), frente (vv. 2528), cejas (vv. 29-32), orejas (vv. 32- 40), mejillas (vv. 41-44), boca (vv. 4548), nariz (vv. 49-60), barbilla (vv. 61-64), garganta (vv. 65-68), pechos (vv. 69-80; 105-108), brazos (vv. 81-84), manos (vv. 85-96), espalda (vv. 97100), talle (vv. 101-104), sexo (vv. 109-124), piernas (vv. 125-136) y pies (vv. 137-144). Esta pormenorizada descripción se cerrará con una síntesis de la belleza de la dama, que pese a no lucir joyas adelanta a todas las demás en piedras preciosas. El broche final será una crítica jocosa al matrimonio, como medio efectivo para mantener la castidad.

Llama la atención la baja estofa de la dama que se describe en este baile, antintética al ideario petrarquista. Presenta similitudes con la composición A una dama señora, hermosa por lo rubio (POC, 854), con la que coincide en lo "apicarada de tonos/ donde de motes y chistes/ navega el Amor el

\footnotetext{
${ }^{77}$ La edición de Felicidad Buendía, cuya fuente no indica, viene acompañada de un título: Descaminos encaminados a sujeto en vulgar disimulo. Hay algunas diferencias de trascripción respecto de nuestra edición, que publicamos en el apéndice adjunto.
} 
golfo" (vv. 2-4). Aparece otra alusión a una picarilla en el romance Efectos del amor y los celos (POC, 768):

\author{
Verbigracia, un dotorazo, \\ que toma a la barba alforzas, \\ que está chorreando leyes, \\ que está rebosando glosas, \\ pretendiente de una plaza \\ para encaramarse en otra, \\ atisba por esas calles \\ una picarilla rota (vv. 61-68)
}

Asimismo, el Potosí como topónimo de la riqueza, que aparece en el presente baile para retratar los cabellos dorados de la amada, es muy utilizado por Quevedo:

no pudo el Potosí guardar la plata ni el mar, que ondoso y próvido le aleja. (POC, 75, vv. 3-4)

Juntas grande tesoro, y en Potosí y el Lima ganas jornal al cerro y a la sima. (POC, 145, vv.124-126)

Maridillo hay que retrata los cuchillos verdaderos, que al principio tiene aceros y al cabo en cuerno remata; mas su mujer de hilar trata el cerro de Potosí. (POC, 651, vv. 58-63) 
El baile "Picarilla, picarilla...", asimismo, contiene descripciones muy picantes sobre la belleza femenina. Detengámonos en la pintura de los pechos de la dama:

\author{
No engañes con los jazmines, \\ tapa la pechuga, hermana, \\ y no descubra buen pecho \\ quien tiene malas entrañas. \\ En dos cumbres las divides \\ y las tienen coronadas \\ dos pezones tan chiquillos \\ que aún no saben decir mama. \\ Ajusta en tu doncellez \\ si les falta o no les falta \\ la leche, porque tus pechos \\ ya saben que son la nata. (vv. 69-80)
}

Este pasaje entronca con la paródica descriptio puellae del romance $D a$ señas de sí una dama recién venida, y refiere sus condiciones (POC, 688):

\author{
Y no vendo por de leche \\ a los mamones mis labios; \\ mis manos sí, que por pechos \\ me las chuparan muchachos. (vv. 29-32)
}

Pero el baile "Picarilla, picarilla...", sobre todo, destaca en sus poco veladas alusiones sexuales, que rompen con el pudor característico de las prosopografías petrarquistas: 
La flor de tu madreselva,

aunque no ha puesto cabaña,

dice el discurso que está

de perfecciones cuajada.

Fuerza es, que mil gracias tenga,

harto mi amor se alegrara

que fueran gracias mohosas, ${ }^{78}$

sólo por verlas tomadas.

Desde aquí hasta la cintura

aún los tienes, te falta,

y quedas cabal con esto,

porque no tienes hijada.

El enigma de tus muslos

es una escondida farsa,

que a nadie se representa

estando siempre en las tablas. (vv. 109-124)

Destaquemos el neologismo hijada para aludir a la descendencia de la dama, que es un vocablo nuevo construido conforme a procedimientos típicamente quevedescos. Por otra parte, en la poesía de Quevedo, debido a la presión de la censura inquisitorial, hay pocas alusiones directas al órgano sexual femenino. Seguramente, pocas veces tan explícitas como en el primer terceto del soneto 609:

${ }^{78}$ La alusión a las "gracias mohosas" (v. 115) nos evoca forzosamente al título de la pieza recientemente representada de Feliciana Enríquez de Guzmán, construida a partir de sus Entreactos (1624). El poema citado no coincide, sin embargo, con ninguno de los pasajes de esta obra. 


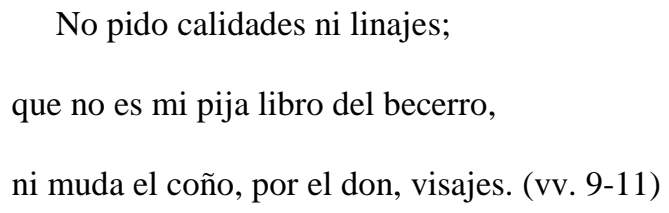

Uno de los rasgos que más nos llaman la atención de este supuesto baile de Quevedo es el condimento erótico de los versos que aluden a los atributos sexuales de la dama. A decir verdad, son escasos los estudios sobre el erotismo en la obra de don Francisco. En el volumen Poesía erótica del Siglo de Oro, publicado por Alzieu, Jammes y Lissorgues, se nos brinda un comentario al respecto, con el que no estamos necesariamente de acuerdo:

Nuestro concepto del erotismo suponía en efecto la exclusión de las poesías de Quevedo o de inspiración quevedesca, en las que la violencia del lenguaje y lo concreto de las evocaciones están siempre puestas al servicio de un antifeminismo que no es más que un aspecto de una actitud terriblemente negativa ante la belleza y el amor. En cuanto Góngora, mucho más abierto a todo lo que expresa la alegría de la vida, y cuya poesía se amolda casi totalmente a nuestra definición de erotismo (...) [1985: XI]

Salta a la vista que esta nota tendenciosa para con el erotismo y la poesía de Quevedo está fuera de lugar. ${ }^{79}$

"Picarilla, picarilla...", en todo caso, llega a la altura de los versos más logrados de Quevedo. De ser suyo, podríamos clasificar este baile dentro de su poesía amatoria antipetrarquista, puesto que hace burla de las metáforas

\footnotetext{
${ }^{79}$ Para comprobarlo, léase cualquier poema incluido en la sección de sus Poemas amorosos (POC, 292- 441) o de Canta sola a Lisi (POC, 442- 511).
} 
fosilizadas más recurrentes mediante el recurso de la literalización de las mismas. $^{80}$

Pero ha llegado el momento de detenerse en lo que caracteriza la materia prima del teatro de Quevedo: los usos lingüísticos del conceptismo, su fuerza verbal desrealizadora, la parodia del idioma.

${ }^{80}$ Tras la fijación del Canzoniere de Petrarca -o, mejor dicho, los Rerum Vulgarium Fragmenta- como modelo lírico y canon amoroso por parte de Pietro Bembo en sus Gli Asolani y en la Prose della volgar lingua, afloraron gran cantidad de seguidores. El ideal de belleza de la dama fue difundido a través de tratados como I ritratti (1524) de Trissino, el Dialogo delle bellezze delle donne intitolato Celso (1548) de Firenzuola o el Libro della bella donna (1554) de Luigini. En España, es bien sabido que Garcilaso, incitado por su amigo Boscán -véase la célebre carta "A la duquesa de Soma"- se convertiría en el faro del petrarquismo y que su poesía sería a su vez ampliamente comentada en las Anotaciones del Brocense (1574) y de Fernando de Herrera (1580). Mientras que Góngora estableció un asiduo coloquio con los principales representantes del petrarquismo italiano - Bernardo y Torcuato Tasso, Ariosto, Sannazzaro, Tansillo, Angelo Grillo, Matteo Maria Boiardo, Luigi Groto, Giovan Battista Marino-, el número de interlocutores quevedianos fue bastante menor. Exceptuando resonancias temáticas de Sannazzaro, Marino, Guarini y Tebaldeo; las influencias de los petrarquistas italianos en Quevedo se reducen, fundamentalmente, a dos: Torcuato Tasso y Luigi Groto. 
- 550 - 
Capítulo VIII

LA FUERZA VERBAL DE QUEVEDO.

ELEMENTOS SEMIÓTICOS DE SU TEATRO BREVE 
- 552 - 


\section{EL PIROTÉCNICO DEL LENGUAJE}

\section{UN JUEGO LITERARIO}

El teatro actúa como mundo abreviado. Implica la condensación de una época a través del uso genuino del lenguaje. La capacidad operativa del verbo se despliega a través de la técnica de miniaturización o filigrana. Esta reducción arabesca para Quevedo estaba en concomitancia con la habilidad sintética de lo que la crítica literaria ha denominado conceptismo, término que, como veremos más adelante, ha sido confrontado sin fundamento al culteranismo.

Quevedo jugaba con el idioma. Todo escritor genial lo hace, experimenta con la materia prima de su arte. Don Francisco esculpía la palabra, practicaba el malabarismo verbal, la pirotecnia lingüística. Desbrozó los manuales de retórica, leyó y tradujo a los clásicos, recorrió calles y tabernas en busca de vocablos escondidos en la boca de los maleantes, los pobres, los desarraigados. ${ }^{1}$ Recordemos que él mismo denominó sus primeros pinitos literarios Juguetes de la niñez.

Desvalijaba las jergas de la minoría para encontrar el diamante, sentía atracción por los tecnicismos de los oficios (llegó hasta a conocer el

\footnotetext{
1 Así lo glosa Dámaso Alonso en su célebre ensayo sobre nuestro autor, "El desgarrón afectivo en la poesía de Quevedo", incluido en Poesía española [1971: 577]. “Este hombre que se había criado en el edificio de palacio, con su cruz de Santiago al pecho [...], que estaba impregnado de erudición antigua, era enormemente pueblo.”
} 
lenguaje cifrado de los alquimistas ${ }^{2}$ ), buceaba en el idioma. Dotó al castellano de peculiaridades de otras lenguas -wordbuilding- en su dinámica construcción de neologismos. Llegó, incluso, a enriquecer los diccionarios académicos con nuevas entradas. ${ }^{3}$

Nuestro autor dispone de toda una serie de técnicas verbales al servicio del juego lingüístico. El espectáculo verbal, acústico y conceptual, se desarrolla mediante la manipulación lúdica de las palabras. González Salas en sus Ilustraciones al Parnaso cree que esta habilidad de combinar conceptos sólo tiene parangón con la de Ovidio:

De ansí, fecundo ingenio, rico y copioso en la multiplicación de los conceptos, sólo hay memoria que le pueda semejar, como los eruditos saben, el perspicuo, blando y opulentísimo poeta Ovidio Nasón. [ed. Blecua, 1999: I, 92]

La visión quevedesca del lenguaje podría asimilarse a lo que Ezra Pound denomina logopoeia, que significa "danza del intelecto entre palabras."4 Atisbamos la seducción estética de la palabra, que gira sobre sí misma mostrando sus múltiples aristas. ${ }^{5}$

\footnotetext{
2 Como nota Alessandro Martinengo [1983].

3 Cfr. Antonio Garrido, "Creación léxica quevedesca en la segunda impresión del diccionario académico (1770)", en Quevedo en Manhattan [2004: 135-139].

4 Cfr. P. Cabañas [1991: 292].

5 Así lo expresa Alexander A. Parker [1952:360]: "El haber un abismo entre los términos de comparación, el cual se pretende salvar por medio de un salto del ingenio, es lo que diferencia el concepto de la metáfora normal".
} 


\section{AgUdeZA E INGENIO}

Quizá sea peligroso utilizar el término conceptismo para estudiar las claves de la codificación del lenguaje de Quevedo. Acuñar conceptos teóricos definitorios para la crítica literaria tiene los inconvenientes de la cama de Procusto: es generar un estándar arbitrario para el que se fuerza una conformidad exacta.

Efectivamente, se ha hablado de culteranismo en Quevedo y de conceptismo en Góngora. Contraponer a ambos autores mediante etiquetas distintas ha sido un traspié de la crítica literaria, que todavía se perpetua en algunos manuales de secundaria. Hay que evitar simplificaciones.

El concepto constituye, sin embargo, la columna vertebral de la poética de Quevedo: es producto de un ejercicio racional, es el trasvase de un goce intelectual, complejo de concebir para el autor y de descifrar para el lector. ${ }^{6}$ Según las preceptivas auriseculares, es más hijo del esfuerzo de la mente que del artificio. Es para el entendimiento lo que es para los ojos la hermosura y la consonancia para el oído.

Pero el concepto es poco enigmático porque el léxico y la preceptiva del barroco obedecen a cánones estipulados de alusiones y juegos retóricos. Los textos literarios del Siglo de Oro son máquinas perfectas con manual de instrucciones: sus engranajes son predecibles y, por tanto, su interpretación, suele ser unívoca. ${ }^{7}$

\footnotetext{
${ }^{6}$ Cfr. Óscar Osorio [2004: 95].

7 A propósito de los códigos retóricos del Barroco, véase Rosa Navarro, La mirada al texto [1995].
} 
Gracián, en Agudeza y arte de ingenio $(1648)^{8}$ define el concepto como "un acto del entendimiento, que exprime la correspondencia que se halla entre los objetos". Esta correspondencia también pueden abarcar abstracciones, atributos o relaciones del pensamiento. El autor califica de conceptos simples a las ideas engendradas por la razón, que los neoescolásticos denominaban la "primera operación del intelecto" (conceptus simplex). ${ }^{9}$ A continuación, el discurso crea una serie de relaciones o correspondencias intelectuales, "la segunda operación del intelecto" (conceptus complexi), que exigen otro grado más de complicación, a través de un proceso especulativo, imaginativo y artístico.

A través del ingenio, Quevedo transforma el concepto simple en agudeza, es decir, en algo artísticamente espléndido, sorprendente, brillante. El autor armoniza la imitatio aristotélica con la locura platónica, sincretismo que se sistematizó en El libro de la erudición poética (1611) de Carrillo y Sotomayor, obra que don Francisco conoció con creces, puesto que ambos escritores fueron amigos. Este autor anticipa la terminología de Gracián: la agudeza equivale a la dificultad intelectual y el agudo entendimiento es la perspicacia erudita que la capta. Por lo tanto, el culteranismo y conceptismo son dos vías íntimamente ligadas para alcanzar la misma meta estéticointelectual: cuanto más hermético resulte el poema, mayor placer dará a una mente lo bastante culta como para desentrañar el significado. ${ }^{10}$

\footnotetext{
${ }^{8}$ Agudeza y arte de ingenio sistematiza algunos puntales estéticos que cuajaron en el quehacer literario de Quevedo, pese a publicarse después de su muerte.

9 Cfr. Gracián, edición de Evaristo Correa Calderón [2001: 55-56].

${ }^{10}$ Esta es la tesis sostenida por A. Mas [1957: 373], que relaciona a Quevedo con Góngora como artistas de la forma, frente a Lope y Cervantes, artistas del contenido. En la misma
} 
A su vez, Gracián distingue entre la agudeza incompleja y la compuesta. La agudeza incompleja equivale a un concepto único, pese a que pueda tener diversos conceptos secundarios a través de la exploración de sus adjuntos. La compuesta es una construcción basada en muchos conceptos. El concepto orgánico, por último, contribuye a la unidad total de la obra, integrada por diversos conceptos funcionales.

La agudeza incompleja se clasifica en varios tipos generales: [1] la correspondencia y proporción, equivalente a la analogía griega; [2] la desproporción y disonancia, que busca la oposición o desarmonía entre los términos del concepto; [3] la similitud, donde el tema no es comparado con sus propios adjuntos, sino con un término no relacionado; [4] la disimilitud, donde el tema guarda una oposición con un término no relacionado; [5] la paridad, que denota la igualdad de elementos según su importancia, sus operaciones o sus efectos, y [6] la disparidad, una correspondiente desigualdad entre los términos del concepto, contrastados por su relevancia, sus procesos o consecuencias.

Quevedo siente predilección la agudeza incompleja de desproporción y disonancia. Aboga por una dialéctica de contradicciones: su difracción mental engendra figuras y conceptos. ${ }^{11}$ El lenguaje respira con autonomía: su dominio le hace traspasar fronteras expresivas y estéticas. Don Francisco utiliza el lenguaje como valor supremo de la realidad.

línea, José Manuel Blecua sostenía la existencia de un conceptismo de Góngora y un culteranismo de Quevedo.

${ }^{11}$ Cfr. Maurice Molho [1978: 173]. 


\section{LA DICCIÓN ENCORSETADA DE LA COMEDIA QUEVEDESCA}

Pero Quevedo no siempre fue libre a la hora de componer teatro. Una diferencia de calidad abismal separa sus comedias graves de sus obras dramáticas breves. ¿Por qué? Las premuras del encargo palatino, la coautoría, la presión de la censura y la obediencia a la virtud protocolaria, entre otras razones, seguramente mermaron la sutileza verbal de las comedias de nuestro autor. Nada que ver con el espacio carnavalesco de libertad que impera en el teatro breve.

Quevedo a menudo cayó en los vicios retóricos que atacaba. Su crítica a los tópicos teatrales, convenientemente expuesta en su prosa satírica, fue ninguneada en la poética pragmática de sus comedias palatinas. ${ }^{12}$ En las décimas tituladas Búrlase de todo estilo afectado (POC, 693), Quevedo parodia el lenguaje encorsetado de "ni me entiendes, ni me entiendo" (v. 59):

\footnotetext{
No me va bien con lenguaje

tan de grados y corona:

hablemos prosa fregona,

que en las orejas se encaje.

Yo no escribo con plumaje,

sino con pluma, pues ya

tanto bien barbado da

en escribir al revés.

Óyeme tú dos por tres
}

\footnotetext{
${ }^{12}$ Así lo nota Nolthing-Hauff [1974: 208], que observa cómo las frases y expresiones ridiculizadas en la Premática de 1600 y el Cuento de cuentos "las ha empleado él a veces de modo totalmente asatírico".
} 
Como ilustra este poema, Quevedo buscaba, en palabras de Alfonso Rey [2003: I, XXIX], "una dicción culta y no afectada, alejada tanto del plebeyismo como de la dificultad gratuita".

En las Premáticas del Desengaño contra los poetas güeros (1605) el alegórico Desengaño veda las prácticas literarias de los malos escritores y limita el repertorio de tópicos petrarquistas. Estos amaneramientos aflorarán, sin embargo, en Cómo ha de ser el privado.

Sobre estas antagónicas "facetas de autorrepresentación literaria"- the self-fashioning, expresión acuñada por Greenblat- versa un artículo de Carlos M. Gutiérrez [2005], que plantea una nueva hipótesis para comprender la suerte de esquizofrenia literaria que vivieron los primeros autores modernos, entre los que se cifra Quevedo.

El profesor de la Universidad de Cincinnati forja el término interautorialidad para definir las tres vertientes de modelos de producción y recepción literarias que posibilitó la corte madrileña y vallisoletana coetánea a Quevedo: [1] el mecenazgo y el clientelismo por parte de la nobleza española con poder político, [2] el entretenimiento orientado hacia el mercado editorial y [3] la escritura como reto intelectual del creador. La autorrepresentación literaria se hallaría, ante todo, en estas dos últimas manifestaciones del arte, donde la presión del poder es menor.

Carlos M. Gutiérrez argumenta a partir de los postulados de Foucault [1977:124-127], que diferencia entre figura autorial y la función-autor, y señala que el autor aparece "cuando de la naturaleza transgresora de lo escrito pueden derivarse consecuencias penales". Ello quiere decir que el 
acervo lingüístico del autor, a diferencia del de la figura autorial, ultrapasará las barreras de lo académico y lo cortesano, que su escritura apuntará a un mundo referencial mucho más amplio. Esta posibilidad le fue concedida a Quevedo en aquellos géneros literarios que le permitieron explotar la insurrección satírica a los cánones o canalizar sus reflexiones políticomorales. Las obras teatrales serias, en cambio, estaban demasiado supeditadas a las expectativas cortesanas y del público teatral.

Sobre la elección del verso o la prosa en el género dramático, en su crítica a la comedia Eufrosina, Quevedo hace la siguiente observación:

Pocas comedias hay en prosa de nuestra lengua, si bien lo fueron todas las de Lope de Rueda; mas para leídas tenemos la Selvaga, y con superior estimación La Celestina, que tanto aplauso ha tenido en todas las naciones. En portugués hay una de Camoens, dos del doctísimo Corte Real, y esta Eufrosina, de que carecíamos [1951: II, 492].

¿Escribió Quevedo comedias en prosa? Por los testimonios disponibles, observamos que no supo sustraerse del modelo lopesco. A pesar de que, como señala Armando Cotarelo, es erróneo equiparar su ingenio dramático al del Fénix:

Error sería, pues, considerar a Quevedo como un verdadero autor dramático, al modo de Lope, de Vélez o de Tirso. (...) Tuvo, como Luciano, propensión a los temas fantásticos y simbólicos y gustó, como Séneca, de la concisión y profundidad de la frase, sacrificando a lo mejor lo claro por lo nuevo, y estas cualidades de sus dechados preferidos no son muy apropiadas a la escena. Por eso luce más en los géneros menores, libres y joviales, y más tolerantes a lo quimérico y al concepto, a 
la mordacidad y al chiste, que la imitatoria naturalidad de las farsas serias. [1945:

44]

Lope supo combinar con perspicacia el tono bajo o popular con el alto o culto en sus comedias. En el Arte nиеvo estipula la normativa y lógica interna de este teatro comercial, donde los emblemas del poder aparecen simultaneados con criados y demás personajes de baja estofa incapaces de asumir una expresión sublime de la virtud. Su recetario dramático, con todo, no cuadraba bien con el genio satírico de Quevedo; por ello, a nuestro autor, no le hacía demasiado bien emularle. ${ }^{13}$

Las intenciones del Quevedo comediógrafo distaban mucho del consumo comercial y del dinamismo de la acción del teatro lopesco, donde el poder se critica por sus imprudencias y abusos para satisfacer la expectativa de un auditorio popular, que no habría tolerado la relamida alabanza del gobierno. ${ }^{14}$ Pero, a pesar de su vociferada aversión hacia las convenciones literarias, Quevedo tuvo una manera parcialmente lopesca de enfocar sus incursiones de comediógrafo. Urrutia, al final de su estudio "Quevedo en el teatro político", lo nota como un fallo evidente:

\footnotetext{
${ }^{13}$ Así lo expresa C.C. García Valdés [2004: 111]: "La comedia lopesca vigente a la sazón no cuadraba bien con el genio del gran satírico. A Quevedo, que se burla de las convenciones que restan y ahogan la libertad y espontaneidad como los usos estereotipados del lenguaje, las expresiones lexicalizadas, las frases hechas o los esquemas genéricos convencionales, no le merecen buena opinión las convenciones típicas de la comedia nueva ni la nube de poetas que la cultivan -le llama Cervantes en el Viaje al Parnaso-, y así lo deja sentir en varios lugares de sus obras festivas y satíricas."

${ }^{14}$ Véase S. Hernández Araico [1999: 462].
} 
El error de Quevedo fue no romper con la comedia lopesca. Pero eso hubiera ido en contra de la propia razón de ser de la obra: utilizar unos canales y unos sistemas ya experimentados, para hacer propaganda política. Era un callejón sin salida. [1982: 185]

Sea como fuere, las diferencias compositivas entre Lope y Quevedo saltan a la vista: el contraste del Fénix no es el retruécano quevedesco. ${ }^{15} \mathrm{Su}$ música era más sosegada que la de don Francisco, sus argumentos más fluidos para el público, sus ideas más ufanas y menos controvertidas. No era hombre de extremos ni de minorías, su soledad jamás fue tan abrupta, ni observó a través de unos redondos anteojos miopes. Los espejos deformes que más tarde adoptaría Valle-Inclán, en cambio, eran las lentes con las que Quevedo contempló su mundo, venerado u odiado, jamás vivido en la indiferencia.

El espacio de representación de las comedias por encargo, los recintos reales, en que imperaban unas normas de comportamiento muy específicas, (la etiqueta palaciega) eran dirigidas a un público cortesano, organizadas para una ocasión específica (celebraciones de la monarquía) y tenían como autores a músicos o escritores que trabajaban para la corte.

Cuando, apremiado por el encargo y las exigencias del público, Quevedo se vio impelido a componer obras teatrales propagandísticas, su vena original quedó ahogada en el tópico anquilosado. Su dicción se encorsetó en

\footnotetext{
${ }^{15}$ Cfr. Valbuena Prat [1956: 100].
} 
la redacción de obras que, pese a ser fruto de su pluma, apenas le pertenecían. ${ }^{16}$

${ }^{16}$ Armando Cotarelo [1945:43] destaca la improvisación y, a la vez, la falta de espontaneidad en su labor dramática; atropellamiento y diplomacia determinados por las presurosas exigencias mercantiles del teatro aurisecular: "Labor briosa pero atropellada, sin preparación ni lima; obrillas chispeantes, sí, por ser suyas, pero escritas de una vez, sin tachones, y de seguro a lo que saliere. Este carácter de improvisación es común a casi todos los autores de su época, que es la creación de la poesía dramática, época hervorosa de los aciertos y de las caídas; el plan, la corrección, el pulimento, vienen después, en el tranquilo tiempo de la imitación, en la segunda mitad del siglo XVII. [...] Por otra parte, debió de faltar espontaneidad a mucha de su obra de teatro. Dos comedias perdidas sabemos que fueron improvisadas por requerimiento de magnates; de encargo fueron también las loas, y una con asunto forzado. Otras piezas lo serían igualmente, y las obras que así se componen carecen de la frescura y adorno que infunde la inspiración y rinde la complacencia." 


\section{LA LIBERTAD CARNAVALESCA DEL TEATRO BREVE}

\section{ESCARCEOS LINGÜÍSTICOS DE LOS ENTREMESES}

En los entremeses de Quevedo no hay bobos. No sólo por la evolución del género. Las figuras son asombrosamente locuaces. La comicidad reside en su lenguaje, dotado de una prolífica capacidad, casi indecorosa. ${ }^{17}$

Quevedo potencia su discurso mediante el juego ambiguo en la relación entre significante y significado de la palabra. El equívoco posibilita dos niveles de sentido en la lectura. La extrapolación de dos campos semánticos permite transmitir intensamente en un breve espacio anfibologías o disemias, retruécanos, ironías, metonimias irrisorias y parodias.

Así sucede, por ejemplo, en el entremés de La venta, donde comezón aparece con doble significado: como "comida" y como "picor que causa una urticaria o la picadura de un insecto, molestia". Imagínense el indigestivo menú de esta posada.

El equívoco auditivo es paradigmático de figurones de baja estofa. En Doña Bárbara se transfiere con la errónea comprensión de una lengua extranjera. El chapurreo de idiomas era una característica de las comedias renacentistas: Quevedo retoma este recurso para crear la ilusión de bullicio y algarabía.

La geometría verbal, que los autores barrocos juzgaban como rasgo de perfección formal de una obra, potencia que Quevedo utilice en sus entremeses paralelismos en retruécano, isocolon o quiasmo. El dinamismo

\footnotetext{
${ }^{17}$ Pilar Cabañas [1991: 299].
} 
inherente al teatro breve se consigue mediante el engarce diagonal concretado en la reduplicación o anadiplosis. En ocasiones, Quevedo repite frases o sintagmas enteros, epifonemas festivos que se pueden dar en tres modalidades: como mofa de terceros interlocutores ante frases ya pronunciadas, como autocaricatura en un mismo personaje o como iteración de un estribillo (así sucede en Los refranes del viejo celoso).

El autor se ríe de las coletillas expresivas, de los depredadores públicos del lenguaje. Abundantes fórmulas verbales -frases, palabras y modismoshabían tentado a autores de renombre. Es muy significativo el éxito editorial que había atesorado la obra de Juan de Aranda, Lugares comunes de conceptos, dichos y sentencias en diversas materias, publicado en Sevilla, en 1595, por Juan de León y más adelante reimpreso por Juan de la Cuesta en Madrid, en 1613.

La retahíla de pullas, tan abundante en la obra satírica de Quevedo, no es menos relevante en sus entremeses. A menudo el autor aprovecha campos semánticos restringidos para velar mediante expresiones metafóricas la crudeza moral de los interlocutores, como ilustra la jerga de la esgrima en La destreza. En La ropavejera, por ejemplo, observamos a la vieja mellada que "habla con muletas". Esta manipulación lúdica del lenguaje constituye todo un atletismo retórico. ${ }^{18}$

El diálogo entremesil, tan proclive a la función emocional y valorativa del idioma, es profuso en diminutivos y aumentativos. También son frecuentes las recurrencias al santoral mediante exclamaciones

\footnotetext{
${ }^{18}$ Como señalan Evangelina Rodríguez y Antonio Tordera [1982: 35] a propósito del teatro breve calderoniano.
} 
acumulativas, vehículo de connotaciones antisemitas. Aparecen alusiones a santos inexistentes o inventados por la imaginería popular. Estos recursos intensifican el énfasis y la espontaneidad de las figurillas de entremés. En La venta, el mozo de mulas que piropea a la Grajal invoca a "Santa Bárbara bendita", virgen que amparaba contra las tormentas: así, el joven pretende protegerse de los rayos neoplatónicos despedidos por la mirada de la amada.

Don Francisco es propenso a deformar el lenguaje habitual mediante innovaciones idiomáticas. Los neologismos bizarros y de fácil interpretación satírica se consiguen mediante la adopción de sistemas de annominatio o derivaciones burlescas. A menudo son consecuencia del calambur o la creación de una palabra a partir de dos diferentes. Así, en El zurdo alanceador, Quevedo genera genuinos sinónimos de la palabra calvo.

Nuestro autor gustó de escribir entremeses salpicados de palabras germanescas. Esta predilección instigó a Antonio de Sancha, que editó algunos de sus romances junto con los de Juan Hidalgo (Madrid, 1779), a incluir un Vocabulario orientativo en el apéndice de su publicación. Por ejemplo, en el entremés de La venta, Grajal moteja al ventero de gato, que en lenguaje germanesco designaba a los ladrones.

La parodia cultista por descontextualización es un elemento omnipresente en los entremeses de nuestro autor. Hallamos burlas sutiles del petrarquismo, el oxímoron y la hipérbole. ${ }^{19}$

\footnotetext{
${ }^{19}$ Emilio Alarcos García, en su artículo "Quevedo y la parodia idiomática" [2004-2006: 338] estudia los mecanismos quevedescos de la "parodia de palabras y frases vigentes en la lengua".
} 
Los neologismos constituidos condensan afectivamente en una palabra ideas que normalmente se formularían en un grupo semántico de vocablos. En el Niño y Peralvillo de Madrid, por ejemplo, las víctimas de los ardides femeninos, pese a tener su nombre propio -Alonso, Diego, Cosme y Antonio-, son motejadas con la coletilla "alvillo", alusiva a su condición de ajusticiados en el Peralvillo cortesano: Alonso-Alvillo, Diego-Alvillo, Cosme-Alvillo y Antonio-Alvillo.

Con voluntad lúdica, Quevedo aprovecha homonimias para entablar sutiles relaciones de ideas con gran valor expresivo. En El marido pantasma expresa Mendoza, amigo del casamentero Muñoz: "y como hay abrenuncio, ¿no habría/ abremadre, abrevieja y abretía?" (vv. 65-66). El abrenuncio, según el Diccionario de Autoridades designa a la "voz con que se significa la oposición que se tiene a las cosas que pueden ser de mal agüero o de daño conocido".

Quevedo también parodia el lenguaje mediante el remedo de esquemas, genera neologismos a partir de engranajes gramaticales de derivación y composición. Por ejemplo, sirviéndose de los prefijos cachi-, proto- y archi-. En el El marido pantasma, encontramos un "cachimarido, como cachidiablo" (v. 111); en La venta, el ventero rapaz es calificado de "protoladrón" y "archiladrillo" (v.214), al igual que el Dómine Cabra del Buscón es descrito como "archipobre" y "protomiseria". Con el sufijo -ar, se genera el verbo "enyernar" acuñado en el entremés del $E l$ marido pantasma. En el mismo, mediante el esquema des-+ nombre + -ar, que tiene el sentido de privación o negación del sema sustantivo, Quevedo acuña el término "descasar" (v. 220). 
Además, nuestro autor practica la parodia fraseológica, que consiste en sustituir uno de los términos de cualquier combinación léxica fosilizada. En La ropavejera, uno de los clientes, Don Crisóstomo, tiene "barbas de leche" (v. 50), sintagma jocoso que actúa como parodia de los "capones de leche". En La venta se alude a los "vinos de retorno" como "mulas de retorno": las mulas de esta calaña son las que, tras largos viajes, sólo aceptaban pequeñas cargas, pero el "vino de retorno" es el vino tan aguado y de mala calidad que el jarro que lo contiene puede servir de orinal. En El marido pantasma, a su vez, "sacar de suegras es sacar de penas" (v. 166).

También son frecuentes las adaptaciones y modificaciones de refranes. En La venta, por ejemplo, el refrán "A ti te lo digo, nuera; entiéndelo tú, mi suegra" queda deformado en labios de Grajal porque se dirige al ventero: "A ti te lo digo, padre; óyelo tú, mi señor" (vv. 50-51).

Los neologismos de Quevedo, construidos con procedimientos formales o arbitrarios, son generados desde la entraña del idioma. Si bien el Diccionario de Autoridades (1726-1739) integró muchos de ellos, la mayoría fueron omitidos en la segunda impresión y el resto de ediciones, por ser engendrados con voluntad poética, jocosa o expresiva; poco útiles para la pragmática de la lengua. Debemos esta veta de Quevedo a su formación escolástica, a su fantasía desbordada y, ante todo, a su actitud lúdica ante el lenguaje. En definitiva, en los entremeses de nuestro autor, el lenguaje y su diestra manipulación son el goce supremo de su arte. ${ }^{20}$

\footnotetext{
${ }^{20}$ Cfr. Asensio [1965: 243].
} 


\section{TRADICIÓN E INNOVACIÓN}

El teatro breve a menudo recolecta materiales de uso popular, del mundo de la literatura oral y la paremiología, porque las figurillas folclóricas ahorran la delimitación descriptiva del personaje. De este modo, Quevedo sortea la enorme dificultad de dar noticia y caracterizar lo más rápidamente posible la trama y los personajes dramáticos.

Un nombre o una frase fácilmente descodificables por el espectador actúan como claves argumentales idóneas para ofrecer el máximo de información en un espacio restringido a los entreactos de comedia. El nombre de los personajes caracteriza taquigráficamente a los mismos y actúa como confirmación de su comportamiento externo, si bien Quevedo no es permeable a la tendencia germanesca de crear nombres propios con sonidos de intencionalidad despectiva.

Don Francisco acomoda en sus entremeses tramas procedentes de los cuentos, utiliza materia fabliellesca. ${ }^{21}$ Como dice el autor en una Letrilla burlesca (POC, 665):

\footnotetext{
¿Cómo la podré agradar los deseos avarientos, si voy a contarla cuentos, y él da cuentos a contar? (vv. 41-44)
}

${ }^{21}$ Cfr. Alan C. Soons [1976:30]. Maxime Chevalier [2004], asimismo, pese a que nota que Quevedo no es tan prolijo en la inclusión de cuentecillos tradicionales como Mateo Alemán, Lope de Vega o Cervantes, señala algunos ejemplos. 
Quevedo, por lo tanto, a pesar de su encono contra las "vulgaridades rústicas" del habla, no olvidó en sus escritos la fecunda frescura de la literatura oral. Nuestro autor de "facundias polémicas",22, echó mano a todos los recursos y posibilidades que le ofrecía la lengua, sin desdeñar, como en el Cuento de cuentos, la inclusión de estas expresiones familiares, ni que fuera para satirizarlas o trascenderlas con un nuevo enfoque.

Lo mismo sucede con el refranero, que en la comedia burlesca atribuida ¡Qué villano es el amor! doña Aldonza denomina "evangelio chico", expresión que coincide con la de Andrenio en El criticón de Gracián. Ambos autores rechazan el anquilosamiento expresivo, si bien don Francisco, a diferencia de Gracián, se muestra más atento al chiste y la ingeniosidad. Los entremeses y sus comedias burlescas atribuidas, en general, están notablemente influenciados por el refranero, que actúa como autoridad atemporal y confirma la cultura, ritos e instituciones del sistema dominante. El material lexicalizado es subvertido por nuestro autor en su teatro breve. $^{23}$

Nuestro autor formó parte de la reacción antipopularista del barroco contra las locuciones, modismos populares y muletillas lingüísticas. En

\footnotetext{
${ }^{22}$ Como lo califica Chevalier [2004:42].

${ }^{23}$ Cfr. Lázaro Carreter [1980: 207-232]. Recordemos que en el Siglo de Oro abundaban colecciones de refranes como los Adagia (1500) de Erasmo, el Libro de refranes compilado por el orden del $A B C$ de Mosén Pedro de Vallés, de mediados del siglo XVI, los Refranes glosados (1550) de Sebastián de Horozco, Refranes o proverbios en romance (póstumo, 1555) de Hernán Núñez, la Filosofía vulgar (1568) de Mal Lara, el Tesoro (1611) de Covarrubias y, ante todo, el Vocabulario de refranes y frases proverbiales de Gonzalo Correas, redactado antes de 1630 .
} 
Origen y definición de la necedad ya denuncia algunos bordoncillos, al igual que en la Premática que este año de 1600 se ordenó. ${ }^{24}$

Apócrifo o no, el entremés de Los refranes del viejo celoso compara al Vejete con su lenguaje recargado de refranes, las "vejezes". La pedantería de esta figurilla está en contra de los designios vitales de su antagónico, el amante Rincón, más fresco en su lenguaje y juventud. La verborrea arcaizante puede añadirse a los atributos de decrepitud del anciano, y ésta será el elemento definitivo por el cual Justa le abandonará, en pos de una alegre relación adúltera con su joven amante. Rincón se ha aprovechado de los vicios pedantes de su rival para conquistar definitivamente a la dama. Como él dirá: "han de ser terceros sus refranes".

Quevedo terminará con la proverbialización maniática y la senilidad lingüística, generando un carnavalesco desfile con las figuras de los proverbios. Al igual que en La culta latiniparla, don Francisco se

${ }^{24}$ Cfr. Ignacio Arellano en su artículo "Notas sobre el refrán y la fórmula coloquial en la poesía burlesca de Quevedo" [1997: 16]. Herman Iventosch [1962: 177] expresa en su ensayo "Quevedo and the defense of the slandered" que don Francisco hace patente a lo largo de toda su obra un desprecio hacia el lenguaje fosilizado -sea del refranero o del manierismo culterano- y enfatiza las expresiones populares al uso. La trama del Los refranes del viejo celoso constituye un buen ejemplo de personificación dramática de expresiones populares satirizadas: "I think, how the Entremés de los refranes [...] offered Quevedo an example of farce performers who mouth nothing but refranes, this itself a continuation of that long tradition of mockery already seen in our Seraphina, and indeed in Quevedo's own Buscón [...] And the entire idea of applying the mania for proverbs to the "viejo celoso" is of course inseparable from the immemorial conception in all cultures of the old and decrepit who utter proverbs at every step- notably, the "aged" Celestina herself." 
enfrentará a las "palabras murciélagas y razonamientos lechuzas". Censurará la falaz cita de autoridad, siempre proclive a oscurecer la comunicación. Y, es que, los tipos quevedescos representan la dimensión física del lenguaje, son peleles huecos del autor, que mueve sus hilos y los maneja con artes de ventrílocuo. $^{25}$

\section{DIATRIBAS GERMANESCAS EN LAS JÁCARAS Y BAILES}

En una ocasión, Quevedo dijo de sí mismo: “Diome el escorpión ${ }^{26}$ su lengua" (POC, 696). Por no decir el jaque, el jayán, el ladrón, el trampero, el pícaro.

Nuestro autor utiliza en sus jácaras y bailes un léxico lleno de voces de germanía que se combinan con un lenguaje coloquial no exento de juegos conceptistas. Don Francisco se inspira en la destrucción de la frase lexicalizada y la ruptura del cliché que ya habían emergido en la temprana lírica canallesca de Rodrigo de Reinosa. ${ }^{27}$

El léxico de germanía, el aplebeyamiento expresivo, el contexto gestual y otros estilismos procedentes de la marginalidad abren una nueva veta de

${ }^{25}$ Como señala Arellano [1997:20], el cliché “no es un material neutro integrante del idiolecto quevediano, sino un material activo sometido a todas las modificaciones ingeniosas posibles o explotado en su valor semiótico de marca del género o categoría del locutor burlesco". Véase el apéndice incluido al final del estudio de Arellano [1997: 32-38]. Contiene un listado de refranes utilizados por Quevedo con su respectiva ubicación.

26 "Escorpión", en lenguaje de germanía, alude a la persona murmuradora y maldiciente.

${ }^{27}$ Cfr. Alonso Veloso [2005: 109]. 
originalidad para la literatura satírica durante el siglo XVII. Quevedo logra, a través de sus jácaras y bailes, esbozar el trasunto de un cuadro truculento, para deleitarse en el gesto grotesco de una lacra social. Rufianes, prostitutas y otra carne de horca $^{28}$-debidamente escalonados en una particular jerarquía $^{29}$ - poblaron a menudo el formato del romancero y lo hicieron con el sociolecto particular de los delincuentes.

La germanía es el lenguaje de los maleantes en España de los siglos XVI y XVII, también denominada jacaranda, jacarandina, jerigonza, algarabía e, incluso, argot. Ayuda a configurar una atmósfera aguafuertista y sombría, festiva y macabra, que se corresponde con la estética de lo grotesco. Más allá del manierismo del Greco o el aliento fúnebre de Valdés Leal, posibilita una pintura negra muy similar a la que doscientos años después pintara Goya.

Las jácaras y bailes de Quevedo se inscriben dentro de un continuum estilístico, tienen su propia trayectoria interna. Su riqueza figurativa es tan intrincada, que a menudo sólo puede glosarse a través del uso de diccionarios y notas de especialistas. Se constituyen, entonces, como verdaderos jeroglíficos de significado que deben descifrarse en su jerga y formas retóricas. Quevedo, en todo caso, consigue elevar la jácara "al ámbito selecto de la literatura culta e insertarlo en la senda de la popularidad." 30

\footnotetext{
${ }^{28}$ Aludo al título del artículo de Monique Joly, "De rufianes, prostitutas y otra carne de horca", en Nueva Revista de Filología Hispánica, tomo XXIX, nº 1, 1980.

${ }^{29}$ Cfr. Alonso Hernández [1976: 95 y ss.]

${ }^{30}$ Cfr. Alonso Veloso [2005: 93].
} 
Por otra parte, los bailes de don Francisco se caracterizan por utilizar el collage lingüístico de estribillos y canciones populares, expresiones onomatopéyicas que marcan el ritmo y una algarabía rimada de suma vitalidad expresiva. En el Discurso de todos los diablos, el Poeta de los Pícaros (o poeta de los holgazanes) dice al respecto:

¿Quién inventó el Tengue tengue, y Dongolondrón, y Pisaré yo el polvillo, Zarabanda y dura, y Vámonos a Chacona, y ¿Qué es aquello que relumbra, madre mía?, la Gatatumba, y Naqueracuza? ¿Qué es Naqueracuza, infame? ¿Qué quiere decir Gandi, y Urruá, que en la venta está, y iAy, Ay,Ay!, y traer todo el pueblo en un grito? ¿Y Ejecutor de la vara, y daca a Ejecutor de la vara? ¿Y Señor boticario, deme una cala, y Válate Barrabás, El pollo y Guirigay? Y otras cosas que, sin entenderlas tú, ni el que las canta, ni el que las oye, al son de las alcuzas y de los jarros y de los platos, las cantan los muchachos y mozas de fregar con tonillos de aceite, y dos de queso y pella y pastel, que tú compones. [2003: II, 531-532].

Los estribillos del Polvico, la Zarabanda o la Chacona tenían años de antigüedad. Con todo, Quevedo utilizó la mayoría de las letras conocidas para criticar a sus enemigos literarios, que las componen o incluyen en sus obras: por ejemplo, Quiñones de Benavente usa la Naqueracuza, Hurruá aparece en la mojiganga El mundo nuevo de Vicente Suárez, el Viene del Panamá es un estribillo de una canción de La dama boba de Lope. ${ }^{31}$ Don Francisco aprovecha la ocasión para lanzar una pulla a los poetas culteranos:

¿Y llámanme poeta de los pícaros porque sin gasto ni daño alegro y entretengo barato y brioso con Vengo de Panamá y De qué tienes dulce el dedo y Don, don

${ }^{31}$ Véase Cacho Palomar [1997: 282]. 
Camaleón y otras letrillas traviesas de son y comederas? No, sino escribir coruscos, lustros, joven, construyendo, adunco, poro, con trisulca, alcuza, naqueracuza; y, libando, aljófar con si bien, erigiendo piras, canoro concento de liras. (...) Lo uno es culto y lo otro pimienta (...) Yo bien puedo ser poeta de los pícaros, pero ellos son pícaros poetas, y por lo menos a mí no me veda la Inquisición ni tengo examinadores; y míreseme bien mi causa, que yo soy el mejor de todos. [2003: II, 534-535]

Apreciamos el juego literario que daban los estribillos famosos de los bailes coetáneos. Denotación, personificación, animalización, cosificación, sátira social... son recursos utilizados por el Poeta de los Pícaros para burlarse de los "pícaros poetas" de su época.

El léxico de las jácaras y bailes de Quevedo es imprescindible para la comprensión global de estas composiciones. ${ }^{32}$ Hill fue de los primeros compiladores coetáneos de jácaras en su volumen de Poesías germanescas, y rechazó, de hecho, aquellas piezas que lingüísticamente carecían de suficiente léxico de germanía, el lenguaje abultado del mundo marginal. Pero Quevedo aliña esta tradición germanesca con su propio código retórico, la agudeza verbal del conceptismo. Es el "alfarero milagroso" - en términos borgianos ${ }^{33}$ - que toma el "barro sutil y quebradizo" del lenguaje de los pícaros y lo amasa "en vasija de eternidad."

\footnotetext{
${ }^{32}$ Véase la edición anotada de I. Arellano [1984].

${ }^{33}$ Cfr. Borges [1998: 62].
} 


\section{DISPOSITIVOS SEMIÓTICOS DEL TEATRO BREVE}

\section{LA COMUNICACIÓN NO VERBAL}

Centrarnos exclusivamente en el ámbito verbal de la obra dramática de Quevedo sería, sin embargo, un error. El teatro se totaliza sobre un escenario. La dramaturgia farsesca se ampara en los movimientos corporales del actor, que a menudo debía tener dotes acrobáticas, así como en su maquillaje, vestuario, cambios de entonación y todos aquellos recursos fonéticos que son objeto de la paralingüística. ${ }^{34}$

La parte hablada, sobre todo en el teatro breve, se integraba con el canto y el baile, que se entrelazaban a lo largo de toda la pieza. El recitado, acompañado de cuadros y mudanzas, cobra una unidad armónica constitutiva.

Los recursos no verbales guardan tres relaciones posibles con la palabra en el ámbito del teatro barroco: [1] la complementan intensificando la espectacularidad de la escena (en las acotaciones de los actores, las entradas y salidas de personajes, los efectos sonoros o los palos del desenlace), [2] la realizan hasta el extremo de la materialización de los refranes, o [3] la contradicen como ridiculización o sátira al servicio de la comicidad.

Las obras dramáticas conjugan texto, música y coreografía. Son un espectáculo complejo, que debe ser abordado desde diferentes disciplinas.

\footnotetext{
${ }^{34}$ El receptor, medio y objeto literario son mecanismos de lo cómico que Maria Grazia Profeti [1989] esboza en su esquema para el análisis de lo cómico barroco.
} 
Deberían, en rigor, estudiarse desde la perspectiva de la literatura, la musicología ${ }^{35}$ y la historia de la danza. ${ }^{36}$

El espacio teatral también denota significados. Distinguimos entre el espacio privado o doméstico -dentro- y el escenario social representado en un contexto urbano-fuera-. El uso del aparte sirve para simultanear esas dos dimensiones. ${ }^{37}$

${ }^{35}$ No existen estudios musicológicos específicamente referidos a la música del teatro breve. Los análisis de carácter global más relevantes al respecto se inician a finales del siglo XIX con las aportaciones de Felipe Pedrell [1894], Francisco Asenjo Barbieri [1887], Emilio Cotarelo Mori [1911] y José Subirá [1945], que asientan las bases de la historia de este género. El estudio más significativo, al respecto, es el de Louise Stein, Songs of Mortals, Dialogues of the Gods: Music and Theatre in the Seventeenth-Century Spain [1993]. Dentro de esta misma línea de análisis, se inscribe el estudio del musicólogo español Caballero Fernández-Rufete [1997].

${ }^{36}$ El primer intento por sentar las bases de la historia de la danza partió de Francisco Asenjo Barbieri [1887]. Cotarelo Mori [1911] recurre a fuentes como el Diccionario de Autoridades, el Tesoro de la lengua de Covarrubias o tratados coreográficos como el de Arbeau o Esquivel Navarro. También hallamos aproximaciones generales a las formas de danza española del siglo XVII en los estudios de Curt Sachs [1944] o Horst [1966]. Destacamos la tesis doctoral de T. B. Barclay [1957], el estudio del musicólogo Maurice Esses [1993] sobre formas del repertorio de guitarra, arpa y órgano derivadas de la danza, la labor de la coreógrafa española Ana Yepes [1988], de la musicóloga Beatriz Martínez del Fresno [1994] y el trabajo de María José Ruiz Mayordomo [1992].

${ }^{37}$ Véase Evangelina Rodríguez y Antonio Tordera [1982:46-49]. 


\section{LA MÚSICA, LA COREOGRAFÍA Y LOS BAILES}

Si bien a principios del siglo XVII la dinámica de la música, la danza y la coreografía es todavía muy rudimentaria, lejos de ser un mero agregado de "color", está íntimamente ligada al texto y es necesaria para que éste alcance su pleno significado. ${ }^{38}$ La utilización de la música es, todavía, algo incidental en los intermedios anteriores a 1650. Sirve para acompañar la letra de una canción o para cerrar la obra. Todavía no cumple función estructurante alguna.

De hecho, pensamos que muchos de los ejemplos musicales del teatro de Quevedo, como solía suceder, son tomados de piezas anteriores y reutilizados en otras obras cortesanas. No se solía componer música especial para el teatro breve. Los dramaturgos o compositores recurrían frecuentemente a la reutilización de canciones preexistentes ya conocidas por el gran público, que eran adaptadas al texto dramático.

El integrante musical del teatro iba unido casi siempre al canto. Está ligado al teatro desde sus comienzos. Su finalidad estribaba en graduar, realzar y cambiar las mudanzas, la mímica, el baile. En relación con la letra, aparecía en un plano superior de jerarquía escénica.

La música era un elemento imprescindible en toda compañía. Había actores y actrices especializados en ella. Figuraba en las indicaciones de los personajes, a saber: era común la acotación "salen los músicos” o "cantan”;

\footnotetext{
${ }^{38}$ Sobre el baile y la música en el teatro breve del barroco, véase la tesis doctoral de Gaspar Merino Quijano [1981].
} 
en otras ocasiones se sobreentiende. Los músicos, a parte de tocar determinados instrumentos, solían cantar. ${ }^{39}$

El integrante cantado presentaba en el teatro una importante variedad de empleo. Las partes cantadas no siempre eran bailadas necesariamente. El personaje coral “Todos”, fundamentalmente, cumple la función de cantar y bailar.

El baile, asimismo, solía contener movimientos y evoluciones pausados, sin saltos. Los estribillos, exclamaciones y repeticiones del baile de la letra acostumbraban a graduar sus compases.

En los manuscritos de la primera mitad del seiscientos, difícilmente aparecen indicaciones coreográficas junto al texto dramático, tan sólo algunas acotaciones genéricas como "bailan". Estas indicaciones cambian en manuscritos teatrales de la segunda mitad del siglo XVII, donde el desarrollo coreográfico se señala con detalle a la derecha del texto dramático. La tendencia va en aumento a medida que pasan los años, hasta que las coreografías adquieren las características de un pequeño ballet cortesano.

Existen, de hecho, pocos tratados coreográficos españoles del siglo XVII. El más importante es Discursos sobre el arte del danzado del maestro Juan de Esquivel Navarro, que en ningún caso hace alusión a la variante teatral. El Libro de danzar de Don Baltasar de Rojas Pantoja del maestro Antonio Jaque describe la coreografía de bailes como la pavana, la gallarda, las jácaras, las folías, el villano y las paradetas. En el anónimo Reglas del danzar se explica la forma de bailar la alta, la baja y la pavana italiana. En

\footnotetext{
${ }^{39}$ Cfr. Merino Quijano [1981: I, 177-182].
} 
el Breve tratado de los pasos de danzar a la española de Pablo Minguet se describen unos cuarenta cinco pasos que parecen ser extraídos del libro de Esquivel Navarro.

Quevedo, por influjo cervantino, prefiere en su teatro breve los finales en baile que no en palos ${ }^{40}$, kinésicamente más estilizados y divertidos para los espectadores por su dinámica musical. Terminan en canto y baile la primera y segunda parte del Doña Bárbara, la segunda parte del Diego Moreno, La vieja Muñatones, La destreza y La venta.

Los bailes de Quevedo describen movimientos espasmódicos, informes. Incluyen una gesticulación exageradamente sensual. Exponen el conflicto en movimiento coreográfico. ${ }^{41}$ Utilizan las formas estróficas características de la música vocal profana del barroco, en detrimento de la silva de consonantes, prototípica del entremés. ${ }^{42}$ Los temas de los bailes quevedescos afloran en el entremés y ello posibilita que a menudo se incluyan al final de la pieza en un curioso mecanismo de autocita. Así realzan el relieve de la representación engañosa, ayudan a hiperbolizar lo ridículo y a extraer la carcajada del espectador.

Todos estos componentes se vislumbran a través de las acotaciones, que en la obra dramática de Quevedo son, por cierto, pocas. A diferencia de la comedia lopesca, el teatro de don Francisco hace pocas concesiones a estos valores extra-escénicos.

\footnotetext{
${ }^{40}$ El único entremés que termina con matapecados, Los refranes del viejo celoso, actualmente está aceptado como de Quevedo, aunque con notables reservas.

${ }^{41}$ Cfr. Ana María Snell [1994: 174].

${ }^{42}$ Véase Caballero Fernández-Rufete [2002:26].
} 
La censura del texto literario seguramente quedaba compensada por gestos risibles e incluso lascivos, de ascendencia carnavalesca. La calidad del gesto, por ejemplo, del entremés de La destreza, en el que la madre Monda da lecciones sobre el arte de pedir basándose en metáforas de la esgrima, podría haberse reforzado mediante el uso del florete. La falta de alusión a los gestos, ademanes y entonación nos hace suponer que los actores potenciaban libremente los matices cómicos desprendidos de la palabra.

\section{EL VESTUARIO}

El vestuario actúa como paradigma de las costumbres de una época. ${ }^{43} \mathrm{Si}$ bien los textos dramáticos auriseculares ofrecen pocas acotaciones sobre la vestimenta de los actores, sabemos que en el teatro breve la mención al personaje arquetípico llevaba implícita una orientación simbólica sobre su indumentaria, que solía distanciarse de la suntuosidad y anacronismo ${ }^{44}$ de los hatos de vestuario de las obras dramáticas serias, prolijamente descritas en inventarios de bienes, libros de cuentas de palacio y Relaciones de Sucesos.

\footnotetext{
${ }^{43}$ Véase, al respecto, el artículo de Teresa Ferrer Valls "Vestuario teatral y espectáculo cortesano en el Siglo de Oro", editado on-line: http://www.uv.es/entresiglos/teresa/pdfs/espectaculo.PDF

${ }^{44}$ Lope alude a este anacronismo en su Arte Nuevo: "sacar un turco en cuello de cristiano/ y calzas atacadas un romano.” (vv. 360-361)
} 
Dado que la mayoría de tipos del teatro breve pertenecen al mundo hampesco, debían de ir vestidos con remiendos, roturas, retazos y trazas. ${ }^{45}$ El denominado sayo bobo, asimismo, un vestido estrecho, abotonado hasta los pies, era usado comúnmente por los actores que hacían papel cómico en los entremeses. También iban caracterizados con otros elementos con valor escénico, como sombreros, capas o jubones. Para orientarnos, podemos analizar las escasas acotaciones de estas obrillas.

Las jácaras, a diferencia de los bailes más dialogados, no presentan ninguna acotación. El baile Los galeotes (POC, 867) indica cuando salen Juan Redondo y Santurde, que estos van con vestidos de forzados y birretes. La suma de ambos elementos es muy grotesca: unimos el vestido harapiento de los galeotes con el gorro con forma prismática rematado con una borla cuyo uso, durante el siglo XVII, se regularizó en el mundo académico. Más tarde, aparecerá un Bailarín con un pito, y los músicos cantarán lo siguiente:

\footnotetext{
Y cuando el amante espera

que ha de estar el pito mudo,

porque estén de su manera,

siendo el cómitre desnudo,

dice a todos: “¡Ropa afuera!”
}

(Quitanse todos la ropa.)

¡Ah, chusma, ropa afuera!

\footnotetext{
${ }^{45}$ Véase el capítulo que Júarez Almendros dedica al Buscón de Quevedo en su monografía El cuerpo vestido y la construcción de la identidad en las narrativas autobiográficas del siglo de oro [2006: pp. 95 y ss.]
} 


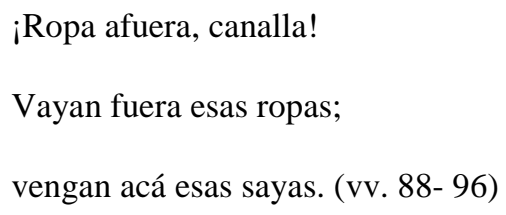

En este pasaje, los músicos hacen que todos los personajes del baile se deshagan de sus ropajes. Piden que se quiten las sayas: este término probablemente alude al sayo de bobo ya descrito.

En el baile Los sopones de Salamanca (POC, 868), si bien no contamos con ninguna acotación, el propio Quevedo brinda una descripción paródica del atuendo del estudiante capigorrón:

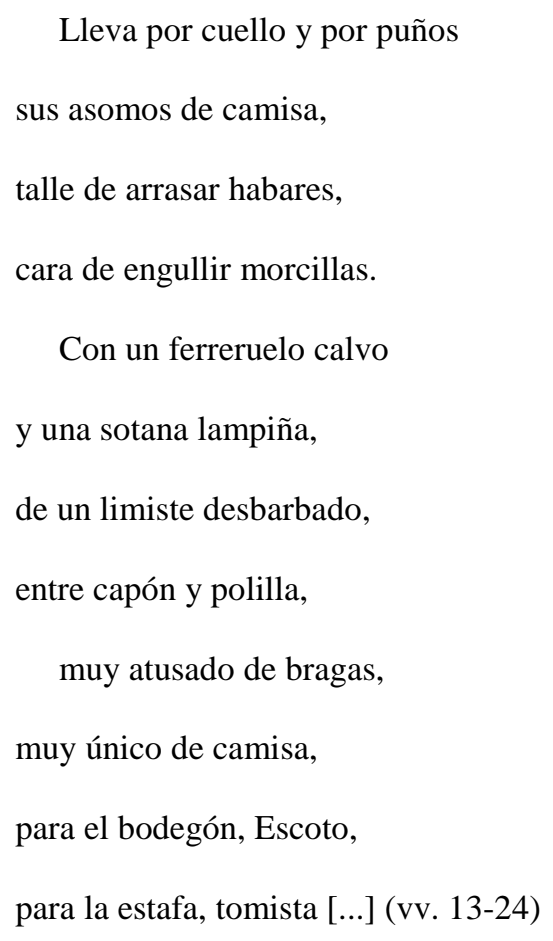

Otro tanto se nos brinda en la descripción del vestuario de la Boda de pordioseros (POC, 872), donde el esposo güero va "muy sombrero a la fiesta/ y al banquete, muy de gorra" (vv. 15,16) y la novia "llevaba 
almidonada/ la cara y no la toca" (vv. 25-26). Asimismo, la protagonista de Las estafadoras (POC, 874):

\author{
Allá va con un sombrero, \\ que lleva, por lo de Flandes, \\ más plumas que la provincia, \\ más corchetes que la cárcel. (vv. 1-4)
}

El vestido durante el Siglo de Oro es utilizado como estrategia de intrusión y de exclusión social. La representación del cuerpo y del atuendo está íntimamente ligada a las corrientes buslesco-carnavalescas.

El traje caracteriza al personaje extravagante. Alcanza su deformación grotesca en Los refranes del viejo celoso, prefiguración de la mojiganga, donde Rincón llegaría a disfrazarse con una rapidez vertiginosa con la finalidad de representar todos los personajes folclóricos por los que se hace pasar.

Otro elemento llamativo en el vestuario es el recurso de la inversión de roles, el fenómeno del mundo al revés ${ }^{46}$. Imaginamos, por ejemplo, en el entremés de Diego Moreno a un maridillo cartujo ataviado con cuernos improvisados con alambre u otro material. También visualizamos el impacto escénico que podría haber generado don Constanzo, en el entremés de El marión, travestido con una suerte de traje ridículo, tal vez compuesto por un híbrido de prendas masculinas y femeninas. ${ }^{47}$

\footnotetext{
${ }^{46}$ Este motivo ha sido estudiado por el doctor Carlos Vaíllo [1982: 364-393].

${ }^{47}$ Así lo postula H. E. Bergman a propósito de Los mariones de Quiñones de Benavente [1965: 124].
} 
Aunque pueda parecer que el discurso lingüístico se hipertrofia en detrimento de la semiótica teatral, el lenguaje exageradamente lúdico de los personajes del teatro breve de Quevedo se refuerza con la visualización de su gesticulación, sus movimientos ridículos y su vestimenta. ${ }^{48}$

\section{Metateatralidad}

Quevedo hace teatro teatral, que no teatro literario. ${ }^{49}$ Sus entremeses y bailes abundan en recursos metateatrales que ayudan a romper la ilusión escénica. La ruptura de la cuarta pared es un recurso prototípico de lo cómico. Los actores hacen comentarios sobre el público y así crean una complicidad que aviva el interés y disfrute del auditorio.

Por momentos, las figuras se saben dentro de una farsa, de una representación. Son fantoches del teatro del mundo. Así, por ejemplo, Muñoz, de El marido pantasma, avanza que su sueño albergará la convencional visión de entremés. La Ropavejera, del entremés homónimo, señala la cazuela teatral para aludir a los remiendos de cirugía estética que ha hecho a mozuelas y viejas. En la Polilla de Madrid, la pidona y sus secuaces representarán una comedia titulada el Robo de Elena, paradigma del "teatro dentro del teatro". E igual sucede en el entremés de La venta, que termina con la entrada de Guevara y su compañía de actores.

\footnotetext{
${ }^{48}$ Véase Susana Hernández Araico [2004: 210].

${ }^{49}$ Cfr. Soons [1970: 434].
} 
Quevedo, en ocasiones, introduce un personaje intermediario o director escénico. ${ }^{50}$ Actúa como titiritero de las figuras entremesiles, marionetas de lo grotesco. Podría aducirse que en Los refranes del viejo celoso Rincón resulta una suerte de autor de compañía que dirige tretas y ademanes de otras figuras, improvisando disfraces folclóricos. ${ }^{51}$ En el $E l$ Niño $y$ Peralvillo de Madrid, el amolador Juan Francés, ${ }^{52}$ al igual que Rincón, coordina la puesta en escena de diversos personajes grotescamente disfrazados con la finalidad de escarmentar al Niño sobre pidonas cortesanas.

Ya hemos analizado, asimismo, las alusiones a movimientos, pasos e instrumentos musicales dentro de algunos bailes de Quevedo, que acostumbraba a elaborarse una poética satírica de los géneros que cultivaba. $^{53}$

Sin embargo, hay quienes consideran que Quevedo apenas se beneficia de la dimensión cómica del juego teatral, dado que la locuacidad de sus personajes eclipsa los resortes no verbales del repertorio escénico. ${ }^{54} \mathrm{Su}$ técnica se ampara, ante todo, en repeticiones y simetrías que favorecen el efecto de comicidad, aun bajo el riesgo de la monotonía. ${ }^{55}$

\footnotetext{
${ }^{50}$ Alonso Hernández [2001:51] alude a este término.

${ }^{51}$ Cfr. S.Hernández Araico [2004: 224].

${ }^{52}$ Este personaje será el protagonista del Entremés nuevo de Juan Francés, de Quiñones de Benavente.

${ }^{53}$ Véase el apartado 6.3. del capítulo VII.

${ }^{54}$ Así lo postula Pilar Cabañas [1991: 299-300].

${ }^{55}$ Guido Mancini [1955: 91].
} 


\section{EL ESPACIO TEATRAL}

Entremeses, bailes y mojigangas eran géneros de raigambre popular que sufrieron algunas modificaciones al ser introducidos en las representaciones palatinas. Estos cambios no fueron caprichosos, dado que respondían a factores como el público destinatario -la nobleza-, la ocasión -la celebración de la familia real- y el espacio en que se llevaba a cabo la puesta en escena el teatro de la corte-. ${ }^{56}$

Quevedo, como Hurtado de Mendoza, Lope de Vega o Vélez de Guevara, escribe para producciones palaciegas, que después pasarían a ser representadas en los corrales por actores y memorillas. La presencia de segundas partes en muchos de los entremeses -Diego Moreno, Doña Bárbara, El marión- son índice de que estos no sólo fueron escenificados, sino que ostentaron considerable éxito.

El teatro breve quevediano destinado a palacio rebaja el tono costumbrista e hiperboliza con saña la hipocresía social. Las circunstancias de representación fueron diversas. Se han documentado las celebraciones del Duque de Lerma en $1617,{ }^{57}$ las de Andalucía en $1624^{58}$ o las del cumpleaños de la reina en $1625 .^{59}$

\footnotetext{
${ }^{56}$ A propósito de este fenómeno, podemos sacar a colación la teoría de la biculturalidad de Roger Chartier [1992]: un grupo social, los cortesanos, se apropia de un objeto cultural, el teatro breve, y lo somete a profundas transformaciones en función de sus propios intereses.

57 Así lo sostiene S. Hernández Araico [2004: 217]: "Sobre El caballero del sol, de hecho, Valbuena Briones aclara que en Lerma, los criados del duque de Lerma ponen la comedia. Shergold, citando las relaciones de Herrera y de Fernando del Caso, explica que las dos semanas de fiestas en Lerma incluyen un "entremés satírico" de Hurtado de Mendoza, unos
} 
Tras la muerte de Quevedo, a partir de la segunda mitad del siglo XVII, con el florecimiento cortesano del teatro breve y la construcción del Coliseo del Buen Retiro (1651) se estrenan muchos entremeses, jácaras y bailes con motivo de bodas, cumpleaños y santorales de los miembros de la familia real. Estas representaciones palaciegas limitaron los espectáculos de los corrales de comedias, para que los figurantes pudieran actuar en la corte cada vez que fueran solicitados. Las piezas de teatro breve merman en contenido satírico y adquieren un trasfondo mitológico. La corte dispone de dramaturgos como Pedro Calderón de la Barca o Juan Hidalgo, que cuentan

espectáculos dirigidos por Mira de Amescua y dos entremeses- uno de ellos sobre una boda fingida, y otro sobre "amateurs teatrales". ¿Podrían ser estos entremeses de Quevedo, aquel quizá el Entremés primero de Bárbara o El marido pantasma y este La venta, alguna versión de La polilla de Madrid que menciona burlescamente a "Mira de Mosca" (v. 155)?" ${ }^{58}$ En la impresión sevillana de Diego Flamenco (1628) de El zurdo alanceador aparece el epígrafe "Representóle Amarilis en Sevilla". Postula Asensio [1965: 237] al respecto que esa época debe remitirse a comienzos de 1624, cuando Felipe IV viaja a Andalucía con la finalidad de inspeccionar las fortificaciones costeñas, dado que tras la ruptura de los proyectos matrimoniales entre la princesa española y el príncipe de Gales, recela de futuros ataques ingleses. Quevedo, que defendió dicha ruptura en la comedia Cómo ha de ser el privado, iba en la comitiva y cuenta los incidentes de este viaje a Andalucía en una carta escrita el 17 de febrero de 1624 al Marqués de Velada y San Ramón. Cfr. Krzysztof Sliwa, [2005: 357]. En efecto, señala Asensio que el Duque de Medinasidonia había contratado las compañías de Tomás Fernández y de Amarilis (alias María de Córdoba) como regalo al monarca. Bernardo Mendonza y Jacinto Herrera y Sotomayor narraron los pormenores de estas representaciones, acaecidas durante el 16 y 17 de mayo de 1624, aunque sin aludir a los títulos de las obras. Véase Jenaro Alenda [1903: 242] y Sánchez-Arjona [1898: 229230].

${ }^{59}$ Como aparece detallado en el capítulo II. 
con una sofisticada maquinaria escénica, iluminación, vestuario y unas pautas coreográficas y musicales muy marcadas.

Los dispositivos semióticos del teatro de Quevedo (coreografías, indicaciones escénicas, partituras musicales, etcétera), en cambio, se han perdido en su mayor medida, sin embargo. ${ }^{60}$ Ante todo, en el ámbito del teatro breve. Actualmente, es prácticamente imposible confrontar las impresiones de lectura del texto a la representación de las obras de don Francisco. ${ }^{61}$ Compartimos la siguiente reflexión de Asensio:

La más penosa cortapisa para una justa apreciación de los méritos del entremés es la imposibilidad de confrontar las impresiones de lectura con la visión inmediata de la presentación escénica a la que se destinaba. Es para nosotros letra muerta, que inútilmente tentamos revivir sobre el tablado de la imaginación. Ignoramos el estilo de recitación, la dosis de convención y realismo, el ritmo que enlazaba la palabra con la música y la danza. [1965: 246]

El investigador actual, lamentablemente, dispone de muy poca información sobre las mudanzas, la mímica, la música y el canto de los bailes. Sobre todo, puede estudiar una parte mínima del mismo, la letra

60 "Todo esto se ha perdido": Así lo refiere Octavio Paz [1985: 312] cuando alude a las indicaciones musicales, escenográficas y coreográficas de las obras dramáticas de Sor Juana Inés de la Cruz, cuyo rastro es prácticamente nulo.

61 Nos consta que, únicamente, se han representado una adaptación del Buscón a cargo de Ricardo López Aranda y otra de Los empeños del mentir, dirigida y rescrita por Fernando Doménech. ¿Serán sólo el principio de una renovación de la cartelera aurisecular? ¿Veremos alguna vez representado el teatro breve de Quevedo? Una escenificación rigurosa sería un verdadero éxito. Véase el apartado bibliográfico destinado a las representaciones teatrales modernas basadas en la obra literaria de Quevedo. 
acomodada a la música. No obstante, somos conscientes de que las pautas musicales y coreográficas son fundamentales para una correcta interpretación de estas obras. 


\section{Capítulo IX}

HACIA UNA FILOSOFÍA DEL TEATRO 
- 592 - 


\section{QUEVEDO Y LOS GÉNEROS}

\section{UNA INMENSA ESCRITURA}

¿Qué posibilidades de expresión halló don Francisco en el teatro? ¿Es lícito aislar éste de los demás géneros que cultivó? El espacio formal de la escritura siempre está al servicio de un mensaje. ¿Acaso no es ésta la esencia de cualquier arte? Conjugar, unir, estrechar. La interconexión de $a$ y b. Desentrañar los vínculos, como dijera Giordano Bruno.

Quevedo tuvo una concepción global de los géneros literarios que concuerda con los impulsos fermentadores y sintéticos del Siglo de Oro. Occidente se había expandido geográficamente, y la maravilla de las nuevas rutas comerciales había enriquecido el lenguaje. Articular el concepto en un engranaje perfecto convertía la literatura en un artefacto. Escribir, como navegar por el Atlántico, era una aventura planificada.

El humanismo conquistó territorios vírgenes a través del pensamiento analógico. Pico della Mirandola había conciliado todos los saberes antiguos conjugando a Platón con Aristóteles y al cristianismo con la cábala. Erasmo había armonizado la lectura de los clásicos con la de las Sagradas Escrituras. Guillaume Postel en De orbis terrae concordia (1544) había especulado sobre la comunión cósmica. Para cualquier humanista, el hombre actuaba como nodo unificatore del mondo. Esta postura, con el añadido de la ortodoxia y el absolutismo de los Austrias, se extendió a la España del siglo XVII.

Don Francisco albergó la idea de una inmensa escritura. Con esta expresión había definido el Rómulo de Malvezzi, que merecía su más honda 
admiración. ${ }^{1}$ El autor desgranó los géneros convencionales -leyes, cédulas, decretos, pragmáticas, memoriales, aranceles, capitulaciones- y los caricaturizó al transmutarlos en canal de su escritura individual.

Quevedo, que contaba con una sólida formación filológica, se enfrentó con casi todos los géneros de su época, y lo hizo de una manera vasta y polifónica. ${ }^{2}$ Buscó en ellos la oportunidad y no la restricción: su debilidad era la parodia idiomática. ${ }^{3}$ Por ello, su teatro está vertido hacia la materialidad de la palabra: se convirtió, como hemos desentrañado a lo largo del capítulo anterior, en un espectáculo verbal.

\section{QUÉ ES LO DRAMÁTICO}

Para don Francisco, la buena literatura se trabaja con la industria del orfebre: la técnica es oficiosa. ${ }^{4}$ Nuestro autor subordina los logros de su teatro a los de la lucidez del propio lenguaje que los delimita. El verbo, eficaz y deslumbrante, vehiculado con decoro en la voz de los personajes, configura la ingeniosidad de las piezas.

En el teatro de Quevedo, la escritura gobierna la literatura. El género es un pretexto de estilo: determina un nivel verbal en sentido utilitario y no

1 Véase Quevedo [1951: II, 1399].

2 Estas observaciones concuerdan con la tesis del artículo de Claudio Guillén "Quevedo y el concepto retórico de la literatura", insertado a modo de capítulo final de su estudio $E l$ primer Siglo de Oro. Estudios sobre géneros y modelos [1988: 234-267].

3 Como notara Alarcos [2004].

4 Véase E. Asensio [1965: 85]. 
representativo. ${ }^{5}$ Su desenfado ante el encorsetamiento genérico y su visión burlesca y lúdica del lenguaje le permiten anular la sumisión a las convenciones lingüísticas. La agudeza dificulta el encasillamiento retórico.

El sincretismo pangenérico de Quevedo reconcilia aparentes contradicciones. Esto nos permite sostener, casi paradójicamente, que su obra dramática está desdramatizada y que su obra no teatral abunda en el empleo de recursos propios de las tablas.

Pongamos un ejemplo. En La constancia y paciencia del Santo Job (1641), Quevedo inicia su discurso concibiendo el libro bíblico en términos teatrales:

Este libro (llamémosle así) es en cierto género un poema dramático, una gravísima tragedia, en que hablan personas dignas de ella, todos reyes y príncipes; el lenguaje y locución digna de coturno; magnífica y decorosamente grande. [1951: II, 1187]

El autor define su obra a partir de los principios neoaristotélicos: personajes, dicción, magnitud. ${ }^{6}$

Recordemos, por otra parte, que el teatro breve barroco tiene su origen en la poesía y homilética medieval. Quevedo, en su obra dramática burlesca, retrata al hombre como animal risible desde una perspectiva eminentemente cristiana: hace algo muy similar a Prudencio en la Psycomachia. Al igual que los Padres de la Iglesia -San Juan Crisóstomo, Gregorio el Magno y

5 Cfr. Claudio Guillén [1988: 243].

${ }^{6}$ Quevedo había asimilado estos conceptos. Como veremos, en las anotaciones que ilustraron su edición latina de la Retórica figuran resúmenes e indagaciones sobre el teatro clásico grecolatino. 
otros-, Quevedo fue consciente de la teatralidad del vicio, cuyo locus classicus encontramos en la carta a Demetria de las Epístolas de San Jerónimo. $^{7}$ El pecado es un personaje camaleónico, surtido de los múltiples disfraces que dispensa la hipocresía, como ilustra el siguiente pasaje de la Vida de Marco Bruto:

Es el pecado grande representante: hace, con deleite de quien lo oye, infinitas figuras y personajes, no siendo alguno dellos. Es hijo y padre de la hipocresía, pues primero para ser pecado es hipócrita, y es hipócrita luego que es pecado. [2000: 105]

Esta visión de la representabilidad del pecado induce a Quevedo a definir, en la silva Roma antigua y moderna (POC, 137), a la ciudad como un "teatro lastimoso" (v. 132) durante la guerra civil. Esta concepción también explica que sus Lamentaciones de Jeremías se hayan relacionado con la sobria gravedad de los dramas cristianos de Racine. ${ }^{8}$

La primacía del lenguaje sobre la acción dramática genera que el teatro de Quevedo se fundamente en el showing de figuras virtuosas (en el caso de las comedias palatinas) o vituperables (en las comedias burlescas, entremeses, jácaras y bailes). La estructura de estas obras se basa en yuxtaposiciones de elementos líricos o cómicos que se autojustifican. La eficacia dramática se sacrifica en pro de la acrobacia lingüística. Para Quevedo, la palabra misma es acción. Como demiurgo literario, parece arrancar del mismo Génesis: el verbo genera realidad.

\footnotetext{
7 Cfr. Asensio [1965:179].

${ }^{8}$ Cfr. C. Guillén [1988: 236].
} 


\section{LA TEATRALIDAd DE LA PROSA SATÍRICA DE QUEVEDO}

Antes de que Quevedo cultivase el teatro, había experimentado con géneros abiertos y flexibles: la sátira onírica de los Sueños, el azaroso itinerario del Buscón, los caprichos paródicos de los Juguetes. En ellos, la realidad y la invención podían coexistir libremente. Puesto que cabían en el marco frívolo del entremés, Quevedo remolcó a la escena sus chistes, obsesiones y hallazgos lingüísticos. ${ }^{9}$

La novela picaresca se caracteriza por el fluido devenir de figurillas cómicas y pecadoras, casi siempre con un narrador testigo como eje focalizador de la acción. Por ello, en palabras de Edmon Cros, existe cierta theatralité dans le récit picaresque. ${ }^{10} \mathrm{La}$ ascendencia carnavalesca, la escatología cómica y las alusiones inquisitoriales del Buscón están vinculadas al teatro. ${ }^{11}$

9 Cfr. Pilar Cabañas [1991: 292].

${ }^{10}$ Cfr. E. Cros [1980: 35-37]. Así lo corrobora la adaptación teatral del Buscón por parte de Carlos Moreno, de la compañía Odisea Teatro, dirigida por Ángel García Suárez y estrenada el 16 de marzo de 2001 en el Centro Cultural de Alpedrete.

${ }^{11}$ Dice, a propósito de ello, Aurora Egido [1978: 186-187]: "En toda la obra se respira esta relación con el género teatral, y dentro de éste, con las capas más cómicas, aquellas que parten de la deformación de los personajes y que hacen que autor y espectador se unan por encima de la baja consideración que les merecen los tipos que los integran. La inversión de valores será el quicio sobre el que se asentarán, como en el teatro cómico, las burlas, la parodia de la nobleza y la degradación más absoluta. De ahí que no interese la vida interior de los seres que conforman la obra y sólo se nos dé su apariencia de fantoches, la pintura de sus harapos o su porte, las voces agermanadas o el talante paródico de las situaciones en 
Los personajes que habitan el mundo picaresco son como los arquetípicos avaros, alguaciles, maridos consentidos, falsos hidalgos y pillastres que pueblan los entremeses. Como en las Danzas de la muerte, son personajes representativos de lo mundano, de la caduca carnalidad. ${ }^{12}$

Quevedo, en la mayoría de casos, se desenvuelve en la pintura de cuadros o escenas. Por sus dotes de retratista, se han equiparado los Sueños a la pintura del Bosco. Sus descripciones conceptistas son poderosas en la imaginación del lector, que puede visualizar con vivos colores una galería de figuras arquetípicas. No en vano, en la aprobación portuguesa de los Sueños y discursos, del 20 de diciembre de 1628, escrita en San Bernardo de Lisboa por Feliziano Moutel, se compara esta obra con una comedia:

nam ouvera no mundo comedias, contos, nem autos pera entretemiento da gente, do que se siguira mayor dano, que de ser ler em hum Autor huma ociosidade. [Krzysztof Sliwa, 2005: 425]

¿Hasta qué punto, además, han influido la commedia dell'arte, los títeres, los tutilimundi, el retablillo mecánico, las tarascas y la linterna mágica en la peculiar edificación de los personajes de la prosa satírica de Quevedo? Quizás asoma el Pantaleón de bonete rojo y máscara con nariz ganchuda en la figura del Dómine Cabra. Los matapecados entremesiles -cachiporras de

que se mueven. Pues el motivo es la risa y hacia ella van dirigidos todos los esfuerzos de Quevedo."

${ }^{12}$ Así lo ha demostrado, aunque a propósito de la obra cervantina, Domingo Ynduráin [1966: 321-334] argumentando que ese "entremés llamado Monipodio" fermenta la composición de Rinconete y Cortadillo. 
los títeres- se transfiguran en la lluvia de hortalizas que recibe Pablos como rey de gallos y al final de su mala representación de comedia. La defecación y las lavativas son escatológicos legados de Arlequín.

Los chistes y alucinaciones que Quevedo había utilizado en su prosa satírica cabían, por lo tanto, en el libre entremés, acertado para sus códigos populistas, bromas lingüísticas y personajes coloridos. Podía, en su flexibilidad, contener el dinamismo de los cuerpos danzantes. En el teatro, obviamente, el narrador testigo desaparece. El papel de juez moral le corresponde al público.

Quevedo decora su teatro breve con el atrezzo temático de su obra no dramática que, en su vertiente cómica, se recrea con una óptica deformante de la realidad. El espectáculo regocijado de la obra satírica de Quevedo se recrea en los entremeses, donde ciertos tipos recurrentes -como la tomajona, la vieja, el calvo o el cornudo - resucitan en las tablas con mayor carnalidad. La obra no dramática de Quevedo se caracteriza por su plasticidad, circunstancia que facilita su adaptación teatral. Los entremeses se alinean con escenas de los Sueños, el Buscón y La Fortuna con seso. Coinciden temáticamente en la visión del caos de lo mundano, regido por la liviandad sexual, el dinerismo y las ambiciones del pueblo llano. ${ }^{13}$

${ }^{13}$ Así lo sostiene Pilar Cabañas [1991: 302]: "puede postularse el carácter entremesil de muchas de sus obras, teniendo en cuenta, por ejemplo, la abundancia del recurso de los palos en las mismas, el carácter gesticulante de las figuras y su naturaleza subhumana. Por este camino llegaríamos a la constatación de la presencia de una actitud básica común en gran parte de las producciones de Quevedo, más allá de los moldes estructurales elegidos en cada caso, y a la posibilidad de proponer la formulación de una definición supragenérica 
Charlas sin objeto, dardo sin meta, fantasmagoría. ${ }^{14}$ Cada situación se convierte en pretexto de una incesante madeja verbal. Quevedo transmite el sentimiento del demiurgo, el sentimiento estético.

para su prosa de ficción al descubrir una similitud de recursos a la hora de lograr la comicidad entre la producción entremesil y otras facetas de la misma."

${ }^{14}$ Lázaro Carreter [1974: 95] define el Buscón en estos términos. Esta glosa es extensible a la obra entremesil de Quevedo. 


\section{QUEVEDO, CRítICO TEATRAL}

\section{EL FLAGELO DE LOS DRAMATURGOS MEMOS}

Decía Cervantes en el Viaje del Parnaso que Quevedo, muy fiel a "su Marcial", es el "flagelo de poetas memos". Flagelo que no sólo debemos relacionar con la mala literatura, sino que actúa como instrumento de la "violencia en prosa y verso: pasión llameante, ataque sangriento, relatos y retratos devastadores". ${ }^{15}$ La cláusula es perfectamente aplicable a la visión grotesca del género dramático que Quevedo dispersó en su obra satírica. El poeta de cuatro ojos ${ }^{16}$ transforma alquímicamente el verbo, arrojando nueva luz sobre los tópicos, y se encierra deliberadamente "en sus propias conchas de maravillas o ataúdes y escorias de sombras". ${ }^{17}$ Por ello, ante el sinfín de poetas dramáticos que, según Quevedo, "Dios ha enviado a España por castigo de nuestros pecados", nuestro autor procederá como providencial exterminador de las plagas de langostas. ${ }^{18}$

De entrada, podría parecer que don Francisco, más que un pragmático comediógrafo, fue un mordaz censor del teatro. Nuestro autor albergó una actitud paradójica, una suerte de "doble personalidad"19 que le generó oxímoros apreciativos y dislexias literarias. Su talante satírico, desde una

\footnotetext{
${ }^{15}$ Cfr. Raimundo Lida [1958: 149].

${ }^{16}$ Así se denomina Quevedo a sí mismo en la Premática de aranceles generales. Véase la ed. de I. Arellano [2003: 43].

${ }^{17}$ Valbuena Prat [1956: 77],

${ }^{18}$ Recojo la cita de E. Reyes Dávila [1981: 49].

${ }^{19}$ Así lo señala, categórico, Ettinghausen [1982]
} 
órbita metaliteraria, le indujo a señalar con exageración y hartazgo los defectos de las piezas que cultivaban los dramaturgos auriseculares. Pero observamos, sin embargo, que su condición cortesana le forzó, en el contexto palatino, a la diplomática difusión de los tópicos vapuleados por su sarcasmo. Con todo, pudo decantarse con rigor filológico por la condena de las repetitivas inercias del poliédrico género teatral.

\section{SÁTIRAS DE LOS POETAS CHIRLES Y HEBENES}

Quevedo dispersó una Poética - o más bien, Antipoética- en diversos pasajes de su obra satírica. Analizaremos muy sucintamente las alusiones peyorativas al mundo farandulesco que aparecen en las Premáticas del Desengaño contra los poetas güeros, el Cuento de cuentos, El alguacil endemoniado, El sueño de la muerte, El sueño del infierno, El discurso de todos los diablos y La hora de todos.

En las Premáticas del Desengaño contra los poetas güeros (1605), mediante la parodia del texto legal, nuestro autor centra sus diatribas en la elocutio verbal y a través de varios ítems jocosos asesora en materia de entremeses y comedias. Los malos dramaturgos, rama bambalinesca de los malos poetas (recordemos que el teatro aurisecular acostumbraba a ser rimado), pertenecen a la raza de "poetas chirles y hebenes", vacíos y aparentes. Son "públicos y cantoneros" como las meretrices, y "despedazadores y tahúres de vocablos". El autor se burla de los tropos petrarquistas omnipresentes en la comedia lopesca, de los hortelanos de 
facciones y los metalúrgicos de bustos femeninos, hambrientos pobretones que concentran todas sus riquezas en la descriptio puellae de sus versos. Las composiciones fraudulentas son dignas de ser utilizadas como envoltorios de especerías. Ante todo, son reprehensibles los parásitos que viven y beben de las malas versificaciones, esto es, los representantes (ciegos, farsantes y sacristanes):

Pero advertiendo, con ojos de piedad, que hay tres géneros de gentes en esta república tan sumamente miserables que no pueden vivir sin los tales poetas, como son ciegos, farsantes y sacristanes, permitimos que hallan algunos oficiales desta arte conocidos, los cuales tengan carta de examen del cacique que fuere en aquellas partes, limitando a los de las comedias que no acaben en casamientos ni hagan las trazas con papeles y bandos, y a los de ciegos que no subcedan los casos en Tetúan, y que para decir "la presente obra" no digan "zozobra"; y a los de villancicos que no jueguen del vocablo ni metan más en ellos a Gil ni a Pascual, porque se quejan; ni hagan pensamientos de tornillo que, mudado el nombre, se vuelvan a todas las fiestas. [2003: I, 16].

¿Y qué sucede con los dramaturgos de baja estofa? Los farsantes, supeditados a un cacique poético, vigilarán ante todo los finales de las comedias (tendrán que encontrar una alternativa más original a la culminación en boda) y serán víctimas de horrorosas tramas argumentales que solían estar al servicio de encargos y edictos. Los ciegos reprimirán su apresurado e imperfecto recitado y el impulso de referir altercados entre 
moros y cristianos ("los casos en Tetuán"). ${ }^{20}$ Por último, los sacristanes habrán de aludir menos a Giles, Blases y Pascuales, pastorcillos omnipresentes en todo villancico, como el autor reitera en el poema 700:

\author{
Concepto de los poetas \\ vinculado a villancicos \\ que, entre Giles y Pascuales, \\ te están deshaciendo a gritos. (vv. 33-36)
}

"Ciegos, farsantes y sacristanes" habrán, pues, de medir sus actuaciones. El autor traza un crudo retrato de los malos versificadores del teatro: una rama muy particular de poetas güeros.

Quevedo, sea como fuere, siempre saca a vergüenza "todo el asco de nuestra conversación", como afirma en Cuento de cuentos (1628), entresijo paródico de expresiones y usos lingüísticos. La segunda parte del opúsculo hace desfilar un conjunto de figurones entremesiles, algunos de los cuales, como Chisgarabís o Trochimochi, reaparecen en el entremés de Los refranes del viejo celoso y en El sueño de la muerte. El final de esta "historia enredada" ${ }^{21}$ es en boda, como los recelados desenlaces de comedia. ${ }^{22}$

\footnotetext{
${ }^{20}$ Este tópico subvertido da lugar a la temática de una de las comedias burlescas atribuidas a Quevedo: la risueña paz entre ambos colectivos religiosos que tiene lugar en iQué villano es el amor!

${ }^{21}$ Alfonso Rey, ed. [2003: I, XXX].

${ }^{22}$ La privanza desleal termina con varios matrimonios consolidados $\mathrm{y}$, por lo tanto, obedece al tópico. De este desenlace hará notable burla Gorrión, el gracioso de la comedia inédita y atribuida El galán fantasma, que desde el inicio, como contrapartida de las
} 
Dentro de los tratadillos con distintos argumentos que componen los Sueños (Barcelona, 1627), también encontramos múltiples alusiones jocosas al género dramático. En El alguacil endemoniado, Quevedo expresa que los poetas condenados a peores penas son los teatrales, por la cantidad de reinas fabricadas, las infantas deshonradas, los casamientos desiguales y los palos recibidos al final de los entremeses:

Mas los que peor lo pasan y más mal lugar tienen son los poetas de comedias, por las muchas reinas que han hecho, las infantas de Bretaña que han deshonrado, los casamientos desiguales que han hecho en los fines de las comedias y los palos que han dado a muchos hombres honrados por acabar en los entremeses. Mas es de advertir que los poetas de comedias no están entre los demás, sino que, por cuanto tratan de hacer enredos y marañas, se ponen entre los procuradores y solicitadores, gente que solo trata deso. [2003: I, 257]

Don Francisco, al igual que Mateo Alemán y Cervantes, ridiculiza a los comediógrafos amparándose en tópicos satíricos que harán eco en el Pasajero de Suárez de Figueroa. Para él, la compleja trama de las comedias hace que sus autores sean equiparables a los funcionarios de justicia en sus marañas. La denuncia del enrevesamiento y la decadencia de la escena dramática barroca nos aproxima, aunque con arpón satírico, a las disquisiciones dieciochescas sobre las desmesuradas comedias del barroco tardío. $^{23}$

pasiones desaforadas de los amos, introduce toda una serie de pullas de la "posdata de soltería".

${ }^{23}$ Acerca de los juicios dieciochescos sobre la comedia áurea, véase René Andioc [1976]. 
Seguimos el hilo onírico e infernal y en El sueño de la muerte, además de la diatriba contra los disparates de Juan del Encina ${ }^{24}$ (también presente en el entremés de Los refranes del viejo celoso), la consorte de un comediógrafo llamada doña Fáfula esgrime sus quejas. Señala que todos los personajes de comedia son cobardes y hambrientos y que sus peripecias para conseguir la dote son el núcleo del enredo. Se mofa de los protocolos en la relación del rey y sus vasallos, la insistencia en el tema de la honra de las infantas y los finales en matrimonio:

Fui mujer de mucho valor y tuve con mi marido, el poeta, mil pesadumbres sobre las comedias, autos y entremeses. Decíale yo que por qué cuando en las comedias un vasallo arrodillado dice al rey «Dame esos pies», responde siempre: «Los brazos será mejor»; que la razón era, en diciendo: «dame esos pies» responder: «¿con qué andaré yo después?». Sobre la hambre de los lacayos y el miedo, tuve grandes peloteras con él, y tuve buenos respetos, que le hice mirar al fin de las comedias por la honra de las infantas, porque las llevaba de voleo y era compasión; no me pagarán esto sus padres de ellas en su vida. Fuile a la mano en los dotes de los casamientos para acabar la maraña en la tercera jornada, porque no hubiera rentas en el mundo; y en una comedia, porque no se casasen todos, le pedí que el lacayo, queriéndole casar su señor con la criada, no quisiese casarse ni hubiese remedio, siquiera porque saliere un lacayo soltero. [2003: I, 452 $]^{25}$

\footnotetext{
${ }^{24}$ Véase [2003: I, 412-413].

${ }^{25}$ Veremos más adelante cómo el gracioso de la comedia El galán fantasma, Gorrión, cumple con estas expectativas: al final de la obra se niega rotundamente a casarse.
} 
Quevedo, ventrílocuo de estos pensamientos, denuncia de los autos sacramentales el contraste entre el diablo parlanchín e hiperactivo con un Cristo prácticamente autista. No tenemos noticia, por cierto, de que este subgénero teatral fuera cultivado por nuestro autor, a pesar de su profunda adhesión a los debates teológicos:

Donde mayores voces tuvimos, que casi me quise descasar, fue sobre los autos del Corpus. Decíale yo: «Hombre del diablo, ¿es posible que siempre en los autos del Corpus ha de entrar el diablo con grande brío, hablando a voces, gritos y patadas, y con un brío que parece que todo el teatro es suyo y poco para hacer su papel, como quien dice: ¡Huela la casa al diablo!, y Cristo muy encogido, que parece que apenas echa la habla por la boca? Por vida vuestra que hagáis un auto donde el diablo no diga esta boca es mía, y pues tiene por qué callar, no hable; y que hable Cristo, pues puede y tiene razón, y enójese en un auto, que aunque es la misma paciencia, tal vez se indignó y tomó el azote y trastornó mesas y tiendas y cátedras y hizo ruido». Hícele que, pues podía decir «Padre eterno», no dijese «Padre eternal», ni «Satán», sino «Satanás», que aquellas palabras eran buenas cuando el diablo entra diciendo «bu, bu, bu» y se sale como cohete. [2003: I, 452-453]

Don Francisco, asimismo, conocía bien el objeto reiterado de los entremeses, todos ellos destinados a entretener con malicia mediante deshonras femeninas, la afrenta de maridos y el hincapié en costumbres desdeñables:

Desagravié los entremeses, que a todos les daban de palos, y con todos sus palos hacían los entremeses; cuando se dolían de ellos, «duélanse (decía yo) de las comedias, que acaban en casamientos y son peores, porque son palos y mujer». Las comedias, que oyeron esto, por vengarse, pegaron los casamientos a los entremeses, 
y ellos por escaparse y ser solteros, algunos se acaban en barbería, guitarricas y cántico. [2003: I, 453-454]

Según leemos, para doña Fáfula, la mujer de un comediógrafo, los entremeses y comedias se han intercambiado los finales. Pero las tramas de los entremeses quedan desagraviadas por el correspondiente castigo a palos, aunque a menudo se embravan con los jocosos y escapistas desenlaces musicales.

Quevedo también ofrece su subjetivo análisis de la vida nómada y libertina de las compañías teatrales. En El sueño del infierno - otrora denominado Las zahúrdas de Plutón- alude a la difícil vida de los "faranduleros miserables" de bululú, recitantes sueltos que aparecen congregados en el infierno, tan denostados en su desidia que si ellos mismos no se encaminaran hacia el averno, los diablos no irían por ellos. ${ }^{26}$

El teatro aurisecular fue un reiterado objeto de polémica. ${ }^{27}$ Por ello, en El discurso de todos los diablos (1628), el alegato del Poeta de los Pícaros, que ha llenado el mundo de disparates y locuras, de "letrillas y húes y ayes y arrorrós, cuzas y pipiritandos", nos ofrece una particular censura del género dramático.

El poeta de los holgazanes pide licencia para hablar y critica seis clases de los que irónicamente denomina poetas de los honrados: el autor de

\footnotetext{
${ }^{26}$ Véase la edición de las Obras completas en prosa de Castalia [2003: I, 294].

${ }^{27}$ Tal y como confirman las controversias que Cotarelo y Mori [1904] recoge en un extenso compendio bibliográfico donde se reproduce un múltiple abanico de juicios sobre la licitud del teatro.
} 
comedias de enredo, entremeses, autos sacramentales, romances, villancicos y poemas petrarquistas.

La escritura de comedias, para el Poeta de los Pícaros, supone gastar doce pliegos de papel con idas y venidas de personajes para casar a un lacayo sin reprensiones. Sobre los entremeses, cuyo objeto es deshonrar mujeres, afrentar maridos, tachar costumbres y entretener con malicia, señala que, además de terminar en palos, lo hacen "en barbería, guitarricos y cántico", esto es, en música, "que es peor". Componer autos sacramentales es, asimismo, "dar qué decir a Satanás, pedir el alma, llover ángeles a pura nube y dejar a Plutón sin ánima, que todas se las lleva el Buen Pastor". Y la misma crítica hace de los romances que divulgan experiencias amorosas propias y ajenas, los villancicos de Giles y Blases y los preciosistas poemas del petrarquismo, cuyas musas andan gastando "auroras en mejillas y perlas en lágrimas." 28

La Fortuna con seso, por otro lado, es la última gran obra satírica de Quevedo. El 12 de marzo de 1636 se la dedicó a don Álvaro Monsalve, canónigo de la catedral de Toledo. La escribió en La Torre de Juan Abad, con la pretensión de erigir una "fantasía moral" que contiene todas sus obsesiones entremesiles: la crítica a tipos satíricos como pretendientes, letrados, alcahuetas, dueñas o alquimistas. Todo ello, cercenado con pequeños excursos políticos sobre la actualidad en Italia, Flandes, las Indias. Retomando el tema predilecto de las comedias de Quevedo, en el cuadro de la Isla de los Monopantos, don Francisco idea una grotesca camarilla de judíos encabezados por el Conde-Duque de Olivares, el privado negligente.

\footnotetext{
${ }^{28}$ Véase [2003: II, 533-534].
} 
La hipócrita realidad se desenmascara tras la intervención de una inusitada "Fortuna con seso", que ha perdido su obrar caprichoso. Si el mundo es un gran teatro, los dramaturgos lo ponen del revés, en todo caso.

\section{El TEATRO EN El BUSCÓN}

La mejor manera de plasmar una idea es vivificándola en la conciencia de un pillastre en un Liber Vagatorum. La experiencia de un mozo cuyo conocimiento ontológico del mundo se ciñe a los vapores del hambre y el sueño, cuya máxima felicidad -Jauja- pertenece al reino de los cinco sentidos, es el vehículo idóneo para catapultar una crítica feroz.

El Buscón (publicado en 1626) es un relato satírico de carácter costumbrista que se proyecta cuando los lectores del XVII ya han paladeado El Guzmán de Alfarache $(1599,1604)$ de Mateo Alemán. El Buscón, obra que don Francisco nunca reconoció como suya, ${ }^{29}$ representa con fidelidad los estratos sociales más bajos (mendigos, desheredados, delincuentes) en escenarios urbanos que Quevedo conocía muy bien (Segovia, Alcalá, Madrid y Sevilla), aunque también asoma de manera intermitente la endogamia aristocrática.

Parte del capítulo IX del Libro III del Buscón, está dedicado al contexto de los comediógrafos, actores y saltimbanquis. La mirada del pícaro apenas

29 Aparte de los editores, el primer autor en señalar su autoría fue Tomás Tamayo de Vargas en una de las redacciones iniciales de la Junta de Libros. Cfr. Jauralde [1999: 133]. 
intercede en la realidad contemplada. Él es un espectador del "Teatro de la Comedia Humana". 30

Pablos se encuentra con un clérigo poeta que ha compuesto una comedia en dos días titulada El arca de Noé, en la que ha utilizado cinco manos de papel -esto es, unos 125 pliegos, cantidad considerable si nos atenemos al hecho de que la primera parte del Quijote tenía 83 pliegos-. En esta comedia, poco madurada y escrita con rapidez, todos los personajes son animales, como en las Fábulas de Esopo. Ha de ser representada por papagayos, tordos y picazas:

me comenzó a recitar una comedia que tenía más jornadas que el camino de Jerusalén. Decíame:

- Hícela en dos días, y este es el borrador.

Y sería hasta cinco manos de papel. El título era El arca de Noé. Hacíase toda entre gallos y ratones, jumentos, raposas, lobos y jabalíes, como fábulas de Isopo. Yo le alabé la traza y la invención, a lo cual me respondió:

- Ello cosa mía es, pero no se ha hecho otra tal en el mundo, y la novedad es más que todo; y si yo salgo con hacerla representar, será cosa famosa.

-¿Cómo se podrá representar -le dije yo-, si han de entrar los mismos animales, y ellos no hablan?

-Esta es la dificultad; que a no haber esa ¿había cosa más alta? Pero yo tengo pensado de hacerla toda de papagayos, tordos y picazas, que hablan, y meter para el entremés monas. [2005: II, 50] $]^{31}$

\footnotetext{
${ }^{30}$ Así lo ha notado Aurora Egido [1978: 178].

${ }^{31}$ Sigo la edición de Rosa Navarro Durán [2005: II, 1-129], que, como Pablo Jauralde y Edmond Cros, trascribe como codex optimus el ms. B. El mentado códice, conservado en la Fundación Lázaro Galdiano de Madrid, fue propiedad de Juan José Bueno, bibliotecario de la Universidad de Sevilla. Los otros testimonios manuscritos, $S$, de la Biblioteca
} 
De camino a Toledo, Pablos se hará representante y poeta de comedias (III, IX). En este pasaje, Quevedo hace eco de la amoralidad y libertinaje con que eran tachados los actores del Barroco español. Alude, por ejemplo, a una bailarina que hasta su propio marido trata de meretriz:

Íbamos barajados hombres y mujeres; y una entre ellas, la bailarina, que también hacía las reinas y papeles graves en la comedia, me pareció extremada sabandija. Acertó a estar su marido a mi lado, y yo, sin pensar a quien hablaba, llevado del deseo de amor y gozarla, díjele:

- A esta mujer, ¿por qué orden la podremos hablar para gastar con Su Merced unos veinte escudos, que me ha parecido bien por ser hermosa?

- No me lo está a mí el decirlo, que soy su marido -dijo el hombre- ni tratar de eso; pero sin pasión (que no me mueve ninguna), se puede gastar con ella cualquier dinero, porque tales carnes no tiene el suelo, ni tal juguetoncica. [2005: II, $117-$ $118]$.

Más adelante, Pablos representa un fragmento de la Comedia de San Alejo, que aparece en el Cancionero general de la doctrina cristiana (Alcalá, 1579) de Juan López de Úbeda ${ }^{32}$ y, tras ello, es incorporado como miembro de la compañía. Acepta su contrato como farandulista por instintos pasionales y primarios. Estos son, al fin $\mathrm{y}$ al cabo, mecanismos de supervivencia del pícaro:

Menéndez Pelayo de Santander, y $C$, ubicado en la Catedral de Córdoba, los utiliza en su edición para subsanar las lecturas erróneas. Véase Rosa Navarro [2005: II, XIV].

${ }^{32}$ Cfr. Américo Castro [1927: 255]. Véase también el Catálogo de piezas manuscritas de Paz y Melia [1899]. 
Yo, acaso, comencé a representar un pedazo de la Comedia de San Alejo, que me acordaba de cuando muchacho; y representelo de suerte que les di cudicia. Y sabiendo, por lo que yo le dije a mi amigo que iba en la compañía, mis desgracias y descomodidades, díjome si quería entrar en la danza con ellos. Encareciéronme tanto la vida de la farándula, y yo, que tenía necesidad de arrimo y me había parecido bien la moza, concerteme por dos años con el autor. Hícele escritura de estar con él, y diome mi ración y representaciones. [2005: II, 118]

Las primeras tareas como representante de Pablos consisten en recitar unas loas ${ }^{33}$, composiciones cortas y apologéticas que solían entonarse antes de la comedia y que terminaban solicitando la atención del público. Quevedo satiriza sobre su temática -todas versan sobre naves-, su lenguaje grandilocuente -en ocasiones hermético para el pueblo-, y su manía de llamar "senado" 34 al auditorio:

Diéronme que estudiar tres o cuatro loas y papeles de barba, que los acomodaba bien con mi voz. Yo puse cuidado en todo y eché la primera loa en el lugar. Era de una nave, de lo que son todas, que venía destrozada y sin provisión; decía lo de: "Este es puerto"; llamaba a la gente "senado"; pedía perdón de las faltas y silencio, y entreme. Hubo un víctor de rezado y, al fin, parecí bien en el teatro. [2005: II, 118]

Después Pablos alude a la representación de una comedia escrita por un actor de su compañía y a la anterior monopolización del género por parte de

\footnotetext{
${ }^{33}$ La loa cuenta con una monografía completa compuesta por Flecniakoska [1975].

${ }^{34}$ Paradójicamente, como ya hemos visto, así finalizará La privanza desleal y voluntad por la fama.
} 
Lope de Vega y Fray Alonso Ramón. ${ }^{35}$ En la línea de lo sostenido en la Premática del desengaño contra los poetas güeros, Quevedo arremete contra aquellos que osan escribir sin ser doctos y sabios:

Representamos una comedia de un representante nuestro. Que yo me admiré de que fuesen poetas, porque pensaba que el serlo era de hombres muy doctos y sabios, y no de gente tan sumamente lega. $\mathrm{Y}$ está ya de manera esto que no hay autor que no escriba comedias, ni representante que no haga su farsa de moros y cristianos; que me acuerdo yo antes, que si no eran comedias del buen Lope de Vega, y Ramón, no había otra cosa. [2005: II, 118-119]

Y he aquí los datos sobre el argumento de la susodicha comedia, ininteligible, pastiche indigesto, llena de efectismos desmesurados y reyes extranjeros, sin coherencia argumental:

Al fin, hízose la comedia el primer día, y no la entendió nadie. Al segundo, empezámosla, y quiso Dios que empezaba por una guerra, y salía yo armado y con rodela, que, si no, a manos de mal membrillo, tronchos y badeas, acabo. No se ha visto tal torbellino, y ello merecíalo la comedia, porque traía un rey de Normandía

${ }^{35}$ Sobre este fraile comediógrafo, apenas estudiado, apunta Américo Castro: "Fray Alonso Ramón o Remón, poeta dramático celebrado también por Cervantes y Lope, y autor además de obras de erudición religiosa; sus comedias debieron representarse muy a comienzos de siglo: El español entre todas las naciones y clérigo agradecido, Las tres mujeres en una, etc. Las obras escasas que conocemos de dicho fraile no justifican ese elogio de los más altos escritores de su tiempo. Quizá entre sus comedias perdidas, las hubiera importantes; nadie, que sepa, ha intentado estudiar a este dramaturgo. Hay que no olvidar, sin embargo, que los encomios de nuestros antiguos escritores fueran a veces muy arbitrarios." [1927: 257]. 
sin propósito, en hábito de ermitaño, y metía dos lacayos por hacer reír; y al desatar de la maraña, no había más de casarse todos, y allá vas. [2005: II, 119]

Después, el pobre poeta güero confiesa que él no ha hecho sino remendar muchos asuntos de otras comedias, un plagio colectivo mal zurcido, pero que no es en absoluto falta suya, sino que es el mecanismo común de los farsantes para contribuir a la proliferación del género:

Tratamos todos muy mal al compañero poeta, y yo principalmente, diciéndole que mirase de la que nos habíamos escapado y escarmentase. Díjome que ijurado a Dios!, que no era suyo nada de la comedia, sino que, de un paso tomado de uno y otro de otro, había hecho aquella capa de pobre, de remiendo, y que el daño no había estado sino en lo mal zurcido. Confesome que los farsantes que hacían comedias, todo les obligaba a restitución, porque se aprovechaban de cuanto habían representado, y que era muy fácil, y que el interés de sacar trecientos o cuatrocientos reales les ponía [a] aquellos riesgos. Lo otro, que, como andaban por esos lugares, les leían unos y otros comedias:

Tomámoslas para verlas, llevámonoslas y, con añadir una necedad y quitar una cosa bien dicha, decimos que es nuestra.

Y declarome cómo no había habido farsante jamás que supiese hacer una copla de otra manera. [2005: II, 119]

Tras recibir este recetario de escritor, contraespejo del lopesco Arte nuevo, Pablos decide hacerse él mismo poeta y comediógrafo. Aquí Quevedo asume el grado máximo de la sátira, dado que nos ha ido desplegando paulatinamente los recovecos del mundo farandulesco a través de un narrador testigo, el pícaro: 
me desvirgué de poeta en un romancico y luego hice un entremés, y no pareció mal. Atrevime a una comedia y, porque no se escapase de ser divina cosa, la hice de Nuestra Señora del Rosario. Comenzaba con chirimías, había sus ánimas de purgatorio y sus demonios, que se usaban entonces, con su "bu, bu", al salir, y "ri, ri” al entrar; caíale muy en gracia al lugar el nombre de Satán en las coplas y el tratar luego de si cayó el cielo y tal. En fin, mi comedia se hizo, y pareció muy bien. [2005: II, 120]

En el Buscón se menciona el bullicio y alegría de las compañías teatrales itinerantes, su promiscuidad incipiente, la multiplicidad de papeles -donde la bailarina también representa a las reinas de las comedias- y el sino aciago de un oficio precario: los actores, efectivamente, solían terminar endeudados y encarcelados. Quizás esta compañía tenga como modelo real la de Baltasar Pinedo, que aparece nombrado en la novela, recitante célebre que representó algunas comedias de Lope y que trabajó en Toledo, como Pablos, por lo menos en 1604 y $1613 .{ }^{36}$

Quevedo denuncia en su obra satírica los tópicos y entumecimientos del género teatral. La experiencia de Pablos sigue los pasos que su modelo, el falso Guzmán de Mateo Luján de Sayavedra, que en el capítulo VII del libro tercero, profesa el arte cómico por estar prendado de una farsanta. ${ }^{37}$ Más tarde, Cervantes imitaría la parodia quevedesca del género teatral en su Coloquio de los perros, donde Berganza le explica a Cipión sus desventuras con una compañía de teatro.

\footnotetext{
${ }^{36}$ Cfr. Armando Cotarelo Valledor [1945: 49].

${ }^{37}$ Véase la Segunda parte de la vida del pícaro Guzmán de Alfarache, de Mateo Luján de Sayavedra [1980].
} 
Tras la sarcástica crítica literaria, el lector entrevé la férrea voluntad de agotar registros obsoletos, composiciones opacas, tiradas de versos $\sin$ vibración. Con incipiente modernidad, se involucra en la búsqueda de un nuevo sendero literario, mediante la crítica de contraejemplos vituperables. 


\section{UN FILÓLOGO DEL TEATRO}

\section{LA FORMACIÓN DE UN HUMANISTA}

Pero don Francisco no sólo satirizó contra los vicios teatrales de su tiempo. También cultivó una crítica literaria constructiva, amparada en sus esquemas, resúmenes, repertorios de citas y traducciones de ejemplares y tratados de teatro clásico a los que pudo acceder durante su vida.

Durante el Siglo de Oro afloraron dos teorías en pugna respecto a la dirección que debía asumir el teatro. La primera proponía una forma nacional profundamente tradicionalista: era la propuesta de Lope de Vega en su comedia nueva. ${ }^{38}$ La segunda era partidaria de la imitación antigua: González Salas la defendía en una exégesis de la Poética de Aristóteles titulada Nueva idea de la tragedia antigua. ${ }^{39}$ Quevedo mantuvo una posición ecléctica ante ellas: bebió de ambas y las reconcilió en su escritura.

Quevedo, como Cervantes, Góngora o los Argensola, fue más literato que cómico. Perteneció al gremio de escritores que cultivaron el teatro sin tener notable éxito de representación, más partidarios de una obra dramática verbal, para ser leída. Quevedo quería, tal vez, un teatro intelectual que recogiera el legado de los clásicos, sin apenas acotaciones e indicaciones semióticas. Recitaba de memoria Las Troyanas de Séneca, pero aparentemente nunca cultivó la tragedia. A pesar de que González Salas, en

\footnotetext{
${ }^{38}$ Por ella abogaba Josef Pellicer de Salas Tovar en su Idea de la comedia de Castilla.

${ }^{39}$ Véase la edición de Luis Sánchez Laílla. Cfr. González de Salas [2003].
} 
la musa Melpómene del Parnaso Español, aludiera a su traducción conjunta de tragedias grecolatinas. ${ }^{40}$

Recordemos, al respecto, su postura como traductor. En las graves páginas del prólogo a su traducción de la Introducción a la vida devota, la obra más famosa del obispo de Ginebra Francisco de Sales (1567-1622), Quevedo exponía que todo traductor ha de tratar al texto original como se limpia el oro: sin afectación, con desvelo religioso. Y así, seguramente, habría traducido las tragedias grecolatinas, esas versiones que lamentablemente no se han conservado o no hemos logrado ubicar. Así lo comenta González Salas en el siguiente pasaje:

Verdad es que a la tragedia grande y perfecta, que desvelo fue, y el argumento principal de Aristóteles en su Poética, acometió algunas veces; pero divertido con la intermisión de accidentes, que le sobrevinieron en varias ocasiones, se malograron aquellos impulsos. Por muchos años conferimos los dos en la valiente empresa de traer a nuestro lenguaje alguna de las tragedias superiores de griegos o latinos, para contemplar, decíamos, aquella acción valerosa del ingenio humano, y que admiración había sido en las mejores edades de las mismas dos naciones doctísimas, que imagen figurase vestida del decoro, elegancia y cultura de nuestras palabras. A mí me empeñaba en ese asunto, cuando a su ejecución mis porfías se instaban, y ambos emprendimos no una vez sola, desfalleciendo en la dificultad de la perseverancia. [ed. Blecua, 1999: 112]

El mismo alega en sus Ilustraciones al "Parnaso" que don Francisco tuvo una gran facultad poética, más por su naturaleza que por su cultura. Y

\footnotetext{
${ }^{40}$ Véase la edición de Blecua, que incluye los Preliminares al Parnaso de González de Salas [1999: I, 113].
} 
que no conocía a ningún otro poeta vivo más versado de hebreos, grecolatinos, italianos y franceses. $^{41}$ ¿Qué dramaturgos leyó en estas lenguas? Tradujo, al parecer, varias tragedias de Séneca y disponemos de unas valiosísimas anotaciones a la obra de Plauto adjuntas a la versión autógrafa de su España defendida. Tampoco fue ajeno al comento y la cita de Terencio, como reproduce la edición de Astrana Marín [1945: 1577b]. Y, como analizaremos más adelante, hace notables comentarios a la Poética de Aristóteles, muchos de ellos relacionados con la materia teatral.

Quevedo se consagró a las tareas del humanista cristiano. Tradujo e interpretó a autores clásicos que contenían en su doctrina la simiente de los evangelios. Eligió particularmente las obras que contaban con una versión latina, ya que el latín era la lingua franca de los estudiosos de la cultura clásica. $^{42}$ Todo apunta a que sus conocimientos del griego eran menos profundos. ${ }^{43}$ Sus traducciones no se decantan por la literalidad, sino por el resultado final en lengua castellana. Sus primeros juegos filológicos son con poemas de Estacio, Teócrito, Anacreonte y Píndaro; prosigue con composiciones más conocidas de Juvenal, Marcial, Catulo, Persio, Horacio

${ }^{41}$ Jauralde [1999: 878-879] hace una revisión del conocimiento real de las lenguas que leía y escribía Quevedo.

${ }^{42}$ Cfr. Sagrario López Poza, "La cultura de Quevedo: cala y cata", en ed. de Santiago Fernández Mosquera, Estudios sobre Quevedo. Quevedo desde Santiago entre dos aniversarios. [1995: 75].

${ }^{43}$ La decadencia del estudio del griego durante el siglo XVII fue bastante general en España, así como en Italia, más que en otros países. Véase Lía Schwartz, De Fray Luis a Quevedo. Lecturas de los clásicos antiguos. [2005: 141] 
y Virgilio. Hacia 1607, versiona en castellano obras de Focílides ${ }^{44}$ y Anacreonte, autores griegos de los que no aún había traducciones. También trabaja los salmos de Jeremías -Lágrimas de Hieremías castellanas- , de notable impronta en su Heráclito cristiano (1613). ${ }^{45}$

Pero, ¿qué opinión le mereció a Quevedo el teatro clásico? ¿Con qué evidencias manuscritas contamos?

\section{LA BIBLIOTECA DE QUEVEDO}

Han sido varios los intentos de reconstruir la biblioteca de Quevedo. Contamos, sobre todo, con las aportaciones de Maldonado [1975]. También sabemos que actualmente Isabel Pérez Cuenca anda enfrascada con una catalogación de libros de su propiedad. Hemos intentado hacer acopio de aquellos ejemplares que poseen anotaciones autógrafas del autor. Y también de aquellas notas sueltas con datos relevantes sobre sus lecturas teatrales.

Lector infatigable, como señala Tarsia en su Biografía, Quevedo llevaba consigo un museo portátil con más de cien tomos de letra pequeña que cabían en sus alforjas. Disponía de algunos artilugios para leer con comodidad:

${ }^{44}$ El pseudo Focílides circula al principio manuscrito. Hasta 1635 no se imprime junto con las versiones de Epicteto. Todo parece indicar que manejó una edición latina, la de Vitius Amerbachus (1547): Poemata Pythagorae, et Phocylides: cum duplici interpretacione Viti Amerbachij. Cfr. Jauralde [1999: 182].

${ }^{45}$ En su versión de los Trenos saca a coalición sus conocimientos rudimentarios de lengua hebrea. 
Tenía un estante con dos tornos, a modo de atril, y en cada uno cabían cuatro libros, que ponía abiertos, y sin más dificultad que menear el torno, se acercaba el libro que quería, alimentando a un tiempo el entendimiento y el cuerpo.

Y en las noches de insomnio:

tenía una mesa larga, que cogía el ancho de la cama, con cuatro ruedas en los pies, para llegarla con facilidad, despertando la noche para estudiar, y en ella muchos libros prevenidos, y pedernal, y yesca para encender la luz. ${ }^{46}$

Don Francisco se sumerge en un torbellino de lecturas. No sólo poseía una regular biblioteca. En el capítulo IV de su España defendida cita algunas "librerías de España" a las que tuvo acceso, entre las que destaca la de Diego Sarmiento de Acuña. Como buen erudito, también debió de nutrirse de la biblioteca del Condestable de Castilla, con el que coincidió en Valladolid, y de la del Conde de Gondomar. ${ }^{47}$

Quevedo no se resiste al consuelo neoestoico. Conoce bien el Enchiridion de Epicteto, La Tabla de Cebes, Séneca, Teofrasto y Plutarco. Estos autores, aunque sea en su vertiente doctrinal, influyen en su teatro.

En la España defendida (1609) Quevedo alude a un tratado que hoy día es ilocalizable, tal vez por inconcluso: De la común razón de las letras y las lenguas, donde daría razón de sus disquisiciones lingüísticas. Esta obra filológico-política se plantea como un entramado enciclopédico en el que escasean, con todo, las alusiones al género dramático.

\footnotetext{
${ }^{46}$ Cfr. Tarsia [1729:12].

${ }^{47}$ Véase Jauralde [1999:217 ] y Lía Schwartz [2005: 121].
} 
Razonan conmigo los libros, cuyas palabras oigo con los ojos. Así se expresa Quevedo en una bella epístola que escribe desde la soledad y en espera de la muerte cuando es prisionero en San Marcos hacia 1641. Por algo, ya en el siglo XX, Claudio Guillén lo llamó el último y más grande de los humanistas y, José Bergamín, el único humanista enteramente humano. ${ }^{48}$ Esta condición no debe desligarse de su concepción del teatro.

\section{LOS MODELOS CLÁSICOS}

La literatura grecolatina fue un asunto central del humanismo y la filología renacentista, que recuperó el legado de los clásicos a partir de estudios y ediciones como las de Henri Etienne (1531-1598), Joseph Scaliger (1530-1609), Isaac Casaubon (1559-1614) y Justo Lipsio (15471606), que actuaron como intermediarios de su recepción y transmisión. ${ }^{49}$ Quevedo conoció los trabajos y publicaciones de todos ellos: en los Sueños, condena al infierno a Joseph Scaliger y a Henri Etienne. Por otra parte, es bien conocida su relación amistosa con Justo Lipsio, que le orientó considerablemente en su labor filológica.

Cuando hablábamos del teatro jesuítico, mencionábamos que los principales modelos clásicos, por su dimensión moral asimilable al cristianismo más genuino, eran las tragedias de Séneca, las comedias de Plauto y, con mayor reticencia, las de Terencio. Estos autores influyeron notablemente en el teatro aurisecular. Pese a que Lope, en su Arte Nuevo,

\footnotetext{
${ }^{48}$ Cfr. Mario Campaña [2003: 11].

${ }^{49}$ Véase Lía Schwartz [2005: 120].
} 
desdeñara el influjo de Terencio y Plauto (vv. 40-43), fue notablemente condicionado por el patrón de estos modelos canónicos. Recuérdese, a modo de anécdota, que en la Universidad de Salamanca, a partir del año 1574, fue prohibida la escenificación de otras comedias latinas a excepción de las de Plauto y Terencio. No es asombroso, entonces, que las principales anotaciones autógrafas de Quevedo en materia teatral que se han encontrado hasta ahora se correspondan con estos referentes.

\subsection{LAS TRAGEDIAS DE SÉNECA}

El Séneca trágico fue un autor muy conocido por los primeros humanistas: Dante, Petrarca o Nicolás Trevet comentaron su teatro con detenimiento, y eruditos del cinquecento lo adularon por encima de los tragediógrafos griegos. Esta hegemonía se debió a la base doctrinal de sus tragedias: los pensamientos filosóficos estoicos estaban muy hermanados con el pensamiento cristiano. ${ }^{50}$ Por esta razón, Quevedo simplemente le adoraba: le llamaba "mi Séneca". Conocía, seguramente, la traducción castellana completa de sus tragedias en el siglo XV, quizá consumada por el Marqués de Santillana, además de las traducciones de fragmentos de Fedra y Tiestes realizadas por Hernando de Herrera y Fray Luis de León, así como la edición y comentarios de Justo Lipsio. ${ }^{51}$

\footnotetext{
${ }^{50}$ Cfr. Jesús Luque Moreno, “Introducción” a las Tragedias de Séneca [1997:68-71].

${ }^{51}$ Véase Lida de Malkiel, La tradición clásica en España [1975: 376].
} 
El teatro de Séneca era uno de los tesoros más preciados de la biblioteca de don Francisco. Fernández Guerra cita en nota ${ }^{52}$ que una obra con las Tragedias de Séneca, códice del siglo XIV, está dedicada a Quevedo entre 1613 y 1615. Esta fecha coincide con su estancia en Sicilia: fue un regalo de Antonio Amico, un historiador panormitano al que conoció en Italia. Hoy se guarda en la biblioteca de El Escorial.

González de Salas, en su comento a la musa Melpómene del Parnaso (1648) reflexiona sobre la tragedia, remitiendo a la poética aristotélica, y saca a colación lecturas dramáticas del teatro clásico que compartía con don Francisco, especialmente las de Séneca:

Yo, empero, últimamente, después de haber dado principio a la Medea y al Hypólito de nuestro Lucio Séneca, y no haberlas proseguido, elegí por más perfecta y regular las Troyanas del propio divino filósofo, y en la continuación de una destemplanza mía melancólica fue pasto a la funebridad de aquel humor hasta llegarla al fin. El juicio que hizo de ella nuestro Francisco, sábenlo los que se la oyeron repetir de memoria casi entera, y el lugar que ha alcanzado en la estimación de los extranjeros (...) [ed. Blecua, 1999: 113]

La gran mayoría de alusiones a la relación de Quevedo con las Tragedias del estoico, de hecho, vienen de boca de González de Salas, que escribió prolijamente sobre ellas en la Nueva idea de la tragedia antigua.

El influjo trágico de Séneca en don Francisco es considerable. El soneto 452 del Canta sola a Lisi, por ejemplo, imita un verso del Hercules Oetaeus. A su vez, recientemente, Crosby ha publicado una carta inédita de

\footnotetext{
${ }^{52} B A E$, I, XLIX; y en $S B A, 86$ y nota.
} 
Quevedo, escrita el 30 de octubre de 1642, que cita un pasaje de las Troyanas:

Dice mi Séneca, "Nemo miser, nisi comparatus"] Troades, v. 1023: "Est misere nemo nisi comparatus" (tragedia de Séneca, también titulada a veces Hecuba o Hecate); "Nadie es desafortunado salvo comparado con otros". [2005: 248]

Séneca escribió sus Tragedias como obras pedagógicas ad usum delphini, concebidas como manuales para adoctrinar filosófica y políticamente a Nerón. ¿Acaso Quevedo no albergó la misma intención para con Felipe IV en la escritura de Cómo ha de ser el privado? Debieron de impresionarle las peligrosas relaciones del teatro de Séneca con la política, así como los pilares estoicos de la concepción del hombre, la vida y la muerte que fundamentan el mensaje de estas obras, donde se reflexiona sobre el capricho de la Fortuna y la atrocidad de las pasiones que desvían al ser humano de la rectitud moral. Estas Tragedias tenían el valor didáctico de unos exempla y, al igual que las comedias de privanza de Quevedo, pretendían la exposición programática de una doctrina filosófica. Estas obras de Séneca fueron, al igual que el teatro grave de nuestro autor, piezas fundamentadas en una compleja arquitectura de procedimientos retóricos, encaminados a dar forma a unas ideas y sentimientos sobre la tiranía y la lucha interna del hombre tentado por los vicios. Composiciones con un gran sentido ético, no tan empeñadas en la dimensión escénica o la catarsis aristotélica, sino en una especie de shock moral.

Don Francisco vio en Séneca una fuerza dramática que residía en el lenguaje. El estoico había cultivado un teatro antiteatral, que nuestro autor 
recitaba de memoria y admiraba como poesía viva de alta doctrina. Le fascinó la expresión brillante, la sobrecarga de imágenes, antítesis y efectismos, la profusión de citas eruditas y mitológicas, el peso del discurso retórico de la persuasión en el ejercicio dramático y la sentencia, utilizada como broche de oro, de uno de sus filósofos más adorados.

\subsection{Las Comedias de Plauto}

Las comedias de Plauto, que durante la Edad Media habían sido despreciadas por su supuesto contenido inmoral, empezaron a ser leídas y valoradas entre los precursores del Renacimiento. Dante sitúa al comediógrafo latino en el primer círculo de su Comedia, y Petrarca conocía las ocho comedias que durante su época circulaban de este autor. En 1492, Nicolás de Cusa lleva a Roma un manuscrito que contiene 16 comedias plautinas, una docena de las cuales había permanecido en el olvido durante varios siglos. Este descubrimiento, junto con la invención de la imprenta, facilita la difusión de la obra de este autor, hecho que acrecenta el interés de los humanistas. Ludovico Ariosto, que Quevedo leyó con devoción, escribió La cassaria (1508) inspirada en Plauto.

En España, durante el siglo XVI, Plauto era estudiado en las universidades y sus obras se representaban en días festivos. Su primera traducción es el Amphytrion del doctor Francisco L. de Villalobos, que contó con numerosas impresiones: Alcalá, 1517; Zamora, 1543; Zaragoza, 1547; Sevilla, 1550, 1554, 1574. Le siguió el Anfitrión de Hernán Pérez de 
Oliva (Sevilla, 1525), El milite glorioso y Los menechmos de traductor anónimo (Amberes, 1555), Amphtrión y Los Menemnos de Juan Timoneda. Su influjo en la literatura aurisecular es notable: la Celestina; la Asinaria y Mostellaria de Torres Naharro; o Los engañados de Lope de Rueda. Ya en el XVII, lo tuvieron de inspiración y faro algunos autores como Juan Timoneda, Matías de los Reyes, Juan Ruiz de Alarcón, Agustín Moreto, Calderón o María de Zayas. ${ }^{53}$

Pero, ¿cuál es la relación entre el teatro de Quevedo y la obra de Plauto? En la Real Academia de la Historia, el ms. 9-805, contiene unas anotaciones autógrafas de nuestro autor acerca de las comedias plautinas, que siguen al autógrafo de su España defendida. ${ }^{54}$ He aquí nuestra trascripción paleográfica:

[f. 143r] En las comedias de Plauto, Preço ${ }^{55}$ era el que pedía el silençio; Grex. los que a fin de la comedia dezían al auditorio lo que del fin de la fábula no se representaba. Llamábase Grex. porque uno de todos los que hablaban en la ultima scena dezía lo que faltava para el fin de la fábula.

Prólogo. Era el que dezía antes de empezar la comedia el argumento, i mandaba al Preço pedir silençio. En el Milite glorioso, sólo está el prólogo dentro de la comedia.

Grex. en los Captibos dize que aquella comedia toda perteneze a las buenas costumbres, i exemplo sin personaxe torpe, ni acçión desonesta, i que destas comedias pocas hallan los poetas. Es mui considerable este remate de los Captibos. El Grex. de la Asinaria disculpa al viexo.

53 Véase la "Introducción” de José Román Bravo a las Comedias de Plauto [1993:I, 84-86].

${ }^{54}$ Publicado por Astrana Marín, en Obras completas. Prosa. [1945: 1566]

55 Astrana Marín lee "Praeco". 
El Grex. en la Cistelaria se llama Caterva i dize que no esperen a que salgan los que entraron que no an de salir i adentro [143v] se averiguarán, i cada uno tendrá lo que mereçiere.

El Grex . en el Epidico es de dos bersos. Dize solo este es el viexo que hallo su libertad en su maliçia.

El Grex. en las Bachides da la causa de que los viexos canos fuesen lascivos i es moral.

Colíxese que en todas las comedias que abía algo que advertir en el fin o en el intento del actor, y en la intención del poeta, en la fábula o moralidad, açerca de las personas acababa el Grex., que en una comedia llamo caterba la representaçión.

Las anotaciones citadas aluden a aspectos estructurales y al contenido moral de las comedias plautinas.

Don Francisco detiene su atención en el objetivo del prólogo: hacer una exposición de lo que se da por acaecido y de lo que sucederá en la escena. En efecto, es una particularidad de la comedia nueva latina, que tiene como precedente el drama euridipiano. En las anotaciones a la Retórica aristotélica, Quevedo define el prohemio como la "prelocución con que se declara la imagen de la futura disputación” [1547:359], análogo al prefacio de las fábulas y del verso heroico y semejante al prólogo del sermón y de la obra heroica. El prólogo es, además, una guía para el espectador, que gracias a él puede ponerse a tono y prepararse para vivenciar la obra. Quevedo nota que todos los prólogos plautinos encabezan las piezas, a excepción del que se incluye en el Miles Gloriosus. En este caso, se olvida de nombrar la Cistellaria, cuyo prólogo también se intercala después del primer acto. 
Quevedo, por otra parte, incide en el papel del grex, es decir, de la compañía, al final de las obras dramáticas de Plauto. Esta intervención justificaba la intencionalidad moral del autor en la representación.

Nuestro autor, más adelante, toma apuntes en latín sobre pasajes de la obra plautina, que ante todo le han llamado la atención por su sugestión lingüística.

Plautus in "Penulo": qui huc venisti nos captatum Micdilips bisulca lingua quasi proserpens bestia. Micdilips soboccius quali mixtur lips, ad cartaginenses aludens, quos bilingues etiam vocat Virgilius primo Aeneidos: quippe domum timet ambiguam tyriosque Bilingues, lingua enim Africa et tyria utebantur.

Algunas frases latinas de Plauto, que literalmente se usan en el mismo sentido en castellano.

Menaechmi, I, scena II, 43: Hunc comburamus diem. Dies quidem jam ad umbilicum est dimidiatus mortuus. Tercer acto, scena II, 6: Non, hercle, is sum, qui sum. Así en español: "No seré yo quien soy".

Mostellaria, II acto, scena II, 44: Capitalis caedis jacta'st; por infesta. Defodit insepultum. Defodere non est sepelire; sepultus dicitur qui solemnibus inferis defoditur. Guttam haut habeo sanguinis. Lo mismo en español: "No me quedó gota de sangre".

Menaechmi, acto III, scena I, 16: cum corona exit foras, sublatum est convivium. "Esta era la señal."

Mostellaria, acto II, scena II, 3: Pradium mihi uxor perbonum dedis Nunc dormilum me jubet ire minume.Non bonus somnus est de prandio: spage. [...]

Trinumno, acto II, scena II: Polpudere, quam pigere praestat, totidem literis dícese en español: "Más vale vergüenza en cara que mancilla en corazón." Deum virtute habemus. Scena III: Salillum animae: qui quum extemplo amisimus. Aeque mendicus, atque ille opulentissimus. Censetur censu ad Acherontem mortuus. 
"Decimos que el alma sirve de sal solamente al inútil, que sólo le conserva el cuerpo."

De estas anotaciones se infiere que Quevedo había leído a fondo las comedias plautinas. ¿Cómo pudieron sugestionarle? Don Francisco sabía que el mérito esencial de Plauto, ya a juicio de sus primeros comentaristas (como Varrón), radica en el lenguaje. Si Terencio se luce en los caracteres, Plauto se lleva la palma en su dominio del sermo vulgaris, el parlamento plebeyo de sus personajes.

Nuestro autor pudo apreciar en Plauto que la comedia no es sólo diverbia, una serie de diálogos o monólogos versificados. La comedia es también cantica, una composición con fragmentos líricos. Quevedo sigue el patrón de Plauto en su habilidad para crear en su teatro una lengua poética con gran variedad de metros, voluntariamente popular y urbana en su teatro breve, que no desvirtúa la vis comica original.

Los elementos enfáticos del discurso dramático, como las aliteraciones, los juegos de palabras o el uso de proverbios y asonancias, son ingredientes que tanto Plauto como Quevedo en su teatro burlesco utilizaron para condimentar la expresividad verbal. Astracanada, ingénita fogosidad, exabruptos escénicos, verbo plebeyo... estos dos autores tenían mucho en común. 


\subsection{Notas al EUNUCo, de TERENCIO}

Terencio impregna el humanismo: entusiasmaba a Petrarca, Justo Lipsio, Casaubón, Erasmo (que lo editó en Basilea, en 1532), Vives y Melanchtón. En el siglo XVI se había publicado una antología de frases suyas titulada Vulgaria Terenti, que influyó notablemente en todas las literaturas europeas.

En España, el Marqués de Santillana le debe su Comedieta de Ponza y lo señala como una de sus fuentes en el prólogo de los Proverbios de gloriosa e fructuosa enseñanza. También Torres Naharro se ve muy imbuido por el autor: sobre todo en el Eunuco. Y qué decir de La Celestina, que recoge muchos nombres terencianos (Pármeno, Sosia, Crito, Traso, Cremes, etc.) y tipología de personajes. ${ }^{56}$ Quevedo era conocedor del modelo terenciano de estas obras citadas.

Terencio influyó en muchos autores coetáneos a nuestro autor. A pesar de sus teóricas reticencias expresadas en el Arte Nuevo, Lope escribirá con el referente de La Andriana y el Heautontimorumenos sus comedias tituladas La guardia cuidadosa y La isla bárbara. Cervantes presentará analogías a las obras de Terencio en su La fuerza de la sangre y La ilustre fregona, que inspiran algunos de sus personajes en la Hecyra y La Andriana, respectivamente. Pero, ante todo, será Alarcón con La verdad sospechosa el mayor émulo de Terencio: compartirá con él la urbanidad ática y la intención moral.

${ }^{56}$ Cfr. Webber, E. J. "The literary reputation of Terence and Plautus in medieval and PreRenaissance Spain”, Hispanic Review 24 (1956): 191-202. 
Abundan las ediciones españolas de Terencio de los siglos XVI y XVII. ${ }^{57}$ En cambio, sólo contamos con una traducción, la del humanista Pedro Simón Abril, que don Francisco conocía muy bien. Para él, este traductor “más que Abril es Diciembre". ${ }^{58}$ Su crítica será discordante dentro de la nutrida nómina de alabanzas a la misma traducción, entre las que se cifrarán, más adelante, la de Mayans (1762).

Se ha conservado, por otra parte, una nota escueta de Quevedo escrita en latín a una expresión lingüística que aparece en comedia de Terencio, el Eunисо ${ }^{59}$ La citamos a continuación:

${ }^{57}$ Así lo constata Lisardo Rubio [1991: LXXIV-LXXV]: "Las ediciones españolas de Terencio forman un grupo considerable. Ya en el siglo XV aparece la primera en Barcelona en 1498: Terentius cum duobus comentis. Los dos comentarios son el de Donato y el de Johannes Calphurnius. Este incunable es estremadamente raro, como lo es igualmente otro impreso del mismo año en Tarragona (impr. Rosembach): Super Terentii comoediis. Del siglo XVI hemos localizado las comedias siguientes: 1524, edición de Zaragoza; 1552, edición de Medina del Campo; 1569, edición de Valencia; 1573, edición de Salamanca; 1577, ediciones de Zaragoza y Barcelona; 1579, edición de Salamanca; 1583, edición de Alcalá; 1585 y 1599, ediciones de Barcelona. Siglo XVII: 1602, edición de Huesca; 1617 y 1621, ediciones de Barcelona; 1628, edición de Zaragoza; 1635, 1644, 1662, ediciones de Lugo."

${ }^{58}$ Apareció en Zaragoza (1577), titulada Las seis comedias de Terencio escritas en latín y traduzidas en vulgar castellano por Pedro Simón Abril. Tuvo dos ediciones más en Alcalá (1583) y Barcelona (1599).

${ }^{59}$ El eunисo, que se representó con toda seguridad hacia el año 161 dC., es la comedia más exitosa de Terencio. Toma por base la comedia homónima de Menandro, tal y como el autor especifica en el prólogo. 
Terentii, Eunuchus, acto III, scena V, 601.

Ego limis specto.

Deest oculis, nam limis est transversus: unde limem dicitur quoque, quod ingredientibus, exeuntibusque transversum est. Cum autem dissimulant homines se videre quod vident, et non recta facie, sed transversa intuentur, limes dicuntur aspicere. Cum vero limi dicantur obligui generaliter; hoc tamen proprie de oculis dicitur. $^{60}$

El pasaje, como apreciamos, es una glosa de la expresión "ego limis specto", esto es, "miro de reojo": una mirada que se esconde. Como en el caso de las citas latinas de Plauto, Quevedo se centra, ante todo, en el comento de aspectos lingüísticos de las comedias.

Por lo demás, El Eunuco, que había sido una de las obras predilectas entre Cicerón, Horacio y Quintiliano, los grandes literatos latinos, fue una lectura que Quevedo tenía muy asentada. Persio y San Agustín la citan con frecuencia.

¿Qué pudo notar don Francisco en las comedias terencianas? La originalidad de Terencio residía, ante todo, en la exactitud del dibujo de los caracteres más que en la intriga mejor o peor argumentada. Su preocupación radicaba, ante todo, en el arte de composición de sus comedias, que no utilizaban el prólogo como Plauto. Buscaba la verosimilitud y la naturalidad. Heredó los modelos de la comedia griega antigua: los tipos tradicionales y lugares comunes, pero les infundió un alma nueva. Al

${ }^{60}$ Cfr. Astrana Marín, Obras completas en prosa. 1945: 1577b. En la trascripción hay un pequeño error que hemos subsanado. La escena es la V, no la IV. 
contrario que Plauto, fue comedido en la vis comica, y ello pudo hacerle pasar desapercibido ante un auditorio vulgar. Pero su cortesía verbal, modélica del sermo urbanus, donde predomina el diálogo sobre la música, le convirtió en el paradigma de la literatura refinada y regular. Evitaba el chiste grosero y los neologismos grotescos: sólo admitía la risa delicada.

\subsection{ANOtACIONES a LA RetóRICA DE ARISTÓteles}

La "poética especulativa" de Aristóteles tuvo su aplicación pragmática en la comedia nueva del siglo XVII. Así se transfiguró en una "poética experimental". Lope de Vega, en su Arte nuevo (1609), resume lo que para el sabio peripatético fue el principio de la comedia (vv. 77-82). Aristóteles, según el Fénix, es un autor que deben conocer los ingenios antes de componer sus obras dramáticas (v. 141-143). Le citará como filón de la necesaria unidad de tiempo (vv. 188-195) y, tras ello, lo mentará en un paréntesis acerca de la inclusión del baile en los entreactos de comedia (v. $225) .^{61}$

${ }^{61}$ Cfr. Jesús G. Maestro [2003], http//:www.cervantesvirtual.com: "la comedia nueva puede entenderse como el resultado de una concepción poética en la que los paradigmas fundamentales del aristotelismo, es decir, del pensamiento antiguo, que en el terreno de la estética y de la poética sistematiza el neoclasicismo del Renacimiento italiano, siguen plenamente vigentes en la uniformidad de sus presupuestos más fundamentales: fábula, sujeto y decoro, es decir, el dominio de lo monológico en todo acto de construcción, percepción e interpretación de acciones, personajes o formas de discurso lingüístico." 
Quevedo, como Lope y Cervantes, fue un ávido lector de la "poética especulativa" aristotélica. Nos ha llegado un ejemplar de la Retórica, en la traducción latina de Hermolao Barbaro, impreso en Lyon en 1547 y profusamente anotado por él. Con toda probabilidad, reencuadernó el volumen e intercaló hojas en blanco para disponer de espacio para sus notas. $^{62}$

Este ejemplar, publicado facsimilarmente y estudiado por Luisa López Grigera [1996; 1998], contiene interesantes observaciones sobre el teatro clásico. Vislumbramos otra arista más del poliédrico pensamiento quevedesco: el pacto con el canon literario en la forja de su obra creativa. ${ }^{63}$

Las notas quevedescas a la Retórica están homogéneamente distribuidas a lo largo de los tres libros, sin centrarse, en contra de lo que podría pensarse, en la elocución. ${ }^{64}$ Abundan en alusiones a las conductas humanas (elementos paraverbales del teatro), pautas de composición dramática,

\footnotetext{
${ }^{62}$ Se trata del ejemplar 1.089 de la Biblioteca de Menéndez Pelayo, un impreso que, tal y como indica la anotación manuscrita de la primera página, "fue de uso de D. Fran ${ }^{\mathrm{co}}$ de Quevedo y tiene varias notas originales de su puño". Don Francisco leyó una traducción latina de la Retórica porque su dominio del latín era mayor que el del griego (así lo demuestran sus epístolas a Justo Lipsio).

${ }^{63}$ Véase Luisa López Grijera [1996: 132]: “[La obra de Quevedo] no parece haber surgido de una genialidad espontánea en la que se expresan vivencias personales, sino de una composición rigurosa, trabajada con preceptiva clásica, combinada en muchos aspectos - a veces atendida, a veces rechazada- para lograr nuevos géneros y nuevos estilos."

${ }^{64}$ Esta práctica de buscar referencias compositivas en un tratado de retórica, recibe el nombre de letteraturizzazione, ya patente en tiempos de Herodóto y Tucídides, como señala George Kennedy [1963].
} 
reflexiones sobre lo trágico y lo cómico y su ejemplificación mediante la cita de caracteres y modos de hacer de los clásicos dramaturgos griegos.

Dentro del libro primero, Aristóteles estudia las causas de las acciones humanas y su poder catártico sobre las tablas. En poesía, como en teatro, ante la duda, "se ha de seguir lo honesto, y no lo útil" como "en el Aquiles de Homero, que por Patroclo, por serle honesto el morir, aunque le era más útil el vivir, se ofreció al peligro" [1547: 35]. ${ }^{65}$ Quevedo circunscribe su obra dramática al showing o muestreo de ejemplos de conducta en detrimento de la acción.

La "admirable filosofía y mente" de Homero dice que "las cosas que no tienen precio ni premio son despreciadas del bien y del mal por serviles" [1547:157]. He aquí un motivo flagrante de por qué el mecanismo del castigo y la recompensa, el panegírico y el vituperio, actúan en la obra dramática de nuestro autor como evidencias morales, a pesar de que Quevedo, en su natural pesimismo, no fuera partícipe de la rectificación del error humano, causa que justifica el ácido condimento de la burla en sus entremeses.

Frente a la oscuridad culterana -combatida en la Culta Latiniparla, en los preliminares a las poesías de Fray Luis de León y de Francisco de Torre y en sus sátiras contra Góngora-, Quevedo subraya en sus notas que la verdad reside en lo claro y lo simple, "porque Píndaro empezó diciendo que verdad buena es el agua siendo cosa tan común.” [1547: 68]

${ }^{65}$ Cito directamente del ms. 1089 de la Biblioteca Menéndez Pelayo de Santander. He modernizado la ortografía de los comentarios autógrafos de Quevedo. Conservo la fecha de publicación del ejemplar impreso, a pesar de que las anotaciones serían obviamente posteriores. 
La hipocresía, en cambio, tiene los tornasolados disfraces del carnaval. En anotaciones posteriores, el autor hará incursión en uno de los ingredientes básicos para el éxito teatral, concluyente en el Arte nuеvo de Lope: no olvidar nunca que el proceso comunicativo requiere de emisor y receptor, y que uno debe estar a la altura del código lingüístico del espectador, empatizar con sus intereses estéticos. Queda así expresado:

Nada importa al orador tanto como que su oración tenga y siga las costumbres de los que la oyen porque lo contrario es hablar a unos por otros. Pues quien persuade a los mozos con palabras semejantes a las costumbres de los viejos no es menos loco que aquel que quisiese persuadir a los ausentes que no le oyen. [1547:227]

De esta afirmación se infiere la exigencia teatral de adaptar el lenguaje a las expectativas del auditorio. En el Arte nuevo, Lope había dicho de las comedias que "como las paga el vulgo, es justo/ hablarle en necio para darle gusto.”. Así lo asimila Quevedo:

En la multitud parece que habla más fuerte y probablemente el indocto que el docto, esto enseñan los poetas diciendo que en juntas del vulgo los ignorantes parece que hablan con más vigor y más a propósito. [1547: 252]

Hallamos relevantes notas quevedescas en el capítulo onceno. Así, para Quevedo, la ira o el llanto, sentimientos que expresan horrores anímicos surtidos en la escena, pueden provocar deleite, como opina Aristóteles respaldándose en Homero.

Si, como reza la máxima de un anónimo poeta, "molesto es todo cuanto oprime" [1547:104], la función del teatro reside en liberar al público 
mediante lo catártico. El deleite del receptor se logra cuando éste puede ver plasmadas en el escenario las razones de esa angustia. Entonces, como defienden Homero y Aristóteles, "la ira es más dulce que la miel porque nadie se aira con aquel de quien no se puede vengar" [1547:107] y también hay placer en las lágrimas porque llorar es "mover conmiseración y afectos con hermosura enternecida" [1547:108].

Entre las figuras de pensamiento, preceptuadas para mover el ánimo del espectador, encontramos el estilo directo y la evidentia, que designa la presentación sensorial de los hechos y que produce el efecto del realismo patente, por ejemplo, en el Lazarillo, la Celestina, Quevedo y Cervantes. ${ }^{66}$ Este requisito de verosimilitud es fundamental para el teatro del Siglo de Oro.

En el libro segundo, Aristóteles ahonda en el carácter del orador y las pasiones que genera en el receptor: la ira, el desprecio, la calma, el amor y el odio, el temor y el valor, la vergüenza, la compasión, la indignación, la envidia y la emulación. De entre todas ellas, Quevedo se ocupa especialmente de la envidia, por su subjetiva incumbencia. Este pecado capital es el que en el teatro impulsa las acciones pueriles. Tendrá su característica relevancia en De la cuna a la sepultura:

La pueril acción es cierto dolor que nace de la excelencia que vemos en otro igual, que nosotros no juzgamos capaz, y no da dolor porque el otro la tiene sino porque nosotros (...) no la tenemos. Es dolor generoso como la envidia vil y infame. [1547: 214]

\footnotetext{
${ }^{66}$ Cfr. López Grigera [1996: 125].
} 
Quevedo también anota ante el pasaje en que Aristóteles define la risa y lo ridículo: Facetiae sunt urbana et castigata convitia. Es decir, las burlas son básicamente insolencia educada. El autor, a propósito de ello, lamenta la pérdida del "tratado De ridiculis que dice Aristóteles escribió de parte en la Poética, y falta". [1547: 103] Otra anotación particularmente útil y sugerente para el análisis del teatro quevedesco es la definición de comedia antigua, que la preceptiva áurea (Pinciano, L. Alfonso de Carballo, Cascales o Bances Candamo, entre otros) acostumbraba a equiparar al entremés:

\section{Comedia antigua.}

Dice que se temen los que no tienen otro negocio sino inquirir los iconos de otros como son los envidiosos sátiros, autores de comedias, o escritores porque todos esos son maldicientes y mordaces. Colígese que los que representaban las comedias se llamaban sátiros. [1547: 208]

En el libro tercero, a propósito de las virtudes de la elocución, aparece la alusión a la "oración pedestre", esto es, aquella no sujeta a ritmo ni medida, que Quevedo dice ser el primero en trasladar al español, denominándola "silva". El autor confiesa la relevancia de hallar una voz propia mediante este mecanismo lúdico del lenguaje. ${ }^{67}$

El enaltecimiento estilístico de lo bajo a través de la sátira es enfático en Quevedo y visible en la composición de sus jácaras y entremeses, al igual que Velázquez pintaba a enanos y deformes otorgándoles, sin embargo, un aplomo natural. ${ }^{68}$ Quevedo subraya el pasaje en que Aristóteles autoriza la

\footnotetext{
${ }^{67}$ Cfr. Véanse las anotaciones de Quevedo [1547: 299].

${ }^{68}$ Cfr. López Grigera [1999: 129].
} 
libertad de hablar de todo, incluso de lo obsceno -como Petronio, Marcial, Juvenal y Terencio-, pero siempre con propiedad y sin torpeza. De ello, deducimos que, para nuestro autor, la sátira del teatro burlesco, a pesar de su retórica basada en la vis comica, nunca debe de ser soez o evidente. Ningún pretexto puede dispensar de la agudeza y el ingenio:

Briso juzga que nadie puede hablar torpemente aunque la cosa sea obscena y se diga con su propio nombre clara y abiertamente. Advierte Aristóteles con agudeza recóndita que muchos que no dicen [...] cosas torpes y deshonestas son más deshonestos y torpes que los que las dicen porque en las translaciones y circunlocuciones con que se ocultan las palabras deshonestas enseñan lo más y peor deshonesto de la deshonestidad. [1547: 204]

Mediante la lectura de Aristóteles, Quevedo consigna a los trágicos griegos en su consecución de logros dramáticos. Aparte de la oración pedestre, concepto esclarecedor para comprender la parodia idiomática quevedesca, nuestro autor destaca la homonimia ambigua de Marcial y los epigramáticos [1547: 300], los diminutivos de Aristófanes en sus Babilonios [1547: 306] o los prólogos y digresiones de Sófocles [1547: 369; 384]. Asimismo, particularmente interesante es su definición de la oración fría, que consiste en la "ficción y composición de nombres en un elenco", recurso que enriqueció tanto el ingenio de nuestro autor:

Se lee en Licofrón que llamó al cielo muchifrente y a la tierra grandiverticen y a la orilla augustocallu. Gorgias usó la oración fría llamando a los aduladores mendigohablantes. [1547: 306] 
El cuarto género de la oración fría son las translaciones reprendidas por Eurípides, eufemismos o elusiones ingeniosas:

Eurípides reprende las translaciones duras y el haber dicho "regnare capulos" porque la palabra "reinar" levanta y engrandece demasiadamente las cosas y no puede acomodarse bien a la palabra "capulos". [1547: 303]

Asimismo, en relación con Eurípides, uno de los recursos literarios favoritos de nuestro autor - muy utilizado en su teatro y en su obra en general- es el uso del equívoco:

Los equívocos. Los griegos los usaron. Eurípides en la Hécuba dice con razón reclama a Venus, Aphrodite, pues hace a los hombres Aphrodites, que es locos, sin juicio. [1547: 275]

Para don Francisco, Eurípides estructura su obra considerando que "apetece un hombre ser más que los otros por dignidades y honras". Es decir, las tramas teatrales han de plasmar la pugna humana por la gloria, ya sea espiritual o mundana. Aspiración que asoma en las envidias cortesanas de los dramas de privanza de Quevedo.

En su reflexión sobre lo cómico, nuestro autor remarca que, para Aristóteles, "lo ridículo es agradable y todo lo agradable es ridículo" [1547: 114], de lo que se infiere el placer de la risa frente al turpitudo et deformitas de lo grotesco. Más adelante, enfatiza que, para Eurípides, el virtuoso alberga una confianza natural en el ser humano: 
[Aristóteles] colige dél que tememos cuando a alguien pedimos algo la primera vez, dice que el remedio es empezar esperando el bien conforme a lo que Eurípides respondió bien a los de Siracusa en esta conformidad en la que no da el filósofo; es porque el que pide algo que nunca ha pedido, si espera de él el bien que desea, se obliga con tenerlo por bueno y poderoso y, virtuoso, le estima. [1547:208]

Con la voluntad de cristianizar a los autores paganos, impulso que cristalizó en la Defensa de Epicuro, Quevedo alude al dramaturgo Sófocles, que "para ejemplificar que entre las gentes que no tienen ley hay justicia universal refiere que dijo en la Antígona que era justo enterrar a Polinice muerto" [1547: 126].

Con todo, tal vez la idea más destacable de las anotaciones quevedescas a la Retórica aristotélica es la subordinación de la representación trágica o cómica a la Poética. Quevedo, amparado en Aristóteles, señala que la representación "es poner delante de los ojos de tal manera las cosas que se vea lo que se oye" [1547: 340]. Esta definición confirma teóricamente lo que podemos inducir mediante la lectura de su obra dramática: es decir, nuestro autor confiere a la palabra un peso notable en el teatro: su grandeza continúa siendo verbal. Por ello, "todo es necesario a la locución poética y se debe observar por ley indispensable" y "la oración tiene fuerza en dos cosas: en sentido y en palabras" [1547: 298].

Cuando Quevedo reflexiona sobre la tragedia, la relaciona con la poética, parentesco inherente al origen del género:

Porque al principio los propios poetas representaban sus tragedias, y porque este género pertenece a las poéticas, pertenece a las retóricas, de que se colige que la Retórica enseña la Poética. [1547: 293] 
Mas la diferencia entre poesía y teatro radica en que la representación requiere un modo de decir y obrar, esto es, precisa de habilidades comunicativas no verbales: "Esta arte de la acción y pronunciación hace que las voces se oigan y se vean, y que los afectos interiores toman cuerpo visible, así lo digo yo.” [1547: 294]. La dicción del actor escénico difiere de la del orador, dado que en el representante el peso de la gestualidad y de la entonación está supeditada a la materialización estética de las palabras dotadas de sentimiento.

El representante no ha de tener un discurso persuasivo sino decoroso, ya que el carácter ficticio o fabulístico del teatro así lo requiere. Los poetas dramáticos "usan de palabras humildes y a veces propias, y poco acomodadas" [1547: 298]. La magnificencia de la oratoria, por lo tanto, debe oponerse a la humildad poética, ya despojada de la gravedad de las palabras. 


\section{HOMME DU DIEU: EL TEATRO DEL ORDEN}

\section{EL SERMÓN DISFRAZADO}

Hemos visto con anterioridad que Quevedo tuvo una sólida formación jesuítica. El teatro de la Compañía de Jesús aspiraba a ser un "sermón disfrazado", que se amparaba en la funcionalidad docente del ejemplo, surgido de las artes praedicandi.

Como las parábolas evangélicas, el ejemplo es un recurso retórico que se utiliza desde el cristianismo primitivo con fines didácticos. Como dice el aforismo atribuido a San Ambrosio, exempla facilius suadent quam verba. ${ }^{69}$ La orientación moralizante de la predicación en el teatro jesuítico a menudo derivaba en la minuciosa narración de la conducta aberrante del pecador, con un realismo detallado.

Creemos que no podemos desligar el concepto y significado del teatro de Quevedo sin atender a los vericuetos de la retórica sacra. Don Francisco cultivó los dos polos opuestos del género dramático: la mordacidad vituperante del teatro breve y el encomio a la ortodoxia de la comedia

${ }^{69}$ Los homiliarios antiguos recogen múltiples ejemplos extraídos de las Sagradas Escrituras. Papas como León Magno o Gregorio Magno son acérrimos defensores de su uso. El adoctrinamiento programado en el IV Concilio de Letrán (1215) abogaba por este tipo de literatura más asequible a las mentes poco habituadas a razonamientos abstractos. A finales del siglo XV y, ante todo, a raíz del Concilio de Trento, se opta por una predicación privada de ficciones ajenas a la Biblia, pero circunscrita a un público cultivado. No obstante, la predicación popular y la pedagógica sigue con los lemas de "predicar con el ejemplo" o "asistir al ejemplo". Cfr. Menéndez Peláez [1995: 52-54]. 
palatina. Entre ambos existen tensiones dialécticas que debemos reconciliar con la finalidad de comprender la concepción global de Quevedo frente al teatro. ¿Tenía razón don Pedro Aldrete en su "Prólogo" a Las tres musas (1670)?

Todas las obras de don Francisco de Quevedo, mi tío, así en verso como en prosa, sacras, serias y burlescas, se dirigen a la reformación de costumbres y contienen alta enseñanza [...] [Blecua, 1999: I, 141]

Según el sobrino del poeta, la única intención de don Francisco, alto y nunca bien esclarecido ingenio, fue reformar vicios. Se valió de la verdad de las Sagradas Escrituras y de los Padres de la Iglesia. Como dice la aprobación del Padre Juan Eusebio de Nieremberg a La cuna y la sepultura, Quevedo sabe representar "los sentimientos estoicos de más vivo color a luz cristiana". Y se deshace en elogios:

Parece que Epicteto se nos ha vuelto español, que Crisipo claro, que Zenón tratable, que Antipatro breve, que Cleantes vivo, que Séneca cristiano. [1951: II, XXVI, b]

Quevedo siempre concibió la escritura como un instrumento moralizador. Su postura era similar a la de Calderón, que definía los autos sacramentales como "sermones/ puestos en verso, en idea representable cuestiones/ de la 
sacra Teología." ${ }^{70}$ El teatro, entonces, podía ser concebido como un sermón de fermosa cobertura, un género espiritual y devoto, acomodado a adoctrinar con deleite. Como rezaba el tópico latino, delectare et prodesse.

\section{EJEMPLOS MORALES DEL TEATRO GRAVE}

El teatro es un alimento espiritual para todas las clases de público: así lo afirma Quevedo en el prólogo que escribió a la traducción española de la comedia Eufrosina [1951: II, 492]. Según su parecer, el pueblo comprenderá antes cuál es la esencia de las buenas acciones acudiendo a una ejemplar comedia que escuchando las oscuras palabras de un juez. Los examinadores de los entremeses (v.g. El Examinador Míser Palomo de Hurtado de Mendoza) delatan la crudeza moral de sus inculpados con un lenguaje más comprensible.

Los valores cristianos deben prevalecer en las obras. El contenido moral del teatro es fundamental. Así lo expresa Quevedo en la aprobación que escribe a las Doce comedias de Lope de Vega, fechada el 19 de mayo de 1635:

Por mandato de Vuestra Alteza he visto estas Doce comedias de Frey Lope Félix de Vega Carpio, del hábito de San Juan. Son todas de muy honesta enseñanza, y otros tantos ejemplos, elegantes y entretenidos para la advertencia moral. Merecen

${ }^{70}$ Véase Calderón de la Barca, "Loa a la segunda esposa", en Obras completas, III. Autos sacramentales. Edición y prólogo de Ángel Valbuena Prat. Madrid: Aguilar, 1967, 2ª ed., p. 427. 
ser leídas; y en la impresión, la aprobación igual al aplauso con que se oyeron en los teatros. El grande nombre de su autor las acredita, y sus estudios las aseguran de palabra indecente o mal sonante a las buenas costumbres o a la verdad de nuestra sagrada religión. [2005: 504].

Nuestro autor, profundamente preocupado por la moral de su tiempo, utilizó exempla -"ejemplos elegantes y entretenidos"- para ilustrar con modelos vivientes los senderos de la virtud, a veces en notable encrucijada. $^{71}$

El neoestoicismo de Quevedo le llevó a concebir estos patrones no como intachables héroes de inmejorable conducta, como sucedía en las epopeyas grecolatinas o los libros de caballerías, ${ }^{72}$ sino como hombres de carne y hueso que intentan trascender sus dudas existenciales con un fuerte acopio de voluntad y de fe. Don Francisco prefigura en su teatro el concepto de hombre de bien, que parte del Barroco español y que se instauraría

${ }^{71}$ Modelos similares a los que Gracián expuso en su Oráculo Manual y Arte de Prudencia, publicado en 1647: "El prudente frecuenta las casas de los hombres eminentes, pues son escenarios de grandeza más que palacios de la vanidad. Hay señores reputados de prudentes que son oráculos de toda grandeza con su ejemplo y en su trato. Pero, además, el grupo de sus acompañantes es una cortesana academia de sensatez, tacto e ingenio." [1993: 6-7].

${ }^{72}$ Así podemos explicar su ironía al comparar al Príncipe de Gales en Cómo ha de ser el privado con el Amadís de Gaula: "Solamente en los teatros/ y en los libros fabulosos/ estos ejemplos hallamos." [1927: 28]; “este Príncipe que tiene/ cosas de Amadís de Gaula" [1927: 67]. 
plenamente en la Ilustración: era más verosímil y humano que el héroe caballeresco. $^{73}$

Las comedias apologéticas de Quevedo, al igual que sus poemas de elogio, ${ }^{74}$ se sirven de los modelos clásicos de los "Epitafios" y "Encomia" de la Antología Planudea ${ }^{75}$, variedades epigramáticas que el polígrafo emuló en las clases recibidas por los jesuitas, puesto que eran ejercicios explicitados en la Ratio Studiorum. ${ }^{76}$ Los dramatis personae de las comedias de Quevedo suelen caracterizarse a partir de alusiones mitológicas, bíblicas y legendarias fosilizadas.

Quevedo, el "desgarrón afectivo" personificado, atenderá a modelos palpitantes tentados a pecar, contemplará las presiones de la siempre frívola

${ }^{73}$ Se concreta la restringida vigencia de los abigarrados protagonistas de la caballería andante. Comenta A. Bell [1928: 209], al respecto: "A century earlier to be called an Amadis would have been the hightest praise, but now, as Velez de Guevara tells us about this time (in 1641), Amadis was only read by pages and girls of between ten and seventeen; and an old folio of that enchanting tale would be mistaken (por lo viejo y letras antiguas) for a book of magic, as occurs in the story El Castigo de la Miseria by María de Zayas."

${ }^{74}$ En sus elogios poéticos vemos alabanzas destinadas a los reyes Felipe III (POC, 211, 212), Carlos V (POC, 214), Felipe IV (POC, 219, 220, 221,222, 229, 233), los Duques de Osuna (POC, 215, 223, 242, 243, 244), de Maqueda (POC, 217) de Lerma (POC, 224, 225, 237, 241, 246) y Rodrigo Calderón (POC, 252), entre otros personajes nobles e influyentes de su época.

${ }^{75}$ Véase la edición de Gredos [I: 1993; II: 2004].

${ }^{76}$ Cfr. E. Gil [1992]. Sagrario López Poza [2006:171] relaciona esta práctica genérica con los Elogia de Paolo Giovio y los Heroes de Julio César Escalígero. La autora postula que, aplicado en la técnica laudativa y demostrativa, probablemente Quevedo tuvo en mente "coleccionar un Museo epigramático, una galería de elogios (que, como hemos dicho, el género incluye tanto la alabanza como el vituperio)." 
y cruel opinión ajena. Se decantará por un panegírico de los personajes loables y por una degradación caricaturesca de aquellos que se dejan arrastrar por la liviandad de lo mundano.

¿Qué patrones predominan en los modelos femeninos de virtud (speculum mulierum)? La dama virtuosa y deificada del teatro grave de Quevedo contrasta con la pidona, foco satírico de chistes soeces del mundo hampesco y prostibulario que emerge en el teatro breve. Como sucede en su poesía amorosa, el modelo femenino se ampara estéticamente en la prosopografía petrarquista $^{77}$ y si bien su etopeya participa del desdén y la crueldad en algunos casos (residuo de la midons trovadoresca), aspira a la virtud entendida en su sentido cristiano.

En cuanto a los modelos masculinos, Quevedo apuesta por la galería de retratos de los poderosos. ${ }^{78}$ Múltiples reyes históricos de la corona española son rememorados al inicio de Cómo ha de ser el privado inmediatamente después de la entronización de Felipe IV. Los antiguos monarcas, como dioses penates de la realeza, son diacrónicamente enumerados con sus respectivos epítetos: Fernando el Católico (v. 39), Fernando III el Santo (v.72), Alfonso X el Sabio (v. 77), Felipe II el Prudente (v.81) y Pedro I el Cruel (v.90). ${ }^{79}$

\footnotetext{
${ }^{77}$ Acerca de las imágenes petrarquistas más comunes para representar metafóricamente la belleza de la dama, véase Manero Sorolla [1990].

${ }^{78}$ Con este procedimiento estilístico clausura, por ejemplo, sus Grandes anales de quince días.

${ }^{79}$ En Cómo ha de ser el privado el monarca se define como "viva y humana ley" (v. 99), expresión que, según Roncero López [1991: 134] está ligada a la tradición medieval que consideraba al rey como iudex. Quevedo, probablemente, compartía la visión que plasma
} 
Nuestro autor no piensa que la nobleza esté lejos de la corrupción. No considera que la codicia y la bajeza moral escapen de aquellos que no han de recurrir a las chanzas y ardides de la picaresca en pos del pedazo de pan. Ello explicaría particularmente su siguiente anotación a su ejemplar de la Retórica de Aristóteles, donde establece las diferencias entre los adjetivos noble y generoso:

Noble, el que desciende de nobles. Generoso, el que confirma la virtud de sus ascendientes y no degenera de ellos en sus costumbres, y no solamente son cosas diferentes generoso y noble, sino tan diferentes que pocas veces se juntan. [1547: 227]. ${ }^{80}$

Como se deduce de la polémica comedia La privanza desleal y voluntad por la fama, en ocasiones un conde puede ostentar una conducta más justa que la del rey al que sirve, e incluso llegar a destronarle. Tal es el caso de Albano, una suerte de Lanzarote aurisecular. A juzgar por su final ascendente, el Conde Albano es sumamente afortunado si lo comparamos con el "ministro culpado" Rodrigo Calderón, ejecutado públicamente el 21 de octubre de $1621 .^{81}$

Erasmo en el Enchiridion o Manual del Caballero Cristiano, donde se apela a la necesidad de que el príncipe encarne la ley. Como señalaría Saavedra Fajardo [1999: 356] en una de sus Empresas políticas: "Por una letra sola dejó el rey de llamarse ley. Tan uno es con ella, que el rey es ley que habla, y la ley un rey mudo.”

${ }^{80}$ A pesar de que las anotaciones de Quevedo son posteriores, cito el impreso de su ejemplar de la Retórica a partir de su fecha de publicación.

${ }^{81}$ Quevedo le escribió un epitafio (POC, 811). 
Quevedo tiene sus dudas respecto a la honorabilidad cortesana, como hábilmente expresó en su obra satírica. El mensaje ideológico de sus composiciones burlescas ha de diferenciarse de las cavilaciones sobre las circunstancias de su siglo. Para comprender el modelo de conducta del que Quevedo hace apología, hemos de subsanar los matices de coacción política y defensa de los intereses de la corte que se infieren de sus opúsculos por encargo palatino: obras como, por ejemplo, El chitón de las taravillas y Cómo ha de ser el privado.

En todo caso, el editor de Fray Luis de León escogió, al igual que su admirado salmantino, al paciente Job como ejemplo de hombre que superpone su amor a la divinidad por encima de las inclemencias de la Fortuna. También al apóstol San Pablo, tan humano y sacrificado en sus Epístolas, o a Agustín de Hipona, el santo que en sus Confesiones explicaba implorando a la misericordia divina cómo en su juventud había robado no por necesidad, sino por el placer del hurto. Sobre privados, el modelo clave será Séneca, el consejero del tirano Nerón.

El modelo de virtud para Quevedo reincide en la resistencia estoica frente a la adversidad, actitud reconciliable con la imagen de un Cristo sufriente, mártir del pecado. Nuestro autor, en definitiva, practicó la vertiente didáctica del teatro, ante todo en las comedias palatinas. Efectivamente, como repitió Tarsia hasta la saciedad, toda su vida fue una milicia continuada. 


\section{HOMME DU DIABLE: EL TEATRO DEL DESORDEN}

\section{DELECTARE ET PRODESSE}

Existe una tradición literaria que vuelve la mirada hacia las clases marginales, que encuentra un filón en la expresividad espontánea, que conjuga la palabra vivaracha y el aliento renovado. Al otro lado de la línea, donde los parias urden sus pasiones y crímenes, en el lodo del delito y lo prohibido, algunos escritores descomponen la decadencia de un reino avergonzado, que se entrega al hedonismo con hambruna e inconsciencia.

El teatro breve, desde luego, se acomoda a esta tradición, con la que simpatizaba el genio satírico de Quevedo. Las reglas de este liviano molde literario -condensación, concisión, efectismo- le permiten reproducir sus temas burlescos predilectos. La vena cáustica del escritor y su capacidad para bosquejar caracteres ridículos se encauza en una urdimbre salpicada de pullas y epigramas, bien semejantes a los que cultivaron Catulo y Marcial. ${ }^{82}$ Como el resto de su obra festiva, el teatro breve de don Francisco está al servicio de la risa, que implica una denuncia de lo grotesco. ${ }^{83}$

"La risa está fundada en un no se qué de torpe y feo": López Pinciano [1959:33], en su Philosophia antigua poética (1596), retomaba esta

${ }^{82}$ Véase la comparación que hace González de Salas entre Quevedo, Catulo y Marcial en la ed. de Blecua [1999: I, 95].

${ }^{83}$ Lo cómico se inscribe en las diversas esferas de negatividad que constituyen lo bufo y en la arquitectura de la farsa (caos, ironía y multiplicación de figuras). Iffland [1978] distingue entre las siguientes esferas de negatividad: creaturality, ersatz, fake o fraudulent y confusion and struggle. 
definición aristotélica de la risa. Había conjeturado que se produce ante lo anormal. Que la risa confirma la superioridad del modelo reinante y no cuestiona la cultura vigente. Que la risa, amparada en lo disparatado, lo descompuesto, lo escatológico, lo picaresco y lo erótico, se regodea ante un mundo en desorden.

La literatura festiva de ascendencia carnavalesca está influenciada por la risa ritual: recordemos algunas celebraciones litúrgicas de ascendencia medieval como la "fiesta de los bobos" (festa stultorum), la "fiesta del asno" o la risa pascual (risus paschalis). ${ }^{84}$ A lo largo del siglo XVII, la labor de algunas órdenes eclesiásticas -ante todo, los jesuitas- ayudó a conocer los ademanes y prácticas de estos moradores de los bajos fondos: el material de escritura, sin embargo, no se tomaba directamente de la realidad, sino de un estatuto literario ya fijado. La carcajada se disparaba ante la irrupción de elementos extraños e irreverentes, pero el contrafactum no debía ser tomado como síntoma de rebeldía, sino como el mal ejemplo que avalaba el sistema: un mal necesario.

La literatura satírica sólo podía franquear la barrera de la censura justificándose como mundo al revés, la excepción que confirma la regla, la amoralidad que revela el camino equivocado. Podía leerse en clave teológica: entonces el fantoche o el pecador sólo formarían parte de retablos infernales, casos tópicos del escarmiento. El teatro breve aurisecular se revolvía violentamente contra los valores transferidos por la comedia, de la

\footnotetext{
${ }^{84}$ A propósito de este concepto, véase el célebre estudio de M. Bajtín La cultura popular en la Edad Media y en el Renacimiento. El contexto de François Rabelais [2005: 10].
} 
que constituyó un negro ensayo: desfiguraba sus retratos de virtud y nobleza y atacaba sus tópicos de viva voz. ${ }^{85}$

\section{LA CAÍDA DEL HOMBRE}

La risa de Quevedo no es inocente. Él utiliza el sofismo para degradar un motivo hacia aspectos externos o nimios, hasta sacarlo de quicio y volcarlo en una situación absurda e inhabitable. Don Francisco, para algunos lectores como Octavio Paz, persigue una carcajada existencial, una mueca que nace del grito de horror:

La caída fue una de las obsesiones de Quevedo, lo mismo la física que la moral. Una y otra le inspiraron tanto burlas y chanzas como consideraciones morales y religiosas. Caídas de Lucifer y de Sancho, uno del cielo y el otro de un asno; caídas hacia arriba de Cristo y de San Pablo. Vi en Quevedo al protagonista -testigo y víctima- de una situación que, siglos más tarde, vivirían casi todos los poetas de la modernidad: la caída en nosotros mismos, el silencioso despeñarse de la conciencia en su propio vacío. [1996:14]

Conocer el mal es un requisito inexpugnable para no caer en él: los antídotos contra los venenos suelen estar fabricados a partir del veneno mismo. Exponer el pecado no ha de ser motivo de censura. Así había procedido San Agustín en sus Confesiones.

\footnotetext{
${ }^{85}$ Véase José Amezcua [1981:22].
} 
Los variopintos personajes que ilustran los vicios en el teatro breve son fantoches desalmados, dignos de chanzas, que no disponen de un sólo átomo de dignidad y que constituyen futura carnaza del averno. Quevedo asume en su literatura la caída del hombre, la negación del paraíso por los deseos livianos, la mengua de la voluntad frente a los pecados capitales. Si el Cántico espiritual de San Juan de la Cruz escenifica la comunión mística con la divinidad, Quevedo es su reverso y muestra la caída de la conciencia en sí misma: la escisión. Para comprobarlo, basta cotejar sus respectivas versiones del Cantar de los cantares. ${ }^{86}$

También Faetón e Ícaro son figuras que representan dicha caída. En el Sermón estoico de censura moral (POC, 145), Quevedo entrevé estas figuras míticas como metáfora de las pretensiones frustradas del hombre, cuya osadía de vuelo define como "teatro de espumas" (v. 55).

Don Dinero, el poderoso caballero, es el que rige los avatares del mundo. En su carencia, puede convertir a los hombres en santos (los verdaderos ascéticos, vejados por sufrimientos corporales pero iluminados por su fe divina) o en corrompidos diablillos (pícaros dados al vicio y al robo, goliárdicos de tradición, que apenas se acuerdan de un Dios que los dejó a la intemperie).

La decadencia del Barroco es el marco económico, político y social que delimita toda la literatura del momento: el Siglo de Oro español atesora ese desfile de pobres célebres, astutos y briboncillos por necesidad. Vislumbraremos a la "puta vieja" Celestina y a sus biznietas Ropavejera y Muñatones, al hambriento Lazarillo y sus descendientes pícaros, al fogoso

\footnotetext{
${ }^{86}$ Cfr. Quevedo, POC, 198.
} 
Don Juan, al evasivo Quijote, al jaque Escarramán -incluso "a lo divino"- y al cornudo Diego Moreno, junto con todas las pidonas del mundo, mujeres dispuestas a explotar su sensualidad en pro de una artifara en el tablón. Es esta una curiosa antítesis: los tesoros literarios de nuestro Siglo de Oro proceden del panteón de los fracasados, pícaros harapientos, vagamundos carismáticos.

\section{ANTIPETRARQUiSMo}

Durante el siglo XVII, algunos escritores como Quevedo consideraron el petrarquismo como una enfermedad crónica de la literatura italiana. ${ }^{87} \mathrm{La}$ incorporación del petrarquismo a la literatura aurisecular pronto dio lugar a una reacción crítica, no sólo en un sentido formal, como el estipulado por Cristóbal de Castillejo en la Reprensión contra los poetas españoles que escriben en verso italiano o en el soneto Garcilaso y Boscán, siendo allegados ${ }^{88}$ sino que también en lo concerniente a los tópicos de la temática amorosa, cuya filosofía era de filiación fundamentalmente neoplatónica. La reacción crítica, conocida como antipetrarquismo, significó una repulsa directa del petrarquismo o una parodia de su código. Con todo, el objeto de la crítica no era precisamente Petrarca, sino sus malos imitadores.

\footnotetext{
${ }^{87}$ Así lo postula Ignacio Navarrete [1997: 244-307] en su volumen publicado en 1994 y traducido al español en 1997: Los huérfanos de Petrarca. Cfr. Graf [1916].

${ }^{88}$ Véase Blecua, Poesía de la Edad de Oro. Renacimiento [1991: I, 57-59].
} 
La obra burlesca de Quevedo consiste en una inversión de los valores de la literatura amorosa seria de raíces petrarquistas: "frente a la espiritualización, la reducción al sexo; frente a la fe, la promiscuidad; frente a los inaguantables desasosiegos y dolores, la serena despreocupación."89 Del amor purus de la poesía seria en estilo sublime pasamos al amor mixtus y al amor ferinus. Detrás de los ideales neoplatónicos, Francisco de Quevedo, ávido lector de Il Trattato dell' Amore Humano (1567) de Flaminio Nobili, reconoce que en la vida real difícilmente existen Lavinelos. ${ }^{90}$ En El alguacil endemoniado, Quevedo alude a la hipócrita conducta de los enamorados platónicos:

Son de ver los que han querido doncellas, enamorados de doncellas con las bocas abiertas y las manos extendidas, destos unos se condenan por tocar sin tocar pieza, hechos bufones de los otros, siempre en vísperas del contento, sin tener jamás el día, y con sólo el título de pretendientes. Otros se condenan por el beso como Judas, brujuleando siempre los gustos, sin poderlos descubrir. Detrás destos en una mazmorra están los adúlteros; éstos son los que mejor viven y peor lo pasan, pues otros les sustentan las cabalgaduras y ellas las gozan. [2003: I, 260-261]

Quevedo se enfrenta sobre todo con la vertiente filosófica del petrarquismo, la plasmada por León Hebreo en los Diálogos de amor. ${ }^{91}$ Dirige sus esfuerzos a la recuperación de la tradición castellana mediante un proceso de autocanonización personal patente en el cancionero amoroso a Lisi, donde el poeta pretende "reescribir la historia literaria de España y

\footnotetext{
${ }^{89}$ Conforme a lo señalado por López Gutiérrez [2001: 147].

${ }^{90}$ Esta influencia la remarca Olivares [1995: 2].

${ }^{91}$ Véase la edición de José M $M^{\text {a }}$ Reyes Cano: León Hebreo [1993].
} 
corregir su relación con la de Italia." $^{92}$ Intenta moralizar contra el petrarquismo italianizante de Góngora. No obstante, utiliza profusamente los recursos paradigmáticamente culteranos, como el hipérbaton y la bimembración. $^{93}$

Existe un paralelismo entre la ilusión nacional - en el siglo XVII el poder mundial de España había declinado- y la ilusión del amor como quimera, claro potenciador del antipetrarquismo. ${ }^{94}$ El petrarquismo acabó convirtiéndose en un juego literario que se podía tomar tanto de manera grave como frívola. ${ }^{95}$

Probablemente, esta concepción del amor extendida en la poesía satírica de Quevedo se debe al influjo del pensamiento antiguo, sobre todo el estoico y epicúreo, dentro del marco del pesimismo nacional y el desengaño. ${ }^{96} \mathrm{La}$

${ }^{92}$ Cfr. Navarrete [1997:297].

${ }^{93}$ Conforme a lo señalado por otros autores como Pozuelo Yvancos [1979: 296-314] y Santiago Fernández Mosquera [1999].

${ }^{94}$ Cfr. Anthony Zahareas y T. Mc.Callum [1978:90-99].

${ }^{95}$ Como sostiene Leonard Forster [1969: 66-67]: "lo que para Petrarca era de fundamental importancia, fue sólo un juego para sus sucesores y como tal podía ser tomado en serio o no según requiriesen las circunstancias. Pero aunque se trataba de un juego, o tal vez porque lo era, proveía el marco dentro del cual eran posibles el amor y el cortejo genuinos que culminan en el matrimonio. Por otro lado, no era necesario que fuese nada más que eso, un juego, tan serio o tan frívolo como se quisiese. Fue sin duda a esta flexibilidad que se debió su prolongada y enorme popularidad."

${ }^{96}$ Conforme a lo estudiado por H. Ettinghausen [1972] en Francisco de Quevedo and the Neostoic Movement. A este influjo filosófico alude Octavio Paz [1991: 142]: "Es el poeta de la conciencia de la separación o, más exactamente, de la desgarradura que nos hace hombres. Aunque este sentimiento es universal -es el fondo de la condición humana- en la 
visión atomista del mundo queda patente en el libro IV de De rerum natura de Lucrecio, donde se ofrece una prolongada queja ante las ciegas ilusiones que produce el amor. Horacio, asimismo, compara con las prostitutas a las mujeres adúlteras (Sátiras, I. 2): “¿Qué más da si pecas con matrona o con esclava entogada?" (v. 63); y Marcial también lanza duras invectivas contra el matrimonio en los epigramas I, 24; I, 84 y X, 81, donde alude a solteros que se erigen como pater familias tras gozar a sus esclavas o retrata el libertino ménage à trois.

El escepticismo frente al amor es la antesala de la concepción del matrimonio como estatuto social fundado en la hipocresía y el engaño. Así aflora en el teatro breve de Quevedo, jocoso abrenuncio de las capitulaciones matrimoniales.

\section{SUSTRATO FILOSÓFICO Y MORAL}

Desde la perspectiva del estoicismo cristiano, Quevedo no puede dejar de despreciar la inexorable putrefacción de la carne. Las figuras, cerradas y redondas, se aíslan dentro de roles que jamás trascienden, porque el

época moderna alcanza una suerte de exasperación debido, quizá, al paulatino e inexorable desvanecimiento de la noción de trascendencia. Vivimos el ocaso del Ser. Uno de los primeros que vivió esta situación fue Quevedo, poeta más estoico que cristiano. Su geometría está hecha de claroscuros que no ocultan el hoyo por el que todos nos despeñamos -el hoyo del tiempo y de la muerte." 
desengaño y los palos (tan visuales en el teatro) no les confieren virtud, sino picardía.

El hambre y su miedo limitan el hipotético libre albedrío del ser humano. No es baladí que los ladrones Hozinguera y Panarizo del Paso Quinto de Lope de Rueda [1979:81-89] engañen al simple Mendrugo con "aquellos contecillos de la tierra de Jauja": el paraíso de los pícaros no es celestial, sino terreno. ${ }^{97}$

El recurso de animalización de lo humano, presente en De humana physionomia (1586) de J. Bautista della Porta, es una nota sugestiva de Quevedo, especialmente reflejada en El Buscón y el entremés de La venta. El autor utiliza tramoyas para mostrar la discrepancia de la apariencia y la interioridad, tal y como sucede en El mundo por de dentro, La fortuna con seso y Virtud militante.

Quevedo identifica la figura con el vicio, notablemente alejado del in medio virtus que predica Villava en sus Empresas espirituales (I, f. 51v). Como revela el siguiente pasaje de El alguacil endemoniado: "Todo el infierno es figuras, y hay muchas, porque el sumo poder, libertad y mando les hace sacar a las virtudes de su medio y llegan los vicios a su extremo." [2003: I, 264].

Al dramatizar a sus personajes, Quevedo juega con una perspectiva dual: los tipos amorales hacen apologías de sí mismos y a la vez son espejados por otras figuras que censuran su conducta.

${ }^{97}$ El alimento del cuerpo -visualmente señalizado en ríos de miel y de leche, fuentes de mantequillas y requesones, árboles cuyos troncos son tocino y sus frutos buñuelos, huevos en vez de guijarros, asadores por doquier con toda clase de reses, etcétera- es más atractivo que la depuración espiritual del alma. Cfr. Lope de Rueda [1979: 81-89]. 


\section{REGODEOS CARNAVALESCOS}

A raíz del célebre estudio de Bajtin La cultura popular en la Edad Media y el Renacimiento: El contexto de François Rabelais, se ha especulado acerca del influjo carnavalesco en la obra satírica de Quevedo, también dotada de la hibridación y la hipérbole grotesca y escatológica de aquellas celebraciones. $^{98}$

Como se deduce del libelo Anatomía de la cabeza del Cardenal Richelieu, Quevedo es un gran conocedor del mapa político y cultural francés y, por ende, de las obras de Rabelais. El autor recrea en sus entremeses un mundo de encantamientos, apariencias, burlas y cosificación trazados mediante abstracciones y juegos lingüísticos, con perspectivismo carnavalesco. Deslexicaliza los vocablos y urde descripciones descompuestas. Emula los retratos desgajados de Arcimboldo: rostros y cuerpos desintegrados como los primeros palimpsestos anatómicos que imaginaba Empédocles, facciones inarmónicas por su inmoralidad.

Eugenio Asensio [1965: 229] dice que el entremés "es en lo básico un remozamiento del Carnaval, tan ligado al origen cómico." Tal es la propuesta de estudio de Edmond Cros [1974] en L'Aristocrate et le Carnaval des gueux a propósito del Buscón y el motivo carnavalesco de "la fiesta del rey de gallos", una celebración en la que el pícaro es coronado rey por un breve lapso de tiempo, para luego ser destronado. En esta celebración, Cros cree ver una metáfora de lo grotesco de las aspiraciones a

\footnotetext{
${ }^{98}$ Recordemos, asimismo, que gran parte de la poesía satírica de Quevedo está ligada a la época de Carnaval. Cfr. POC, 770 (v.87), 682 (v. 103), 707 (v. 87), 754 (v.126).
} 
la nobleza del protagonista. Las conclusiones de su investigación son perfectamente aplicables a los personajes de los entremeses quevedescos:

l'actant est presenté comme une figure de Carnaval, tandis que le récit autobiographique se présente à son tour comme un texte mystificateur, auquel s'oppose un second texte qui démystifie et démasque le premier.

C'est en fonction de cette simplification comique et de l'impératif auquel doit se soumettre Quevedo de maintenir le decoro de son personnage que l'on doit tenter d'apprécier le sentiment de honte qui est prêté à l'actant. [1974:104]

El proceso comprende un ciclo de mitificación y desmitificación, una puesta del mundo al revés durante un breve lapso temporal: representa la lucha fallida en la sociedad castellana del siglo XVII por prosperar en el escalafón social. $^{99}$

La controversia respecto a la voluntad trasgresora u oficialista de la burla es común en todos los tratados sobre la función de la risa y lo cómico. La aparente peligrosidad moral del entremés es contrarrestada por su brevedad inherente y el castigo de los personajillos infractores, que justifica la lluvia

\footnotetext{
${ }^{99}$ Este tópico del mundo invertido, tan vinculado al universo carnavalesco, ha sido objeto de estudio de Carlos Vaíllo [1982: 364-393], que lo emparenta con los adynata o impossibilia de los clásicos grecolatinos y lo documenta en obras no dramáticas de Quevedo como La fortuna con seso y múltiples composiciones poéticas. El mundo al revés explica la inversión de sexos del entremés El marión o las antipetrarquistas damas pedigüeñas de La destreza.
} 
de chanzas y palos a la que están expuestos. ${ }^{100}$ El desarrollo acelerado y atractivo de las acciones entremesiles debe borrar en el desenlace cualquier enseñanza nociva. De acuerdo con el tópico del mundo al revés, el escritor adoctrina mediante fantoches ridículos sumergidos en el vicio. ${ }^{101}$ En ocasiones, los mismos personajes del teatro breve introducen la crítica a la inmoralidad, aunque participen de ella. Grajal, por ejemplo, la moza que ayuda al ventero del entremés de La venta a sus tramposos fines, introduce comentarios irónicos sobre la villanía de su amo.

Por otra parte, se han interpretado los entremeses de Quevedo como una inversión de los roles establecidos en la comedia. ${ }^{102}$ Notaba Lope en su Arte nuevo (1609) que "entremés de rey jamás se ha visto", en el sentido de que los entremeses se fundamentan en el vituperio, al contrario que la comedia que suele mostrar personalidades ejemplares y virtuosas. ${ }^{103}$

Para comprender la faceta moralizante del teatro breve hemos de atenernos al concepto de lo cómico: su relación de proximidad respecto de

${ }^{100}$ Guido Mancini [1965: 224], en su estudio Gli entremeses nell' arte di Quevedo, insiste en la faceta didáctica y moralizante del teatro de Quevedo, perspectiva crítica que Asensio considera exagerada.

101 Asensio [1965:195] señala que "el propio personaje, inconsciente de su doblez, funciona a la vez como panegirista y acusador de sí mismo".

${ }^{102}$ Tal es la tesis del artículo de José Amezcua "El negro ensayo de la comedia. Notas sobre los entremeses de Quevedo" [1981: 25]: "El entremés de Quevedo impone una distensión, la carcajada y el absurdo, de conductas conocidas divulgadas por la comedia. Pero no es en el entremés quevediano donde la idea de cultura sustentada por el drama nacional será atacado frontalmente, sino en el propio género de la comedia."

${ }^{103}$ Todo ello, a pesar de la presencia testimonial del rey en entremeses como El toreador de Calderón. 
la comedia y su burla enfocada al concepto clásico del turpitudo et deformitas. El entremés invierte la proporción, armonía y decoro de la comedia porque su esfera de acción es lo ridículo. Es heredero de los sátiros y mimos, según dictaron preceptistas del Barroco como Pinciano, el padre José Alcázar o Juan Caramuel. ${ }^{104}$

Quevedo maneja a sus figuras como a marionetas de guiñol y las juzga desde la superioridad, "levantado en el aire", como describiría Valle-Inclán al esperpento siglos más tarde. El entremés, por su parangón con la comedia, alberga una estructura tripartita, "con exposición, complicación, y una resolución lúdicamente repentina": la comedia termina en boda y el entremés quevedesco, en baile. ${ }^{105}$

Otras facciones de la crítica han considerado que el teatro breve parte de la subversión carnavalesca y que es de moralidad dudosa, hecho que explicaría las polémicas auriseculares acerca de la licitud del teatro. ${ }^{106}$

${ }^{104}$ Cfr. El estudio introductorio de Evangelina Rodríguez y Antonio Tordera (Calderón [1982: 18-21] y F. Sánchez Escribano y A. Porqueras [1972: 306-309].

${ }^{105}$ Como señala S. Hernández Araico [2004: 227].

106 Amezcua [1981: 25] considera, por ejemplo, que el baile final de los entremeses puede constituir de "lo más contestatario de la ideología" de nuestro autor. No obstante, son varios los argumentos de neutralización del potencial revulsivo del entremés. Así lo señala F. Serralta [1989: 106]: "No hay que olvidar que mundo al revés no significa en absoluto mundo como debiera ser, sino mundo como no es". Otra postura es la defendida por P. Cabañas [1991: 296-297], que califica el empleo de lo grotesco no como medio, sino como fin, convirtiéndolo en un ejercicio autotélico. De acuerdo con esta interpretación, Quevedo supeditaría la moralidad a una obsesiva voluntad de pirotecnia lingüística: los entremeses supondrían ejercicios gratuitos de invención grotesca, la sátira sería relegada a un segundo plano. Sus razonamientos coinciden con los postulados por Iffland en Quevedo and the 
Los entremeses, jácaras y bailes de Quevedo, en definitiva, pueden interpretarse como retablos de figuras que explicitan lo pasajero de la vida mundana, constantemente expuesta a la degradación y lo corrosivo, aquejada por la vejez y amores interesados, regida por hombres pobres de espíritu que encarnan el vicio que debe rehuirse. ${ }^{107}$

La omnipresente y ácida carcajada del miope tiene mucho de escepticismo ante la probabilidad de salvación de un mundo que se derrumba -como el imperio español en la crisis del Barroco-, un ácido retorno a Sodoma y Gomorra. Con todo, don Francisco posee la virtud de transmutar alquímicamente la realidad, de volcar las lágrimas de desesperación en una expansiva risotada.

La máscara que utiliza Quevedo es la de la sátira, la carcajada de Demócrito ante los títeres del teatro del mundo. No sólo se aprende tras el llanto de Heráclito, puesto que desde antiguo existe el tópico del delectare

grotesque [1978: II, 153], que en todo caso apunta que la sátira de Quevedo no es correctiva, sino punitiva, dado que sólo ridiculiza destructivamente a sus figuras, sin dar opción a su enmienda moral.

107 Así lo expresa Carlos Vaíllo [1982: 392], que interpreta la evidencia de un mundo al revés como subrayado implícito de un mundo al derecho: " Por el conducto del tópico podemos aproximarnos al pensamiento moral y a la ideología en general que subyacen a las burlas. El tono predominantemente festivo no debe ocultarnos el hecho que tales obras surgen de una conciencia moral exacerbada. Claro es que ninguna propuesta de reformación de los vicios se arbitra en esta sátira, volcada a la crítica destructiva y al revulsivo. Tales mofas (y no entro en la espinosa cuestión de su legitimidad o conveniencia) no son sino el primer paso en el camino del desengaño, a cuyo cabo está esperando el autor con sus tratados morales o su poesía grave para ofrecer otras opciones de estar en el mundo." 
et prodesse, la técnica de entremezclar la doctrina moral con una vestimenta agradable y liviana.

Don Francisco, como hemos visto, penetró al unísono en el mundo ideal del símbolo -el anhelo angustioso de infinito- y los bajos fondos de la realidad cotidiana. ${ }^{108}$ Nuestro homme du dieu, homme du diable, fue capaz de reconciliar mundos opuestos y aparentemente contradictorios: la comedia como "teatro del orden" y las piezas dramáticas breves como "teatro del desorden". Supo moverse entre estos dos planos, impregnado, como estaba, del realismo picaresco del barroco.

${ }^{108}$ Véase Valbuena Prat [1956: 116]. 


\section{TEATRO DEL MUNDO, TEATRO DE LA CONCIENCIA}

\section{El GRAN TEATRO DEL MUNDO}

Sacaremos a colación una antigua metáfora, la del gran teatro del mundo. ${ }^{109}$ Un mundo que, además de ser teatro, puede ser al revés, construido sobre una inmensa negativa moral. Un mundo que puede transfigurarse en mesón ${ }^{110}$ o laberinto.

La metáfora del mundo como teatro es muy antigua. Diógenes Laercio [1982: II, 103] en Vidas de los más ilustres filósofos griegos explica que Pitágoras, además de gozar de la trasmigración de su alma sin previo olvido de sus existencias anteriores -libre a los efectos del Leteo-, "comparaba la vida humana a un concurso festivo de todas gentes; pues así como unos vienen a él a luchar, otros a comprar y vender, y otros, que son los mejores, a ver; también en la vida unos nacen esclavos de la gloria; otros, cazadores de los haberes, y otros filósofos, amantes de la virtud." Plotino en las

${ }^{109}$ Cfr. Maravall [1986: 320 y ss.].

${ }^{110}$ Un documento, fechado el 27 de agosto de 1631, es una aprobación de Quevedo a una obra titulada El mesón del mundo, de Rodrigo Fernández de Ribera. Cfr. Krzysztof Sliwa [2005:466]. Asimismo, en una carta al canónigo toledano Alonso Mesía, del 7 de diciembre de 1629, don Francisco alude a la venta como metáfora de nuestra vida mundana: "No he visto hombre malo contento con una culpa, ni cansado con muchas. Ya que nuestro cuerpo sabe ser venta siempre, sepamos ser huéspedes alguna vez. Si no supiéramos evitar los hurtos, riñámoslos, siquiera hagamos de nuestra alma el caso que hizo aquel de un sombrero viejo, advirtiendo que el caminante está en la venta de paso y nosotros de por vida. Vivamos como entre ladrones, pues sabemos que vivimos en venta, no cuándo saldremos de ella." [Krzysztof Sliwa, 2005: 450] 
Eneadas (II ,III; XVI, XVII) glosaría el mismo concepto. Un ejemplo de la cotidianidad con que Quevedo utilizaba este tópico figura en el prólogo de los Sueños (1627):

no sé en qué manos ni en qué lenguas ha de dar este libro que sale agora al teatro del mundo, donde nunca faltan censurantes y mal contentos [2003: I, 205].

El Marqués de Valisero, al inicio de Cómo ha de ser el privado, también se siente desnudo ante el gran teatro del mundo. Entona un dubitativo parlamento a la Fortuna, temeroso de su futuro como valido:

\author{
Fortuna, expuesto me dejas \\ en el teatro del mundo \\ a ser blanco sin segundo \\ de sus invidias y quejas. (I, vv. 69-72)
}

En El discurso de todos los diablos (1628) se describe la vida humana como una representación con papel asignado, ya sin sentido cuando los espíritus difuntos aguardan en el palco del Juicio Final:

Y no acabara de ensartar epítetos y blasones de su locura si no le dijera el fiscal que callase, que ya aquel papel le había representado en la vida y que, acabada la comedia del mundo, era ya reo acusado. [2003: II, 511].

En vano puede agitarse un alma en el infierno que ya ha sido despojada de sus atributos. El guión del papel cae en la laguna Estigia cuando el 
vocinglero Caronte tiene la amabilidad de trasladarnos a las orillas del Más Allá. ${ }^{111}$

La grandeza de Calderón de la Barca, veinte años más joven que Quevedo, se debe a su capacidad para plasmar el perenne arquetipo de la falsedad de las apariencias mundanas en una obra metateatral y de resonancias bíblicas, de arrolladora fuerza moral. ¿El título de la obra? Obrar bien, que Dios es Dios. ¿La única frase del apuntador? Es fácil de recordar: Ama al otro como a ti, y obra bien, que dios es dios.

El gran teatro del mundo, escrito hacia 1645 y representado en 1649, de fama mundial y de universalidad latente, se debe a una fuente indiscutible. ${ }^{112}$ El neoestoico Quevedo, ávido lector y traductor de las Epístolas a Lucilio de Séneca ${ }^{113}$, publicaba años antes una libre traducción en verso, Epicteto y Focílides en español con consonantes (Madrid, 1635) ${ }^{114}$ en la que figuraba un pasaje en silva de consonantes bajo el epígrafe "La

${ }^{111}$ Patrimonio de esa concepción de la vida pasajera, se conservan todavía múltiples “capillas de huesos” legadas del siglo XVII, sobre todo en Italia y Portugal. En Évora, ciudad que atesora uno de los más relevantes manuscritos quevedianos teatrales, se encuentra una de las "capelas dos ossos” más emblemáticas.

${ }^{112}$ Cfr. Valbuena [1941]. La edición que hemos manejado de El gran teatro del mundo es la de Eugenio Frutos Cortés, útil en cuanto a la especificación de las fuentes de la obra [1997: 25-26].

${ }^{113}$ Véanse las Noventa epístolas de Séneca traducidas y anotadas por Quevedo. FernándezGuerra [1951, II: 381-389].

${ }^{114}$ Don Francisco conocería la traducción del Epicteto (Salamanca, 1600) por el Brocense (que tuvo tres reediciones en 1612 en Madrid, Barcelona y Pamplona), las versiones de De beneficiis de Gaspar Ruiz Montiano, el Espejo de bienhechores y agradecidos (Barcelona, 1606); la Doctrina moral de las epístolas que Lucio Aeneo Séneca escribió a Luzilo de J. 
vida es una comedia, el mundo teatro, los hombres representantes, Dios el autor, a él toca repartir los personajes, y a los hombres representarlos bien" (capítulo XIX):

No olvides que es comedia nuestra vida

y teatro la farsa el mundo todo

que muda el aparato por instantes,

y que todos en él somos farsantes;

acuérdate que Dios, de esta comedia

de argumento tan grande y tan difuso,

es autor que la hizo y la compuso.

Al que dio papel breve,

sólo le tocó hacerle como debe;

y al que le dió largo,

sólo el hacerle bien dejó a su cargo.

Si te mandó que hicieses

la persona de un pobre o de un esclavo,

de un rey o de un tullido,

haz el papel que dios te ha repartido;

pues sólo está a tu cuenta

hacer con perfección el personaje,

en obras, en acciones, en lenguaje;

que al repartir los dichos y papeles,

la representación o mucha o poca

sólo al autor de la comedia toca. [1953: III, 395]

Mendo de Sande (Madrid, 1612); la versión de Carrillo Sotomayor de De la brevedad de la vida y el Desengaño de la Fortuna de Gutierre Marqués de Careaga. 
Aquejado por la fiebre estoica del humanismo, Quevedo había leído los típicos Thesaurus europeos, gavillas morales entre las que destacaban corpus de autores de moda, encuadernados en libros de faltriquera del estilo del Philosophiae moralis: Epicteto, los Caracteres de Teofrasto, Pitágoras, Séneca, La Tabla de Cebes... Obras doctrinales y expositivas que influyeron notablemente en su teatro serio y que expresaban en términos filosóficos la teatralidad de la vida mundana.

En el epistolario de nuestro autor hemos hallado una carta destinada al amigo y colaborador teatral Antonio Hurtado de Mendoza escrita desde Madrid en 1632. En ella, con sinceridad sangrante y desnudo intimismo, Quevedo reflexiona acerca de la muerte y la fragilidad del ser humano. Apela a las citas de sus consagrados autores paganos (Séneca, Epicteto, Marcial, Platón, Salustio, Lucrecio) y de personajes bíblicos (Job, San Pablo, David), con una particular aceptación estoica y cristiana del sepulcro. En ella emerge el tópico del mundo como teatro:

Todo fue mentira y representación. "Hasta la vida propia (como dice Epicteto) es una comedia. Conviene a cada uno de nosotros hacer bien nuestro papel, sea el que fuere; pero a Dios toca dárnosle. No es de nuestro poder el escoger el del rey, o el del pobre, o el de ignorante, o el de discreto; que eso, y darle largo o corto, toca al autor de la farsa". Sólo nos ha de consolar ver que el ser rey, papa, pobre y humilde, dura sólo mientras hacemos las figuras en el tablado de la vida; que en entrando en el vestuario de la sepultura, todos somos igualmente representantes, y se reconoce que la diferencia estuvo sólo en los vestidos.

Hizo mi amigo ya su personaje: dióle Dios el papel corto; acabóle en pocos años; desnudóse la ropa del cuerpo, dejóla en el vestuario de la tierra, y descansa ya del 
oficio trabajos; que así (como dice San Pablo) "pasa la figura de este mundo". [Krzysztof Sliwa, 2005: 475]

Sea pues, el mundo, un teatro. La tierra se erige como escenario, árboles y flores son sus bambalinas, los astros generan los efectos de iluminación y Dios, el autor y público de la representación -creador y juez ambivalente-, distribuye papeles a sus personajes, que se lanzarán a la escena sin previo ensayo y que después recibirán abucheos o aplausos, en función de su calidad de actores.

\section{EL GRAN TEATRO DE LA CONCIENCIA}

Quevedo había visto el tríptico del Bosco, hoy denominado El carro de heno, expuesto en el Museo del Prado de Madrid desde la Guerra Civil. Lo contempló en el Escorial, donde lo había ubicado Felipe II tras comprárselo a don Felipe de Guevara en 1570.

Don Francisco vio las dos tablas laterales que, al cerrarse, representan un pasaje titulado "El Camino de la vida", donde figura un viajero rodeado por los obstáculos del trayecto. Abiertas, la de la izquierda ilustra la creación, el pecado original y la expulsión del Edén, y la de la derecha, el infierno, coronado por una torre maligna y los cuerpos compungidos de los pecadores: gritos casi audibles en el pictórico silencio.

El cuadro central está protagonizado por el carro de heno que confiere el título a la obra, en alusión al siguiente pasaje bíblico: “mis días cual humo 
se desvanecen/ y arden mis huesos como fogón./ Requemado, cual heno, mi corazón se seca,/ pues me olvido aún de comer mi pan.” [Salmos, 102:4-6]

Pero, ¿a qué viene esta somera descripción de un cuadro? Pues bien: $E l$ carro de heno plasma pictóricamente algo que caracteriza, a nuestro juicio, la obra dramática de Quevedo: el teatro de la conciencia.

Todo genio que se precie es supraconsciente. Don Francisco fue un hombre de violentos y abruptos contrastes, autor de la Providencia de Dios y de la Introducción de la vida devota, pero también del Buscón. ${ }^{115} \mathrm{Su}$ rica y compleja psicología le empujó a escribir una obra donde se alternan santos y bufones, una mixtura de cinismo y devoción. Su individualismo es, probablemente, producto y víctima del Renacimiento, si bien con el añadido de lo "fatalmente Barroco". Supo adaptar sus contradicciones a los géneros que cultivó. Reflejó la vía del pecado a través de su caricaturización grotesca, la vis comica, y retrató el sendero del bien en lo que muchos llaman su "obra seria", de rigor teológico y moral.

¿Cuál es el camino correcto?¿Con qué signos cuenta el ser humano para no desorientarse en su búsqueda de la verdad? El investigador actual, postnietzscheano, puede plantearse estas cuestiones con cierto escepticismo o un irónico arqueamiento de cejas. Sería, sin embargo, un anacronismo proceder así. Estos interrogantes eran absolutamente indispensables en la literatura aurisecular y nos servirán para comprender la alegoría de los dos

115 Aubrey Bell [1928: 203-211]. Américo Castro en su edición del Buscón [1927: 78] ya había aludido al "complejo dualismo" de nuestro escritor, que Gracián en El Criticón había comparado con el tabaco, más propenso al vicio que a lo beneficioso. 
senderos o bivium. Esta dicotomía, con todo, es un precepto que ya estaba presente en el Evangelio:

Entrad por la puerta angosta, porque amplia es la puerta y ancho el camino que conduce a la perdición, y son muchos los que entran por ella. ¡Qué angosta es la puerta y estrecho el camino que conduce a la Vida, y qué pocos son los que la encuentran! [Mateo, 7:13-14].

Quevedo, como buen neoestoico y aspirante a sabio (proficiens), en contraposición al necio (stulti), distinguió claramente entre los designios de la voluntad humana y los caprichosos azares de la Fortuna, la sesuda y desmemoriada vieja mitológica que invierte sus caprichos en La hora de todos.

El proficiente aspira a avanzar por un camino de perfección -valga el eco de la obra de Teresa de Ávila-, sortear los posibles obstáculos y escoger la vía adecuada ante cada bifurcación. El homo viator, peregrino en la tierra, debe utilizar su libre albedrío para elegir el sendero de la virtud cuando se encuentra en la bifurcación de caminos, sesuda elección que también se ha conocido como $Y$ pitagórica, Littera Pythagorica, o también Furca Pitagórica o Cruz Ypsilon. ${ }^{116}$

${ }^{116}$ Otro tópico para designar semejante encrucijada moral -vigente en el arcano VI del Tarot de Marsella- es el Hercules Prodicius, o Bivium virtutis et vitii, en donde Vicio y Virtud, alegóricamente representados por dos bellas mujeres, muestran al héroe el aparentemente fácil camino del pecado frente a la angosta vía del bien. Así lo pintaron Rafael (El sueño del caballero, 1501), Paolo Veronese (Joven entre la Virtud y el Vicio, 1580), Annibale Carraci (Hércules en la encrucijada, 1596) o Nicolas Poussin (La elección de Hércules, 1636). 
Por otra parte, en la Tabla de Cebes - probablemente del siglo I d.C- , el primer texto griego leído y traducido de la Ratio Studiorum, se ofrece una explicación de un cuadro pintado lleno de figuras que representa la vida, donde el hombre es un extranjero perdido en una bifurcación de caminos. Quevedo conocía muy bien este texto: manejó la traducción de Hieronymus Wolf, editada junto con el Enchiridion de Epicteto en Colonna, en 1596. ${ }^{117}$ En el diálogo filosófico, emparentado con la ékphasis griega, las figuras están dispuestas en una suerte de teatro moral, donde el peregrino se enfrenta a la elección entre el camino del vicio y la virtud. No en vano la versión de 1669 llevó por título Theatro moral de toda la Philosophia de los antiguos y modernos [...] y la edición de Francisco Foppens de 1672 se intituló Theatro moral de la vida humana.

Los personajes incluidos en el teatro de Quevedo podrían obedecer a la clasificación que ofrece Ambrosio de Morales en el Argumento y breve declaración de la Tabla de Cebes, que se reconcilian con los pecadores y los santos del imaginario cristiano, si bien los segundos de esta lista pueden aspirar a la bienaventuranza:

117 Señala, al respecto, Sagrario López Poza [1994: 95]: "Esta obra está entre las ciento setenta y seis que pertenecieron a Quevedo, que se relacionan en los inventarios hallados en el Archivo de Protocolos de Madrid y que dio a luz Felipe C. R. Maldonado.De las versiones en español, es muy posible que Quevedo conociera la traducción de Juan de Jarava, el médico erasmista que también había traducido el Sueño de Escipión y el Icaromenipo de Luciano; asimismo, es bastante posible que conociera la versión de Ambrosio de Morales, a quien él admiraba como historiador." 
Unos caminan con la sola guía de sus apetitos y sensualidad. Estos tienen por ley su sola voluntad. En ellos tiene absoluto poderío el deleite. Merecen ser vituperados y aborrecidos.

Otros, guiados por la razón y rigiéndose por ella. Ponen a sí mismos en buena sujeción. Prevalece en ellos la razón y buen juicio. Pero en teniendo un buen arte u oficio frenan su deseo de ascenso hacia la verdadera felicidad. Es meritorio que no se dejen de arrastrar de apetitos, pero es censurable que se queden en ocupaciones mundanas.

La tercera clase de hombres, caminan derechos a la virtud. Su grandeza de ánimo y la excelencia de su entendimiento los ensalza a cosas mayores sin contentarse con menos. Son justamente alabados y envidiados. [Cfr. López Poza, 1994: 92-93]

Reza el lema latino: Augusta per angusta. El sendero de la gloria es angosto, tal y como había dicho Virgilio en la Eneida y Dante en la Comedia. ${ }^{118}$ Quevedo hace notar en el Sueño del infierno a dónde llegan sus ojos peregrinos:

Tendí los ojos, cudiciosos de ver algún camino por buscar compañía, y veo, cosa digna de admiración, dos sendas que nacían de un mismo lugar, y una se iba apartando de la otra como que huyesen de acompañarse. [2003:I, 277]

El camino de la virtud es, decíamos, duro y estrecho; recorrerlo exige el desdén de los placeres corporales, pobreza, ascesis, fuerza de voluntad, represión ante las tentaciones y fe en la divinidad. Esta senda es la que busca Quevedo en sus obras político-morales y, por extensión, en Cómo ha

${ }^{118}$ Cfr. Sobre las relaciones entre Dante y Quevedo, resulta de sumo interés el estudio de Rodrigo Cacho, basado en un ejemplar anotado de la Comedia actualmente depositado en la Biblioteca de la Universidad de Illinois [2003]. 
de ser el privado. Basta pensar en la firmeza de Job para entrever la capacidad de sufrimiento que requiere todo aspirante al reino de Dios:

Era la de la mano de la derecha tan angosta que no admite encarecimiento, y estaba, de la poca gente que por ella iba, llena de abrojos, y asperezas y malos pasos. Con todo, vi algunos que trabajaban en pasarla, pero por ir descalzos y desnudos se iban dejando en el camino unos el pellejo, otros los brazos, otros las cabezas, otros los pies, y todos iban amarillos y flacos, pero noté que ninguno de los que iban por allí miraba atrás, sino todos adelante. [2003: I, 277]

El jocoso protagonista pregunta a un mendigo si es posible recorrer el camino a caballo, y éste le responde que incluso San Pablo perdió su rocín justo antes de su iluminación. ${ }^{119}$ Pecador como se retrata, Quevedo pronto desdeña un sendero sin ventas ni carruajes:

Di un paso atrás y salíme del camino del bien, que jamás quise retirarme de la virtud que tuviese mucho que desandar ni que descansar. Volví a la mano izquierda y vi un acompañamiento tan reverendo, tanto coche, tanta carroza cargada de competencias al sol en humanas hermosuras, y gran cantidad de galas y libreas, lindos caballos, mucha gente de capa negra y muchos caballeros. Yo, que siempre oí decir "Dime con quien fueres y direte cuál eres", por ir con buena compañía puse el pie en el umbral del camino y sin sentirlo me hallé resbalado en medio dél como el que se desliza por el hielo, y topé con el que había menester, porque aquí todos eran bailes y fiestas, juegos y saraos, y no el otro camino, que por falta de sastres iban en

${ }^{119}$ La caída específicamente del caballo, no obstante, no aparece en la Biblia (Hechos de los apóstoles, 9: 3-7 y 26, 12 y ss.), ni la avala San Agustín o la iconografía bizantina. Masucio consideraba que la alusión al caballo de San Pablo es de origen luterano. Cfr. Valentina Nider en su edición crítica de La caída para levantarse [1994: 131]. 
él desnudos y rotos, y aquí sobraban mercaderes, joyeros, y todos oficios. [2003: I, 279-280]

Quevedo nos ha descrito el escenario moral de su teatro breve. Un espacio urbano lleno de colorido, fiestas y oficios diversos, repleto de pidonas, coimas, cornudos, viejos pedantes y jayanes, un sinfín de figuras ligadas al interés de sus estómagos flemáticos. En el Mundo por de dentro, el andrajoso Desengaño le mostrará esta "calle mayor del mundo", cuyo nombre es Hipocresía [2003:I, 362]; y, en el Sueño de la Muerte desfilarán, precisamente, estos personajes actuando para su fantasía como en una obra de teatro:

Luego que desembarazada el alma se vio ociosa sin la traba de los sentidos exteriores, me embistió desta manera la comedia siguiente, y así la recitaron mis potencias a escuras siendo yo para mis fantasías auditorio y teatro. [2003: I, 391]

Don Francisco quiere representar el teatro de la conciencia humana. Existe una vía de reconciliación entre Quevedo y el género teatral a través del eximente teológico. La felicidad suma es la auténtica sabiduría, por lo que el sabio (sapiens) redactará múltiples tratados morales para que su discípulo no tuerza su camino. ¿El título de la obra? Obrar bien, que Dios es Dios. 
- 680 - 


\section{CONCLUSIón}

Llegados a este punto, hemos conocido a un Quevedo calidoscópico: aficionado a la farándula, escritor palatino por encargo, crítico teatral y moralista contrariado que vivió bajo el reinado de Felipe II, Felipe III y Felipe IV. Hemos insistido en la relevancia de revisar la bibliografía descriptiva y cotejarla con nuestras propias hipótesis, extraídas directamente de la bibliografía enumerativa existente. ${ }^{1}$

Esta aventura planificada tenía, desde el principio, dos objetivos fundamentales: el rescate de textos inéditos y la aportación de nuevos enfoques en el estudio literario de don Francisco. Con todo, no sólo pretendíamos la sistematización de la nómina del teatro de Quevedo y la confección de un catálogo de los testimonios manuscritos e impresos del mismo, sino también señalar los vínculos temáticos entre éste y el conjunto global de su inmensa escritura.¿Qué novedades aportamos?¿Qué conclusiones extraemos?

Hemos elaborado, en el capítulo I -EL TEATRO DE QUEVEDO Y SUS TESTIMONIOS DOCUMENTALES-, una herramienta filológica, un catálogo de los testimonios manuscritos e impresos conservados del teatro de Quevedo. ¿Por qué? Porque scripta volant; porque la fijación del teatro aurisecular ha

1 "Quisiera concluir con dos observaciones: hacer una tesis significa divertirse y la tesis es como el cerdo, todo tiene provecho." Son muy sinceras estas palabras de Umberto Eco. También dice que escribir una tesis doctoral es una gimnasia mental muy saludable. Siguiendo su consejo, he procurado no desarrollar esa enfermedad que él denomina neurosis de la tesis doctoral, que empieza a presentar una clara sintomatología pasado el límite de los tres años de investigación. 
sido vapuleada por censores, memorillas y malos copistas y requiere de un sólido registro; porque muchos manuscritos de Quevedo se dispersaron en 1643, después de su prendimiento en San Marcos de León, y todavía hoy en día pueden aflorar nuevos testimonios; y porque disponer de una nómina del corpus dramático es un requisito indispensable para entrar en materia y recomponer el rompecabezas del pasado. Es tan pantanoso el territorio sobre el que queríamos cimentar este trabajo, que un catálogo como il faut era nuestro chaleco salvavidas. ${ }^{2}$ Los documentos conservados son las únicas pruebas irrefutables de nuestras argumentaciones.

Durante la recensio, recorrimos aquellas bibliotecas que figuraban en las ediciones modernas y, sobre todo, en catálogos posteriores a la edición de Blecua, como el de Isabel Pérez Cuenca [Catálogo de los manuscritos de Francisco de Quevedo en la Biblioteca Nacional, 1997] o el de Miranda [Manuscritos quevedianos en las bibliotecas portuguesas, 1988]. Como ya hemos visto, nuestro periplo abarcó la BNE, el IT de Barcelona, la BMP de Santander, la BC de Sevilla, la BHSA de Nueva York (gracias a la ayuda de Júlia), la BN de Portugal, la Biblioteca Pública de Évora y la Biblioteca de la Universidad de Coimbra.

De estas pesquisas surgieron algunos títulos actualmente inéditos atribuidos a Quevedo: a saber, la comedia de valimiento presuntamente perdida y recuperada por Germán Vega [1993], La privanza desleal y voluntad por la fama, ubicada en cajas sin catalogar de la BNE; la comedia

2 Esperemos que el Catálogo bibliográfico del teatro de Quevedo sea útil a todo futuro editor del teatro de Quevedo: formará parte del Diccionario filológico de los siglos XVI y XVII que Castalia ha proyectado editar en un futuro próximo. 
homónima a la de Calderón El galán fantasma, erróneamente catalogada como entremés en el IT; dos entremeses atribuidos a Miguel de Mussa o Mulsa (nombre que se había confundido con un pseudónimo de juventud de Quevedo), emplazados en la BNE y con copias autógrafas de Cotarelo y Mori y Aureliano Fernández Guerra conservadas en el IT; la comedia burlesca inacabada ¿Qué villano es el amor!, conservada en la BNE, la "jácara" A los amores del Rey Rodrigo y la Cava de la Universidad de Coimbra y dos bailes por consignar "Picarilla, picarilla..." y la Comedia de las dependencias de España, en un códice manuscrito de la BNE. Obras que, por cierto, hemos editado sucintamente en un apéndice, con la finalidad de que puedan seguirse estudiando.

También nos dispusimos a elaborar una descripción pormenorizada de la caligrafía, el ductus y la forma particular de puntuar, sangrar y unir palabras de Quevedo. Una información que el investigador suele asimilar muy intuitivamente a partir del cotejo de autógrafos corroborados, pero que todavía no se ha descrito profusamente. Esta es otra herramienta de trabajo filológico: en el momento en que uno reconoce la escritura manuscrita de un autor determinado, podemos deducir qué documentos nacieron efectivamente de su puño y letra. Vemos que los entremeses que pertenecieron a Crosby, hoy localizados en la BHSA, Los refranes del viejo celoso y El hospital de los malcasados, si los comparamos con el listado de autógrafos de nuestro autor - que ha delimitado, de momento, Alfonso Rey [1985: 64-65] en el prefacio a su edición de Virtud militante- no surgieron directamente de la pluma de Quevedo. 
Del capítulo II -QUEVEDO Y EL TEATRO CORTESANO- hemos podido extraer una biografía teatral de Quevedo. Hemos remarcado las circunstancias más dramáticas de su vida. Nos sorprende imaginarlo estudiando el teatro escolar de los jesuitas, en malandanzas con comediantes poco escrupulosos y un Duque de Osuna muy abocado a lo farandulesco, o conociendo la nata y crema de la escena teatral italiana. Lo vemos ejerciendo de dramaturgo por encargo cortesano, amparado por el mecenazgo aristocrático, pero también desengañado de las vanidades del teatro y alejado del Buen Retiro, ya hacia el final de su existencia, muy aferrado a las polémicas sobre la licitud teatral y desengañado, en realidad, del mundanal ruido.

El capítulo III- ENTRE COMEDIAS Y DRAMATURGOS- ha enfatizado en los vínculos de Quevedo con otros escritores auriseculares con los que colaboró teatralmente, sobre todo Hurtado de Mendoza, también llamado el discreto de palacio, que acató las mismas misiones propagandísticas que nuestro autor, si bien en un tono más sosegado, menos mordaz y atrabiliario. Poco sabemos de Mateo Montero, el otro socio teatral destacado por las Relaciones de Casiano Pellicer, y la relación que mantuvo con Quevedo: nos quedamos con su complicidad amistosa y la anécdota de que fueron compañeros de viaje -y de caída- durante la expedición a Andalucía de Felipe IV, en 1624.

¿Qué opinaba Quevedo de la escena de su tiempo? En La Perinola dejaba las tablas a Lope, Calderón o Vélez de Guevara. Nosotros hemos analizado sus anotaciones a la traducción de la celestinesca Comedia Eufrosina, de Jorge Ferreira de Vasconcellos: en estas insinúa la relevancia 
del mensaje moral, del delectare et prodesse, de un mass media como el teatro. A continuación, hemos profundizado en la relación de respeto y mutua admiración literaria que entablaron Lope y Quevedo: ambos participaron en las fiestas monárquicas de 1631, cuando don Francisco compone, junto con Hurtado de Mendoza, Quien más miente, medra más y Lope escribe La noche de San Juan; don Francisco, además, alaba, en su aprobación, la alta doctrina de las Veinte y una parte verdadera de las comedias de Félix Lope de Vega Carpio.

Luego, al otro lado de la balanza, nos encontramos con los dramaturgos cuyo estilo Quevedo rechazó... o que la crítica literaria ha hecho repudiar. Nos arriesgamos, en primer lugar, a relacionar una desconocida comedia en prosa contra don Francisco, por cuya autoría encarcelaron a Pacheco de Narváez, con los Peregrinos discursos, redactados en forma de diálogo, que ridiculizan la Política de Dios. Aludimos, asimismo, a la feroz invectiva quevedesca de La Perinola contra Pérez de Montalbán, el licenciado libruno, que nuestro autor acusa de plagiario de Lope. También aventuramos que, tal vez, Quevedo redactara una réplica dramática contra El Retraído de Jáuregui, que habrían firmado su mecenas, el Duque de Medinacelli, y su testaferro, don Alonso Mejía de Leiva, puesto que siempre tiene más empaque la defensa ajena que la propia. Mencionamos, por supuesto, las pullas de Quevedo contra el Antecristo de Juan Ruiz de Alarcón, al que acusa de plagiador y artífice de pastiches. Y, por último, le conciliamos con un autor que la reciente historia literaria se ha empecinado en antagonizar: ¡Góngora, por supuesto! Efectivamente, la mayoría de poemas antigongorinos de Quevedo se cimentan sobre un solo testimonio 
sin atribución (así lo han señalado algunos gongoristas como Robert Jammes o Antonio Carreira). ¿No es sorprendente que Tarsia, el primer biógrafo de don Francisco, apenas aluda a esta enemistad? ¿No es increíble que no haya ni una sola carta en el epistolario de Quevedo en la que el autor se desahogue criticando a don Luis? ¿Y el testimonio de Francisco Manuel de Melo al respecto? La obra dramática de Góngora presenta algunas similitudes con la de Quevedo, por cierto. No pretendemos convencer a nadie, pero quisiéramos dar qué pensar. La historia de la literatura puede rescribirse: es nuestra hipótesis de partida.

¿Cuáles son las huellas de Quevedo en el teatro aurisecular? La relación es bidireccional. Sus comedias promovieron el aplauso cortesano, sus entremeses sirvieron de modelo a Quiñones de Benavente y otros dramaturgos más celebrados que él mismo, fue pionero de la jácara (así lo muestra su célebre Carta de Escarramán a la Méndez), contribuyó a la fijación del baile entremesado e inspiró de algunos motivos del teatro calderoniano. A pesar de los notables silencios críticos al respecto, una consciente búsqueda de testimonios solventes muestra que Quevedo fue una figura clave en la producción dramática de su tiempo.

El capítulo IV- EL QUEVEDO COMEDIÓGRAFO- analiza, entre otros aspectos, la relación entre la doctrina política de don Francisco y su única comedia de atribución segura, Cómo ha de ser el privado. Esta pieza palatina pertenece al subgénero de las comedias de privanza. Al contrario que lo estipulado en el Arte nиevo de Lope, en esta obra la doctrina neoestoica predomina sobre la acción dramática, que es mínima y se sustenta sobre tres motivos: el panegírico del Conde Duque de Olivares, la 
alusión al matrimonio frustrado entre el Príncipe de Gales y la Infanta Margarita y la tentación del monarca a la infidelidad. Estatismo teatral, acciones dramáticas truncadas y una lírica entrevista amorosa en sonetos (que eran más propios para monologar, según la fórmula lopesca) son los rasgos característicos de una obra que, a todas luces, estuvo escrita bajo las premisas del encargo palatino.

¿Qué sucede con las comedias que nos han llegado incompletas? La segunda escena de la comedia Pero Vázquez de Escamilla, parodia del estilo culterano, se inicia con un parlamento de don Pedro que ofrece ligeras variantes del poema Llama a Aminta al campo en amoroso desafío (POC, 389), publicado en la Segunda parte de las flores de poetas ilustres de Juan Antonio Calderón [1611: 226 y ss.]. Tal vez la obra dramática inconclusa estuviera escrita con la premura del encargo palatino y pretendiera reaprovechar el mentado poema. Por otra parte, vemos esbozado el tópico contra el matrimonio en el Breve fragmento de comedia: una pieza inconclusa de once redondillas que, como el entremés del Marido pantasma, ve en las nupcias más inconvenientes que atractivos.

La comedia perdida Quién más miente, medra más, que se representó la noche de San Juan de 1631, tal vez puede reconstruirse a partir de la comedia Los empeños del mentir de Antonio Hurtado de Mendoza. Reforzamos la hipótesis de Doménech [2002] agregando un dato curioso: la crítica apenas ha relacionado la comedia perdida con la Loa para la comedia "Más medra quien miente más" que se hizo en el Buen retiro, el día de San Pedro de 1634 de Hurtado de Mendoza, que nos induce a creer que la obra fue escenificada de nuevo en esa fecha, quizá reelaborada por éste. 
Lo más novedoso del capítulo, sin duda, es la alusión a dos comedias inéditas y atribuidas a Quevedo. Germán Vega nos indicó la signatura del impreso de La privanza desleal, ubicada en cajas sin catalogar de la BNE. Su escritura despersonalizada puede cimentarse en su carácter por encargo o se debe a una posible coautoría. Es una pieza sui generis, en la que intrigas amorosas de poco ingenio relegan el tema de la privanza a un segundo plano. Abunda en extravagancias argumentales, y sus poco fructíferos juegos lingüísticos nos hacen dudar de una supuesta copaternidad quevedesca.

También hemos analizado una comedia atribuida a Quevedo y homónima a una de Calderón, El galán fantasma, camuflada en el catálogo del IT por su confusión con el entremés del Marido pantasma. El, de momento, testimonio único de esta comedia está cribado por tres censores distintos (entre los que destaca Navarro de Espinosa), tiene múltiples borrones y pasajes tachados y la letra de tres amanuenses distintos del siglo XVII. Es una clásica comedia de enredo que despunta, sin embargo, en una peculiaridad: el gracioso tiene una dicción muy quevedesca. Al final de la obra, como aconsejaba doña Fáfula a su marido comediante en El sueño de la muerte, sale soltero, contraviniendo al tópico de los desenlaces en boda.

Las dificultades de edición de esta obra han inspirado un proyecto que actualmente estoy valorando con el asesoramiento del CSIC, la elaboración de una nueva herramienta filológica: la aplicación de la reflectología de infrarrojos a manuscritos censurados por la Inquisición. Esta tecnología, que actualmente se aplica a obras pictóricas (el Museo del Prado es pionero, en 
este sentido) permitiría realizar ediciones más fidedignas, leer detrás de la mancha de tinta, sortear la feroz censura del barroco.

En el capítulo V- LOS ENTREMESES DE QUEVEDO-, indagamos en el nuevo mundo de la risa entremesil: un retablo de personajes vituperables y arquetípicos, de verbo fluido y canallesco. Es importante ubicar los leitmotivs satíricos de nuestro autor en estas obrillas: el arte de desplumar femenino, la crítica contra el matrimonio y el cuadro de figuras examinadas moralmente. Muchos de los personajes femeninos beben de la tradición celestinesca. Vetulas como la Ropavejera, la Vieja Muñatones o la Madre Monda enseñan a sus pícaras discípulas las artes de pedir y robar la bolsa, a veces con metafóricos movimientos de esgrima.

La pidona, antagónica a la dama ideal del renacimiento, es seductora y mundana, representa la perdición del hombre y de su hacienda. La relación con ella, desemboca en el peor sambenito: el matrimonio. Quevedo da forma al arquetipo del marido cornudo o consentido en su Diego Moreno, invierte los roles maritales en El marión y manifiesta el temor de enyernar y el placer de quedar viudo en El marido pantasma.

A lo largo de este capítulo, también exponemos las conjeturas de atribución de Los refranes del viejo celoso, que Blecua acepta con reservas. Bergman asigna esta pieza a Quiñones de Benavente, y devuelve a don Francisco el entremés de Las sombras, actualmente considerado apócrifo. Destacamos, por otra parte, el entremés de La venta como retablo costumbrista de tipos satíricos, muy impregnado de voces de germanía y recursos metateatrales y El zurdo alanceador como ejemplo de entremés a examen de arquetipos risibles condenados moralmente. 
Como novedad, comprobamos que dos entremeses atribuidos a un tal Miguel de Mulsa no fueran en realidad de Quevedo, escritos bajo un seudónimo de juventud. No estamos convencidos de la autoría quevedesca de estas obrillas. Miguel Mussa no parece, entonces, un alias de nuestro autor, sino el nombre de un escritor vallisoletano de segundas.

En el capítulo VI - Dos COMEDIAS BURLESCAS ATRIBUIDAS A QUEVEDOanalizamos El premio de la hermosura y ¡Qué villano es el amor! Astrana Marín desechaba la autoría de la primera alegando que no era otra que la homónima de Lope, publicada en la XVI parte de sus comedias. Si hubiera cotejado este testimonio con la comedia del Fénix habría visto que se tratan de obras completamente diferentes. A pesar de que el manuscrito que se conserva tiene letra del siglo XVIII, por su temática y usos lingüísticos bien podría ser del XVII: pertenece a la tradición lucianesca de la parodia de los dioses olímpicos y confluye temática y retóricamente con la obra satírica de Quevedo. Cotarelo y Mori tenía preparada una edición de esta pieza, que no se ha llevado a cabo hasta 2003, a cargo de Alberto Rodríguez.

Respecto a la comedia inacabada ¡Qué villano es el amor!, Astrana Marín también rechazó la autoría quevedesca apelando a que la obra, por estar escrita con letra del siglo XVIII, no pertenecía al barroco español. Encontramos, por suerte, en el Fondo Sedó del IT una copia del ms. de la BNE anotado por Cotarelo y Mori, donde decía: "Por los retrúecanos puede muy bien ser de Quevedo. Que pertenece al siglo XVII no cabe duda."

¡Qué villano es el amor!, pieza inédita que publicamos por primera vez, volvería a aparecer más adelante. En el ms. 324 de la Universidad de Coimbra, el romance $A$ los amores del rey Rodrigo y la Cava, sin autor 
explícito pero contiguo a unos poemas de Quevedo, contiene un verso idéntico al título de la comedia burlesca inacabada que nos ocupa (v. 246). Este hecho nos induce a establecer una relación entre ambas obras.

En el capítulo VII - JÁCARAS Y BAILES- abordamos las composiciones dramáticas breves que González de Salas editó y aglutinó por primera vez bajo la apostilla de la musa V del Parnaso (1648), Terpsícore.

Las jácaras son piezas escritas en jerga de germanía, que narran la vida y milagros de los jaques, cuyas cualidades antiheroicas están prefiguradas en la novela picaresca y llegan a tener unas contrapartidas creativas harto curiosas. El estoicismo del bribón que es carne de horca se trasciende en las ejecuciones públicas, que le confieren el aspecto de un Cristo sufriente. Don Francisco da fuelle a este subgénero dramático a partir de su celebérrima Carta de Escarramán a la Méndez (POC, 849) y lo inserta en su comedia inacabada Pero Vázquez de Escamilla. Nos cuestionamos, sin embargo, en qué medida la jácara se desmarca de la lírica para pertenecer al ámbito dramático. Hay algunas composiciones tildadas de jácaras en sus testimonios auriseculares que, sin embargo, a ojos del crítico actual, pasarían por simples romances sin ninguna dimensión espectacular. Tal es el caso de La toma de Vallesronces, cuya atribución Blecua justifica, y la pieza inédita A los amores del rey Rodrigo y la Cava.

Asimismo, los bailes de Quevedo, de métrica variable y asuntos que parten de los modelos grecolatinos -según justifica el mismo González de Salas-, prosiguen con la descripción del mundo hampesco y las notas de color lingüístico de la jerga de germanía. Abundan, a su vez, en recursos metateatrales. Son sumamente interesantes en la medida en que albergan 
una sátira de las danzas antiguas. Constituyen un testimonio literario de la evolución que, a lo largo del XVII, entraña este género teatral, que poco a poco va ganando autonomía para con los finales de los entremeses y alcanza su clímax dramático en las composiciones de Quiñones de Benavente. Analizamos dos piezas atribuidas a Quevedo en sus testimonios más antiguos: descartamos definitivamente la paternidad de la Comedia de las dependencias de España y, por otra parte, ubicamos "Picarilla, picarilla..." (pieza que editó Felicidad Buendía y que eludió Blecua en su $P O C$ por razones que desconocemos) en la línea de la poesía amatoria antipetrarquista más lograda de nuestro autor, que literaliza con jocosidad las metáforas fosilizadas de la descriptio puellae.

En el capítulo VIII- LA FUERZA VERBAL DE QUeVEDO. Elementos SEMIÓTICOS DE SU TEATRO BREVE- discurrimos sobre la materia prima del arte literario, el lenguaje de Quevedo. Pirotécnico verbal, juega y experimenta hasta la genialidad con los recursos del idioma. Bajo la premura del encargo palatino, sin embargo, no consolida la libertad expresiva en su teatro grave, todo lo contrario de lo que sucede con su obra dramática breve, donde despliega las alas de la libertad carnavalesca, innova sobre la tradición y amolda los parlamentos de sus personajes más canallas al argot de la delincuencia aurisecular, la germanía.

Pero el teatro no sólo transcurre con palabras. El teatro es también gesto, música y coreografía, atrezzo y espectáculo. Por ello, indagamos en algunos aspectos semióticos de su obra dramática más lograda, su teatro breve. Esto es relevante en tanto que el teatro es un arte cuya culminación y sentido pleno se alcanza sobre un escenario. Tal vez las modestas pistas que 
proporcionamos animen a algún director dramático del siglo XXI a aventurarse en la interpretación de piezas nunca representadas en la actualidad.

En el capítulo IX- HACIA UNA FILOSOFÍA DEL TEATRO- pretendemos, como su propio nombre indica, filosofar sobre la obra dramática de don Francisco. Llegados a este punto, disponemos de datos e información necesaria para alzar el vuelo del intelecto e indagar en aspectos teóricos que nos atañen como la concepción genérica de nuestro autor, la antipoética teatral que dispersa a lo largo de su obra satírica en prosa y la labor filológica de humanista que nos transmite en materia teatral cuando analizamos los ejemplares de su biblioteca y las anotaciones autógrafas que actualmente se conservan sobre la Retórica de Aristóteles y las obras de Plauto, Terencio y Séneca.

También, en este capítulo, nos hemos adentrado en la intención, la calidad estética y el sustrato teológico-moral del teatro de Quevedo. El homme du dieu dispone las figuras como exempla de conducta virtuosa en las comedias de privanza: ve en las tablas la posibilidad de transmitir un sermón disfrazado por la fermosa cobertura del delectare et prodesse. A su vez, el homme du diable juega con la entropía del caos mundano: enseña ese mundo vituperable en el teatro breve, muestra un retablo de figuras grotescas que serán carne del Averno, contraejemplos de la moral cristiana.

La eficacia del fondo depende, en todo caso, de la ingeniosidad de la forma, porque el habla de los personajes teatrales está convenientemente enriquecida con una dicción que va del tópico petrarquista en los nobles y damiselas refinados de las comedias palatinas a la adquisición de 
neologismos, refranes y vocablos germanescos en boca de jayanes y pícaros del teatro breve. Quevedo, que para Octavio Paz representaba el escritor de la caída del hombre, plasma en su teatro no sólo un teatro del mundo. Orbita sobre su obra dramática, como en el Jardín de las delicias del Bosco, un teatro de la conciencia humana. 


\section{Agradecimientos}

Esta tesis está escrita con miles de manos. Mi pulso ha trabajado, organizado y tecleado los conceptos, es cierto, pero el entusiasmo, materia prima de este trabajo, ha sido infundido por las personas maravillosas a las que envío mis más profundos agradecimientos:

A mi madre, María Fernández, y a Patricia Mateos, mi mejor amiga, que me ven desde la mirilla del cielo.

A mi hijo Sàgar, nacido en el ojo del huracán, el bebé -cada vez menos bebé- que me enseña diariamente a hacer las cosas con cariño.

A mi cómplice Marçal Font, porque siempre hablamos de literatura en el terrado.

A Rosa Navarro Durán, mapa, faro y brújula del camino, por su confianza y apoyo.

A Pablo Jauralde Pou y el grupo Edad de Oro de la BNE: compañeros de viaje, amigos encontrados que me contagiaron su libropesía.

A Germán Vega, por proporcionarme la signatura de La privanza desleal $y$ voluntad por la fama. Por orientarme con amabilidad cuando tuve alguna duda.

A Carlos Vaíllo, por prestarme la edición de Cómo ha de ser el privado de L. Gentilli, y esas charlas fugaces frente a la fotocopiadora.

A Júlia Ibarz Pascual, aventurera incansable, que me hizo recados en la Hispanic Society de Nueva York.

A Rodrigo Cacho, que ha asistido a todas mis ponencias sobre el teatro de Quevedo y me ha infundido ánimos.

A José Manuel Blecua, que se me apareció en sueños. 
A Eugenio Asensio, que tocó conmigo el manuscrito evorense y justificó un maravilloso viaje a la tierra del fado y la saudade.

A mis hermanos Toni, Nico y Zaza; y a mi padre, Antonio Hernández Carpio: gracias por vuestro amor incondicional, ese que me abocó a la literatura desde la más tierna infancia.

A Anna Espí Boscà, Jordi Font-Agustí y Gerard Font Espí, por su cariño y apoyo logístico. Por nuestros encuentros junto al mar.

Y, sobre todo, a Quevedo, del que he sido chupatintas durante unos años. Como dijo Pero Grullo: "Sin él, nada de esto sería posible." 


\section{BIBLIOGRAFÍA}

- 697 - 
- 698 - 


\section{EDICIONES MODERNAS DEL TEATRO DE QUEVEDO}

\section{EDICIONES ÍNTEGRAS}

Teatro inédito de don Francisco de Quevedo y Villegas. Edición y estudio introductorio de Miguel Artigas. Madrid: RAE, 1927.

Obras en verso, Obras completas. Edición de Astrana Marín. Madrid: Aguilar, 1932, pp. 535- 668. Entre los entremeses publicados, hallamos algunos que la crítica posterior no ha considerado de Quevedo: Pan Durico, El Médico, El caballero de la Tenaza y El hospital de los malcasados. La edición fue más adelante retomada por Felicidad Buendía (1960) en la reimpresión de las obras completas de Aguilar.

Obras. Poesías. Colección ordenada y corregida por Don Florencio Janer. Madrid: Rivadeneira, BAE, 1953, vol. III. Incluye los entremeses de Las tres musas últimas (pp. 274-286) y los definitivamente no pertenecientes a Quevedo La endemoniada fingida y chistes de Bacallao, La infanta Palancona, El Médico, El Muerto y Las sombras (pp. 501-525).

Obra poética. Teatro y traducciones poéticas (vol. IV). Edición de José Manuel Blecua. Madrid: Castalia, 1981.

Cómo ha de ser el privado, edición crítica, introducción y notas de Luciana Gentilli. Viareggio-Lucca: Mauro Baroni, 2004. 


\section{Publicaciones en Revistas, estudios y antologías}

AREllano, I. (ed.) "Entremés de la ropavejera de Quevedo", La Perinola, 5 (2001): 25-38.

Arellano, I. "La jácara inicial de Pero Vázquez de Escamilla de Quevedo". Crítica textual y anotaciones filológicas de las obras del Siglo de Oro. Ed. I. Arellano y J. Cañedo. Madrid, Castalia, 1991, pp. 13-15.

Arellano, I. "Anotación filológica de textos barrocos: el Entremés la vieja Muñatones de Quevedo", Notas y Estudios Filológicos (Pamplona), 1(1984): 87-117.

Arellano, I., García Valdés, C.C. (ed.) "El entremés del Marido pantasma de Quevedo", La Perinola, 1 (1997): 41-68.

Arellano, I., García VAldÉs, C.C. (ed.) "El Entremés de la venta, de Quevedo", La Perinola, 10 (2006): 345-360.

AsEnsio, E. Itinerario del entremés. Madrid: Gredos, 1965. Como apéndice del estudio hallamos la reproducción de los entremeses de Quevedo incluidos en el ms. de la Biblioteca de Évora (pp. 259-264).

Bergman, H.E. (ed.) Ramillete de entremeses y bailes. Madrid: Castalia, 1970. Incluye el entremés La ropavejera (pp. 109-115).

BuendíA, F. (ed.) Antología del entremés. Madrid: Aguilar, 1965. Incluye el Entremés famoso de la venta (pp. 369-381) y el Entremés de la ropavejera (pp. 382-391).

BuEzo, C. (ed.) Mojigangas dramáticas (siglos XVI y XVII). Madrid: Cátedra, 2005. Incluye Los refranes del viejo celoso (pp. 97-110). 
Buezo, C. (ed.) Teatro breve de los Siglos de Oro: antología. Madrid: Castalia, 1992. Contiene Los refranes del viejo celoso (pp. 61-74).

CROSBY, O. "Dos entremeses y un romance", En torno a la poesía de Quevedo. Madrid: Castalia, 1967, pp. 205-228. Analiza y edita paleográficamente dos manuscritos que por entonces eran de su propiedad: el Entremés de los refranes del viejo celoso (pp. 207-215), y el Famoso entremés del Hospital de los malcasados (pp. 219-225), del que Blecua desestima la autoría de Quevedo.

GARCIA VALDÉS, C.C. (ed.) Entremesistas y entremeses barrocos. Madrid: Cátedra, 2005. Incluye La venta (pp. 67-81), Los enfadosos (pp. 91109) y Los refranes del viejo celoso (pp. 117- 135).

Garcia ValdÉs, C.C. (ed.) Antología del entremés barroco. Barcelona: Plaza \& Janés, 1985. Incluye La venta (pp. 161-175), Los enfadosos (pp. 176-194) y Los refranes del viejo celoso (pp. 195-214).

Huerta Calvo, J. (ed.) Teatro breve de los siglos XVI y XVII. Madrid: Taurus, 1985. Incluye la primera parte de Diego Moreno (pp. 153-162) y La Venta (pp. 164-171).

RodríGUEZ, A. (ed.) El premio de la hermosura. Comedia satírica en un acto, en Comedias burlescas del Siglo de Oro. Tomo IV. Madrid / Frankfurt: Iberoamericana / Vervuert, 2003. 


\section{LAS OTRAS OBRAS DE QUEVEDO}

Cartas, documentos, y escrituras de Francisco Gómez de Quevedo y Villegas (1580-1645). Edición de Krzysztof Sliwa. Mutilva Baja (Navarra): EUNSA, 2005.

Defensa de Epicuro contra la común opinión. Edición de Eduardo Acosta Méndez. Madrid: Tecnos, 1984.

Discurso de las privanzas. Estudio preliminar, edición y notas de Eva María Díaz Martínez. Pamplona. : EUNSA, 2000.

El Buscón. Edición de Américo Castro. Madrid: Imprenta de la Ciudad Lineal, 1927.

El Chitón de las tarabillas. Edición de M. Urí Martín. Madrid: Castalia, 1998.

Epistolario completo. Edición de L. Astrana Marín. Madrid: Reus, 1946.

La caída para levantarse. El ciego para dar vista, el montante de la Iglesia en la vida de San Pablo Apóstol. Edición de Valentina Nider. Pisa: Giardini, 1994.

La hora de todos y La fortuna con seso. Edición y notas de Luisa López Grigera. Madrid: Castalia, 1975.

La vida del buscón. Edición de D. Yndurain; texto fijado por F. Lázaro Carreter. Madrid: Cátedra, 1983.

La vida del buscón. Edición crítica y estudio preliminar de Fernando Lázaro Carreter. Salamanca: Universidad, 1985. 
La vida del buscón, en Novela picaresca, II. Edición y prólogo de Rosa Navarro Durán. Madrid: Fundación José Antonio de Castro, 2005, pp. 1129.

Lágrimas de Hieremías castellanas. Prólogo, edición y notas de Edward M. Wilson y José Manuel Blecua. Madrid: CSIC, 1953.

Obra poética. Edición de J. M. Blecua. Madrid: Castalia, 1999, 3 volúmenes.

Obras completas en prosa. Edición dirigida por Alfonso Rey. Madrid: Castalia, 2003 (vol. I, 2 tomos) y 2005 (vol. III).

Obras completas. Poesía original. Edición, introducción y notas de J. M. Blecua. Barcelona: Planeta, 1963.

Obras completas. Verso. Prosa. Edición, introducción y notas de Astrana Marín. Madrid: Aguilar, 1932 y 1945.

Obras de don Francisco de Quevedo Villegas. Edición de Aureliano Fernández- Guerra y Orbe (tomos I y II) y Florencio Janer (tomo III). Madrid: Atlas (BAE, 69), 1951-1953.

Obras Completas de Don Francisco de Quevedo Villegas, Sociedad de Bibliófilos Andaluces. Edición crítica ordenada e ilustrada por Aureliano Fernández Guerra de la Real Academia Española, con notas y adiciones de Don Marcelino Menéndez y Pelayo de la misma Academia. Sevilla: Imprenta de E. Rasco, I, 1897.

Obras festivas. Edición de Pablo Jauralde Pou. Madrid: Castalia, 1981.

Poemas escogidos. Edición de J. M. Blecua. Madrid: Castalia, 1972.

Poemas satíricos y burlescos. Prólogo, edición y notas de E. M. Wilson y J. M. Blecua. Barcelona: Ocnos, 1974. 
Poesía amorosa y metafísica de Quevedo. Prólogo, edición y notas de E.

M. Wilson y J. M. Blecua. Barcelona: Planeta, 1976.

Poesía selecta. Edición de Lía Schwartz e Ignacio Arellano. Barcelona: PPU, 1989.

Poesía original completa. Edición y notas de J. M. Blecua. Barcelona: Planeta, 1983.

Poesía varia. Edición de James A. Crosby. Madrid: Cátedra, 1981.

Política de Dios, gobierno de Cristo y tiranía de Satanás. MadridUrbana: Castalia-Prensa Universitaria de Illinois, 1966.

Prosa festiva completa. Edición de C.C. García Valdés. Madrid: Cátedra, 1993.

Prosa satírica. Edición de Ignacio Arellano. Barcelona: Mondadori, 2003.

Sueños y discursos. Edición, introducción y notas de Felipe C.R. Maldonado. Madrid: Castalia, 1978.

Vida de Marco Bruto. Madrid: Espasa-Calpe, 2000.

Virtud militante. Edición crítica de Alfonso Rey. Santiago: Universidad, 1985. 


\section{SOBRE EL TEATRO DE QUEVEDO}

\section{COMEDIAS Y ENTREMESES}

ACEREDA, A. “La Consultación de los gatos de Quevedo: Relaciones con Lope de Vega y el teatro menor de la época." El escritor y la escena, IV: Estudios sobre el teatro español de los Siglos de Oro: Homenaje a Alfredo Hermenegildo. Ed. Ysla Campbell. México D.F.: Universidad Autónoma de Ciudad Juarez, pp. 83-91.

ALONSO HERNÁNDEZ, J.L. "Ausencia y presencia del carnaval en los entremeses de Quevedo". Cuadernos de teatro clásico, 12 (1999): 101-130.

ALONSO HERNÁNDEZ, J.L. "Transformaciones carnavalescas en los entremeses de Quevedo". Foro Hispánico, 19 (2001): 41-53.

AMEZCUA, J. "El negro ensayo de la comedia- nota sobre los entremeses de Quevedo". Thesis. Nueva Revista de Filosofía y Letras, 3.10 (1981): 2225.

ARELlano, I. "Anotación filológica de textos barrocos: el Entremés la vieja Muñatones de Quevedo", Notas y Estudios Filológicos (Pamplona), 1(1984): 87-117.

Arellano, I. "La esperpentización del otro en la literatura del Siglo de Oro: Dos calas en Quevedo y Barrionuevo". Alba de América: Revista Literaria, 13. 24-25 (1995): 115-127.

ARRANZ LAGO, D. "Prontuario para frustrar embelecos: usos lingüísticos carnavalescos en las Cartas del caballero de la Tenaza de Francisco de Quevedo.” La Perinola 9 (2005): 243-256. 
Arranz Lago, D. "De don Pablos a Diego Moreno: la ironía verbal de Quevedo", en Actas del congreso "El Siglo de Oro en el Nuevo Milenio". Edición de Carlos Mata y Miguel Zugasti. Pamplona: EUNSA, 2005, pp. 201-215.

AsEnsio, E. "Hallazgo de Diego Moreno, entremés de Quevedo y vida de un tipo literario", Hispanic Review, 27(1959): 397-412.

ASENSIO, E. Itinerario del entremés. Madrid: Gredos, 1965.

Bergman, H. "Los refranes del viejo celoso y obras afines". Nueva Revista de Filología Hispánica, 24 (1975): 376-397.

Bell, A. "Teatro inédito de Don Francisco de Quevedo y Villegas. Edited by Don Miguel Artigas", en Litteris, 3 (1928): 203-211.

CABAÑas, P. "El espectáculo verbal. Comicidad y sátira en los entremeses de Francisco de Quevedo". Comedias y comediantes: Estudios sobre el teatro clásico español. Ed. Manuel V. Diago and Teresa Ferrer. Valencia, Universidad de Valencia: 1991, pp. 291-303.

Chauchadis, C. "Risa y honor conyugal en los entremeses". Risa y sociedad en el teatro español del Siglo de Oro. París: Editions du C.N.R.S., 1980, pp. 165-173.

Chevalier, M. "Caricatura quevediana y figuras del entremés". Los géneros menores en el teatro español del Siglo de Oro (Jornadas de Almagro, 1987). Ed. L. García Lorenzo. Madrid: Ministerio de Cultura, 1988, pp. 149-161.

Cotarelo, A. (1911) Colección de entremeses, loas, bailes, jácaras y mojigangas desde fines del siglo XVI a mediados del XVIII. Granada: Universidad de Granada, 2000, 2 vols. 
Cotarelo, A. "El teatro de Quevedo. Madrid", Boletín de la Real Academia Española, 24 (1945): 41-104.

Cotarelo, A. El teatro de Quevedo. Madrid: S. Aguirre, 1945.

CROS, E. "Ecriture expressionniste et théâtralité dans le récit picaresque." Baroque: Revue Internationale 9-10 (1980): 34-37.

Crosby, J.O. En torno a la poesía de Quevedo, Madrid, Castalia, 1967.

García De EnTERría, M. C. "Pruebas escritas de una amistad. Francisco de Quevedo y Antonio Hurtado de Mendoza." Homenaje a Eugenio Asensio. Madrid: Gredos, 1988, pp. 199-213.

García VAldés, C. C. "El teatro de Quevedo", Sobre Quevedo y su época. Actas de las jornadas (1997-2004): Homenaje a Jesús Sepúlveda. Coordinado por Felipe Blas Pedraza Jiménez, Elena E. Marcello. Universidad de Castilla-La Mancha, 2007, pp. 475-498.

García VAldÉs, C. C. "Introducción", Antología del entremés barroco. Barcelona: Plaza Janés, 1985, pp. 33-45.

García VAldÉs, C. C. ( (ed.) Quevedo esencial, Madrid, Taurus, 1990.

GARCía VALDÉs, C. C. "Hacia una edición crítica y anotada de los entremeses de Quevedo: situaciones cómicas y agudeza verbal", en En torno al teatro del Siglo de Oro, Actas de las Jornadas XIV celebradas en Almería, marzo 1997. Ed. I. Pardo Molina, L. Ruiz Martínez y A. Serrano. Almería: Instituto de Estudios Almerienses, 1999, pp. 55-70.

GARRIDO CAMACHO, P. "La anagnórisis en el drama español del primer tercio del XVII: Góngora y Quevedo", Actas del IV Congreso de la AISO. Alcalá: Universidad de Alcalá, 1998, I, pp. 661-668. 
Gervais, B. "Analyse littéraire des entremeses de Francisco de Quevedo". D.E.S. Paris: Faculté des Lettres, 1970.

GutiÉRREZ, C. M. "Narrador, autor y personaje: facetas de autorrepresentación literaria en Góngora, Lope, Cervantes y Quevedo". Espéculo, 31 (2005).

También en http://www.ucm.es/info/especulo/numero31/autorref.html

HERNÁNDEZ ARAICO, S. "Teatralización de estatismo: poder y pasión en Cómo ha de ser el privado de Quevedo". Hispania 82.3 (1999): 461-471.

HERNÁNDEZ ARAICO, S. "Pintura y estatismo teatral en Cómo ha de ser el privado de Quevedo". Ínsula, 648 (2000): 30-32.

HERnÁNDEZ ARAICO, S. "El teatro breve de Quevedo y su arte nuevo de hacer ridículos en las tablas: lego-pro-menos a una representación riescénica." La Perinola, 8 (2004): 201-234.

Huerta Calvo, J. "Cómico y femenil bureo. Del amor y las mujeres en los entremeses del Siglo de Oro", Criticón, 23 (1983): 5-68.

Huerta CAlvo, J. El nuevo mundo de la risa: estudios sobre el teatro breve y la comicidad en los siglos de oro. Barcelona: Libergraf, 1995.

IGLESIAS, R. "El imposible equilibrio entre el encomio cortesano y la reprimenda política: hacia una nueva interpretación de Cómo ha de ser el privado de Quevedo". La Perinola, 9 (2005): 267-298.

Iventosch, H. "Quevedo and the Defense of the Slandered: The Meaning of the Sueño de la Muerte, the Entremés de los refranes del viejo celoso, etc.". Hispanic Review, 30 (1962): 94-115 y 173-193.

JANER Y GRAELLS, F. "Una nota sobre la bibliografía de Quevedo", Revista Castellana (Valladolid), V (1919), 38-46. 
KopPEnFELS, W. "Plutarch, Shakespeare, Quevedo und das Drama der Ermordung Caesars". Germanisch-Romanische Monatsschrift (Neue Folge) 20 (1970): 1-23.

LaGrone, G.G. "Quevedo and Salas Barbadillo". Hispanic Review 10 (1942): 223-243.

LIDA, R. "Cómo ha de ser el privado: de la comedia de Quevedo a su Política de Dios". Libro jubilar de A. Reyes. Mexico: U. Nacional de México, 1958, pp. 203-212. También en Letras hispánicas, pp. 149-156 y en Prosas de Quevedo. Barcelona: Crítica, 1980, pp.159-179.

Maestro, J.G. "Las formas de lo cómico en los entremeses de Quevedo.” La Perinola, 12 (2008): 79-106.

Mancini, G. Gli "entremeses" nell'arte di Quevedo. Pisa: Goliardica 1955.

MARAÑón RIPOLL, M. "Sobre Migajas quevedianas: los fragmentos manuscritos de El entremetido y la dueña y el soplón." Voz y letra 6.1. (1995): 59-72.

OteIZA, B. "Notas al teatro de Quevedo". Ínsula, 648 (2000): 28-30.

RESTREPO-GAUtier, P. "Risa y género en los entremeses de "mariones" de Francisco de Quevedo y de Luis Quiñones de Benavente." Bulletin of the Comediantes, 50.2 (1998): 331-344.

Roncero LÓPEZ, V.; AREllano, I. (ed.) Quevedo en Manhattan: actas del congreso internacional, Nueva York, noviembre, 2001. Madrid: Visor, 2004. 
SÁEz RAPOSO, F. "De criadas, mozas y dueñas en el teatro breve de Quevedo". La criada en el teatro del Siglo de Oro. Coordinado por Luciano García Lorenzo. Madrid, Fundamentos, 2008, pp. 183-200.

SOMERS, M. "Quevedo's ideology in Cómo ha de ser el privado". Hispania, 39 (1956): 261-68.

SoONS, A. "Los entremeses de Quevedo. Ingeniosidad lingüística y fuerza cómica.”, Filologia e Letteratura, 16 (1970): 424-439.

Urrutia, J. "Quevedo en el teatro político", Homenaje a Quevedo: Actas de la Academia Literaria Renacentista de la Universidad de Salamanca. Ed. Víctor García de la Concha. Salamanca: Caja de Ahorros y Monte de Piedad, 1982, pp. 173-185.

Urzáiz ToRTAJADA, H. "Pérez de Montalbán y otros autores de la primera mitad del siglo XVII", en Historia del teatro español. Volumen I. De la Edad Media a los siglos de oro, ed. por Javier Huerta Calvo. Madrid: Gredos, 2003. Se centra específicamente en Quevedo en las pp. 868-870.

Vega García Luengos, G.; "La privanza desleal y voluntad por la fama: el encuentro, al fin, con una comedia perdida atribuida a Francisco de Quevedo", Manuscrt. Cao, 5 (1993), 109-21.

Vermeylen, A. "Sur la comédie de la vie dans Calderón et dans Quevedo". Études de philologie romane et d'histoire littéraire offerts à Jules Horrent à l'occasion de son soixantième anniversaire. Eds. Jean Marie D’Heur et Nicoletta Cherubini. Tournai: Gedit, 1980. pp. 823-829.

YNDURAIN, F. "Refranes y frases hechas en la estimativa literaria del siglo XVII", AFA, 7 (1955): 113-114. 
Zamudio De Predan, J. A. "La metáfora del Teatro del mundo en Quevedo", Cuadernos del Sur (Bahía Blanca, Argentina) 5 (1966): 23-26.

\section{JÁCARAS Y BAILES}

Alonso Veloso, M.J. "Los preliminares no ineruditos de González Salas a la Musa V, Terpsícore, de Quevedo". Memoria de palabra: Actas del VI Congreso de la AISO. Edición de $\mathrm{M}^{\mathrm{a}}$ Luisa Lobato y Francisco Domínguez Matito. Madrid/ Frankfurt: Ibeoamericana/ Vervuert, 2004, I: 229-249.

Alonso Veloso, M.J. Tradición e ingenio en las letrillas, las jácaras y los bayles de Quevedo. Vigo: Universidade de Vigo, 2005.

Arellano, I. "La jácara inicial de Pero Vázquez de Escamilla de Quevedo". Crítica textual y anotaciones filológicas de las obras del Siglo de Oro. Ed. I. Arellano y J. Cañedo. Madrid, Castalia, 1991, pp. 13-15.

BANURA BADUi DE ZogBI, M. "El valiente Escarramán. De la jácara al entremés". Cervantes, Góngora y Quevedo. II Simposio Nacional Letras del Siglo de Oro Español. 5, 6 y 7 de octubre de 1995. Mendoza-República Argentina: Zeta Editores, 1997, pp. 115-126.

BLECUA, J.M. "La transmisión textual del Baile de los pobres de Quevedo. Revista Hispánica moderna, 31(1965): 78-97.

BODENMÜLLER, T. El mundo del hampa a través de Quevedo: análisis de la jácara “Estábase el padre Ezquerra”. Augsburg: Institut für Spanien-und Lateinamerikanstudien, 1977. 
CACHO PAlOMAR. M.T. "Quevedo. Los bailes y los cancioneros musicales mediceos.", Música y literatura en la península ibérica: 16001750. Actas del Congreso Internacional. Valladolid, 20, 21 y 22 de febrero, 1995. Ed. M. A. Virgili Blanquet, G. Vega García-Luengos y C. Caballero Fernández-Rufete. Valladolid, Junta de Castilla y León, Universidad de Valladolid-Central Hispano, 1997, pp. 275-286.

CARreIRA, A. "El conceptismo en las jácaras de Quevedo: Estábase el Padre Esquerra. La Perinola, 4 (2000): 91-106.

CATALÁN, D. "Una jacarilla barroca hoy tradicional en Extremadura y en el Oriente". Revista de Estudios Extremeños, 8 (1952): 377-387.

Chevalier, M. "Triunfo y naufragio de la jácara aguda". Scripta Philologica in Honorem Juan M. Lope Blanch a los 40 años de docencia en la UNAM y a los 65 de vida. Ed. E. Luna Traill. México, D.F: Instituto de Investigaciones Filológicas, UNAM, 1992. III: 141-151.

FERnÁNDEZ RufETE, C. "Baile dramático", en Diccionario de la Comedia del Siglo de Oro. Madrid: Castalia, 2002, pp. 25-29.

FLECNIAKOSKA, La loa. Madrid: SGEL, 1975.

GÓmEZ IGLESIAS, A. "Nota al baile VIII de Quevedo". Revista de la Biblioteca, Archivo y Museo del Ayuntamiento de Madrid, 14 (1945): $437-$ 450.

HeUER, B. J. “The Discourse of the Ruffian in Quevedo's jacaras". Diss. State U of New York: Stony Brook, 1991.

HidAlgo, J. y QUEVEDO, F. Romances/ de Germanía/ de varios autores/ con el/vocabulario/ por la orden del a.b.c. [...] Madrid: por don Antonio de Sancha, 1779. 
HILL, J.M. "Una jácara de Quevedo". Revue Hispanique, 72 (1928): 493503.

MARIGNO, E. "Les hypotextes des jácaras de Quevedo et leur synthèse dans la germania." Regards sur le passé dans l'Europe des XVIème et XVIIème siècles. Ed. Francine Wild. Berlin: Peter Lang, 1997, pp. 1-12.

MCCAW, R. J. "The Liberated Word: Africans and Carnivalesque Imaginery in Francisco de Quevedo's Boda de Negros", Afro-Hispamoc Review, 18.2 (1999): 10-14.

Merino QuiJano, G. Los bailes dramáticos del siglo XVII. Madrid: Universidad Complutense, 1981, 2 vols.

Pensado Tomé, J. L. "Noticias de Sarmiento sobre una jácara de Quevedo". Cuadernos de Estudios Gallegos, 24 (1969): 259-274.

PEÑA, M. "El Escarramán: una jácara de Quevedo en un manuscrito americano". Literatura entre dos mundos. Interpretación crítica de textos coloniales y peninsulares. México D. F. UNAM, Ediciones del equilibrista, 1992, pp. 49-69.

PÉREZ CuEnCA, I. "Del jaque al bandolero: las jácaras de Quevedo". Le bandit et son image au Siècle d'Or/ El bandolero y su imagen en el siglo de Oro. Actas del Coloquio Internacional, Madrid,1989. Ed. Juan Antonio Martínez Comeche. París: PU de la Sorbonne, 1991, pp. 193-200.

SNELl, A.M. "El lenguaje de los bailes de Quevedo", Edad de Oro, 13 (1994): 171-179. 


\section{QUEVEDO, PERSONAJE DRAMÁTICO}

Alonso CortÉs, N. "Quevedo en el teatro", Revista de la Biblioteca, Archivo y Museo del Ayuntamiento de Madrid, V (1929): 1-22.

GARnER, S. "Prólogo y notas" a su edición de Manuel Bretón de los Herreros, ¿Quién es ella? Comedia en cinco actos. Nueva York: 1905. [Uno de los personajes es Quevedo].

GARCíA VALDÉS, C.C. "Con otra mirada: Quevedo personaje dramático". La Perinola, 8 (2004): 171-185.

\section{ADAPTACIONES ESCÉNICAS}

LóPeZ ARAndA, R. El Buscón. Teatro. Obras escogidas. T. 2 Madrid: Asociación de Autores de Teatro, 1998, pp. 395-504. Edición digital de la Biblioteca Virtual Miguel de Cervantes por cortesía del autor.

Doménech, F., Hurtado de Mendoza, A.; Quevedo villegas, F. Los empeños del mentir. Madrid : Fundamentos : Real Escuela Superior de Arte Dramático, 2002. 


\section{SOBRE QUEVEDO, LO QUE NO ES TEATRO}

AguilerA, I. "Sobre tres romances atribuidos a Quevedo", en BBMP, XXI (1945): 494-523.

Alarcos García, E. "Quevedo y la parodia idiomática". Archivum (Oviedo) 5 (1955): 3-38. También en Homenaje al Profesor Alarcos García. I. Sección antológica de sus escritos. Valladolid: Sever-Cuesta, 1965, pp. 443-472. On-line en Las sátiras de Quevedo y su recepción. Antología crítica. Ed. Lía Schwarz. Madrid: Centro Virtual Cervantes (2004).

Alarcos García, E. "El dinero en las obras de Quevedo". Discurso de apertura del curso 1942-1943 de la Universidad de Valladolid. . También en Homenaje al Profesor Alarcos García. I. Sección antológica de sus escritos. Valladolid: Sever-Cuesta, 1965, pp. 375-442. On-line en Las sátiras de Quevedo y su recepción. Antología crítica. Ed. Lía Schwarz. Madrid: Centro Virtual Cervantes (2004).

Arellano, I. "El diestro del Juicio Final de Quevedo, y su identidad", Busquemos otros montes y otros ríos. Estudios de literatura del Siglo de Oro dedicados a Elías L. Rivers. Madrid: Castalia, 1992, pp. 11-17.

Arellano, I. Poesía satírico burlesca de Quevedo. Pamplona: Universidad de Navarra, 1984.

ARELlanO, I. "Notas sobre el refrán y la fórmula coloquial en la poesía burlesca de Quevedo", La Perinola, 1 (1997): 15-38. 
ARRANZ LAGO, D. "Prontuario para frustrar embelecos: usos lingüísticos carnavalescos en las Cartas del caballero de la tenaza de Francisco de Quevedo". La Perinola, 9 (2005): 243-246.

AStRANA MARÍn, L. Ideario de don Francisco de Quevedo. Madrid: Biblioteca Nueva, 1940.

Borges, J.L. (1952). "Quevedo", Otras inquisiciones. Madrid: Alianza Editorial, 1998.

CAMPAÑA, M. Francisco de Quevedo. Barcelona: Omega, 2003.

CANDElas Colodrón, M.A. "Los exempla femeninos en la obra grave de Quevedo". La Perinola, 9 (2005): 33-54.

Cauvin, Sister M. A. "The Comedia de Privanza in the Seventeenth Century". Diss. U. of Pennsylvania, 1957.

CROS, E. L'aristocrate et le carnaval des gueux. Étude sur le Buscón de Quevedo. Montpellier: Études sociocritiques, 1975.

Crosby, J. O. Nuevas cartas de la última prisión de Quevedo. London: Tamesis Books, 2005.

Chevalier, M. Quevedo y su tiempo: la agudeza verbal. Barcelona: Crítica, 1992.

Chevalier, M. "Cuentecillos y chistes tradicionales en la obra de Quevedo”, en Las sátiras de Quevedo y su recepción. Antología crítica. Ed. Lía Schwarz. Madrid: Centro Virtual Cervantes, 2004, pp. 17-43:

http://cvc.cervantes.es/obref/satiras_quevedo/indice.htm

CHIAPPINI, G. Francisco de Quevedo e i suoi "auctores": miti, simboli e idee. Firenze: Alinea, 1997. 
DAVENPORT, R.L. "Encuentros cercanos del tercer tipo. Una lectura del episodio de Diego Moreno en el Sueño de la muerte." La Perinola 6 (2002): 303-322.

DAvieS, G. A. A poet at Court: Antonio Hurtado de Mendoza (15861644). Oxford: UP, 1971.

Elliott, J. H. "Quevedo and the Count-Duke of Olivares", en Quevedo in Perspective. Ed. J. Iffland (Newark, 1982), pp. 227-250.

EGIDO, A. "Retablo carnavalesco del Buscón don Pablos". Hispanic Review 46 (1978): 173-192.

ERASMO, D. Manual del cavaller cristià. Barcelona: Proa, 1991.

EtTinghausen, H. "Quevedo, ¿un caso de doble personalidad?", en Homenaje a Quevedo. Actas de la II Academia literaria Renacentista. Ed. V. García de la Concha. Salamanca: Universidad de Salamanca, 1982, pp. $27-44$.

Fernández Mosquera, S.; Azauste Galiana, A. Índices de la poesía de Quevedo. Barcelona: PPU, 1993.

Fernando Rubio, P. "El Discurso de las privanzas, de Quevedo, y el Tratado del perfecto privado, del P. Pedro Maldonado, O.S.A." Anuario Jurídico Escurialense, 5 (1964): 575-585.

GuILLÉN, C. El primer Siglo de Oro. Estudios sobre géneros y modelos. Barcelona: Editorial Crítica, 1988.

GonZÁlez, M. A. "El narrador dialógico y la ironía en Grandes anales de quince días". Romance Languages Annual, 4 (1992): 466-468.

GonZÁLEZ, M. A. "Quevedo y Francia: La elocuencia y el texto dialógico y monológico." Romance Languages Annual, 5 (1993): 414-418. 
Jauralde Pou, P. Francisco de Quevedo (1580-1645). Madrid: Castalia, 1999.

LÁZARO CARRETER, F. Estilo barroco y personalidad creadora. Madrid: Cátedra. 1974.

LeÓn Pinelo, A. DE. Anales de Madrid. Madrid: Instituto de Estudios Madrileños, 1971.

LEVISI, M. "Las figuras compuestas en Arcimboldo y Quevedo." Comparative Literature 20 (1968): 217-235.

LitLE, E.P. "The Coimbra ms. 362 of Quevedo's Manzanares, Manzanares". Romance Notes, 17.3 (1977): 1-4.

LÓPEZ GRIGERA, L. "Quevedo comentador de Aristóteles: un manuscrito inesperado". Revista de occidente, 185 (1996): 119-132.

LÓPEZ GRIGERA, L. Anotaciones de Quevedo a la Retórica de Aristóteles. Salamanca: Gráficas Cervantes, 1998.

LóPEZ GutiéRreZ, L. "Posibles ecos de Luciano en Quevedo. La burla de los mitos paganos y las premáticas jocosas.” Dicenda 20 (2002): 197-212.

LÓPEZ GutiéRREZ, L. "Los «gustos de amores» en la poesía de Quevedo", La Perinola 5 (2001): 147-163.

LóPez PozA, S. "La Tabla de Cebes y los Sueños de Quevedo", Edad de Oro, XIII (1994): 85-101. También disponemos del texto online en Las sátiras de Quevedo y su recepción. Antología crítica. Ed. Lía Schwarz. Madrid: Centro Virtual Cervantes, 2004:

\section{http://cvc.cervantes.es/obref/satiras_quevedo/indice.htm}

LÓPEZ PoZA, S. "Autores italianos en la transmisión de la tradición del elogio en tiempo de Quevedo". La Perinola,10 (2006): 159-173. 
LóPez PozA, S. Francisco de Quevedo y la literatura patrística. La Coruña: U. da Coruña, 1992.

Llano Gago, M. T. La obra de Quevedo. Algunos recursos humorísticos. Salamanca: Ediciones Universidad de Salamanca, 1984.

Madroñal Durán, A. "El vejamen de Antonio Hurtado de Mendoza en Sevilla (1624) y su relación con una carta de Quevedo". La Perinola, 8 (2004): 235-255.

Madroñal Durán, A. "Un romance de Quevedo atribuido a Quiñones de Benavente y notas sobre las relaciones entre ambos". Manuscrt. cao, V (1993): 15-24.

MaldonAdo, F. C. R. "Quevedo y sus caricaturas de la mujer", $L a$ estafeta literaria, 538 (1974): 11-12.

MALDONADO, R. C. R. "Algunos datos sobre la composición y dispersión de la biblioteca de Quevedo", Homenaje a la memoria de don Antonio Rodríguez-Moñino, 1910-1970. Madrid: Castalia, 1975, pp. 405-428.

MARAÑón, G. El conde-duque de Olivares (la pasión de mandar). Madrid, Espasa Calpe, 1972.

Martinengo, A. "Dos jayanes, el bíblico y el clásico, frente a la Pidona". La Perinola 9 (2005): 113-124.

MARTINENGO, A. La astrología en la obra de Quevedo: una clave de lectura. Madrid: Alhambra, 1983.

MARTINENGO, A. Quevedo: fronteras de la filología. Barañáin (Navarra): EUNSA (Ediciones de la Universidad de Navarra), 2006.

MAS, A. La caricature de la femme, du mariage et de l'amour dans l'oeuvre de Quevedo. París: ed. Hispano-Americanas, 1957. 
MolL, J. "El proceso de formación de las Obras completas de Quevedo". Homenaje a Eugenio Asensio. Ed. Luisa López Grigera y Agustín Redondo. Madrid: Gredos, 1988, pp. 321-330.

Molho, M. Semántica y poética (Góngora, Quevedo). Barcelona: Crítica, 1978.

Moore, R. "Lisi, Lisa and the Caballero de la Tenaza". Boletín de la Biblioteca Menéndez Pelayo, 56 (1980): 215-224.

Morreale, M. "Luciano y Quevedo: la humanidad condenada", on-line en Las sátiras de Quevedo y su recepción. Antología crítica. Ed. Lía Schwarz. Madrid: Centro Virtual Cervantes (2004).

FERnÁndeZ MosquerA, S. La poesía amorosa de Quevedo. Madrid: Gredos, 1999.

Nolthing-HAUfF, I. Visión, sátira y agudeza en los Sueños de Quevedo. Madrid: Gredos, 1974.

OliVARes, J. La poesía amorosa de Francisco de Quevedo. Madrid: Siglo XXI, 1995.

PARKER, A. A. "La agudeza en algunos sonetos de Quevedo. Contribución al estudio del conceptismo", Estudios dedicados a Menéndez Pidal (Madrid, 1952), III, pp. 345-360.

PAZ, A. “Gongora...¿y Quevedo?”. Criticón, 75 (1999): 29-47.

PAZ, O. Reflejos: réplicas. Diálogos con Francisco de Quevedo. México: Vuelta -El Colegio Nacional, 1996. También editado en Madrid: La Palma, 1996.

PAZ, O. "Una poesía de convergencias" (Conversación con Benjamín Prado), en Convergencias. Barcelona, Seix Barral, 1991, pp. 138 y ss. 
PlatA, F. "Contribución al estudio de las fuentes de la poesía satírica de Quevedo: Ateneo, Berni y Owen", La Perinola, 3 (1999): 225-247.

PÉRez CuencA, I.; Schwartz, L. "Las tres musas últimas castellanas: problemas de atribución." Actas del XIII Congreso de la Asociación Internacional de Hispanistas. Ed. F. Sevilla y C. Alvar. Madrid: Castalia, 2000, pp. 659-669.

Place, E. B. "Salas Barbadillo, Satirist". Romanic Review, 17 (1926): 230-242.

Pozuelo Yvancos, J.M. El lenguaje poético de la lírica amorosa de Quevedo. Murcia: Universidad, 1979.

QUÉRILLACQ, R. "Ensayo de una lectura socioeconómica de la obra de Quevedo." Criticón, 17 (1982): 13-66.

RABELL, C. R. "Carnaval, representación y fracaso en El Buscón 1.4." Revista Chilena de Literatura, 51 (1997): 59-79.

Rebollo Torío, M. A. "El personaje de la vieja en la obra de Quevedo". Quevedo en su centenario. Cáceres, 1980, pp. 91-104.

Reyes DÁvila, E. (ed.) Diccionario privado de Francisco de Quevedo, recopilado y ordenado por...Madrid: Altalena, 1981.

RIANDIÈRE LA Roche, J. "Editar a Quevedo: textos y contextos." La edición de textos. Actas del I Congreso Internacional deHispanistas del Siglo de Oro. Ed. Pablo Jauralde, Dolores Noguera y Alfonso Rey. London: Tamesis, 1990, pp. 393-404.

RIQUER, M. DE. Traducciones castellanas de Ausiàs March en la Edad de Oro. Barcelona: Instituto Español de Estudios Mediterráneos, 1946, pp. 427 y ss. 
RocAmORA, P. "Quevedo y la política internacional de su tiempo". Arbor, 108. 423 (1981): 7- 18.

ROMANOS, M. "Sobre la semántica de figura y su tratamiento en las obras satíricas de Quevedo." Actas del VII Congreso de la Asociación Internacional de Hispanistas (Venice, 1980). Rome: Bulzoni, 1982, pp. 903-911.

Romanos, M. "Sobre la semántica de figura y su tratamiento en las obras satíricas de Quevedo", Actas del VII congreso de la Asociación Internacional de Hispanistas (Venecia, 1980). Roma: Bulzoni, 1982, pp. 903-911.

Romanos, M. "La composición de las figuras en El mundo por de dentro." Revista de la Facultad de Filología y Letras de la Pontificia Universidad Católica Arg. Santa María de los Buenos Aires, 6-7 (19821983), pp. 174-184. También disponible en Las sátiras de Quevedo y su recepción. Antología crítica. Comp. Lía Schwartz. Madrid: Centro Virtual Cervantes (2004). http://cvc.cervantes.es/obref/satiras_quevedo/ indice.htm

ROMERO FríAS, M. "Una polémica sobre la edición de Las tres musas de Quevedo." Annali della Facoltà di Magisterio (Cagliari) 7 (1979).

RONCERO LÓPEZ, V. El humanismo de Quevedo: filología e historia. Pamplona: EUNSA, 2000.

RONCERO LÓPEZ, V. Historia y política en la obra de Quevedo. Madrid: Pliegos, 1991.

Rubio, P. F. "El Discurso de las privanzas de Quevedo y el Tratado del perfecto privado del P. Pedro Maldonado, O.S.A." Anuario Jurídico Escurialense, 5 (1964): 575-585. 
SÁnCHEZ AlOnso, B. "Los satíricos latinos y la sátira de Quevedo", online en Las sátiras de Quevedo y su recepción. Antología crítica. Comp. Lía Schwartz. Madrid: Centro Virtual Cervantes (2004):

http://cvc.cervantes.es/obref/satiras_quevedo/ indice.htm

SCHWARTZ, L. "Quevedo y las antigüedades griegas: los Deipnosophistae en su obra", en Actas del V Congreso de la AISO. Münster, 1999, ed. C. Strosetzki, Madrid-Frankfurt, Vervuert: Iberoamericana, 2001, pp. 11901201.

SCHWARTZ, L. De Fray Luis a Quevedo. Lecturas de los clásicos antiguos. Málaga: Servicio de Publicaciones de la Universidad de Málaga, 2005 .

Schwartz, L. Política y literatura en Quevedo: el prudente consejero de la monarquía. Santander: Universidad de Cantabria, 2006. Lección de apertura del curso académico 2006-2007.

TARSIA, P.A. DE. Vida de don Francisco de Quevedo. Aranjuez: Ara Iovis, 1998.

UMBRAL, F. "Quevedo y el surrealismo”. Cuadernos del Norte 1 (1980): $11-13$.

VAíllo TORRAS, C. "El mundo al revés en la poesía satírica de Quevedo". Cuadernos Hispanoamericanos, 380 (1982): 364-393. También disponible en Las sátiras de Quevedo y su recepción. Antología crítica. Comp. Lía Scharz. Madrid: Centro Virtual Cervantes (2004): http://cvc.cervantes.es/obref/satiras_quevedo/ indice.htm

VAíllo TORRAS, C. "La vieja indigna en las poesías de Quevedo y algunos poetas franceses". Actas del IX Simposio de la Sociedad Española 
De Literatura General y Comparada. Ed. Tua Blesa, María Teresa Cacho, Carlos García Gual, Mercedes Rolland, Leonardo Romero Tobar y Margarita Smerdou Altolaguirre. Zaragoza: Universidad de Zaragoza, 1994, I, pp. 391-399.

VAlladares Reguero, A. "La sátira quevedesca contra Luis Pacheco de Narváez", EPOS. XVII (2001): 165-194.

VAlladares Reguero, A. "Peregrinos discursos y tardes bien empleadas: una obra desconocida de Pacheco de Nárvaez contra la Política de Dios de Quevedo." La Perinola 1 (1997): 237-56.

Zahareas, A. ; McCallum, T. "Toward a Social History of the Love Sonnet: The Case of Quevedo's Sonnet 331", Ideologies and Litterature 2 (1978): 90-99. 


\section{TEATRO Y DRAMATURgos DEL Siglo de Oro}

ABEL, L. Metatheatre: A New View of Dramatic Form. New York: Hill and Wang, 1963.

Alarcón, J. R. Obras completas, tomo I, ed. de Millares Carlo. México: FCE, 1957.

AREllano, I. "Edición crítica y anotación filológica en textos del Siglo de Oro. Notas muy sueltas", en Crítica textual y anotación filológica en obras del Siglo de Oro. Ed. I. Arellano y J.Cañedo. Madrid: Castalia, 1991, pp. 13-45.

Arellano, I. Historia del teatro español del siglo XVII. Madrid: Cátedra, 1995.

AREllano, I. Convención y recepción. Estudios sobre el teatro del siglo de Oro. Madrid: Gredos, 1999.

AREllano, I. Arquitecturas del ingenio. Estudios sobre el teatro de Tirso de Molina. Madrid-Pamplona: GRISO- Revista de Estudios, 2001.

BARBIERI, F. A. "Bailes y danzas de España en los siglos XVI y XVII", La Ilustración Española y Americana. Madrid (1887, nº XLIII-XLIV).

BARClay, T.B. The role of the Dance and Dances lyrics in the Spanish Comedia to the early XVIII century. Tesis doctoral (mecanografiada). Toronto: Universidad de Toronto, 1957.

Bergman, H. E. Luis Quiñones de Benavente. New York: Twayne, 1972.

Bergman, H. E. Luis Quiñones de Benavente y sus entremeses. Madrid: Castalia, 1965. 
Bergman, H. "Para la fecha de Las civilidades", en NRFH, X (1956): 187-193.

Bernardo Quirós, F. DE. Obras. Aventuras de don Fruela, ed. C.C. García Valdés, Madrid: Instituto de Estudios Madrileños, 1984.

BRADNER, L. "The Theme of privanza in Spanish and English drama (1590-1625)", en Homenaje a William L. Fichter. Estudios sobre el teatro antiguo hispánico y otros ensayos. Madrid: Castalia, 1971, pp. 97-106.

BuEzo, C. (ed.) Mojigangas dramáticas (siglos XVII y XVIII). Madrid: Cátedra, 2005.

CAlderón DE LA BARCA, P. El gran teatro del mundo. Edición de Eugenio Frutos Cortés. Madrid: Cátedra, 1997.

CALDERÓN DE LA BARCA, P. Entremeses, jácaras y mojigangas. Edición, estudio y notas de Evangelina Rodríguez y Antonio Tordera. Madrid: Castalia, 1982.

CANNAVAgGio, J. Un mundo abreviado: aproximaciones al teatro áureo. Madrid: Iberoamericana, 2000.

CAPARRÓS ESPERANTE, L. Entre validos y letrados. La obra dramática de Damián Salucio del Poyo. Valladolid: Universidad -C.A.M.P. de Salamanca, 1987, pp. 61-162.

Cervantes, M. DE. Entremeses. Madrid: Espasa-Calpe, 1952.

Cervantes, M. De. Don Quijote de la Mancha. Introducción y notas de Martí de Riquer. Barcelona, RBA, 1994.

Cervantes, M. Viaje del Parnaso. Edición de Vicente Gaos. Madrid: Castalia, 2005. 
CORTIJO OCAÑA, A. "La burla barroca: el entremés El rollo de Luis Belmonte Bermúdez", eHumanista, V (2005), pp. 142-186. Disponible en la red:

http://www.ehumanista.ucsb.edu/volumes/volume_05/articles/Cortijo.pdf

CHARTIER, R. El mundo como representación. Estudios sobre historia cultural, Barcelona, Gedisa, 1992.

ESSES, M. Dance and instrumental diferencias in Spain during the 17th and early 18th centuries. 3 Vols. Stuyvesant, New York: Pendragon Press, 1993.

FERRER VALLS, T. "El juego de poder: Lope de Vega y los dramas de la privanza." Seminario Internacional Modelos de vida en la España del Siglo de Oro. I. Madrid: Casa de Velázquez, 2004, pp. 15-30.

FERRER VALLS, T. "Bucolismo y teatralidad cortesana bajo el reinado de Felipe II", Felipe II (1597-1598). Europa y la Monarquía Católica, dirigido por J. Martínez Millán, t. IV, coordinado por V. Pinto Crespo. Madrid: Editorial Parteluz, 1998, pp. 133-143.

GARCía VALDÉS, C.C. "Comedias de moros y cristianos en el teatro de Tirso de Molina”, en El ingenio cómico de Tirso de Molina: Actas del Congreso Internacional, Pamplona, Universidad de Navarra, 27-29 de abril de 1998. Madrid: Pamplona, Instituto de Estudios Tirsianos, 1998.

GóNGORA, L. Las firmezas de Isabela. Edición, introducción y notas de Robert Jammes. Madrid: Castalia, 1984. 
GonZÁlez de SAlas, J. A. Nueva idea de la tragedia antigua. Edición y estudio preliminar de Luis Sánchez Laílla. Kassel : Reichenberger, 2003, 2 vols.

GutiÉRreZ, J. La “Fortuna bifrons"en el teatro del Siglo de Oro. Santander: Sociedad Menéndez Pelayo, 1975.

HEIDENREICH, H. Figuren und komik in den spanischen "Entremeses" des goldenen Zeilalters. Munich: Ludwig-Maximilian Univ., 1962.

HERRERO, M. Madrid en el teatro. Madrid: CSIC, 1963.

Horst, L. Formas pre-clásicas de danza. Buenos Aires: Eudeba, 1966.

Hurtado De Mendoza, A. Obras poéticas. Edición de Rafael Benítez Claros. Madrid: Gráficas Ultra, 1947, 3 volúmenes.

JACK, W.S. The early Entremés in Spain: the Rise of a Dramatic Form. Filadelfia: University of Pennsylvania, 1923.

LoPe De RuedA. Pasos completos. Prólogo de F. García Pavón. Madrid: Taurus, 1979.

LoPe DE VegA, F. Cartas. Edición de Nicolás Marín. Madrid: Castalia, 1985.

LoPe DE Vega, F. Obras escogidas. Edición de Federico Carlos Sainz de Robles. Madrid: Aguilar, 1958-1962. (3 vols.)

LOPE DE VEGA, F. Obras poéticas. Edición, introducción y notas de José Manuel Blecua. Barcelona: Planeta, 1983.

Lope DE Vega, F. Rimas. Edición de Felipe B. Pedraza. Jiménez. Fuenlabrada, Madrid: Universidad de Castilla- La Mancha, 1993. (2 vols.)

Lope DE VegA, F. La Dorotea. Edición de E. S. Morby. Madrid: Castalia, 1968. 
MacCuRDY, R.R. The Tragic Fall: Don Alvaro de Luna and other Favorites in Spanish Goleen Age Drama. Chapel Hill: University of North Carolina, 1978.

MAdroñal Durán, A. “Don Luis Cernúsculo de Guzmán, un poeta toledano confundido con Quevedo", Boletín de la Real Academia de Bellas Artes y Ciencias Históricas de Toledo, II, 26 (1991): 183-194.

Maestro, J.G. “Aristóteles, Cervantes y Lope: el Arte nuevo. De la Poética especulativa a la Poética experimental.” Alicante: Biblioteca Virtual Miguel de Cervantes, 2003. También editada en Anuario Lope de Vega, núm. 4, pp. 193-208.

Maestro, J.G. El personaje nihilista. La Celestina y el teatro europeo. Madrid: Vervuert, 2001.

Maravall, J. A. Teatro y literatura en la sociedad barroca. Barcelona: Crítica, 1990.

MARTíneZ DEL Fresno, B. "La danza española en el siglo XVII", en Francisco Bances Candamo y el teatro musical de su tiempo (1662-1704), Curso de verano de la Universidad de Oviedo, La Granda-Avilés, julio de 1992. Edición a cargo de José Antonio Gómez Rodríguez y Beatriz Martínez del Fresno, Oviedo, Servicio de Publicaciones de la Universidad de Oviedo, 1994.

Matas Caballero, J. Juan de Jáuregui. Poesía y poética. Sevilla: Diputación Provincial, 1990.

MCKendricK, M. El teatro en España (1490-1700). Palma de Mallorca: José J. de Olañeta, 1994. 
MenÉndez Peláez, J. Los Jesuitas y el Teatro en el Siglo de Oro. Gijón: Universidad de Oviedo, 1995.

MetFord, J.C.L. "The Enemies of the Theatre in the Golden Age". Bulletin of Hispanic Studies, 28 (1951): 76-92.

Moreto, A. Loas, entremeses y bailes. Edición de $\mathrm{M}^{\mathrm{a}}$ Luisa Lobato. Kassel: Reichenberguer, 2003.

Morley, S.G.; Bruerton, C. Cronología de las comedias de Lope de Vega. Versión española de M.R. Cartes. Madrid: Gredos, 1968.

NAVARro DurÁn, R. "El entremés, espacio para la trasgresión. Los disparates de La infanta Palancona." En torno al teatro del Siglo de Oro. Jornadas XVI-XVII. Almería: Instituto de Estudios Almerienses, 2003, pp. 101-115.

Newels, M. Los géneros dramáticos en las Poéticas del siglo de Oro. Londres: Tamesis Book, 1974.

Olson, E.; WARDROPPER, B. W. Teoría de la comedia. Barcelona: Ariel, 1978.

PEDRELl, F. Diccionario biográfico y bibliográfico de músicos y escritores de música, españoles, portugueses e hispanoamericanos, antiguos y modernos, s. 1., s.ed., 1894.

PELLICER, C. Tratado histórico sobre el origen y progreso de la comedia y del histrionismo en España. Ed. J.M. Díez Borque. Barcelona: Labor, 1975.

PÉREZ PASTOR, C. Nuevos datos acerca del histrionismo español en los siglos XVI y XVII. Madrid: Imprenta de la Revista Española, 1901. 
PinTo, E. La tradición escarramanesca en el teatro del Siglo de Oro. Madrid: Iberoamericana, 2005.

Quiñones de Benavente, L. Entremeses. Edición de Hannah E. Bergman. Salamanca: Anaya, 1968.

RODRÍGUEZ MARÍN, F. "Nuevas aportaciones para la historia del histrionismo español de los siglos XVI y XVII", BRAE, I (1914): 339-340.

RodrígueZ Villa, A. La Corte y la monarquía de España en los años de 1636 y 1637. Madrid, 1886.

Rojas ViLlandrando, A. El viaje entretenido. Edición, introducción y notas de Jacques Joset. Madrid: Espasa-Calpe, 1977.

Rose, C.H. "On attributtion", en Editing the Comedia, II. Michigan Romance Studies, XI (1991): 125-137.

RozAS, J.M. "Textos olvidados sobre preceptiva y licitud del teatro barroco", en Estudios sobre literatura y arte dedicados al profesor Emilio Orozco Díaz. Granada: Universidad, 1979, III, pp. 149-161.

RuANO DE la HaZA, J.M. "Dos censores de comedias de mediados del siglo XVII", en Estudios sobre Calderón y el teatro de la Edad de Oro. Homenaje a K. y R. Reichenberger. Barcelona: PPU, 1989, pp. 201- 229.

Ruiz Mayordomo, M. J. y ValcÁrcel Rivera, C. "Palabras en movimiento: Indicaciones coreográficas en tres manuscritos teatrales (Ms. 4.123, Ms. 16.291 y Ms. 16.292) del siglo XVII de la Biblioteca Nacional de Madrid", en Manuscrit.Cao, V (1992), pp. 67-101.

RuIZ MAYORDOMO, M.J. "Jácara y zarabanda son una mesma cosa", Edad de oro, 23 (2003), pp. 283-307. 
SACHS, C. Historia universal de la danza. Buenos Aires: Ediciones Centurión, 1944.

SÁEZ RAposo, F. Juan Rana y el teatro cómico breve del siglo XVII. Madrid: Fundación Universitaria Española, 2005

SÁNCHEZ ARJONA, J. Noticias referentes a los Anales del teatro en Sevilla desde Lope de Rueda hasta fines del siglo XVII. Sevilla: Ayuntamiento, 1994.

Sánchez Escribano, F.; Porqueras Mayo, A. Preceptiva dramática española del Renacimiento y el Barroco. Madrid: Gredos, 1972.

SÁNCHEZ MARIANA, M. "Repertorios manuscritos de obras y colecciones dramáticos conservados en la Biblioteca Nacional", en Estudios sobre Calderón y el teatro de la Edad de Oro. Homenaje a K. y R. Reichenberger. Barcelona: PPU, 1989, pp. 233-258.

SANZ AYÁn, C. "Felipe II y los orígenes del teatro barroco", Cuadernos de Historia Moderna, 23 (1999: 47-78).

SANZ AyÁN, C.; GARCÍA GARCÍA, B.J. "El oficio de representar en España y la influencia de la comedia dell'arte (1567-1587)", en Cuadernos de Historia Moderna, 16 (1995), pp. 475-500.

SENTAURENS, J. "Bailes y entremeses en los escenarios teatrales sevillanos de los siglos XVI y XVII: ¿géneros menores para un público popular?", en El teatro menor de España a partir del siglo XVI. Madrid: CSIC, 1983, pp. 67-87.

Serralta, F. "Comedia de disparates", Cuadernos Hispanoamericanos, 311 (1976): 450-461. 
SERRALTA, F. "La comedia burlesca: datos y orientaciones", en Risa y sociedad en el teatro español del Siglo de Oro. Toulouse, CNRS, 1980, pp.99-114.

SERralta, F. "La religión en la comedia burlesca del siglo XVII", Criticón, 12 (1980): 55-75.

SUBIRÁ, J. Historia de la música teatral en España. Barcelona: Labor, 1945

Thompson, P. E. The Triumphant Juan Rana: A Gay Actor of the Spanish Golden Age. University of Toronto Press, 2006.

Valbuena, Prat, A. Calderón. Su personalidad, su arte dramático, su estilo y sus obras. Barcelona: Juventud, 1941.

Valbuena, Prat, A. Historia del teatro español. Barcelona: Noguer, 1956.

VAREY, J.E. Y SHERGOLD, N.D. Genealogía, origen y noticias de los comediantes en España.. London: Tamesis, 1985

VAREY, J.E. Y SHERGOLD, N.D. "Datos históricos sobre los primeros teatros de Madrid: prohibiciones de autos y comedias y sus consecuencias". Bulletin Hispanique 62 (1960): 286-325.

VAREY, J.E. Y SHERGOLD, N.D. Teatros y comedias en Madrid: 16001650. Estudio y documentos. London: Tamesis, 1971.

VAREY, J.E. Y SHERGOLD, N.D. Representaciones palaciegas: 16031699. London: Tamesis, 1982.

ViTsE, M. Historia del teatro en España. Madrid: Taurus, 1990. Tomo I.

YEPES, A. "Pequeño panorama de los pasos y danzas españolas en los tratados de los siglos XVI, XVII y XVIII", en IIIa. Semana de Música 
española: el Renacimiento, Madrid: Festival de Otoño de la Comunidad de Madrid (editor), Consejería de Cultura, 1988, vol. II, p. 198.

YNDURÁIN, D. “Rinconete y Cortadillo: del entremés a la novela”, BRAE, 46 (1966): 321-334. 


\section{LITERATURA Y SOCIEDAD DEL XVII}

Alemán, M. Guzmán de Alfarache. Madrid: Cátedra, 1981-1984.

AlzIEU, P.; JAMMES, R.; LISSORGUES, Y. Floresta de poesías eróticas del Siglo de Oro. Barcelona: Crítica, 1984.

ARCO, R. "La dueña en la literatura española", Revista de Literatura, 3 (1953): 293-344.

AStRana MARín, L. Don Luis de Góngora y Argote. Biografía y estudio crítico. Madrid: 1925.

ARELLANO, I. "Una alusión oscura y una enmienda: "Meléndez" en varios textos de Quevedo", Filología, XXII, 1 (1987): 65-70.

Blecua, J.M. (ed.) Poesía de la edad de Oro. Madrid: Castalia, 1991, 2 volúmenes.

BRISSET MARTín, D.E. "Fiestas hispanas de moros y cristianos. Historia y significados." Gazeta de Antropología, 17 (2001). En la web: http://www.ugr.es/ pwlac/G17_03DemetrioE_Brisset_Martin.html

Caballero Fernández-Rufete, C. Arded, Corazón, Arded. Tonos humanos del barroco en la Península Ibérica, Valladolid, Las Edades del Hombre, 1997.

CARreira, A. Gongoremas. Barcelona: Península, 1998.

CERVAntes, M. DE. Obras completas. Madrid: Aguilar, 2003.

CÉSPEDES, B. Discurso de las letras humanas llamado el Humanista. Edición de P. Gregorio de Andrés. El Escorial: 1965.

Chevalier, M. Cuentecillos tradicionales en la España del Siglo de Oro. Madrid: Gredos, 1975. 
Deleito y Piñuela, J. La mala vida en la España de Felipe IV. Madrid: Espasa-Calpe, 1967.

Domínguez Ortiz, A. Política y hacienda de Felipe IV. Madrid: Pegaso, 1983.

Caro Baroja, J. El Carnaval. Madrid: Taurus, 1979.

CARRASCo Urgoiti, M.S. El moro de Granada en la literatura (del siglo XV al XX). Madrid: Revista de Occidente, 1956 (ed. Facsímil, Granada, 1989).

Chevalier, M. Tipos cómicos y folklore (siglos XVI y XVII). Madrid: Edi-6, 1982.

ELIAS, N. La sociedad cortesana. Madrid: FCE, 1993.

Elliott, J.H. The Count-Duke of Olivares: The Statesman in an Age of Decline. New Have: Yale UP, 1986.

Elliott, J.H. Richelieu and Olivares. New York: Canto, 1991.

ELliot, J.H. The Thirty years' War. Ed. Geoffrey Parker. New York: Military Heritage, 1987.

Ettinghausen, H. Noticias del Siglo XVII: relaciones de sucesos naturales y sobrenaturales. Barcelona: Puvill, 1995.

García de Enterría, M. C. Sociedad y poesía de cordel en el Barroco. Madrid: Taurus, 1973.

GIL, E. El sistema educativo de la Compañía de Jesús. La "Ratio Studiorum". Madrid: UPCO, 1992.

GÓNGORA, L. DE. Obras poéticas. Edición de R. Foulché-Delbosc. New York: 1921. 
GóngORA, L. DE. Sonetos completos. Edición de B. Ciplijauskaité. Madrid: Castalia, 1992.

GóngorA, L. DE. Soledades. Edición de Robert Jammes. Madrid: Castalia, 1994.

Gracián, B. El arte de la prudencia. Oráculo Manual. Madrid: Temas de Hoy, 1993.

GrACIÁN, B. El criticón. Estella (Navarra): Orbis, 1989, 2 volúmenes.

HEISE, U.K. "Transvestism and the Stage Controversity in Spain and England, 1580- 1680". Theatre Journal 44.3 (1992): 357-374.

Herrera Puga, P. Sociedad y delincuencia en el Siglo de Oro. Granada: Universidad, 1971.

HoRnEdo, R. Historia de la Iglesia en España. Madrid: B.A.C., 1980.

Hume, M. The Court of Philip IV. Spain in Decadence. New York: Putnam's Sons, 1907. Traducción al español por P. M. G. en Barcelona: Ediciones Mercedes, 1949.

JAMMES, R. La obra poética de Don Luis de Góngora y Argote. Madrid: Castalia, 1987.

JuÁREZ AlmENDROS, E. El cuerpo vestido y la construcción de la identidad en las narrativas autobiográficas del siglo de oro. London: Tamesis Books, 2006.

LujÁn De SAYAVedra, M. Segunda parte de la vida del pícaro Guzmán de Alfarache. Madrid: Aguilar, 1980.

MARIANA, J. Obras. Madrid: Ryvadeneira, 1864. 
LÁzARO CARRETER, F. "Literatura y folclore en los refranes" y "La lengua de los refranes, ¿espontaneidad o artificio?". Estudios de lingüística. Barcelona: Crítica, 1980, pp. 207-232.

LEA, K. M. Italian Popular Comedy. A Study in the Commedia dell'arte, 1560-1620. Oxford, 1934.

LIPSIO, J. Políticas. Estudio preliminar y notas de J. Peña Echeverría y M. Santos López, traducción de Bernardino de Mendoza. Madrid: Tecnos, 1997.

Lisón TolosAna, C. La imagen del rey. Monarquía, realeza y poder ritual en la Casa de los Austrias. Madrid: Espasa-Calpe, 1991.

LÓPEZ BARALT, L. Huellas del Islam en la Literatura Española (De Juan Ruiz a Juan Goytisolo). Madrid: Hiperión, 1985.

LÓPEZ DE MONTOYA, P. Libro de la buena educación y enseñanza de los nobles. Madrid: Viuda de P. Madrigal, 1595.

LujÁn, N. Madrid de los últimos Austrias. Barcelona: Planeta, 1989.

Maravall, J. A. La cultura del Barroco. Análisis de una estructura histórica. Barcelona: Ariel, 1986.

MÁRQUEZ, A. Literatura e Inquisición en España. Madrid: Taurus, 1980.

Martínez Alcubilla, M. Códigos antiguos de España. Madrid: 1885.

MoRA, J. Discursos morales... Madrid: Pedro Madrigal, 1589.

Profeti, M. G. "Código ideológico-social, medios y modos de la risa en la comedia del siglo XVII", en Risa y sociedad en el teatro español del Siglo de Oro. París: Editions du C.N.R.S., 1989, pp. 13-23.

Querol Gavalda, M. La música en las obras de Cervantes. Barcelona: Comptalía, 1948. 
Reinosa, Rodrigo De. Poesía de germanía. Edición de María Inés Chamorro Fernández. Madrid: Visor, 1988.

REINOSA, RodRigo DE. La poesía de Rodrígo de Reinosa. Estudio y edición de José M. Cabrales Arteaga. Santander: Institución Cultural de Cantabria, 1980

RUMEU DE ARMAS, A. Historia de la censura literaria gubernativa en España. Madrid: Aguilar, 1940.

SAAVEDRA FAJARDo, D. Empresas políticas. Edición de Sagrario López Poza. Madrid: Cátedra, 1999.

SoOns, A.C. Haz y envés del cuento risible en el Siglo de Oro. Londres: Támesis Book, 1976.

STEIN, L. Songs of Mortals, Dialogues of the Gods: Music and Theatre in Sevententh-Century Spain. Oxford: Clarendon Press, 1993.

STEIN, L. "The Origins and Character of recitado" en Journal of Seventeenth-Century Music (JSCM), volume 9 (2003), No. 1 (boletín electrónico http://www.sscm-jscm.org/jscm/v9/no1/Stein.html )

TENORIO Gómez, P. Las madrileñas del mil seiscientos: imagen y realidad. Madrid: Horas y Horas, 1993.

TimonedA, J. Cancioneros llamados Enredo de amor, Guisadillo de amor y El truhanesco. Edición de Antonio Rodríguez-Moñino. Valencia: Castalia, 1951.

WÜRTENBERGER, F. El manierismo. Barcelona: Rauter, 1964. 


\section{ClÁSICOS GRECOLATINOS Y CRISTIANOS}

Anthologie grecque. Edición y traducción de Pierre Waltz. París: Les Belles Lettres, 1928-1970, 12 volúmenes.

Apuleyo. El asno de oro. Edición de José María Royo. Madrid: Cátedra, 1991.

ARISTÓfAnes. Los Arcanienses. Los caballeros. Las Tesmoforias. La Asamblea de las mujeres. Madrid: Cátedra, 2005.

ARISTÓfANES. Las Nubes. Las Ranas. Pluto. Madrid: Cátedra, 2004.

ARISTÓFANES. Las avispas. La Paz. Las aves. Lisístrata. Madrid: Cátedra, 2004.

Biblia, La. Versión crítica sobre los textos hebreo, arameo y griego por Francisco Cantera Burgos y Manuel Iglesias González. Edición ilustrada. Madrid: Salvat-Editores, 1975, 8 volúmenes.

Homero. Ilíada. Barcelona: Orbis, 1982.

HoMERO. Odisea. Madrid: Gredos, 1993.

HorACiO. Sátiras. Epístolas. Arte poética. Edición bilingüe de Horacio Silvestre. Madrid: Cátedra, 2003.

JUVEnAl. Sátiras. Traducción, estudio introductorio y notas de Bartolomé Segura Ramos. Madrid: CSIC, 1996.

LuCiANO DE SAmOSATA. Obras. Madrid: Gredos, 1981-1992.

LUCRECIO, De la naturaleza de las cosas. Barcelona: Folio, 2002.

MARCIAL. Epigramas. Introducción y notas de Francisco Socas. Madrid: Alianza Editorial, 2004.

MARCo Aurelio. Meditaciones. Barcelona: Planeta-Agostini, 1995. 
QueVEDO, F. DE. Anotaciones manuscritas de Francisco de Quevedo a la retórica de Aristóteles traducida por Hermógenes Hermolao. Reproducción facsimilar de la edición impresa por Theobaldus Paganus: Lyon, 1547. Las anotaciones de Quevedo son naturalmente posteriores. Madrid: Sociedad Menéndez Pelayo. Ollero \& Ramos Editores, 1997.

SÉNECA, L. A. Cartas morales a Lucilio. Introducción de Eduardo Sierra Valentí. Barcelona: Planeta, 1985.

SÉNECA, L. A. Tragedias. Introducciones, traducción y notas de Jesús Luque Moreno. Madrid. Gredos, 1997 y 1999, 2 volúmenes.

TERencio. Comedias. Texto revisado y traducido por Lisardo Rubio. Madrid: CSIC, 1991, vol. I.

Ovidio Nasón, P. Metamorfosis. Edición de Consuelo Álvarez y Rosa Mª Iglesias. Madrid: Cátedra, 2004.

Plauto. Comedias. Traducción y edición de José Román Bravo. Madrid: Cátedra, 1993, 2 vols.

PÍNDARO. Odas y fragmentos. Madrid: Gredos, 1995.

Plutarco. El erótico. Diálogo filosófico sobre Eros y la confrontación de los amores pederástico y conyugal. Introducción, texto y traducción y notas de Pau Gilabert Barberà. Barcelona: PPU, 1991.

PLUTARCO. Vidas paralelas. Introducción general, traducción y notas de Aurelio Pérez Jiménez. Madrid: Gredos, 1985.

VIRGILIO. Eneida. Traducción de Javier de Echate- Sustaeta. Madrid: Gredos, 2000.

Vives Coll, A. Luciano de Samosata en España (1500-1700). Valladolid : Sever-Cuesta, 1959. 


\section{Literatura Medieval Y DEL RENACIMIENTo}

Alfonso X, Antología. Prólogo y selección de Alejandro Bermúdez Vivas. Barcelona: Orbis, 1983.

AnónIMO. Cantar de Rodrigo. Edición de Luis Guarner. Gerona: Ediciones Aubi, 1972.

Bembo, P. Gli Asolani. Los Asolanos. Edición, introducción y notas de José María Reyes Cano. Barcelona: Bosch, 1990.

Castillo, H. Selección del Cancionero General. Ed. de José Ma Reyes Cano, PPU, 1987.

Castiglione, B. El cortesano. Edición de Mario Pozzi. Madrid: Cátedra, 2003.

CONTRAIT, R. Histoire et poésie. Le comte Fernán González: Genèse et legende. Grenoble: Imprimerie Allier, 1977.

Ferreira de VAsConcellos, J. Comedia Eufrosina. Edición, prólogo y notas de Eugenio Asensio. Madrid: Impresor C. Bermejo, 1951.

FiCINO, M. De amore. Comentario a "El Banquete" de Platón. Traducción y estudio preliminar de Rocío de la Villa Ardura. Madrid: Tecnos, 2001.

FORSTER, L. The Icy Fire: Five Studies in European Petrarchism. Cambridge: Cambridge University Press, 1969.

GRAF, A. Attraverso il Cinquecento. Torino: Loescher, 1916.

Hebreo, L. Diálogos de amor. Traducción por Carlos Mazo del Castillo, edición de José María Reyes Cano. Barcelona: PPU, 1993. 
HerRera, F. DE. Anotaciones a la poesía de Garcilaso. Edición de Inoria Pepe y José María Reyes Cano. Madrid: Cátedra, 2001.

LeÓn, Fray LuIS DE. La perfecta casada. Edición de Javier San José Lera. Madrid: Espasa-Calpe, 1992.

MANERo SOROLla, M. P. Imágenes petrarquistas en la lírica española del Renacimiento. Repertorio. Barcelona: PPU, 1990.

MANRIQUE, J. Obra completa. Madrid: Espasa-Calpe, 1977.

MÁrquez Sterling, M. Fernán González, First Count of Castile: The Man and the Legend. University of Mississipi: Romance Monographs, Inc., núm. 40, 1980.

MENÉndEz PidAL, R. "Notas para el romancero de Fernán González." In Homenaje a Menéndez Pelayo. Madrid, 1899. 1:429-507.

MENÉNDEZ PidAL, R. "Fernán González en el teatro español." Boletín de la Institución Fernán González 170/171 (1968): 107-16, 246-58.

Navarrete, I. Los huérfanos de Petrarca. Poesía y teoría en la España renacentista. Madrid, Gredos, 1997. Ante todo destacamos el último capítulo: "Góngora, Quevedo y el fin del petrarquismo en España", pp. 244307.

PÉReZ de Urbel, J. Fernán González. El héroe que hizo a Castilla. Buenos Aires- México: Espasa-Calpe, 1952.

Torres Naharro, B. Comedias: Soldadesca, Tinelaria, Himenea. Madrid: Castalia, 1973.

VALDÉS, A. Diálogo de Mercurio y Carón. Edición, introducción y notas de Rosa Navarro Durán. Madrid: Cátedra, 1999. 
VALDÉS, A. La vida de Lazarillo de Tormes y de sus fortunas y adversidades. Introducción de R. Navarro Durán. Barcelona: Octaedro, 2003.

VIROLI, M. La sonrisa de Maquiavelo. Barcelona: Tusquets, 2002. 


\section{TEORÍA Y METODOLOGÍA LITERARIA}

AuERBACH, E. "Figura", en Scenes from the Drama of European

Literature. New York: Meridian Books, 1959, pp. 11-76.

Bajtín, M. La cultura popular en la Edad Media y en el Renacimiento: el contexto de François Rabelais. Versión de Julio Forcat y César Conroy. Madrid : Alianza, 1998.

BlecuA, A. Manual de crítica textual. Madrid: Castalia, 1990.

BUTLER, J. Gender Trouble: Feminism and the Subversion of Identity. New York: Routledge, 1990.

CASCAles, F. Tablas poéticas. Madrid: Espasa-Calpe, 1975.

Coy, J; Y Hoz, J. Estudios sobre los géneros literarios, II (Tipología de los personajes dramáticos). Salamanca: Universidad, 1984.

ECO, U. Cómo se hace una tesis. Barcelona: Círculo de lectores, 1989.

FRENZEL, E. Diccionario de motivos de la literatura universal. Madrid: Gredos, 1980.

Foucault, M. "What is an Author?" Language, Counter-Memory, Practice. Ed. Donald F. Bouchard. NY: Cornell University Press, 1977, pp. 124-127.

Gracián, B. Agudeza y arte de ingenio. Edición de Evaristo Correa Calderón. Madrid: Castalia, 2001.

HENRÍQUEZ UREÑA, P. La versificación irregular en la poesía castellana. Madrid: Publicaciones de la RFE, 1920.

Jauralde Pou, P. (dir.) Poesía manuscrita. Manual de investigadores. Madrid: Calambur, 2003. 
LóPez Pinciano, A. Philosophia antigua poética. Madrid: BAE, 1959, tomo III.

Maestro, J.G. El personaje nihilista. La Celestina y el teatro europeo. Madrid: Iberoamericana, 2001.

NAVARro Durán, R. La mirada al texto. Comentario de textos literarios. Barcelona: Ariel, 1995.

NAVArro Durán, R. Mitos del mundo clásico. Versión libre de las Metamorfosis de Ovidio. Madrid: Alianza, 2002.

PANOFSKY, E. El significado de las artes visuales. Madrid: Alianza, 1983

Rico, F. (dir.) Imprenta y crítica textual en el siglo de Oro. Valladolid: Universidad, 2000.

RODRÍGUEZ SÁNCHEZ DE LEÓN, M. J. La crítica ante el teatro barroco español (siglos XVII-XIX). Salamanca: Almar, 2000.

VILlAnUeVA, D. El polen de ideas. Barcelona: PPU, 1991.

Wellek, R. y Warren, A. Teoría literaria. Prólogo español de Dámaso Alonso. Madrid: Gredos, 1966. 


\section{CATÁlogos Y REPERTORIOS BIBLIOGRÁFICOS}

Artigas, M. y SÁnchez Reyes, E. Catálogos de la Biblioteca de Menéndez Pelayo. I. Manuscritos (primera parte con 40 fotograbados). Santander: Cuerpo Facultativo de Archiveros, Bibliotecarios y Arqueólogos y Sociedad Menéndez Pelayo, 1957.

Barrera y Leirado, C. A. DE LA. Catálogo bibliográfico y biográfico del teatro antiguo español, desde sus orígenes hasta mediados del siglo XVIII. Madrid: Rivadeneyra, 1860. Véase la entrada a F. de Quevedo y Villegas. También disponible on-line en:

http://www.cervantesvirtual.com/FichaAutor.html?Ref=193.

BlecuA, J. M. "Catálogo", en Obra poética. Vol. I. Madrid: Castalia: 1981, pp. 3-21.

BuEndíA, F. Bibliografía. Obras completas. Obras en verso. Madrid: Aguilar, 1960, pp. 1113-1384.

COTARElo y MORI, E. Bibliografía de las controversias sobre la licitud del teatro en España. Madrid: Tipografía de Revistas y Archivos, 1904.

Cotarelo y Mori, E. Catálogo abreviado de una Colección Dramática española hasta fines del siglo XIX y de obras relativas al teatro español. Madrid: V.e H. de T. Rotas, 1930.

FERnÁndez Guerra, A. Noticia de las comedias ms. de la Biblioteca del Duque de Osuna. Copia de las portadas de las Colecciones de entremeses, bailes y sainetes, publicados con diversos títulos desde 1600 a 1770. Institut del Teatre (Barcelona), ms. 62.070, s.f. 
Granja, Agustín DE LA; LOBATO, MARÍA LUISA. Bibliografía descriptiva del teatro breve español (siglos $X V$-XX). Madrid: Universidad de Navarra-Iberoamericana. Vervuert, 1999.

Heliodoro DA Cunha, J. Catálogo dos manuscritos da Biblioteca Pública Evorense. Lisboa, 1868.

JANER Y GRAELLS, F. "Una nota sobre la bibliografía de Quevedo", Revista Castellana (Valladolid), V (1919), 38-46.

JAURALDE Pou, P. "Nuevos textos manuscritos de la poesía de Quevedo". $B R A E$, LXVI (1986), pp. 63-73.

MiRANDA, M.R. Manuscritos quevedianos en las Bibliotecas portuguesas. Una nueva versión del poema "A cristo resucitado" (1) de Quevedo en un manuscrito de la Biblioteca Nacional de Lisboa, en Revista del Instituto de Lengua y Cultura Españolas. Pamplona, IV, I, 1988: 87119.

Montaner, J. La colección teatral de don Arturo Sedó. Barcelona: Seix Barral, 1951.

PAZ Y MELIÁ, A. Catálogo de las piezas de teatro que se conservan en el departamento de manuscritos de la Biblioteca Nacional. Madrid: BNE, 1899. También editado en Madrid: Patronato de la Biblioteca Nacional, 1934.

PÉREZ CuencA, I. Catálogo de los manuscritos de Francisco de Quevedo en la Biblioteca Nacional. Madrid: Ollero \& Ramos, 1997.

RIESCO TERRERO, A. Diccionario de abreviaturas hispanas de los siglos XIII al XVIII. Salamanca: 1983. 
RodríGUEZ-MoÑInO, A. Catálogo de manuscritos poéticos castellanos existentes en la Biblioteca de The Hispanic Society of America (siglos XV, XVI y XVII). New York: Hispanic Society of America, 1965-66.

SÁez Guillén, J. F. Catálogo de manuscritos de la Biblioteca Colombina de Sevilla. Sevilla: Cabildo de la Santa Metropolitana y Patriarcal Iglesia Catedral de Sevilla, 2002, 2v.

SiMÓN DíAZ, J. Bibliografía de la Literatura Hispánica. Madrid: CSIC, 1992.

Simón Palmer, M.C. Manuscritos dramáticos del Siglo de Oro de la Biblioteca del Instituto del Teatro de Barcelona. Madrid: CSIC, 1977.

SCHAEFFER, A. Katalog der Bibliothek Altspanischer Druche. Leipzig: 1898.

VÁZQUEZ EstéVEZ, A. Impresos dramáticos españoles de los Siglos XVI y XVII en las Bibliotecas de Barcelona. La transmisión teatral impresa. (3 vols.) Kassel: Reichenberger, 1995.

Vega García-Luengos, G.; Fernández LeRA, R.; DEL Rey SAyaguéS, A. Ediciones del teatro español en la Biblioteca de Menéndez Pelayo. Kassel: Reichenberguer, 2001. 


\section{DiCCIONARIOS Y VOCABULARIOS}

Alonso Hernández, J.L. Léxico del marginalismo del Siglo de Oro. Salamanca: Universidad, 1976.

AlOnSO HeRnánDEZ, J.L. El lenguaje de los maleantes españoles de los siglos XVI y XVII. Salamanca: Universidad, 1979.

AlzieU, P.; JAMMES, R.; LissorgueS, Y. "Vocabulario" final en su edición Floresta de poesías eróticas del Siglo de Oro. Barcelona: Crítica, 1984.

Corominas, J. Y PASCUal, J. A. Diccionario crítico-etimológico castellano e hispánico. Madrid: Gredos, 1980.

CORREAS, G. Vocabulario de refranes y frases proverbiales (1627). Edición de Louis Combet. Madrid: Castalia, 2000.

Covarrubias Orozco, S. Tesoro de la lengua castellana o española. Madrid: Castalia, 1994

Diccionario de Autoridades. Edición facsímil de la R.A.E. Madrid: Gredos, 1984. También en la web oficial de la Real Academia Española: http//:www.rae.es

HILL, J.M. (ed.) Voces germanescas. Bloomington (Indiana): Indiana University Publications, 1949.

LAVANDEIRA FERNÁNDEZ, A. “Adiciones a un diccionario de seudónimos literarios españoles", Dicenda 2 (1983): 175-184.

Rogers, P.P.; LAPUENTE, F.A. Diccionario de seudónimos literarios españoles. Madrid: Gredos, 1977. 
Tesón GonzÁlez, J. Léxico de cosméticos y afeites en el Siglo de Oro.

Salamanca: Universidad de Extremadura, 1990. 